\title{
De directe werking van de grondrechten van de Europese Unie
}

Citation for published version (APA):

de Mol, M. (2014). De directe werking van de grondrechten van de Europese Unie. [Doctoral Thesis, Maastricht University]. Wolf Legal Publishers. https://doi.org/10.26481/dis.20141002mm

Document status and date:

Published: 01/01/2014

DOI:

10.26481/dis.20141002mm

Document Version:

Publisher's PDF, also known as Version of record

\section{Please check the document version of this publication:}

- A submitted manuscript is the version of the article upon submission and before peer-review. There can be important differences between the submitted version and the official published version of record.

People interested in the research are advised to contact the author for the final version of the publication, or visit the DOI to the publisher's website.

- The final author version and the galley proof are versions of the publication after peer review.

- The final published version features the final layout of the paper including the volume, issue and page numbers.

Link to publication

\footnotetext{
General rights rights.

- You may freely distribute the URL identifying the publication in the public portal. please follow below link for the End User Agreement:

www.umlib.nl/taverne-license

Take down policy

If you believe that this document breaches copyright please contact us at:

repository@maastrichtuniversity.nl

providing details and we will investigate your claim.
}

Copyright and moral rights for the publications made accessible in the public portal are retained by the authors and/or other copyright owners and it is a condition of accessing publications that users recognise and abide by the legal requirements associated with these

- Users may download and print one copy of any publication from the public portal for the purpose of private study or research.

- You may not further distribute the material or use it for any profit-making activity or commercial gain

If the publication is distributed under the terms of Article $25 \mathrm{fa}$ of the Dutch Copyright Act, indicated by the "Taverne" license above, 


\section{DE DIRECTE WERKING VAN DE}

\section{GRONDRECHTEN VAN DE EUROPESE UNIE}

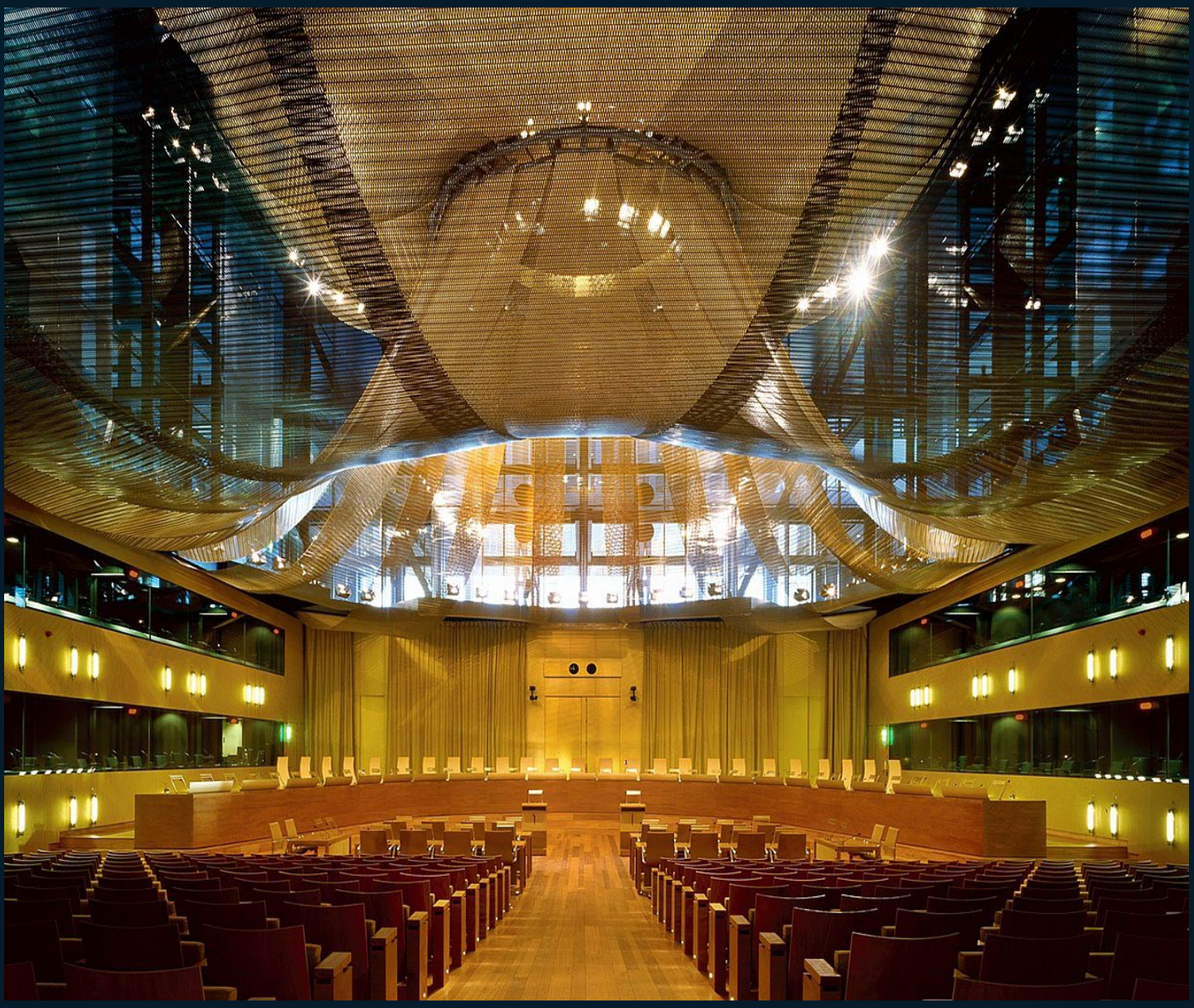




\section{DE DIRECTE WERKING VAN DE GRONDRECHTEN VAN DE EUROPESE UNIE}




\section{De directe werking van de grondrechten van de Europese Unie}

Mirjam de Mol

ISBN: 978-94-6240-166-2

\section{Omslag:}

De grote zittingszaal van het Hof van Justitie van de Europese Unie te Luxemburg (bron: "Hof van Justitie van de Europese Unie")

\section{Uitgever:}

Wolf Legal Publishers (WLP)

Postbus 313

5060 AH Oisterwijk

E-Mail:info@wolfpublishers.nl

www.wolfpublishers.com

Niets uit deze uitgave mag worden vermenigvuldigd, opgeslagen in een geautomatiseerd gegevensbestand of openbaar worden gemaakt, in enige vorm of op enige wijze, hetzij elektronisch, door fotokopieën, opnamen of op enig andere manier, zonder voorafgaande toestemming van de auteur(s) en de uitgever. Voor het opnemen van gedeelte(n) uit deze uitgave in bloemlezingen, readers en andere compilatiewerken (artikel 16 Auteurswet 1912) dient men zich tot de uitgever te wenden.

(C) M. de Mol/WLP 2014 


\title{
DE DIRECTE WERKING VAN DE GRONDRECHTEN VAN DE EUROPESE UNIE
}

\author{
PROEFSCHRIFT
}

ter verkrijging van de graad van doctor aan de Universiteit Maastricht,

op gezag van de Rector Magnificus, prof. dr. L.L.G. Soete

volgens het besluit van het College van Decanen,

$$
\text { in het openbaar te verdedigen }
$$

op donderdag 2 oktober 2014 om 14.00 uur

$$
\text { door }
$$

Mirjam de Mol 


\section{Promotores}

Prof. dr. H.E.G.S. Schneider

Prof. dr. B. De Witte

Beoordelingscommissie

Prof. dr. M. Claes, (voorzitter)

Prof. dr. L.F.M. Besselink (Universiteit van Amsterdam)

Dr. A.P. Van der Mei

Prof. dr. H.G. Sevenster (Lid van de Raad van State)

Prof. dr. E. Vos 
Voor Leo, Wouter Domingo, Olivia en Leonora 



\section{VERKORTE INHOUDSOPGAVE}

Uitgebreide inhoudsopgave op blz. 403

\section{Deel I Inleidende hoofdstukken}

Hoofdstuk 1 Algemene inleiding 3

Hoofdstuk 2 Unierechtelijke systeem van 19

grondrechtenbescherming

Deel II Verticale directe werking

Hoofdstuk 3 Definiëring en constitutionele context 61

Hoofdstuk 4 Wachauf-uitvoering $\quad 87$

Hoofdstuk 5 ERT-uitvoering 133

Hoofdstuk 6 Geen uitvoering: Annibaldi 157

\section{Deel III Horizontale directe werking}

Hoofdstuk 7 Definiëring en constitutionele context 193

Hoofdstuk 8 De erkenning: Mangold en verder 227

Hoofdstuk 9 Nadere analyse van de rechtspraak 257

Hoofdstuk 10 Discriminatieverboden 283

Deel IV Synthese, conclusies en aanbevelingen

Hoofdstuk 11 Directe werking op dreef en op drift 309

Summary $\quad 345$

Valorisatie-addendum $\quad 359$

Lijst van aangehaalde jurisprudentie $\quad 367$

Lijst van aangehaalde literatuur \& overige bronnen 377

Lijst van gebruikte afkortingen $\quad 399$

Curriculum Vitae $\quad 401$

Uitgebreide inhoudsopgave $\quad 403$

Dankwoord 411 



\section{DEEL I}

\section{INLEIDENDE HOOFDSTUKKEN}





\section{HOOFDSTUK 1}

\section{ALGEMENE INLEIDING}

\subsection{De directe werking van Uniegrondrechten: een reveil}

Het onderwerp van dit proefschrift is de rechtspraak van het Hof van Justitie van de Europese Unie (hierna: Hof) inzake de directe werking van de grondrechten van de Unie. Het leerstuk van de directe werking van Unierecht in het nationale recht (hierna: 'directe werking van Unierecht') en het Unierechtelijke systeem van grondrechtenbescherming zijn bijna zo oud als het Verdrag van Rome. ${ }^{1}$ De beide doctrines zijn vindingen van het Hof die dateren van de prille begintijd van het proces van Europese eenwording.

Het leerstuk van de directe werking lanceerde het Hof in 1962 in het arrest Van Gend en Loos. ${ }^{2}$ Op grond van dit leerstuk werkt het Unierecht ${ }^{3}$ in beginsel direct (dat wil zeggen zonder tussenkomst van nationaal recht) door in de nationale rechtsorde als zelfstandige toetsingsmaatstaf voor de nationale rechter. In de periode 1969-1974 blijkt uit het drieluik Stauder, Internationale Handelsgesellschaft en Nold II, dat de grondrechten een bestanddeel uitmaken van de algemene rechtsbeginselen waarvan het Hof de eerbiediging verzekert. ${ }^{4}$

De beide doctrines vormen essentiële elementen van de Unierechtelijke rechtsorde; de directe werking als motor voor de effectieve en uniforme toepassing van (materieel) Unierecht en de Unierechtelijke grondrechtenbescherming als de 'rule of law'-veiligheidsklep ervan. ${ }^{5}$ Het uitgangspunt was aanvankelijk dat de Unie zelf de Uniegrondrechten moest eerbiedigen. In een later stadium, in 1989, bleek uit het arrest Wachauf, dat ook de lidstaten verplicht kunnen zijn om de grondrechten van de Unie te eerbiedigen. ${ }^{6}$ Sindsdien is de directe werking van Uniegrondrechten in geschillen tussen particulieren en de over-

\footnotetext{
$1 \quad$ Anno 1957.

2 HvJEU van 5 februari 1963, zaak 26/62, Van Gend en Loos.

3 Indertijd 'gemeenschapsrecht', maar ik spreek gemakshalve over het algemeen van Unierecht.

4 HvJEU 12 november 1969, zaak 29/69, Stauder. HvJEU van 17 december 1970, zaak 11/70, Internationale Handelsgesellschaft. HvJEU van 14 mei 1974, zaak 4/73, Nold II, punt 13.

5 Zie verder hoofdstuk 2.1.

6 HVJEU van 13 juli 1989, zaak 5/88, Wachauf. Zie voor een samenvatting van dit arrest paragraaf 3.3.5.2.
} 
heid (verticale directe werking) een feit. Het doel van deze directe werking is om er voor te zorgen dat de grondrechten van de Unie worden geëerbiedigd bij de toepassing van het materiële Unierecht in de nationale rechtsorde. Het fenomeen 'directe werking van Uniegrondrechten' trok in de doctrine en rechtspraktijk aanvankelijk weinig aandacht. Hierin is verandering gekomen door een tweetal ontwikkelingen in 2005 en 2009.

\section{Anno 2005- het arrest Mangold}

In 2005 is het Hof een geheel nieuwe en controversiële weg ingeslagen door in het arrest Mangold de directe werking van een Uniegrondrecht (het verbod van discriminatie op grond van leeftijd als algemeen beginsel van Unierecht) in een geschil tussen particulieren te erkennen. ${ }^{7}$ Begin 2010, in het arrest Kücükdeveci, ${ }^{8}$ werd deze mogelijkheid van horizontale directe werking bevestigd. Het gevolg van deze rechtspraak is dat de grondrechten van de Unie door de directe toepassing door de rechter nadelige effecten voor particulieren met zich kunnen brengen. Dit is nieuw. Het Uniesysteem van grondrechtenbescherming is immers geënt op de rechtstaatgedachte waarin grondrechten dienen als middel ter bescherming tegen overheidsmacht. Uniegrondrechten zijn derhalve begunstigend voor particulieren; eerder een bron van rechten dan één van plichten. De mogelijkheid dat grondrechten ook inroepbaar zijn tegen particulieren is niet alleen nieuw, maar ook controversieel. In het merendeel van de lidstaten is de directe toepassing door de rechter van grondrechten vis-à-vis particulieren niet mogelijk. Een prikkelend aspect van de beide arresten is verder, dat het gebruik van het grondrecht lijkt neer te komen op omzeiling van bepaalde door de Uniewetgever gemaakte keuzes. Het feit dat de beide arresten mager zijn gemotiveerd draagt niet bij aan de acceptatie van de aanpak en maakt het bovendien moeilijk om de reikwijdte ervan te overzien. Zo zijn er vragen als: ${ }^{9}$ In welke situaties is sprake van horizontale directe werking? Komen alle Uniegrondrechten ervoor in aanmerking? De twee arresten veroorzaakten vanuit diverse hoeken een storm van kritiek die nog niet is gaan liggen. ${ }^{10}$ De

7 HvJEU van 22 november 2005, zaak C-144/04, Mangold.

8 HvJEU van 19 januari 2010, zaak C-555/2007, Kücükdeveci.

9 Zie ook Mazák \& Moser 2013, p. 84.

10 Mazák \& Moser 2013: “The critical reactions were (...) strikingly broad-based”. De wetenschap: Zie bijvoorbeeld Redactioneel CMLR 2006; Redactioneel CMLR 2008; Schmidt 2005; Schiek 2006; Mazák \& Moser 2013. Anders: Fontanelli 2011 (zie ook zijn verwijzingen in voetnoot 4). Pers: R. Herzog and L. Gerken, 'Stop the European Court of Justice', EU Observer, 10 September 2008 and F. Kuitenbrouwer, 'Onbescheiden rechters', NRC Handelsblad, 7 februari 2006. Advocaten-generaal: A-G Geelhoed van 16 maart 2006, zaak C-13/05, Chacón Navas, A-G Mazák van 15 februari 2007, zaak C411/05, Palacios de la Villa, A-G Colomer van 24 januari 2008, gevoegde zaken C-55/07 en C-56/07, Michaeler, A-G Maduro van 31 januari 2008, zaak C-303/06, Coleman, A-G 
voornaamste kritiek laat zich raden: het Hof is zijn boekje te buiten gegaan en de arresten veroorzaken rechtsonzekerheid. ${ }^{11}$

\section{Anno 2009- het Handvest}

De commotie rond de erkenning van horizontale directe werking in Mangold leidde niet tot bijzondere aandacht voor de reeds lang bestaande directe doorwerking van Uniegrondrechten in verticale verhoudingen. Hierin is verandering gekomen sinds het bindend worden van het Handvest van de Grondrechten van de Europese Unie (hierna: Handvest) op 1 december 2009. Het thema van Uniegrondrechten staat sindsdien volop in de belangstelling. Dit is ook precies de bedoeling van het Handvest, dat onder andere als doelstelling heeft het 'zichtbaar maken' van Uniegrondrechten. ${ }^{12}$ Één van de aandachtspunten is de toepassing van Uniegrondrechten op nationale handelingen. De belangstelling voor dit onderwerp is tweeledig.

Ten eerste bestaat (bijvoorbeeld bij de regeringen van de lidstaten) de vrees dat het Hof 'gewapend' met het bindende Handvest, de Uniegrondrechten van toepassing zal verklaren op nationale maatregelen die in wezen los staan van het Unierecht. Dit zou een ongerechtvaardigde expansie van het Unierecht betekenen ten koste van de soevereiniteit van de lidstaten, en meer in het bijzonder ten koste van de nationale stelsels van grondrechtenbescherming. ${ }^{13}$ Het zijn overigens niet alleen de lidstaten die waken voor de onterechte toepassing van Uniegrondrechten op het nationale recht. Ook de Europese

Trstenjak van 29 maart 2007, zaak C-80/06, Carp, A-G Sharpston van 22 mei 2008, zaak C-427/06, Bartsch en van 30 november 2006, zaak C-227/04 P, Lindorfer en A-G Bot van 7 juli 2009, zaak C-555/07, Kücükdeveci. Regeringen van de Lid-Staten: Zo namen in zaak Kücükdeveci bijvoorbeeld deel: Duitsland, Tsjechië, Denemarken, Ierland, Nederland en het Verenigd Koninkrijk). Tot slot wordt gewezen op een procedure voor het Duitse Constitutionele Hof waarin werd gesteld dat Mangold een 'ultra vires' handeling is 2 BvR 2661/06, Honeywell Bremsbelag GmbH.

11 Overigens vormde de erkenning van het verbod van discriminatie op grond van leeftijd in Mangold eveneens onderwerp van kritiek. Ik laat dat verder buiten beschouwing. Zie hierover Mazák \& Moser 2013, p. 76-79.

12 Conclusies van het voorzitterschap Europese Raad Keulen 3 en 4 juni 1999, bijlage IV. Mededeling van de Commissie betreffende het Handvest van de grondrechten van de Europese Unie ingediend door de heer Vitorino in overeenstemming met de Voorzitter, COM/2000/0559 def., punt 7. Mededeling van de Commissie over de aard van het Handvest van de grondrechten van de Europese Unie. COM/2000/0644 def., punt 12.

13 Zie Lenaerts \& Gutiérrez-Fons 2010, p. 1629; Hancox 2013, p. 1425. Zie over de positie van nationale constitutionele hoven: Sarmiento 2013, p. 1268; Reestman \& Besselink 2013, p. 171; Redactioneel NTM/ NJCM -Bull. 2013, p. 191. Zie ook de aandacht voor en na HvJEU van 26 februari 2013, zaak C-617/10, Åkerberg Fransson die wordt besproken in hoofdstuk 4.5 . 
Commissie gaat uit van een terughoudende toepassing van het Handvest. Ladenburger schrijft hierover: ${ }^{14}$
“3.1.4. (...) the EU institutions should not strive to extend the scope of the Charter as largely as ever possible, by accepting any theoretically construable nexus of the situation submitted to EU law. Instead, the guiding question should be whether there really is a convincing justification for adding, as regards the category of Member State action at hand, a layer of fundamental rights protection at EU level, on top of the two existing levels of the ECHR and the national constitutions. (...)”

De tweede reden voor aandacht is dat het onduidelijk is in welke situaties Uniegrondrechten van toepassing zijn op nationale handelingen. ${ }^{15}$ Dit werkt door in de nationale rechtspraktijk, rechters en procespartijen weten niet waar ze aan toe zijn. ${ }^{16}$ Het veroorzaakt ook andere misverstanden. Zo schrijft de Europese Commissie in het Verslag over de toepassing van het Handvest: ${ }^{17}$

"De belangstelling van de mensen voor het Handvest is groot en zij koesteren
hoge verwachtingen rond de toepassing daarvan. Het Handvest is echter niet
van toepassing in alle situaties waarin de grondrechten in de Europese Unie
aan de orde zijn. In 2010 ontving de Commissie meer dan 4000 brieven van
burgers in verband met de grondrechten. Ongeveer driekwart daarvan betrof
zaken die buiten het toepassingsgebied van het recht van de Unie vallen.

14 Ladenburger 2012, p.16.

15 Zie bijvoorbeeld Reestman \& Besselink 2013, p. 171: "the scope of application of EU law, the outer limits (...), remain shrouded in mist”; Sarmiento 2013: p. 1279: 'we are still missing the overall picture' ACA 2011, vragenlijst en algemeen rapport, thema C en discussiepaper I.

16 Fontanelli 2014, p. 9: "Ordinary courts, which are unable to extract from Article 51 of the Charter a workable test, might end up applying or disapplying national measures with the best intentions, but for the wrong reasons" en p. 11:" national courts (...) must be able to know when the Charter offers to them the silver bullet of disapplication. In the alternative, recourse to the constitution or the Convention might require ordinary courts to embark upon alternative procedures (resulting, often, in a pronouncement by the constitutional tribunal) that are more burdensome and increase-by definition-the length of the main proceedings".

17 Europese Commissie, Verslag over de toepassing van het EU-Handvest van de grondrechten 2010, punten 1 en 2.3. Zie ook Ladenburger 2012, p. 16.: "3.1.3. The European Commission is constantly called upon to apply Article 51 (1), in its replies to an ever increasing amount of parliamentary questions, petitions and complaints on fundamental rights issues arising in Member States. (...) Only in a limited number of cases since the Charter's entry into force did the Commission find a sufficient nexus allowing it to examine the situation submitted from a fundamental rights angle.” 
Hieruit blijkt dat er veel misverstanden bestaan over het doel van het Handvest en de situaties waarin het Handvest al dan niet van toepassing is."

Het Handvest geeft weliswaar in artikel 51, lid 1 een criterium voor de toepasselijkheid op nationale handelingen, namelijk dat sprake moet zijn van nationale maatregelen die Unierecht 'uitvoeren' of 'toepassen', maar de precieze reikwijdte van dit criterium blijkt (nog steeds) lastig te bepalen. Fontanelli merkt anno 2014 op: ${ }^{18}$

"Indeed, neither the relevant provisions nor the case-law have managed to devise a reliable judicial test that could be used to get a yes/no answer to the question whether the 'implement[ation of] Union law' is performed by certain state measures.”

Soms is het klip en klaar of aan het criterium is voldaan, bijvoorbeeld als het gaat om een nationale wet die een richtlijn implementeert. De grondrechten van de Unie zijn dan van toepassing. Eenvoudig zijn ook zaken waarin naast het inroepen van het Uniegrondrecht, geen andere aanknoping met het Unierecht bestaat. Het betreft dan een zuiver nationale situatie waarin Uniegrondrechten niet van toepassing zijn. In veel gevallen echter is het antwoord op de vraag naar de toepasselijkheid van Unierechtelijke grondrechten complex. Met name naarmate de band tussen het Unierecht en de nationale handeling verder verwijderd is en de nationale handeling niet is bedoeld als uitvoering van Unierecht.

De onzekerheid over het precieze toepassingsgebied van Uniegrondrechten is overigens niet nieuw. In het pre-Handvest tijdperk bestonden gelijke vragen met betrekking tot het toepassingsgebied van de toen reeds bestaande bron van Uniegrondrechten, de 'court-made' algemene beginselen van Unierecht. ${ }^{19}$ Ook toen was het lastig om te definiëren in welke situaties de Uniegrondrechten van toepassing waren, mede ook omdat de rechtspraak van het Hof over het toepassingsgebied van Uniegrondrechten door zijn veelomvattende casuïstiek ondoorzichtig was.

18 Fontanelli 2014, p. 4; Hij spreekt ook van een 'unpredictable test', p. 33.

19 Zie bijvoorbeeld Tridimas 2006, blz. 37-42; Prechal 2010-1, p. 8-11; De Witte 1999, p. 870; A-G Sharpston van 22 mei 2008, zaak C-427/06, Bartsch, punt 69; A-G Bot van 5 april 2011, zaak C-108/10, Scattolon, punt 110 en bijbehorende voetnoot 59. 


\subsection{Doel en probleemstelling}

Uit het bovenstaande blijkt dat de directe werking van de grondrechten van de Unie in zowel de verticale als in de horizontale context is omgeven door rechtsonzekerheid en argwaan. Het doel van dit onderzoek is om meer duidelijkheid te verschaffen over de directe werking van Uniegrondrechten door beantwoording van de volgende drie vragen:

i. In welke situaties hebben Uniegrondrechten op grond van de rechtspraak van het Hof directe werking (stand van het recht)?

ii. In hoeverre is deze rechtspraak, met name in het licht van het beginsel van allocatie van bevoegdheden, legitiem (legitimiteit en rechterlijk activisme)?

iii. Op welke punten moet het leerstuk van directe werking van Uniegrondrechten nog verder worden uitgewerkt (openstaande vragen en aandachtspunten)?

De algemene probleemstelling kan als volgt worden geformuleerd: In welke situaties hebben de grondrechten van de Unie op grond van de rechtspraak van het Hof directe werking en is deze rechtspraak, met name in het licht van het beginsel van allocatie van bevoegdheden, legitiem?

Het onderwerp van het onderzoek betreft derhalve de rechtspraak van het Hof inzake de directe werking van Uniegrondrechten. Met 'Uniegrondrechten' wordt bedoeld de grondrechten uit hoofde van de algemene beginselen van Unierecht en uit hoofde van het Handvest. De beide bronnen van Uniegrondrechten worden nader toegelicht in hoofdstuk 2. Het concept 'directe werking' wil zeggen 'de toepassing van Unierechtelijke grondrechten door de nationale rechter als zelfstandige toetsingsmaatstaf. Hierbij wordt onderscheid gemaakt tussen directe werking in gedingen tussen particulieren en de overheid (verticale directe werking) en directe werking in gedingen tussen particulieren onderling (horizontale directe werking). Deze begrippen worden uitgebreider toegelicht in de hoofdstukken 3 (verticale directe werking) en 7 (horizontale directe werking).

In het onderzoek komt ook aan de orde de vraag in hoeverre ${ }^{20}$ de rechtspraak van het Hof inzake de directe werking van Uniegrondrechten legitiem is. Er

20 Adams e.a. 2013, p. 8: "Ultimately of course, legitimacy is not a binary thing but something that comes in gradations". 
bestaat geen eenduidige definitie van legitimiteit, ${ }^{21}$ Weiler noemt het "the most underspecified concept in political theory and social science.”22

In dit proefschrift gebruik ik het beginsel van 'allocatie van bevoegdheden' (hierna ook: allocatiebeginsel) als voornaamste graadmeter voor de legitimiteit en voor het bestaan van 'rechterlijk activisme'. Onder rechterlijk activisme versta ik primair rechtspraak die spanning oplevert met het allocatiebeginsel. ${ }^{23}$ Het allocatiebeginsel bevat een horizontale (interne) dimensie en een verticale (externe) dimensie. ${ }^{24}$

De horizontale verdeling van bevoegdheden wordt ook wel institutioneel evenwicht of het beginsel van de scheiding der machten in de Europese Unie ${ }^{25}$ genoemd. Het ziet op de verhouding tussen de instellingen van de Unie onderling. In de context van dit onderzoek is met name relevant de verhouding tussen het Hof en de Uniewetgever. Het allocatiebeginsel is weergegeven in artikel 13, lid 2, VEU dat luidt als volgt:

"2. Iedere instelling handelt binnen de grenzen van de bevoegdheden die haar in de Verdragen zijn toegedeeld en volgens de daarin bepaalde procedures, voorwaarden en doelstellingen. De instellingen werken loyaal samen."

Advocaat-generaal Trstenjak verduidelijkt dit beginsel in de zaak Audiolux als volgt:26

"106. (...) De eerbiediging van het institutionele evenwicht houdt in, dat elke instelling haar bevoegdheden dient uit te oefenen met inachtneming van de bevoegdheden van de andere instellingen (...)

107. Het Hof maakt (...) eveneens deel uit van dit institutionele evenwicht. Deze omstandigheid brengt mee dat het Hof in zijn hoedanigheid van rechtsprekende instelling (...) tot taak heeft om in het kader van zijn bevoegdheid de eerbiediging van het recht bij de uitlegging en toepassing van het Verdrag te verzekeren, de wetgevende bevoegdheden van de Raad en het Parlement respecteert. (...) Het Hof kan weliswaar teruggrijpen op de algemene

21 Zie bijvoorbeeld de verschillende invalshoeken voor legitimiteit die worden gehanteerd in de verschillende bijdragen in Adams e.a. 2013, met name ook p. 4-6.

22 Weiler 2013, p. 235.

23 Zie ook Muir 2013-2, p. 76. Zie uitgebreid over rechterlijk activisme en het Hof: De Waele 2009, met name de hoofdstukken 3 en 4.

24 Zie ook Prechal, De Vries en Van Eijken 2010, p. 213-215.

25 HvJEU van 18 april 2013, zaak C-413/11, Germanwings, punt 22.

26 A-G Trstenjak van 30 juni 2009, zaak C-101/08, Audiolux. Zie verder over het beginsel van institutioneel evenwicht: De Witte 2000, p. 150-152; Jacqué 2004. 
rechtsbeginselen teneinde vanuit het oogpunt van de doelstellingen van het Verdrag adequate oplossingen te vinden voor aan hem gestelde uitleggingsvragen, maar mag niet op de stoel van de communautaire wetgever plaatsnemen wanneer deze een hiaat in een regeling kan dichten.”

Bij de verticale verdeling van bevoegdheden gaat het om de verdeling van de bevoegdheden tussen de Unie en de lidstaten. ${ }^{27}$ Dit beginsel dat ook bekend is onder de naam, attributiebeginsel, is neergelegd in artikel 5, lid 2, VEU:

"2. Krachtens het beginsel van bevoegdheidstoedeling handelt de Unie enkel binnen de grenzen van de bevoegdheden die haar door de lidstaten in de Verdragen zijn toegedeeld om de daarin bepaalde doelstellingen te verwezenlijken. Bevoegdheden die in de Verdragen niet aan de Unie zijn toegedeeld, behoren toe aan de lidstaten."

De toepassing van Unierechtelijke grondrechten in het nationale recht is vanuit het oogpunt van de verticale verdeling van bevoegdheden delicaat. Uitbreiding van het toepassingsgebied van de grondrechten impliceert uitbreiding van het toepassingsgebied van het Unierecht, wat ten koste gaat van de zuiver nationale zone van de lidstaten. ${ }^{28}$

Het precieze toetsingskader voor het allocatiebeginsel wordt in de proefschrift nader uitgewerkt in de hoofdstukken 3 en 7.

Hoewel het onderzoek naar de legitimiteit van de rechtspraak primair is gekoppeld aan het allocatiebeginsel, als een inhoudelijke norm van het institutionele recht van de Unie, komen in het proefschrift ook andere maatstaven aan bod die betrekking hebben op de kwaliteit (en daarmee de legitimiteit) van de rechtspraak. ${ }^{29}$

27 Zie bijvoorbeeld HvJEU van 7 juli 2011, zaak C-310/10, Agafiţei, punt 47.

28 Lenaerts \& Gutiérrez-Fons 2010, p. 1629: "the application of general principles may displace long-standing legal traditions at odds with the constitutional foundations of the Union. Even in areas where the Union does not enjoy legislative competence as such, the joint application of the substantive law of the Union and of general principles may force the national legislature to accommodate its policy choices to EU law. Stated differently, where a national measure falls within the scope of EU law, general principles may "circumscribe" (or "frame") the powers retained by the Member States."

29 Zie ook Mazák \& Moser 2013 , p. 66, Lenaerts 2013-2, p. 1306: "In addition, internal legitimacy looks at courts as rational actors, by focusing on the soundness of their legal reasoning.' The question whether courts enjoy legitimacy thus amounts to examining whether their rationale is sufficiently transparent and easy to understand or whether it is cryptic; whether the grounds of judgment are strong enough to be convincing and adequately meet the arguments put forward by the parties; whether the court's rulings are 
Een eerste maatstaf is de helderheid en deugdelijkheid van de motivering van de rechtspraak. Een heldere en deugdelijke motivering draagt bij tot de overtuigingskracht en in het verlengde daarvan ook tot de aanvaardbaarheid van rechtspraak. ${ }^{30}$ Voorts voorkomt het onduidelijkheid over de betekenis en reikwijdte van rechtspraak. Lenaerts tekent hier bij aan, dat het Hof op basis van het beginsel van collegialiteit werkt en het daardoor beperkt kan zijn in de wijze en uitwerking van de motivering: ${ }^{31}$

"As consensus-building requires to bring on board as many opinions as possible, the argumentative discourse of the ECJ is limited to the very essential. In order to preserve consensus, the ECJ does not take "long jumps" when expounding the rationale underpinning the solution given to novel questions of constitutional importance. On the contrary, the persuasiveness of its argumentative discourse is built up progressively, i.e. "stone-by-stone." This means that, in order to fully apprehend the approach of the ECJ in an area of EU law, a critical observer should not limit him- or herself to studying the "groundbreaking" case, but he or she should also read the relevant case-law predating as well as postdating that case."

Ik meen dat met deze realiteit inderdaad rekening moet worden gehouden bij de evaluatie van de rechtspraak van het Hof op het punt van de duidelijkheid van de motivering. Het Hof kan door het collegialiteitsbeginsel beperkt zijn in de mogelijkheid tot uitgebreide motiveringen. Het is ook begrijpelijk dat dit met name ook bij principiële en ingewikkelde rechtsvragen kan resulteren in een voorzichtige 'steen voor steen' of 'stap voor stap' benadering. Tegelijk denk ik dat het collegialiteitsbeginsel geen afbreuk zou mogen doen aan een minimum van vereiste duidelijkheid, vooral ook bij de inzet van nieuwe lijnen in de rechtspraak of bij de beantwoording van lastige vraagstukken. Er moet worden gebouwd op een fundament. Voorts wijst Lenaerts er terecht op, dat het van belang is om baanbrekende arresten te bezien en te analyseren in de context van voorgaande en opvolgende rechtspraak. In dit proefschrift zal dit ook worden gedaan. Ik meen echter dat hier ook een taak ligt voor het Hof zelf. Indien een 'steen voor steen' -aanpak heeft geresulteerd in een bouwsel, is het ook goed om dit bouwsel te benoemen in de rechtspraak. Bijvoorbeeld door de lijn van

coherent with the existing case-law and based on impartial criteria known in advance or whether they are simply unpredictable and arbitrary."

30 Zie ook Mazák \& Moser 2013 , p. 66: "quality and soundness -and consequently, of the persuasiveness- of the judicial reasoning”. Zie ook de Visser 2013-2, p. 202-204: Zij wijst op het gevaar van een "one-sided line of reasoning" waarbij de argumenten van het 'verliezende standpunt' niet worden behandeld.

31 Lenaerts 2013-2, p. 1251. 
arresten te noemen in de overwegingen, maar ook daar waar mogelijk gebruik te maken van meer algemene formuleringen en criteria.

De tweede maatstaf is de consistentie en coherentie van de rechtspraak. Het gaat hierbij vooral ook om consistentie en coherentie binnen een reeks van arresten in dezelfde lijn. In de context van dit proefschrift is van belang dat de te onderzoeken rechtspraak consistent en coherent is met de rechtspraak inzake het algemene Unierechtelijke systeem van rechtsbescherming waarvan het leerstuk van de directe werking deel uitmaakt. ${ }^{32}$

De derde maatstaf is het rechtszekerheidsbeginsel. ${ }^{33}$ Directe werking is het middel bij uitstek om de effectiviteit en uniformiteit van Uniegrondrechten te garanderen, maar deze doelen heiligen niet het middel van directe werking als daarbij de rechtszekerheid van justitiabelen in de knel komt.

\section{$1.3 \quad$ Belang}

Het onderzoek ziet op het fundament van het Unierecht, namelijk op de doorwerking van het Unierecht in het nationale recht. Het onderzoek betreft bovendien een onderwerp dat actueel en volop in beweging is: de Uniegrondrechten. Daarnaast raakt het onderwerp aan nationale constitutionele debatten inzake de constitutionalisering van private verhoudingen (ook wel genoemd de derdenwerking van grondrechten). De toegevoegde waarde van dit onderzoek ligt allereerst in de gezamenlijke behandeling van zowel verticale als horizontale directe werking van Uniegrondrechten. Dit resulteert in een totaaloverzicht van de directe werking van Uniegrondrechten. Verder wordt er naar gestreefd om op basis van een analyse van de rechtspraak van het Hof zo precies mogelijk aan te gegeven in welke situaties sprake is van directe werking. Met het oog op de vraag naar de legitimiteit van de rechtspraak wordt bovendien een toetsingskader geformuleerd dat kan dienen als basis voor de evaluatie ervan. Tot slot worden onduidelijkheden getraceerd en benoemd. Op basis van de onderzoeksresultaten zal ik ook aanbevelingen voor het Hof formuleren.

Ik richt mij nadrukkelijk ook tot de nationale rechtspraktijk. Kennis omtrent het toepassingsgebied van Uniegrondrechten en de nog openstaande vragen is van

32 Zie ook Mazák \& Moser 2013, p. 66.

33 Zie ook Mazák \& Moser 2013 , p. 66: "legal certainty (...) presupposes, in particular, that the law is judicially interpreted and applied in a way that its meaning, at least in its essential contours, remains reasonably predictable to participants in the legal interpretative community." 
belang voor nationale rechters en procespartijen. Wanneer kunnen Uniegrondrechten zonder meer worden ingeroepen en in welke situaties is aanleiding voor voorzichtigheid en/of het stellen van prejudiciële vragen? Voorts is precieze kennis van de stand van de rechtspraak van het Hof relevant voor de actoren bij de procedures voor het Hof. Met het oog op een doelmatige procesvoering is kennis van de al gelopen races en de nog te lopen races noodzakelijk. Daarbij is het voor deze groep van belang te weten waar sprake is van (dreigende) bevoegdheidsoverschrijding. Ook wetgevers, bestuurders en beleidsmakers moeten beschikken over precieze kennis van het toepassingsgebied van Uniegrondrechten, zodat duidelijk is wanneer de overheid is gebonden aan Uniegrondrechten. Tot slot is de toepassing van Uniegrondrechten gekoppeld aan het materiële Unierecht. Nieuwe Uniewetgeving heeft gevolgen voor het toepassingsgebied van Uniegrondrechten, dit geldt ook voor Uniewetgeving die niet ziet op de uitwerking van grondrechten. Dit betekent dat ook de nationale onderhandelaar in Brussel baat heeft bij een goede sensor voor het 'binnenhalen' van Uniegrondrechten in deelgebieden van het nationale recht door nieuwe Uniewetgeving.

\subsection{Methode}

De belangrijkste methode van onderzoek is de traditionele juridische onderzoekmethode. Het gaat hier om inventarisatie, analyse, systematisering en evaluatie van literatuur en van de rechtspraak van het Hof. ${ }^{34}$ Daarbij is ook gebruik gemaakt van processtukken van belangrijke zaken voor het Hof. ${ }^{35}$ Tijdens het onderzoek heb ik reeds deelresultaten ervan gepubliceerd. ${ }^{36}$ Voorts heb ik tijdens mijn onderzoek verschillende malen de gelegenheid gehad om van dichtbij te zien hoe in de rechtspraktijk wordt omgegaan met de toepassing van het Handvest in het nationale recht. Ik was betrokken bij de voorbereiding van het seminar van de ‘Europese Vereniging van Raden van Staten’ en hoogste administratieve gerechten (hierna: 'ACA') ${ }^{37}$ over de betekenis van het Handvest voor de nationale bestuursrechtspraak dat op 24 november 2011

34 Rechtspraak tot 13 juli 2014.

35 Met name van de verwijzingsbeschikkingen en de schriftelijke opmerkingen van de Commissie. De Nederlandse versies van verwijzingsbeschikkingen kunnen worden geraadpleegd op de site van het Expertise Centrum Europees Recht http://www. minbuza.nl /ecer. De inbreng van de Commissie kan in afgeronde Hofzaken worden opgevraagd via http://ec.europa.eu/transparency/regdoc.

36 De Mol 2014 -1; De Mol 2014-2; De Mol 2012-1; De Mol 2012-2; De Mol 2011-1; De Mol 2010-1; De Mol 2010-2; De Mol, Pahladsingh \& van Heijningen 2012. Voorzover deze publicaties syntheses bevatten van dit proefschrift wordt hiernaar verder niet meer verwezen.

37 Voor meer informatie over ACA-Europe: zie www.aca-europe.eu. 
plaats vond bij de Raad van State. ${ }^{38}$ Het toepassingsgebied van het Handvest op nationale handelingen was één van de centrale thema's. ${ }^{39}$ Mijn betrokkenheid bij dit seminar, alsook cursussen en lezingen die ik heb gegeven over de toepassing van Uniegrondrechten in het nationale recht aan de rechterlijke macht, de Directie Advisering van de Raad van State en de rijksoverheid hebben mijn beeld bevestigd, dat in de praktijk sprake is van voortschrijdende bewustwording van de mogelijke doorwerking van Uniegrondrechten in het nationale recht en er behoefte bestaat aan concrete handvatten. Een andere bron van inspiratie voor dit onderzoek was mijn vorige functie als gemachtigde van de Nederlandse regering voor het Hof, met name vanwege mijn betrokkenheid bij de Nederlandse inbreng voor het Hof in de zogenaamde 'post-Mangold zaken'. In de zaak Kücükdeveci heb ik de schriftelijke opmerkingen namens de Nederlandse regering geconcipieerd alsmede het Nederlands standpunt in die zaak voor het Hof bepleit. 40

\subsection{Taal}

Dit proefschrift is geschreven in het Nederlands. Dit is een bewuste keuze. Ik vind het belangrijk dat het Nederlands als wetenschappelijke taal behouden blijft ook op het gebied van het Unierecht. Het zou mijns inziens geen automatisme moeten zijn om in het Engels, Frans of Duits te publiceren. Dit principe is niet ingegeven door een hang naar behoud van eigen nationale identiteit. Al zou dit in de context van het Unierecht niet eens zo gek zijn. ${ }^{41}$ Mijn belangrijkste motief is dat het enkel publiceren in de, in beginsel, breed toegankelijke talen

38 Het seminar had het karakter van een expertmeeting. Aan het seminar namen de volgende landen deel: Nederland (voorzitter), België, Finland, Verenigd Koninkrijk, Polen, Frankrijk, Duitsland, Hongarije, Spanje, Litouwen en Oostenrijk. Voorts namen deel S. Prechal en T. Von Danwitz, beide rechter bij het Hof van Justitie van de Europese Unie, D. Spielmann (rechter bij het Europees Hof voor de Rechten van de Mens) en L. Romero Requena (directeur-generaal van de Juridische Dienst van de Europese Commissie).

39 Alle stukken zijn te vinden op http://www.aca-europeeu/ en/ colloquiums /sem_ 2011_theHague. Het betreft de volgende stukken: (i) nationale rapporten op basis van uitgebreide vragenlijst, (ii) een rapport van rechter T. Von Danwitz (op persoonlijke titel) op basis van dezelfde vragenlijst, (iii)een algemeen rapport op basis van de nationale rapporten, het rapport van rechter T. Von Danwitz en de mondelinge inbreng van de deelnemers tijdens het seminar (inclusief de inbreng van Prechal, Spielmann en Romero Requena) (iv) drie discussiepapers opgesteld die dienden als basis voor de discussie tijdens het seminar.

40 Ik was tevens betrokken bij de post -Mangold zaken HvJEU van 23 september 2008, zaak C-427/06, Bartsch; HvJEU van 1 april 2008, zaak C-267/06, Tadao Maruko en HvJEU van 16 oktober 2007, zaak C-411/05, Palacios de la Villa.

41 Met een knipoog naar de artikelen 4(2) VEU en 53 (6) van het Handvest. 
Engels, Frans of Duits niet alleen tot vergroting van het potentiële lezerspubliek leidt, maar ook het risico van verenging van het lezerspubliek met zich brengt. Mijn inschatting is dat publicaties in de gebruikelijke talen Engels, Frans of Duits over het algemeen gunstig zijn om grote groep van Unierechtjuristen aan te trekken, en wel met name academici of juristen werkzaam bij de instellingen van de Unie, maar in mindere mate zullen worden geraadpleegd door juristen van allerlei pluimage (fiscalisten, strafrechtjuristen, staats- en bestuursrechtjuristen en civilisten) uit de nationale rechtspraktijken. Bij het onderwerp van dit proefschrift, dat ziet op de toepassing van Unierecht in het nationale recht in een potentieel breed scala aan rechtsgebieden, is het juist van belang om ook deze groep te betrekken bij het wetenschappelijke debat. Daar komt bij dat er in het Nederlands verhoudingsgewijs weinig diepgaande literatuur is over de directe werking van grondrechten of deelaspecten daarvan. De keerzijde van deze keuze is dat mijn onderzoeksbevindingen niet worden ontsloten aan een aanzienlijke groep van niet-Nederlandstalige EU-experts. Ik hoop dit te (hebben) ondervangen door het publiceren van deelartikelen in het Engels. ${ }^{42}$

\section{$1.6 \quad$ Opzet}

\section{Algemeen}

Het onderzoek bestaat uit twee delen. Het eerste deel gaat over de directe werking van Uniegrondrechten in de verhouding tussen overheid en particulieren (deel II: hoofdstukken 3-6). Het tweede deel gaat in op de directe werking van Uniegrondrechten in de verhouding tussen particulieren onderling (deel III: hoofdstukken 7-10). De delen worden voorafgegaan door een algemene inleiding in het Unierechtelijke stelsel van grondrechtenbescherming (hoofdstuk 2 van dit deel). De delen II en III hebben gemeen dat ze op grond van de rechtspraak van het Hof in kaart brengen in welke situaties sprake is van directe werking en op welke punten onduidelijkheden bestaan.Voorts is in de beide delen steeds sprake van een evaluatie van de legitimiteit van relevante rechtspraak en wel met name in het licht van het beginsel van allocatie van bevoegdheden. Hiertoe wordt in elk deel een toetsingskader geformuleerd. Voor het overige hebben de twee delen hun eigen opzet. Dit verschil in opzet komt doordat de verticale directe werking van Uniegrondrechten al een zekere volwassenheid heeft bereikt. Er kan worden geput uit een zee aan rechtspraak met vaste ankers en zichtbare kustlijnen. Horizontale directe werking staat echter nog in de kinderschoenen. Er is slechts een handvol rechtspraak met veel

42 Overigens zijn drie publicaties vertaald in het Roemeens. Dit bevestigt dat er ook behoeft bestaat aan literatuur over dit onderwerp in de minder breed toegankelijke talen dan Engels, Frans en Duits: De Mol 2013; De Mol 2011-2 en De Mol 2011-3. 
losse eindjes.

Verticale directe werking (Deel II)

In het eerste hoofdstuk van dit deel (hoofdstuk 3) wordt het leerstuk verticale directe werking gedefinieerd en in de constitutionele context geplaatst. In vergelijking met het leerstuk van de horizontale directe werking is de constitutionele context van het leerstuk van verticale directe werking tamelijk overzichtelijk. Het raakt met name aan de verdeling van de bevoegdheden tussen de Unie en de lidstaten, waarbij het bestaan van verticale directe werking als zodanig geen pijnpunt is. Het moeilijke punt in deze context is het bepalen van in welke nationale situaties de toepassing van Uniegrondrechten legitiem is in het licht van het beginsel van allocatie van bevoegdheden. Het algemene uitgangspunt hierbij is dat de toepassing van Uniegrondrechten in een zuiver nationale context inbreuk maakt op de bevoegdheden van de lidstaten. Buiten gevallen waarin er geen enkele aanknoping met het Unierecht is, kan het lastig zijn om te bepalen wanneer sprake is van een Unierechtelijke context die de toepassing van Uniegrondrechten rechtvaardigt. In hoofdstuk 3 wordt voor deze vraag daarom een toetsingskader geformuleerd. De basis voor dit toetsingskader is artikel 51, lid 1, van het Handvest en in het verlengde daarvan de drie lijnen in de rechtspraak die volgen uit de arresten Wachauf, ERT en Annibaldi.43 De eerste twee zijn richtingwijzers om te onderscheiden in welke situaties Uniegrondrechten kunnen worden toegepast. Het Annibaldi-arrest fungeert als boegbeeld voor de niet-toepasselijkheid van Uniegrondrechten.

De overige hoofdstukken van dit deel hebben alle drie dezelfde structuur. Ze bevatten een weergave van de stand van het recht en de openstaande vragen op basis van een analyse van de rechtspraak, alsmede een evaluatie van de legitimiteit van de rechtspraak en wel met name in het licht van het beginsel van allocatie van bevoegdheden. Zoals gezegd bestaat er een zee aan rechtspraak op het gebied van verticale directe werking van Uniegrondrechten. De hoofdstukken zijn daarom allereerst ingedeeld aan de hand van de drie ankers Wachauf (hoofdstuk 4), ERT (hoofdstuk 5), en Annibaldi (hoofdstuk 6). Vervolgens is per hoofdstuk gebruik gemaakt van nieuwe bakens om gemakkelijker koers te houden.

Horizontale directe werking (deel III)

Evenals in deel II gaat deel III van dit proefschrift van start met het definiëren van het leerstuk van horizontale directe werking, alsmede met een schets van de

43 HvJEU van 13 juli 1989, zaak 5/88, Wachauf; HvJEU van 18 juni 1991, zaak C-260/89, ERT; HvJEU van 18 december 1997, zaak C-309/96, Annibaldi. 
constitutionele context (hoofdstuk 7). Zoals zal blijken is het constitutionele speelveld complex. Horizontale directe werking raakt niet alleen aan de verdeling van bevoegdheden tussen de Unie en de lidstaten, maar ook aan de taakverdeling tussen rechter en wetgever en aan de scheidslijn tussen het publieke en private domein. Het complexe speelveld komt ook tot uiting in de definiëring. Het is noodzakelijk om het Unierechtelijke concept van horizontale directe werking onder te verdelen in twee varianten: toetsing van overheidshandelen en de toetsing van particulier handelen. De intensiteit van de doorwerking van het Uniegrondrecht in het nationale recht is bij de beide varianten hetzelfde, echter zij hebben wel verschillende gradaties van derdenwerking. De 'toetsing van overheidshandelen' impliceert in vergelijking met de variant 'de toetsing van particulier handelen' een derdenwerking 'light'. Een belangrijk verschil met het leerstuk van verticale directe werking is dat ook de legitimiteit van het bestaan van horizontale directe werking ter discussie staat. In hoofdstuk 7 ligt de aandacht dan ook op het in kaart brengen van de elementen die relevant zijn voor de beoordeling van de legitimiteit van het bestaan van horizontale directe werking.

In hoofdstuk 8 wordt de ontwikkeling van het leerstuk van de horizontale directe werking van Uniegrondrechten in beeld gebracht op basis van de rechtspraak van het Hof. Het gaat om een handvol rechtspraak die qua hoeveelheid in geen verhouding staat tot de rechtspraak uit deel II, maar die (potentieel) verstrekkend is. De belangrijkste arresten zijn Mangold en Kücükdeveci. ${ }^{44}$ In deze arresten heeft het Hof de stap gezet tot de expliciete erkenning van de mogelijkheid van horizontale directe werking van een Unierechtelijk grondrecht uit hoofde van een algemeen rechtsbeginsel. Uit AMS blijkt dat dezelfde benadering ook kan gelden voor het Handvest. 45 In het hoofdstuk wordt volledigheidshalve ook aandacht besteed aan de samenloop van de horizontale directe werking van Verdragsbepalingen met het inroepen van grondrechten in de arresten Viking Line en Laval, Dynamic Medien en Las. ${ }^{46}$ In deze arresten is echter geen sprake van horizontale directe werking van Uniegrondrechten.

In hoofdstuk 9 worden de toepassingsvereisten van horizontale directe werking à la Kücükdeveci geformuleerd. $\mathrm{Nu}$ de rechtspraak nieuw, onduidelijk en bovendien controversieel is, wordt uitgegaan van een terughoudende uitleg op

44 HvJEU van 22 november 2005, zaak C-144/04, Mangold; HvJEU van 19 januari 2010, zaak C-555/2007, Kücükdeveci.

45 HvJEU van 15 januari 2014, zaak C-176/12, AMS.

46 HvJEU van 11 december 2007, zaak C-438/05, Viking Line; HvJEU van 18 december 2007, zaak C-341/05 Laval; HvJEU van 14 februari 2008, zaak C-244/06, Dynamic Medien; HvJEU van 16 april 2013, zaak C-202/11, Las. 
grond waarvan horizontale directe werking enkel kan worden aangenomen in situaties die in vergaande mate vergelijkbaar zijn aan de situaties in Mangold en Kücükdeveci. Uit Mangold en Kücükdeveci, gelezen in samenhang met AMS kunnen vier toepassingsvereisten voor horizontale directe werking worden gedestilleerd. Als alle voorwaarden zijn vervuld kan het bestaan van horizontale directe werking van het Uniegrondrecht worden aangenomen. Als één van de voorwaarden niet is vervuld, hoeft dit niet automatisch de diskwalificatie voor horizontale directe werking te betekenen. Dit komt omdat het bestaan van twee van de vier voorwaarden onzeker is. Aan het slot van dit hoofdstuk wordt de legitimiteit van de rechtspraak van het Hof geëvalueerd en wel in het bijzonder in het licht van het beginsel van allocatie van bevoegdheden.

In hoofdstuk 10 worden de concrete gevolgen van Mangold en Kücükdeveci voor discriminatieverboden uit hoofde van het non-discriminatiebeginsel en artikel 21 van het Handvest in beeld gebracht. De reden om de bespreking van de concrete gevolgen te beperken tot discriminatieverboden is, dat dit het enige grondrecht is waarvan het Hof de horizontale directe werking heeft erkend. ${ }^{47}$ De horizontale directe werking van andere grondrechten bevindt zich nog in een veel priller stadium. Ook de bevindingen in dit hoofdstuk worden besproken in het licht van het beginsel van allocatie van bevoegdheden.

\section{Conclusies en aanbevelingen (deel IV)}

Het onderzoek wordt in hoofdstuk 11 afgerond met een eindconclusies en aanbevelingen. Hierbij wordt een onderscheid gemaakt tussen verticale en horizontale directe werking. De drie deelonderzoeksvragen worden per onderdeel separaat behandeld: (1) stand van het recht, (2) legitimiteit en (3) openstaande punten. De aanbevelingen zijn onderverdeeld in aanbevelingen voor enerzijds het leerstuk van de verticale directe werking en anderzijds het leerstuk van de horizontale directe werking.

47 Rechtspraak tot 13 juli 2014. 


\section{HOOFDSTUK 2}

\section{UNIERECHTELIJKE SYSTEEM VAN GRONDRECHTENBESCHERMING}

\subsection{Inleiding}

De Europese gemeenschap ging van start zonder grondrechtenbescherming. Het Verdrag van Rome van 1957 bevatte geen grondrechtencatalogus en zelfs geen verwijzing naar de bescherming van grondrechten. Dit lijkt geen welbewuste keuze te zijn geweest, maar eerder een gevolg van de aard van het Verdrag. ${ }^{1}$ De focus lag op de oprichting van een gemeenschappelijke markt. Bovendien werd de bescherming van grondrechten op Europees niveau vormgegeven binnen de Raad van Europa. In de aanloop naar de Europese integratie van de zes eerste landen is wel gedebatteerd over de rol van grondrechten. Dit debat vond echter plaats in het kader van de voorbereiding van de Europese Politieke Unie, die er uiteindelijk niet is gekomen. ${ }^{2}$

Al snel echter, in de jaren 1963-1964, bestempelde het Hof de nieuwe opgerichte gemeenschap als een 'eigen' en 'nieuwe' rechtsorde die een rechtstreekse en autonome bron van rechten en plichten vormt voor de lidstaten en haar burgers. Kenmerkend voor deze rechtsorde is dat het gemeenschapsrecht direct en met voorrang doorwerkt in het nationale recht. ${ }^{3}$ In de periode 19691974 volgde in de arresten Stauder, Internationale Handelsgesellschaft en Nold II de constitutionele vervolgstap hierop; de erkenning van de waarborg van grondrechtenbescherming op communautair niveau door middel van de (ongeschreven) algemene beginselen van gemeenschapsrecht. ${ }^{4}$ Aldus werd uitdrukking gegeven aan, dat de nieuwe rechtsorde berust op de rechtsstaatgedachte ('rule of law'). ${ }^{5}$ Deze waarborg was essentieel, mede ook om het

1 Weiler wijst erop dat de historische verklaring voor deze ommissie niet met zekerheid kan worden gegeven. Zie voor een overzicht van verschillende historische verklaringen, 'historical speculations': Weiler1986, p. 1110-1113.

2 Zie hierover De Búrca 2011, p. 467-475.

3 HvJEU van 5 februari 1963, zaak 26/62, Van Gend en Loos; HvJEU van 15 juli 1964, zaak 6/64, Costa-Enel.

4 HvJEU 12 november 1969, zaak 29/69, Stauder. HvJEU van 17 december 1970, zaak 11/70, Internationale Handelsgesellschaft. HvJEU van 14 mei 1974, zaak 4/73, Nold II, punt 13. In de periode daarvoor had het Hof in eerdere zaken aanvankelijk geweigerd om te toetsen aan grondrechten: Zie voor een meer uitgebreide beschrijving van deze ontwikkeling in de rechtspraak: Weiler 1986, p. 1113-1121.

5 Zie over de Unie en het beginsel van rechtstaat: Pech 2010. 
communautaire recht, dat zo krachtig in het nationale recht zou moeten doorwerken, legitimiteit te verschaffen. Weiler zegt hierover: 6

"How could one assert the direct effect and supremacy of European law vesting huge constitutional power in the political organs of the Communitywithout postulating embedded legal and judicial guarantees on the exercise of such power?”

De erkenning van een communautair stelsel van grondrechtenbescherming hing derhalve nauw samen met de erkenning van de directe werking en de voorrang van het communautaire recht. ${ }^{7}$ Op dit punt werd ook druk uitgeoefend door nationale rechters (vooral de Duitse en Italiaanse constitutionele hoven). Hun bereidwilligheid om het communautaire recht rechtstreeks en met voorrang te laten doorwerken in het nationale recht, hing af van de waarborg van grondrechtenbescherming op communautair niveau. Bij afwezigheid hiervan zouden de nationale rechters zich genoodzaakt zien om het communautaire recht te toetsen aan hun nationale grondrechten. Hetgeen ten koste gaan van de uniforme uitleg en toepassing van communautaire recht. ${ }^{8}$

Het arrest Internationale Handelsgesellschaft weerspiegelt de verwevenheid van communautaire grondrechten met de directe werking en de voorrang van het communautaire recht, alsmede de druk van de Duitse rechter. ${ }^{9}$ In Internationale Handelsgesellschaft ging het om een communautaire waarborgregeling op het gebied van landbouw. Uit het arrest blijkt dat de Duitse rechter tot dusver bepaalde bepalingen ervan als niet rechtsgeldig beschouwde wegens strijd met de Duitse grondwet. De verwijzende rechter overwoog:

"Dat de waarborgregeling naar het oordeel van het Verwaltungsgericht in strijd is met bepaalde aan het nationale constitutionele bestel ten grondslag liggende beginselen welke in het raam van het gemeenschapsrecht moeten worden gehandhaafd, zodat het primaat van het supranationale recht zou hebben te wijken voor de beginselen van de Duitse grondwet."

6 Weiler 1999-2, p. 108.

7 Weiler noemt de doctrine van communautaire grondrechten één van de vier constitutionele pijlers waarop de communautaire rechtsorde is gebaseerd. De andere pijlers die hij noemt zijn de leerstukken van directe werking, voorrang en 'implied powers'. Weiler 1999-1, p. 19-26.

8 Zie ook Kapteyn 2010, p. 40; De Búrca 2011, p. 477-478.

9 Zie over de nationale reactie ook Tridimas 2006, p. 305-307. 
In reactie hierop wijdde het Hof enkele zeer principiële preliminaire overwegingen aan "de bescherming der grondrechten in de communautaire rechtsorde". Hierbij maakte het Hof eerst duidelijk dat nationale grondrechten geen afbreuk kunnen doen aan het primaat van het gemeenschapsrecht:

“3. Overwegende dat het te baat nemen van aan het nationale recht ontleende regelen of begrippen ter beoordeling van de rechtsgeldigheid der handelingen van de instellingen der gemeenschap de eenheid en het tot gelding komen van het gemeenschapsrecht aantast;dat de geldigheid van zulke handelingen alleen aan het gemeenschapsrecht mag worden getoetst;

Dat immers de aard van het Verdragsrecht, dat zijn oorsprong in een autonome rechtsbron vindt, medebrengt dat daartegenover (...) in rechte geen beroep op enige nationale rechtsregel mag worden gedaan;

Dat derhalve beweerde inbreuken op grondrechten zoals die in de constitutie van een lidstaat zijn neergelegd of op de beginselen van het constitutioneel bestel van een lidstaat, aan de rechtsgeldigheid van een handeling der Gemeenschap of aan de werking dier handeling op het grondgebied van die staat niet kunnen afdoen"

Vervolgens maakte het Hof duidelijk dat respect voor de grondrechten op het communautaire niveau worden gewaarborgd:

"4. Overwegende dat evenwel dient te worden onderzocht of niet enige soortgelijke in het gemeenschapsrecht verankerde garantie is miskend;

Dat immers de eerbiediging der grondrechten een bestanddeel uitmaakt van de algemene rechtsbeginselen welker eerbiediging door het Hof van Justitie wordt verzekerd;

Dat de handhaving dezer rechten, ofschoon uit de gemeenschappelijke constitutionele traditie der lidstaten voortvloeiende, in het kader van het communautaire bestel en van de doelstellingen der gemeenschap moet worden verzekerd;

Dat derhalve termen aanwezig zijn om, gezien de twijfel welke ten deze bij het Verwaltungsgericht is gerezen, na te gaan of de waarborgregeling indruiste tegen rechten van fundamentele aard, welker eerbiediging in de communautaire rechtsorde moet worden verzekerd."

Na de 'kick off' in de periode 1969-1974 van het Uniesysteem van grondrechtenbescherming waarin duidelijk werd dat de instellingen en organen van de gemeenschap de Uniegrondrechten moeten eerbiedigen, volgden in de periode 1989-1991 de arresten Wachauf en ERT. Deze arresten maken duidelijk, dat Uniegrondrechten ook kunnen doorwerken in het nationale recht en dat de lidstaten in bepaalde Unierechtelijke situaties gehouden zijn om de 
Uniegrondrechten te eerbiedigen. ${ }^{10}$ In de periode 2005-2010 wees het Hof de arresten Mangold en Kücükdeveci die duidelijk maken dat Uniegrondrechten niet alleen rechtstreeks kunnen doorwerken in nationale gedingen tussen overheid en burger (verticale gedingen), maar tevens in gedingen tussen particulieren (horizontale gedingen). ${ }^{11}$

Ondertussen werd na de lancering door het Hof van het Uniesysteem van grondrechtenbescherming ook op het politieke niveau aandacht besteed aan de grondrechten. In de Europese Akte (1986) verwezen de Verdragssluitende lidstaten voor het eerst naar de grondrechten en wel naar 'de grondrechten die worden erkend in de grondwetten en de wetten van de lidstaten, in het EVRM, in het Europees sociaal handvest, met name de vrijheid, de gelijkheid en de sociale rechtvaardigheid.' Sinds het Verdrag van Maastricht (1992) is het bestaan en de oorsprong van grondrechten uit hoofde van algemene beginselen gecodificeerd in artikel 6, lid 3, VEU die luidt als volgt:12

“3. De grondrechten, zoals zij worden gewaarborgd door het Europees Verdrag tot bescherming van de rechten van de mens en de fundamentele vrijheden en zoals zij voortvloeien uit de constitutionele tradities die de lidstaten gemeen hebben, maken als algemene beginselen deel uit van het recht van de Unie."

In 2000 werd de stap gezet naar een geschreven grondrechtencatalogus: het Handvest. De aanleiding hiervoor was het besluit van de Europese Raad van Keulen (3-4 juni 1999) ter gelegenheid van de vijftigste verjaardag van de Universele Verklaring van de Rechten van de Mens in december 1998 om een geschreven communautaire grondrechtencatalogus op te stellen. De eerste versie van het Handvest van de grondrechten van de EU werd plechtig afgekondigd tijdens de Europese Raad van Nice op 7 december 2000 (hierna: 'Handvest 2000'). Het Handvest 2000 was echter niet bindend. Vervolgens werd het Handvest 2000 aangepast tijdens de Europese Conventie en de Intergouvernementele Conferentie van 2003-2004. De aanpassingen betroffen met name de algemene bepalingen ervan. De aangepaste versie van het Handvest is op 12 december 2007 ondertekend door de voorzitters van de Commissie, de Raad en het Europees Parlement. Deze versie van het Handvest

10 HVJEU van 13 juli 1989, zaak 5/88, Wachauf; HvJEU van 18 juni 1991, zaak C-260/89, ERT. Zie verder deel II van deze dissertatie.

11 HvJEU van 22 november 2005, zaak C-144/04, Mangold; HvJEU van 19 januari 2010, zaak C-555/07, Kücükdeveci. Zie verder deel III van deze dissertatie.

$12 \mathrm{Zie}$ voor een overzicht van de verschillende tekstversies in het Verdrag en een vergelijking met de formulering in de rechtspraak Besselink 2012, p. 79. 
is thans bindend sinds de inwerkingtreding van het Verdrag van Lissabon op 1 december 2009.13 Het Handvest heeft de status van primair recht. Dit volgt uit artikel 6 , lid 1, VEU die luidt als volgt: ${ }^{14}$

"De Unie erkent de rechten, vrijheden en beginselen die zijn vastgesteld in het Handvest van de grondrechten van de Europese Unie van 7 december 2000, als aangepast op 12 december 2007 te Straatsburg, dat dezelfde juridische waarde als de Verdragen heeft."

Tot slot is relevant dat de Unie zal toetreden tot het EVRM. Op grond van artikel 6, lid 2, VEU, is de Unie verplicht om toe te treden. Ten tijde van de afronding van dit proefschrift is de toetreding nog geen feit. Hoewel de onderhandelaars van de Europese Unie en de 47 lidstaten van de Raad van Europa op 5 april 2013 overeenstemming hebben bereikt over de ontwerptekst voor het toetredingsverdrag van de Europese Unie tot het EVRM en de daarbij behorende ontwerpdocumenten, zoals het ontwerp toelichtend rapport, zal de uiteindelijke toetreding nog even op zich laten wachten. Voordat de 47 landen die partij zijn bij het EVRM het toetredingsverdrag kunnen ratificeren, moet er nog een gang naar Luxemburg en een rondje Brussel worden gemaakt. ${ }^{15}$ Het EVRM is daarom voorlopig nog geen "formeel in de rechtsorde van de Unie opgenomen rechtsinstrument". ${ }^{6}$ Het Unierecht verplicht dan ook nog niet tot de doorwerking van het EVRM als zodanig in het nationale recht. In Åkerberg Fransson oordeelde het Hof hierover als volgt: ${ }^{17}$

13 Zie ook Protocol nr. 30 betreffende het Handvest van de Grondrechten van de Europese Unie op Polen en het Verenigd Koninkrijk volgens welke het Handvest het Hof noch enige rechterlijke instantie van het Verenigd Koninkrijk en Polen "de bevoegdheid verleent te bepalen dat de wetten, verordeningen of administratieve bepalingen, praktijken of maatregelen van het VK in strijd zijn met de grondrechten, vrijheden en beginselen die in het Handvest zijn vastgelegd”. Tevens van toepassing voor Tsjechië.

14 Zie ook A-G Sharpston van 18 oktober 2012, zaak C-396/11, Radu, punt 44.

15 De thans te nemen vervolgstap is dat de Europese Commissie bij het HvJEU advies vraagt over de verenigbaarheid van de voorgenomen overeenkomst met de EUverdragen. Daarna volgt de interne besluitvormingsprocedure binnen de Unie (de Raad van de EU moet met unanimiteit besluiten tot ondertekening respectievelijk tot sluiting van het verdrag, welk laatste besluit door het Europees Parlement moet worden goedgekeurd). Vervolgens kunnen de landen van de raad van Europa ratificeren. Zie over de rechtsvragen met betrekking tot de toetreding: Cragl 2014; Lock 2011.

16 HvJEU van 18 juli 2013, zaak C-501/11 P, Schindler, punt 32. Zie ook HvJEU van 24 april 2012, C-571/10, Kamberaj, punten 59-62; HvJEU van 26 februari 2013, zaak C-617/10, Åkerberg, punt 44 .

17 HvJEU van 26 februari 2013, zaak C-617/10, Åkerberg Fransson. 
"44. Aangaande om te beginnen de gevolgen die de nationale rechter verbinden aan een conflict tussen het nationale recht en het EVRM, moet eraan worden herinnerd dat (...) zolang de Unie er geen partij bij is, geen formeel in de rechtsorde van de Unie opgenomen rechtsinstrument is. Bijgevolg regelt het Unierecht niet de verhouding tussen het EVRM en de rechtsordes van de lidstaten en bepaalt het evenmin welke gevolgen de nationale rechter moet verbinden aan een conflict tussen de door dat verdrag gewaarborgde rechten en een regel van nationaal recht (...).”

$\mathrm{Na}$ de toetreding van de EU tot het EVRM zal dit anders zijn en zal de EU beschikken over een derde rechtsbron van grondrechten die uit hoofde van het Unierecht doorwerkt in het nationale recht. Uit de rechtspraak van het Hof over internationale overeenkomsten van de Unie blijkt immers dat het Hof in beginsel een monistische opvatting hanteert, internationale overeenkomsten kunnen vanaf de inwerkingtreding daarvan een integrerend bestanddeel van de communautaire rechtsorde vormen. ${ }^{18}$ Het Hof hanteert hierbij echter wel de eis dat de betreffende internationale overeenkomsten -technisch- geschikt zijn om directe werking te produceren. Bij de vraag naar de technische geschiktheid hanteert het Hof soms een restrictieve benadering. Het resultaat hiervan is dat sommige internationale overeenkomsten wel direct doorwerken in de Unie rechtsorde (bijvoorbeeld de associatieovereenkomst met Turkije), maar anderen niet (bijvoorbeeld WTO overeenkomsten). ${ }^{19}$ Het EVRM zal vermoedelijk wel direct doorwerken in de Unie rechtsorde (en daarmee in de nationale rechtsstelsels). Zo stelde het Hof in Schindler: ${ }^{20}$

"32. Voorts maken de door het EVRM gewaarborgde grondrechten, zoals artikel 6, lid 3, VEU bevestigt, als algemene beginselen weliswaar deel uit van het recht van de Unie en bepaalt artikel 52, lid 3, van het Handvest weliswaar dat rechten uit het Handvest die corresponderen met rechten die zijn gegarandeerd door het EVRM, dezelfde inhoud en reikwijdte hebben als die welke er door genoemd verdrag aan worden toegekend, maar is het EVRM, zolang de Unie er geen partij bij is, geen formeel in de rechtsorde van de Unie opgenomen rechtsinstrument (cursivering MdM)."

Bij de huidige stand van het recht zijn er derhalve twee algemene rechtsbronnen van Uniegrondrechten: de algemene rechtsbeginselen en het Handvest. ${ }^{21}$ Dit

18 HvJEU van 22 oktober 2009, zaak C-301/08, Irène Bogiatzi, punt 23.

19 Zie voor een kort en helder overzicht met literatuurverwijzingen: De Witte 2011 p. 336 337.

20 HvJEU van 18 juli 2013, zaak C-501/11 P, Schindler, punt 32.

21 Voor de volledigheid wordt opgemerkt wordt dat ook het Verdrag bepalingen kent die uitwerkingen van grondrechten bevatten, zoals bijvoorbeeld de artikelen 18 en 157 
neemt niet weg dat het EVRM ook nu wel degelijk relevant is. De door het EVRM gewaarborgde grondrechten maken als algemene beginselen deel uit van het recht van de Unie (artikel 6, lid 3, VEU). Tevens bepaalt artikel 52, lid 3, van het Handvest dat rechten uit het Handvest die corresponderen met rechten die zijn gegarandeerd door het EVRM, dezelfde inhoud en reikwijdte hebben als die welke er door genoemd verdrag aan worden toegekend.

In de volgende paragrafen wordt dieper op de beide rechtsbronnen van Uniegrondrechten in gegaan. Paragraaf 2.2 behandelt de grondrechten uit hoofde van algemene rechtsbeginselen. Met name wordt aandacht besteed aan de belangrijkste kenmerken van algemene rechtsbeginselen. Het Handvest komt aan de orde in paragraaf 2.3. Hierbij wordt met name ingezoomd op de algemene (ook wel horizontale) bepalingen ervan. De artikelen 53 (beschermingsniveau) en artikel 52, lid 5 (onderscheid tussen rechten en beginselen) van het Handvest krijgen verhoudingsgewijs de meeste aandacht, omdat zij van invloed (kunnen) zijn op het leerstuk van de directe werking.

\subsection{Grondrechten uit hoofde van algemene rechtsbeginselen}

\subsubsection{Rechtsbron de 'algemene beginselen van Unierecht'22}

Artikel 6, lid 3, TEU bepaalt dat de grondrechten als algemene beginselen deel uitmaken van het recht van de Unie. Er bestaat echter geen eenduidige definitie van wat 'algemene rechtsbeginselen van Unierecht' zijn. ${ }^{23}$ De in de rechtspraak van het Hof gebruikte terminologie is ook niet eenduidig. Wel is duidelijk, dat het bij deze rechtsbron gaat om fundamentele ongeschreven 'court-made' beginselen. Binnen het Unierecht bestaan echter ongeschreven 'court-made' beginselen van verschillende pluimage. ${ }^{24}$ Tridimas noteert: ${ }^{25}$

VWEU.

22 Voorheen genoemd: algemene beginselen van gemeenschapsrecht. Voor het eerst 'algemene beginselen van Unierecht genoemd' in: HvJEU van 19 januari 2010, zaak C555/07, Kücükdeveci, punt 21.

23 Zie ook Groussot 2006, p. 129: "In the European legal order, the general principles of law appear to have a wide and blurred meaning. The 'principles' (general or not) (...) developed by the jurisprudence of the ECJ have taken such a wide-ranging scope that is a cumbersome task to agree on their meaning and content'.” A-G Trstenjak van 30 juni 2009, zaak C-101/08, Audiolux, punt 67; Bengoetxea 2010, p. 1173-1174.

24 Voor een algemeen beeld zie: Bernitz \& Nergelius 2000.

25 Tridimas 2006, p. 2. 
"In EU law the term 'general principles' is manifold"

In het kader van dit proefschrift wordt uit gegaan van een enge definitie van 'algemene beginselen van Unierecht. Met het concept 'algemene rechtsbeginselen van Unierecht' wordt steeds bedoeld wat genoemd zou kunnen worden de 'klassieke algemene rechtsbeginselen'. Dat wil zeggen de groep van algemene rechtsbeginselen die primair zijn bedoeld om door justitiabelen te worden ingeroepen voor de nationale rechter als toetsingsmaatstaf of als instrument van uitleg. De beginselen uit deze groep worden in de meeste gevallen ook door het Hof expliciet bestempeld als 'algemene beginselen van Unierecht'. ${ }^{26}$ De grondrechten vormen een subcategorie van de 'klassieke algemene rechtsbeginselen'. Andere 'klassieke algemene beginselen' van Unierecht zijn bijvoorbeeld het beginsel van gerechtvaardigd vertrouwen, het evenredigheidsbeginsel en het rechtszekerheidsbeginsel.

Voorbeelden van fundamentele beginselen die niet onder de noemer 'klassieke algemene rechtsbeginselen' vallen zijn het beginsel van directe werking, het beginsel van staatsaansprakelijkheid wegens schending van Unierecht en institutionele beginselen als het beginsel van voorrang en institutioneel evenwicht. ${ }^{27}$ Voorts wordt er voor de volledigheid op gewezen dat het Unierecht ook nog fundamentele beginselen van deelgebieden van Unierecht kent, zoals 'het recht van elke werknemer op jaarlijkse vakantie met behoud van loon' dat een 'bijzonder belangrijk beginsel van sociaal recht is' 28 en 'het beginsel van fiscale neutraliteit, en inzonderheid het recht op aftrek van de BTW' dat een 'fundamenteel beginsel van de gemeenschappelijke BTW-regeling' is. ${ }^{29}$ Tot slot kent ook het Handvest 'beginselen' die niet moeten worden verward met 'algemene rechtsbeginselen'. Zij komen aan bod in paragraaf 2.3.7.

De klassieke algemene beginselen van Unierecht kunnen het best worden omschreven aan de hand van een aantal kenmerken. Allereerst vormen zij een uitdrukking van de 'rule of law'. Ten tweede zijn ze 'court-made' en ongeschreven. Ten derde hebben ze een algemene gelding. Ten vierde kunnen ze fungeren als instrument van uitleg en als zelfstandige toetsingsmaatstaf voor de geldigheid of rechtmatigheid van Uniehandelingen en nationale handelingen.

26 Tridimas noemt deze groep 'beginselen die voortvloeien uit de 'rule of law', daarnaast onderscheidt hij de categorie van beginselen die ten grondslag liggen aan de constitutionele structuur en die het Unierechtssysteem definiëren. Tridimas 2006, p. 4.

27 Zie De Witte 2000, p. 143-161

28 HvJEU van 20 januari 2009, gevoegde zaken C-350/06 en C-520/06, Bectu, punt 22.

29 HvJEU van 29 oktober 2009, zaak C-174/08, NCC Construction Danmark, punt 40; HvJEU van 27 april 2010, gevoegde zaken C-536/08 en C-539/08, X, punt 28. 
'Rule of Law'-ratio

De klassieke algemene beginselen van Unierecht vormen een uitdrukking van de rechtstaat gedachte ('rule of law') waarop de Unie is gegrondvest. ${ }^{30}$ Dat wil zeggen de opvatting dat overheidshandelen niet ongelimiteerd is, maar gebonden aan het recht. Het zijn publiekrechtelijke beginselen die dienen als beschermingsmiddel voor individuen tegen overheidsmacht. ${ }^{31}$ Ze weerspiegelen dan ook fundamentele waarden die ten grondslag liggen aan het Unierechtsstelsel. ${ }^{32}$ Het Hof spreekt in dit verband over het grondwettelijk karakter of de constitutionele status van algemene rechtsbeginselen. ${ }^{33}$ Advocaat-generaal Trstenjak duidt deze constitutionele status als volgt: ${ }^{34}$

"In de regel belichamen algemene rechtsbeginselen fundamentele rechtsopvattingen en waarden die inherent zijn aan een rechtsorde (...)."

Groussot noemt de klassieke algemene rechtsbeginselen 'operative general principles' en karakteriseert ze als volgt: ${ }^{35}$

"It may be said that these general principles, protecting individual rights, constitute the concretization of the principle of justice, fairness or certainty"

Groussot tekent hierbij aan dat de algemene rechtsbeginselen door het Hof niet alleen worden gebruikt ter bescherming van individuele rechten, maar tevens ter bescherming van de effectiviteit, uniformiteit en coherentie van de Unie rechtsorde. 36

\section{'Court-made' en ongeschreven}

Zoals gezegd zijn de algemene rechtsbeginselen 'court-made', hierdoor kwalificeren ze als ongeschreven recht. 'Court-made' wil niet zeggen, dat de

30 Het Hof over de Unie als een rechtstaat: HvJEU van 23 april 1986, zaak 294/83, Les Verts, punt 23. HvJEU van 14 december 1991, advies 1/91, EER, punt 21. Zie over de rol van algemene rechtsbeginselen als uitdrukking of verwezenlijking van de rechtstaatgedachte: Tridmas 2006, p. 4; Herdegen 2008, p. 344.

31 Tridimas 2006, p. 26.

32 Dit sluit ook aan bij de definitie van Dworkin 1977, p. 22: "I call a 'principle' a standard that is to be observed, not because it will advance or secure an economic, political, or social situation deemed desirable, but because it is a requirement of justice or fairness or some other dimension of morality."

33 HvJEU van 15 oktober 2009, zaak C-101/08, Audiolux, punt 63; HvJEU van 29 oktober 2009, zaak C-174/08, NCC Construction Danmark, punten 42 en 45.

34 A-G Trstenjak van 30 juni 2009, zaak C-101/08, Audiolux, punt 87.

35 Groussot 2006, p. 130.

36 Groussot 2006, p. 9-10 en p. 130-131. Zie ook paragraaf 2.1. 
algemene rechtsbeginselen door het Hof zijn uitgevonden of geschapen. De beginselen zijn latent en intrinsiek aanwezig in de Unierechtsorde. ${ }^{37}$ De functie van het Hof is om hun bestaan te destilleren, te ontdekken uit enerzijds de nationale rechtsstelsels en de internationale instrumenten, en anderzijds de tekst en doelstelling van de verdragen. ${ }^{38}$ Advocaat-generaal Trstenjak vat het als volgt samen: 39

"94. Volgens een in de rechtsliteratuur verdedigde definitie behoren tot de algemene rechtsbeginselen die fundamentele bepalingen van het ongeschreven primaire Unierecht, die inherent zijn aan de rechtsorde van de Europese Unie of gemeenschappelijk zijn aan alle rechtsstelsels van de lidstaten. In beginsel kan worden onderscheiden tussen algemene beginselen van Unierecht in strikte zin, dat wil zeggen enerzijds de uitsluitend op basis van de geest en de systematiek van de Verdragen ontwikkelde rechtsbeginselen betrekking hebbend op specifieke Unierechtelijke problemen, en anderzijds de algemene rechtsbeginselen die gemeenschappelijk zijn aan de nationale rechts- en constitutionele stelsels van de lidstaten. Terwijl de eerste categorie algemene rechtsbeginselen rechtstreeks uit het primaire Unierecht kan worden afgeleid, gaat het Hof wat de rechtsbeginselen van de tweede categorie betreft in wezen uit van een kritisch-normerende rechtsvergelijking, daarbij geenszins het criterium van de kleinste gemeenschappelijke noemer hanterend. Evenmin behoeven de aldus geformuleerde rechtsbeginselen in hun concrete uiteindelijke definitie op Unieniveau altijd in alle vergeleken rechtsstelsels tegelijk voor te komen."

Bij het proces van erkenning van algemene beginselen van Unierecht is de rode draad, dat binnen de Unie sprake moet zijn van een zekere algemene heersende rechtsovertuiging, een zekere graad van consensus. Als een door het Hof erkend beginsel voor de justitiabelen uit de lucht komt vallen of lijkt te komen vallen, doet dit afbreuk aan de legitimiteit ervan. Koopmans zegt hierover: 40

"Principles don't fall from heaven, except perhaps in very metaphorical sense, they have to be found and to be elaborated, and there is only one way to do that by reasoned argument"

37 Mazák \& Moser 2013, p. 68-69: “ In order for general principles to be legitimately considered as part of the law, when they are so-to-speak 'made' by the judge, they must remain linked to and founded in the legal order.".

38 Voorbeeld van de niet-erkenning als algemeen rechtsbeginsel wegens het ontbreken van draagvlak: HvJEU van 12 juli 2001, zaak C-189/01, Jippes, punten 71-75.

39 A-G Trstenjak van 8 september 2011, zaak C-282/10, Dominguez.

40 Koopmans 1993 p. 78. 
Een deugdelijke en transparante motivering is een essentieel element voor de legitimiteit van algemene rechtsbeginselen. Herdegen brengt dit als volgt onder woorden: ${ }^{41}$

“(...) the legitimacy of the European Court of Justice's jurisprudence depends on a transparent methodological approach in developing and applying general principles of law and a judicial process (...)."

Die zichtbare legitimiteit is vooral ook zo belangrijk, omdat algemene rechtsbeginselen door hun 'court-made' karakter een potentiële ondermijning zijn van zowel de verticale als de horizontale verdeling van bevoegdheden, of althans zij daarvan kunnen worden 'verdacht'. 42

\section{Algemene gelding}

Algemene beginselen van Unierecht hebben een algemene, veelomvattende, overkoepelende gelding. ${ }^{43}$ Hoe algemeen de gelding van een rechtsbeginsel moet zijn voor het predicaat 'algemeen' is onduidelijk. Vast staat dat het niet is vereist dat het beginsel relevant is voor het gehele rechtssysteem. Zo is het legaliteitsbeginsel (voor strafbare feiten en straffen) een voorbeeld van een algemeen beginsel dat ziet op een deelgebied van het Unierecht (namelijk het strafrecht)..44 Advocaat-generaal Trstenjak bepleit (zelfs) dat het 'recht op jaarlijkse vakantie met behoud van loon' kwalificeert als algemeen rechtsbeginsel. 45 Met betrekking tot het punt van de 'algemene gelding' merkt ze op, dat het recht niet is beperkt tot een bepaald rechtsgebied, maar veeleer sectoroverstijgend, voor een veelvoud van beroepsvelden zowel op het gebied van het arbeids- als op het ambtenarenrecht in alle lidstaten geldt. Het Hof kwalificeert het 'recht op jaarlijkse vakantie met behoud van loon' echter niet als algemeen beginsel van Unierecht maar noemt het in navolging van eerdere rechtspraak als 'bijzonder belangrijk beginsel van sociaal recht van de Unie'. ${ }^{46}$

41 Herdegen 1999, p. 1.

42 Herdegen 2008, p. 344; zie ook Mazák \& Moser 2013, p. 63: "The general principles of EU law therefore constitute, without doubt, a powerful judicial instrument in the hands of the Court, to be handled with care and responsibility."

43 Zie Mazák \& Moser 2013, p. 69, zij voegen hier aan toe dat het begrip algemeen ook verwijst naar de "Overarching importance and pertinence, which is -owing to the fact that they express fundamental structures and values underpinning the legal order as a whole and, accordingly, transgress the interest of specific situations - inherent in general principles"

44 HvJEU van 10 november 2011, zaak C-405/10, Garenfeld, punt 48.

45 A-G Trstenjak van 8 september 2011, zaak C-282/10, Dominguez, punten 110-113.

46 HvJEU van 24 januari 2012, zaak C-282/10, Dominguez, punt 16. 
Functies

De klassieke algemene rechtsbeginselen hebben twee functies die aansluiten bij hun 'rule of law'-ratio. Ten eerste dienen ze als instrument van uitleg van geschreven recht. ${ }^{47}$ Het geschreven recht dient zo uitgelegd te worden, dat het in overeenstemming is met de algemene rechtsbeginselen. Dit geldt voor zowel het geschreven Unierecht als ook voor nationaal recht dat valt binnen het toepassingsgebied van het Unierecht. Ten tweede fungeren algemene beginselen als toetsingsmaatstaf voor de geldigheid of rechtmatigheid van Uniehandelingen. ${ }^{48}$ In het verlengde hiervan kunnen ook nationale handelingen die vallen binnen het toepassingsgebied van algemene rechtsbeginselen worden getoetst aan de algemene rechtsbeginselen (directe werking). ${ }^{49}$ Voorts wordt dikwijls gewezen op een derde functie van algemene rechtsbeginselen, namelijk dat zij kunnend dienen om leemtes in het recht op te vullen. ${ }^{50} \mathrm{Bij}$ deze functie staat de autonomie en coherentie van de Unie rechtsorde centraal. ${ }^{51}$ Een vroeg voorbeeld is de zaak Algera waarin het Hof vast stelt dat hij wegens het ontbreken van een oplossing in het Verdrag 'op straffe van rechtsweigering' gehouden was een vraagstuk op te lossen 'aan de hand van de regels, welke in de wetgeving, de wetenschap en de rechtspraak der deelnemende landen zijn aanvaard' en aanvaardde hij op basis daarvan 'het beginsel dat onwettige handelingen binnen een redelijke termijn kunnen worden herroepen'. ${ }^{52}$ Bekende voorbeelden (buiten de categorie van de 'klassieke algemene rechtsbeginselen') zijn verder het beginsel van de directe werking en het beginsel van staatsaansprakelijkheid wegens schending van Unierecht. Het Hof heeft voorts met de erkenning van Uniegrondrechten een belangrijk rechtstatelijk gat gedicht. Zij danken derhalve hun bestaan aan een leemte.

\subsubsection{Grondrechten uit hoofde van algemene beginselen}

Zoals gezegd vormen de grondrechten een subcategorie van de algemene beginselen van Unierecht. De in de vorige paragraaf beschreven karakteristieken zijn derhalve ook op hen van toepassing. Ten aanzien van sommige karakteris-

47 Tridimas 2006, p. 29-31.

48 Tridimas 2006, p. 31-35; zie ook Mazák \& Moser 2013, p. 71 die opmerken: "It is in those functions that the general principles of EU law unveil their fundamental and (...) constitutional nature."

49 HVJEU van 13 juli 1989, zaak 5/88, Wachauf. HvJEU van 18 juni 1991, zaak C-260/89, ERT.

50 Zie bijv. Lenaerts \& Gutiérrez-Fons 2010, p. 1629. Zie ook Tridimas 2006, p. 17-19.

51 Lenaerts \& Gutiérrez-Fons 2010, p. 1631-1636.

52 HvJEU van 12 juli 1957, gevoegde zaken $7 / 56$ en 3 t/m 7/57, Algera e.a., onder deel III. 
tieken wordt in het volgende nog enkele aanvullende opmerkingen gemaakt die in het bijzonder relevant zijn voor de Uniegrondrechten.

\section{Rule of law-ratio}

In de vorige paragraaf kwam aan de orde dat de klassieke algemene beginselen van Unierecht een uitdrukking vormen van de 'rule of law'. Dit betekent dat ze dienen als beschermingsmiddel voor individuen tegen overheidsmacht. ${ }^{53}$ Voorts zijn ze een weerspiegeling van fundamentele waarden. Het element van bescherming tegen overheidsmacht komt duidelijk naar voren het drieluik Stauder, Internationale Handelsgesellschaft en Nold II die de basis van het communautaire systeem van grondrechtenbescherming vormt. ${ }^{54} \mathrm{Bij}$ de functie als beschermingsmiddel tegen overheidsmacht zijn twee aspecten bij grondrechten in het bijzonder van belang. ${ }^{55}$ Ten eerste gaat het om de bescherming van de diepste menselijke waarden; de kernwaarden van het mens zijn en in het verlengde hiervan van de autonomie en zelfbeschikking, de vrije zone van individuen. Weiler brengt dit treffend onder woorden. Hij zegt dat grondrechten zijn ${ }^{56}$

"an expression of a vision of humanity which vests the deepest values in the individual which, hence may not be compromised by anyone. Probably one of the oldest and most influential sources of this vision is to be found in the Pentateuch: "And God created man in his own image, in the image of God created He him". With this trademark, what legislator has the authority to transgress the essential humanity of the species? Naturally, there are secular, humanist parallels to this vision aplenty."

Ten tweede gaat het bij overheidsmacht niet alleen om de bescherming tegen willekeur en machtsmisbruik, maar dienen grondrechten in het bijzonder ook als veiligheidsklep voor wat wel genoemd wordt de tirannie van de meerderheid. Grondrechten bieden minderheden tegenwicht aan democratisch genomen meerderheidsbesluiten.

\section{Effectiviteit, uniformiteit en coherentie van de Unierechtsorde}

Tot slot wordt opgemerkt dat ook bij grondrechten naar voren komt dat algemene rechtsbeginselen naast de verwezenlijking van de 'rule of law' tevens dienen als middel ter bescherming van de effectiviteit, uniformiteit en coherentie

\footnotetext{
53 Tridimas 2006, p. 26.

54 Paragraaf 2.1. Zie ook De Witte 1999, p. 870.

55 Zie ook Weiler 1999-2, p. 103-107.

56 Weiler 1999-2, p. 103.
} 
van de Unie rechtsorde. Illustratief is het arrest Hauer waarin het Hof overwoog dat: 57

“14. Naar het Hof in zijn arrest(...) Internationale Handelsgesellschaft (...) heeft overwogen, kan de vraag of er in een handeling van een instelling der gemeenschappen een inbreuk op grondrechten besloten ligt, ook alleen in het kader van het gemeenschapsrecht worden besproken. De introductie van bijzondere, onder de wetgeving of constitutionele orde van een bepaalde lidstaat vallende maatstaven zou aan de materiële eenheid en aan de feitelijke gelding van het gemeenschapsrecht afbreuk doen en daarmede onvermijdelijk de eenheid van de gemeenschappelijke markt doorbreken en de communautaire saamhorigheid in gevaar brengen.”

\section{'Court-made'}

Ten aanzien van het 'court-made' karakter is met name van belang, dat het Hof heeft gekozen voor het 'creëren' van een eigen en autonome bron van grondrechten die 'in het kader van het communautaire bestel en van de doelstellingen der gemeenschap moet worden verzekerd', maar die als oorsprong hebben de gemeenschappelijke constitutionele tradities van de lidstaten en de internationale rechtsinstrumenten. ${ }^{58}$ De communautaire grondrechtencatalogus is derhalve geen blauwdruk van nationale en internationale grondrechtencatalogi, maar vormt een synthese daarvan die rekening houdt met de specifieke context ${ }^{59}$ van het Unierecht. Het geheel geeft blijk van een delicaat evenwicht. Tridimas noteert treffend: 60

"On the one hand, the Court reiterates the supremacy of Community law and takes the principle of primacy to its utmost limits: Community law takes precedence even over the most precious provisions of the national constitutions. On the other hand, the Court reassures the Member States that the Treaty shares their constitutional values and ensures ideological continuity. At the same time, it takes care to safeguard the autonomy of Community law. The national constitutional traditions provide 'inspiration' for respect of human rights in the Community legal order. There their function ends"

57 HvJEU van 13 december 1979, zaak 44/79, Hauer.

58 HvJEU van 17 december 1970, zaak 11/70, Internationale Handelsgesellschaft, punt 3. HvJEU van 14 mei 1974, zaak 4/73, Nold II, punt 13. Zie ook HvJEU van 13 december 1979, zaak 44/79, Hauer, punt 15 waarin het EVRM met name wordt genoemd.

59 De belangen die in deze specifieke context een rol spelen zijn 'de noodzaak van een eenvormige toepassing van het recht van de Unie en de eisen in verband met de totstandbrenging van een ruimte van vrijheid, veiligheid en recht'. A-G Bot van 2 oktober 2012, zaak C-399/11, Melloni, punt 112.

60 Tridimas 2006, p. 302. 


\subsection{Het Handvest}

\subsubsection{Algemeen}

Sinds 1 december 2009 kent het Unierecht een geschreven grondrechtencatalogus: het Handvest. Artikel 6, lid 2, VEU bepaalt dat het Handvest dezelfde juridische waarde heeft als de Verdragen. Het Handvest heeft hiermee de status van primair recht. Uit de preambule blijkt dat het Handvest een bevestiging is van

"de rechten die in het bijzonder voortvloeien uit de constitutionele tradities en de internationale verplichtingen die de lidstaten gemeen hebben, uit het Europees Verdrag tot bescherming van de rechten van de mens en de fundamentele vrijheden, uit de door de Unie en de Raad van Europa aangenomen sociale handvesten, alsook uit de jurisprudentie van het Hof van Justitie van de Europese Unie en van het Europees Hof voor de rechten van de mens.”

In het Handvest staan in één tekst rechten die daarvoor verspreid waren over diverse internationale en nationale rechtsinstrumenten. Aldus vertegenwoordigt het Handvest 'de kern van het gemeenschappelijke Europese "acquis" op het gebied van de grondrechten'.61

Het doel van het Handvest is om (1) Unie grondrechten meer zichtbaar te maken, (2) de bevordering van de rechtszekerheid, en (3) versterking van de legitimiteit van de Unie. ${ }^{62}$

Het Handvest bevat in totaal 54 bepalingen en is onderverdeeld in zeven hoofdstukken: hoofdstuk I 'Waardigheid',63 hoofdstuk II 'Vrijheden',64

61 Mededeling van de Commissie over de aard van het Handvest van de grondrechten van de Europese Unie. COM/2000/0644 def.

62 Conclusies van het voorzitterschap Europese Raad Keulen 3 en 4 juni 1999, bijlage IV. Mededeling van de Commissie betreffende het Handvest van de grondrechten van de Europese Unie ingediend door de heer Vitorino in overeenstemming met de Voorzitter, COM/2000/0559 def., punten 7 en 10. Mededeling van de Commissie over de aard van het Handvest van de grondrechten van de Europese Unie. COM/2000/0644 def., punt 12.

63 Menselijke waardigheid, recht op leven, recht op menselijke integriteit, verbod van folteringen en van onmenselijke of vernederende behandelingen of bestraffingen, en verbod van slavernij en dwangarbeid.

64 Recht op vrijheid en veiligheid, eerbiediging van het privéleven en het familie- en gezinsleven, bescherming van persoonsgegevens, recht te huwen en recht een gezin te stichten, vrijheid van gedachte, geweten en godsdienst, vrijheid van meningsuiting en van informatie, vrijheid van vergadering en vereniging, vrijheid van kunsten en wetenschappen, recht op onderwijs, vrijheid van beroep en recht om te werken, vrijheid van 
hoofdstuk III ' Gelijkheid',65 hoofdstuk IV 'Solidariteit',66 hoofdstuk V 'Burgerschap', ${ }^{67}$ hoofdstuk VI 'Rechtspleging', ${ }^{68}$ en hoofdstuk VII bevat algemene bepalingen betreffende de uitlegging en toepassing van het Handvest. Het Handvest beschikt over een Toelichting die blijkens artikel 52, lid 7 is opgesteld om richting te geven aan de uitlegging van het Handvest en die door de rechterlijke instanties van de Unie en van de lidstaten naar behoren in acht moet genomen. ${ }^{69}$ Dit laatste volgt ook uit artikel 6, lid 1 VEU, die voorschrijft dat bij de uitleg en toepassing van de rechten, vrijheden en beginselen uit het Handvest de Toelichting "terdege in acht moet worden genomen". ${ }^{70}$

Uit artikel 6, lid 1 en lid 3, VEU kan worden afgeleid dat de twee grondrechtenbronnen naast elkaar bestaan en wel op voet van gelijkheid. ${ }^{71}$ Sommige grondrechten gelden derhalve als algemeen rechtsbeginsel en als Handvestbepaling. Gezien hun gemeenschappelijke kenbronnen zullen corresponderende grondrechten vermoedelijk dezelfde inhoud hebben als algemeen rechtsbeginsel en als Handvestbepaling. ${ }^{72}$

ondernemerschap, recht op eigendom, asielrecht en bescherming bij verwijdering, uitzetting en uitlevering.

65 Gelijkheid voor de wet, non-discriminatie, verscheidenheid van cultuur, godsdienst en taal, gelijkheid van mannen en vrouwen, rechten van het kind, rechten van ouderen en integratie van personen met een handicap.

66 Recht op informatie en raadpleging van de werknemers binnen de onderneming, recht op collectieve onderhandelingen en collectieve actie, recht op toegang tot arbeidsbemiddeling, bescherming bij kennelijk onredelijk ontslag, rechtvaardige en billijke arbeidsomstandigheden en -voorwaarden, verbod van kinderarbeid en bescherming van jongeren op het werk, beroeps- en gezinsleven, sociale zekerheid en sociale bijstand, recht op toegang tot preventieve gezondheidszorg en op medische verzorging, toegang tot diensten van algemeen economisch belang, milieubescherming, consumentenbescherming.

67 Actief en passief kiesrecht bij de verkiezingen voor het Europees Parlement, actief en passief kiesrecht bij gemeenteraadsverkiezingen, recht op behoorlijk bestuur, recht van inzage in documenten, ombudsman, recht van petitie, vrijheid van verkeer en van verblijf, diplomatieke en consulaire bescherming.

68 Recht op een doeltreffende voorziening in rechte en op een onpartijdig gerecht, vermoeden van onschuld en rechten van de verdediging, legaliteitsbeginsel en evenredigheidsbeginsel inzake delicten en straffen en het 'ne bis in idem' -beginsel.

69 Toelichtingen bij het Handvest van de grondrechten, PB 14.12.207, C 303/17.

70 Zie ook HvJEU 22 december 2010, zaak C-279/09, DEB, punt 32.

71 Zie ook A-G Trstenjak van 8 september 2011, zaak C-282/10, Dominguez, punt 127; AG Sharpston van 18 oktober 2012, zaak C-396/11, Radu, punt 48; A-G Cruz Villalón van 6 juli 2010, zaak C-306/09 I.B., punt 44.

72 A-G Trstenjak van 8 september 2011, zaak C-282/10, Dominguez, punt 127. 


\subsubsection{Toepassingsgebied: artikel 51, lid 1}

Artikel 51, lid 1, van het Handvest bepaalt wanneer het Handvest van toepassing is. De bepaling luidt als volgt:

"De bepalingen van dit Handvest zijn gericht tot de instellingen, organen en instanties van de Unie met inachtneming van het subsidiariteitsbeginsel, alsmede, uitsluitend wanneer zij het recht van de Unie ten uitvoer brengen, tot de lidstaten. Derhalve eerbiedigen zij de rechten, leven zij de beginselen na en bevorderen zij de toepassing ervan overeenkomstig hun respectieve bevoegdheden en met inachtneming van de grenzen van de bevoegdheden zoals deze in de Verdragen aan de Unie zijn toegedeeld."

Artikel 51, lid 1, van het Handvest vormt een weerspiegeling van de 'rule of law'-ratio van de grondrechten uit hoofde van algemene beginselen. Het Handvest dient als limitering van overheidsmacht. Het geeft immers een opsomming van de verschillende overheden die in hun handelen gebonden zijn aan de Handvestgrondrechten. Deze ratio komt ook terug in de preambule van het Handvest waarin staat

"De Unie (...) berust op het beginsel van democratie en het beginsel van de rechtsstaat"

Artikel 51, lid 1, van het Handvest maakt hierbij onderscheid tussen de Unieoverheden en nationale overheden. Het Handvest is altijd van toepassing op handelingen van de Unie overheden (instellingen, organen en instanties van de Unie). ${ }^{73}$ Nationale overheden zijn enkel gebonden aan het Handvest, wanneer zij Unierecht uitvoeren. In de Toelichting wordt gesproken van de 'toepassing van Unierecht'. Dit betekent dat de grondrechten van de Unie niet van toepassing zijn buiten de context van het Unierecht, in zuiver nationale situaties. Dit klinkt (redelijk) eenvoudig en logisch, maar de praktijk wijst uit dat de het trekken van de scheidslijn tussen enerzijds situaties waarin het Unierecht van toepassing is (en daarmee de Uniegrondrechten) en anderzijds zuiver nationale situaties (waarin Uniegrondrechten buiten spel blijven) precair is. De vraag naar waar deze scheidslijn ligt, of zou moeten liggen, vormt het onderwerp van deel II van dit proefschrift. De precieze betekenis van artikel 51, lid 1, van het Handvest komt daar dan ook uitgebreid aan de orde.

73 Zie arrest Prigge waarin het o.a. ging om de vraag wanneer hiervan sprake is. HvJEU van 13 september 2011, zaak C-447/09, Prigge. 


\title{
2.3.3 Mogelijkheid van beperkingen: artikel 52, lid 1
}

Het Handvest kent een algemene beperkingclausule die is neergelegd in artikel 52 , lid 1 , en die luidt als volgt:

\begin{abstract}
"Beperkingen op de uitoefening van de in dit Handvest erkende rechten en vrijheden moeten bij wet worden gesteld en de wezenlijke inhoud van die rechten en vrijheden eerbiedigen. Met inachtneming van het evenredigheidsbeginsel kunnen slechts beperkingen worden gesteld, indien zij noodzakelijk zijn en daadwerkelijk beantwoorden aan door de Unie erkende doelstellingen van algemeen belang of aan de eisen van de bescherming van de rechten en vrijheden van anderen."
\end{abstract}

De algemene beperkingclausule bevat derhalve vier voorwaarden. Beperkingen op de uitoefening van Handvest rechten en vrijheden moeten (1) bij wet zijn gesteld, (2) de wezenlijke inhoud van die rechten en vrijheden eerbiedigen en (3) noodzakelijk zijn en (4) (a) daadwerkelijk beantwoorden aan door de Unie erkende doelstellingen van algemeen belang of (b) aan de eisen van de bescherming van rechten en vrijheden van anderen. ${ }^{74}$ De gebruikte formulering is blijkens de Toelichting geïnspireerd op de jurisprudentie van het Hof, hierbij wordt gewezen op de volgende overweging van het Hof in het arrest Karlsson aangaande de toepassing van het non-discriminatie beginsel op een nationale uitvoeringshandeling (toewijzing van melkquota): ${ }^{75}$

\begin{abstract}
“45. (...)Volgens vaste rechtspraak kan de uitoefening van deze fundamentele rechten, met name in het kader van een gemeenschappelijke marktordening, evenwel aan beperkingen worden onderworpen, voor zover die beperkingen werkelijk beantwoorden aan de doeleinden van algemeen belang die de Gemeenschap nastreeft en, het nagestreefde doel in aanmerking genomen, niet zijn te beschouwen als een onevenredige en onduldbare ingreep, waardoor de gewaarborgde rechten in hun kern worden aangetast."
\end{abstract}

Bij de toepassing van artikel 52, lid 1, Handvest dient eveneens de werking van artikel 52, lid 3, Handvest in aanmerking te worden genomen. Deze bepaling die wordt besproken in paragraaf 2.3.5 ziet op de rechten uit het Handvest die corresponderen met rechten welke zijn gegarandeerd door het EVRM.

74 Zie voor de toepassing van artikel 52, lid 1, Handvest door het Hof: HvJEU van 9 november 2010, gevoegde zaken C-92/09 en C-93/09, Schecke, punten 65-89 (terzake van de geldigheid van een bepaling van Unierecht). Zie ook A-G Cruz Villalón van 12 december 2013, Gevoegde zaken C-293/12, C-594/12, Digital Rights Ireland, punten 106152.

75 Arrest van 13 april 2000, zaak C-292/97, Karlsson. 


\subsubsection{De verhouding van het Handvest met de Verdragen: artikel 52, lid 2, van het Handvest}

Artikel 52, lid 2, van het Handvest luidt als volgt:

"De door dit Handvest erkende rechten die voorkomen in bepalingen van de Verdragen, worden uitgeoefend onder de voorwaarden en binnen de grenzen die door deze Verdragen zijn gesteld."

Volgens de Toelichting verwijst deze bepaling naar rechten die reeds uitdrukkelijk waren gewaarborgd in het Verdrag tot oprichting van de Europese Gemeenschap en die in het Handvest zijn erkend en nu zijn ondergebracht in de Verdragen (met name de rechten die voortkomen uit het burgerschap van de Unie). Tevens wordt verduidelijkt dat dergelijke rechten onderworpen blijven aan de voorwaarden en grenzen die van toepassing zijn op het recht van de Unie waarop zij zijn gebaseerd en die worden omschreven in de Verdragen. Tot slot vermeldt de Toelichting, dat het Handvest geen wijziging aanbrengt in de regeling van de rechten die bij het EG-Verdrag werden verleend en die zijn overgenomen in de Verdragen.

In het arrest Gardella past het Hof deze bepaling toe op artikel 15, lid 2, Handvest. ${ }^{76}$

Op grond van deze bepaling is iedere burger van de Unie vrij om in iedere lidstaat werk te zoeken, te werken, zich te vestigen en diensten te verrichten. In deze zaak ging het om de vraag naar de verenigbaarheid van een nationale regeling inzake de overdracht van pensioenrechten. Gardella beriep zich zowel op de verdragsbepalingen inzake het vrije verkeer als op artikel 15 , lid 2, van het Handvest. Voor de vraag naar de toepasselijkheid van artikel 15, lid 2, van het Handvest wijst het Hof op artikel 52, lid 2, Handvest. Hij overweegt op grond van de Toelichting, dat artikel 15, lid 2, van het Handvest onder meer het in artikel 45 VWEU gewaarborgde vrije verkeer van werknemers herhaalt. Om die reden oordeelde het Hof dat kon worden volstaan met een onderzoek van de nationale regeling aan de artikelen 45 en 48 VWEU (vrije verkeer van werknemers).

\subsubsection{Uitlegging en de rol van internationaal en nationaal recht: de artikelen 52 leden 3, 4 en 6}

De grondrechten uit het Handvest, zijn net als de algemene rechtsbeginselen

76 HvJEU van 4 juli 2013, zaak C-233/12, Gardella, punten 39-41. 
weliswaar 'eigen' en 'autonome' Uniegrondrechten, maar ze bestaan niet in een vacuüm. Het Handvest voorziet nadrukkelijk in interactie met andere nationale en internationale bronnen van grondrechtenbescherming. Artikel 52 van het Handvest bevat verschillende uitleggingsregels die zien op de co-existentie van het grondrechtenstelsel van de Unie met het internationale en nationale recht.

Met het EVRM corresponderende rechten: artikel 52, lid 3

Het Handvest bevat een (groot) aantal rechten die corresponderen met rechten die worden gegarandeerd door het EVRM (hierna: 'met het EVRM corresponderende rechten'). Artikel 52, lid 3 bepaalt ten aanzien van deze rechten als volgt:

\begin{abstract}
"Voor zover dit Handvest rechten bevat die corresponderen met rechten welke zijn gegarandeerd door het Europees Verdrag tot bescherming van de rechten van de mens en de fundamentele vrijheden, zijn de inhoud en reikwijdte ervan dezelfde als die welke er door genoemd verdrag aan worden toegekend. Deze bepaling verhindert niet dat het recht van de Unie een ruimere bescherming biedt."
\end{abstract}

De Toelichting verduidelijkt dat de inhoud en reikwijdte van de gewaarborgde rechten niet alleen worden bepaald door de tekst van het EVRM en de daaraan gehechte protocollen, maar ook door de jurisprudentie van het EHRM en van het Hof. ${ }^{77}$ Voorts kan de Unie een ruimere bescherming waarborgen, maar mag het door het Handvest geboden beschermingsniveau nooit lager zijn dan het niveau dat door het EVRM wordt gewaarborgd. Het EVRM vormt dus de minimummaatstaf. De Toelichting vermeldt tevens een (niet-statische) lijst van rechten die als met het EVRM corresponderend rechten kunnen worden aangemerkt. Hierbij wordt onderscheid gemaakt tussen (1) artikelen van het Handvest met dezelfde inhoud en reikwijdte als de daarmee corresponderende artikelen van het EVRM en (2) artikelen van het Handvest waarvan de inhoud dezelfde is als die van de daarmee corresponderende artikelen van het EVRM, maar waarvan de reikwijdte ruimer is.

77 Zie bijvoorbeeld HvJEU van 9 november 2010, gevoegde zaken C-92/09 en C-93/09, Schecke, punt 52: "beperkingen die mogen worden gesteld aan het recht op bescherming van de persoonsgegevens [moeten] overeenkomen met die welke worden toegelaten in het kader van artikel 8 EVRM.”; HvJEU van 5 oktober 2010, C-400/10 PPU, McB, punt 53. HvJEU van 26 februari 2013, zaak C-399/11, Melloni, punt 50. Zie ook A-G Sharpston van 18 oktober 2012, zaak C-396/11, Radu, punt 58. 
Rechten die voortvloeien uit constitutionele tradities: artikel 52, lid 4

Het Handvest bevat tevens rechten die voortvloeien uit constitutionele tradities. Artikel 52, lid 4 bepaalt hierover als volgt:

"Voor zover dit Handvest grondrechten erkent zoals die voortvloeien uit de constitutionele tradities die de lidstaten gemeen hebben, moeten die rechten in overeenstemming met die tradities worden uitgelegd."

De Toelichting verduidelijkt dat de uitleggingsregel in lid 4 is gebaseerd op de formulering van artikel 6, lid 3, van het VEU en rekening houdt met de benadering van gemeenschappelijke constitutionele tradities die door het Hof van Justitie wordt gevolgd. Ter illustratie wordt gewezen op de arresten Hauer en $A M \& S .{ }^{78}$ Volgens de Toelichting beoogt de uitleggingsregel in lid 4 van artikel 52 een zodanige uitleg van de betrokken rechten van het Handvest dat een hoge beschermingsnorm wordt gegarandeerd die strookt met het recht van de Unie en die spoort met de gemeenschappelijke constitutionele tradities, in plaats van een strikte aanpak te volgen waarbij een minimale gemeenschappelijke basis wordt gezocht.

Rol van nationale wetgevingen en praktijken: artikel 52 , lid 6

Voorts vermeldt artikel 52, lid 6 voor wat betreft de uitlegging van de bepalingen van het Handvest:

"Met de nationale wetgevingen en praktijken moet ten volle rekening worden gehouden, zoals bepaald in dit Handvest."

De Toelichting vermeldt hierover, dat lid 6 verwijst naar de diverse artikelen in het Handvest die in de geest van de subsidiariteit verwijzen naar nationale wetgevingen en praktijken. Voorbeelden van dit soort bepalingen zijn artikel 27 (het recht op informatie en raadpleging van de werknemers binnen de onderneming), artikel 28 (het recht op collectieve onderhandelingen en op collectieve actie), artikel 30 (bescherming bij kennelijk onredelijk ontslag), artikel 34 (sociale zekerheid en sociale bijstand), artikel 35 (de gezondheidszorg) en artikel 36 (de toegang tot diensten van algemeen economisch belang).

\subsubsection{Samenloop van de toepassing van het Handvest met nationale grondrechten: artikel 53}

Artikel 53 getiteld 'Beschermingsniveau' luidt als volgt:

78 HvJEU van 13 december 1979, zaak 44/79, Hauer; HvJEU van 18 mei 1982, zaak 155/79, AM\&S. Zie ook hoofdstuk 7.5.2. 
“Geen van de bepalingen van dit Handvest mag worden uitgelegd als zou zij een beperking vormen van of afbreuk doen aan de rechten van de mens en de fundamentele vrijheden welke binnen hun respectieve toepassingsgebieden worden erkend door het recht van de Unie, het internationaal recht en de internationale overeenkomsten waarbij de Unie of alle lidstaten partij zijn, met name het Europees Verdrag tot bescherming van de rechten van de mens en de fundamentele vrijheden, alsmede door de grondwetten van de lidstaten.”

De Toelichting vermeldt dat deze bepaling de handhaving beoogt van het beschermingsniveau dat momenteel, binnen hun respectieve werkingssferen, wordt geboden door het recht van de Unie, het recht van de lidstaten en het internationale recht. Het EVRM wordt met name genoemd, gezien het belang ervan.

Artikel 53 anticipeert op het bestaan van verschillende naast elkaar bestaande systemen van grondrechtenbescherming en de mogelijkheid van conflicten tussen die verschillende bronnen van grondrechtenbescherming. De 'oplossing' die de bepaling biedt is dat het Handvest aan grondrechten uit hoofde van (i) het recht van de Unie, (ii) het internationaal recht en de internationale overeenkomsten waarbij de Unie of alle lidstaten partij zijn, met name het EVRM en (iii) de grondwetten van de lidstaten geen afbreuk mag doen. Aldus brengt de bepaling tot uitdrukking dat het Handvest beoogt de genoemde bronnen van grondrechten aan te vullen. Het Handvest is niet bedoeld als vervanging of als verlaging van het beschermingsniveau ervan. ${ }^{79}$

De verwijzing naar het 'recht van de Unie' maakt duidelijk, dat een verdergaande bescherming op grond van primair en secundair recht mogelijk is. De verwijzing naar het internationale recht en in het bijzonder naar het EVRM duidt erop, dat het Handvest niet mag worden gehanteerd als een argument voor een restrictieve uitleg van deze rechtsbronnen. ${ }^{80}$ Tot slot kan de uitleg van het Handvest niet leiden tot een verlaging van de nationale standaard. Dit laatste punt geeft de meeste aanleiding tot discussie, omdat het kan worden uitgelegd als een uitzondering op het beginsel van voorrang. De vraag die rijst is deze: wat moet er gebeuren in situaties waarin de nationale grondwet een verdergaande bescherming biedt dan het Handvest? ${ }^{81}$

79 De Witte 2013; A-G Bot van 2 oktober 2012, zaak C-399/11, Melloni, punten 131-134.

80 De Witte 2013.

81 Zie A-G Bot van 2 oktober 2012, zaak C-399/11, Melloni, punten 107-112 over het spreken in termen van een 'hoger' of 'lager ' niveau van grondrechtenbescherming. Hij tekent aan dat het te bereiken niveau van bescherming van grondrechten nauw is verbonden met de context van de betreffende rechtsorde. 
Bij de beantwoording van deze vraag moet worden bedacht, dat artikel 53 van het Handvest pas aan de orde is als op grond van artikel 51 van het Handvest blijkt dat het Handvest in de gegeven situatie van toepassing is. Immers, als het Handvest niet van toepassing is, wordt niet aan artikel 53 toegekomen en is de nationale standaard onverkort van toepassing. Indien echter vast staat dat het Handvest in een gegeven situatie wel van toepassing is, leidt dit tot een situatie waarin zowel nationale grondrechten als de Uniegrondrechten van toepassing kunnen zijn. Indien de toepassing van deze beide bronnen van grondrechten leidt tot verschillende uitkomsten, fungeert artikel 53 van het Handvest als 'conflictregel'.82 Indien het Handvest het hoogste beschermingsniveau biedt, geldt het Handvest. Indien de nationale standaard hoger is dan kan deze in beginsel worden toegepast. De uitzondering hierop is de situatie waarin de toepassing van het nationale grondrecht afbreuk zou doen aan de voorrang, eenheid en werking van het recht van de Unie. Dit volgt uit het arrest Melloni. ${ }^{83}$

In de zaak Melloni staat centraal de tenuitvoerlegging van een Europees Aanhoudingsbevel (voor de uitvoering van een straf) uit hoofde van Kaderbesluit 2002/584. Het ging om een verzoek tot overlevering door Spanje van de heer Melloni ter uitvoering van de tegen hem bij verstek uitgesproken veroordeling tot een gevangenisstraf in Italië. Melloni betoogde dat het Italiaanse procesrecht niet voorziet in de mogelijkheid van verzet tegen bij verstek uitgesproken veroordelingen en dat de tenuitvoerlegging van het Europees aanhoudingsbevel dus, in voorkomend geval, afhankelijk dient te worden gesteld van de voorwaarde dat de Italiaanse Republiek garandeert dat hij kan opkomen tegen het vonnis waarbij hij is veroordeeld. Het Kaderbesluit gebiedt echter onvoorwaardelijke overlevering en laat geen ruimte voor het stellen van een dusdanige voorwaarde. Volgens de verwijzende rechter (het Spaanse constitutionele Hof) zou een dusdanige onvoorwaardelijke overlevering in strijd zijn met het Spaanse grondwettelijke recht op een eerlijk proces.

Uit het arrest blijkt dat het Kaderbesluit onvoorwaardelijke overlevering gebiedt en dat dit niet in strijd is met artikel 47 van het Handvest. Hierdoor kwam het Hof toe aan de principiële vraag naar hoe dan ingevolge artikel 53 van het Handvest moet worden omgegaan met het hogere Spaanse grondwettelijke beschermingsniveau. Met name ging het Hof in op de vraag of het beginsel van voorrang van het Unierecht door artikel 53 van het Handvest

82 Sarmiento 2013, p. 1288.

83 HvJEU van 26 februari 2013, zaak C-399/11, Melloni. Zie ook over dit arrest: De Visser 2013-1; Gazin 2013. 
wordt doorbroken. Het Hof oordeelde, dat deze bepaling geen afbreuk doet aan de het beginsel van voorrang van Unierecht. De toepassing van handelingen van Unierecht die volledig in overeenstemming zijn met het Handvest (in casu het Kaderbesluit), kan niet worden belemmerd door nationale grondrechten. Het Hof herhaalde de vaste rechtspraak op grond waarvan bepalingen van nationaal recht, ook al zijn deze van constitutionele aard, niet kunnen afdoen aan de werking van het recht van de Unie. Tevens ging het Hof in op de betekenis van artikel 53 Handvest. Deze bepaling bevestigt:

“60. (...) dat, wanneer een handeling van Unierecht nationale uitvoeringsmaatregelen vereist, het de nationale autoriteiten en rechterlijke instanties blijft vrijstaan de nationale grondrechtenbescherming toe te passen, mits daardoor het beschermingsniveau van het Handvest, zoals door het Hof uitgelegd, en de voorrang, eenheid en werking van het recht van de Unie niet in het gedrang komen."

In de zaak Melloni zou de toepassing van de nationale grondrechten nu juist wel leiden tot een inbreuk op het beginsel van voorrang. In die zaak ging het immers om het inroepen van het hogere nationale beschermingsniveau tegen de toepassing van bepalingen van Unierecht (het Kaderbesluit). Hierbij speelde ook nog een rol dat het Kaderbesluit, nu juist mede tot doel had een oplossing te vinden voor de problemen bij de wederzijdse erkenning van verstek vonnissen doordat er tussen de lidstaten verschillen bestaan op het gebied van de grondrechtenbescherming. ${ }^{84}$ Het Hof oordeelde dan ook dat het Kaderbesluit voorziet

"62. (...) in een harmonisatie van de tenuitvoerleggingsvoorwaarden van een bij een veroordeling bij verstek uitgevaardigd Europees aanhoudingsbevel, die een weerspiegeling is van de door alle lidstaten bereikte consensus over de reikwijdte die krachtens het recht van de Unie moet worden verleend aan de procedurele rechten van bij verstek veroordeelden tegen wie een Europees aanhoudingsbevel is uitgevaardigd.

63. Indien een lidstaat zich op artikel 53 van het Handvest zou kunnen beroepen om de overlevering van een bij verstek veroordeelde afhankelijk te stellen van de in kaderbesluit 2009/299 niet genoemde voorwaarde dat de veroordeling in de uitvaardigende lidstaat kan worden herzien ter voorkoming dat inbreuk wordt gemaakt op het recht op een eerlijk proces en de rechten van de verdediging, welke in de grondwet van de uitvoerende lidstaat zijn gewaarborgd, zou bijgevolg afbreuk worden gedaan aan de beginselen van wederzijds vertrouwen en wederzijdse erkenning, die het kaderbesluit beoogt te verster-

84 Brkan 2013, p. 144. 
ken, en zou de doelmatigheid van dit kaderbesluit dus in het gedrang komen doordat de uniformiteit van de in dit kaderbesluit vastgestelde grondrechtenbescherming ter discussie wordt gesteld."

Cruciaal was dus dat het Kaderbesluit in de gegeven situatie het handelen van de lidstaten volledig bepaalde. In het arrest Åkerberg Fransson van dezelfde dag, ging het Hof in op de situatie waarin ook sprake is van uitvoering ex artikel 51 van het Handvest, maar waarin 'het optreden van de lidstaten niet volledig door het Unierecht wordt bepaald' ${ }^{85}$ In dit scenario is ruimte voor toepassing van de nationale maatstaven voor de bescherming van de grondrechten, op voorwaarde dat deze toepassing niet onder het Handvest- beschermingsniveau komt en dat niet wordt afgedaan aan de voorrang, eenheid en doeltreffendheid van het Unierecht.

Samenvattend kan worden gezegd dat het Handvest ruimte laat voor een aanvullende toepassing van nationale grondrechten, mits de voorrang, eenheid en werking van het recht van de Unie niet in het geding is. Het beginsel van voorrang blijft dus van toepassing, Artikel 53 van het Handvest vormt daarop geen uitzondering. Voor de duidelijkheid moet worden opgemerkt, dat het bij het beginsel van voorrang niet zozeer gaat om de voorrang van het Handvest ten opzichte van de nationale grondrechten, maar om de voorrang van materieel Unierecht (dat voldoet aan de eisen van het Handvest) ten opzichte van nationale grondrechten. Het beginsel van voorrang brengt met zich dat de aanvullende bescherming van nationale grondrechten geen afbreuk mag doen aan de eenheid en werking van het materiële Unierecht.

Concreet zal er met name ruimte zijn voor de aanvullende toepassing van nationale grondrechten in situaties waarin de lidstaten beschikken over discretie ten aanzien van de uitvoering van Unierecht. Indien de nationale uitvoeringshandeling geheel wordt gedicteerd door het (materiële) Unierecht (er is geen sprake van beoordelingsruimte), is er geen ruimte voor aanvullende nationale grondrechtenbescherming. 86 Kortom: de mogelijkheid voor de toepassing van aanvullende nationale grondrechtenbescherming is gekoppeld aan de speelruimte waarover de lidstaten op grond van het relevante materiële Unierecht beschikken voor uitvoering in de zin van artikel 51, lid 1, van het Handvest. Naarmate deze speelruimte groter is, bestaat er meer ruimte voor nationale afwijkingen en zal de voorrang, eenheid en werking van het recht van de Unie minder snel in het geding zijn.

85 HvJEU van 26 februari 2013, zaak C-617/10, Åkerberg Fransson, punt 29.

86 De Witte 2013; Thym 2013, p. 401-404; Sarmiento 2013, p. 1287-1298; De Boer 2013, p. 1096. 


\subsubsection{Onderscheid tussen Handvest-rechten en Handvest- beginselen: artikel 52, lid 5}

\subsubsection{Algemeen}

Het Handvest maakt onderscheid tussen zogenaamde 'rechten' en 'beginselen'. ${ }^{87}$ Deze beginselen moeten niet worden verward met de algemene rechtsbeginselen. Sommige bepalingen in het Handvest zijn tevens algemene rechtsbeginselen en dit hoeven niet noodzakelijkerwijze 'beginselen' in de zin van het Handvest te zijn, het kunnen ook 'rechten' zijn. Om verwarring te voorkomen zal in het volgende ook worden gesproken van 'Handvest-beginselen'. Het onderscheid tussen Handvest-rechten en Handvest-beginselen blijkt uit de artikelen 51, lid 1, en artikel 52, lid 5, van het Handvest. ${ }^{88}$ Het onderscheid tussen de rechten en beginselen in het Handvest is het resultaat van een compromis naar aanleiding van een intens debat tijdens de Conventie. Hierbij speelden verschillende politieke gevoeligheden, alsmede verschillen in constitutionele tradities ten aanzien van het bestaan en de afdwingbaarheid van met name de sociale rechten, een rol. ${ }^{89}$ Voor het onderscheid tussen rechten en beginselen heeft de Conventie met name gekeken naar het Spaanse en het Franse constitutionele recht. ${ }^{90}$

Het Handvest geeft geen definitie van wat 'rechten' en 'beginselen' zijn. Wel makkt artikel 51, lid 1, Handvest duidelijk, dat rechten moeten worden 'geëerbiedigd' en beginselen moeten worden 'nageleefd'. ${ }^{91}$ Blijkens de Toelichting, bevat artikel 52, lid 5, Handvest een verduidelijking van het onderscheid tussen 'rechten' en 'beginselen'. De bepaling zoemt louter in op de 'beginselen'. Uit het eerste deel van deze bepaling blijkt dat aan beginselen uitvoering kan worden gegeven. Uit het tweede deel van de bepaling blijkt, dat ten aanzien van beginselen een beperking van de rechterlijke bevoegdheid geldt. De bepaling luidt als volgt:

"Aan de bepalingen van dit Handvest die beginselen bevatten, kan uitvoering worden gegeven door wetgevings- en uitvoeringshandelingen van de

87 Deze paragraaf is in belangrijke mate gelijk aan De Mol, Pahladsingh en Van Heijningen 2012, p. 222-237.

88 Zie ook de preambule, slotalinea waarin staat wordt gesproken van "rechten, vrijheden en beginselen”. Over dit onderscheid ook Craig 2010, pag. 216-221.

89 Zie Meyer 2011, Art. 51, punt 10.

90 Zie voor een uitgebreide beschrijving van de totstandkomingsgeschiedenis Tettinger e.a. 2006, Art. 52, punten 7 en 10; Meyer 2011, Art. 52, punt 45b.

91 In de Engelse en Franse taalversie 'respect'| 'respectent' respectievelijk 'observe'|'observent'. 
instellingen, organen en instanties van de Unie en door handelingen van de lidstaten wanneer zij het recht van de Unie ten uitvoer brengen, bij de uitoefening van hun respectieve bevoegdheden. De rechterlijke bevoegdheid ten aanzien van die bepalingen blijft beperkt tot de uitlegging van genoemde handelingen en de toetsing van de wettigheid ervan."

In het kader van deze subparagraaf zal kort worden ingegaan op de identificatie van Handvest-beginselen. De uit hoofde van artikel 52, lid 5, Handvest geldende beperking van de rechterlijke bevoegdheid wordt in de volgende subparagraaf apart belicht wegens de samenhang met de directe werking van grondrechten. Zoals gezegd geeft het Handvest geen definitie van wat 'rechten' en 'beginselen' zijn. Daarnaast blijkt uit het Handvest niet welke bepalingen moeten worden gekwalificeerd als 'recht' en welke als 'beginsel'. Zo zijn de 'rechten' en 'beginselen' niet afzonderlijk geclusterd in bijvoorbeeld verschillende hoofdstukken. ${ }^{92}$ Sterker nog uit de Toelichting blijkt dat sommige bepalingen elementen van zowel een 'recht' als een 'beginsel' kunnen bevatten. Het is ook niet zo, dat het onderscheid tussen 'rechten" en 'beginselen' samenvalt met het onderscheid tussen enerzijds de klassieke, civiele en politieke, grondrechten en anderzijds de sociaaleconomische grondrechten. ${ }^{93}$ Het onderscheid 'recht' en 'beginsel' valt evenmin samen met het onderscheid 'overheidsonthouding' (verbodsbepalingen) en 'overheidsbemoeienis' (positieve actie-bepalingen). ${ }^{94}$ Voorts vermelden de betreffende bepalingen niet of het gaat om een 'recht' of om een 'beginsel'. In sommige gevallen blijkt dit wel uit de Toelichting van het betreffende artikel zelf 95 of van artikel 52, lid 5, Handvest. ${ }^{96}$ Tot slot moet voorzichtigheid worden betracht met het gebruik van het woord 'recht' in bepalingen van het Handvest. Dit betekent niet automatisch dat ook sprake is van een 'recht'. Zo staat in artikel 25 van het Handvest vermeld: "het recht van ouderen". Dit lijkt te impliceren dat deze bepaling een 'recht' betreft. Echter, uit de Toelichting bij de artikelen 52, lid 5, en 25 staat expliciet vermeld dat deze bepaling een 'beginsel' is. ${ }^{97}$ Dit alles maakt de identificatie van de bepalingen

92 Zo vallen de in de Toelichting bij artikel 52, lid 5 expliciet als beginselen benoemde artikelen 25 en 26 onder Titel III-Gelijkheid, terwijl artikel 37 dat ingevolge de Toelichting eveneens kwalificeert als beginsel onder Titel IV-Solidariteit.

93 Craig 2010, p. 218.

94 Craig 2010, p. 218.

95 Zie bijvoorbeeld de artikelen 34, lid 1, 35, 36, 37 en 38. Zie ook over de kwalificatie van artikel 38 als beginsel: A-G Wahl van 12 december 2013, zaak C-470/12, Pohotovost, punt 66.

96 De eerder genoemde artikelen 25, 26 en 37 van het Handvest.

97 Hetzelfde geldt voor artikel 26, die spreekt van het 'recht' van personen met een handicap. 
van het Handvest als 'recht' of als 'beginsel' niet gemakkelijk. ${ }^{98}$ De intentie bij de Conventie was om dit over te laten aan de rechtspraak van het Hof waarbij de Toelichting in acht diende te worden genomen. ${ }^{99}$

Op dit moment is er nog geen rechtspraak van het Hof over de kwalificatie van 'rechten' en 'beginselen'. Het Hof lijkt er niet al te happig op om zich hier over uit te laten. De zaak Dominguez zou een mogelijkheid zijn geweest om uit te maken of artikel 31, lid 2, Handvest (maximum arbeidsduur, rusttijden en jaarlijkse vakantie met behoud van loon) een 'recht' of 'beginsel' is, ${ }^{100}$ maar het Hof is er niet aan toegekomen. ${ }^{101}$ De advocaat-generaal heeft zich wel uitgesproken, zij meent dat de bepaling een 'recht' is en geen 'beginsel'. ${ }^{102}$ In de zaak AMS betoogde de advocaat-generaal dat artikel 27 (het recht op informatie en raadpleging van de werknemers binnen de onderneming) kwalificeert als een 'beginsel'. 103 Ook in deze zaak gaat het Hof niet in op de kwalificatie als 'recht' of 'beginsel'. ${ }^{104}$ In de zaak Pohotovost bestempelt advocaat-generaal Wahl artikel 38 van het Handvest (consumentenbescherming) als beginsel. ${ }^{105}$ In het arrest echter komt de kwalificatie als 'recht' of 'beginsel' niet terug. 106

Wat behelst nu in grote lijnen het verschil tussen 'rechten' en 'beginselen'? Heel algemeen kan worden gezegd, dat 'rechten' relatief wat preciezer en onvoorwaardelijker zijn geformuleerd en dat 'beginselen' relatief vager zijn, een ruimere beoordelingsmarge laten en uitvoering behoeven. ${ }^{107}$ Relatief; omdat grondrechten naar hun aard abstract zijn en ruimte laten voor nadere invulling. ${ }^{108}$ Een belangrijke vraag voor het onderscheid tussen 'rechten' en 'beginselen' is of de betreffende bepaling individuele of subjectieve rechten schept zonder dat uitwerking in wet- of regelgeving nodig is. Indien zulks het

98 Dougan 2008, p. 663-664.

99 CONV 354/02 van 22 februari 2002, pag. 8.

100 Vergelijk ACA-rapport 2011, T. Von Danwitz (rechter bij het Hof) onder punt E.2.

101 HvJEU van 24 januari 2012, zaak C-282/10, Dominguez.

102 A-G Trstenjak van 8 september 2011, zaak C-282/10, Dominguez, punten 75-79.

103 A-G Cruz Villalón van 18 juli 2013, zaak C-176/12, AMS, punt 56.

104 HvJEU van 15 januari 2014, zaak C-176/12, AMS. Zie echter HvJEU van 22 mei 2014, zaak C-356/12, Glatzel, punt 78. De zaak Glaztel wordt besproken in de volgende subparagraaf. Voor hier volstaat het op te merken dat het in Glaztel onmiskenbaar ging om een Handvest-beginsel (namelijk artikel 26 van het Handvest). De verwijzing naar AMS zou erop kunnen duiden dat het ook in AMS ging om een Handvest-beginsel

105 A-G Wahl van 12 december 2013, zaak C-470/12, Pohotovost, punt 66.

106 HvJEU van 27 februari 2014, zaak C-470/12, Pohotovost.

107 Zie ook Van Elsuwege, Devisscher \& Van Bossuyt 2010, punt 34; Heringa \& Verhey 2001, p. 14.

108 Vergelijk A-G Trstenjak van 8 september 2011, zaak C-282/10, Dominguez, punten 78. 
geval is zal sprake zijn van een recht. ${ }^{109}$ Advocaat-generaal Cruz Villalón spreekt van dat beginselen een 'opdracht' aan overheden bevatten en rechten een omschrijving geven van een 'individuele rechtssituatie'. ${ }^{110}$ Advocaat-generaal Wahl stelt dat artikel 38 van het Handvest een beginsel is, omdat het "geenszins verband houdt met een individuele rechtssituatie die rechtstreeks wordt omschreven”. 111

De beantwoording van de vraag of een bepaling subjectieve rechten creëert is geen zwart/wit kwestie. Beantwoording van deze vraag is dan ook niet eenvoudig. In met name de Duitse literatuur zijn criteria geformuleerd die als leidraad kunnen worden gebruikt bij de identificatie van beginselen. ${ }^{112} \mathrm{Zo}$ is relevant de vraag of de bepaling er duidelijk (ook) toe strekt individuen te beschermen. Indien zulks zo is, zal vermoedelijk eerder sprake zijn van een recht. Verder is de formulering van de norm van belang. ${ }^{113}$ Hoe concreter hoe groter de kans dat sprake is van een 'recht'. Een grote 'concretiseringsbehoefte' daarentegen wijst weer in de richting van een 'beginsel'. In de literatuur wordt er verder op gewezen, dat voor bepalingen die 'beginselen' bevatten veelal beginnen met woorden als: "De Unie erkent en eerbiedigt..." of een zinsnede van gelijke strekking (die neerkomt op een erkennings- of eerbiedigingsplicht voor de Unie). ${ }^{114}$ Illustratief is artikel 34 Handvest. Deze bepaling wordt door de Toelichting bij artikel 52, lid 5 Handvest genoemd als bepalingen die elementen van zowel 'rechten' als ‘beginselen' bevat. De bepaling luidt als volgt:

"Sociale zekerheid en sociale bijstand

1. De Unie erkent en eerbiedigt onder de door het recht van de Unie en de nationale wetgevingen en praktijken gestelde voorwaarden het recht op toegang tot sociale zekerheidsvoorzieningen en sociale diensten die bescherming bieden in omstandigheden zoals moederschap, ziekte, arbeidsongevallen, afhankelijkheid of ouderdom, alsmede bij verlies van arbeid.

2. Een ieder die legaal in de Unie verblijft en zich daar legaal verplaatst, heeft recht op sociale zekerheidsvoorzieningen en sociale voordelen overeenkomstig het recht van de Unie en de nationale wetgevingen en praktijken.

3. Om sociale uitsluiting en armoede te bestrijden, erkent en eerbiedigt de Unie het recht op sociale bijstand en op bijstand voor huisvesting, teneinde eenieder die niet over voldoende middelen beschikt, onder de door het recht van de

109 Zie ook A-G Trstenjak van 8 september 2011, zaak C-282/10, Dominguez, punten 76 -78.

110 A-G Cruz Villalón van 18 juli 2013, zaak C-176/12, AMS, punten 49 en 50.

111 A-G Wahl van 12 december 2013, zaak C-470/12, Pohotovost, punt 66.

112 Tettinger e.a. 2006, pag. 806-607.

113 Tettinger e.a. 2006, Art. 52, punt 98.

114 Denman 2010, p. 354. Zie ook A-G Trstenjak van 8 september 2011, zaak C-282/10, Dominguez, punten 76. 
Unie en de nationale wetgevingen en praktijken gestelde voorwaarden een waardig bestaan te verzekeren.

(cursivering door auteur)"

Uit de Toelichting bij de bepaling lijkt te volgen, dat het eerste en derde lid kwalificeren als beginsel en het tweede als recht. ${ }^{115}$ Een andere aanwijzing zou kunnen zijn het ontbreken van een titularis. Bepalingen zonder titularis, zullen eerder aangemerkt worden als 'beginsel' dan als 'recht'. Overigens is het omgekeerde niet waar; bepalingen die titularissen bevatten zijn niet automatisch een recht. ${ }^{116}$ Het is tenslotte zeer aannemelijk dat alle met het EVRM corresponderende rechten moeten worden aangemerkt als 'rechten'.117

\subsubsection{Handvest-beginselen en directe werking}

Zowel 'rechten' als 'beginselen' zijn bindend. ${ }^{118}$ Het verschil tussen de twee smaken uit het Handvest is, dat'rechten' over het algemeen wat preciezer en onvoorwaardelijker zijn geformuleerd en dat 'beginselen' relatief vager zijn, een ruimere beoordelingsmarge laten en uitvoering behoeven. De vraag rijst of de kwalificatie als Handvest-beginsel gevolgen heeft voor de (mogelijkheid van) directe werking van de betreffende bepaling. ${ }^{119}$

Deze vraag rijst ten eerste, omdat Handvest-beginselen naar hun aard uitvoering behoeven en over het algemeen abstracter zijn geformuleerd. Welnu deze karakteristieken staan op zich niet in de weg aan de mogelijkheid van directe werking. Het enkele feit, dat 'beginselen' over het algemeen een grote beoordelingsruimte bevatten of uitvoering behoeven, maakt ze op zich niet

115 Voor lid 1 expliciet, voor de leden 2 en 3 impliciet. Zie bijvoorbeeld ook de artikelen 25, 26 en 37 die in de Toelichting zijn gekwalificeerd als 'beginsel'. Zie verder de artikelen 22, 36,38 die vermoedelijk beginselen zijn.

116 Vergelijk de artikelen 25 en 26 die in de Toelichting expliciet zijn benoemd als 'beginselen', maar die wel duidelijk maken dat het gaat om rechten van ouderen en van gehandicapten.

117 In de Toelichting bij artikel 52, lid 3, Handvest staat vermeld welke bepalingen dit zijn: Artikelen 2 (recht op leven), 4 (folteringsverbod), 5 leden 1 en 2 (verbod van slavernij en dwangarbeid), 6 (recht op vrijheid en veiligheid), 7 (eerbiediging van het privéleven en van het familie- en gezinsleven), 10, lid 1, (vrijheid van gedachte, geweten en godsdienst), 11 (vrijheid van meningsuiting en van informatie), 17 (recht van eigendom), 19 (bescherming bij verwijdering, uitzetting en uitlevering), 48 (vermoeden van onschuld en rechten van verdediging) en 49 (legaliteitsbeginsel en evenredigheidsbeginsel inzake delicten en straffen).

118 Artikel 51, lid 1, Handvest, zegt immers dat beginselen moeten worden nageleefd.

119 Dit onderwerp is ook behandeld in: De Mol, Pahladsingh en Van Heijningen, 2012, p. 222-237. Zie meer algemeen over het leerstuk van directe werking paragraaf 3.2. 
ongeschikt voor rechtstreekse werking. ${ }^{120}$ Het is wel zo dat de aanwezigheid van een beoordelingsmarge gevolgen kan hebben voor de intensiteit van de toetsing, hoe groter de marge hoe marginaler de toetsingsmogelijkheid. Overigens volgt uit artikel 52, lid 5, Handvest, expliciet dat Handvest-beginselen a priori directe werking kunnen hebben; met betrekking tot Handvestbeginselen wordt immers expliciet gesproken van de mogelijkheid van beginselconforme uitleg (indirecte werking) en wettigheidstoetsing (dit is een vorm van directe werking). ${ }^{121}$

De vraag of de kwalificatie als Handvest-beginsel gevolgen heeft voor de (mogelijkheid van) directe werking van de betreffende bepaling, rijst ten tweede doordat op grond van artikel 52, lid 5, Handvest ten aanzien van Handvestbeginselen een beperking van de rechterlijke bevoegdheid geldt. De tekst van deze bepaling luidt als volgt:

"5. Aan de bepalingen van dit Handvest die beginselen bevatten, kan uitvoering worden gegeven door wetgevings- en uitvoeringshandelingen van de instellingen, organen en instanties van de Unie en door handelingen van de lidstaten wanneer zij het recht van de Unie ten uitvoer brengen, bij de uitoefening van hun respectieve bevoegdheden. De rechterlijke bevoegdheid ten aanzien van die bepalingen blijft beperkt tot de uitlegging van genoemde handelingen en de toetsing van de wettigheid ervan.”

In de Toelichting staat nog vermeld:

“(...) Beginselen kunnen worden toegepast door middel van wetgevings- of uitvoeringshandelingen (die door de Unie worden vastgesteld op grond van haar bevoegdheden, en door de lidstaten alleen wanneer zij het recht van de Unie tot uitvoering brengen); dit betekent dat zij alleen van belang zijn voor de rechter wanneer die handelingen worden geïnterpreteerd en getoetst. Zij geven echter geen aanleiding tot directe eisen tot het nemen van positieve maatregelen door de instellingen van de Unie of de overheden van de lidstaten. Die benadering spoort met de jurisprudentie van het Hof van Justitie (zie onder meer jurisprudentie betreffende het "voorzorgsbeginsel" van artikel

120 Zie de rechtspraak van het Hof inzake de directe werking van richtlijnen en met name ook de volgende arresten waaruit blijkt dat ook bepalingen met een ruime beoordelingsmarge rechtstreekse werking kunnen hebben HvJEU van 1 februari 1977, zaak 51/76, VNO; HvJEU van 24 oktober 1996, zaak C-72/95, Kraaijeveld; HvJEU van 7 september 2004, zaak C-127/02, Kokkelvissers. Zie De Witte 2011, p. 330-331.

121 Zie ook HvJEU van 24 april 2012, zaak C-571/10, Kamberaj, punt 92. Hier lijkt het te gaan om de directe werking van artikel 34, lid 3, Handvest, dat vermoedelijk een 'beginsel' is. 
191, lid 2, van het Verdrag betreffende de werking van de Europese Unie: het arrest van het GEA van 11 september 2002 in zaak T-13/99, Pfizer tegen Raad, waarin meermaals verwezen wordt naar vroegere jurisprudentie; en een reeks arresten met betrekking tot artikel 33 (ex 39) betreffende de beginselen van de landbouwwetgeving, bijvoorbeeld het arrest van het Hof van Justitie in zaak 265/85, Van den Berg, Jurispr. 1987, blz. 1155: onderzoek van het beginsel van marktstabilisatie en het vertrouwensbeginsel) en met de benadering van "beginselen" in de constitutionele stelsels van de lidstaten, met name op het gebied van sociale wetgeving. (...)"

De vraag rijst waar deze beperking van de rechterlijke bevoegdheid in is gelegen en of deze van invloed is op de mogelijkheid van directe werking. De tekst van artikel 52, lid 5, Handvest is onduidelijk en vatbaar voor verschillende wijzen van uitleg. Zoals reeds eerder opgemerkt, kan in ieder geval niet worden gezegd, dat uit artikel 52, lid 5, Handvest volgt dat 'beginselen' per definitie geen directe werking hebben. Bij de vraag waarin de beperking van de rechterlijke bevoegdheid dan wel is gelegen kunnen uit artikel 52, lid 5, Handvest de volgende mogelijkheden worden afgeleid. ${ }^{122}$

i. Alleen directe werking ten aanzien van uitvoeringshandelingen van beginselen

Gezien de laatste zin van artikel 52, lid 5, Handvest bestaat allereerst de mogelijkheid dat het gaat om een beperking van de handelingen waarop 'beginselen' kunnen worden toegepast. Immers in die zin staat, dat de rechterlijke bevoegdheid beperkt is tot "genoemde handelingen", waarmee wordt verwezen naar "wetgevings- en uitvoeringshandelingen (...) van de Unie en door handelingen van de lidstaten wanneer zij het recht van de Unie ten uitvoer leggen.” Dit zou kunnen betekenen dat de rechter Handvest-beginselen alleen kan toepassen ten aanzien van handelingen die (uitdrukkelijk) uitvoering geven aan 'beginselen'. ${ }^{123}$ Hetzelfde lijkt te staan in de Toelichting die vermeldt:

"Beginselen kunnen worden toegepast door middel van wetgevings- of uitvoeringshandelingen (die door de Unie worden vastgesteld op grond van haar bevoegdheden, en door de lidstaten alleen wanneer zij het recht van de Unie tot uitvoering brengen); dit betekent dat zij alleen van belang zijn voor de rechter wanneer die handelingen worden geïnterpreteerd en getoetst." (cursivering door auteur)

122 Zie ook ACA 2011, discussiepaper II. De auteur van dit proefschrift was betrokken bij het concipiëren van deze discussiepaper.

123 Zie bijvoorbeeld Barkhuysen, Bos \& Ten Have 2011, p. 6; Denman 2010, p. 355. 
Voor de toepassing op nationale handelingen zou dit betekenen dat voldaan moet worden aan een dubbele eis. De betreffende handeling moet ten eerste kwalificeren als een handeling die het Unierecht uitvoert ingevolge artikel 51, lid 1, van het Handvest. ${ }^{124}$ Voorts zou het dan moeten gaan om een handeling die het betreffende Handvest-beginsel uitvoert of toepast. Hier zouden dan zowel handelingen onder vallen die de lidstaten (uit eigen beweging) nemen ter uitvoering van deze 'beginselen', als handelingen die uitvoering geven aan Unierecht dat toepassing geeft aan deze 'beginselen'. ${ }^{125}$ Hoewel deze uitleg op grond van de tekst goed verdedigbaar is, wijst het vervolg van de Toelichting in een andere richting. De zin die volgt op hierboven aangehaalde passage luidt immers:

"Zij geven echter geen aanleiding tot directe eisen tot het nemen van positieve maatregelen door de instellingen van de Unie of de overheden van de lidstaten."

Dit duidt er eerder op dat de rechterlijke beperking beoogt te voorkomen dat de Handvest-beginselen dienen als basis voor de toekenning van subjectieve rechten. Als de nadruk op deze zin wordt gelegd, lijkt het daarom minder noodzakelijk om de toetsing te beperken tot uitvoeringshandelingen van Handvest-beginselen. Vooral ook omdat in de Toelichting wordt gesteld, dat de benadering van 'beginselen' spoort met de rechtspraak van het Hof inzake het voorzorgsbeginsel, het beginsel van marktstabiliteit en het vertrouwensbeginsel. Uit deze rechtspraak blijkt niet, dat de toepassing van deze beginselen beperkt is tot 'uitvoeringshandelingen' van de betreffende beginselen. ${ }^{126} \mathrm{Bij}$ toepassing van het vertrouwensbeginsel is dit sowieso niet aan de orde, omdat het niet voor de hand ligt dat sprake zou zijn van uitvoering. ${ }^{127}$ Het is derhalve twijfelachtig of een dergelijke letterlijke lezing van artikel 52, lid 5, Handvest, juist zou zijn. ${ }^{128}$ Ook vanuit het oogpunt van het nuttig effect van het Handvest

124 Zie paragraaf 2.3.2 en deel II van deze dissertatie.

125 Anders: A-G Wahl van 12 december 2013, zaak C-470/12, Pohotovost, punt 66, die uit lijkt te gaan van een engere uitleg, waarbij de rechterlijke bevoegdheid bij Handvestbeginselen beperkt blijft tot de uitlegging en de toetsing van de rechtmatigheid van de wetgevingshandelingen van de Unie.

126 Zie ook Craig, p. 220 met voorbeelden van rechtspraak HvJEU met betrekking tot de toepassing van het voorzorgsbeginsel op handelingen die niet uitvoeringshandelingen van dit beginsel waren.

$127 \mathrm{Zie}$ voor rechtspraak inzake de toepassing van het vertrouwensbeginsel op nationale handelingen, bijvoorbeeld HVJEU van 14 september 2006, zaak C-181/04, Elmeka, punten 26-35 en HVJEU van 26 april 2005, zaak C-376/02, Stichting Goed Wonen, punten 31 en 35.

128 Aldus ook Craig 2010, p. 220; A-G Cruz Villalón van 18 juli 2013, zaak C-176/12, AMS, punten 69 en 70 . 
kan aan een dergelijke uitleg worden getwijfeld. Het zou immers betekenen dat rechtens niet kan worden opgetreden tegen handelingen die (flagrante) schendingen van beginselen behelzen. Bovendien zouden zij zonder uitvoeringsmaatregelen een lege huls blijken te zijn.

\section{ii. Alleen wettigheidstoetsing}

Een tweede mogelijkheid is, dat artikel 52, lid 5, Handvest de wijze waarop 'beginselen' in rechte kunnen worden toegepast beperkt. Namelijk in de zin dat 'beginselen' alleen kunnen worden toegepast (i) als instrument van uitleg en (ii) als grond voor de toetsing van wettigheid (geldigheid) van overheidshandelen. 'Beginselen' zouden daarentegen niet kunnen dienen als zelfstandige gronden voor de toewijzing van positieve maatregelen. Anders gezegd: 'beginselen' zouden geen zelfstandige grond voor de toekenning van subjectieve rechten kunnen vormen. ${ }^{129}$ Subjectieve rechten zouden enkel kunnen worden ontleend aan handelingen van de Unie of de lidstaten die 'beginselen' uitvoeren (concretiseren). 'Rechten' zouden daarentegen dus wel aanleiding kunnen geven tot directe eisen tot het nemen van positieve maatregelen. ${ }^{130}$ Steun voor deze uitleg kan worden gevonden in de laatste zin van artikel 52, lid 5, Handvest ${ }^{131}$ en wel met name in samenhang met de hierboven aangehaalde passage in de Toelichting die vermeldt dat 'beginselen' geen aanleiding geven tot directe eisen tot het nemen van positieve maatregelen. Uit de arresten die in de Toelichting staan vermeld, blijkt ook dat het steeds gaat om een wettigheidstoetsing. Het ging niet om de toekenning van subjectieve rechten of positieve maatregelen: er wordt enkel bekeken of de betrokken handeling in het licht van het desbetreffende beginsel 'wettig' is, dat wil zeggen, of de handeling wel genomen had moeten worden. De uitleg past ook bij de gedachte dat het kenmerkende verschil tussen 'rechten' en 'beginselen' het al dan niet creëren van subjectieve rechten is. ${ }^{132}$ Tot slot doet de uitleg zowel recht aan de speciale positie van 'beginselen' die bij de onderhandelingen zo expliciet aan de orde is gekomen als aan hun nuttig effect. Deze uitleg lijkt derhalve zeer overtuigend te zijn. ${ }^{133}$

129 Zo zou het bijvoorbeeld artikel 25 van het Handvest (de rechten van ouderen) niet kunnen fungeren als zelfstandige grond voor de toekenning tot een recht op gratis toegang tot musea.

130 Zie ook Jacqué 2002, p. 115 en Craig 2010, p. 219.

131 De rechterlijke bevoegdheid ten aanzien van die bepalingen blijft beperkt tot de uitlegging van genoemde handelingen en de toetsing van de wettigheid ervan.

132 Zie paragraaf 2.3.7.1.

133 Zie ook ACA-rapport rechter T. VonDanwitz onder punt E.4. 
iii.

Dubbele beperking: alleen wettigheidstoetsing van handelingen die beginselen uitvoeren

De meest strikte uitleg van artikel 52, lid 5, Handvest zou zijn een gecombineerde uitleg van de twee bovenbesproken mogelijkheden. In deze uitleg is de toepassing van 'beginselen' beperkt tot (i) handelingen die uitvoeringshandelingen van de betreffende beginselen zijn en (ii) instrument van uitleg en grond van wettigheidstoetsing. Deze uitleg zou het meest recht doen aan de letter van de bepaling, maar stuit gedeeltelijk op dezelfde bezwaren als de eerst besproken uitleg. ${ }^{134}$

\section{iv. Louter symbolische politieke functie?}

In de zaak AMS (die uitgebreid wordt behandeld in deel III) ${ }^{135}$ stond mede ter discussie de vraag artikel 27 van het Handvest moet worden aangemerkt als Handvest -beginsel in de zin van artikel 52 lid 5, van het Handvest en zo ja wat daarvan de gevolgen zouden zijn voor directe werking. De advocaat-generaal meende dat artikel 27 van het Handvest inderdaad een Handvest-beginsel is. Het Hof gaat niet in op deze vraag, maar gaat direct door naar de vraag of artikel 27 van het Handvest in deze zaak voldoet aan de technische eisen voor directe werking. Betekent dit nu dat op basis van AMS kan worden vastgesteld dat artikel 52, lid 5, van het Handvest een louter symbolische waarde heeft? Ik meen van niet. De stilte rondom de problematiek van het onderscheid tussen Handvest-rechten en Handvest-beginselen duidt er enkel op dat het in deze zaak niet relevant is. Dit is ook verklaarbaar in het licht van de analyse van artikel 52, lid 5, van het Handvest hierboven. In deze analyse werd voorop gesteld dat deze bepaling niet in de weg staat aan directe werking als zodanig, maar hoogstens aan directe werking die verder gaat dan de wettigheidstoetsing. Welnu in de onderhavige zaak ging het om een wettigheidstoetsing van nationale wetgeving en deze mogelijkheid staat expliciet in artikel 52, lid 5, van het Handvest genoemd. Verder is het zoals hierboven uiteengezet op grond van de tekst en Toelichting van artikel 52, lid 5, van het Handvest onzeker of Handvest-beginselen alleen mogen worden toegepast op (nationale) maatregelen die uitvoering geven aan Handvest-beginselen of dat ze ook mogen worden toegepast op (nationale) maatregelen die dat niet doen. In de zaak AMS ging het echter om de toetsing van een nationale maatregel die kwalificeert als implementatie van een richtlijn die weer kan worden gezien als een uitwerking van artikel 27 van het Handvest. Dit betekent dat artikel 52, lid 5, van het Handvest in de zaak AMS ook bij de meest restrictieve uitleg van de

\footnotetext{
134 Namelijk bezwaren vanuit het oogpunt van het nuttig effect van Handvestbeginselen en de verwijzing in de Toelichting naar de benadering van het Hof met betrekking tot het vertrouwensbeginsel, het voorzorgsbeginsel en het marktstabilisatiebeginsel.

135 Zie voor de samenvatting van het arrest 8.3.3.
} 
toepassing van Handvest-beginselen, geen obstakel zou zijn geweest. Hetgeen kan verklaren waarom het Hof de vraag overslaat. Naar mijn mening moet er voorlopig niet van worden uitgegaan dat de bepaling een louter symbolische functie heeft.

\section{Het arrest Glatzel}

Tot slot wijs ik op het recente arrest Glaztel. ${ }^{136}$ In deze zaak ging het Hof in op de geldigheid van Uniewetgeving (een onderdeel van richtlijn 2006/126 betreffende het rijbewijs) onder meer op grond van artikel 26 van het Handvest (Integratie van personen met een handicap). Van deze bepaling staat op grond van de Toelichting bij artikel 52, lid 5, van het Handvest vast dat het een Handvest-beginsel is. Hoewel in Glaztel niet gaat om de toepassing van een beginsel op nationale handelingen (directe werking), maar om de toepassing op Uniewetgeving, is het arrest wel relevant voor de functie van Handvest-beginselen en meer in het bijzonder voor de uitleg van artikel 52, lid 5, van het Handvest. Het lijkt er in eerste instantie op, dat het Hof een uitleg van artikel 52, lid 5, van het Handvest hanteert op grond waarvan beginselen enkel kunnen worden toegepast op uitvoeringshandelingen van beginselen. Het Hof overweegt namelijk als volgt:

"74. Zoals blijkt uit artikel 52, leden 5 en 7, van het Handvest en de toelichtingen bij het Handvest van de grondrechten (PB 2007, C 303, blz. 17) over de artikelen 26 en 52, lid 5, van het Handvest, is de bevoegdheid van de rechter ten aanzien van artikel 26 van het Handvest beperkt tot de uitlegging en de toetsing van de wettigheid van de wetgevende handelingen van de Unie die het in dat artikel vervatte beginsel, namelijk de integratie van personen met een handicap, ten uitvoer brengen.

(...)

76. Aangezien richtlijn 2006/126 een wetgevingshandeling van de Unie vormt waarbij het in artikel 26 van het Handvest vervatte beginsel ten uitvoer wordt gebracht, kan deze bepaling dus op het hoofdgeding worden toegepast."

Bij lezing van deze overwegingen lijkt de conclusie te zijn dat een wettigheidstoetsing aan een beginsel enkel mogelijk is ten aanzien van wetgevende handelingen (in casu: van de Unie) die het betreffende beginsel ten uitvoer brengt. Toch aarzel ik, omdat het Hof in de volgende overweging in gaat op de algemene in artikel 51, lid 1, tweede volzin van het Handvest vervatte verplichting dat Handvest-beginselen moeten worden nageleefd en als volgt overweegt:

136 HvJEU van 22 mei 2014, zaak C-356/12, Glatzel. 
“77. Bovendien bepaalt artikel 51, lid 1, tweede volzin, van het Handvest dat de wetgever van de Unie de beginselen van het Handvest dient na te leven en de toepassing ervan dient te bevorderen. Aangaande het beginsel van de integratie van personen met een handicap, bepaalt artikel 26 van het Handvest dat de Unie het recht van personen met een handicap op maatregelen die beogen hun zelfstandigheid, hun maatschappelijke en beroepsintegratie en hun deelname aan het gemeenschapsleven te bewerkstellingen, erkent en eerbiedigt.

78. Hoewel artikel 26 van het Handvest dus gebiedt dat de Unie het recht van gehandicapten op integratiemaatregelen erkent en eerbiedigt, verplicht het in dat artikel vervatte beginsel de wetgever van de Unie daarentegen niet bepaalde maatregelen te nemen. Dit artikel verkrijgt immers pas zijn volle werking nadat het nader is bepaald in Unierechtelijke en nationaalrechtelijke voorschriften. Bijgevolg kan dit artikel op zich particulieren geen subjectief recht verlenen waarop als zodanig een beroep kan worden gedaan (...).”

Hieruit volgt zonder twijfel, dat artikel 26 van het Handvest aan particulieren geen subjectief rechten verleent waarop als zodanig een beroep kan worden gedaan. ${ }^{137}$ Het is echter de vraag of de verwijzing naar de algemene in artikel 51 , lid 1, tweede volzin van het Handvest vervatte verplichting dat Handvestbeginselen moeten worden nageleefd, tevens is bedoeld om de mogelijkheid van een wettigheidstoetsing op wetgevende handelingen die niet de uitvoering van het betreffende beginsel betreffen, open te laten. Dit arrest laat derhalve twijfel omtrent de functie en mogelijkheden van Handvest-beginselen.

Ik meen dat de bepaling aldus moet worden uitgelegd, dat de rechterlijke bevoegdheid ten aanzien van beginselen is beperkt in de zin dat toewijzing van positieve maatregelen (de uitoefening van een subjectief recht) op basis van enkel het beginsel, dat wil zeggen in afwezigheid van uitvoeringsmaatregelen, niet is toegestaan. ${ }^{138}$ Een wettigheidstoetsing van maatregelen die geen wetgeving uitvoeren zou mijns inziens in beginsel mogelijk moeten zijn, al zal die in de praktijk zeer marginaal zijn vanwege het globale karakter van Handvestbeginselen.

\subsection{Conclusies}

1. De Unie kent twee bronnen van algemene grondrechten: de algemene beginselen van Unierecht en het Handvest. De grondrechten als algemene

137 Ik merk op dat het Hof deze conclusie verbindt aan de tekst van artikel 26 van het Handvest en niet uit de kwalificatie van Handvest-beginsel als zodanig.

138 A-G Cruz Villalón van 18 juli 2013, zaak C-176/12, AMS, punt 68. 
beginselen van Unierecht zijn 'court -made' en ongeschreven. Het Handvest is sinds 1 december 2009 bindend. De grondrechten van de Unie vormen een uitdrukking van de rechtstaat gedachte ('rule of law') waarop de Unie is gegrondvest. Dit geldt zowel voor de algemene rechtsbeginselen als voor het Handvest. Aldus dienen zij als middel ter bescherming tegen overheidsmacht. De beide soorten grondrechten kunnen direct doorwerken in de nationale rechtsorde. Dit blijkt uit de arresten Wachauf en ERT en uit artikel 51, lid 1, van het Handvest. Uit de arresten Mangold en Kücükdeveci blijkt dat grondrechten niet alleen kunnen doorwerken in gedingen tussen overheid en burger (verticale gedingen), maar ook direct kunnen doorwerken in gedingen tussen particulieren (horizontale gedingen).

2. De grondrechten uit hoofde van het EVRM zijn relevant via de band van de algemene rechtsbeginselen (artikel 6, lid 3, VEU) en het Handvest (artikel 52, lid 3, van het Handvest). Het gaat dan om zogenaamde 'met het EVRM corresponderende rechten'. Indien hiervan sprake is fungeert de waarborg van het EVRM als minimummaatstaf. Op dit moment werkt het EVRM niet zelfstandig rechtstreeks door in het nationale recht, althans niet uit hoofde van het Unierecht. Dit zal in de toekomst veranderen als de Europese Unie toe is getreden tot het EVRM.

3. In situaties waarin de grondrechten van de Unie direct doorwerken in het nationale recht is in beginsel ook ruimte voor de toepassing van nationale grondrechten. Indien de toepassing van deze beide bronnen van grondrechten leidt tot verschillende uitkomsten, fungeert artikel 53 van het Handvest als 'conflictregel'. Indien het Handvest het hoogste beschermingsniveau biedt, geldt het Handvest. Indien de nationale standaard hoger is, kan deze in beginsel worden toegepast. De uitzondering hierop is de situatie waarin de toepassing van het nationale grondrecht afbreuk zou doen aan de voorrang, eenheid en werking van het (materiële) recht van de Unie (arrest Melloni). Concreet zal er met name ruimte zijn voor de aanvullende toepassing van nationale grondrechten in situaties waarin de lidstaten beschikken over discretie ten aanzien van de uitvoering van de betreffende Unierechtelijke regel. Indien de nationale uitvoeringshandeling geheel wordt gedicteerd door het (materiële) Unierecht (er is geen sprake van beoordelingsruimte), is er geen ruimte voor aanvullende nationale grondrechtenbescherming. Naarmate de lidstaten meer speelruimte hebben bij de uitvoering, bestaat er meer ruimte voor nationale afwijkingen en zal de voorrang, eenheid en werking van het recht van de Unie minder snel in het geding zijn.

4. Het Handvest kent twee soorten grondrechten: Handvest-rechten en Handvest -beginselen. De beide varianten hebben directe werking. Voor Handvest-beginselen geldt vermoedelijk een beperking, namelijk dat ze 
enkel kunnen fungeren als maatstaf voor de toetsing van de wettigheid van nationaal handelen en geen subjectieve rechten en plichten in het leven kunnen roepen. Dit blijkt uit artikel 52, lid 5, van het Handvest. Er is thans nog geen rechtspraak over dit onderwerp die uitsluitsel geeft over de precieze omvang van de rechterlijke beperking. 



\section{DEEL II}

\section{VERTICALE DIRECTE WERKING}





\section{HOOFDSTUK 3}

\section{DEFINIËRING EN CONSTITUTIONELE CONTEXT}

\subsection{Inleiding}

Dit deel van het proefschrift gaat over de directe doorwerking van Uniegrondrechten in procedures tussen burgers en nationale overheden (verticale directe werking). De verhouding van dit leerstuk met het beginsel van allocatie van bevoegdheden is, in vergelijking met het leerstuk van de horizontale directe werking, redelijk overzichtelijk. Het raakt met name aan de verdeling van de bevoegdheden tussen de Unie en de lidstaten, waarbij het bestaan van verticale directe werking als zodanig geen pijnpunt is. Het lastige punt in deze context is het bepalen van in welke nationale situaties de toepassing van Uniegrondrechten legitiem is. Het algemene uitgangspunt hierbij is dat de toepassing van Uniegrondrechten in een zuiver nationale context een inbreuk maakt op de bevoegdheden van de lidstaten. Buiten gevallen waarin er geen enkele aanknoping met het Unierecht is, kan het lastig zijn om te bepalen wanneer sprake is van een Unierechtelijke context die de toepassing van Uniegrondrechten rechtvaardigt. In dit hoofdstuk wordt, nadat het concept "verticale directe werking' is gedefinieerd (paragraaf 3.2), voor deze vraag een toetsingskader geformuleerd (paragraaf 3.3). Dit toetsingskader fungeert als basis voor de andere hoofdstukken in dit deel. Zoals zal blijken is de directe werking van Uniegrondrechten gerechtvaardigd voor zover de grondrechtconforme toepassing van het Unierecht in het geding is.

\subsection{Definiëring verticale directe werking}

\subsubsection{Algemeen}

Het concept 'directe werking' ziet op de wijze waarop Unierechtelijke grondrechten doorwerken (effect sorteren) in het nationale recht. ${ }^{1}$ Het gaat derhalve om de wijze waarop het grondrecht door een nationale rechter moet worden toegepast. De werking kwalificeert als 'direct' indien het Unie grondrecht wordt toegepast als zelfstandige grond voor toetsing van nationale (rechts)handelingen. Tegenover 'directe werking' staat 'indirecte werking'. Bij 'indirecte werking' werkt het Unierechtelijk grondrecht eveneens door in het nationale recht en moet de nationale rechter het toepassen. Het gaat hier echter

1 Zie over directe werking: De Witte 2011, p. 329-333; Prechal 2005, p. 226-270. 
niet om de toepassing door de rechter als zelfstandige toetsingsmaatstaf, maar als instrument van uitleg van nationaal recht.

De definitie van het concept 'directe werking' in dit proefschrift luidt derhalve als volgt:

De toepassing van Unierechtelijke grondrechten door de nationale rechter als zelfstandige toetsingsmaatstaf.

Deze vorm van toetsing omvat ten eerste situaties waarin het gaat om de rechtmatigheids- of wettigheidstoetsing van nationale handelingen. Het grondrecht fungeert hier als schild, als afweer tegen onrechtmatige of onwettige wetof regelgeving. Ten tweede ziet het op situaties waarin de werking van het grondrecht fungeert als zwaard, als een bron van subjectieve rechten en plichten. De beide situaties vallen onder de noemer directe werking van Unierecht. ${ }^{2}$ De precieze toepassingswijze (schild of zwaard) wordt niet door het Unierecht bepaald, maar door het nationale rechtskader. Deze twee varianten kunnen dan ook worden gezien als 'gevolgen' of 'effecten' van de directe werking van een norm van Unierecht in de nationale procedure. Ik kom hierop uitgebreider terug in paragraaf 3.2.2 van dit hoofdstuk. De directe werking van Unierecht hangt nauw samen met de voorrang van Unierecht. Voorrang wil zeggen dat een Unierechtelijke norm voorrang heeft boven het nationale recht.

De duiding 'verticaal' ziet op het soort geschillen waarin sprake is van directe werking. Bij verticale directe werking gaat het om geschillen tussen nationale overheden en burgers. Voor de vraag of sprake is van een verticale situatie wordt aangesloten bij de rechtspraak van het Hof. Het Hof hanteert een zeer ruime definitie voor het begrip lidstaat. Voor de vraag of sprake is van een verticale situatie doet het niet ter zake in welke hoedanigheid de lidstaat optreedt. Het kan gaan om de lidstaat in hoedanigheid van bestuurder, (decentrale)wetgever, rechter of werkgever. Voorts doet ook de rechtsvorm niet ter zake. Doorslaggevend is enkel of het betreffende orgaan krachtens een handeling van het openbaar gezag onder toezicht van dat gezag met de uit-

2 Sommige auteurs (bijv. Lenaerts \& Corthout 2006, p. 310) hanteren een enger begrip van directe werking. Ze maken onderscheid tussen enerzijds het gebruik van een Unienorm als grond voor de toetsing van rechtmatigheid en anderzijds het gebruik van de een Unienorm als zelfstandige grond voor de toekenning van een subjectief recht (toepassing als positieve rechtsnorm). De variant rechtmatigheidstoetsing zou dan geen directe werking behelzen, maar enkel de voorrang van het Unierecht tot uitdrukking brengen. De toepassing van het Unierecht blijft op het niveau van een normenconflict, maar behelst geen directe toepassing op het rechtssubject. Zie A-G Léger van 11 januari 2000, zaak C-287/98, Linster, punten 71-73 en Dougan 2007. Zie voor een heldere vergelijking tussen de twee definities van 'directe werking': Muir 2001, p. $42-47$. 
voering van een dienst van openbaar belang is belast en daartoe over bevoegdheden beschikt die verder gaan dan de voor de betrekkingen tussen particulieren geldende regels. ${ }^{3}$

Het vertrekpunt in dit proefschrift is dat de beide bronnen van Uniegrondrechten, het Handvest en de algemene rechtsbeginselen, in beginsel verticale directe werking hebben. Dit volgt uit de rechtspraak inzake de toepassing van algemene beginselen van Unierecht. ${ }^{4}$ Inmiddels is er ook rechtspraak waaruit blijkt dat bepalingen uit het Handvest directe werking kunnen hebben. ${ }^{5}$

Of een specifiek Uniegrondrecht directe werking kan hebben hangt af van de vraag of het betreffende grondrecht technisch geschikt is voor toepassing door de rechter als zelfstandige toetsingsmaatstaf. Hiervoor is vereist dat een rechter in staat is om op grond van de Unierechtelijke norm een verplichting te destilleren die voldoende duidelijk en onvoorwaardelijk is. Het betreft de vraag of de bepaling naar zijn aard (technisch) geschikt is voor rechtstreekse toepassing zonder dat er behoefte is aan uitvoering door wetgever of bestuur. Van belang hierbij is dat het bestaan van een beoordelingsmarge niet in de weg staat aan de technische mogelijkheid van directe werking. Een ruime beoordelingsmarge kan wel van invloed zijn op de intensiteit van de toetsing. ${ }^{6}$ Dit vraagstuk naar de technische geschiktheid van het grondrecht hangt samen met de rol van de rechter en de afbakening van rechterlijke taak met die van de wetgever. De technische vereisten van directe werking hebben als doel om te voorkomen dat aan de rechter een wetgevende functie wordt toegekend. De vraag naar de technische geschiktheid van grondrechten voor directe werking wordt in dit proefschrift niet nader uitgewerkt. Het uitgangspunt is steeds dat het gaat om grondrechten die technisch geschikt zijn om directe werking te hebben.

De focus van dit deel ligt op het onderzoek naar in welke situaties sprake kan zijn van directe werking van Uniegrondrechten in het algemeen. Zoals zo dadelijk uiteen wordt gezet komt dit onderzoek neer op de vraag naar de

3 HvJEU van 24 januari 2012, zaak C-282/10, Dominguez, punt 39 en aldaar aangehaalde jurisprudentie.

4 HVJEU van 13 juli 1989, zaak 5/88, Wachauf; HvJEU van 18 juni 1991, zaak C-260/89, ERT. Zie ook De Witte 2011, p. 338: "general principles serve primarily for use in adjudication, and one could therefore say that they have direct effect by their nature."

5 Bijv. HvJEU van 22 december 2010, zaak C-279/09, DEB.

6 Zie de rechtspraak van het Hof inzake de directe werking van richtlijnen. Zie met name ook de volgende arresten waaruit blijkt dat ook bepalingen met een ruime beoordelingsmarge rechtstreekse werking kunnen hebben HvJEU van 1 februari 1977, zaak 51/76, VNO; HvJEU van 24 oktober 1996, zaak C-72/95, Kraaijeveld; HvJEU van 7 september 2004, zaak C-127/02, Kokkelvissers. 
betekenis van artikel 51, lid 1, van het Handvest. Voor de volledigheid wordt opgemerkt, dat het mogelijk kan zijn dat Uniegrondrechten in het algemeen ingevolge artikel 51, lid 1, van het Handvest van toepassing zijn, maar dat een specifiek grondrecht dat niet is. ${ }^{7}$

\subsubsection{Gevolgen directe werking}

Zoals is opgemerkt kan de directe werking van een Uniegrondrecht verschillende gevolgen (effecten) hebben in de nationale procedure. Het grondrecht kan dienen als toetsingsmaatstaf voor de rechtmatigheid van een nationale handeling en/of de directe werking van het grondrecht kan leiden tot het aannemen van subjectieve rechten van individuen of verplichtingen van de lidstaten.

\section{Rechtmatigheidstoetsing}

Een voorbeeld van een zaak waarin het grondrecht fungeert als grond voor toetsing van de rechtmatigheid van een nationale handeling is de zaak Eman en Sevinger. ${ }^{8}$ Het ging hier om de toepassing van het algemene gelijkheidsbeginsel

7 Bijvoorbeeld artikel 42 (recht van inzage in documenten). Een ander voorbeeld is artikel 41 van het Handvest (recht op behoorlijk bestuur) dat niet tot de lidstaten maar uitsluitend tot de instellingen en organen van de Unie is gericht. Deze bepaling van het Handvest is daarom ratione personae niet van toepassing op de Lid-Staten. Maar artikel 41 van het Handvest vormt wel een 'afspiegeling" van een algemeen beginsel van Unierecht dat wel van toepassing is op de lidstaten. Relevante rechtspraak: HvJEU van 21 december 2011, zaak C-482/10, Cicala, punt 28; HvJEU van 22 november 2012, zaak C-277/11, M.M., punten 81-84; A-G Bot van 26 april 2012, zaak C-277/11, M.M., punt 32; HvJEU van 8 mei 2014, zaak C $\square 604 / 12$, H.N., punt 49; A-G Sharpston van 12 december 2013, gevoegde zaken C-141/12, C-372/12, Y.S., punten 86-88. Anders: A-G Wathelet van 25 juni 2014, zaak C $\square 249 / 13$, Boudjlida, punt 47: "Het lijkt mij niet coherent noch in overeenstemming met de rechtspraak van het Hof dat de bewoordingen van artikel 41 van het Handvest aldus een uitzondering op de in artikel 51 ervan geformuleerde regel zouden kunnen introduceren, op grond waarvan de lidstaten een artikel van het Handvest buiten toepassing zouden mogen laten, zelfs wanneer zij het Unierecht ten uitvoer brengen. Het verdient in mijn ogen dan ook duidelijk de voorkeur om de lidstaten aan artikel 41 van het Handvest gebonden te achten wanneer zij het Unierecht ten uitvoer brengen. Zoals de Franse regering opmerkt, is het recht om te worden gehoord volgens vaste rechtspraak echter hoe dan ook een algemeen beginsel van het Unierecht, dat „niet alleen onder het in artikel 41 van het Handvest neergelegde recht op behoorlijk bestuur valt, maar ook onder de in de artikelen 47 en 48 van het Handvest gewaarborgde rechten van verdediging en het recht op een eerlijk proces”. Het recht om te worden gehoord dient dus in elk geval om die reden te worden geëerbiedigd door de autoriteiten „,van alle lidstaten wanneer zij beslissingen nemen die binnen de werkingssfeer van het Unierecht vallen”." Zie over artikel 41 van het Handvest: Bousta 2013; Hofmann \& Mihaescu 2013. 
op het deel van de Nederlandse Kieswet dat voorzag in het actief en passief kiesrecht voor de verkiezingen van het Europees Parlement. Op grond van de Nederlandse wet werd ten aanzien van Nederlandse onderdanen die niet op het grondgebied van Nederland verblijven onderscheid gemaakt tussen ingezetenen van de Nederlandse Antillen of van Aruba, en ingezetenen van een derde land. De eerste groep genoot geen kiesrecht en de tweede groep wel. Het Hof oordeelde dat het beginsel van gelijke behandeling eraan in de weg staat dat de gekozen criteria meebrengen dat onderdanen die zich in vergelijkbare situaties bevinden, zonder objectieve rechtvaardiging ongelijk worden behandeld.

In het algemeen dienen nationale rechters regelingen die onverenigbaar zijn met het Unierecht buiten toepassing te laten. Deze verplichting geldt ook voor bepalingen die in strijd zijn met Uniegrondrechten (mits de Uniegrondrechten van toepassing zijn). ${ }^{9}$ Hierop zijn ook uitzonderingen mogelijk. Zo oordeelde het Hof over schendingen van het recht om te worden gehoord in Kamino als volgt: 10

"78. Zoals de Commissie heeft opgemerkt, brengt de verplichting van de nationale rechter om de volle werking van het Unierecht te waarborgen niet mee dat een beschikking die wordt aangevochten omdat zij is vastgesteld in strijd met de rechten van de verdediging, in het bijzonder het recht om te worden gehoord, altijd nietig dient te worden verklaard.

79. Schending van de rechten van de verdediging, in het bijzonder het recht om te worden gehoord, leidt naar Unierecht immers pas tot nietigverklaring van het na afloop van de betrokken administratieve procedure genomen besluit, wanneer deze procedure zonder deze onregelmatigheid een andere afloop had kunnen hebben $(. .$.

80. Bijgevolg leidt schending van het beginsel van eerbiediging van de rechten van de verdediging slechts tot nietigverklaring van het betrokken besluit indien de procedure zonder deze schending een andere afloop had kunnen hebben.”

In zaken waarin het gaat om nationale wetgeving die onverenigbaar is met het gelijkheidsbeginsel hanteert het Hof bovendien als regel dat de benadeelde groep in dezelfde situatie moet worden gebracht als de bevoordeelde groep. Het Hof oordeelde in het arrest Rodríguez Caballero als volgt: ${ }^{11}$

9 A-G Bot van 2 april 2014, zaak C-112/13, A/B, punt 61.

10 HvJEU van 3 juli 2014, gevoegde zaken C $\square$ 129/13 en C $\square$ 130/13, Kamino; Zie ook het hierna te bespreken arrest HvJEU van 10 september 2013, zaak C-383/13 PPU, G. en R., punten 37-39.

11 HvJEU van 12 december 2002, zaak C-442/00, Rodríguez Caballero. Dat deze stelregel van het Hof ook lastig kan zijn blijkt uit A-G Bot van 28 november 2013, gevoegde zaken C-501/12 tot en met C-506/12, C-540/12 en C-541/12, Specht, punten 93-108, het ging 
“42. Wanneer een met het gemeenschapsrecht strijdige discriminatie is vastgesteld, kan, zolang er geen maatregelen zijn getroffen om deze discriminatie op te heffen, de eerbiediging van het gelijkheidsbeginsel alleen worden verzekerd door de leden van de benadeelde groep dezelfde voordelen toe te kennen als de leden van de bevoordeelde groep genieten.

43. In een dergelijk geval dient de nationale rechter elke nationale discriminerende bepaling buiten beschouwing te laten, zonder dat hij de opheffing ervan door de wetgever heeft te vragen of af te wachten, en dient hij op de leden van de door die discriminatie benadeelde groep dezelfde regeling toe te passen als op de andere werknemers (...)”

Soms nemen gedane zaken geen keer. In de zaak Eman en Sevinger vroeg de Raad van State of het Unierecht eisen stelt aan de aard van het te bieden rechtsherstel, indien de nationale rechter tot het oordeel zou komen dat personen ten onrechte uitgesloten zijn geweest van Europees Parlement verkiezingen die al achter de rug zijn. ${ }^{12}$ Het Hof antwoordde dat het aan de rechtsorde van elke lidstaat staat om de rechtsmiddelen vast te stellen voor het rechtsherstel. Deze middelen, die een vergoeding kunnen omvatten van de schade die is veroorzaakt door de aan de staat toe te rekenen schending van het gemeenschapsrecht, moeten de beginselen van gelijkwaardigheid en doeltreffendheid eerbiedigen.

Een ander voorbeeld waarin het gaat om de toetsing van een nationale regeling aan Uniegrondrechten is de zaak Steffensen. ${ }^{13}$ Het ging om de toetsing van een nationale regeling inzake bewijsvoering aan artikel 6 EVRM ( recht op een eerlijk proces voor een rechterlijke instantie) als algemeen beginsel van Unierecht. Over de gevolgen van de directe werking van dit Uniegrondrecht oordeelde het Hof:

“79. Indien de verwijzende rechter tot het oordeel zou komen dat de aanvaarding als bewijsmiddel van de in het hoofdgeding aan de orde zijnde analyseresultaten schending van het beginsel van hoor en wederhoor en derhalve van het recht op een eerlijk proces tot gevolg heeft, zou hij deze resultaten als bewijsmiddel moeten uitsluiten om die schending te voorkomen.”

hier om leeftijdsdiscriminatie waarbij het identificeren van twee groepen moeilijker is dan bijvoorbeeld het geval is in geslachtsdiscriminatie-zaken.

12 HvJEU van 12 september 2006, zaak C-300/04, Eman en Sevinger, punten 56-61.

13 HvJEU van 10 april 2003, zaak C-276/01, Steffensen. Zie voor samenvatting paragraaf 4.5.1.1. 
Subjectieve rechten voor particulieren of verplichtingen voor de lidstaten Het arrest Wachauf is een voorbeeld van een zaak waarin de toepassing van het recht op eigendom en het recht op vrije beroepsuitoefening, een Uniegrondrecht, leidde tot de verplichting voor de lidstaat tot toekenning van een compensatie. ${ }^{14}$ Het arrest M.M. is een recenter voorbeeld van een zaak waarin de directe werking van het grondrecht leidde tot het aannemen van een verplichting voor de lidstaat. ${ }^{15}$ In deze zaak ging het om het recht om te worden gehoord in het kader van de behandeling van een door een Rwandese onderdaan krachtens Richtlijn 2004/83/EG ingediend verzoek om subsidiaire bescherming. Deze subsidiaire bescherming wordt verleend aan elke onderdaan van een derde land die niet voor de vluchtelingenstatus in aanmerking komt, maar ten aanzien van wie er zwaarwegende gronden bestaan om aan te nemen dat hij, wanneer hij naar zijn land van herkomst terugkeert, een reëel risico loopt op ernstige schade. In bijna alle lidstaten bestaat een zogenaamd 'één-loket"-stelsel waarbij verzoeken om asiel en subsidiaire bescherming in een procedure worden behandeld. In Ierland werd echter gebruik gemaakt van twee onderscheiden en op elkaar volgende procedures voor de behandeling van het asielverzoek respectievelijk het verzoek om subsidiaire bescherming. Bij de behandeling van het tweede verzoek (het verzoek om subsidiaire bescherming) en vóór de afwijzing ervan, werd betrokkene niet opnieuw gehoord, op grond dat hij, reeds was gehoord in het kader van de procedure inzake zijn eerste verzoek strekkende tot toekenning van de vluchtelingenstatus. De verwijzende rechter wenste van het Hof te vernemen of het Unierecht de bevoegde autoriteit verplicht om, alvorens een afwijzende beslissing te nemen nadat reeds een asielaanvraag is afgewezen, de gegevens mee te delen op basis waarvan zij deze beslissing wil nemen en aanvrager te horen. $\mathrm{Nu}$ deze plicht niet volgde uit het van toepassing zijnde secundaire recht werd de vraag beantwoord op grond van de artikelen 47 en 48 van het Handvest (eerbiediging van de rechten van de verdediging) en artikel 41, lid 2, van het Handvest (recht op behoorlijk bestuur).

Het Hof oordeelde ten aanzien van het recht om te worden gehoord dat:

"85. (...) dit recht van toepassing is in iedere procedure die tot een bezwarend besluit kan leiden (...)

86. Volgens de rechtspraak van het Hof moet dit recht worden geëerbiedigd, ook al voorziet de toepasselijke wetgeving niet uitdrukkelijk in een dergelijke formaliteit (...).”

14 HVJEU van 13 juli 1989, zaak 5/88, Wachauf, punt 22. Zie voor een samenvatting van dit arrest paragraaf 3.3.5.2.

15 HvJEU van 22 november 2012, zaak C-277/11, M.M., punt 86. Zie ook HvJEU van 18 december 2008, zaak C-349/07, Sopropé, punt 38. 
In het arrest Kamino overwoog het Hof als volgt over het recht om te worden gehoord: 16

“34. Uit de voorgaande overwegingen volgt niet alleen dat de nationale bestuursorganen verplicht zijn om de rechten van de verdediging te eerbiedigen wanneer zij besluiten nemen die binnen de werkingssfeer van het Unierecht vallen, maar ook dat de belanghebbenden zich voor de nationale rechter rechtstreeks op de eerbiediging ervan moeten kunnen beroepen.

35. Bijgevolg moet op de eerste vraag worden geantwoord dat op het beginsel van eerbiediging door de administratie van de rechten van de verdediging en het daaruit voortvloeiende recht van eenieder om te worden gehoord alvorens een besluit wordt genomen dat zijn belangen op nadelige wijze kan beïnvloeden, zoals die gelden in het kader van het douanewetboek, door particulieren rechtstreeks een beroep kan worden gedaan voor de nationale rechter.”

Voor wat betreft de gevolgen die moeten worden verbonden aan schending van het recht om te worden gehoord, wordt gewezen op het arrest G. en R. ${ }^{17}$ Deze zaak betrof een prejudiciële verwijzing van de Raad van State in een geschil tussen twee illegaal in Nederland verblijvende onderdanen van derde landen, en de Staatssecretaris van Veiligheid en Justitie over de rechtmatigheid van maatregelen tot verlenging van hun bewaring, die zijn genomen krachtens de Terugkeerrichtlijn (richtlijn 2008/115/EG) in het licht van artikel 41, lid 2, sub a, van het Handvest (het recht om te worden gehoord). Aan de inhoudelijke voorwaarden voor de verlenging van de opgelegde bewaringsmaatregelen was voldaan. Bij de totstandkoming van deze maatregelen waren de rechten van verdediging echter geschonden. De Raad van State vroeg aan het Hof welke gevolgen aan een dergelijke schending zouden moeten worden verbonden; diende de bewaring zonder meer en in alle gevallen te worden opgeheven? Het Hof bepaalde dat niet elke schending van het recht om te worden gehoord automatisch en verplicht zou moeten leiden tot de nietigverklaring van het litigieuze besluit (in casu zou dat leiden tot de opheffing van een vreemdelingenbewaring). De nationale rechter beschikt in dit geval over een beoordelingsbevoegdheid en moet nagaan of de administratieve procedure een andere afloop had kunnen hebben. ${ }^{18}$

16 HvJEU van 3 juli 2014, gevoegde zaken C $\square$ 129/13 en C $\square$ 130/13, Kamino.

17 HvJEU van 10 september 2013, zaak C-383/13 PPU, G. en R., punten 37-39.

18 Zie ook HvJEU van 3 juli 2014, gevoegde zaken $C \square 129 / 13$ en C $\square$ 130/13, Kamino, punten 74-80. 
Tot slot wordt gewezen op de zaak $D E B$ als voorbeeld dat duidelijk maakt dat een Uniegrondrecht direct rechten kan creëren. ${ }^{19}$ Het Hof verklaarde voor recht:

"Het in artikel 47 van het Handvest van de grondrechten van de Europese Unie neergelegde beginsel van daadwerkelijke rechterlijke bescherming moet aldus worden uitgelegd dat het niet is uitgesloten dat daarop door rechtspersonen een beroep wordt gedaan, en dat de overeenkomstig dit beginsel verleende bijstand onder meer de vrijstelling van betaling van het voorschot op de proceskosten en/of de bijstand door een advocaat kan behelzen."

\subsection{Toetsingskader voor de legitimiteit}

\subsubsection{Algemeen}

In dit deel van het proefschrift ligt de aandacht op de vraag in welke situaties sprake is van verticale directe werking. Dit wordt in kaart gebracht op basis van een analyse van de rechtspraak van het Hof. Tevens wordt bekeken of de rechtspraak legitiem is en wel met name hoe het zich verhoudt met het beginsel van allocatie van bevoegdheden. Met het oog op die analyse wordt in deze paragraaf een toetsingskader geformuleerd. Zoals zal blijken vormt artikel 51, lid 1, van het Handvest de basis van het toetsingskader. Het is daarom noodzakelijk om dieper in te gaan op de betekenis van deze bepaling.

\subsubsection{Samenhang tussen gebondenheid en directe werking}

De eerste stap in het onderzoek naar de legitimiteit van verticale directe werking is de vaststelling dat het bestaan van directe werking impliceert dat sprake is van bindende (dwingende) rechtsregels. Binnen het Unierecht gaan gebondenheid en directe werking hand in hand. Directe werking is alleen mogelijk als de rechtspartij tegen wie de rechtsnorm wordt ingeroepen gebonden is aan die rechtsnorm. Andersom impliceert deze gebondenheid in beginsel de mogelijkheid van directe werking. Directe werking fungeert als het middel bij uitstek om de effectieve en uniforme toepassing van de dwingende rechtsnorm te verzekeren. Dit samenspel tussen 'directe werking' en 'gebondenheid' komt bijvoorbeeld terug in de rechtspraak over de (verticale) directe werking van richtlijnen. ${ }^{20}$ In het arrest Van Duyn oordeelde het Hof als volgt: ${ }^{21}$

19 HvJEU van 22 december 2010, zaak C-279/09, DEB. Zie voor samenvatting van dit arrest paragraaf 4.5.1.1.

20 Zie ook Prechal 2005, p. 218-220. 
“12. (...) Dat het met de dwingende werking, die in artikel 189 aan de richtlijn wordt toegekend, onverenigbaar ware indien men in beginsel zou uitsluiten dat een daarbij opgelegde verplichting kan worden ingeroepen door personen op wie zij betrekking heeft"

Voor de vraag naar de legitimiteit van verticale directe werking van Uniegrondrechten is derhalve primair van belang of de Uniegrondrechten dwingend (kunnen) zijn voor de lidstaten. Zoals al eerder is opgemerkt kunnen de beide bronnen van Uniegrondrechten (het Handvest en de algemene beginselen van Unierecht) dwingende werking hebben voor de lidstaten, maar is deze dwingende werking beperkt tot specifieke situaties. Verticale directe werking is in die situaties derhalve legitiem. De vraag is dan ook wat de relevante toetsingscriteria zijn om te bepalen om welke situaties het gaat.

\subsubsection{Artikel 51, lid 1, van het Handvest als vertrekpunt}

Het logische vertrekpunt voor de beantwoording van de vraag in welke situaties de lidstaten gebonden zijn aan Uniegrondrechten is artikel 51, lid 1, van het Handvest. Hierin wordt bepaald wanneer de bepalingen van het Handvest zijn gericht tot de lidstaten; namelijk "uitsluitend wanneer zij het recht van de Unie ten uitvoer brengen”. De Toelichting verduidelijkt dat het moet gaan om het optreden van de lidstaten "binnen het toepassingsgebied van het recht van de Unie”. Hierbij wordt verwezen naar een viertal arresten inzake het toepassingsgebied van grondrechten uit hoofde van de algemene beginselen van Unierecht: Wachauf, Karlsson, ERT en Annibaldi. ${ }^{22}$ Voorts is van belang, dat het Handvest het toepassingsgebied van het recht van de Unie niet verder uitbreidt dan de bevoegdheden van de Unie reiken, geen nieuwe bevoegdheden of taken voor de Unie, schept en ook geen wijziging aanbrengt in de Verdragen omschreven bevoegdheden en taken (artikel 6, lid 1, VEU en artikel 51, lid 2, van het Handvest). De grenzen van artikel 51, lid 1, van het Handvest zijn derhalve bepalende voor de legitimiteit van de directe werking van grondrechten. Uit deze bepaling en de Toelichting erop kan het volgende worden afgeleid.

21 HvJEU van 4 december 1974, zaak 41/74, Van Duyn. Zie ook HvJEU van 26 februari 1986, zaak 152/84, Marshall, punt 47 en HvJEU van 14 juli 1994, zaak C $\square 91 / 92$, Faccini Dori, punt 22; HvJEU van 8 april 1976, zaak 43/75, Defrenne II, punten 39-40 (over een Verdragsbepaling).

22 HVJEU van 13 juli 1989, zaak 5/88, Wachauf; HvJEU van 13 april 2000, zaak C-292/97, Karlsson, punt 37; HvJEU van 18 juni 1991, zaak C-260/89, ERT; HvJEU van 18 december 1997, zaak C-309/96, Annibaldi. 


\section{EU-aanknoping vereist}

Ten eerste blijkt dat het Handvest niet zelfstandig (dat wil zeggen automatisch op elk overheidshandelen) kan worden toegepast. ${ }^{23}$ Er moet steeds een onderscheid worden gemaakt tussen een Unierechtelijke context waarin het Handvest wel van toepassing is en zuiver nationale situaties waarin het Handvest niet van toepassing is. ${ }^{24}$ Artikel 51, lid 1, van het Handvest maakt duidelijk dat er een band moet bestaan tussen de nationale handeling en een specifieke regel van materieel Unierecht. De aanwezigheid van een (andere) aanknoping met het Unierecht is dus een minimumvereiste voor de toepassing van het Handvest. Voor wat betreft de doorwerking in het nationale recht hebben Uniegrondrechten derhalve een accessoir karakter; ze werken niet alleen, los, of zelfstandig door, maar hand in hand met materieel Unierecht. ${ }^{25}$ Situaties waarin geen andere (materiële) aanknoping met het Unierecht is, zijn zuiver nationaal; de toepassing van de grondrechten van de Unie is dan niet aan de orde.

\section{Codificatie van de rechtspraak inzake de algemene beginselen van Unierecht}

Ten tweede is het toepassingsgebied van het Handvest geen verruiming of verenging ten opzichte van het toepassingsgebied van de algemene rechtsbeginselen. Integendeel, artikel 51 van het Handvest is een codificatie van de rechtspraak inzake de toepassing op nationale handelingen van de algemene rechtsbeginselen. ${ }^{26}$ De Toelichting verwijst immers naar deze rechtspraak. Aldus wordt een parallel getrokken tussen het toepassingsgebied van de twee Unierechtelijke bronnen van grondrechten (Handvest en algemene rechtsbeginselen). ${ }^{27}$ De toepassingsgebieden van de beide bronnen is dus gelijk. De

23 Met 'zelfstandige toepassing' van het Handvest wordt bedoeld 'toepassing onafhankelijk van een andere bepaling van materieel Unierecht'. Zie ook A-G Sharpston die zich aldus uitdrukt, dat het Handvest geen 'losstaande grondrechten verleent'. A-G Sharpston van 12 december 2013, zaak C-456/12, O, punt 60. De term 'zelfstandige toepassing' moet worden onderscheiden van het gebruik van het Handvest als 'zelfstandige grond voor toetsing'. Hiermee wordt bedoeld de 'directe werking' van het Handvest.

24 Aldus ook: Groussot, Pech, en Petursson 2011, p. 16 en p. 23: "What is nevertheless crystal-clear is that the Charter cannot enable the European Court of Justice to function in a way similar to operation of the US Supreme Court, that is, to define a "federal" standard against which all national rules may be evaluated and eventually set aside."; Kokott en Sobotta 2010, p. 6: "One could dare to think that it might harmonize the fundamental rights for the entire European Union. In this case all of its rights, freedoms and principles could benefit any citizen of the union under any circumstance. However, it is exactly this comprehensive application which is not intended."

25 Zie ook A-G Sharpston van 22 mei 2008, zaak C-427/06, Bartsch, punt 73.

26 A-G Kokott van 6 juni 2013, zaak C-276/12, Sabou, punt 38.

27 A-G Cruz Villalón van 12 juni 2012, zaak C-617/10, Åkerberg Fransson, punt 25. 
rechtspraak inzake de algemene rechtsbeginselen kan derhalve worden toegepast bij de uitleg van artikel 51, lid 1, Handvest en vice versa. Het Hof heeft de parallel tussen de toepassingsgebieden van de beide rechtsbronnen bevestigd in het arrest Åkerberg Fransson. ${ }^{28}$ De unificatie van het toepassingsgebied van de algemene rechtsbeginselen en het Handvest is vanuit het oogpunt van de coherente en eenduidige bescherming van Unierechtelijke grondrechten een logische en wenselijke keuze. ${ }^{29}$

Voor wat betreft het gebruik van de rechtspraak van het Hof inzake de algemene rechtsbeginselen kan overigens breed worden gekeken; naast de rechtspraak inzake de subcategorie van de grondrechten is ook rechtspraak inzake andere algemene rechtsbeginselen relevant. De werkingssfeer van alle algemene beginselen van Unierecht is namelijk gelijk. Het Hof maakt geen onderscheid naar gelang het betrokken rechtsbeginsel. Dit is ook logisch. Een graduele toepasbaarheid strookt niet met het karakter van algemene beginselen die allen een uitdrukking zijn van het rechtstaatbeginsel en die als bijzondere eigenschap hebben 'algemeen' van toepassing te zijn binnen het rechtssysteem van de Unie. Hun bereik is in principe niet beperkt tot specifieke gebieden of situaties. ${ }^{30}$ Dit betekent, dat bij het onderzoek naar de toepassing van Unierechtelijke grondrechten uit hoofde van algemene beginselen van Unierecht op nationale handelingen ook de rechtspraak inzake andere algemene rechtsbeginselen (bijvoorbeeld het evenredigheidsbeginsel) in aanmerking kan worden genomen. 31

\section{Bindend criterium = uitvoering van Unierecht = binnen het toepassingsgebied van Unierecht}

Ten derde geldt als het bindende criterium voor de toepassing van Uniegrondrechten op nationale handelingen, dat de betreffende nationale handeling het

28 HvJEU van 26 februari 2013, zaak C-617/10, Åkerberg Fransson, punten 17-19; zie ook HvJEU van 10 juli 2014, zaak C-198/13, Julian Hernández, punt 33: “ Zoals blijkt uit de toelichting bij artikel 51 van het Handvest (...) bevestigt het in artikel 51 gebruikte begrip "ten uitvoer brengen" de vóór de inwerkingtreding van het Handvest ontwikkelde rechtspraak van het Hof over de toepassing van de grondrechten van de Unie als algemene rechtsbeginselen van het Unierecht (arresten Wachauf, 5/88, EU:C:1989:321; ERT, C-260/89, EU:C:1991:254, en Annibaldi, C-309/96, EU:C:1997:631)”.

29 Zie over de coherente toepassing van de twee bronnen van Unierechtelijke grondrechten A-G Trstenjak van 8 september 2011, zaak C-282/10, Dominguez, punten 127-132.

$30 \mathrm{Al}$ zijn sommige rechtsbeginselen naar hun aard beperkt tot bepaalde deelgebieden van het recht, zoals bijvoorbeeld de beginselen 'ne bis in idem' en 'pacta sunt servanda'.

31 Zie ook Prechal, De Vries \& Van Eijken 2010, p. 216. Anders: Jacobs 2001, p. 337. Hij meent dat de verschillende algemene beginselen, gezien hun diverse karakter, een verschillende werkingsfeer zouden moeten kunnen hebben. 
Unierecht 'ten uitvoer brengt'. Uit de Toelichting kan worden afgeleid dat alle maatregelen die 'binnen het toepassingsgebied' van het Unierecht kwalificeren als 'uitvoering'. Ook dit wordt bevestigd door het arrest Åkerberg Fransson: ${ }^{32}$

"21. De door het Handvest gewaarborgde grondrechten moeten dus worden geëerbiedigd wanneer een nationale regeling binnen het toepassingsgebied van het Unierecht valt, zodat er geen gevallen kunnen zijn waarin het Unierecht geldt zonder dat die grondrechten toepassing vinden. Wanneer het Unierecht toepasselijk is, impliceert dit dat de door het Handvest gewaarborgde grondrechten toepassing vinden.”

Het toepassingsgebied van de algemene beginselen op nationale handelingen wordt in de rechtspraak ook wel beschreven in bewoordingen als 'binnen het kader van het Unierecht' en 'binnen de werkingssfeer van het Unierecht'.

\section{Lijnen Wachauf en ERT doorslaggevend}

De vraag rijst vervolgens wanneer een nationale regeling binnen het toepassingsgebied van het Unierecht valt. Waar ligt nu de scheidslijn tussen Unierechtelijke situaties en een zuiver nationale context? Uit de pre-Handvest doctrine komt niet één concreet en helder toetsingscriterium naar voren. In plaats daarvan wordt gebruik gemaakt van het omschrijven van categorieën van situaties waarin de algemene rechtsbeginselen van toepassing zijn op nationale handelingen. Meestal gaat het om drie categorieën van nationale maatregelen waarop de algemene beginselen van Unierecht van toepassing worden geacht. ${ }^{33}$ De categorieën worden door de verschillende auteurs weliswaar anders gedefinieerd, maar geven als algemeen beeld dat sprake is van twee bestendigde categorieën; een eerste categorie op basis van het arrest Wachauf, ${ }^{34}$ die ziet op nationale maatregelen die Unierecht uitvoeren. Waarbij de ene auteur uitgaat van een ruime uitleg (uitvoering in ruime zin) en de andere van een enge uitleg (enkel omzetting in de klassieke zin van het woord). De tweede bestendigde categorie vloeit voort uit het arrest ERT.35 De rode draad is hier de toepassing van Unierechtelijke rechtvaardigingsgronden. Voorts worden de arresten Garage Molenheide en Karner in de doctrine over het algemeen gezien als

32 HvJEU van 26 februari 2013, zaak C-617/10, Åkerberg Fransson; zie ook HvJEU van 26 september 2013, zaak C-418/11, Texdata Software, punt 73.

33 Zie bijvoorbeeld Tridimas 2006 blz. 37-42; A-G Sharpston van 22 mei 2008, zaak C $\square$ 427/06, Bartsch, punt 69; Prechal 2010-1, p. 8-11; A-G Bot van 5 april 2011, zaak C108/10, Scattolon, punt 110 en bijbehorende voetnoot 59. Zie voor een overzicht van de omschrijvingen van de categorieën: De Mol 2012-2, p. 12-14.

34 HVJEU van 13 juli 1989, zaak 5/88, Wachauf.

35 HvJEU van 18 juni 1991, zaak C-260/89, ERT. 
indicatief voor het mogelijke bestaan van nog een derde categorie. Een categorie die in tegenstelling tot de eerste twee categorieën nog niet is bestendigd, laat staan is uitgekristalliseerd.

Uit artikel 51, lid 1, van het Handvest volgt mijns inziens dat slechts sprake is van twee categorieën van uitvoering. Dit leid ik af uit de Toelichting die verwijst naar vier arresten inzake de algemene beginselen van Unierecht: Wachauf, Karlsson, ERT en Annibaldi.

Enerzijds kan uit de verwijzing naar Wachauf en ERT (Karlsson is een bevestiging van Wachauf) worden afgeleid dat de beide situaties van toepasselijkheid van Uniegrondrechten op nationale handelingen onder artikel 51, lid 1, van het Handvest vallen. ${ }^{36}$ Overigens merk ik op, dat in de doctrine twijfel is geuit over of de $E R T$-situatie onder artikel 51, lid 1, van het Handvest zou kunnen worden gebracht. ${ }^{37}$ Ook hebben sommige regeringen voor het Hof bepleit dat de ERTsituatie niet onder artikel 51, lid 1, van het Handvest zou moeten vallen. ${ }^{38} \mathrm{Ik}$ acht het gezien de expliciete vermelding van ERT in de Toelichting evident, dat de opstellers van het Handvest de ERT-situatie ook onder artikel 51, lid 1, van het Handvest hebben willen brengen. Dit is ook niet strijdig met het in artikel 51, lid 1, van het Handvest gehanteerde criterium van 'ten uitvoer brengen'. Het in acht nemen van verbodsbepalingen van Unierecht door de lidstaten kan immers evenzeer worden gezien als een vorm van uitvoering van Unierecht. Deze uitleg is inmiddels bevestigd in het arrest Åkerberg Fransson waarin het Hof oordeelde dat het criterium 'ten uitvoer brengen' ruim moet worden geïnterpreteerd en hetzelfde betekent als 'binnen het toepassingsgebied van Unierecht'. Het Hof verwees hierbij ook naar ERT. ${ }^{39}$ In het arrest Pfleger overweegt het Hof expliciet, dat: ${ }^{40}$

“36. (...) Het gebruik door een lidstaat van de in het Unierecht neergelegde uitzonderingen om een belemmering van een door het Verdrag gewaarborgde

36 Aldus ook: Kokott \& Sobotta 2010, p. 7; Van Elsuwege, Devisscher \& Van Bossuyt 2010, punt 14; A-G Trstenjak van 15 mei 2012, zaak C-40/11, Iida, punt 74; Ladenburger 2012, p. 18.

37 Zie bijvoorbeeld Huber 2008, p. 190.

38 Dit blijkt bijvoorbeeld uit A-G Sharpston van 14 november 2013, zaak C-390/12, Pfleger, punt 35-38. Zie ook HvJEU van 30 april 2014, zaak C-390/12, Pfleger, punt 30.

39 HvJEU van 26 februari 2013, zaak C-617/10, Åkerberg Fransson, punten 19 en 21. Vergelijk ook HvJEU van 12 november 2010, zaak C-339/10, Estov, punt 13, HVJEU van 14 december 2011, gevoegde zaken C-483/11 en C-484/11, Boncea, punt 29 en HvJEU van 7 juni 2012, zaak C-27/11, Vinkov, punt 56 waarin de term 'toepassen' (in Franse taalversie: 'appliquer') wordt gehanteerd.

40 HvJEU van 30 april 2014, zaak C-390/12, Pfleger. 
fundamentele vrijheid te rechtvaardigen, moet derhalve (...) worden geacht „het recht van de Unie ten uitvoer [te] brengen” in de zin van artikel 51, lid 1, van het Handvest."

Anderzijds kan uit het aanhaken bij de arresten Wachauf en ERT worden afgeleid dat er buiten deze twee lijnen geen andere situaties denkbaar zijn waarin het Handvest van toepassing is. De opstellers van het Handvest lijken deze mogelijkheid door de verwijzing naar het arrest Annibaldi zelfs nadrukkelijk te hebben willen afwijzen. Deze verwijzing is in een later stadium welbewust toegevoegd en het arrest staat symbool voor verschillende aanknopingen met het Unierecht die niet leiden tot het van toepassing zijn van het Handvest. ${ }^{41}$ Voorts werd in een eerder tekstvoorstel van het Handvest niet gesproken van 'uitvoering van Unierecht', maar van de op het oog bredere term 'binnen de werkingssfeer'. Deze -op het eerste gezicht- bredere term is expliciet vervangen. Daar komt bij dat het moeilijk denkbaar, dat er naast Wachauf en $E R T$-uitvoering nog andere varianten van nationale uitvoering bestaan. ${ }^{42} \mathrm{Ik}$ ga er daarom vanuit dat de lijnen Wachauf en ERT de sleutel vormen voor de uitleg van wanneer sprake is van uitvoering in de zin van artikel 51, lid 1, van het Handvest.

\subsubsection{De betekenis van Wachaufen ERT}

\subsubsection{Algemeen}

$\mathrm{Nu}$ de lijnen Wachauf en ERT de basis vormen van de gebondenheid van de lidstaten aan de grondrechten is het nodig dieper in te gaan op de betekenis van deze arresten. Wanneer voert een nationale maatregel Unierecht uit in de zin van de arresten Wachauf en ERT? Helaas spreekt dit niet voor zich. Er komt geen handzame 'toverformule' uit de arresten of hun opvolgers naar voren. Vooral de lijn Wachauf bevat een brede en op het eerste gezicht onoverzichtelijke waaier van situaties van uitvoering. De vraag rijst op welke wijze de reikwijdte van art. 51, lid 1, Handvest dan preciezer kan worden afgebakend. Ik meen dat dit met name zou moeten geschieden op grond van de gemeenschappelijke ratio van de twee lijnen Wachauf en ERT.

41 Zie verder over totstandkomingsgeschiedenis artikel 51 Handvest: Ladenburger 2012, p. 14-15.

42 Hierbij is met name relevant dat, zoals in hoofdstuk 4 zal blijken, Wachauf-uitvoering een brede waaier aan situaties omvat. Tevens is de ERT-ratio niet beperkt tot vrije verkeersituaties, maar reikt het verder. Dit wordt verder onderbouwd in hoofdstuk 5. 


\subsubsection{Het arrest Wachauf}

Het eerste arrest waaruit blijkt dat de grondrechten van de Unie ook de lidstaten kunnen binden is het arrest Wachauf ${ }^{43}$ In dit arrest ging het (aanvankelijk) om de geldigheid van Verordening 1371/84 met de grondrechten en wel met de name de bepaling op grond waarvan de lidstaten aan pachters van melkproducerende bedrijven aan het einde van de pacht in bepaalde omstandigheden een vergoeding konden toekennen voor het definitief staken van de melkproductie. In het hoofdgeding ging het om een pachter die het door hem opgebouwde melkbedrijf definitief had opgegeven, maar desondanks niet in aanmerking kwam voor een dergelijke vergoeding. De centrale vraag was of de weigering tot toekenning van een vergoeding dwingend uit de verordening voortvloeide en of de weigering strookte met de als algemene rechtsbeginselen erkende - grondrechten.

Het arrest leest in eerste instantie als een arrest waar het Hof de conformiteit van de betreffende Verordening met het eigendomsrecht en het recht op vrije beroepsuitoefening onderzoekt. ${ }^{44}$ Dit is echter slechts de eerste laag. Het Hof oordeelde namelijk dat de weigering onverenigbaar is met de Uniegrondrechten, maar dat de verordening toch in overeenstemming is met de Uniegrondrechten. De reden hiervoor was de vaststelling dat de Verordening de lidstaten voldoende beoordelingsvrijheid bood om de pachters een met de eisen van de bescherming van de grondrechten strokende, adequate vergoeding toe te kennen. Het Hof oordeelde daarom dat de lidstaten verplicht waren om een vergoeding toe te kennen om de toepassing van de verordening in overeenstemming te doen zijn met de Uniegrondrechten. De relevante overwegingen in Wachauf luidden als volgt:

"19. (...) een gemeenschapsregeling die tot gevolg heeft dat de pachter aan het einde van de pacht zonder schadeloosstelling van de vruchten van zijn inspanningen en van zijn investeringen in het gepachte bedrijf zou worden beroofd, [is] onverenigbaar (...) met de eisen van de bescherming van de fundamentele rechten in de communautaire rechtsorde. Aangezien deze eisen de Lid-Staten ook bij de uitvoering van gemeenschapsregelingen binden, zijn de Lid-Staten gehouden, deze regelingen zo veel mogelijk in overeenstemming met bedoelde eisen toe te passen .

$(\ldots)$

43 HVJEU van 13 juli 1989, zaak 5/88, Wachauf, punt 19. Zie ook HvJEU van 13 april 2000, zaak C-292/97, Karlsson, punt 37.

44 Zie punten 23, 24 en dictum. 
22. (...) de beoordelingsvrijheid die de onderhavige gemeenschapsregeling aan de bevoegde nationale autoriteiten heeft gelaten, [is] zodanig ruim dat zij deze regeling in overeenstemming met de uit de bescherming van de fundamentele rechten voortvloeiende eisen kunnen toepassen, hetzij door de pachter zijn referentiehoeveelheid geheel of gedeeltelijk te laten behouden wanneer hij de melkproduktie wil voortzetten, hetzij door hem een vergoeding toe te kennen, wanneer hij zich verbindt deze produktie definitief te staken.”

Cruciaal is derhalve de algemene vaststelling, dat

"de eisen van de bescherming van de fundamentele rechten in de communautaire rechtsorde de Lid-Staten ook bij de uitvoering van gemeenschapsregelingen binden.”

Het Hof gaat niet in op de ratio van deze gebondenheid aan de fundamentele rechten. Kennelijk spreekt het vanzelf, hetgeen ook wordt bevestigd door de conclusie van Advocaat-Generaal Jacobs in de zaak Wachauf die zegt: 45
"22. (...) Het lijkt mij (...) vanzelfsprekend dat op de Lid-Staten, wanneer zij handelen op grond van bevoegdheden die zij an het gemeenschapsrecht ont- lenen, in ieder geval wat het beginsel van de eerbiediging van de fundamentele rechten aangaat, dezelfde verplichtingen rusten als op de gemeenschaps- wetgever."

Het gaat in het arrest Wachauf dus om een gebondenheid van de lidstaten aan Uniegrondrechten in situaties waarin zij optreden als vertegenwoordiger van de Unie. De achterliggende gedachte is, dat daar waar de Unie, uit hoofde van het rechtstaatbeginsel, zelf verplicht is om de fundamentele rechten te eerbiedigen op de lidstaten, in hun hoedanigheid als uitvoerders van Unierecht (Unie -vertegenwoordigers) dezelfde plicht rust. Aldus gaat het in wezen om een van de Unie afgeleide gebondenheid aan de Uniegrondrechten die ertoe dient om de grondrechtconforme toepassing van Unierecht te verzekeren. ${ }^{46}$ Deze gebondenheid van de lidstaten aan de grondrechten is van groot praktisch belang. De uitvoering van Unierecht ligt immers voor het overgrote deel in handen van de lidstaten. ${ }^{47}$ Voorts wordt de conformiteit met de grondrechten van Unierecht in veel gevallen pas werkelijk relevant op het niveau van de

45 A-G Jacobs van 27 april 1989, zaak 5/88, Wachauf. Zie ook Jacobs 2001, p. 333-334.

46 Zie ook Kokott \& Sobotta 2010, p. 7: "the application of the Union's fundamental rights does not aim at an overall harmonization of fundamental rights in the Member States, but rather to ensure a uniform application of other European Union law."

47 Aldus ook: Weiler 1996, p. IV.A: "the Member States often act as, indeed are, the executive branch of the Community". 
concrete toepassing van het Unierecht, dat wil zeggen op het niveau van de toepassing op het nationale niveau. Illustratief is de volgende overweging van het Hof in de zaak Lindqvist: ${ }^{8}$

"85. Het is dus veeleer in het stadium van de concrete toepassing op nationaal niveau van de regeling tot omzetting (...), dat een juist evenwicht tussen de betrokken rechten en belangen moet worden gevonden.

90. (...) Het staat aan de nationale autoriteiten en rechterlijke instanties die belast zijn met de toepassing van de nationale regeling tot omzetting (....) een juist evenwicht te verzekeren tussen de betrokken rechten en belangen, met inbegrip van de door de communautaire rechtsorde beschermde grondrechten.”

\subsubsection{Het arrest ERT}

De zaak ERT betrof een verbodsactie van de Griekse radio- en televisieomroeponderneming ERT (staatsmonopolist) tegen de oprichting van een televisiestation die inbreuk maakt op haar exclusieve rechten. De oprichters van het nieuwe televisiestation beriepen zich onder meer op het vrije verkeer van diensten en op artikel 10 EVRM (de vrijheid van meningsuiting). ${ }^{49}$ Ten aanzien van de toepassing van artikel 10 EVRM oordeelde het Hof als volgt:

"41. Wat artikel 10 van het Europees Verdrag tot bescherming van de rechten van de mens betreft, (...) zij eraan herinnerd, dat de fundamentele rechten volgens vaste rechtspraak integrerend deel uitmaken van de algemene rechtsbeginselen welker eerbiediging het Hof verzekert. (...) Daaruit volgt, zoals het Hof heeft bevestigd in het arrest van 13 juli 1989 (zaak 5/88, Wachauf, Jurispr. 1989, blz. 2609, r.o. 19), dat in de Gemeenschap geen maatregelen kunnen worden toegelaten die zich niet verdragen met de aldus erkende en gewaarborgde rechten van de mens.

(...)

43. In het bijzonder wanneer een Lid-Staat zich beroept op het bepaalde in artikel 56 juncto artikel 66 ter rechtvaardiging van een regeling die de uitoefening van de vrijheid van dienstverrichting kan belemmeren, moet deze door het gemeenschapsrecht geboden rechtvaardigingsgrond worden uitgelegd in het licht van de algemene rechtsbeginselen en met name de fundamentele rechten. Aldus kan de betrokken nationale regeling slechts in aanmerking komen voor de in artikel 56 juncto artikel 66 genoemde

48 HvJEU van 6 november 2003, zaak C-101/01, Lindqvist. Vergelijk ook A-G Bot van 12 juni 2012, zaak C-283/11, Sky Österreich, punt 68.

49 HvJEU van 18 juni 1991, zaak C-260/89, ERT, punten 41-43. 
uitzonderingen, wanneer zij in overeenstemming is met de fundamentele rechten waarvan het Hof de eerbiediging verzekert.

44. Daaruit volgt, dat de nationale rechter, en in voorkomend geval het Hof, in een dergelijk geval de toepassing van die bepalingen dient te toetsen aan alle regels van het gemeenschapsrecht, daaronder begrepen de in artikel 10 van het Europees Verdrag neergelegde vrijheid van meningsuiting, zijnde een algemeen rechtsbeginsel waarvan het Hof de eerbiediging verzekert.”

Uit het arrest ERT en de daarop volgende rechtspraak blijkt, dat de Unierechtelijke grondrechten ook van toepassing zijn op nationale maatregelen die in beginsel in strijd zijn met een verbodsbepaling van Unierecht, maar waarbij de overheid een beroep doet op een Unierechtelijke rechtvaardigingsgrond (hierna ook: 'nationale maatregelen die een beroep doen op een Unierechtelijke rechtvaardigingsgrond'). Zulks omdat deze maatregelen komen 'binnen het toepassingsgebied' van het Unierecht en

"41. (...) in de Gemeenschap geen maatregelen kunnen worden toegelaten die zich niet verdragen met de (...) erkende en gewaarborgde rechten van de mens."

Dit arrest weerspiegelt hiermee dezelfde ratio als in Wachauf; namelijk de grondrechtconforme toepassing van Unierecht. ${ }^{50}$ Daar waar nationale handelingen in overeenstemming moeten zijn met het Unierecht, moeten zij voldoen aan het gehele Unierecht, inclusief de Unierechtelijke grondrechten. ${ }^{51}$ Uit het rechtstaatbeginsel volgt, dat op basis van het Unierecht geen maatregelen kunnen worden toegestaan (gerechtvaardigd) die onverenigbaar zijn met de Unierechtelijke grondrechten. ${ }^{52}$ De gebondenheid kan ook hier dus worden gezien als een afgeleide van de gebondenheid van de Unie zelf aan de grondrechten.

Ondanks deze gemeenschappelijke ratio tussen Wachauf en ERT is er ook een verschil tussen de twee lijnen. De hoedanigheid waarin de lidstaat ingevolge de ERT-lijn wordt benaderd is anders. De lidstaten worden benaderd in hun hoedanigheid als rechtssubject van het Unierecht in plaats van zoals bij Wachauf het geval is, in hun hoedanigheid als vertegenwoordiger van de Unie (vooruitgeschoven Uniepost). Bij ERT gaat het derhalve niet zozeer om de concrete toepassing van Unierecht door de lidstaten als Unievertegenwoordiger,

50 Zie ook Eeckhout 2002, p. 978.

51 Zie ook Lenaerts 2000, p. 590.

52 Zie ook: Weiler 1996, p. IV.B: "the scope of the derogation and the conditions for its employment are all 'creatures' of Community law”. 
maar veeleer om de eerbiediging en toepassing van Unierecht door de lidstaten als rechtssubject van de Unie.

\subsubsection{De grondrechtconforme toepassing van Unierecht als grondslag}

Zoals hierboven uiteen is gezet, is het vertrekpunt in Wachauf \& ERT hetzelfde: de gebondenheid van de Unie aan de grondrechten uit hoofde van het rechtstaatbeginsel, de noodzaak tot de grondrechtconforme toepassing van Unierecht en in het verlengde daarvan de gebondenheid van de lidstaten. ${ }^{53}$ Of korter gezegd: de plicht van de lidstaten om Unierechtelijke grondrechten te eerbiedigen ligt in het verlengde van de plicht van de Unie om dit zelf te doen. Dit gegeven is mijns inziens wezenlijk bij de analyse van artikel 51, lid 1, van het Handvest. Er bestaat geen plicht voor de lidstaten tot eerbiediging van de grondrechten die niet kan worden herleid tot de gebondenheid van de Unie zelf aan de grondrechten. Het is in dit licht dat artikel 51, lid 1, van het Handvest moet worden begrepen. In dit verband wordt gewezen op het arrest Siragusa, waarin het Hof als volgt overwoog: 54

“31. Voorts dient rekening te worden gehouden met de doelstelling van de bescherming van de grondrechten in het Unierecht, te weten ervoor te zorgen dat deze rechten niet worden geschonden op de gebieden waarop de Unie optreedt, ongeacht of dit gebeurt vanwege het optreden van de Unie of vanwege het ten uitvoer brengen van het Unierecht door de lidstaten.

32. Het nastreven van dit doel is ingegeven door de noodzaak te vermijden dat een bescherming van de grondrechten die zou kunnen variëren naar gelang het betrokken nationale recht, afbreuk doet aan de eenheid, de voorrang, en de werking van het Unierecht (zie in die zin arresten van 17 december 1970, Internationale Handelsgesellschaft, 11/70, Jurispr. blz. 1125, punt 3, en 26 februari 2013, Melloni, C-399/11, nog niet gepubliceerd in de Jurisprudentie, punt 60). (...)."

De relevante vraag is steeds deze: is in een gegeven situatie de (grondrechtconforme) toepassing van het Unierecht of Uniehandelen in het geding? Of anders gezegd: is sprake van een situatie waarin materieel Unierecht in het spel is waaraan de betreffende nationale handeling 'uitvoering' of 'toepassing'

53 Zie ook Jacobs 2002, p. 333-334; Eeckhout 2002, p. 978.

54 HvJEU van 6 maart 2014, zaak C-206/13, Siragusa. 
geeft?55 Bij een ontkennende beantwoording van deze vragen geldt dat de toepassing van Uniegrondrechten niet legitiem is wegens bevoegdheidsoverschrijding. Bij een bevestigende beantwoording daarentegen, geldt dat de Uniegrondrechten onvermijdelijk van toepassing zijn. Vandaar ook dat het Hof in Åkerberg Fransson overweegt: ${ }^{56}$

"21. (...) Wanneer het Unierecht toepasselijk is, impliceert dit dat de door het Handvest gewaarborgde grondrechten toepassing vinden."

Er zijn talloze situaties waarin de grondrechtconforme toepassing van het Unierecht in het geding kan zijn. In de hoofdstukken 4 tot en met 6 wordt op grond van een analyse en ordening van de rechtspraak inzake de (niet) toepasselijkheid van algemene beginselen van Unierecht en het Handvest gepreciseerd in welke situaties het Hof Uniegrondrechten (niet) van toepassing acht. Hierbij wordt bijzondere aandacht besteed aan recente rechtspraak en aan de vraag of inderdaad steeds sprake is van een situatie waarin de grondrechtconforme toepassing van het Unierecht in het geding is. Vooruitlopend hierop wordt gewezen op de volgende relevante aanwijzingen:

a. Is een regel van materieel Unierecht in het geding?57 of

b. Is de nationale maatregel terug te herleiden tot een Unierechtelijke verplichting?58 of

c. Dient het Unierecht als 'machtiging' voor een nationale handeling?59 of

d. Is de nationale maatregel anderszins gebaseerd op Unierecht (vindt de nationale handeling zijn grondslag in het recht van de Unie)?60

55 Hieronder valt niet alleen de situatie waarin nationale handelingen toepassing geven, maar situaties waarin nationale handelingen van toepassing zouden moeten zijn. Zie hierover hoofdstuk 4.4.

56 HvJEU van 26 februari 2013, zaak C-617/10, Åkerberg Fransson; zie ook HvJEU van 26 september 2013, zaak C-418/11, Texdata Software, punt 73; Groussot, Pech \& Petursson 2011,p. 1.

57 Zie ook ACA 2011- algemeen rapport, thema C, p. 7, Rechter von Danwitz (HVJEU) and Directeur-Generaal Romero Requena (Juridische Dienst Europese Commissie): “A general, comprehensive criterion concerning the applicability of the Charter ratione materiae was considered not to be feasible. Nonetheless, it was proposed to use the question of whether a situation at hand was "substantively governed by EU law" as an approximate test for the applicability for the Charter."

58 Vergelijk A-G Maduro van 12 september 2007, zaak C-380/05, Centro Europa, punt 20.

59 De ERT-situatie. 


\subsubsection{Verschillende technieken voor grondrechtconforme toepassing}

In de vorige paragraaf is vastgesteld dat de ratio van de directe werking van Uniegrondrechten is de noodzaak tot de grondrechtconforme toepassing van Unierecht. Voor de volledigheid merk ik op de directe werking van grondrechten niet de enige techniek is om het resultaat van een grondrechtconforme toepassing van Unierecht te bewerkstelligen. Hiervoor zijn verschillende technieken die kunnen worden onderverdeeld in enerzijds de toepassing van grondrechten op Uniehandelingen (A) en anderzijds de toepassing van grondrechten op nationale handelingen (B). Binnen de beide varianten A en B kan steeds onderscheid worden gemaakt tussen het gebruik van het grondrecht als instrument van uitleg (1) en het gebruik van het grondrecht als zelfstandige toetsingsmaatstaf (2).

A. Toepassing van Uniegrondrecht op handelingen van de Unie

A. 1 Als instrument van uitleg: de grondrechtconforme uitleg van Unierecht. Hiervan is sprake als het Hof een bepaling van Unierecht, bijvoorbeeld een bepaling van een verordening, uitlegt in het licht van de Unie grondrechten. ${ }^{61}$ Als deze techniek wordt gebruikt dan beïnvloedt het Uniegrondrecht het nationale recht via de toepasselijke materiële Unierechtelijke bepalingen (indirect), en zonder dat de nationale rechter zelf het Uniegrondrecht toepast. De toepassing van het Uniegrondrecht is al geïncorporeerd in de uitleg van het Unierecht zelf.

A.2 Als toetsingsmaatstaf: de toetsing van (de geldigheid van) Unierecht aan Uniegrondrechten

Een Uniegrondrecht kan ook worden gebruikt om de geldigheid van een Unieregeling te toetsen. Indien een Unierechtelijke regeling in strijd is met een Uniegrondrecht, wordt de regeling ongeldig verklaard. De overeenstemming van het Unierecht met de grondrechten wordt ook hier zonder 'tussenkomst' van het nationale recht opgelost. ${ }^{62}$

60 Zie A-G Kokott van 6 juni 2013, zaak C-276/12, Sabou, punt 43: "Indien een lidstaat handelt op de grondslag van het Unierecht, brengt hij in dat opzicht ook Unierecht ten uitvoer, zelfs indien daaruit geen verplichting voor hem voortvloeit.”

61 HvJEU van 29 maart 2012, zaak C-1/11, Interseroh Scrap, punten 41-46; HvJEU van 8 mei 2014, zaak C-329/13, Stefan, punt 32.

62 Zie bijvoorbeeld HvJEU van 9 november 2010, gevoegde zaken C-92/09 en C-93/09, Schecke, punten 53-89. HvJEU van 1 maart 2011, zaak C-236/09, Association Belge des Consommateurs Test-Achats. 
B. Toepassing van Uniegrondrechten op nationale handelingen

B.1 Als instrument van uitleg: grondrechtconforme uitleg nationaal recht

Bij deze variant gaat het om de uitleg van nationaal recht in het licht van Uniegrondrechten. Over het algemeen zal een nationale rechter eerst hiertoe overgaan alvorens over te gaan tot de meer ingrijpende variant B.2.63

B.2 Als toetsingsmaatstaf: de toepassing van Uniegrondrechten door de nationale rechter als zelfstandige toetsingsmaatstaf (=directe werking grondrecht)

Bij deze variant gaat het om de toepassing van Unierechtelijke grondrechten door de nationale rechter als zelfstandige toetsingsmaatstaf van een nationale (rechts)handeling.

De verschillende hierboven genoemde technieken zijn door hun gezamenlijke doelstelling onderling met elkaar verbonden, hetgeen tot uitdrukking komt in de onderlinge wisselwerking. Zo gaat een poging tot het gebruik van het grondrecht als instrument van uitleg (varianten A.1 en B.1) over het algemeen vooraf aan het gebruik als toetsingsmaatstaf. Voorts kan de toepassing van het grondrecht op nationaal niveau (variant B) voorkomen dat moet worden overgegaan tot het ongeldig verklaren van een Unieregeling (variant A.2). Een voorbeeld is het arrest Wachauf dat is behandeld in paragraaf 3.3.4.2. In dit arrest was het vertrekpunt het onderzoek naar de geldigheid van de betreffende verordening. Uiteindelijk werd de verordening geldig geacht juist omdat deze de lidstaten voldoende beoordelingsvrijheid bood om de toepassing van de verordening in overeenstemming te doen zijn met de Uniegrondrechten (variant B.2). Het omgekeerde geldt ook: de omstandigheid dat het Uniegrondrecht is toegepast op de Unieregeling (variant B) kan maken dat aan toepassing op nationaal niveau niet wordt toegekomen. ${ }^{64}$

Voor de afbakening van het onderzoek is het voorts van belang dat de techniek van de directe werking van grondrechten in het nationale recht (variant B.2) heel dicht aan kan liggen tegen de techniek van de uitleg van Unierecht (bijvoorbeeld van een verordening) in het licht van grondrechten (variant A.1). Soms spreekt het Hof zelfs in de termen van uitleg van de Unierechtelijke

63 Zie bijvoorbeeld HvJEU van 15 mei 2014, zaak C135/13, Szatmári Malom, punt 70 (over het gelijkheidsbeginsel). Zie ook de horizontale zaak: HvJEU van 29 januari 2008, zaak C-275/06, Promusicae, punten 68 en 70: In deze zaak maakt het Hof gebruikt van een tweetrapsraket door erop te wijzen dat de lidstaten (1) verplicht zijn om hun nationale recht richtlijnconform uit te leggen en (2) de richtlijn grondrechtconform uit te leggen.

64 HvJEU van 5 oktober 2010, zaak C-400/10 PPU, McB, punt 52. 
regeling, terwijl het in werkelijkheid gaat over autonome toetsing van de nationale uitvoeringsregeling aan het grondrecht. Dit geldt bijvoorbeeld bij de directe werking in ERT-situaties. De directe werking van Uniegrondrechten ligt hier dicht aan tegen de techniek van uitleg van Unierecht in het licht van Uniegrondrechten; namelijk van de uitleg van een Unierechtvaardigingsgrond in het licht van Uniegrondrechten. ${ }^{65}$ Over het algemeen geldt dat daar waar de directe werking (variant B.2) dicht aan ligt tegen de grondrechtconforme uitleg van Unierecht (variant A.1) en daarvan moeilijk is te onderscheiden, vermoedelijk zal zijn voldaan aan de ratio van directe werking (het verzekeren van een grondrechtconforme toepassing van Unierecht). De nationale maatregel is dan zo innig verstrengeld met de Uniemaatregel dat de kwalificatie als uitvoeringsmaatregel van Unierecht in de zin van artikel 51, lid 1, van het Handvest buiten kijf staat.

\subsection{Conclusies}

1. Het concept 'verticale directe werking' betekent in dit proefschrift 'de toepassing van Unierechtelijke grondrechten door de nationale rechter als zelfstandige toetsingsmaatstaf in geschillen tussen de nationale overheden en burgers'. Verticale directe werking kan, afhankelijk van het toepasselijke nationale rechtskader, verschillende gevolgen hebben. Het kan bijvoorbeeld leiden tot de niet-toepasselijkheid van nationale regelgeving of subjectieve rechten en plichten in het leven roepen.

2. Het bestaan van verticale directe werking als zodanig is legitiem uit hoofde van het rechtstaatbeginsel. Het vertrekpunt is de gebondenheid van de Unie aan de Uniegrondrechten en in het verlengde daarvan ligt de gebondenheid van de lidstaten. De uitvoering en toepassing van het Unierecht vindt immers voor een groot deel plaats op het nationale niveau. In situaties die de toepassing van Unierecht betreffen is de gebondenheid van de lidstaten aan de grondrechten van de Unie (en de daarmee gepaard gaande mogelijkheid van verticale directe werking) een noodzakelijk vereiste om te garanderen dat de toepassing van Unierecht in overeenstemming is met deze grondrechten. Verticale directe werking is echter niet legitiem in situaties

65 Een ander voorbeeld die illustratief is voor dat de scheidslijn niet zo strikt is, is HvJEU van 6 juni 2013, zaak C-648/11, MA, punten 57-60: In de punten 58 en 60 lijkt het Handvest te worden gebruikt als instrument van uitleg van de verordening, terwijl in punt 59 sprake is van de directe werking van het grondrecht. Voorts wordt gewezen op HvJEU van 8 mei 2014, zaak C-329/13, Stefan: in deze zaak wijst het Hof zowel op de noodzaak van grondrechtconforme uitleg van Unierecht (punt 32), als op de directe werking van het Unierecht (punt 34). 
waarin de toepassing van Unierecht niet in het geding is (zuiver nationale situaties). Het vorenstaande wordt thans bevestigd in artikel 51, lid 1, van het Handvest.

3. Het is steeds relevant om na te gaan of sprake is van een Unierechtelijke situatie die de toepassing van Uniegrondrechten rechtvaardigt. Leidend criterium is de vraag of sprake is van nationale uitvoering of toepassing van Unierecht. Hierbij kunnen twee hoofdvormen worden onderscheiden: uitvoering in de lijn van het arrest Wachauf en uitvoering in de lijn van het arrest ERT. Wachauf - uitvoering ziet op nationale maatregelen waarmee de lidstaten Unierecht uitvoeren als vertegenwoordigers van de Unie. ERTuitvoering ziet op nationale maatregelen die in beginsel in strijd zijn met een verbodsbepaling van Unierecht, maar waarbij de lidstaat een beroep doet op een Unierechtelijke rechtvaardigingsgrond. De relevante vraag is steeds deze: is in een gegeven situatie de (grondrechtconforme) toepassing van het Unierecht of Uniehandelen in het geding? Of anders gezegd: is sprake van een situatie waarin materieel Unierecht in het spel is waaraan de betreffende nationale handeling 'uitvoering' of 'toepassing' geeft?

4. Overigens is de directe werking van grondrechten niet de enige techniek om het resultaat van een grondrechtconforme toepassing van Unierecht te bewerkstelligen. Hiervoor zijn verschillende technieken die kunnen worden onderverdeeld in enerzijds de toepassing van grondrechten op Uniehandelingen (A) en anderzijds de toepassing van grondrechten op nationale handelingen (B). Binnen de beide varianten A en B kan steeds onderscheid worden gemaakt tussen het gebruik van het grondrecht als instrument van uitleg (1) en het gebruik van het grondrecht als zelfstandige toetsingsmaatstaf (2). 



\section{HOOFDSTUK 4}

\section{WACHAUF -UITVOERING}

\subsection{Algemeen}

In dit hoofdstuk staat het concept 'Wachauf-uitvoering' centraal.' Zoals in het vorige hoofdstuk uiteengezet gaat het in zijn algemeenheid om handelingen waarmee de lidstaten als vertegenwoordiger van de Unie uitvoering geven aan het Unierecht. Het gaat hier om het handen en voeten geven aan Unierecht in nationaal recht. Of anders gezegd: Wachauf-uitvoering betreft de concrete toepassing van Unierecht in de nationale rechtsorde. Uit de rechtspraak die volgt na Wachauf blijkt dat Wachauf-uitvoering vele vormen kan aannemen. In dit hoofdstuk wordt onderzocht op welke wijze het Hof de lijn Wachauf heeft uitgewerkt. Tevens wordt gekeken naar de legitimiteit van de uitwerking van Wachauf in de rechtspraak, en wel met name hoe het zich verhoudt tot het beginsel van de allocatie van bevoegdheden. Hierbij geldt het in het vorige hoofdstuk geformuleerde uitgangspunt, dat de nationale gebondenheid aan de fundamentele rechten legitiem is zolang deze noodzakelijk is om de grondrechtconforme toepassing van Unierecht te waarborgen. ${ }^{2}$ Het moet gaan om de toepassing van Uniegrondrechten op nationale handelingen, die kunnen worden bestempeld als Uniemaatregelen, maar onder nationale vlag. De toepassing van grondrechten op nationale handelingen die niet is te herleiden tot het doel van de grondrechtconforme toepassing van Unierecht levert spanning met het beginsel van de allocatie van bevoegdheden op.

Het concept Wachauf-uitvoering bevat een brede waaier aan situaties waardoor het concept zich moeilijk laat vatten in één precieze definitie die concretiseert waar het om gaat. Het is wel mogelijk om de rechtspraak van het Hof onder te brengen in verschillende subcategorieën van Wachauf-uitvoering. ${ }^{3}$ Allereerst behelzen klassieke omzettingsmaatregelen Wachauf-uitvoering van Unierecht (paragraaf 4.2). Dat wil zeggen nationale maatregelen die op grond van specifieke Unierechtelijke omzettingsverplichtingen worden genomen. Ten

$1 \mathrm{Nu}$ het in de Toelichting bij artikel 51, lid 1, van het Handvest genoemde arrest Karlsson een bevestiging is van Wachauf wordt gesproken van 'Wachauf-uitvoering', 'Wachaufgebondenheid' of 'Wachauf-lijn'.

2 Zie hoofdstuk 3.3.5.

3 Zie voor een classificatie in drie 'triggering rules'(mandating rules, optioning rules en remedial rules): Sarmiento 2013, p. 1280-1285. 
tweede valt onder 'uitvoering' de uitoefening van op grond van Unierecht verleende bevoegdheden (paragraaf 4.3). Dat wil zeggen de uitoefening van bevoegdheden die de lidstaten ontlenen aan het Unierecht. Bijvoorbeeld omdat de Unieregeling voorziet in de mogelijkheid om af te wijken van de implementatieverplichting of voorziet in optionele uitzonderingen op de hoofdverplichting/regel. Overigens is deze tweede categorie van 'uitvoering' niet altijd strikt te onderscheiden van de eerste. Deze twee categorieën tezamen kunnen ook wel worden omschreven als de materiële implementatie. Ten derde zijn de Unierechtelijke grondrechten van toepassing op nationale maatregelen die binnen de werkingssfeer van specifieke materiële bepalingen van Unierecht vallen (paragraaf 4.4). Bij deze categorie gaat het in wezen om het verzuim tot uitvoering. Ten vierde moeten nationale handelingen die dienen ter effectuering, sanctionering of handhaving van Unierecht eveneens worden gekwalificeerd als uitvoeringsmaatregelen. Dit zijn maatregelen die in feite de uitvoering van artikel 4, lid 3, VEU (beginsel van loyale samenwerking) behelzen (paragraaf 4.5). Op basis van het beginsel van loyale samenwerking zijn in de rechtspraak tal van plichten voor lidstaten geconcretiseerd. De meeste ervan komen neer op de plicht om er voor te zorgen dat het Unierecht effectief is. In tegenstelling tot de 'klassieke omzettingsmaatregelen' gaat het hierbij om algemene niet nader gespecificeerde plichten om het Unierecht handen en voeten (en tanden) te geven, waarbij de lidstaten een grote vrijheid genieten die desalniettemin wordt begrensd door de Unierechtelijke grondrechten. De categorie zou ook geduid kunnen worden als 'procedurele implementatie'.

\subsection{Klassieke omzettingshandelingen}

\subsubsection{Analyse van de rechtspraak van het Hof}

In de eerste plaats gaat het bij Wachauf-uitvoering van Unierecht (natuurlijk) om klassieke omzettingsmaatregelen (of implementatie). Dat wil zeggen nationale maatregelen die op grond van specifieke Unierechtelijke omzettingsverplichtingen worden genomen. Het gaat om situaties waarin de lidstaten handelen als vooruitgeschoven posten van de Unie (bijvoorbeeld Uniewetgever, Uniebestuurder of Unierechter). De klassieke omzettingshandelingen van Unieregelingen vormen de meest zuivere en directe vorm van 'uitvoering'.

\section{Verschillende Unieregelingen}

Allereerst is bij deze categorie van belang dat, hoewel de arresten Wachauf en Karlsson beide betrekking hebben op de uitvoering van verordeningen, de Wachauf-gebondenheid aan de fundamentele rechten hiertoe niet is beperkt. Zo kan het ook gaan om de uitvoering van richtlijnen, Verdragsbepalingen of 
externe akkoorden. Dit blijkt reeds uit het gebruik van de term 'regelingen' en wordt bevestigd door latere rechtspraak.

Zo erkende het Hof in het arrest Booker Aquaculture de gebondenheid van lidstaten aan de Unierechtelijke grondrechten expliciet ten aanzien van de omzetting van richtlijnen. ${ }^{4}$ Deze stap is een logisch vervolg op het arrest Wachauf. ${ }^{5}$ De positie van de lidstaat bij de uitvoering van verordeningen is in de kern gelijk aan die bij de implementatie van richtlijnen. In de beide situaties handelen de lidstaten als vooruitgeschoven posten van de Unie (bijvoorbeeld Uniewetgever, Uniebestuurder of Unierechter). ${ }^{6}$ Bovendien kan in geval van implementatiemaatregelen in strijd met Unierechtelijke grondrechten niet worden gezegd dat sprake is van een correcte implementatie. ${ }^{7}$ Een recenter voorbeeld van de toepassing van een Unierechtelijke grondrecht (namelijk van het algemene beginsel van non-discriminatie op grond van leeftijd) op nationale maatregelen die een richtlijn implementeren is het arrest Mangold. In dit arrest ging het om richtlijn 1999/70 inzake arbeidsovereenkomsten voor bepaalde tijd. De richtlijn was in Duitsland omgezet in de wet inzake deeltijdarbeid en overeenkomsten voor bepaalde tijd. Het Hof past op deze wet het algemene beginsel van non-discriminatie op grond van leeftijd toe, omdat de wet als uitvoeringsmaatregel van richtlijn 1999/70 binnen de werkingssfeer van het Unierecht valt. ${ }^{8}$

De eerbiediging van de Unierechtelijke grondrechten geldt ook bij de uitvoering van primair recht (de Verdragen). Dit blijkt uit het arrest Eman en Sevinger. ${ }^{9}$ Het ging hier om de toepassing van het algemene gelijkheidsbeginsel op het deel van de Nederlandse Kieswet dat toepassing gaf aan artikel 19, lid 2, EG (thans artikel 22 VWEU) op grond waarvan iedere EU burger actief en passief kiesrecht heeft voor de verkiezingen van het Europees Parlement in de lidstaat waar hij verblijft 'onder dezelfde voorwaarden als de onderdanen van die staat'. ${ }^{10}$

4 HvJEU van 10 juli 2003, gevoegde zaken C-20/00 en C- 64/00, Booker Aquaculture, punt 88.

5 Zie ook Eeckhout 2002, p. 966; Knook, p. 383.

6 Vergelijk A-G Mischo 20 september 2001, gevoegde zaken C-20/00 en C-64/00, Booker Aquaculture, punten 57 en 58.

7 De Witte 1999, p. 873: "respect for fundamental rights is an implicit part of the result to be achieved' under the directive".

8 HvJEU 22 november 2005, zaak C-144/04, Mangold, punten 16 en 75.

9 HvJEU van 12 september 2006, zaak C-300/04, Eman en Sevinger, punten 56-61.

10 Op grond van de Nederlandse wet wordt ten aanzien van Nederlandse onderdanen die niet op het grondgebied van Nederland verblijf houden onderscheid gemaakt tussen ingezetenen van de Nederlandse Antillen of van Aruba, en ingezetenen is van een derde 
Tot slot dienen de Unierechtelijke grondrechten ook bij de uitvoering van externe verdragen in acht te worden genomen. Een voorbeeld is de uitvoering van Besluit 1/80 van de Associatieraad. ${ }^{11}$ Advocaat-generaal Bot zegt hierover in zaak Dülger 12

34. (...) Op grond van artikel 51, lid 1, ervan zijn deze bepalingen van toepassing wanneer de lidstaten het recht van de Unie ten uitvoer brengen. Zoals het Hof heeft aangegeven in punt 23 van het arrest Kahveci en Inan, is artikel 7 van besluit $\mathrm{nr}$. 1/80 een bestanddeel van de rechtsorde van de Unie en zijn de lidstaten dus aan de ingevolge deze bepaling op hen rustende verplichtingen gebonden op precies dezelfde wijze als zij de in de Unieregeling verankerde rechten moeten eerbiedigen.'

\section{Niet alleen implementatiewetgeving}

Het gaat bij deze categorie niet alleen om de implementatiewetgeving als zodanig maar ook om nationale (bestuurlijke of administratieve) handelingen die daarop zijn gebaseerd. Zij liggen in het verlengde van de implementatie stricto sensu, en moeten daarom ook worden gekwalificeerd als 'uitvoering'. Zo oordeelde het Hof in de zaak M.M. dat de bevoegde autoriteit verplicht is om het algemene beginsel van de eerbiediging van de rechten van de verdediging en het recht op behoorlijk bestuur in acht te nemen in het kader van een verzoek

land. De eerste groep geniet geen kiesrecht en de tweede groep wel. Het Hof oordeelt dat hoewel artikel 19, lid 1 EG zich niet verzet tegen het omlijnen van het actief en passief kiesrecht bij de verkiezingen voor het Europees Parlement op basis van een woonplaatscriterium, het beginsel van gelijke behandeling eraan in de weg staat dat de gekozen criteria meebrengen dat onderdanen die zich in vergelijkbare situaties bevinden, zonder objectieve rechtvaardiging ongelijk worden behandeld.

11 Besluit nr. 1/80 is te vinden in Associatieovereenkomst en protocollen EEG-Turkije en andere basisteksten, Bureau voor officiële publicaties der Europese Gemeenschappen, Brussel, 1992. Zie ook HvJEU van 28 maart 2000, zaak C-7/98, Krombach, punten 18-28 (inzake de toepassing van fundamentele rechten m.b.t. de uitvoering van het Executieverdrag).

12 A-G Bot van 7 juni 2012, zaak C-451/11, Dülger. Zie ook HvJEU van 28 maart 2000, zaak C-7/98, Krombach, punten 18-28; HvJEU van 17 september 2009, zaak C-242/06, Sahin (toepassing evenredigheidsbeginsel op de nationale verplichting van Turkse staatsburgers om leges te betalen voor hunverblijfsvergunning); HvJEU van 29 maart 2012, gevoegde zaken C-7/10 en C-9/10, Kahveci en Inan: "23. Vooraf moet worden vastgesteld dat artikel 7 van besluit nr. 1/80 een bestanddeel van de rechtsorde van de Unie vormt (...). De lidstaten zijn dus aan de ingevolge deze bepaling op hen rustende verplichtingen gebonden op precies dezelfde wijze als zij de in de Unieregeling verankerde rechten moeten eerbiedigen.”. 
tot subsidiaire bescherming uit hoofde van richtlijn 2004/83.13

\section{Beoordelingsruimte}

Voorts dienen de lidstaten de Unierechtelijke grondrechten ook (of juist) te eerbiedigden indien zij beschikken over een beoordelingsruimte. ${ }^{14}$ De Unierechtelijke grondrechten dienen als begrenzing van de beoordelingsruimte. ${ }^{15}$ Dit volgt impliciet al uit de toepasselijkheid van algemene beginselen op de implementatie van richtlijnen. Het bestaan van beoordelingsruimte is immers inherent aan richtlijnen. Ook uit de rechtspraak met betrekking tot verordeningen blijkt dat het bestaan van beoordelingsruimte de toepassing van de algemene rechtsbeginselen niet in de weg staat. ${ }^{16}$ Integendeel, het is juist binnen die beoordelingsruimte dat de lidstaten beschikken over de nodige armslag om de tenuitvoerlegging van Unierecht te verzoenen met de algemene rechtsbeginselen. ${ }^{17}$

13 HvJEU van 22 november 2012, zaak C-277/11, M.M., punten 86 en 89 (zie voor samenvatting van het arrest paragraaf 3.2.2 );Vergelijk A-G Bot van 26 april 2012, zaak C-277/11, M.M., punt 32: "Bijgevolg moet het recht om te worden gehoord in acht worden genomen bij de behandeling door de bevoegde nationale autoriteit van een verzoek om internationale bescherming overeenkomstig de in het kader van het gemeenschappelijk Europees asielstelsel vastgestelde voorschriften.”. Zie verder HvJEU van 18 december 2008, zaak C-349/07, Sopropé, punten 35 en 38 (inzake de bestuurlijke inning van douaneschulden); HvJEU van 22 oktober 2013, zaak C-276/12, Sabou, punt 38 (inzake handelingen van de belastinginspecteur).

14 Met beoordelingsruimte wordt bedoeld de vrijheid van de lidstaten om op eigen wijze vorm te geven aan de implementatieverplichting. Deze vrijheid is niet altijd even goed te onderscheiden van het in de volgende paragraaf besproken bestaan van 'discretionaire bevoegdheden'.

15 Aldus ook A-G Bot van 27 maart 2012, zaak C-83/11, Rahman, punt 68 en 70.

16 HVJEU van 13 juli 1989, zaak 5/88, Wachauf, punt 22; HvJEU 27 juni 2006, zaak C$540 / 03$, EP/Raad, punt 104. Zie voor een andere voorbeelden waarin de algemene rechtsbeginselen beoordelingsruimte beperken: HvJEU van 23 april 2009, gevoegde zaken C-378/07 tot en met C-380/07, Angelidaki, punt 85 (vrijheid om invulling te geven aan de verplichting ex richtlijn 1999/70 om te voorzien in specifieke maatregelen om misbruik als gevolg van opeenvolgende arbeidsovereenkomsten of arbeidsverhoudingen voor bepaalde tijd te voorkomen); HvJEU van 1 december 2011, zaak C-145/10, Painer, punt 105 (beoordelingsvrijheid t.a.v. beperking auteursrechten op basis van openbare veiligheid). Zie ook A-G Bot van 27 september 2012, gevoegde zaken C-356/11 en C357/11, O en S, punten 58-63 (toepassing van artikel 7 van het Handvest (recht op gezinshereniging) op de uitoefening van de beoordelingsmarge uit hoofde van de Gezinsherenigingsrichtlijn, richtlijn 2003/86).

17 Opgemerkt wordt dat indien een Unierechtelijke bepaling geen beoordelingsruimte laat, de toetsing van de nationale maatregel aan Unierechtelijke grondrechten niet aan de orde zal zijn. Veeleer zal het dan gaan om een toetsing van de Uniebepaling aan grondrechten (of grondrechtconforme uitleg) waarbij in het uiterste geval de geldigheid van de 


\section{Impliciete implementatie}

Als het gaat om nationale handelingen die specifiek de implementatie van Unierecht tot doel hebben, zal het over het algemeen niet lastig zijn om een de nationale handeling te identificeren als een 'uitvoeringshandeling' van Unierecht. $\mathrm{Bij}$ implementatie gaat het echter niet alleen om nationale bepalingen die uitdrukkelijk strekken tot de implementatie (expliciete implementatie) van Unierecht. Ook reeds bestaande nationale bepalingen die geschikt zijn ter verzekering van de overeenstemming van het nationale recht met het Unierecht kwalificeren als implementatie. Na inwerkingtreding van de Unieregeling verschieten zij van kleur en worden zij van zuivere nationale tot Unierechtelijke uitvoeringsmaatregelen. ${ }^{18}$ Hetzelfde geldt voor maatregelen die na de eigenlijke omzetting de reeds vastgestelde nationale regels aanvullen of wijzigen. ${ }^{19}$

Een andere mogelijkheid is dat de Unie regeling voor haar toepassing verwijst naar nationaal recht. Bijvoorbeeld doordat een Unierechtelijk begrip is gekoppeld aan het nationale recht (meestal is de koppeling impliciet). Hierdoor fungeert het nationaal recht in de context van de toepassing van de betreffende Unieregeling als (impliciete) implementatie.

Een voorbeeld van een arrest waarin het gaat om de toepassing van het algemene gelijkheidsbeginsel is het arrest Rodríguez Caballero. ${ }^{20}$ In dit arrest stond richtlijn 80/987/EG inzake de bescherming werknemers bij insolventie werkgevers centraal. De richtlijn verplicht de lidstaten tot het instellen van waarborgfondsen die onvervulde loonaanspraken van werknemers honoreren. De lidstaten zijn op grond van de richtlijn vrij om het begrip 'loonaanspraken' te definiëren en de inhoud ervan te bepalen. De mogelijkheid om te bepalen welke uitkeringen onder het waarborgfonds vallen is echter wel onderworpen

betreffende Uniebepaling in het geding kan zijn. Zie in dit verband HvJEU van 29 maart 2012, zaak C-1/11, Interseroh Scrap, punt 46.

18 HvJEU 7 september 2006, zaak C-81/05, Cordero Alonso, punt 29.

19 HvJEU 22 november 2005, zaak C-144/04, Mangold, punten 16 en 19 in samenhang met de punten 51-54 en 75. Nationale maatregelen die een ander doel nastreven, maar die wel dezelfde materie betreffen als de Unieregeling, kwalificeren niet als implementatie.

20 HvJEU van 12 december 2002, zaak C-442/00, Rodríguez Caballero, punten 29-32. Zie ook HvJEU van 16 december 2004, zaak C-520/03, Olaso Valero, punt 34; HvJEU van 13 december 2005, zaak C-177/05, Guerrero Pecino, punten 25 en 26; HvJEU van 24 april 2012, zaak C-571/10, Kamberaj, punten 77, 80 en 92; A-G Bot van 12 juni 2014, zaak C311/13, Tümer, punt 71: "Wanneer, in het kader van de in artikel 2, lid 2, van richtlijn 80/987 opgenomen verwijzing naar het nationale recht, een lidstaat de categorieën werknemers omschrijft waarop deze richtlijn van toepassing kan zijn, brengt hij het Unierecht ten uitvoer en moet hij dus het beginsel van gelijke behandeling en nondiscriminatie in acht nemen." 
aan het algemene gelijkheidsbeginsel (en andere algemene rechtsbeginselen en grondrechten).

Een ander voorbeeld hiervan is het arrest Soukupová. ${ }^{21}$ Deze zaak betrof de nationale uitvoering van verordening 1257/1999 inzake landbouwsteun en meer in het bijzonder de Europese gefinancierde steun voor de vervroegde uittreding van landbouwers. Eén van de voorwaarden die de verordening stelt is, dat de aanvrager de „normale pensioengerechtigde leeftijd” nog niet mag hebben bereikt. Met het begrip "normale pensioengerechtigde leeftijd" wordt (impliciet) verwezen naar de toepasselijke nationale pensioenwetgeving. De Tsjechische nationale wetgeving bevatte een verschil in behandeling op grond van geslacht. In deze zaak overwoog het Hof, dat het niet in overeenstemming is met het algemene gelijkheidsbeginsel dat de „normale pensioengerechtigde leeftijd" in de zin van de Verordening krachtens de nationale pensioenregeling een verschil in behandeling op grond van geslacht bevat. Volgens vaste rechtspraak diende de benadeelde groep in dezelfde situatie worden gebracht als de bevoordeelde groep. Dit zolang geen maatregelen zijn genomen om de gelijke behandeling te herstellen.

\section{Enkel beroep onvoldoende}

Tot slot wordt volledigheidshalve opgemerkt dat het enkele feit dat een beroep wordt gedaan op nationale wetgeving die het Unierecht omzet niet volstaat om de Unie grondrechten te activeren. Hierbij is tevens vereist dat de betreffende implementatiemaatregel (en daarmee het recht van de Unie) werkelijk van toepassing is op de situatie van het hoofdgeding. Dit volgt uit het arrest Iida die in hoofdstuk 6 verder wordt behandeld. ${ }^{22}$ Tevens wordt gewezen op de beschikking Sindicato dos Bancários do Norte die eveneens wordt behandeld in hoofdstuk $6 .{ }^{23}$ Hieruit blijkt dat voorzichtigheid moet worden betracht bij nationale handelingen zijn genomen met het oog op zeer algemene Unieresultaatsverplichtingen.

\subsubsection{Beschouwing in het licht van de allocatie van bevoegdheden}

In hoofdstuk 3 is reeds opgemerkt, dat de Wachauf-gebondenheid aan de fundamentele rechten als zodanig legitiem is. Het gaat immers om de toepassing van Unierechtelijke grondrechten op nationale maatregelen die doordat zij Unierecht uitvoeren in feite kunnen worden gezien als Uniemaatregelen onder

21 HvJEU van 11 april 2013, zaak C-401/11, Soukupová.

22 Zie hoofdstuk 6.3 onder kopje 'Enkel beroep op implementatiewetgeving is niet voldoende'.

23 HvJEU van 7 maart 2013, zaak C-128/12, Sindicato dos Bancários do Norte, punt 12. 
nationale vlag. De klassieke omzettingshandelingen van Unieregelingen vormen de meest zuivere en directe vorm van 'uitvoering'. De Wachauf-ratio (de grondrechtconforme toepassing van Unierecht) is op deze categorie zonder twijfel van toepassing. Er doen zich dan ook geen problemen voor met het oog op de allocatie van bevoegdheden.

Meer in het bijzonder wekt het geen bevreemding dat geen onderscheid gemaakt wordt ten aanzien van de aard van de Unieregeling die wordt omgezet (bijvoorbeeld richtlijn, verordening of verdrag). Evenmin is het discutabel dat de grondrechten van toepassing zijn op zowel expliciete als impliciete omzettingsmaatregelen. Tot slot is het begrijpelijk dat daar waar het Unierecht beoordelingsruimte verschaft deze beoordelingsruimte wordt begrensd door de Unierechtelijke grondrechten. Een andere opvatting zou kunnen leiden tot situaties waarin het Unierecht machtigt tot nationale maatregelen in strijd met Unierechtelijke grondrechten. ${ }^{24}$

Voorts blijkt uit de rechtspraak dat als begrippen in een Unieregeling zijn gekoppeld aan het nationale recht, de betreffende nationale regeling in de context van de toepassing van de Unieregeling de grondrechten van de Unie moet eerbiedigen. Dit kan ingrijpend zijn en gevoelig liggen. Hetgeen wordt geillustreerd door het behandelde arrest Soukupová. ${ }^{25}$ Het ging hier immers om de toepassing van Uniegrondrechten op nationale wetgeving inzake de pensioengerechtigde leeftijd. Dit soort wetgeving behoort tot een gevoelig terrein dat valt binnen de bevoegdheid van de lidstaten. De lidstaat hoeft in beginsel bij de vaststelling van pensioengerechtigde leeftijden geen rekening te houden met de Uniegrondrechten. Echter in situaties waarin deze wetgeving wordt gebruikt bij de uitvoering van Unierecht, zijn de Unierechtelijke grondrechten wel van toepassing. In Soukupová ging het om de voorwaarden waaronder Unielandbouwsteun mocht worden uitgedeeld. Eén van de voorwaarden die de verordening stelt is, dat de aanvrager de "normale pensioengerechtigde leeftijd" nog niet mag hebben bereikt waarbij met het begrip "normale pensioengerechtigde leeftijd" wordt verwezen naar de toepasselijke nationale pensioenwetgeving. Hierdoor boog het Hof zich over de verenigbaarheid met de Uniegrondrechten van nationale wetgeving inzake de pensioengerechtigde leeftijd. ${ }^{26}$ Hoewel dit inderdaad ingrijpend is, levert het

24 Vergelijk A-G Kokott van 30 september 2010, zaak C-236/09, Association Belge des Consommateurs Test-Achats, punt 30.

25 HvJEU van 11 april 2013, zaak C-401/11, Soukupová.

26 Overigens toont het Hof zich hier behoedzaam. De toetsing aan het beginsel van gelijke behandeling vindt nadrukkelijk plaats in de context van de (EU) steun van vervroegde uittreding. Zie punten 30 en 34 van het arrest. 
geen spanning op met het allocatiebeginsel. Immers door de koppeling in de Unieregeling aan het nationale recht, fungeert het nationale recht in die context als uitvoering van Unierecht. Het gaat om de toekenning van Unielandbouwsteun. Hierbij moet de Unie de grondrechten van de Unie in acht nemen en in het verlengde hiervan ook de lidstaten voor zover zij belast zijn met de uitvoering ervan. ${ }^{27}$

In het algemeen verhoudt de uitwerking van de Wachauf-lijn zich met betrekking tot klassieke omzettingsmaatregelen dus goed met het beginsel van de allocatie van bevoegdheden. Er is echter ook een uitspraak van het Hof die ogenschijnlijk past binnen de Wachauf-lijn, maar toch ver daar buiten gaat: het arrest Chatzi. ${ }^{28}$

In deze zaak stond centraal de raamovereenkomst inzake ouderschapsverlof. Op grond van de raamovereenkomst moet een ouderschapsverlof worden toegekend van minimaal drie maanden. De raamovereenkomst laat de lidstaten vrij in de uitwerking van de voorwaarden en modaliteiten van het verlof. ${ }^{29}$ De verwijzende rechter stelde vragen over de toepassing van het Unierechtelijke ouderschapsverlof op tweelingen. Het Hof antwoordde, dat de raamovereenkomst niet de verplichting oplegt om automatisch een recht te verlenen op evenveel ouderschapsverloven als dat er kinderen zijn geboren. ${ }^{30}$ Het Hof voegde daar aan toe, dat op de uitvoering van het recht op ouderschapsverlof het gelijkheidsbeginsel van toepassing is (als algemeen rechtsbeginsel en zoals neergelegd in artikel 20 Handvest). ${ }^{31}$ Tot zover loopt het arrest in de pas met de lijn Wachauf. Het Hof stelde vast waartoe de raamovereenkomst verplicht en voegt daaraan toe dat op de uitvoering van de raamovereenkomst het gelijkheidsbeginsel van toepassing is. Echter, uit het vervolg van het arrest blijkt dat veel verder wordt gegaan dan de toepassing van het gelijkheidsbeginsel op de nationale uitvoering van de betreffende raamovereenkomst.

27 Zie ook HvJEU van 26 september 2013, zaak C-195/12, Industrie du bois de Vielsalm, punt 49. Vergelijk ook HvJEU van 15 mei 2014, zaak C-135/13, Szatmári Malom, punten 60 e.v.: in deze zaak ging het om de toepassing van het Unierechtelijke gelijkheidsbeginsel op nationale subsidievoorwaarden voor het verlenen van uit het Elfpo (Europees Landbouwfonds voor Plattelandsontwikkeling) gefinancierde steun.

28 HvJEU van 16 september 2010, zaak C-149/10, Chatzi. Zie ook Muir 2013-2, p. 89-90.

29 Chatzi, punt 69.

30 Chatzi, punt 62.

31 Chatzi, punt 63. In de Nederlandse taalversie wordt de term 'uitwerking' gebruikt, die vermoedelijk synoniem is voor 'uitvoering'. Zie de Engelse taalversie spreekt van 'implementing' en de Franse taalversie van 'mise en œuvre'. 
Het Hof oordeelde namelijk, dat de lidstaten op grond van het algemene gelijkheidsbeginsel verplicht zijn om er voor te zorgen dat het wettelijke regime inzake het ouderschapsverlof rekening houdt met de bijzondere noden van ouders van tweelingen. Deze materiële invulling is op zich reeds gedurfd. Uit de vaststelling dat "de ouders van tweelingen zich in een bijzondere situatie bevinden", blijkt dat volgens het Hof sprake is van ongelijke gevallen. Hoewel niet expliciet blijkt welk vergelijkingscriterium is gehanteerd, ${ }^{32}$ vergelijkt het Hof de situatie van ouders waar een tweeling wordt geboren vermoedelijk met de situatie van ouders waar een eenling wordt geboren. Het relevante verschil lijkt te zijn, dat de verzorging van een tweeling intensiever is. Dit is een feitelijke vaststelling waar weinig op valt af te dingen.

Desondanks verklaart dit niet op grond waarvan het Hof in punt 68 tot het oordeel komt dat de nationale wetgever rekening moet houden met het verschil tussen de twee groepen. Deze aanname ligt niet voor de hand, zeker niet nu uit een eerder deel van het arrest volgt dat het verschil juist niet relevant is voor de toekenning van ouderschapsverlof. ${ }^{33}$ Door het opleggen van de positieve verplichting rekening te houden met de bijzondere noden van ouders van tweelingen gaat het Hof op de stoel van de wetgever zitten.

Afgezien - of in het verlengde - hiervan is ook sprake van toepassing van het gelijkheidsbeginsel op nationale maatregelen die niet kwalificeren als 'uitvoering' van Unierecht. Uit de uitspraak blijkt namelijk, dat de nationale rechter bij de vraag of er voldoende mogelijkheden worden geboden om in een concreet geval tegemoet te komen aan deze bijzondere noden, de gehele nationale regeling in aanmerking moet nemen. ${ }^{34}$ Vervolgens blijkt uit het arrest, dat het in aanmerking nemen van de nationale regeling in haar geheel, ruim moet worden opgevat. De nationale rechter kan ook kijken naar het deel van de nationale regeling dat verder gaat dan de bij Unierecht voorziene minimumharmonisatieverplichting. Zo kan bijvoorbeeld worden gekeken naar het deel van de nationale maatregel, dat voorziet in een ouderschapsverlof van langer dan de voorgeschreven minimum duur. Indien het nationale regime voorziet in een gevoelig langere duur dan het Unierechtelijke minimum van drie maanden, kan dit een aanwijzing zijn dat de nationale maatregel voldoet aan het gelijkheidsbeginsel. De nationale rechter mag zelfs voorzieningen buiten de nationale ouderschapsverlofregeling in aanmerking nemen bij de beoordeling of is voldaan aan het gelijkheidsbeginsel. Het Hof noemt als voorbeeld het

32 Vergelijk Chatzi, punten 66 en 67.

33 Vergelijk Chatzi, punt 58.

34 Chatzi, punten 74 en 75 . 
bestaan van flexibele organisatievormen van arbeid en materiële ondersteuning voor ouders met tweelingen bijvoorbeeld terzake van kinderopvang. ${ }^{35}$ De rode draad lijkt te zijn, dat het gaat om "maatregelen die de eisen van het beroepsleven verzoenen met de bijzondere moeilijkheden die de opvoeding van een tweeling met zich brengt." 36

Uit het arrest blijkt derhalve, dat ook nationale maatregelen die niet kwalificeren als uitvoeringsmaatregelen, betrokken worden in de toets aan het gelijkheidsbeginsel. Immers het deel van nationale regelingen dat een langer verlof toekent dan het Unierechtelijk minimum van drie maanden, moet worden aangemerkt als een 'verdergaande beschermingsmaatregel' die buiten het toepassingsgebied van het Unierecht valt. ${ }^{37}$ Voorts vallen maatregelen inzake flexibele organisatievormen van arbeid en financiële tegemoetkomingen eveneens buiten de uitvoering van de raamovereenkomst. In feite laat het Hof bij de toepassing van het gelijkheidsbeginsel het terrein van het ouderschapsverlof los en trekt de zaak breder, namelijk naar het eenvoudiger maken om de eisen van het beroepsleven te verzoenen met de bijzondere moeilijkheden die het opvoeden van een tweeling met zich brengt. Het gelijkheidsbeginsel gaat aldus een eigen leven leiden los van de raamovereenkomst en krijgt daardoor een zelfstandige werking (dat wil zeggen een werking los van de Unierechtelijke aanknoping). Het Hof wijkt hiermee af van zijn eigen jurisprudentie inzake de toepasselijkheid van grondrechten en andere algemene rechtsbeginselen en treedt buiten de grenzen van artikel 51, lid 1, van het Handvest.

\subsection{Uitoefening van op grond van Unierecht verleende bevoegdheden}

\subsubsection{Analyse van de rechtspraak van het Hof}

\subsubsection{Een eerste verkenning}

Ten tweede valt onder 'Wachauf-uitvoering' de uitoefening van op grond van Unierecht verleende bevoegdheden. Dat wil zeggen de uitoefening van bevoegdheden die de lidstaten ontlenen aan het Unierecht. Bijvoorbeeld omdat de Unieregeling voorziet in de mogelijkheid om af te wijken van de implementatieverplichting of voorziet in optionele uitzonderingen op de hoofdverplichting/regel. Deze tweede subcategorie ligt in sommige gevallen dicht aan

35 Chatzi, punten 72 en 73.

36 Chatzi, punt 72.

37 Zie verder hoofdstuk 6.3 onder het kopje 'verdergaande beschermingsmaatregelen'. 
tegen de eerste subcategorie ('klassieke omzetting'), met name waar het gaat om het benutten van Unierechtelijke beoordelingsruimte. Hoewel de twee niet altijd strikt kunnen worden onderscheiden (en dit is ook niet nodig), is het omwille van de helderheid toch dienstig om het als een aparte categorie te benoemen. Vooral ook omdat de gebondenheid aan Unierechtelijke grondrechten bij de uitoefening van Unie bevoegdheden niet altijd nauw is verweven met klassieke omzettingshandelingen en verschilt van klassieke omzetting. Het belangrijkste verschil tussen de twee categorieën is, dat het bij klassieke omzetting gaat om verplichte uitvoering (al dan niet gecombineerd met vrijheid van middelen) en bij de uitoefening van bevoegdheden gaat het in beginsel om onverplichte uitvoering van Unierecht.

Dat de lidstaten de Uniegrondrechten moeten eerbiedigen bij de uitoefening van op grond van Unierecht verleende bevoegdheden blijkt al uit het arrest Wachauf. In deze zaak ging het om de toepassing van Uniegrondrechten op de uitoefening van een discretionaire bevoegdheid. Advocaat-generaal Trstenjak merkt hier het volgende over op: 38

\begin{abstract}
"Alhoewel het Hof in het arrest Wachauf in eerste instantie is ingegaan op de conformiteit van de litigieuze verordening met de grondrechten, heeft het althans impliciet bevestigd dat ook de beslissingen over de toekenning van een vergoeding aan vertrekkende pachters, die door de nationale autoriteiten in de uitoefening van de hen door verordening $\mathrm{nr}$. 1371/84 verleende discretionaire bevoegdheid worden genomen, voor zover enigszins mogelijk verenigbaar moeten zijn met de eisen van de bescherming van de grondrechten. Hiermee heeft het Hof tegelijkertijd bekrachtigd dat waar het gaat om de bescherming van de grondrechten in de Unie, ook beslissingen die de lidstaten op basis van een hen uit hoofde van een regeling van de Unie verleende discretionaire bevoegdheid nemen, moeten worden beschouwd als handelingen tot uitvoering van die regeling van de Unie."
\end{abstract}

Het arrest Piek is een voorbeeld van een zaak waarin het Hof expliciet verwoordt, dat de algemene rechtsbeginselen dienen als begrenzing van discretionaire bevoegdheid. ${ }^{39}$ In deze zaak ging het om de bevoegdheid van lidstaten om uit hoofde van landbouwverordening 857/84 specifieke referentiehoeveelheden toe te kennen. Het Hof oordeelde, dat

38 Zie A-G Trstenjak van 22 september 2011, zaak C-411/10, N.S., punt 82.

39 HvJEU van 11 januari 2007, zaak C-384/05, Piek, met name het kopje boven de punten 32 e.v. "Grenzen van de krachtens artikel 3, sub 1, van verordening nr. 857/84 uitgeoefende beoordelingsbevoegdheid". 
“(...) wanneer de nationale autoriteiten maatregelen tot uitvoering van een communautaire regeling vaststellen, zij hun discretionaire bevoegdheid dienen uit te oefenen met inachtneming van de algemene beginselen van gemeenschapsrecht (...)"

In een ander arrest op het terrein van landbouw, het arrest Dokter, oordeelde het Hof dat de bevoegdheid van de lidstaten om op grond van de mond- en klauwzeer richtlijn (85/511/EEG) maatregelen te nemen ter bestrijding van mond - en klauwzeer slechts kunnen worden genomen met eerbiediging van de algemene rechtsbeginselen, waaronder ook de grondrechten..$^{40}$

De toepasselijkheid van algemene rechtsbeginselen op de uitoefening van door het Unierecht verleende bevoegdheden komt sterk naar voren op het terrein van de BTW, en wel met name op het terrein van de Zesde BTW richtlijn. ${ }^{41}$ Een nadere analyse van deze rechtspraak is daarom nuttig om de systematiek van deze subcategorie van Wachauf-uitvoering in kaart te brengen (paragraaf 4.3.1.2).42 Zulks ook mede gelet op struikelblokarrest Garage Molenheide, die zoals is opgemerkt in hoofdstuk $3.3^{43}$ in de doctrine wordt beschouwd als indicatief voor het bestaan van een derde categorie van toepasselijkheid van Uniegrondrechten. ${ }^{4}$ De in deze paragraaf te behandelen voorbeelden uit de rechtspraak hebben betrekking op zogenaamde 'andere' algemene rechtsbeginselen (niet zijnde grondrechten). In meer recente rechtspraak inzake het Handvest zijn ook voorbeelden van deze subcategorie te vinden. Paragraaf 4.3.1.3 behandelt daarom de rechtspraak die ziet op de toepassing van het Handvest.

\subsubsection{BTW-rechtspraak en het arrest Garage Molenheide}

\section{Algemeen}

Karakteristiek van de Zesde BTW richtlijn is dat het niet de volledige harmonisatie van de BTW-stelsels beoogt, maar enkel voorziet in een uniforme grondslag die de neutraliteit van het systeem dient te waarborgen. Bij de tenuitvoerlegging van sommige bepalingen van de Zesde BTW richtlijn beschikken

40 HvJEU 15 juni 2006, zaak C-28/05, Dokter, punt 71; zie ook HvJEU 10 maart 2005, gevoegde zaken C-96/03 en C-97/03, Tempelman en Van Schaik, punt 31.

41 Het gaat in deze rechtspraak overigens om de toepassing van zogenaamde 'andere' algemene rechtsbeginselen dan grondrechten. Zoals is opgemerkt in hoofdstuk 3.3.3. is het toepassingsgebied van alle algemene rechtsbeginselen echter gelijk.

42 Zie verder over de doorwerking van algemene rechtsbeginselen in de BTW: Bomer 2012.

43 Onder het kopje "Lijnen Wachauf en ERT doorslaggevend".

44 Hoofdstuk 3.3.3. 
de lidstaten over 'een betrekkelijk grote ruimte'. ${ }^{45}$ Het gaat dan om nationale bevoegdheden inzake de uitvoering van het BTW stelsel als zodanig, bijvoorbeeld nationale maatregelen inzake de bewijslast met betrekking tot BTW vrijstellingen, ${ }^{46}$ termijnen voor teruggaaf $\mathrm{BTW},{ }^{47}$ hoofdelijke aansprakelijkheid ${ }^{48}$ etc. Deze bevoegdheden zijn begrensd door de algemene rechtsbeginselen.

Dit is allereerst het geval indien de bevoegdheid expliciet uit de betreffende bepalingen van de Zesde BTW richtlijn volgt. Een voorbeeld hiervan is artikel 15 van de Zesde BTW richtlijn op grond waarvan het aan de lidstaten is om de voorwaarden voor de toepassing van de vrijstelling voor een exportlevering van goederen buiten de Unie vast te stellen. De bepaling verduidelijkt dat de lidstaten voorwaarden mogen stellen om onder meer 'fraude, ontwijking en misbruik' te voorkomen. Ten aanzien van de toepasselijkheid van de algemene rechtsbeginselen oordeelde het Hof in de zaak Netto Supermarkt: 49

"18. (...) dat de lidstaten, bij de uitoefening van de hun door de communautaire richtlijnen verleende bevoegdheden, de algemene rechtsbeginselen die deel uitmaken van de communautaire rechtsorde, waaronder het rechtszekerheids- en het evenredigheidsbeginsel, alsook het vertrouwensbeginsel, moeten naleven"

Een ander voorbeeld is de bevoegdheid van de lidstaten om op grond van de Zesde BTW richtlijn de aftrek van BTW te herzien. In de zaak Stichting "Goed Wonen" oordeelde het Hof, dat het vertrouwens- en het rechtszekerheidsbeginsel moet worden nageleefd door de lidstaten in de uitoefening van de hun door gemeenschapsrichtlijnen verleende bevoegdheden. ${ }^{50}$

45 HvJEU 6 juli 1995, BP Supergaz, zaak C-62/93, punt 34.

46 HvJEU 27 september 2007, zaak C-409/04, Teleos, punt 45; HvJEU van 27 september 2007, zaak C-184/05,Twoh, punt 25.

47 HvJEU van 10 juli 2008, zaak C-25/07, Sosnowska.

48 HvJEU van 11 mei 2006, zaak C-384/04, Federation of Technological Industries, punt 29; HvJEU 21 december 2011, Vlaamse Oliemaatschappij, zaak C-499/10, punten 19-20.

49 HvJEU van 21 februari 2008, Netto Supermarkt, punt 18; zie ook Vlaamse Oliemaatschappij, zaak C-499/10, punten 19-20.

50 HvJEU van 26 april 2005, zaak C-376/02, Stichting Goed Wonen, punt 32. Zie ook punt 34 waarin wordt gesproken van de vaststelling door de nationale wetgever van een regelingen "die onder het gemeenschapsrecht valt". Zie ook HvJEU 14 september 2006, gevoegde zaken C-181/04 tot en met C-183/04, Elmeka, punt 31 waarin ook wordt gesproken van "de uitoefening van door het gemeenschapsrecht verleende bevoegdheden" en zie dictum van dat arrest waarin staat "in het kader van het gemeenschappelijk stelsel van BTW moeten de nationale belastingautoriteiten het vertrouwensbeginsel in acht nemen”. 
Ten tweede, is het ook mogelijk dat de discretie impliciet volgt uit de Zesde BTW richtlijn, namelijk daar waar de Zesde BTW richtlijn niets regelt. Een voorbeeld hiervan is het arrest Elmeka. In dit arrest overweegt het Hof heel algemeen: ${ }^{51}$

"36. (...) dat in het kader van het gemeenschappelijke stelsel van btw de nationale belastingdiensten het vertrouwensbeginsel in acht moeten nemen $(\ldots)$ "

\section{Arrest Garage Molenheide}

Een ander voorbeeld van de toepassing van algemene rechtsbeginselen op de uitoefening van een bevoegdheid die impliciet uit het Unierecht volgt is het arrest Garage Molenheide. ${ }^{52}$ Zoals gezegd verdient dit arrest bijzondere aandacht, omdat het in de doctrine dikwijls wordt genoemd als indicatief voor het bestaan van een derde categorie van situaties waarin de Unierechtelijke grondrechten van toepassing zijn. Ik deel deze opvatting niet, en meen dat het arrest een variant is van Wachauf-uitvoering.

In Garage Molenheide ging het om nationale invorderingsmaatregelen ter zake van de BTW. Centraal stonden nationale maatregelen op grond waarvan een voor teruggaaf vatbaar BTW bij wege van bewarende maatregel kon worden ingehouden ingeval van ernstige vermoedens van belastingfraude of ingeval van het bestaan van een betwiste BTW-schuldvordering van de belastingadministratie op de belastingplichtige. Één van de vragen was of het Unierechtelijke evenredigheidsbeginsel op dit soort maatregelen van invloed kan zijn. De mogelijke aanknoping met het recht van de Unie was de Zesde BTW richtlijn. De nationale regeringen die in de procedure voor het Hof opmerkingen hadden ingediend, alsmede de Europese Commissie betoogden dat dusdanige nationale maatregelen buiten het bereik van de Zesde BTW richtlijn vielen en derhalve onder de uitsluitende bevoegdheden van de lidstaten.

Het Hof stelde allereerst vast dat de Zesde BTW richtlijn zich in beginsel niet verzet tegen de litigieuze nationale maatregelen. Vervolgens overwoog het Hof als volgt:

"45. Wat vervolgens de mogelijke invloed van het evenredigheidsbeginsel in deze context betreft, zij beklemtoond, dat ofschoon de Lid-Staten in beginsel dergelijke maatregelen kunnen vaststellen, deze niettemin van invloed kunnen

51 HvJEU 14 september 2006, gevoegde zaken C-181/04 tot en met C-183/04, Elmeka.

52 HvJEU van 18 december 1997, Gevoegde zaken C-286/94, C-340/95, C-401/95 en C47/96, Garage Molenheide. 
zijn op de verplichting van de nationale autoriteiten uit hoofde van artikel 18, lid 4, van de Zesde richtlijn om onmiddellijk tot teruggaaf over te gaan.

46. Ook moeten de Lid-Staten in overeenstemming met het evenredigheidsbeginsel middelen aanwenden waarmee het door het nationale recht nagestreefde doel weliswaar doeltreffend kan worden bereikt, doch die de doelstellingen en beginselen van de betrokken gemeenschapsregeling zo min mogelijk aantasten.

47. Ofschoon het geoorloofd is, dat de maatregelen van de Lid-Staten de rechten van de schatkist zo doelmatig mogelijk proberen te beschermen, mogen zij niet verder gaan dan voor dit doel noodzakelijk is. Zij mogen dus niet op zodanige wijze worden aangewend, dat zij een systematische belemmering voor het recht op BTW-aftrek opleveren, welk recht een basisbeginsel is van het bij de desbetreffende gemeenschapsregeling ingevoerde gemeenschappelijke BTW-stelsel.

48. Terzake moet dus worden geantwoord, dat het evenredigheidsbeginsel van toepassing is op nationale maatregelen als in de hoofdgedingen aan de orde zijn, welke door een Lid-Staat in de uitoefening van zijn bevoegdheid op het gebied van de BTW worden genomen, voor zover deze maatregelen, indien zij verder gaan dan nodig is voor het bereiken van het daarmee beoogde doel, de beginselen van het gemeenschappelijke BTW-stelsel en in het bijzonder de aftrekregeling, een wezenlijk bestanddeel daarvan, aantasten. (cursivering MdM)"

Hoewel het Hof zich hier bedient van een op het oog ingewikkelde constructie die ertoe heeft geleid dat het arrest in de pre Handvest doctrine als indicatief werd gezien voor het mogelijke bestaan van een derde lijn van situaties van toepasselijkheid van grondrechten (naast Wachauf en ERT), ${ }^{53}$ gaat het mijns inziens in wezen om de toepassing van grondrechten op de uitoefening van een (impliciete) discretionaire bevoegdheid die zijn grondslag vindt in het Unierecht. Het vertrekpunt van het Hof is, dat de vaststelling dat de nationale bewarende maatregel van invloed kan zijn op de verplichting om uit hoofde van artikel 18, lid 4, Zesde BTW richtlijn onmiddellijk over te gaan tot teruggaaf van teveel betaalde BTW. Het Unierecht staat in beginsel toe, dat de lidstaten trachten de schatkist zo doelmatig mogelijk proberen te beschermen bijvoorbeeld door middel van conservatoire maatregelen op het recht op teruggaaf. Deze bevoegdheid is echter begrensd door de algemene rechtsbeginselen, in casu het evenredigheidsbeginsel.

Ik meen dan ook dat het arrest kan worden gepast in de lijn Wachauf. Dit blijkt ook uit latere rechtspraak waarin naar het arrest wordt verwezen met betrek-

53 Zie hierover hoofdstuk 3.3 onder het kopje 'Lijnen Wachauf en ERT doorslaggevend'. 
king tot situaties die zonder twijfel vallen onder Wachauf-uitvoering. ${ }^{54} \mathrm{Zo}$ wordt in de zaak Sosnowska verwezen naar Garage Molenheide. ${ }^{55}$ In deze zaak ging het om een nationale regeling die, voor een categorie van belastingplichtigen de termijn voor teruggaaf verlengt, zulks met het doel belastingfraude te voorkomen. Het Hof overwoog, dat de lidstaten bij de vaststelling van de regeling voor de teruggaaf van BTW-overschot, een zekere bewegingsvrijheid hebben. ${ }^{56}$ Voorts overwoog het Hof, dat de lidstaten er rechtmatig belang bij hebben om maatregelen te nemen ter bescherming van de financiële belangen en belastingfraude tegen te gaan. Ze moeten er echter wel voor zorgen dat het recht op aftrek van BTW zo min mogelijk wordt aangetast. ${ }^{57}$ Een ander voorbeeld is de hierboven besproken zaak Netto Supermarkt. Onder verwijzing naar onder andere de punten 45-48 van het arrest Garage Molenheide overwoog het Hof dat de lidstaten, bij de uitoefening van de hun door de communautaire richtlijnen verleende bevoegdheden, de algemene rechtsbeginselen die deel uitmaken van de communautaire rechtsorde, waaronder het rechtzekerheidsen het evenredigheidsbeginsel, alsook het vertrouwensbeginsel, moeten naleven. 58

\subsubsection{Rechtspraak inzake het Handvest}

In de vorige subparagraaf is de categorie van 'de uitoefening van op grond van Unierecht verleende bevoegdheden' toegelicht en geillustreerd op basis van de pre-Handvest rechtspraak inzake de BTW richtlijnen die met name zag op andere algemene rechtsbeginselen dan grondrechten. Recente rechtspraak laat zien dat, deze categorie van Wachauf-uitvoering ook wordt toegepast met betrekking tot het Handvest.

Een voorbeeld is het arrest $O$ en $S .{ }^{59}$ Deze zaak gaat over de bevoegdheid van de

54 Dit neemt niet weg dat het arrest Garage Molenheide vragen oproept, die in paragraaf 4.3.2 nader worden besproken.

55 HvJEU van 10 juli 2008, zaak C-25/07, Sosnowska.

56 HvJEU van 10 juli 2008, zaak C-25/07, Sosnowska, punt 17.

57 HvJEU van 10 juli 2008, zaak C-25/07, Sosnowska, punt 23. Zie ook HvJEU van 12 juli 2012, zaak C-284/11, EMS-Bulgaria Transport, punt 69 en HvJEU van 18 oktober 2012, zaak C-525/11, Mednis, punt 32: Uit beide arresten volgt dat de lidstaten weliswaar maatregelen mogen nemen ter bestrijding van belastingfraude en ontduiking, maar dat hierbij het evenredigheidsbeginsel in acht moet worden genomen opdat de doelstellingen en beginselen van de wetgeving van de Unie, zoals het fundamentele beginsel van het recht op aftrek van btw, zo min mogelijk worden aangetast.

58 HvJEU van 21 februari 2008, Zaak C-271/06, Netto Supermarkt, punt 18.

59 HvJEU van 6 december 2012, gevoegde zaken C-356/11 en C-357/11, O. en S., met name punt 81 en het dictum. 
lidstaten om op grond van Gezinsherenigingsrichtlijn 2003/86 te vragen om bewijs dat de gezinshereniger beschikt over stabiele en regelmatige inkomsten die volstaan om hemzelf en zijn gezinsleden te onderhouden. Het Hof oordeelde, dat deze bevoegdheid moet worden uitgeoefend tegen de achtergrond van de artikelen 7 (eerbiediging privé en gezinsleven) en 24, leden 2 en 3, (rechten van het kind) van het Handvest. Hetgeen betekent, dat de bevoegde nationale autoriteiten de verzoeken om gezinshereniging moeten onderzoeken in het belang van de betrokken kinderen en met als doel het gezinsleven te begunstigen. Waarbij ze tevens moeten vermijden dat afbreuk wordt gedaan aan het doel van de richtlijn en aan het nuttig effect ervan. ${ }^{60}$

Vermeldenswaardig is ook de zaak Sabou. De zaak betrof een geding tussen profvoetballer Sabou en de Tjechische belastingautoriteiten over zijn belastbaar inkomen over $2004 .{ }^{61}$ In zijn aangifte verklaarde Sabou, dat hij in verschillende lidstaten uitgaven had gedaan met het oog op zijn eventuele transfer als voetballer naar een voetbalclub in die Staten. Deze uitgaven hadden zijn belastbaar inkomen navenant verminderd. De Tsjechische belastingdienst betwijfelde of die uitgaven daadwerkelijk waren gedaan en verrichtte controle waarbij onder meer bij de belastingautoriteiten van Spanje, Frankrijk en het Verenigd Koninkrijk om inlichtingen werd verzocht op grond van bijstandsrichtlijn 77/799. Uit de antwoorden van deze autoriteiten bleek dat geen van de door Sabou genoemde voetbalclubs Sabou of zijn lasthebber kende. Na afloop van zijn controle volgde een verhoging van de belastingaanslag 2004. Sabou kwam hier tegen in beroep. Hij stelde onder meer dat de Tsjechische belastingdienst inlichtingen op onrechtmatige wijze had verkregen wegens schending van zijn recht om gehoord te worden. De Commissie stelde zich op het standpunt dat het Handvest niet van toepassing is, omdat de inlichtingenprocedure uit hoofde van bijstandsrichtlijn 77/799 slechts een facultatieve stap is in de procedure van vaststelling van de inkomstenbelasting. De vaststelling van de inkomstenbelasting is niet door het Unierecht geharmoniseerd en is daarom een nationale aangelegenheid. Het Hof oordeelde dat het Handvest wel van toepassing is. De omstandigheid dat de verzoekende lidstaat niet verplicht is om een andere lidstaat te verzoeken om bijstand, betekent niet dat de regels betreffende het inlichtingenverzoek en het gebruik van de verkregen inlichtingen door deze lidstaat buiten de toepassingssfeer van het Unierecht vallen. Wanneer een lidstaat op deze vorm van bijstand een beroep wil doen, moet hij zich schikken naar de regels van richtlijn $77 / 799.62$

60 Zie ook het arrest van het Hof van 18 juli 2013, zaak C-234/12, Sky Italia; A-G Kokott van 16 mei 2013, zaak C-234/12, Sky Italia, punt 23.

61 HvJEU van 22 oktober 2013, zaak C-276/12, Sabou, punten 26 en 27.

62 Overigens ging het in deze zaak om het recht om te worden gehoord. Het Hof oordeelde, 
Het oordeel van het Hof sluit aan bij de conclusie van advocaat-generaal Kokott, zij betoogde: 63
" 41 . Het is juist dat bijstandsrichtlijn $77 / 799$ geen verplichting voor de lidstaten bevat om een andere lidstaat om inlichtingen te verzoeken (...)
42. De stelling dat het recht van de Unie enkel ten uitvoer wordt gebracht in de zin van artikel 51, lid 1, van het Handvest wanneer de lidstaten een verplichting van Unierecht nakomen, kan mij echter niet overtuigen. De lidstaten brengen het recht van de Unie juist ook ten uitvoer wanneer zij gebruik maken van een door het Unierecht verleend recht, zoals het geval is in het kader van bijstandsrichtlijn 77/799. Deze richtlijn stelt de lidstaten met het inlichtingenverzoek van artikel 2 een Unierechtelijke procedure ter beschik- king, waarmee zij van een andere lidstaat informatie kunnen verkriigen die relevant is voor de belastingheffing. Wanneer een lidstaat deze Unierechtelijke procedure toepast, dan brengt hij ook Unierecht ten uitvoer.
43. Een andere opvatting zou betekenen dat een onderscheid wordt gemaakt in de toepasselijkheid van de algemene rechtsbeginselen en van het Handvest naargelang het Unierecht verplichtingen oplegt aan een lidstaat dan wel hem rechten verleent. Bepalend is echter of een handeling op het Unierecht is gebaseerd of niet. Indien een lidstaat handelt op de grondslag van het Unierecht, brengt hij in dat opzicht ook Unierecht ten uitvoer, zelfs indien daaruit geen verplichting voor hem voortvloeit."

Uit de hierboven besproken arresten blijkt, dat de grondrechten in de eerste plaats dienen als begrenzing van de discretionaire bevoegdheid. ${ }^{64}$ De invloed van grondrechten op de uitoefening van discretionaire bevoegdheden uit hoofde van Unierecht kan echter nog een stap verder gaan. Het is namelijk mogelijk, dat de eerbiediging van de grondrechten de verplichte uitoefening van discretionaire bevoegdheden meebrengt. ${ }^{65}$ Dit betekent dat niet alleen de

dat dit recht niet van toepassing was. Wanneer een overheid inlichtingen op grond van richtlijn 77/799 vergaart, is zij niet verplicht de belastingplichtige hiervan in kennis te stellen en hem om zijn standpunt te vragen.

63 A-G Kokott van 6 juni 2013, zaak C-276/12, Sabou, punten 40-44.

64 Zie bijvoorbeeld ook HvJEU van 12 juni 2014, zaak C-314/13, Peftiev, punten 24 en 29: "29. Uit het voorgaande volgt dat de bevoegde nationale autoriteit bij het beoordelen van een verzoek om vrijstelling van de bevriezing van tegoeden en economische middelen in de zin van artikel 3, lid 1, sub b, van verordening nr. 765/2006 niet over een absolute beoordelingsvrijheid beschikt, maar haar bevoegdheden moet uitoefenen met inachtneming van de in artikel 47, tweede alinea, tweede volzin, van het Handvest opgenomen rechten (...)."

65 Zie ook A-G Trstenjak van 27 juni 2012, zaak C-245/11, K, punten 63-77. Het Hof komt in deze zaak niet toe aan de toepassing van Unierechtelijke grondrechten. Bovendien wordt de vraag niet beantwoord aan de hand van de facultatieve bepaling, artikel 15, lid 1, 
uitoefening van de discretie kan worden getoetst, maar ook de niet-uitoefening van de discretie. 66

Een voorbeeld is het arrest N.S.. ${ }^{67}$ In deze zaak ging het om de toepassing van de Dublin II-verordening (Verordening 343/2003). Op grond van deze verordening is slechts één lidstaat verantwoordelijk voor de behandeling van een asielverzoek. De verordening wijst aan welke lidstaat dat is, maar bevat ook een soevereiniteitsclausule die de lidstaten het recht toekent om in afwijking van de normale verantwoordelijkheidsregels een op hun grondgebied ingediend asielverzoek zelf te behandelen in plaats van dit aan de primair verantwoordelijke lidstaat over te laten (evocatierecht). Uit het arrest N.S blijkt dat de gebondenheid aan de Unierechtelijke grondrechten (in dit geval artikel 4 Handvest) er - in bijzondere omstandigheden - toe kan leiden dat het evocatierecht neerkomt een op evocatieplicht, namelijk als er een ernstig risico bestaat van systematische schending van grondrechten. ${ }^{6}$

Spiegelbeeld van de zaak N.S. is de zaak Detiček. ${ }^{69}$ Deze zaak maakt duidelijk, dat de plicht tot eerbiediging van de grondrechten ook mee kan brengen, dat een discretionaire bevoegdheid juist niet mag worden uitgeoefend. Het ging ter zake om een kwestie op het terrein van internationaal privaatrecht. De zaak speelde in het kader van een echtscheidingsprocedure en zag op een verzoek om een voorlopige voorziening aan de Sloveense rechter tot verlening van het ouderlijk gezag aan Detiček. De Italiaanse rechter, die bevoegd was om over het

van Vo. 343/2000, maar op grond van de verplichte bepaling artikel 15, lid 2: HvJEU van 6 november 2012, zaak C-245/11, K., punt 28.

66 Zie ook Tridimas 2006, p. 42.

67 HVJEU van 21 december 2011, gevoegde zaken C-411/10 en C-493/10, N.S., punten 55, 68-69 en 106-108.

68 Zie voor een verdere uiteenzetting over de Griekse noodsituatie A-G Trstenjak van 22 september 2011, N.S., punten 99-105. Het arrest N.S. is verfijnd in HvJEU van 14 november 2013, zaak C-4/11, Puid: Uit dit arrest blijkt dat, de onmogelijkheid om een asielzoeker over te dragen aan de lidstaat die aanvankelijk als verantwoordelijke lidstaat was aangewezen, niet automatisch betekent dat de lidstaat die bepaalt welke lidstaat verantwoordelijk is voor de behandeling van het asielverzoek, op grond van artikel 3, lid 2 , van de verordening verplicht is dat verzoek zelf te behandelen. Deze lidstaat moet de criteria van hoofdstuk III verder hanteren om na te gaan of een andere lidstaat kan worden aangewezen als lidstaat die verantwoordelijk is om het asielverzoek te behandelen. Wel blijft van belang, dat de procedure om de verantwoordelijke lidstaat te bepalen niet onredelijk lang duurt. Indien nodig, dient deze lidstaat het verzoek zelf te behandelen overeenkomstig artikel 3, lid 2 van de verordening. Ook op grond van het arrest Puid kan derhalve worden afgeleid dat de directe werking van Uniegrondrechten onder omstandigheden kan leiden dat het evocatierecht evocatieplicht wordt.

69 HvJEU van 23 december 2009, zaak C-403/09 PPU, Detiček, punten 34, 55-57. 
ouderlijk gezag te beslissen, had echter eerder bepaald dat het gezag voorlopig zou worden toegekend aan de andere ouder en dat het kind voorlopig in een tehuis in Rome zou worden geplaatst. Detiček had hierop Italië verlaten en het kind meegenomen naar Slovenië. De vragen van de verwijzende rechter zagen op artikel 20 van verordening nr. 2201/2003 betreffende de bevoegdheid en de erkenning en tenuitvoerlegging van beslissingen in huwelijkszaken en inzake de ouderlijke verantwoordelijkheid. Deze bepaling ziet op de bevoegdheid om voorlopige en bewarende maatregelen te nemen en bepaalt onder meer:

"1. In spoedeisende gevallen vormt deze verordening voor de gerechten van een lidstaat geen beletsel om met betrekking tot personen of goederen die zich in die staat bevinden, voorlopige en bewarende maatregelen te nemen waarin de wetgeving van die lidstaat voorziet, zelfs indien krachtens deze verordening een gerecht van een andere lidstaat bevoegd is om ten gronde over de zaak te beslissen."

Gevraagd wordt of een gerecht op grond hiervan in omstandigheden zoals in het hoofdgeding een voorlopige maatregel met betrekking tot de ouderlijke verantwoordelijkheid mag nemen.”

Bij de beantwoording ging het Hof in op de toepasselijkheid van artikel 24 Handvest (rechten van het kind) en overwoog hier over als volgt:

“55. Artikel 20 van verordening nr. 2201/2003 kan niet worden uitgelegd op een wijze waardoor dat grondrecht zou worden geschonden.

56. Een kind dat ongeoorloofd wordt overgebracht ten gevolge van een eenzijdige beslissing van een van zijn ouders, wordt meestal de mogelijkheid ontnomen om regelmatig persoonlijke betrekkingen en rechtstreekse contacten met de andere ouder te onderhouden.

57. Artikel 20 van verordening nr. 2201/2003 kan bijgevolg niet aldus worden uitgelegd dat de ouder die het kind ongeoorloofd heeft overgebracht, van dit artikel gebruik kan maken om de door zijn ongeoorloofde handelwijze ontstane feitelijke situatie langer te laten duren of om de gevolgen van deze handelwijze te doen erkennen.”

Hoewel het Handvest in deze zaak 'de jure' wordt toegepast als instrument van uitleg van artikel 20 van de verordening, is het 'de facto' resultaat dat de nationale rechter zijn bevoegdheid tot het gelasten van bewarende maatregelen uit hoofde van deze bepaling niet mag uitoefenen.

Tot slot moet nog worden besproken de zaak Toshiba op het gebied van mede- 
dingingsrecht, een wat vreemde eend in de bijt. $^{70}$ Onderwerp van de procedure was een internationaal actief kartel, waaraan een reeks bekende Europese en Japanse ondernemingen uit de elektrotechnische branche hadden deelgenomen. Verschillende nationale mededingingsautoriteiten en ook de Europese Commissie zijn hiertegen opgetreden en hebben forse boetes opgelegd. In de onderhavige zaak ging het om de door de Tsjechische mededingingsautoriteit opgelegde boete. Deze mededingingsautoriteit paste uitsluitend nationaal kartelrecht toe en bestrafte enkel de gevolgen van het kartel op het grondgebied van de Tsjechische Republiek. Voor het Hof speelde onder meer de vraag of artikel 50 Handvest (ne bis in idem) kon worden toegepast op de door de Tsjechische mededingingsautoriteit opgelegde boete op basis van nationale mededingingsrecht. De Europese Commissie betoogde in deze zaak dat het Handvest enkel van toepassing is bij de handhaving van het Unierecht. Aangezien de Tsjechische mededingingsautoriteit in haar litigieuze beschikking enkel het interne recht (in casu nationaal mededingingsrecht) toepaste, zou zij niet aan het Handvest gebonden zijn geweest. ${ }^{71}$

Het Hof achtte het Handvest wel van toepassing. Blijkens punt 95 van dit arrest gaat het Hof er vanuit dat sprake is van 'Unierechtelijke context' , maar legt dit niet uit. Advocaat-generaal Kokott deed dit wel. Over de toepasselijkheid van het Handvest merkte ze het volgende op:

"104. Zoals gezegd, zijn namelijk de formeelrechtelijke bepalingen van verordening $\mathrm{nr}$. 1/2003 (...) van toepassing (...). Hiertoe behoren niet in de laatste plaats ook de bepalingen en de beginselen over de afbakening van de bevoegdheden binnen het netwerk van de Europese mededingingsautoriteiten dat bij verordening nr. 1/2003 in het leven is geroepen. Deze bepalingen en beginselen moeten in overeenstemming met het primaire Unierecht, inclusief de Unierechtelijke grondrechten, worden uitgelegd en toegepast.

105. De Tsjechische mededingingsautoriteit mag daarom (...) een kartelrechtelijke boeteprocedure naar nationaal mededingingsrecht slechts uitvoeren wanneer en voor zover de in het licht van de Unierechtelijke grondrechten uitgelegde en toegepaste verordening nr. 1/2003 hiertoe ruimte biedt."

70 HvJEU van 14 februari 2012, zaak C-17/10, Toshiba, punt 95 en dictum.

71 A-G Kokott van 8 september 2011, zaak C-17/10, Toshiba, punt 102. De relevante passage in schriftelijke opmerkingen van de Europese Commissie d.d. 26 april 2010 luidt als volgt (punt 29, pagina 14):

'La Commission est d'avis que la Charte n'est, en tant que telle, pas applicable dans la présente affaire car, ainsi qu'il ressort de son article 51, paragraphe 1, les dispositions de la Charte s'adressent aux États membres «uniquement lorsqu'ils mettent en oeuvre le droit de l'Union». Or dans la présente affaire, la partie défenderesse n'applique pas le droit de l'UE, mais son droit interne.' 
$\mathrm{Zij}$ zoemt derhalve in op de afbakening van de bevoegdheden op grond van Verordening 1/2003. De verdeling van de bevoegdheden volgt hieruit. Derhalve zijn de Unierechtelijke grondrechten van toepassing op de (Unierechtelijke) verdeling van bevoegdheden ex Verordening 1/2003 en daarmee ook op de vraag of de nationale mededingingsautoriteit haar bevoegdheid mocht uitoefenen.

\subsubsection{Beschouwing in het licht van de allocatie van bevoegdheden}

\section{Nationale maatregelen uit hoofde van expliciete Uniebevoegdheden}

Nationale maatregelen die zijn genomen in uitoefening van expliciet door Unierecht verleende bevoegdheden zijn een minder directe vorm van uitvoering van Unierecht dan de klassieke omzettingshandelingen. Desalniettemin liggen ze dicht aan tegen klassieke omzetting en zijn ze daarvan soms niet eens strikt te onderscheiden. Het belangrijkste verschil is, dat het bij klassieke omzetting gaat om verplichte uitvoering (al dan niet gecombineerd met vrijheid van middelen) en bij de uitoefening van bevoegdheden sprake is van een Unierechtelijke keuze om de bevoegdheid al dan niet uit te oefenen. Voor de legitimiteit van de toepassing van Uniegrondrechten doet dit verschil niet ter zake. Het facultatieve karakter van een Unieregeling leidt er niet toe, dat de regels en het gebruik ervan buiten de toepassingssfeer van het Unierecht vallen. ${ }^{72}$ Dit sluit mijns inziens mening aan bij de ratio van de lijnen Wachauf en ERT. Doorslaggevend voor de legitimiteit is dat het Unierecht de grondslag is voor het handelen van de lidstaten. Het resultaat van dit handelen dient daarom Unierecht conform te zijn. De basisgedachte hier is dezelfde als die naar voren komt in ERT: het Unierecht kan de lidstaten geen machtiging verleent voor maatregelen die in strijd zijn met de Uniegrondrechten. ${ }^{73}$ Het feit dat ook onverplichte uitvoering onder het bereik van Uniegrondrechten kan vallen noopt tot voorzichtigheid bij het formuleren van toetsingscriteria voor de toepassing van het Handvest die uitgaan van het bestaan van 'verplichtingen uit hoofde van het Unierecht'. ${ }^{74}$

72 Zie met name HvJEU van 22 oktober 2013, zaak C-276/12, Sabou. A-G Kokott van 6 juni 2013, zaak C-276/12, Sabou, punten 40-44.

73 Vergelijk A-G Kokott van 30 september 2010, zaak C-236/09, Association Belge des Consommateurs Test-Achats, punt 30.

74 Dit wordt bijvoorbeeld gedaan door A-G Sharpston van 12 december 2013, zaak C456/12, O, punt 61: "naar een rechtssituatie moet door de bril van het Handvest worden gekeken indien, maar alleen indien, een Unierechtelijke bepaling een positieve of een negatieve verplichting op de lidstaat legt (ongeacht of die verplichting ontstaat op basis van de Verdragen dan wel op basis van afgeleid Unierecht)." Ik meen dus dat dit criterium de lading niet dekt. 
De in de vorige paragraaf besproken zaak $O$ en $S .{ }^{75}$ illustreert dat de toepassing van Uniegrondrechten op discretionaire bevoegdheden uit hoofde van het Unierecht voor de hand ligt. Hier ging het immers om de behandeling van verzoeken om gezinshereniging uit hoofde van het Unierecht. Het is logisch dat Uniegrondrechten op de gehele behandeling van toepassing zijn. Dat een bepaalde nationale voorwaarde is genomen op grond van een discretie doet hier niet aan af. Deze discretie volgt immers uit het Unierecht. Bovendien zou het alternatief zijn, dat een deel van de procedure als zuiver nationaal zou moeten worden bestempeld, terwijl het gaat om de toekenning van een verblijfsrecht uit hoofde van het Unierecht. Ook is het duidelijk dat de toepasselijkheid van Uniegrondrechten in een zaak als N.S. noodzakelijk is om het Unierecht (in casu het Unieasielrecht) grondrechtconform te doen zijn. De toepassing van de Uniegrondrechten is buiten twijfel gekoppeld aan de toepassing van de Dublin II verordening en daarmee niet controversieel.

Het past dan ook, dat de algemene rechtsbeginselen en het Handvest de grenzen van de bevoegdheid van de lidstaten op grond van het Unierecht bepalen en in het uiterste geval zelfs kunnen leiden tot de verplichte uitoefening van een discretionaire bevoegdheid, zoals in het arrest N.S. het geval was. Dit levert geen principiële spanning op met het beginsel van de verdeling van de bevoegdheden. De bron (grondslag) van de bevoegdheid, het Unierecht, rechtvaardigt de toepasselijkheid van de Unierechtelijke grondrechten.

Een wat vreemde eend in de bijt is de mededingingsrechtelijke zaak Toshiba inzake het 'ne bis in idem' beginsel (artikel 50 Handvest). ${ }^{76}$ Zoals gezegd ging het hier om de toepassing van uitsluitend nationaal kartelrecht. De Europese Commissie meende om die reden dat het Handvest niet van toepassing was. ${ }^{.7}$ Het Hof ging desondanks uit van een 'Unierechtelijke context' waarin het Handvest wel van toepassing was. De toepassing van Uniegrondrechten in de zaak Toshiba lijkt daarmee controversieel. Nu het Hof ook niet ingaat op het standpunt van de Europese Commissie, blijft in de lucht hangen wat de grondslag is van de toepassing van het Handvest. Dit draagt niet bij aan de overtuigingskracht van het arrest en helpt ook niet om de betekenis ervan te duiden. Desondanks acht ik de toepassing van het Handvest wel in overeenstemming met artikel 51, lid 1, van het Handvest en wel op grond van de benadering zoals wordt verdedigd door advocaat-generaal Kokott. Zij

\footnotetext{
75 HvJEU van 6 december 2012, gevoegde zaken C-356/11 en C-357/11, O. en S., met name punt 81 en het dictum.

76 HvJEU van 14 februari 2012, zaak C-17/10, Toshiba, punt 95 en dictum.

77 A-G Kokott van 8 september 2011, zaak C-17/10, Toshiba, punt 102.
} 
situeert de zaak in de kwestie van de afbakening van de bevoegdheden tussen de Commissie en de nationale mededingingsautoriteiten ingevolge Verordening $1 / 2003$. Aldus bezien lijkt het in Toshiba niet te gaan om de toepassing van het Unierechtelijke ne bis in idem-beginsel op de nationale kartelprocedure, maar om Unierechtelijke kwestie van de bevoegdheidsverdeling tussen de Commissie en de nationale mededingingsautoriteiten uit hoofde van Verordening 1/2003. De toepassing van het Handvest in het Toshiba ligt daarmee op de grens van waar het Unierecht ophoudt en het nationaal (kartel) recht begint en lijkt aldus bezien geen spanning op te leveren met het beginsel van de allocatie van bevoegdheden.

\section{Nationale maatregelen uit hoofde van impliciete Uniebevoegdheden}

Uit de rechtspraak blijkt tevens dat de Unierechtelijke grondrechten ook van toepassing zijn op nationale maatregelen die niet zijn genomen in uitoefening van expliciet door Unierecht verleende bevoegdheden, maar op grond van bevoegdheden waarvan het Hof aanneemt dat ze impliciet volgen uit het Unierecht. Dit scenario is verder verwijderd van de klassieke omzettingshandelingen en kan daarom ook gevoeliger liggen vanuit het oogpunt van de allocatie van bevoegdheden. Op zichzelf genomen is de toepassing van Uniegrondrechten op de uitoefening van impliciete Uniebevoegdheden niet problematisch. Hiervoor geldt dezelfde rechtvaardiging als hierboven is besproken met betrekking tot de uitoefening van expliciete Uniebevoegdheden. De toepassing van Unierechtelijke grondrechten is echter wel heikel als de kwalificatie (door het Hof) als 'uitoefening van impliciet door Unierecht verleende bevoegdheden' arbitrair is.

Het arrest Garage Molenheide is illustratief voor dit spanningsveld. In dit arrest stelde het Hof eerst vast dat de gemeenschappelijke BTW -regeling niet ziet op bewarende maatregelen, maar oordeelde vervolgens toch dat dit soort maatregelen geschieden in de uitoefening van (door het Unierecht toegekende) bevoegdheid op het gebied van de BTW. Dit lijkt een grote stap in het verlengde waarvan ook de toepassing van algemene rechtsbeginselen of het Handvest op dit soort maatregelen kan wringen. Toch kan ik het Hof hier volgen. Het vertrekpunt van het Hof is immers het Unierecht op onmiddellijke teruggaaf van BTW. Dit recht is een basisbeginsel van het BTW-stelsel. Het opleggen van bewarende maatregelen op het recht op teruggaaf vormt een beperking van dit recht. Hoewel het Hof aanvaardt dat een lidstaat legitieme redenen kan hebben om dit te doen en het Unierecht dit niet a priori verbiedt, is het niet vreemd dat de voorwaarden waaronder dit recht kan worden beperkt worden beheerst door het Unierecht. Of anders gezegd: dat de bevoegdheid om dit te kunnen doen volgt uit het Unierecht. Voorts is ook sprake van het van toepassing zijn 
van materieel Unierecht: namelijk in casu het Unierecht op teruggaaf van BTW. In zekere zin doet de redenering in Garage Molenheide ook wel denken aan de systematiek in de nog te bespreken ERT-lijn. In deze lijn staat centraal dat bepaalde nationale handelingen hun bestaansrecht ontlenen aan een Unierechtelijke 'machtiging' en dat deze 'machtiging' niet kan worden verleend aan nationale handelingen die strijdig zijn met de Unierechtelijke grondrechten (zie verder hoofdstuk 6).

\subsection{Maatregelen die onder de werkingssfeer van materieel Unierecht vallen}

\subsubsection{Analyse van de rechtspraak van het Hof}

Zoals gezegd in paragraaf 4.2 is van 'uitvoering' niet enkel sprake bij nationale bepalingen die uitdrukkelijk strekken tot de implementatie (expliciete implementatie) van Unierecht, maar ook om reeds bestaande nationale bepalingen die geschikt zijn ter verzekering van de overeenstemming van het nationale recht met het Unierecht (impliciete implementatie). Meer algemeen kan zelfs worden gezegd, dat de Unierechtelijke grondrechten van toepassing zijn op nationale maatregelen die binnen de werkingssfeer van specifieke materiële bepalingen van Unierecht vallen. ${ }^{78}$

Dit komt impliciet naar voren in het arrest Rundfunk. ${ }^{79}$ In deze zaak ging het om een Duitse regeling die rechtspersonen die onder toezicht van de Rekenkamer staan, verplicht om gegevens te verstrekken over salarissen en pensioenen boven een bepaald plafond met vermelding van de naam van de begunstigden, ten behoeve van de opstelling van een jaarverslag dat ter beschikking wordt gesteld van het grote publiek. Nadat het Hof had vast gesteld, dat de nationale regeling kwalificeerde als de verwerking van persoonsgegevens in de zin van richtlijn 95/46/EG betreffende de bescherming van persoonsgegevens, werd de nationale regeling getoetst aan artikel 8 EVRM als algemeen rechtsbeginsel. Het Hof overwoog hiertoe:

78 Aldus ook Craig 2010, p. 213. Zie ook Groussot, Pech, \& Petursson, p. 7. Zij omschrijven deze variant als volgt: "EU fundamental rights bind Member States/National Authorities not only when they adopt administrative or legislative acts in order to implement EU rules but more generally, when they interpret or apply any domestic legal provision that falls within the scope of EU law.”

79 HvJEU van 20 mei 2003, gevoegde zaken C-465/00, C-138/01 en C-139/01, Rundfunk, punten 47, 68 en 91. Zie voor kritiek op dit arrest Knook 2005, p. 387-389. Hij stelt dat het terzake gaat om een zuiver interne situatie, althans dat de band met het Unierecht slechts zeer indirect is. 
“68. Bovendien moet richtlijn 95/46, voor zover zij de verwerking regelt van persoonsgegevens die afbreuk kunnen doen aan de fundamentele vrijheden, inzonderheid het recht op persoonlijke levenssfeer, noodzakelijkerwijs worden uitgelegd op basis van de grondrechten, die volgens vaste rechtspraak integrerend deel uitmaken van de algemene rechtsbeginselen welker eerbiediging het Hof verzekert (...).”

Voor wat betreft de rechtsgevolgen voor nationale regelingen die onverenigbaar zouden zijn met artikel 8 EVRM overwoog het Hof als volgt:

“91. Ingeval de verwijzende rechterlijke instanties tot de conclusie komen dat de betrokken nationale regelgeving niet strookt met artikel 8 EVRM, kan deze evenmin voldoen aan het in de artikelen 6 , lid 1 , sub c, en artikel 7, sub c of e, van richtlijn 95/46 neergelegde vereiste van evenredigheid. Zij kan dan evenmin vallen onder één van de uitzonderingen van artikel 13 van deze richtlijn, dat ook de eerbiediging van het evenredigheidsvereiste koppelt aan de nagestreefde doelstelling van algemeen belang. Hoe dan ook kan deze bepaling niet in dier voege worden uitgelegd, dat zij een met artikel 8 EVRM strijdige aantasting van het recht op persoonlijke levenssfeer kan rechtvaardigen.”

De toepassing van het algemene rechtsbeginsel wordt derhalve nauw gekoppeld aan de uitleg van de richtlijn. Aldus wordt nog eens duidelijk, dat de grondslag van de toetsing van nationale regelingen aan grondrechten is gelegen in de grondrechtconforme toepassing van het Unierecht zelf.

Een explicieter voorbeeld van het van toepassing zijn van Unierechtelijke grondrechten op nationale maatregelen die binnen de werkingssfeer van specifieke materiële bepalingen van Unierecht vallen, is het arrest Kücükdeveci. ${ }^{80}$ Deze zaak betreft een horizontaal geding en hoort strikt genomen niet in dit deel van het proefschrift thuis. Voor wat betreft het deel van het arrest, dat gaat over de werkingssfeer van algemene rechtsbeginselen wordt echter geen bijzondere aandacht besteed aan de horizontale context. Het betreft een exercitie waarbij een nationale overheidsregeling onder de werkingssfeer van

80 Arrest van het Hof van 19 januari 2010, zaak C-555/07, Kücükdeveci, punten 23-25. Zie 'a contrario' ook HvJEU van 30 september 1987, zaak 12/86, Demirel, punt 28. Het ging in deze zaak om een verblijfsrecht van een Turkse vrouw in het kader van gezinshereniging een verblijfsrecht. Hof overwoog, dat de litigieuze Duitse regeling niet diende ter uitvoering van een communautair rechtsvoorschrift, wegens het ontbreken van een communautaire rechtsnorm die de voorwaarden omschrijft waaronder de lidstaten in geval van legaal in de gemeenschap verblijvende Turkse werknemers gezinshereniging moeten toestaan. Artikel 8 EVRM kon daarom niet als algemeen rechtsbeginsel worden toegepast. 
het Unierecht wordt gebracht. Om die reden komt dit aspect van Kücükdeveci in dit deel van het proefschrift aan bod. Het ging in deze zaak om een Duitse overheidsregeling inzake ontslagvergoedingen. Hierbij werd een systeem van oplopende vergoedingen naar rato van het aantal dienstjaren gehandhaafd, waarbij een drempel werd gehanteerd: arbeidsjaren vervuld in de leeftijd van 25 jaar of jonger telden niet mee.

Het betrof geen omzettingswetgeving, toch oordeelde het Hof, dat het verbod van discriminatie op grond van leeftijd als algemeen rechtsbeginsel van toepassing was op de nationale regeling. Zulks omdat de nationale regeling een materie behandelde die onder de kaderrichtlijn gelijke behandeling (richtlijn 2000/78) valt (namelijk ontslagvoorwaarden). Hierdoor had de richtlijn tot gevolg, dat de voorwaarden voor ontslag binnen de werkingssfeer van het recht van de Unie vielen. Bij richtlijnen geldt deze toepasselijkheid van algemene rechtsbeginselen en het Handvest overigens pas vanaf het verstrijken van de uiterste termijn van implementatie. ${ }^{81}$

\subsubsection{Beschouwing in het licht van de allocatie van bevoegdheden}

De toepasselijkheid van Unierechtelijke grondrechten op nationale maatregelen die - naar nationaal recht - niet bedoeld zijn als omzettingsmaatregel, maar die wel binnen de werkingssfeer van specifieke materiële bepalingen van Unierecht vallen, geeft blijk van een ruime opvatting van 'uitvoering' van Unierecht. Anders dan bij de andere varianten die in dit hoofdstuk worden behandeld kan hier strikt genomen niet worden gesproken van uitvoeringsmaatregelen. Het probleem is juist, dat er niet is uitgevoerd terwijl dat wel had gemoeten. Een nationale maatregel als in Kücükdeveci is derhalve eerder een blijk van een vorm van verzuim tot uitvoering. Richtlijn 2000/78 verplicht de lidstaten immers om leeftijdsdiscriminaties terzake van ontslag op te heffen. ${ }^{82}$ Een discriminatoire nationale regeling die ziet op ontslagtermijnen is een uiting van de niet-implementatie (of onvolledige implementatie) van richtlijn 2000/78.83 $\mathrm{Nu}$ het in een zaak als Kücükdeveci niet gaat om een uitvoeringsmaatregel, zou het beter zijn geweest als het Hof zou hebben uitgelegd waarom in dit scenario de Uniegrondrechten toch van toepassing zijn.

81 Arrest van het Hof van 19 januari 2010, zaak C-555/07, Kücükdeveci, punten 24 en 25; HvJEU van 10 mei 2011, zaak C-147/08, Römer, punt 63. Vergelijk ook de rechtspraak inzake de plicht tot richtlijnconforme interpretatie die eveneens pas geldt na het verstrijken van de omzettingstermijn van de richtlijn: HvJEU van 4 juli 206, zaak C212/04, Adeneler, punt 115.

82 Arrest van het Hof van 19 januari 2010, zaak C-555/07, Kücükdeveci.

83 Of een schending van richtlijn 2000/78. 
Dit neemt niet weg dat ik de toepasselijkheid van de grondrechten op nationale maatregelen die een uiting zijn van een verzuim tot implementatie verdedigbaar acht. De opvatting kan vanuit verschillende gezichtspunten worden begrepen. ${ }^{84}$

Ten eerste hoeft op deze wijze niet te worden nagegaan of sprake is van omzetting in de strikte zin van het woord. ${ }^{85}$ Ten tweede wordt op deze wijze geen onderscheid gemaakt tussen situaties van omzetting, onjuiste omzetting en niet-omzetting. Het zou vreemd zijn als de toepassing van Unierechtelijke grondrechten in een bepaalde situatie zou afhangen van de vraag of de betreffende lidstaat al dan niet is overgegaan tot implementatie. Ten derde is de benadering legitiem vanuit de gedachte dat de lidstaten het Unierecht niet alleen actief moeten uitvoeren, maar zij het Unierecht ook moeten uitvoeren door het zelf na te leven. ${ }^{86}$ Of anders gezegd: in het Kücükdeveci-scenario is sprake van een specifieke regel van materieel Unierecht die van toepassing is en die moet worden geëerbiedigd.

Hoewel de Kücükdeveci-benadering op zichzelf niet bezwaarlijk is vanuit het oogpunt van de verticale en horizontale verdeling van bevoegdheden, dient bij de toepassing van Unierechtelijke grondrechten op nationale handelingen die geen implementatiemaatregelen zijn, maar wel binnen de werkingssfeer van een specifieke Unieregeling komen, voorzichtigheid te worden betracht. Het is zaak zorgvuldig te bekijken of de situatie in het hoofdgeding daadwerkelijk onder de materiële, personele en temporele werkingssfeer van een regel van materieel Unierecht valt. Tot nu toe lijkt het Hof op dit punt inderdaad behoedzaam te zijn. Uit een aantal recente arresten blijkt dat zorgvuldig wordt na gegaan of situaties die raakvlak hebben met materieel Unierecht inderdaad binnen de werkingssfeer van specifieke materiële bepalingen van Unierecht vallen. Het enkele feit, dat de situatie een materie betreft die in het algemeen wordt bestreken door een Unieregeling is voor het Hof niet voldoende. Vereist is dat de materiële Uniebepaling van toepassing is. ${ }^{87}$ Deze rechtspraak wordt

84 Overigens wordt hier buiten beschouwing gelaten, dat de zaak Kücükdeveci een horizontaal geding betreft en dat dit aspect wel degelijk spanning oplevert met het beginsel van allocatie van bevoegdheden. Voor een verdere onderbouwing wordt verwezen naar deel III van dit proefschrift, met name hoofdstuk 9.

85 Zie ook Redactioneel CMLR 2010, p. 1593, In voetnoot 26 wordt opgemerkt: 'it might well be that the court [...] still conceived of the situation in Kücükdeveci as being one of 'implementation', [...].

86 Hier is sprake van vergelijkbaarheid met de in hoofdstuk 5 te behandelen ERT-lijn waarin de lidstaten worden benaderd als rechtssubject in plaats van als uitvoerder van Unierecht.

87 Zie bijvoorbeeld HvJEU van 10 december 2009, zaak C- 323/08, Mayor, punt 59; HvJEU van 15 september 2011, gevoegde zaken C-483/09 en C-1/10, Gueye en Sanchez, punten 50-52, 69; HVJEU van 11 november 2010, zaak C-20/10, Vino I, punten 53, 54, 56, 57 en 
uitgewerkt in hoofdstuk 6.4.

\subsection{De effectuering, sanctionering en handhaving van Unierecht}

\subsubsection{Analyse van de rechtspraak van het Hof}

Een laatste vorm van uitvoering zijn nationale handelingen die dienen ter effectuering, sanctionering of handhaving van Unierecht. Uit de rechtspraak van het Hof blijkt dat ook op dit soort nationale handelingen Uniegrondrechten van toepassing zijn. Het gaat dan met name om maatregelen die ervoor moeten zorgen dat de justitiabelen hun rechten uit hoofde van het Unierecht kunnen effectueren (bijvoorbeeld procedurele regelingen en rechtsmiddelen) en maatregelen die het nuttig effect van Unierecht anderszins beogen te verzekeren (bijvoorbeeld toezicht op de naleving van Unierecht en sanctionering van schending van Unierecht). 88

\subsubsection{De effectuering van Unierechten: nationale procedureregels}

Bij de effectuering van rechten uit hoofde van het Unierecht zal het dikwijls gaan om nationale regels die vallen binnen de zogenaamde nationale procedurele autonomie, zoals bijvoorbeeld nationale regels omtrent onverschuldigd betaalde bedragen, rechtsmiddelen, verjarings- en vervaltermijnen, ontvankelijkheid in rechte. Op grond van de klassieke Rewe-riedel is de procedurele autonomie begrensd door de beginselen van gelijkwaardigheid en doeltreffendheid. ${ }^{89}$ Het doeltreffendheidsbeginsel verbiedt het om de uitoefening van de door Unierecht verleende rechten in de praktijk onmogelijk of uiterst moeilijk te maken. Het gelijkwaardigheidsbeginsel eist dat de procedureregels zonder onderscheid van toepassing zijn op de effectuering van Unierechten en

64; HvJEU van 22 juni 2011, zaak C-161/11, Vino II, punten 38 en 39 (de Vinobeschikkingen zijn niet beschikbaar in het Nederlands); HvJEU van 7 maart 2012, zaak C-178/12, Rivas Montes, punten 39, 42- 45, 47 en 49 en HvJEU van 19 september 2013, zaak C-5/12, Betriu Montull, punten 70-74.

88 Zie bijvoorbeeld m.b.t. de toepassing van algemene rechtsbeginselen: HvJEU van 31 maart 2011, zaak C-546/09, Aurubis Balgaria, punten 41-42 (nationale strafrechtelijke sanctionering van EU douane-overtredingen); HvJEU van 6 december 2011, zaak C329/11, Achughbabian, punten 48 en 49 (nationale strafbaarstelling niet -naleving van de EU terugkeerplicht door illegaal verblijvende onderdanen uit derde landen). Zie bijvoorbeeld m.b.t. de toepassing van het Handvest: HvJEU van 10 november 2011, zaak C-405/10, Garenfeld, punt 48, (nationale strafbaarstelling van niet-naleving EU afvalstoffenverordening 1013/2006).

89 HvJEU van 16 december 1976, zaak 33/76, Rewe-Zentralfinanz en Rewe-Zentral. Zie voor een kort overzicht van de procedurele autonomie Lenaerts 2007, p. 1645-1650. 
gelijkwaardige nationale rechten. Uit latere rechtspraak blijkt dat de procedurele autonomie ook wordt begrensd door de grondrechten van de Unie. ${ }^{90}$ De wijze waarop dit gebeurt is echter niet eenduidig. ${ }^{91}$ Soms is sprake van een aparte eigen toets aan de grondrechten naast de Rewe-riedel ('een Reweriedel-plus ${ }^{92}$ ) en in andere gevallen lijkt de toets aan de grondrechten onderdeel uit te maken van het doeltreffendheidsvereiste. ${ }^{93}$ Voorts maakt het Hof ook gebruik van formules waarin de Rewe-riedel helemaal niet terug komt, maar er enkel wordt verwezen naar de grondrechten en doeltreffendheid van de onderliggende materieelrechtelijke Unieregeling. Een voorbeeld is het arrest VEBIC waarin het Hof als volgt overwoog:94

"63. In dit verband dient erop te worden gewezen dat bij gebreke van een regeling van de Unie de lidstaten overeenkomstig het beginsel van procedurele autonomie bevoegd blijven om het orgaan of de organen van de nationale mededingingsautoriteit aan te wijzen dat/die als verwerende partij kan/kunnen deelnemen aan een voor een nationale rechter gevoerde procedure tegen een beslissing van die autoriteit, met dien verstande dat de eerbiediging van de

90 Zie bijvoorbeeld HvJEU van 10 april 2003, zaak C-276/01, Steffensen, punten 52, 61-72; HvJEU 8 mei 2008, gevoegde zaken C-95/07 en C-96/07; Ecotrade, punten 44-46 en 51; HvJEU van 7 december 2010, zaak C-439/08, VEBIC, punt 63; HvJEU van 18 maart 2010, gevoegde zaken C-317/08, C-318/08, C-319/08 en C-320/08, Alassini, punten 46, 61 en 62; HvJEU van 8 mei 2014, zaak C-604/12, H.N., punt 41. Aldus ook Prechal 2010-1, p. 11-13; zie ook A-G Cruz Villalón van 28 januari 2014, zaak C-583/12, Sintax Trading, punt 50: hij kwalificeert handelingen van de lidstaten in uitoefening van de procedurele autonomie als uitvoering in de zin van artikel 51, lid 1, van het Handvest.

91 Zie ook Sevenster 2010, p. 134-135: Zij wijst op de onduidelijke verhouding tussen de Rewe-riedel en het beginsel van effectieve rechtsbescherming in de rechtspraak en wijst erop dat de rechtspraktijk gebaat zou zijn bij een overzichtelijke benadering. Zie ook Engström 2011, p. 60-64 en Prechal \& Widdershoven 2011(over de verhouding tussen het Rewe- doeltreffendheidsbeginsel en het beginsel van effectieve rechterlijke bescherming).

92 Zie de hierna te behandelen arresten Alassini, Ecotrade en Steffensen. De term 'Rewe-riedelplus' komt van Sevenster 2010, p. 135. Zij gebruikt hem voor de verhouding tussen de Rewe-riedel en het beginsel van effectieve rechtsbescherming, maar de term leent zich ook goed om de verhouding tussen de Rewe-riedel en de grondrechten in het algemeen te beschrijven.

93 Een voorbeeld is HvJEU van 27 februari 2014, zaak C-470/12, Pohotovost, punten 51-56. Het lijkt erop dat het Hof de artikelen 38 (consumentenbescherming) en 47 (recht op effectieve rechtsbescherming) van het Handvest toepast als onderdeel van het doeltreffendheidsbeginsel. Zie ook A-G Jääskinen van 13 maart 2014, zaak C-562/12, MTÜ Liivimaa Lihaveis, punten 47 en 57 die bepleit dat de beginselen van doeltreffendheid en gelijkwaardigheid binnen het bereik van artikel 47 van het Handvest vallen.

94 HvJEU van 7 december 2010, zaak C-439/08, VEBIC; zie ook HvJEU van 8 mei 2014, zaak C-604/12, H.N., punt 41. 
grondrechten en de doeltreffendheid van het mededingingsrecht van de Unie ten volle dienen te worden gewaarborgd."

Uniegrondrechten zijn in deze context niet alleen van toepassing op nationale procedureregels die specifiek zijn uitgevaardigd voor de effectuering van het Unierecht, ${ }^{95}$ maar ook algemene nationale procedureregels kunnen vatbaar zijn voor toetsing aan de Unierechtelijke grondrechten. Hoewel deze regels in hun algemeenheid buiten het toepassingsgebied van het Unierecht vallen, kunnen zij in specifieke situaties wel degelijk een Unierechtelijke dimensie hebben. ${ }^{96}$

Voorbeelden van nationale procedureregels die specifiek samenhangen met de effectuering van het Unierecht zijn de arresten Alassini en Ecotrade. In Alassini ging het om een nationale voorwaarde die specifiek zag op de ontvankelijkheid van geschillen tussen aanbieders en eindgebruikers die vallen onder de Universeledienstenrichtlijn (richtlijn 2002/22). De richtlijn stelde bij dit soort geschillen als voorwaarde, dat eerst een poging tot buitengerechtelijke geschillenbeslechting moest worden gedaan alvorens een beroep in rechte zou kunnen worden ingesteld. Nadat het Hof toetste aan de Rewe-beginselen werd vervolgens nog eens aan het algemene beginsel van effectieve rechtsbescherming getoetst. ${ }^{97}$ In het arrest Ecotrade ging het onder meer om een vervaltermijn met betrekking tot de effectuering van het recht op aftrek van BTW. Uit het arrest volgt, dat hoewel de lidstaten in beginsel bevoegd zijn tot het stellen van vervaltermijnen ten aanzien van het recht van aftrek, deze vervaltermijnen moeten worden getoetst aan de Rewe-beginselen. Voorts moet worden nagegaan of geen sprake is van aantasting van de algemene rechtsbeginselen. In dit geval werd door het Hof getoetst aan het gelijkheidsbeginsel. ${ }^{98}$

Ook procesregels die in hun algemeenheid buiten het toepassingsgebied van het Unierecht vallen, kunnen in een specifieke situatie wel degelijk een Unie-

95 Zie bijvoorbeeld HvJEU van 18 maart 2010, gevoegde zaken C-317/08, C-318/08, C319/08 en C-320/08, Alassini, punten 46, 61 en 62; HvJEU 8 mei 2008, gevoegde zaken C-95/07 en C-96/07; Ecotrade, punten 44-46 en 51; HvJEU van 27 juni 2013, zaak C93/12, ET Agrokonsulting-04-Velko Stoyanov, punten 59 -61 en A-G Bot van 14 maart 2013, zaak C-93/12, Agrokonsulting-04-Velko Stoyanov, punten 30-32.

96 Zie bijvoorbeeld HvJEU van 10 april 2003, zaak C-276/01, Steffensen, punten 52, 61-72.

97 HvJEU van 18 maart 2010, gevoegde zaken C-317/08, C-318/08, C-319/08 en C320/08, Alassini, punten 46, 61 en 62. Zie over de verhouding tussen het doeltreffendheidsbeginsel en het beginsel van effectieve rechtsbescherming Oliver 2011, p. 2023-2040, 2038 en A-G Bot van 14 maart 2013, zaak C-93/12, Agrokonsulting-04Velko Stoyanov, punten 30-32; zie ook HvJEU van 27 juni 2013, zaak C-93/12, ET Agrokonsulting-04-Velko Stoyanov, punten 59 -61.

98 HvJEU 8 mei 2008, gevoegde zaken C-95/07 en C-96/07, Ecotrade, punten 44-46 en 51. 
rechtelijke dimensie hebben en vatbaar zijn voor toetsing aan de Unierechtelijke grondrechten. Voorbeelden van zaken waarin het ging om zulke algemene nationale procedureregels zijn het arrest Steffensen en de recentere Handvestzaken DEB en G.en R..

In het arrest Steffensen ging het om de toepassing van nationale bewijsregels met betrekking tot de eerbiediging van het Unierecht op tegenexpertise uit hoofde van de levensmiddelenrichtlijn, richtlijn 89/397.99 $\mathrm{Nu}$ de toelaatbaarheid van bewijsmiddelen als zodanig niet door Uniewetgeving werd geregeld, viel de aangelegenheid in beginsel onder het nationale recht (procedurele autonomie). Het Hof toetste derhalve eerst aan de Rewe-beginselen. Vervolgens ging het Hof over tot toetsing aan artikel 6 EVRM (recht op een eerlijk proces) als algemeen rechtsbeginsel. Hiertoe overwoog het Hof als volgt:

\begin{abstract}
"71. Aangezien het onderhavige geding betrekking heeft op de eerbiediging van het door het gemeenschapsrecht gewaarborgde recht op een tegenexpertise en de gevolgen die schending van dit recht kan hebben voor de toelaatbaarheid van een bewijsmiddel in het kader van een beroep zoals dat in het hoofdgeding aan de orde is, vallen de toepasselijke nationale bewijsregels binnen de werkingssfeer van het gemeenschapsrecht. Bijgevolg moeten deze regels de uit de fundamentele rechten voortvloeiende vereisten eerbiedigen.”
\end{abstract}

In de zaak $D E B$ ging het om een nationale procesrechtelijke regeling inzake de verplichting tot betaling van een voorschot in proceskosten die werd toegepast in een zaak met betrekking de effectuering van een vordering uit hoofde van staatsaansprakelijkheid wegens schending van het Unierecht. ${ }^{100}$ De litigieuze nationale regeling bepaalde dat voor de indiening van een vordering in rechte de betaling van een voorschot op de kosten wordt verlangd. Bovendien kon aan een rechtspersoon geen rechtsbijstand kan worden verleend, ook al zou deze dit voorschot niet kunnen opbrengen. Het Hof toetste deze nationale voorwaarden voor rechtsbijstandverlening aan artikel 47 Handvest (recht op een doeltreffende voorziening in rechte en op een onpartijdig gerecht). De toepassing van het Handvest werd niet gemotiveerd. Vermoedelijk is de grondslag voor de toepassing van het Handvest dat het ging om de effectuering van een Unierechtelijk recht op schadevergoeding à la Francovich. ${ }^{101}$ Hetgeen ook

99 HvJEU van 10 april 2003, zaak C-276/01, Steffensen, punten 52, 61-72.

$100 \mathrm{HvJEU}$ van 22 december 2010, zaak C-279/09, DEB, punt 28-30.

101 HVJEU van 19 november 1991, gevoegde zaken C-6/90 en C-9/90, Francovich, punten 32 en 36. Vergelijkbaar is A-G Bot van 14 maart 2013, zaak C-93/12, Agrokonsulting-04Velko Stoyanov, punt 21: "Ook al is deze regel niet bedoeld ter omzetting van deze verordening, heeft hij onvermijdelijk gevolgen voor het Unierecht en meer in het 
wordt bevestigd in het arrest Torralbo Marcos. ${ }^{102}$

Tot slot wordt ter illustratie gewezen op de plicht van de nationale rechter tot Unierecht conforme interpretatie van het nationale recht. Uit de rechtspraak blijkt, dat deze verplichting wordt begrensd door de algemene rechtsbeginselen, met name het rechtszekerheidsbeginsel en het verbod van terugwerkende kracht. ${ }^{103}$ Tevens is het aannemelijk dat de Uniegrondrechten van toepassing zijn op het gelasten van voorlopige voorzieningen in gedingen die door het Unierecht worden beheerst. ${ }^{104}$ Dat wil zeggen gedingen waarin uitspraak moet worden gedaan over het bestaan van de rechten waarop krachtens het Unierecht een beroep wordt gedaan. Immers de plicht hiertoe volgt uit het arrest Factortame. ${ }^{105}$ Bovendien gaat het ook in een dusdanige procedure om het veilig stellen van Unierechten.

\subsubsection{Naleving van Unierecht: sanctionering en toezicht}

Uniegrondrechten zijn niet alleen van toepassing bij het veilig stellen van rechten die particulieren ontlenen aan het Unierecht, maar ook bij nationale maatregelen die betrekking hebben op de naleving van Unierecht door particulieren. Ook hier geldt dat voor zover het Unierecht er zelf niets over regelt, de lidstaten vrij zijn om het verzekeren van de naleving van Unierecht zelf vorm te geven (procedurele autonomie). Deze vrijheid wordt begrensd door de eisen van gelijkwaardigheid en doeltreffendheid en de algemene beginselen van Unierecht. Ook hier kan het zowel gaan om nationale maatregelen die specifiek zien op de naleving van Unierecht als om algemene (zuiver) nationale maatregelen (bijvoorbeeld strafrechtelijk) die in een specifieke situatie van kleur

bijzonder voor de rechten die justitiabelen op grond van deze verordening hebben, omdat hun rechten, wanneer blijkt dat deze regel het recht op een doeltreffende voorzienig in rechte aantast, aanzienlijk kunnen worden gewijzigd of zelfs volledig kunnen worden genegeerd."

102 HvJEU van 27 maart 2014, zaak C-265/13, Torralbo Marcos, punt 34.

103 HvJEU van 23 april 2009, gevoegde zaken C-378/07 tot en met C-380/07, Angelidaki, punt 199. Zie ook HvJEU van 8 oktober 1987, zaak 80/86, Kolpinghuis Nijmegen, punt 13. HvJEU van 4 juli 2006, zaak C-212/04, Adeneler, punt 110; HVJEU van 12 juni 2008 (beschikking), zaak C-364/07, Vassilakis, punt 58; HvJEU van 15 april 2008 (Grote Kamer), zaak C-268/06, Impact, punt 100; HvJEU van 28 juni 2012, zaak C-7/11, Caronna, punten 51-56 (toepassing artikel 49 Handvest (legaliteitsbeginsel)).

104 Vergelijk A-G Kokott van 19 april 2012, zaak C-416/10, Križan, punten 171-177 (toepassing van het recht op een eerlijk proces op voorlopige maatregel). Dit punt komt niet terug in het arrest HvJEU van 15 januari 2013, zaak C-416/10, Križan.

105 HvJEU van 19 juni 1990, zaak C-213/89, Factortame, punt 21; HvJEU van 11 januari 2001, C-226/99, Siples, punt 19; HvJEU van 13 maart 2007, C-432/05, Unibet, punt 67. 
kunnen verschieten zodanig dat zij binnen het toepassingsgebied van het Unierecht komen en daarmee ook vatbaar zijn voor toetsing aan de Unierechtelijke grondrechten. ${ }^{106}$

De toepassing van algemene rechtsbeginselen op de nationale maatregelen die worden gebruikt voor het verzekeren van de naleving van Unierecht gebeurde al in vroege rechtspraak. Een vroeg voorbeeld is de zaak Zuckerfabrik Franken inzake het gemeenschappelijke stelsel voor de denaturering van suiker voor voederdoeleinden (verordening 100/72). ${ }^{107}$ Het Hof overwoog dat de lidstaten de nodige maatregelen moeten treffen om te verzekeren dat gedenatureerde suiker enkel voor voederdoeleinden wordt gebruikt. Bij de sanctionering beschikken de lidstaten over een discretie, echter de sancties mogen niet in strijd zijn met hogere normen van het Unierecht. Het Hof wees hierbij in het bijzonder op de algemene rechtsbeginselen van rechtszekerheid en evenredigheid.

Meer recente voorbeelden met betrekking tot de toepassing van andere algemene beginselen van Unierecht (beginselen die geen grondrecht zijn) op nationale sanctieregelingen zijn de zaken Louloudakis en Ntionik en Pikoulas. In het arrest Louloudakis ging het om een nationale sanctieregeling voor overtredingen van het door richtlijn 83/182 ingestelde stelsel van tijdelijke invoer van vervoermiddelen. ${ }^{108}$ Het Hof overwoog met betrekking tot de toepasselijkheid van algemene beginselen als volgt:109

106 Zie ook HvJEU van 26 februari 2013, zaak C-617/10, Åkerberg Fransson, punt 25 (verwijzing naar artikel 4, lid 3, VWEU) en punt 28; Anders: A-G Cruz Villalón van 12 juni 2012, zaak C-617/10, Åkerberg Fransson, punten 50-55. Zie bijvoorbeeld HvJEU van 31 maart 2011, zaak C-546/09, Aurubis Balgaria, punt 41; HvJEU van 6 november 2003, zaak C-101/01, Lindqvist, punten 85-90; HvJEU van 18 mei 2000, zaak C-107/97, Rombi, punt 65 en HvJEU van 10 november 2011, zaak C-405/10, Garenfeld, punt 48.

107 HvJEU van 18 februari 1982, zaak 77/81, Zuckerfabrik Franken, punten 19 en 22; zie ook HvJEU van 29 mei 1997, zaak C-299/95, Kremzow, punt 16 in samenhang met A-G Sharpston van 30 september 2010, zaak C-34/09, Ruíz Zambrano, punt 161, waarin zij opmerkt dat uit Kremzow 'a contrario' lijkt te volgen, dat aanknoping gevonden had kunnen worden wanneer de strafbare feiten verband hielden met een beleidsgebeid van de Unie. Als voorbeeld noemt zij als de strafbare feiten zouden zijn ingesteld teneinde de naleving te verzekeren van een in secundaire Uniewetgeving neergelegde doelstelling van Unierecht.

108 HvJEU van 12 juli 2001, zaak C-262/99, Louloudakis.

109 Zie ook HvJEU van 18 mei 2000, zaak C-107/97, Rombi, punten 63 en 73: In deze zaak overwoog het Hof expliciet, dat de lidstaten zich bij het uitoefenen van toezicht op de naleving van Unieregelingen dienen te houden aan de vereisten die uit de algemene rechtsbeginselen voortvloeien. 
“67. Onder voorbehoud van deze opmerkingen, zij eraan herinnerd, dat nu de gemeenschapswetgeving op het gebied van de toepasselijke sancties in geval van het niet in acht nemen van de voorwaarden van het door deze regeling ingestelde stelsel niet is geharmoniseerd, de lidstaten bevoegd zijn de sancties te kiezen die hun passend voorkomen. Zij moeten deze bevoegdheid echter uitoefenen met eerbiediging van het gemeenschapsrecht en de algemene beginselen daarvan (...)"

In de zaak Ntionik en Pikoulas ${ }^{110}$ ging het om nationale geldboetes in verband met onjuiste gegevens in een door de betrokken vennootschap uitgegeven prospectus terzake van een kapitaalverhoging. De relevante aanknoping met het Unierecht was richtlijn 2001/34 betreffende de toelating van effecten tot de effectenbeurs. Het Hof overwoog, dat het doel van deze richtlijn met name is om een passende informatie van de beleggers te waarborgen en dat de richtlijn niet voorziet in een regeling betreffende sancties voor personen die verantwoordelijk zijn voor het prospectus.

"53. In die omstandigheden is het van belang eraan te herinneren dat, nu de gemeenschapswetgeving niet is geharmoniseerd op het gebied van de sancties op niet-inachtneming van de voorwaarden van het daarbij ingevoerde stelsel, de lidstaten bevoegd zijn de sancties te kiezen die hun passend voorkomen. Zij moeten deze bevoegdheid echter uitoefenen met eerbiediging van het gemeenschapsrecht en de algemene beginselen daarvan, en dus ook met eerbiediging van het evenredigheidsbeginsel (...)”

De arresten Aurubis Balgaria en Achughbabian zijn voorbeelden van arresten waarin het ging om de toepassing van Uniegrondrechten uit hoofde van de algemene rechtsbeginselen. De zaak Aurubis Balgaria ging over de nationale strafrechtelijke sanctionering van Unierechtelijke douaneovertredingen. ${ }^{111} \mathrm{Nu}$ de sancties voor douaneovertredingen niet zijn geharmoniseerd, behoort de sanctionering tot de bevoegdheid van de lidstaten. Deze bevoegdheid moet worden uitgeoefend met eerbiediging van de algemene beginselen, in casu het legaliteitsbeginsel. Het Hof overwoog als volgt:

“41. Inzake douaneovertredingen heeft het Hof gepreciseerd dat aangezien de gemeenschapswetgeving op dit gebied niet is geharmoniseerd, de lidstaten bevoegd zijn de sancties te kiezen die hun passend voorkomen. Zij moeten deze bevoegdheid echter uitoefenen met eerbiediging van het gemeenschapsrecht en de algemene beginselen daarvan (zie arrest van 7 december

110 HvJEU van 5 juli 2007, zaak C-430/05, Ntionik en Pikoulas, punten 50, 52 en 53.

111 HvJEU van 31 maart 2011, zaak C-546/09, Aurubis Balgaria, punt 41. 
2000, de Andrade, C-213/99, Jurispr. blz. I.-11083, punt 20, en arrest HannlHofstetter, reeds aangehaald, punt 18)."

Een ander voorbeeld is de zaak Achughbabian die ziet op de nationale strafbaarstelling van de niet -naleving van de EU terugkeerplicht door illegaal verblijvende onderdanen uit derde landen. ${ }^{112}$ De aanknoping met het Unierecht is de Terugkeerrichtlijn (richtlijn 2008/115). Het Hof oordeelde dat de lidstaten op grond van die richtlijn bevoegd zijn om strafrechtelijke sancties op te leggen, volgens de nationale regels van het strafprocesrecht, aan onderdanen van derde landen op wie de bij de richtlijn ingestelde terugkeerprocedure is toegepast en die illegaal op het grondgebied van een lidstaat verblijven zonder dat er een geldige reden om niet terug te keren is. Ten aanzien van de toepasselijkheid van de grondrechten overwoog het Hof als volgt:

"49. In dit verband dient te worden beklemtoond dat, in het kader van de toepassing van die regels van het strafprocesrecht, bij het opleggen van de in het voorgaande punt genoemde sancties de grondrechten volledig moeten worden geëerbiedigd, met name die welke zijn gewaarborgd bij het op 4 november 1950 te Rome ondertekende Europees Verdrag tot bescherming van de rechten van de mens en de fundamentele vrijheden."

Voorbeelden van arresten waarin het ging om de toepassing van het Handvest zijn de arresten Garenfeld, Åkerberg Fransson en Texdata Software. In Garenfeld ging het om de nationale strafbaarstelling van de niet-naleving van de Afvalstoffenverordening (Vo. 1013/2006). ${ }^{113}$ Met betrekking tot de toepassing van het Handvest, in casu het legaliteitsbeginsel ex artikel 49, lid 1, overwoog het Hof, dat het legaliteitsbeginsel door de lidstaten met name moet worden geëerbiedigd wanneer zij de niet-naleving van bepalingen van het recht van de Unie strafbaar stellen.

In de zaak Åkerberg Fransson ging het om de strafrechtelijke vervolging door het Zweedse Openbaar Ministerie van de heer Åkerberg Fransson wegens ernstige belastingfraude zowel ten aanzien van de inkomstenbelasting als ten aanzien

112 HvJEU van 6 december 2011, zaak C-329/11, Achughbabian, punten 48 en 49; zie ook HvJEU van 6 november 2003, zaak C-101/01, Lindqvist, punten 85-90. Zie voor een voorbeeld van toepassing van fundamentele rechten op nationaal toezicht op de naleving van Unierecht: HvJEU van 18 mei 2000, zaak C-107/97, Rombi, punt 65 (nationale maatregelen inzake het toezicht op de samenstelling van levensmiddelen in verband met richtlijn 89/398).

113 HvJEU van 10 november 2011, zaak C-405/10, Garenfeld, punt 48, (strafbaarstelling niet-naleving afvalstoffenverordening 1013/2006). 
van de BTW. ${ }^{114}$ Ten aanzien van dezelfde feiten waren reeds fiscale sancties opgelegd. Er rezen daarom vragen omtrent de toepasselijkheid van het Unierechtelijke 'ne bis in idem'-beginsel (artikel 50 van het Handvest). Een groot aantal lidstaten, waaronder ook Nederland, en de Europese Commissie stelden zich op het standpunt dat in een zaak als deze niet is voldaan aan het vereiste van artikel 51, lid 1, van het Handvest dat sprake moet zijn van de 'tenuitvoerlegging' van Unierecht.

Het Hof ging hier niet in mee en koppelde de toepassing van het Handvest expliciet aan de uitvoering van de artikelen 4, lid 3, VEU en 325 VEU. Het Hof overwoog dat de aanknoping met het recht van de Unie was dat de belastingboetes en de strafvervolging gedeeltelijk verband houden met het feit dat de heer Åkerberg Fransson zijn aangifteverplichtingen op BTW-gebied niet is nagekomen. Deze aanknoping was relevant, omdat de lidstaten op grond van het Unierecht verplicht zijn om alle wettelijke en bestuurlijke maatregelen te treffen om de volledige inning van de btw te waarborgen en om fraude te bestrijden. Deze verplichting volgt uit BTW-richtlijn 2006/112/EG en uit artikel 4, lid 3, VEU (plicht tot loyale samenwerking). Bovendien is hier ook relevant de verplichting uit hoofde van artikel 325 VWEU om onwettige activiteiten waardoor de financiële belangen van de Unie worden geschaad te bestrijden met maatregelen die afschrikkend werken en doeltreffend zijn. Van belang bij de toepassing van artikel 325 BTW terzake van de BTW, is dat ontvangsten uit BTW tot de eigen middelen van de Unie behoren. Er is derhalve een rechtstreeks verband tussen de inning van BTW en de begroting van de Unie; mankementen in de inning van BTW leiden potentieel tot verlaging van de BTW-middelen van de Unie. Het Hof oordeelde daarom dat met de belastingboetes en strafvervolging wegens verstrekking van onjuiste inlichtingen op BTW-gebied, uitvoering wordt gegeven aan het Unierecht, namelijk aan de genoemde richtlijn 2006/112 en artikel 325 VWEU. Het feit dat de nationale regelingen die als grondslag dienden voor die belastingboetes en strafvervolgingen niet waren vastgesteld om uitvoering te geven aan richtlijn 2006/112, deed hieraan niet af. Voor het Hof was doorslaggevend, dat met de toepassing van deze nationale regelingen werd beoogd schending van de bepalingen van de BTW-richtlijn te bestraffen en dus uitvoering te geven aan de door het Verdrag aan de lidstaten opgelegde verplichting om gedragingen waarmee de financiële belangen van de Unie worden geschaad, effectief te bestraffen.

114 HvJEU van 26 februari 2013, zaak C-617/10, Åkerberg Fransson, punten 26 en 27. Anders: A-G Cruz Villalón van 12 juni 2012, zaak C-617/10, Åkerberg Fransson, punten 50-55. Zie ook voor de toepasselijkheid van het Handvest via artikel 325 VWEU A-G Kokott van 15 december 2011, zaak C-489/10, Bonda. 
Tot slot wordt gewezen op de zaak Texdata Software. ${ }^{115}$ In deze zaak achtte het Hof artikel 47 van het Handvest (recht op een doeltreffende voorziening in rechte en op een onpartijdig gerecht) van toepassing op een sanctieregeling uit hoofde van het Oostenrijkse Wetboek van ondernemingsrecht inzake schending van de openbaarmakingsplicht van boekhoudbescheiden van ondernemingen. Dit omdat het hoofdgeding betrekking heeft op een sanctie wegens niet-nakoming van de openbaarmakinsplicht op grond van Unie vennootschapsrecht (de Elfde vennootschapsrichtlijn). Hierbij overwoog het Hof dat de lidstaten op grond van artikel 12 van de Elfde vennootschapsrichtlijn zijn belast met de vaststelling van passende sancties om nakoming van de openbaarmakingsplicht te verzekeren. De betreffende Oostenrijkse regeling stelde die sancties vast.

\subsubsection{Beschouwing in het licht van de allocatie van bevoegdheden}

De toepassing van Unierechtelijke grondrechten op de effectuering, sanctionering en handhaving van Unierecht lijkt op het eerste gezicht minder voor de hand liggend dan bij de klassieke omzettingshandelingen het geval is. Bij klassieke omzettingshandelingen gaat het immers om de uitvoering van specifieke Unierechtelijke bepalingen. De effectuering, sanctionering en handhaving zijn dikwijls juist zaken die niet door het Unierecht worden geregeld en die worden overgelaten aan de lidstaten. Bovendien gaat het in een groot deel van de gevallen om nationale handelingen die niet specifiek zijn bedoeld als uitvoeringshandelingen van Unierecht, maar om algemene nationale regels die in een specifieke situatie worden toegepast in de context van het Unierecht. Kan dan nog wel van 'uitvoering' in de zin van artikel 51, lid 1, van het Handvest worden gesproken? Ik meen van wel.

Ten eerste is het effectueren, sanctioneren en handhaven door de lidstaten van Unierecht niet vrijblijvend. In feite geven de lidstaten hiermee uitvoering aan hun plicht tot loyale samenwerking uit hoofde van artikel 4, lid 3, VEU. Zo zijn lidstaten op grond van deze bepaling gehouden om, als een Unieregeling geen specifieke sanctie stelt op de overtreding van de bepalingen ervan, of daarvoor verwijst naar nationale bepalingen, alle passende maatregelen te nemen om de doeltreffende toepassing van het Unierecht te verzekeren. ${ }^{116}$ Voorts geldt dat wanneer een Unieregeling niet specifiek in sancties bij overtreding voorziet, of wanneer een Unieregeling wel in bepaalde sancties bij overtreding van het

115 HvJEU van 26 september 2013, zaak C-418/11, Texdata Software, punt 73.

116 HvJEU van 27 februari 1997, zaak C-177/95, Ebony Maritime, punt 35; HvJEU van 10 juli 1990, zaak 326/88, Hansen, punt 17. 
Unierecht voorziet, maar niet uitputtend regelt welke sancties de lidstaten kunnen opleggen, artikel 4, lid 3, VEU de lidstaten verplicht tot het nemen van alle maatregelen waarmee effectief kan worden opgetreden tegen gedragingen die de financiële belangen van de Unie schaden. ${ }^{117}$ Ook de procedurele autonomie moet worden begrepen in het licht van de plicht tot loyale samenwerking. Op grond van dit beginsel in samenhang met het algemene beginsel van effectieve rechterlijke bescherming moeten de lidstaten voorzien in procedurele regelingen ter effectuering van Unierechten. ${ }^{118}$ Het begrip 'autonomie' is dan ook wat misleidend, omdat het volledige autonomie van de lidstaten suggereert terwijl hiervan geen sprake is. ${ }^{119}$ De uitoefening van de procedurele autonomie moet derhalve worden gezien als uitvoering van Unierecht en bij die uitoefening moeten de Unierechtelijke grondrechten worden geëerbiedigd. Overigens kan de plicht tot effectuering, sanctionering en handhaving door de lidstaten van Unierecht niet alleen volgen uit artikel 4, lid 3, VEU, maar ook volgen uit van toepassing zijnde bijzondere bepalingen zoals artikel 325 VWEU (plicht tot fraudebestrijding) ${ }^{120}$ of bepalingen van secundair recht $^{121}$.

Ten tweede valt het effectueren, sanctioneren en handhaven ontegenzeggelijk onder de noemer 'toepassing' van Unierecht, omdat hiermee handen en voeten (of tanden) aan het Unierecht wordt gegeven. Het is bij deze subcategorie wel

117 HvJEU van 28 oktober 2010, zaak C-367/09, SGS Belgium e.a., punt 41; zie ook HvJEU van 8 juli 1999, zaak C-186/98, Nunes en de Matos, punt 14.

118 HvJEU 13 maart 2007, zaak C-432/05, Unibet, punt 38; HvJEU van 15 april 2008, zaak C-268/06, Impact, punt 44. Opgemerkt wordt dat soortgelijke plichten ook kunnen volgen uit secundaire wetgeving: Zie bijvoorbeeld HvJEU van 10 april 1984, Von Colson en Kamann, zaak 14/83, punt 18 (inzake artikel 6 van richtlijn 76/207 betreffende de gelijke toegang van mannen en vrouwen tot arbeid).

119 A-G Trstenjak van 21 januari 2012, zaak C-591/10, Littlewoods, punt 23 en de in voetnoot 10 van die conclusie aangehaalde literatuur.

120 Artikel 325 VEU luidt voor zover relevant als volgt: “1. (...)de lidstaten bestrijden fraude en alle andere onwettige activiteiten waardoor de financiële belangen van de Unie worden geschaad, met overeenkomstig dit artikel te nemen maatregelen die afschrikkend moeten werken en (...) een doeltreffende bescherming moeten bieden. 2. De lidstaten nemen ter bestrijding van fraude waardoor de financiële belangen van de Unie worden geschaad, dezelfde maatregelen als die welke zij treffen ter bestrijding van fraude waardoor hun eigen financiële belangen worden geschaad.” Zie hierover A-G Kokott van 15 december 2011, zaak C-489/10, Bonda, punten 17-20. Het Hof komt niet aan de vraag toe. HvJEU van 5 juni 2012, zaak C-489/10, Bonda.

121 Zie bijvoorbeeld artikel 6 van richtlijn 76/207 betreffende de gelijke toegang van mannen en vrouwen tot arbeid). HvJEU van 10 april 1984, Von Colson en Kamann, zaak 14/83, punt 18; HvJEU van 3 mei 2005, gevoegde zaken C-387/02, C-391/02 en C-403/02, Berlusconi, punten 63 en 64. 
van belang dat steeds nauwkeurig wordt nagegaan of de betreffende nationale handeling inderdaad ziet op de effectuering, sanctionering of handhaving van Unierecht. In feite moet steeds sprake zijn van een dubbele EU-link: Allereerst moet er een identificeerbare plicht tot de effectuering, sanctionering en handhaving van Unierecht zijn op grond van de algemene bepaling artikel 4, lid 3 , VEU (overigens zijn deze plichten 'court-made') of op grond van specifieke Uniebepalingen (bijvoorbeeld artikel $325 \mathrm{VWEU}$ (plicht tot fraudebestrijding) of bepalingen van secundair recht). Ten tweede moet het (uiteindelijk) gaan om de effectuering, sanctionering en handhaving van een bepaling van materieel Unierecht. Hierbij is het niet noodzakelijk, dat de betreffende bepaling van materieel Unierecht van toepassing is op de feiten in het hoofdgeding. Het kan immers ook gaan om de effectuering, sanctionering en handhaving van de nationale implementatie wetgeving (die zelf weer kwalificeert als uitvoering in de zin van artikel 51 , lid 1 , van het Handvest).

In de rechtspraak van het Hof is deze dubbele EU-link steeds aanwezig, al wordt dit meestal niet expliciet benoemd. ${ }^{122}$ Drie recente voorbeelden waarin het Handvest op deze manier werd toegepast zijn de arresten DEB, Åkerberg Fransson en Texdata Software. In DEB ging het om de toepassing van het Uniegrondrecht op een nationale procesrechtelijke regeling inzake een voorschot in de proceskosten in een procedure die zag op een Francovichvordering uit hoofde van staatsaansprakelijkheid wegens schending Unierecht. Helaas brengt het Hof niet onder woorden waarom het Handvest van toepassing is. Desondanks is de toepassing wel gerechtvaardigd in het licht van artikel 51, lid 1, van het Handvest, nu het gaat om een procedure waar de grondslag van de vordering het Unierecht is. De nationale procedure regels dienen ertoe het recht op Francovich-schadevergoeding te effectueren. In de zaak Åkerberg Fransson koppelde het Hof de kwalificatie van de nationale regeling als 'uitvoering van Unierecht' wel expliciet aan de artikelen 4, lid 3, VEU en 325 VEU. Voor het Hof was doorslaggevend, dat met de toepassing van deze nationale regelingen werd beoogd schending van de bepalingen van de BTW-richtlijn te bestraffen en dus uitvoering te geven aan de door het Verdrag aan de lidstaten opgelegde verplichting om gedragingen waarmee de financiële belangen van de Unie worden geschaad, effectief te bestraffen. Ook hier is de band met het Unierecht verdedigbaar en in lijn met eerdere rechtspraak. ${ }^{123}$ Ook

122 Zie in dit verband ook HvJEU van 15 september 2011, gevoegde zaken C-483/09 en C1/10, Gueye en Sanchez, punten 50-52, 69 en HvJEU van 22 mei 2014, zaak C-56/13, Érsekcsanádi Mezögazdasági, punten 52, 55 en 56 als voorbeelden van zaken waarin het Hof de grondrechten niet toepast.

123 Zie ook Vervaele 2013, p. 128-129. Anders: A-G Cruz Villalón van 12 juni 2012, zaak C617/10, Åkerberg Fransson. 
in de zaak Texdata Software is de toepassing van Uniegrondrechten op de nationale regeling in mijn ogen legitiem. ${ }^{124}$ Het verband tussen de sanctie en de Unieregeling is onmiskenbaar. Het gaat ten eerste om schending van een openbaarmakingsplicht die volgt uit de Elfde richtlijn. Ten tweede schrijft die richtlijn specifiek voor dat de lidstaten moeten voorzien in passende sancties terzake van schending die plicht. De zaak kan dus zelfs worden gezien als een geval van klassieke omzetting zoals besproken in paragraaf 4.2.

Hoewel deze subcategorie van uitvoering verenigbaar is met artikel 51 , lid 1 , van het Handvest en het een coherente en reeds langer bestaande lijn in de rechtspraak betreft, verdient deze categorie toch bijzondere aandacht. Het hierboven besproken arrest Åkerberg Fransson heeft namelijk zowel vooraf als achteraf de aandacht getrokken.125 Een relatief groot aantal lidstaten, waaronder ook Nederland, dienden in deze prejudiciële zaak schriftelijke opmerkingen in om te voorkomen dat het Handvest zou worden toegepast. 126 Ook de Europese Commissie bepleitte de niet-toepasselijkheid van het Handvest. Desondanks achtte het Hof het Handvest van toepassing. Krap twee maanden later reageerde het Duitse Bundesverfassunsgericht op het arrest Åkerberg Fransson. ${ }^{127}$ Hoewel het arrest niet 'ultra vires' werd verklaard, vereist het weinig fantasie om in de overwegingen van het Duitse constitutionele Hof een waarschuwing te lezen. ${ }^{128}$ Ook heeft het pennen in beweging gebracht in de doctrine. ${ }^{129}$ Deze reacties maken duidelijk dat het bestaan van deze subcategorie en in het bijzonder van het concept uitvoering van artikel 4, lid 3, VEU (plicht tot loyale samenwerking) nog wat verborgen is en nog niet vanzelf spreekt. Het verdient daarom aanbeveling, dat het Hof in toekomstige zaken de toepassing van Uniegrondrechten op de effectuering, sanctionering en handhaving van Unierecht expliciet benoemt en zorgvuldig motiveert. Dit vooral in gevallen waarin geen specifieke Uniebepalingen van toepassing zijn

124 Zie ook HvJEU van 26 september 2013, zaak C-418/11, Texdata Software, punten 74-75.

125 HvJEU van 26 februari 2013, zaak C-617/10, Åkerberg Fransson, punten 17-19.

126 De andere lidstaten waren: Tsjechië, Denemarken, Duitsland, Ierland, Griekenland, Frankrijk en Oostenrijk.

127 BverG van 24 april 2013, 1 BvR 1215/07, para. 91: "Insofern darf die Entscheidung nicht in einer Weise verstanden und angewendet werden, nach der für eine Bindung der Mitgliedstaaten durch die in der Grundrechtecharta niedergelegten Grundrechte der Europäischen Union jeder sachliche Bezug einer Regelung zum bloß abstrakten Anwendungsbereich des Unionsrecht oder rein tatsächliche Auswirkungen auf dieses ausreiche."

128 Zie Redactioneel 2013, p. 925-930; Fontanelli 2013, p. 315-334.

129 Fontanelli 2014, p. 20 e.v.; Fontanelli 2013; Redactioneel NTM/ NJCM -Bull. 2013; Reestman \& Besselink 2013; Redactioneel CMLR 2013; Hancox 2013; Vervaele 2013; Sarmiento 2013; De Boer 2013. 
die verplichten tot de effectuering, sanctionering en handhaving van Unierecht, zoals bijvoorbeeld artikel 325 VWEU (plicht tot fraudebestrijding) of bepalingen van secundair recht.

Tot slot is er op gewezen, dat ook handelingen die vallen onder de nationale procedurele autonomie uitvoering zijn in de zin van artikel 51, lid 1, van het Handvest. Ik acht dit begrijpelijk, echter de rechtspraak is niet eenduidig voor wat betreft de verhouding tussen de toepassing van Uniegrondrechten en de Rewe-riedel. Soms is sprake van een aparte eigen toets aan de grondrechten naast de Rewe-riedel ('een Rewe-riedel-plus') en in andere gevallen lijkt de toets aan de grondrechten onderdeel uit te maken van het doeltreffendheidsvereiste. Voorts maakt het Hof ook gebruik van formules waarin de Rewe-riedel helemaal niet terug komt, maar er enkel wordt verwezen naar de grondrechten en doeltreffendheid van de onderliggende materieelrechtelijke Unieregeling. Het verdient aanbeveling dat het Hof op dit punt helder en eenduidig overweegt. Een Rewe-riedel-plus verdient mijns inziens de voorkeur waarbij steeds duidelijk een onderscheid wordt gemaakt tussen de toets aan de grondrechten en de toepassing van de Rewe-riedel. ${ }^{30}$ Dit voorkomt onnodig ingewikkelde en kunstmatige constructies waarbij de toets aan de grondrechten moet worden gepast in het stramien van het doeltreffendheidsvereiste. Bovendien komt zo ook duidelijker tot uitdrukking dat handelingen die vallen onder de procedurele autonomie uitvoeringshandelingen in de zin van artikel 51, lid 1, van het Handvest zijn.

\subsection{Conclusies}

1. Uit de rechtspraak van het Hof blijkt dat onder de lijn Wachauf alle nationale maatregelen vallen waarmee op het nationale niveau concreet toepassing wordt gegeven aan het Unierecht. Wachauf-uitvoering bevat een brede waaier aan situaties die kan worden onderverdeelde in vier subcategorieën: klassieke omzettingshandelingen; handelingen op grond van Uniebevoegdheden; handelingen die onder de werkingssfeer van Uniewetgeving vallen en handelingen terzake van de effectuering, sanctionering en handhaving van

130 Zie ook Prechal \& Widdershoven 2011over de verhouding tussen het Rewedoeltreffendheidsbeginsel en het beginsel van effectieve rechtsbescherming. Zij zijn voorstander van een splitsing van de toepassing van deze beginselen: "In our view a separate application of the principles is desirable, because they serve different purposes and are driven by different rationales. While the effectiveness principle (and also the principle of equivalence) primarily aims to guarantee an effective application of substantive EU law, the principle of effective judicial protection is intimately linked to the fundamental right of access to the court and, ultimately, to the idea of the 'Rechtsstaat'." 
Unierecht (oftewel de uitvoering van het beginsel van loyale samenwerking). De genoemde subcategorieën bieden redelijk wat houvast. Desondanks is er ruimte voor verduidelijking en verfijning van de bestaande rechtspraak en wel met name met betrekking tot de laatstgenoemde subcategorie inzake de effectuering, sanctionering en handhaving van Unierecht. De aandacht voor Åkerberg Fransson maakt duidelijk dat deze categorie kampt met een imagoprobleem. Het zou daarom nuttig zijn om in toekomstige zaken bijzondere aandacht te besteden aan de explicitering en motivering ervan. Voorts is sprake van een inconsistente aanpak voor wat betreft de toepassing van Uniegrondrechten op nationale handelingen die vallen binnen de procedurele autonomie van de lidstaten. Hoe verhoudt deze zich met de Rewe-riedel; is sprake van een eigen toets aan de grondrechten ('een Rewe-riedel-plus') of maakt de toets aan de grondrechten onderdeel uit van het doeltreffendheidsvereiste?

2. In het algemeen verhoudt de uitwerking van de Wachauf-lijn zich goed tot het beginsel van de allocatie van bevoegdheden. Een aantal arresten roept echter vragen en/of aandachtspunten op. Zo lijkt het in het arrest Chatzi te gaan om de toepassing van het algemene gelijkheidsbeginsel op een klassieke uitvoeringsmaatregel. De uitkomst van het arrest komt echter neer op een zelfstandige werking van het algemene gelijkheidsbeginsel, dat wil zeggen een werking los van de toepassing van Unierecht. Voorts blijkt uit het arrest Garage Molenheide, dat bij de toepassing van Unierechtelijke grondrechten op nationale handelingen genomen in de uitoefening van op grond van Unierecht verleende bevoegdheden voorzichtigheid moet worden betracht bij het aannemen van impliciete Unierechtelijke bevoegdheden. Een ander punt van aandacht in de lijn Wachauf is het arrest Kücükdeveci. In deze zaak ging het om de toepasselijkheid van Unierechtelijke grondrechten op nationale maatregelen die -naar nationaal recht- niet bedoeld zijn als omzettingsmaatregel, maar die wel binnen de werkingssfeer van specifieke materiële bepalingen van Unierecht vallen. Dit geeft blijk van een ruime opvatting van 'uitvoering' van Unierecht die op zich niet problematisch is. Wel moet met dit arrest voorzichtigheid worden betracht met de te ruime formulering van het begrip werkingssfeer. Hieruit kan mogelijk worden afgeleid, dat bij de bepaling van de materiële werkingssfeer van non-discriminatiebepalingen en regelingen enkel de materie (bijv. arbeid, loon, huisvesting, dienstverlening) van belang is in plaats van de materie en het onderscheidingscriterium (leeftijd, geslacht, ras etc.) tezamen. Het enkel uitgaan van de materie zonder deze te koppelen aan het onderscheidingscriterium zou leiden tot bevoegdheidsoverschrijding. Tot slot blijkt uit het arrest Toshiba dat de Unierechtelijke grondrechten ook van toepassing kunnen zijn op nationale handelingen die zijn genomen op grond 
van een nationale bevoegdheid. Hetgeen dubieus zou kunnen zijn. In deze zaak was dat echter verdedigbaar wegens de samenhang met de Unierechtelijke verdeling van bevoegdheden uit hoofde van verordening 1/2003 en het feit dat het Hof enkel het bestaan van de nationale bevoegdheid toetste aan de Unierechtelijke grondrechten (en niet de uitoefening ervan). 



\section{HOOFDSTUK 5}

\section{ERT-UITVOERING}

\section{$5.1 \quad$ Inleiding}

Uit het arrest ERT en de daarop volgende rechtspraak blijkt, dat de Unierechtelijke grondrechten ook van toepassing zijn op nationale maatregelen die in beginsel in strijd zijn met een verbodsbepaling van Unierecht, maar waarbij de overheid een beroep doet op een Unierechtelijke rechtvaardigingsgrond. ${ }^{1}$ De ratio van de ERT-gebondenheid aan de fundamentele rechten is evenals bij de Wachauf-lijn de uniforme en grondrechtconforme toepassing van Unierecht. ${ }^{2}$ Daar waar nationale handelingen in overeenstemming moeten zijn met het Unierecht, moeten zij voldoen aan het gehele Unierecht, inclusief de Unierechtelijke grondrechten. ${ }^{3}$ Op basis van het Unierecht kunnen geen maatregelen worden toegestaan (gerechtvaardigd) die onverenigbaar zijn met de Unierechtelijke grondrechten. ${ }^{4}$ De gebondenheid kan derhalve ook hier worden gezien als een afgeleide van de gebondenheid van de Unie zelf aan de grondrechten.

In dit hoofdstuk wordt de toepassing van de ERT-route nader onderzocht. Tot nu toe is enkel sprake van een expliciete toepassing van de ERT-route in het kader van de vrije verkeersbepalingen (paragraaf 5.2). Daarnaast lijkt het voor de hand te liggen, dat de ERT-route ook geldt voor nationale handelingen die in beginsel in strijd zijn met Unierechtelijke verbodsbepalingen buiten het vrije verkeer en waarbij een beroep wordt gedaan op een Unierechtelijke rechtvaardigingsgrond. Het Hof lijkt al stappen te hebben gezet met betrekking tot de toepassing van de ERT-route terzake van het Unieburgerschap (paragraaf 5.3). De toepassing van de ERT-route leidt in beginsel niet tot spanning met het beginsel van de allocatie van bevoegdheden, zolang het steeds gaat om de toepassing van Unierechtelijke grondrechten op nationale maatregelen die a priori onder een Unierechtelijke verbodsbepaling vallen.

HvJEU van 18 juni 1991, zaak C-260/89, ERT, punten 41-43.

2 Zie ook Eeckhout 2002, p. 978.

3 Zie ook Lenaerts 2000, p. 590.

4 Zie ook: Weiler 1996, p. IV.B: "the scope of the derogation and the conditions for its employment are all 'creatures' of Community law" 


\subsection{De ERT-route bij beperkingen van het vrije verkeer}

\subsubsection{Analyse van de rechtspraak van het Hof}

De klassieke toepassing van de ERT-route is de rechtstreekse toepassing van Unierechtelijke grondrechten op nationale maatregelen die in beginsel in strijd zijn met een vrije verkeersbepaling van Unierecht, maar waarbij de overheid een beroep doet op een Unierechtelijke rechtvaardigingsgrond. Het gaat met andere woorden om de directe werking van grondrechten ten aanzien van nationale maatregelen die kwalificeren als een beperking (ook wel belemmering) van het vrije verkeer. ${ }^{5}$

Uit het arrest Grogan blijkt, dat de kwalificatie van de nationale maatregel als beperking van het vrije verkeer essentieel is voor de rechtstreekse toepassing van Unierechtelijke grondrechten via de ERT-route. In die zaak kwalificeerde de nationale maatregel niet als beperking; aan de toetsing van de maatregel aan Unierechtelijke grondrechten werd dan ook niet toegekomen. ${ }^{6}$ Dit is ook logisch. Indien een nationale maatregel niet kwalificeert als 'beperking' (en evenmin als Wachauf -uitvoering) is de maatregel zuiver nationaal. De kwalificatie van de betreffende nationale handeling als 'beperking' is derhalve een prealabele voorwaarde voor de toepassing van Unierechtelijke grondrechten. Van directe werking van Unierechtelijke grondrechten kan pas sprake zijn in het kader van de beoordeling van of de nationale (beperkende) maatregel kan worden gerechtvaardigd. Dezelfde systematiek volgt uit het arrest Pelckmans. ${ }^{7}$ In deze zaak ging het om de toepassing van de artikelen 20 en 21 van het Handvest (het gelijkheids- en het non-discriminatiebeginsel) op de Belgische openingsurenwet. Het Hof achtte het Handvest niet van toepassing, omdat de verwijzingsbeschikking geen enkel concreet element waaruit blijkt dat de in het hoofdgeding aan de orde zijnde juridische situatie binnen het toepassingsgebied van het Unierecht valt. Hierbij overwoog het Hof expliciet dat de bepalingen inzake het vrije verkeer van goederen en diensten in beginsel niet van toepassing zijn op nationale winkelsluitingsregelingen.

Het is overigens wel mogelijk dat grondrechten een rol spelen bij de kwalificatie van een nationale handeling als 'beperking'. Dit blijkt uit de arresten Sayn-

5 In het kader van het vrije verkeer van goederen wordt meestal gesproken van een 'maatregel van gelijke werking'.

6 HvJEU van 4 oktober 1991, zaak C-159/90, Grogan, punten 27 en 31.

7 HvJEU van 8 mei 2014, zaak C-483/12, Pelckmans, punten 24-25. 
Wittgenstein en Vardyn. ${ }^{8}$ Deze twee arresten inzake het naamrecht hebben gemeen, dat het Hof reeds in het kader van zijn onderzoek naar het bestaan van een beperking van het vrije verkeer aandacht besteedde aan het recht op bescherming van het privé -leven uit hoofde van de artikelen 8 EVRM en 7 Handvest. Toch wordt hiermee geen afbreuk gedaan aan het hierboven besproken vereiste, dat de kwalificatie van de nationale handeling als 'beperking' een prealabele voorwaarde is voor de directe werking van een Unierechtelijke grondrechten via de ERT-route. Het grondrecht fungeerde in deze zaken niet als zelfstandige toetsingsmaatstaf, maar dienden om het belang van de naam van een persoon te illustreren en te onderstrepen. Aldus werd de toon gezet voor de overwegingen erna waarin het Hof op grond van het criterium het bestaan van 'ernstige ongemakken' naging of sprake is van een beperking van het vrije verkeer.

De directe werking van Unierechtelijke grondrechten ingevolge de ERT-route vindt dus plaats in het kader van de vraag of een nationale beperkende maatregel kan worden gerechtvaardigd. Het resultaat van de toepassing van Unierechtelijke grondrechten via de ERT-route, is dat zij dienen als begrenzing van de mogelijkheden tot rechtvaardiging. ${ }^{9}$ In het arrest Pfleger overwoog het Hof als volgt: ${ }^{10}$

"35. In dat verband heeft het Hof reeds geoordeeld dat wanneer een lidstaat zich beroept op dwingende vereisten van algemeen belang ter rechtvaardiging van een regeling die de uitoefening van de vrijheid van dienstverrichting kan belemmeren, deze door het Unierecht geboden rechtvaardigingsgrond moet worden uitgelegd in het licht van de algemene rechtsbeginselen van het Unierecht en met name de inmiddels in het Handvest neergelegde grondrechten. De betrokken nationale regeling kan dus slechts rechtvaardiging vinden in de bedoelde uitzonderingen, wanneer zij in overeenstemming is met de grondrechten waarvan het Hof de eerbiediging verzekert (...).”

De ERT-systematiek wordt goed duidelijk in het arrest Familiapress. ${ }^{11}$ Het ging hier om een Oostenrijkse wet inzake oneerlijke mededinging die onder andere

8 HvJEU van 22 december 2010, zaak C-208/09, Sayn-Wittgenstein, punt 52; HvJEU van 12 mei 2011, zaak C-391/09, Vardyn, punt 66. Zie verder over deze arresten: Swennen 2012 p.76-81; Van Eijken, 2012-2, p. 809-826.

9 Zie ook A-G Sharpston van 14 november 2013, zaak C-390/12, Pfleger, punt 45.

10 HvJEU van 30 april 2014, zaak C-390/12, Pfleger.

11 HvJEU van 26 juni 1997, zaak C-368/95, Familiapress, punten 12, 26, 34 en dictum. Zie voor andere voorbeelden van de directe werking van grondrechten met betrekking tot nationale maatregelen die het vrije verkeer beperken: HvJEU van 3 juni 2010, zaak C203/08, Sporting Exchange Betfair, punten 50-51; HvJEU van 19 juli 2012, zaak C-470/11, 
verbood om kruiswoordraadsels op te nemen in tijdschriften. Het Hof oordeelde, dat de nationale maatregel in beginsel kwalificeerde als een maatregel van gelijke werking in de zin van artikel 30 EG (thans: artikel 34 VWEU). Bij het onderzoek of de maatregel kon worden gerechtvaardigd op grond van de (ongeschreven) dwingende eisen paste het Hof de fundamentele rechten uit hoofde van de algemene rechtsbeginselen toe. In dit kader stelde het Hof vast de nationale maatregel eveneens kwalificeerde als een aantasting van de vrijheid van meningsuiting in de zin van artikel 10 EVRM.12 Het gevolg was dat de nationale maatregel enkel kon worden gerechtvaardigd indien voldaan was aan de eisen die artikel 10 EVRM als algemeen rechtsbeginsel stelt aan beperkingen van de vrijheid van meninguiting.

Uit de rechtspraak inzake het vrije verkeer blijkt, dat een keur van nationale maatregelen kan kwalificeren als beperking van het vrije verkeer. Dit betekent, dat de lidstaten op talloze terreinen gebonden kunnen zijn aan de Unierechtelijke grondrechten. ${ }^{13}$ De ERT-gebondenheid aan de grondrechten is dan ook ingrijpend. ${ }^{14}$

Voor de volledigheid wordt opgemerkt, dat grondrechten ook nog op een andere manier een rol kunnen spelen bij de toepassing van Unierechtvaardigingsgronden. De lidstaten kunnen (inter)nationale of Unierechtelijke grondrechten namelijk inroepen ter rechtvaardiging van nationale handelingen die in beginsel in strijd zijn met Unierechtelijke verbodsbepalingen. In plaats van dat de grondrechten de mogelijkheid tot rechtvaardiging begrenzen, fungeren zij in dit scenario juist als rechtvaardiging, als 'legitiem doel'. Zo ging het in het arrest Schmidberger om het niet ingrijpen door de Oostenrijkse overheid tegen wegblokkades op een belangrijke verkeersader, de Brennerautoweg. Dit toelaten van de blokkade kwalificeerde als een belemmering van het vrije goederenverkeer. Ter rechtvaardiging van deze belemmering voerde de Oostenrijkse overheid aan de eerbiediging van de grondrechten van betogers zoals neergelegd in het EVRM en de Oostenrijkse Grondwet (vrijheid van meningsuiting en vrijheid van vergadering). Uit het arrest blijkt dat de bescherming van die rechten een legitiem belang vormen, dat in beginsel een

Garkalns, punt 42 inzake het gelijkheidsbeginsel en de daaruit voortvloeiende transparantieverplichting.

12 Zie ook HvJEU van 30 april 2014, zaak C-390/12, Pfleger, punten 57-60.

13 Huber 2008, p. 327.

14 De Witte 1999, p. 873. 
rechtvaardiging kan vormen voor een beperking van door het gemeenschapsrecht opgelegde verplichtingen. ${ }^{15}$

In het arrest Omega ging het om een nationale maatregel die lasersporten verbood. De nationale maatregel kwalificeerde als een beperking van het vrije verkeer van diensten. De Duitse overheid deed een beroep op de exceptie van openbare orde en stelde in dit verband dat het lasersporten inbreuk maakt op een in de nationale grondwet opgenomen fundamentele waarde, namelijk de menselijke waardigheid. Ook uit dit arrest blijkt, dat de bescherming van grondrechten een rechtmatig belang is, dat in beginsel een rechtvaardiging kan vormen voor een beperking van door het Unierecht opgelegde verplichting. ${ }^{16}$

De Omega/Schmidberger- toepassing van grondrechten valt naar mijn mening buiten de ERT systematiek en er is geen sprake van directe werking van grondrechten. De grondrechten hebben hier immers een andere functie. Zij dienen niet als zelfstandige toetsingsmaatstaf en fungeren evenmin als mogelijke begrenzing van nationaal handelen. Zij vervullen integendeel juist de rol van rechtvaardiging van nationale handelingen.

\subsubsection{Beschouwing in het licht van de allocatie van bevoegdheden}

\subsubsection{Algemeen}

De ERT-gebondenheid aan de Unierechtelijke grondrechten is meer controversieel dan de Wachauf-gebondenheid. Met name, omdat de ERT-lijn leidt tot de toepasselijkheid van Unierechtelijke grondrechten op terreinen

15 HvJEU van 12 juni 2003, zaak C-112/00, Schmidberger, punt 74. Zie ook A-G Jacobs van 11 juli 2002, zaak C-112/00, Schmidberger, punten 89 en 94.

16 HvJEU van 14 oktober 2004, zaak C-36/02, Omega, punt 35. Aldus ook HvJEU van 22 december 2010, zaak C-208/09, Sayn-Wittgenstein, punten 82, 88 en 89 (beroep op nationale regeling dat constitutionele rang heeft en uitvoering geeft aan het gelijkheidsbeginsel); HvJEU van 12 mei 2011, zaak C-391/09, Vardyn, punten 85 en 86 (beroep op bescherming van rijke verscheidenheid van cultuur en taal, artikel 22 van het Handvest). Zie ook HvJEU van 10 oktober 2012, C-364/10, Hongarije/Slowakije, punt 51: “(...) de omstandigheid dat een burger van de Unie de functie van staatshoofd vervult, kan rechtvaardigen dat de uitoefening van het hem bij artikel 21 VWEU verleende recht van vrij verkeer wordt beperkt op basis van het internationale recht." (ging hier niet om grondrechten maar om volkenrecht op gebied van diplomatieke betrekkingen); HvJEU van 16 april 2013, zaak C-202/11, Las, punt 26 (beroep op bescherming van rijke verscheidenheid van cultuur en taal, artikel 22 van het Handvest). 
waar de Unie niet specifiek ${ }^{17}$ bevoegd is. De toepassing van de ERT -route kan ingrijpend zijn in de zin dat het de weg opent naar de toepassing van Unierechtelijke grondrechten op een keur aan nationale maatregelen.

Advocaat-generaal Jacobs meent dat bij de toetsing aan Unierechtelijke rechtvaardigingsgronden enkel kan worden getoetst aan de algemene beginselen van proportionaliteit en non-discriminatie op grond van nationaliteit, maar niet aan andere fundamentele rechten. Als op grond van deze toets vaststaat dat de nationale maatregelen door de beugel kan is de kous daarmee Unierechtelijk af. De toets aan de andere fundamentele rechten is vervolgens een zaak van nationaal recht. 18

Ik deel deze mening niet. Zoals gezegd is de ratio van de ERT-gebondenheid aan de fundamentele rechten dezelfde als bij de Wachauf-gebondenheid aan de grondrechten, namelijk de uniforme en grondrechtconforme toepassing van Unierecht. Het enkele feit dat de lidstaten in een andere hoedanigheid worden benaderd (als rechtssubjecten in plaats van als uitvoerders- vertegenwoordigers van Unierecht) doet hier niet aan af. De eerbiediging van Unierecht door de lidstaten is vorm van uitvoering in ruime zin (toepassing).Van belang is wel, dat de toepassing van de ERT-route er niet toe leidt dat materiële verplichtingen worden gecreëerd louter op grond van grondrechten. Zolang echter de ERTgebondenheid aan de fundamentele rechten enkel van toepassing is op nationale maatregelen die in beginsel in strijd zijn met een verbodsbepaling van Unierecht, maar waarbij de overheid een beroep doet op een Unierechtelijke rechtvaardigingsgrond, dreigt dit gevaar niet. Immers in dit scenario moet de nationale maatregel (die a priori onder een Unieverbod valt) zijn bestaansrecht ontlenen aan (een uitzonderingsmogelijkheid op grond van) het Unierecht. $\mathrm{Nu}$ het recht van de Unie in overeenstemming moet zijn met de Unierechtelijke grondrechten, kan het Unierecht enkel het groene licht geven aan nationale maatregelen die in overeenstemming met de Unierechtelijke grondrechten zijn. ${ }^{19}$ In feite ligt de directe werking van Uniegrondrechten via de ERT-route heel dicht aan tegen de uitleg van Unierecht in het licht van Uniegrondrechten, namelijk van een grondrechtconforme uitleg van Unierechtvaardigingsgronden. De ERT-rout eis dus nauw gekoppeld aan de toepassing van materieel Unierecht en dit is reeds een indicatie dat de ERT-route legitiem is.

17 De toevoeging 'specifiek' hangt samen met het feit, dat zodra de bepalingen inzake het vrije verkeer van toepassing zijn de Unie bevoegd is tot wetgeving. Vergelijk de artikelen 114 en 353 VWEU. Zie ook Prechal, de Vries \& van Eijken 2010, p. 235-239.

18 Jacobs 2001, p. 336-338.

19 Zie ook Weiler 1999, p. 121-123. 
Er zijn twee manieren waarop de toepassing van de ERT-route wel op gespannen voet kan komen te staan met het beginsel van de allocatie van bevoegdheden. Ten eerste bij een te ruime uitleg van de materiële werkingssfeer van vrij verkeerbepalingen. Als de drempel om een nationale maatregel als belemmering te kwalificeren laag ligt, wordt daarmee ook de drempel voor de toepasselijkheid van de Unierechtelijke grondrechten verlaagd. Ten tweede als het grondrecht fungeert als zelfstandige toetsingsmaatstaf bij de kwalificatie als 'beperking'. Hierdoor ontstaat het risico van directe werking in zuiver nationale situaties.

\subsubsection{Oprekking van de materiële werkingssfeer van vrije verkeersbepalingen}

De toepasselijkheid van grondrechten via de ERT-route kan controversieel zijn als nationale maatregelen te gemakkelijk onder een verbodsbepaling van het Unierecht worden gebracht door ze te kwalificeren als 'beperking'. Dit gevaar valt strikt genomen buiten het bereik van dit onderzoek, omdat het niet ziet op rechterlijk activisme ten aanzien van het toepassingsgebied van Unierechtelijke grondrechten als zodanig maar om rechtelijk activisme ten aanzien van de uitleg van materieel (Verdrags)recht. Desalniettemin is er een nauwe samenhang. Een ruime uitleg van de materiële werkingssfeer van verbodsbepalingen verruimt ook het toepassingsgebied van Unierechtelijke grondrechten. ${ }^{20}$ Aldus versterkt de $E R T$-route de gevolgen van rechterlijk activisme ten aanzien van de uitleg van materieel recht. Illustratief hiervoor is het arrest Carpenter. ${ }^{21}$

In het arrest Carpenter ging het om een besluit tot uitzetting door het Verenigd Koninkrijk van mevrouw Carpenter, onderdaan van een derde land en echtgenote van meneer Carpenter, onderdaan van het Verenigd Koninkrijk. Het Hof stelde allereerst vast, dat de heer Carpenter gebruik maakt van het door artikel 49 VEG (thans artikel 56 VWEU) gewaarborgde recht op het vrij verrichten van diensten. Zulks omdat een belangrijk deel van zijn beroepsactiviteit erin bestaat, tegen vergoeding diensten te verrichten ten behoeve van in andere lidstaten gevestigde adverteerders. Het Hof oordeelde vervolgens op grond van vaste rechtspraak dat dit recht op vrije verkeer, door een dienstenverrichter kan worden ingeroepen tegenover de staat waar hij is gevestigd, wanneer de diensten worden verricht ten behoeve van in een andere lidstaat gevestigde personen. ${ }^{22}$ Naar het oordeel van het Hof vormde het besluit tot

20 Zie ook De Witte 1999, p. 873. Anders: Huber 2008, p. 328.

21 HvJEU van 11 juli 2002, zaak C-60/00, Carpenter

22 Carpenter, punten 29 en 30. 
uitzetting van mevrouw Carpenter een belemmering van het vrije verkeer van diensten van meneer Carpenter. Hierbij overwoog het Hof als volgt:

\begin{abstract}
“38. Dienaangaande zij eraan herinnerd dat de gemeenschapswetgever heeft erkend dat het belangrijk is, het gezinsleven van de onderdanen van de lidstaten te beschermen teneinde de belemmeringen van de door het Verdrag gewaarborgde fundamentele vrijheden op te heffen, zoals met name blijkt uit de bepalingen van de verordeningen en richtlijnen van de Raad betreffende het vrije verkeer van werknemers en zelfstandigen binnen de Gemeenschap (...)

39. Vaststaat echter dat de scheiding van de echtelieden Carpenter schade zou berokkenen aan hun gezinsleven en, bijgevolg, aan de voorwaarden voor het gebruik van een fundamentele vrijheid door de heer Carpenter. Deze vrijheid zou immers haar volle werking niet kunnen ontplooien, indien de heer Carpenter door obstakels die in zijn land van herkomst aan de toegang en het verblijf van zijn echtgenoot in de weg worden gelegd, ervan zou worden weerhouden, van die vrijheid gebruik te maken (zie in die zin arrest Singh, reeds aangehaald, punt 23).”
\end{abstract}

De maatregel was derhalve enkel toelaatbaar indien deze kon worden gerechtvaardigd. Voor wat betreft de mogelijkheid tot rechtvaardiging overwoog het Hof als volgt:

“40. Dienaangaande zij erop gewezen dat een lidstaat zich ter rechtvaardiging van een nationale maatregel die het vrij verrichten van diensten kan belemmeren, slechts op redenen van algemeen belang kan beroepen wanneer die maatregel in overeenstemming is met de fundamentele rechten waarvan het Hof de eerbiediging verzekert (...)

41. Het besluit tot uitzetting van mevrouw Carpenter vormt een inmenging in de wijze waarop haar echtgenoot gebruik maakt van zijn recht op eerbiediging van zijn gezinsleven in de zin van artikel 8 (...) EVRM, dat deel uitmaakt van de grondrechten die, volgens de - overigens door de preambule van de Europese Akte en artikel 6, lid 2, EU bevestigde - vaste rechtspraak van het Hof in de communautaire rechtsorde worden beschermd.

42. Ook al waarborgt het EVRM als zodanig een buitenlander geen enkel recht om een bepaald land binnen te komen of er te verblijven, het uitsluiten van een persoon uit een land waar zijn naaste verwanten wonen, kan een inmenging zijn in het recht op eerbiediging van het gezinsleven in de zin van artikel 8, lid 1, van het EVRM. Een dergelijke inmenging is in strijd met het EVRM indien zij niet voldoet aan de vereisten van artikel 8, lid 2 ervan, namelijk indien zij niet bij de wet is voorzien", is ingegeven door een of meer met betrekking tot dat lid legitieme doelstellingen, en in een democratische samenleving nodig" is, dat wil zeggen gerechtvaardigd door een dwingende maatschappelijke behoefte en met name evenredig aan het nagestreefde legitieme doel (zie 
onder meer Eur. Hof R.M., arrest van 2 augustus 2001, Boultif/Zwitserland, Recueil des arrêts et décisions 2001-IX, §§ 39, 41 en 46).

43. Een besluit tot uitzetting van mevrouw Carpenter, genomen in omstandigheden als die in het hoofdgeding, eerbiedigt niet het juiste evenwicht tussen de betrokken belangen, namelijk enerzijds het recht van haar echtgenoot op eerbiediging van zijn gezinsleven, en anderzijds de verdediging van de openbare orde en veiligheid.

(...)

46. Gelet op al het voorgaande moet op de gestelde vraag worden geantwoord dat artikel $49 \mathrm{EG}$, gelezen tegen de achtergrond van het fundamentele recht op eerbiediging van het gezinsleven, aldus moet worden uitgelegd dat het zich ertegen verzet dat in een situatie als die in het hoofdgeding, de lidstaat van herkomst van een in diezelfde staat gevestigde dienstverrichter die diensten verricht ten behoeve van personen die in andere lidstaten zijn gevestigd, het verblijf op zijn grondgebied weigert aan de echtgenoot van die dienstverrichter, die onderdaan is van een derde land."

De toepassing van artikel 8 EVRM als algemeen rechtsbeginsel in een zaak als deze is vergaand en heeft ingrijpende gevolgen voor het nationale uitzettingsbesluit, deze houdt immers geen stand. Toch is het in deze zaak niet de toepassing van artikel 8 EVRM als zodanig die controversieel is, maar veeleer de kwalificatie van het intrekkingbesluit als belemmering van het vrije dienstenverkeer. ${ }^{23}$

De samenhang tussen, soms arbitraire, kwalificaties als 'vrije verkeersbeperking' en de toepasselijkheid van grondrechten is voor advocaat-generaal Sharpston reden om een uitbreiding van het toepassingsgebied van Unierechtelijke grondrechten voor te stellen. ${ }^{24} \mathrm{Zij}$ betoogt, dat arbitraire kwalificaties van nationale maatregelen als 'vrije verkeersbeperking' leiden tot een arbitraire toepasselijkheid van Unierechtelijke grondrechten en zelfs leiden tot rechtsongelijkheid. ${ }^{25}$ Naarmate de argumenten om bepaalde effecten van bepaalde maatregelen als ontmoedigend, belemmerend te kwalificeren zwakker worden, worden ook de argumenten om bepaalde effecten als zodanig te diskwalificeren zwakker. Dit leidt tot rechtsonzekerheid en willekeur. Dit

23 Redactioneel CMLR 2003: "the Court in Carpenter, being strongly influenced by the circumstances of the case, extends the scope of the freedom to provide services too far."

24 A-G Sharpston van 30 september 2010, zaak C-34/09, Ruíz Zambrano, punt 167.

25 De A-G doelt op situaties waarin het Hof ontmoedigende effecten aanneemt die op zijn zachtst gezegd weinig overtuigend zijn. Zo wijst A-G Sharpston op HvJEU van 7 juli 1992, zaak C-370/90, Singh; HvJEU van 2 februari 1989, zaak 186/87, Cowan; HvJEU van 11 juli 2002, zaak C-60/00, Carpenter en HvJEU van 23 september 2003, zaak C109/01, Akrich. 
weegt des te zwaarder indien ook de toepasselijkheid van de Unierechtelijke grondrechten aan deze kwalificatie is verbonden.

Advocaat-generaal Sharpston signaleert een aantal wezenlijke problemen. De oplossing hiervan ligt naar mijn mening echter niet in aanpassing van het systeem van de toepasselijkheid van de grondrechten van de Unie. Dit vormt immers niet de kern van het probleem. De kern van het probleem zit hem in de afbakening van de materiële werkingssfeer van de Verdragsbepalingen. De oplossing moet dan ook daar worden gezocht en ligt in een meer consequente en duidelijk gemotiveerde benadering van het Hof op dit vlak.

\subsubsection{Grondrechten bij de kwalificatie als 'beperking'}

Het tweede gevaar voor bevoegdheidsoverschrijding dreigt indien Unierechtelijke grondrechten rechtstreeks worden toegepast op nationale maatregelen die niet binnen de materiële werkingssfeer van een Unierechtelijke verbodsbepaling vallen (en evenmin kwalificeren als 'Wachauf-uitvoering'). Hiervan is sprake als het Uniegrondrecht zelfstandig en rechtstreeks op de nationale handeling wordt toegepast in het stadium van de kwalificatie van een nationale handeling als 'beperking'. Dat wil zeggen op een wijze waarop het Unierechtelijke grondrecht (juridisch of feitelijk) fungeert als zelfstandig toetsingskader. Immers op dat moment ontstaat het risico van het creëren van zelfstandige materieelrechtelijke verplichtingen op grond van de Unierechtelijke grondrechten. Het is dus van belang dat steeds duidelijk onderscheid wordt gemaakt tussen (i) de kwalificatie als 'beperking' en (ii) het onderzoek of een beperkende maatregel gerechtvaardigd kan worden. De toepassing van Uniegrondrechten is 'verdacht' in situaties waarin niet eerst is vastgesteld dat sprake is van een 'beperking'. Voorts is de toepassing van een Uniegrondrecht bij de kwalificatie als beperking 'verdacht'. Het is overigens niet zo dat Unierechtelijke grondrechten helemaal geen rol zouden kunnen spelen in het stadium van een nationale handeling als 'beperking'. Het feit dat de nationale handelingen raken aan bestanddelen van Unierechtelijke grondrechten kan van invloed zijn op de vraag of sprake is van 'beperking'. ${ }^{26}$ Terughoudendheid is hier echter wel op zijn plaats, de scheidslijn tussen het gebruik van het Unierechtelijke grondrecht als element in de beoordeling naar de vraag of sprake is van 'beperking' en het (feitelijk) gebruik van het grondrecht als zelf-

26 Zie bijvoorbeeld de eerder besproken arresten HvJEU van 22 december 2010, zaak C208/09, Sayn-Wittgenstein, punt 52 en HvJEU van 12 mei 2011, zaak C-391/09, Vardyn, punt 66. 
standig toetsingskader, kan dun zijn. ${ }^{27}$ Indien de enkele inmenging in een grondrecht zou volstaan om een nationale maatregel te kwalificeren als een belemmering van het vrije verkeer bestaat het risico, dat het Uniegrondrecht een zelfstandig leven gaat leiden los van de toepassing van materieel Unierecht. Zaken waarin de toepassing van Uniegrondrechten reeds plaats vindt bij de kwalificatie van een nationale maatregel als 'beperkend' zijn daarom heikel en verdienen steeds bijzondere aandacht.

Tot nu toe hanteert het Hof een duidelijke scheidslijn. In het kader van de klassieke ERT toepassing terzake van de vrije verkeersbepalingen fungeren de Unierechtelijke grondrechten pas als zelfstandige grond van toetsing van nationale handelingen als vaststaat dat ze kwalificeren als een beperking (Grogan). ${ }^{28}$ Grondrechten spelen slechts sporadisch een rol in het stadium van de kwalificatie als ‘beperking'. In dit verband wordt gewezen op de hiervoor besproken arresten Sayn-Wittgenstein en Vardyn. ${ }^{29}$ Deze twee arresten inzake het naamrecht hebben gemeen, dat het Hof reeds in het kader van zijn onderzoek naar het bestaan van een beperking van het vrije verkeer aandacht besteedde aan het recht op bescherming van het privé -leven uit hoofde van de artikelen 8 EVRM en 7 Handvest. Zoals gezegd meen ik dat hiermee toch geen afbreuk wordt gedaan aan het hierboven besproken vereiste, dat de kwalificatie van de nationale handeling als 'beperking' een prealabele voorwaarde is om Unierechtelijke grondrechten toe te passen als zelfstandige grond waaraan de nationale handeling kan worden getoetst. Het grondrecht diende in deze zaken namelijk enkel om het belang van de naam van een persoon te illustreren en te onderstrepen. Aldus werd de toon gezet voor de overwegingen erna waarin het Hof op grond van het criterium het bestaan van 'ernstige ongemakken' naging of sprake is van een beperking van het vrije verkeer.

Er is op dit terrein één arrest dat ruimte laat voor twijfel in het licht van het allocatiebeginsel en dat is het arrest Karner. Zoals eerder opgemerkt is dit arrest voor sommigen aanleiding is om naast de lijnen Wachauf en ERT uit te gaan van

27 Vergelijk bijvoorbeeld A-G Maduro van 12 september 2007, zaak C-380/05, Centro Europa, pnt 21-22: Hij betoogt dat schendingen die een probleem van systematische aard aangaande de bescherming van de fundamentele rechten in een lidstaat typeren, wegens hun rechtstreekse bedreiging voor de grensoverschrijdende dimensie van het Europese burgerschap en de integriteit van de EU-rechtsorde, als schendingen van de regels inzake het vrije verkeer moeten worden gekwalificeerd. Dit voorstel lijkt alweer een stap verder te gaan dan de aanpak van het HVJEU in de arresten Sayn-Wittgenstein en Vardyn.

28 HvJEU van 4 oktober 1991, zaak C-159/90, Grogan. Zie 5.2.1.

29 HvJEU van 22 december 2010, zaak C-208/09, Sayn-Wittgenstein, punt 52; HvJEU van 12 mei 2011, zaak C-391/09, Vardyn, punt 66. 
het bestaan van een derde lijn van situaties waarin grondrechten van toepassing zijn. ${ }^{30}$ In die zaak ging het om een nationale maatregel die verbiedt dat in openbare aankondigingen inzake de verkoop van uit faillissement afkomstige goederen die niet meer deel van de boedel uitmaken, wordt vermeld dat de betrokken goederen uit het faillissement afkomstig zijn. Het doel van de maatregel is consumentenbescherming. De gedachte erachter is, dat consumenten bij voorkeur goederen kopen die door de curator in een faillissement worden verkocht. In geval van reclame met betrekking tot de verkoop van goederen die afkomstig zijn uit een failliete boedel is het moeilijk te weten of de verkoop is georganiseerd door de curator of door iemand die de goederen eerder heeft opgekocht uit de failliete boedel.

Het Hof ging allereerst in op de richtlijn misleidende reclame (richtlijn 84/450) en overwoog als volgt:
“33. Zonder dat de door richtlijn 84/450 gerealiseerde graad van harmonisatie nader hoeft te worden geanalyseerd, staat vast dat de lidstaten op basis van artikel 7 bevoegd zijn om voorschriften te handhaven of aan te nemen met het oog op een verdergaande consumentenbescherming dan die waarin de richtlijn voorziet.
34. Bij de uitoefening van deze bevoegdheid moet evenwel het fundamentele beginsel van het vrije verkeer van goederen worden geëerbiedigd, dat tot uitdrukking komt in het in artikel $28 \mathrm{EG}$ gestelde verbod van kwantitatieve invoerbeperkingen en alle maatregelen van gelijke werking tussen de lidstaten $(\ldots)$ "

Vervolgens werd onderzocht of de nationale maatregel een maatregel van gelijke werking in de zin van artikel $28 \mathrm{VEG}$ (thans $34 \mathrm{VWEU}$ ) is. Dit is niet het geval, de maatregel is een verkoopmodaliteit in de zin van het arrest Keck en Mithouard. ${ }^{31}$ Dan wordt overwogen dat niet onderzocht hoeft te worden of de nationale maatregel strijdig is met het vrije verkeer van diensten (artikel 49 VEG, thans 56 VWEU) en wel om de volgende redenen:

" 46 . Wanneer een nationale maatregel zowel het vrije verkeer van goederen als de vrijheid van dienstverrichting beperkt, onderzoekt het Hof de maatregel in beginsel slechts ten aanzien van een van deze twee vrijheden, indien uit de omstandigheden van de zaak blijkt dat een van de vrijheden volledig ondergeschikt is aan de andere en daarmee kan worden verbonden (...)

30 Zie hoofdstuk 3.3.3.

31 HvJEU van 25 maart 2004, zaak C-71/02, Karner, punt 43. 
47. In de omstandigheden van het hoofdgeding is de verspreiding van reclameboodschappen niet een doel op zich. Ten opzichte van de verkoop van de betrokken goederen vormt die verspreiding een ondergeschikt element. Bijgevolg is het aspect van vrij verkeer van goederen belangrijker dan dat van vrijheid van dienstverrichting. $\S 30$, lid 1 , UWG behoeft dan ook niet te worden onderzocht in het licht van artikel 49 EG."

Tot slot ging het Hof in op de verenigbaarheid van de nationale maatregel met het algemene rechtsbeginsel van vrijheid van meningsuiting. De reden voor deze toets aan het algemene rechtsbeginsel is dat de nationale regeling valt "binnen het toepassingsgebied van het gemeenschapsrecht". 32 Waarom dit het geval is wordt niet toegelicht. Wel wordt verwezen naar ERT.

Het probleem in deze zaak is dat het Hof niet expliciet vast stelt dat de nationale maatregel een beperking is van het vrij verkeer. Tegelijkertijd echter laat het Hof open dat zulks wel het geval zou kunnen zijn. Ten aanzien van het vrije dienstenverkeer wordt immers enkel geoordeeld dat de nationale maatregel hieraan niet hoeft te worden getoetst, omdat het vrije dienstenverkeer ondergeschikt is aan het vrije goederenverkeer. Tevens laat het Hof in het midden of de maatregel een uitvoeringsmaatregel van de richtlijn misleidende reclame is of een toegestane verdergaande beschermingsmaatregel. ${ }^{33}$

Indien het hier zou gaan om een zaak waarin zou vaststaan dat de maatregel noch kwalificeert als uitvoeringsmaatregel van de richtlijn misleidende reclame noch als beperking van het vrije verkeer, zou de uitspraak controversieel zijn. Immers het zou dan gaan om de toepassing van Unierechtelijke grondrechten op zuiver nationale maatregelen. Nu dit in deze zaak echter niet vast staat, lijkt de zaak eerder hoogst ongelukkig dan controversieel. Het ligt in elk geval niet voor de hand om op grond van dit arrest een lijn te destilleren die de grenzen van Wachauf en ERT te buiten gaat. Dit wordt ook bevestigd door het feit, dat Karner door het Hof nimmer is angehaald ter ondersteuning van de toepasselijkheid van grondrechten.

32 HvJEU van 25 maart 2004, zaak C-71/02, Karner, punten 48 en 49.

33 Verdergaande beschermingsmaatregelen zijn maatregelen waarop het Unierecht niet van toepassing is. Zie verder hoofdstuk 6.3 . 


\subsection{De ERT-route bij ontzeggingen van Unie burgerschap(srechten)}

\subsubsection{Analyse van de rechtspraak van het Hof}

Een vraag die in toekomstige rechtspraak verder moet worden uitgewerkt is of de ERT-gebondenheid aan de Unierechtelijke grondrechten zich ook kan voordoen in situaties buiten het vrije verkeer. Het lijkt erop dat dit het geval is, en wel met name in situaties zoals in de arresten Rottmann en Ruiz Zambrano. ${ }^{34}$ Uit deze arresten blijkt respectievelijk dat ontneming van EU burgerschap en de "ontzegging van het effectieve genot van de belangrijkste aan de status van burger van de Unie ontleende rechten" (hierna worden beide varianten kortheidshalve omschreven als: 'ontzegging van Unieburgerschap(srechten)' 'of 'ontzegging') binnen de werkingssfeer van artikel 20 VWEU kunnen komen. Zulks ook zonder dat sprake is van een vrije verkeerssituatie.

In Rottmann ging het om een nationale maatregel (intrekkingsbesluit naturalisatie) die zou leiden tot het ('de jure') verlies (ontzegging) van de status van Unieburger. Het intrekkingsbesluit had namelijk tot gevolg, dat de heer Rottmann niet langer de nationaliteit van een lidstaat van de Unie bezat. Het intrekkingsbesluit had daarmee ook het verlies van Unieburgerschap tot gevolg. Het Hof oordeelde, dat de situatie van een burger van de Unie die kan leiden tot het verlies van het Unieburgerschap wegens de aard en de gevolgen ervan onder het Unierecht valt. ${ }^{35}$

In Ruiz Zambrano ging het om een nationale maatregel die zou leiden tot het ('de facto') verlies van essentiële EU burgerschapsrechten. Centraal stond een nationale maatregel waarin een staatsburger van een derde land een arbeidsvergunning werd geweigerd wat als gevolg had dat hem het recht werd ontzegd te verblijven in de lidstaat waar zijn kinderen van jonge leeftijd (staatsburgers van die lidstaat) en te zijnen laste, verbleven. De nationale

34 HvJEU van 2 maart 2010, zaak C-135/08, Rottmann. Zie over arrest Rottmann: Jessurun d'Oliveira 2011, p. 138-150; De Groot \& Seling 2011, p. 150-160. HvJEU van 8 maart 2011, zaak C-34/09, Ruiz Zambrano. Zie verder over het arrest Zambrano: Van der Mei, Van den Bogaert \& De Groot 2011, p. 188-199; Cambien 2011, p.411-413; Van Eijken \& De Vries 2011, p.704-721; Hailbronner \& Thym 2011, p.1253-1270; Hinarejos 2011, p. 309-312; Lansbergen \& Miller 2011, p. 287-307; Van Eijken 2012, p. 4-18.

35 HvJEU van 2 maart 2010, zaak C-135/08, Rottmann, punt 42. Ik meen dat het verlies van het Unieburgerschap als zodanig de situatie onder de werkingssfeer van artikel 20 VWEU heeft gebracht. Zie voor nadere analyse van mogelijke scenario's: De Groot \& Seling 2011, p. 152-154. 
maatregel viel binnen artikel 20 VWEU, omdat aan de betrokken kinderen (Unieburgers) 'het effectieve genot van de belangrijkste aan de status van burger van de Unie ontleende rechten worden ontzegd'. Immers, dergelijke weigeringen leiden ertoe, dat deze kinderen (Unieburgers) worden verplicht het grondgebied van de Unie te verlaten om hun ouders te volgen. Hierdoor komen zij in de feitelijke onmogelijkheid te verkeren om de belangrijkste aan hun status van burger van de Unie ontleende rechten uit te oefenen. ${ }^{36}$

In de beide zaken ging het derhalve om ('de jure' of 'de facto') ontzeggingen van Unieburgerschap(srechten). Welnu, voor zover een nationale maatregel kwalificeert als een 'ontzegging' en er de mogelijkheid bestaat deze ontzegging te rechtvaardigen, ${ }^{37}$ lijkt het waarschijnlijk dat deze rechtvaardigingsmogelijkheid wordt begrensd door de grondrechten van de Unie. Immers, ook hier geldt, dat op basis van het Unierecht geen maatregelen kunnen worden toegestaan (gerechtvaardigd) die onverenigbaar zijn met de Unierechtelijke grondrechten. Overigens wordt deze toepassing van grondrechten logischerwijs eerst relevant als er een mogelijke rechtvaardiging bestaat. Indien, zoals in Ruiz Zambrano het geval was, er geen legitieme redenen bestaan om de ontzegging te rechtvaardigen, wordt aan de toepassing van het Handvest niet toegekomen. ${ }^{38}$

Steun voor toepassing van de ERT-route ten aanzien van artikel 20 VWEU kan worden gevonden in het arrest Rottmann. Het Hof oordeelde, dat nationale voorwaarden voor de verkrijging en het verlies van de nationaliteit voor zover zij de door de rechtsorde van de Unie verleende en beschermde rechten aantasten, vatbaar zijn voor rechterlijke toetsing aan het Unierecht. Het Hof overwoog, dat dusdanige nationale maatregelen verenigbaar met het Unierecht kunnen

36 Zie voor een verduidelijking van het ontzeggings-criterium: HvJEU van 15 november 2011, zaak C-256/11, Dereci, punt 67: "Dit is dus een criterium van zeer bijzondere aard dat ziet op gevallen waarin, ondanks dat het secundaire recht inzake het verblijfsrecht van staatsburgers van derde landen niet van toepassing is, uitzonderlijk geen verblijfsrecht kan worden ontzegd aan een staatsburger van een derde land die lid is van de familie van een staatsburger van een lidstaat, omdat anders de nuttige werking zou worden ontnomen aan het burgerschap van de Unie dat deze laatste staatsburger toekomt." Zie ook HvJEU van 5 mei 2011, zaak C-434/09, MCarthy; A-G Bot van 27 september 2012, gevoegde zaken C-356/11 en C-357/11, O en S, punten 27-55 en HvJEU van 6 december 2012, gevoegde zaken C-356/11 en C-357/11, O.en S., punt 47 e.v.

37 In het Ruiz Zambrano scenario kan worden gedacht aan een geval waarin de desbetreffende ouder een zware crimineel of terrorist is, en waarbij de lidstaat zich beroept op een openbare orde exceptie.

38 Anders: Cambien 2011, p. 411: "Beschouwingen i.v.m. grondrechten hebben mogelijk dus impliciet het Hof geïnspireerd in zijn conclusie dat de Belgische beslissingen in strijd waren met het Unierecht.” 
zijn, als ze kunnen worden gerechtvaardigd uit hoofde van redenen van algemeen belang. In het onderzoek naar de rechtvaardiging paste het Hof het evenredigheidsbeginsel toe. ${ }^{39}$ Uit deze toetsing aan het evenredigheidsbeginsel kan worden afgeleid, dat de algemene rechtsbeginselen van toepassing zijn. ${ }^{40}$ Ook de gebruikte terminologie in het arrest duidt op toetsing aan het (gehele) Unierecht (dat wil zeggen inclusief de grondrechten). Immers, de situatie valt, aldus het Hof, "onder het Unierecht". Hierdoor moeten de lidstaten bij de uitoefening van hun bevoegdheid inzake nationaliteit "het Unierecht" eerbiedigen. Het Hof oordeelde, dat besluiten tot intrekking van naturalisatie als in het hoofdgeding derhalve vatbaar zijn voor rechterlijke toetsing aan het "Unierecht". 41

Voorts zijn er arresten over artikel 20 VWEU waarin het Handvest aan de orde is gesteld; de arresten Dereci, Iida en Ymeraga. ${ }^{2}$ Deze arresten stromen niet over van duidelijkheid, daarom kunnen er slechts voorzichtige conclusies uit worden getrokken. In alle drie de arresten speelde het Handvest een rol.43 Ten eerste duiden deze arresten en vooral Ymeraga erop dat het Handvest inderdaad van toepassing kan zijn in de context van artikel 20 VWEU. De toepasselijkheid van het Handvest wordt namelijk niet op voorhand verworpen, maar passeert integendeel als mogelijkheid de revue. In de arresten Iida en Ymeraga lijkt bovendien naar voren te komen dat het Handvest geen rol speelt in de kwalificatie als 'ontzegging'. Ook Dereci kan op die manier worden gelezen, maar dit arrest is op het punt van de toepasselijkheid van het Handvest helaas niet eenduidig. ${ }^{4}$

In Dereci ging het om vijf derdelanders die wilden samenleven met hun familieleden in Oostenrijk en die Unieburgers zijn, omdat ze de Oostenrijkse nationaliteit hebben. Deze Oostenrijkse familieleden hebben nimmer gebruik gemaakt van hun recht op vrij verkeer en zijn voor hun levensonderhoud niet afhankelijk van de vijf derdelanders die verzoeken om een verblijfsrecht. Bij alle derdelanders wordt het verzoek om verblijf in Oostenrijk afgewezen. De

39 HvJEU van 2 maart 2010, zaak C-135/08, Rottmann, punten 48, 50, 51 en 55.

40 Zoals eerder is opgemerkt is het aannemelijk, dat daar waar het evenredigheidsbeginsel van toepassing is, de grondrechten dat ook zijn. Immers de toepassing van dat beginsel toont aan dat de situatie zich bevindt binnen het toepassingsgebied van het Unierecht. Zie hoofdstuk 3.3. Anders: Eeckhout 2002, p. 963.

41 HvJEU van 2 maart 2010, zaak C-135/08, Rottmann, punten 42 en 47, 48.

42 HvJEU van 15 november 2011, zaak C-256/11, Dereci; HvJEU van 8 november 2012, zaak C-40/11, Iida en HvJEU van 8 mei 2013, zaak C-87/12, Ymeraga.

43 Dereci: artikel 7 van het Handvest; Iida: artikelen 7, 8 en 24 van het Handvest; Ymeraga: artikelen 20, 21, 24, 33 en 34 Handvest.

44 HvJEU van 15 november 2011, zaak C-256/11, Dereci, punten 66-68 en 70-75. 
verwijzende rechter vroeg onder verwijzing naar Zambrano of dit soort weigeringen verenigbaar zijn met artikel 20 VWEU. Het Hof overwoog in de eerste plaats als volgt:

"68. Het enkele feit dat het voor een staatsburger van een lidstaat misschien wenselijk is, om economische redenen of om de eenheid van de familie op het grondgebied van de Unie te bewaren, dat de leden van zijn familie, die niet de nationaliteit van een lidstaat bezitten, bij hem op het grondgebied van de Unie verblijven, volstaat bijgevolg op zich niet om aan te nemen dat de burger van de Unie verplicht zal worden om het grondgebied van de Unie te verlaten indien een dergelijk recht niet wordt toegekend.

69. Dit loopt niet vooruit op de vraag of op andere gronden, onder meer het recht op bescherming van het familie- en gezinsleven, een verblijfsrecht niet geweigerd mag worden. Op deze vraag moet echter worden ingegaan in het kader van de bepalingen inzake de bescherming van de grondrechten en ervan afhankelijk of zij in elk van de gevallen toepassing vinden.”

In de tweede plaats ging het Hof in op het recht op eerbiediging van het privéleven en het familie- en gezinsleven en overwoog als volgt:

"70. Om te beginnen moet eraan worden herinnerd dat artikel 7 van het Handvest van de grondrechten van de Europese Unie (hierna: „Handvest”), betreffende de eerbiediging van het privéleven en het familie- en gezinsleven, rechten bevat die overeenstemmen met die welke worden gewaarborgd door artikel 8, lid 1, van het $\operatorname{EVRM}(\ldots)$

71. Er moet evenwel aan worden herinnerd dat de bepalingen van het Handvest, krachtens artikel 51, lid 1, ervan, enkel tot de lidstaten zijn gericht wanneer zij het recht van de Unie ten uitvoer brengen. Krachtens lid 2 van diezelfde bepaling breidt het Handvest de werkingssfeer van het recht van de Unie niet verder uit dan de bevoegdheden van de Unie reiken, schept het geen nieuwe bevoegdheden voor de Unie, noch wijzigt het de in de Verdragen omschreven bevoegdheden en taken. Het Hof moet dus het recht van de Unie binnen de grenzen van de daaraan toegekende bevoegdheden, in het licht van het Handvest uitleggen (...).

72. Indien de verwijzende rechter in de onderhavige zaak van oordeel is dat, gelet op de omstandigheden van de hoofdgedingen, de situatie van verzoekers in de hoofdgedingen onder het recht van de Unie valt, zal hij moeten onderzoeken of de ontzegging van een verblijfsrecht aan deze laatste, het recht op eerbiediging van hun privéleven en familie- en gezinsleven in de zin van artikel 7 van het Handvest aantast. Wanneer hij daarentegen van oordeel is dat genoemde situatie niet binnen de werkingssfeer van het recht van de Unie valt, zal hij dit onderzoek in het licht van artikel 8, lid 1, van het EVRM moeten verrichten. 
73. Er moet immers aan worden herinnerd dat alle lidstaten partij zijn bij het EVRM, in artikel 8 waarvan het recht op eerbiediging van het privéleven en het familie- en gezinsleven is neergelegd."

Zoals eerder opgemerkt zaait het arrest Dereci omtrent het moment waarop de toepassing van het Handvest eventueel in beeld zou kunnen komen. Enerzijds kan het arrest worden gelezen als een vooruitlopen op de ERT-systematiek waarbij de grondrechten pas een rol spelen nadat is vastgesteld dat de betreffende nationale handeling kwalificeert als 'ontzegging'. In de overwegingen die zien op de kwalificatie als 'ontzegging' speelt het recht op de bescherming van het familie- en gezinsleven immers nog geen rol. 45 Vervolgens gaat het Hof in de overwegingen daarna wel in op de rol van het recht op de bescherming van het familie- en gezinsleven. ${ }^{46}$ Het lijkt erop dat het Hof dit doet voor het geval de verwijzende rechter bij één van de appelanten tot de conclusie zou komen dat zijn of haar situatie onder het recht van de Unie valt. ${ }^{47}$ Anderzijds veroorzaakt (de slotzin van) punt 69 verwarring. Deze zin zou ook kunnen worden gelezen als dat het Handvest van toepassing zou kunnen zijn, zonder dat sprake is van een ontzegging in de zin van artikel 20 VWEU.

In Iida ging het om de weigering aan een onderdaan van een derde land tot afgifte van een "verblijfskaart van een familielid van een burger van de Unie" door de Duitse autoriteiten. Er bestond geen verblijfsrecht op grond van het secundaire recht (richtlijnen 2003/109 en 2004/38). Het Hof stelde vast dat de weigering niet kwalificeert als 'ontzegging van burgerschap' à la Zambrano of als 'belemmering van vrije verkeer' à la McCarthy. ${ }^{48} \mathrm{Bij}$ deze vaststelling werd het Handvest niet betrokken. Vervolgens ging het Hof in op het Handvest. Het Hof onderzocht hiertoe of de weigering tot afgifte van een verblijfskaart kwalificeert als de uitvoering van Unierecht in de zin van artikel 51 van het Handvest. Dit was niet het geval. Het Hof oordeelde derhalve als volgt: ${ }^{49}$

45 Dereci, punten 66-68. Zie ook Lenaerts 2012-2, p. 12: “wanneer deze [de feitelijke omstandigheden] tot een 'ontzeggend effect' aanleiding geven, ontstaat er een materiële aanknoping met de status van burger van de Unie, met als gevolg de toepasselijkheid van het Handvest in de rechtsrelatie tussen die burger en de lidstaat waarvan hij de nationaliteit bezit.”; Lenaerts 2013-1, p. 53, Lenaerts 2013-2: “ Put simply, fundamental rights are not taken into account for the purpose of determining the existence or absence of a 'depriviation effect'”; Vergelijk ook A-G Trstenjak 15 mei 2012, zaak C-40/11, Iida, punten 72 en verder.

46 Dereci, punten 70-75.

47 Met name Dereci, punt 72 .

48 Iida, punt 76.

49 Zie ook Iida, punten 76-82 en punt 35 waarin enkel wordt verwezen naar het VWEU en niet naar het Handvest. 
"81. In die omstandigheden valt de weigering van de Duitse autoriteiten om lida een „verblijfskaart van een familielid van een burger van de Unie” af te geven, niet binnen het kader van de tenuitvoerlegging van het recht van de Unie in de zin van artikel 51 van het Handvest, zodat bij de toetsing van die weigering aan de grondrechten niet kan worden uitgegaan van de in het Handvest neergelegde grondrechten.”

In het recente arrest Ymeraga is het Hof nog weer wat duidelijker. Deze zaak betrof de weigering van de Luxemburgse autoriteiten om de uit Kosovo afkomstige ouders en twee broers van de Luxemburgse Kreshnik Ymeraga een verblijfsrecht als familieleden van een burger van de Unie te verlenen. Kreshnik Ymeraga is als Luxemburgs onderdaan Unieburger, maar heeft zijn recht van vrij verkeer niet uitgeoefend. Ook hier onderzocht het Hof eerst of sprake is van een 'Zambrano'- ontzegging van het effectieve genot van belangrijkste aan de status van burger van de Unie ontleende rechten”. Dit was niet het geval. Het Handvest speelde geen rol bij de kwalificatie als 'ontzegging'. Voorts overwoog het Hof dat de situatie in het hoofdgeding niet werd beheerst door de Gezinsherenigingsrichtlijn 2003/86 en Burgerschapsrichtlijn 2004/38. Het Hof oordeelde daarom als volgt:

“42. De wet betreffende het vrije verkeer beoogt weliswaar het Unierecht ten uitvoer te brengen, maar dit neemt niet weg dat de situatie van verzoekers in het hoofdgeding niet door het Unierecht wordt beheerst (...) en de weigering van een verblijfsrecht aan de familieleden van Kreshnik Ymeraga niet tot gevolg heeft dat hem het effectieve genot van de belangrijkste aan de status van burger van de Unie ontleende rechten wordt ontzegd.

43. In die omstandigheden valt de weigering van de Luxemburgse autoriteiten om de familieleden van Kreshnik Ymeraga een verblijfsrecht als familieleden van een burger van de Unie te verlenen niet onder de tenuitvoerlegging van het recht van de Unie in de zin van artikel 51 van het Handvest, zodat de verenigbaarheid van die weigering met de grondrechten niet aan de hand van de in het Handvest neergelegde grondrechten kan worden onderzocht.” (cursivering auteur)"

Hieruit lijkt te volgen dat het Handvest wel van toepassing zou zijn geweest in situaties waarin de weigering wel kwalificeert als een Zambrano-ontzegging. Opvallend is dat het Hof tot slot ten overvloede overwoog:

“44. Deze vaststelling loopt niet vooruit op de vraag of, op basis van een onderzoek tegen de achtergrond van de bepalingen van het Europees Verdrag tot bescherming van de rechten van de mens en de fundamentele vrijheden, 
waarbij alle lidstaten partij zijn, de betrokken onderdanen van een derde land in het hoofdgeding een verblijfsrecht niet kan worden geweigerd."

Het Hof maakt hiermee nog eens duidelijk dat het de zaak niet heeft onderzocht in het licht van het EVRM.

Uit Iida en Ymeraga lijkt te volgen dat de grondrechten (buiten Wachaufsituaties) pas een rol kunnen spelen, nadat is vastgesteld dat de nationale handeling een ontzegging in de zin van artikel $20 \mathrm{VEU}$ is. Dereci laat weliswaar ruimte voor twijfel, maar ik acht het onwaarschijnlijk dat het Hof hier mee bedoeld heeft de weg te banen voor een zelfstandige toepassing van het Handvest.

\subsubsection{Beschouwing in het licht van de allocatie van bevoegdheden}

Het lijkt erop dat de ERT-gebondenheid aan de Unierechtelijke grondrechten zich ook kan voordoen in situaties buiten het vrije verkeer, bijvoorbeeld bij de toepassing van artikel 20 VWEU. Ik acht dit in overeenstemming met artikel 51, lid 1, van het Handvest. De ratio van ERT (het Unierecht kan niet machtigen tot nationale handelingen die in strijd zijn met Unierechtelijke grondrechten) geldt in alle 'machtigingssituaties'. Ik meen dan ook dat de ERT-route toepasbaar is ten aanzien van alle nationale handelingen die uit hoofde van het Unierecht in beginsel zijn verboden en ten aanzien waarvan de lidstaten een beroep moeten doen op een Unierechtelijke rechtvaardigingsgrond ('machtiging').

Naast artikel 20 TEU kan bijvoorbeeld ook worden gedacht aan een bepaling als artikel 13 van besluit 1/80 van de Associatieraad die is ingesteld op grond van de Associatieovereenkomst tussen de Unie en Turkije. Deze bepaling verbiedt de invoering van nieuwe nationale maatregelen die tot doel of tot gevolg hebben dat aan de gebruikmaking door Turkse staatsburgers van het vrije verkeer van werknemers op het nationale grondgebied, strengere voorwaarden worden gesteld dan die welke golden bij de inwerkingtreding van besluit 1/80 voor de betrokken lidstaat. Uit het arrest Demir blijkt dat de 'rule of reason' ook van toepassing is op dit soort nieuwe beperkende maatregelen. ${ }^{50}$ Het Hof overwoog immers als volgt:

“40. Een dergelijke beperking, die tot doel of tot gevolg heeft dat aan de gebruikmaking door een Turks staatsburger van het vrij verkeer van werknemers op het nationale grondgebied strengere voorwaarden worden gesteld dan die welke golden bij de inwerkingtreding van besluit nr. 1/80, is verboden,

50 HvJEU van 7 november 2013, zaak C-225/12, Demir; zie ook HvJEU van 10 juli 2014, zaak C-138/13, Dogan, punt 37. 
tenzij zij (...) rechtvaardiging vindt in een dwingende reden van algemeen belang, geschikt is om de verwezenlijking van het legitieme doel te waarborgen en niet verder gaat dan nodig is voor het bereiken daarvan.”

Het ligt mijns ziens voor de hand dat in het geval een lidstaat zich ten aanzien van nieuwe beperkende maatregelen beroept op een dwingende reden van algemeen belang de Uniegrondrechten directe werking kunnen hebben via de ERT-route.

Het is bij de toepassing van de ERT-route in het kader van artikel 20 TEU van belang om duidelijk een knip te maken tussen (i) de kwalificatie als 'ontzegging' en (ii) de vraag naar de rechtvaardiging van de ontzegging.

(i) In het eerste stadium moet zeer terughoudend worden omgegaan met de toepassing van het Handvest. Uniegrondrechten zouden niet moeten fungeren als zelfstandige toetsingsmaatstaf. Dit zou immers de autonome toepassing van het Handvest in strijd met artikel 51 Handvest tot gevolg hebben. ${ }^{51}$

Uit de rechtspraak inzake het vrije verkeer, en met name uit de arresten SaynWittgenstein en Vardyn, blijkt desalniettemin dat de invloed van grondrechten in dit stadium niet is uitgesloten.52 Dit zal mogelijk ook zo zijn in het kader van artikel 20 VWEU. De arresten over deze bepaling laten zien dat de toepassing ervan nauw is verweven met het gezinsleven van de Unieburgers die zich erop beroepen. Dit betekent dat ook artikel 7 van het Handvest (bescherming van familie - en gezinsleven) van invloed kan zijn op de vraag of sprake is van een 'ontzegging'. Dit is onvermijdelijk. Advocaat-generaal Sharpston spreekt van een uitlegging van het Unierecht (bijvoorbeeld van artikel 20 VWEU) in het licht van artikel 7 van het Handvest: 53

"62. Indien en voor zover een bepaalde situatie betreffende EU-burgers binnen de werkingssfeer van het Unierecht valt, moet de uitlegging van elke Unierechtelijke bepaling waarbij aan die burgers rechten worden verleend (en waarbij dus aan de lidstaten een verplichting wordt opgelegd om die rechten te eerbiedigen), in overeenstemming zijn met alle relevante rechten in het Handvest, daaronder begrepen het bij artikel 7 van het Handvest gewaarborgde recht op eerbiediging van het privéleven en het familie- en gezinsleven. Dat betekent dat een bepaling als artikel 20 VWEU of 21 VWEU niet louter

51 Aldus ook Lenaerts 2012-1, p. 12-13.

52 HvJEU van 22 december 2010, zaak C-208/09, Sayn-Wittgenstein, punt 52; HvJEU van 12 mei 2011, zaak C-391/09, Vardyn, punt 66.

53 A-G Sharpston van 12 december 2013, zaak C-456/12, O. 
een grondslag voor een verblijfsstatus los van artikel 7 van het Handvest is. Veeleer dringen overwegingen betreffende de uitoefening van het recht op familie- en gezinsleven door in de kern van de EU-burgerschapsrechten. Burgerschapsrechten krachtens artikel 20 VWEU of 21 VWEU moeten op zodanige wijze worden uitgelegd dat de wezenlijke inhoud ervan in overeenstemming is met het Handvest. Dat proces staat los van de vraag of een voor een beperking van het EU-burgerschapsrechten aangevoerde rechtvaardiging, wanneer deze toepassing vinden, in overeenstemming is met het Handvest."

Bij een dusdanige uitleg van artikel 20 VWEU in het licht van Uniegrondrechten (bijvoorbeeld artikel 7 van het Handvest) is het wel van belang dat de toets aan het betreffende grondrecht niet de plaats inneemt van de toets aan het 'ontzeggings-criterium' die 'van zeer bijzondere aard'54 is. Aldus wordt een zelfstandige werking van de Unierechtelijke grondrechten (dat wil zeggende toepassing los van materiële bepalingen van Unierecht) voorkomen. ${ }^{55}$ In de context van artikel 20 VWEU is het immers van belang om ervoor te waken, dat de inroepbaarheid van Unierechtelijke grondrechten niet wordt gekoppeld aan de (enkele) hoedanigheid van Unieburger. Dit is nadrukkelijk niet de bedoeling van het Handvest.

(ii) In het tweede stadium kan het Handvest op grond van de ERT-route wel worden toegepast. Daar waar in de klassieke vrije verkeerszaken het bestaan van een beperking een prealabele voorwaarde is voor toepassing van het Handvest als zelfstandige grond voor toetsing, is bij de toepassing van de ERT-route ten aanzien van artikel 20 VWEU het bestaan van een 'ontzegging' essentieel.

Zoals gezegd is de huidige rechtspraak inzake het Handvest nog onduidelijk over de toepassing van Uniegrondrechten in de context van het Unieburgerschap (artikel 20 VWEU). Wel lijkt het Hof niet genegen te zijn om de inroepbaarheid van Unierechtelijke grondrechten te koppelen aan de hoedanigheid van Unieburger. Uit de arresten Dereci, Iida en Ymeraga, lijkt voorzichtig te kunnen worden afgeleid dat het Handvest geen rol speelt in de kwalificatie als ontzegging. In situaties waarin de nationale rechter gelet op de omstandigheden in het hoofdgeding zou oordelen, dat sprake is van een ontzegging van het effectieve genot, lijkt het Handvest vervolgens wel van toepassing te zijn.

54 Zie bijvoorbeeld HvJEU van 15 november 2011, zaak C-256/11, Dereci, punten 67 en 68.

55 Zie ook Lenaerts 2000, p. 593. 


\subsection{Conclusies}

1. Op grond van de lijn ERT zijn de Unierechtelijke grondrechten ook van toepassing op nationale maatregelen die in beginsel in strijd zijn met een verbodsbepaling van Unierecht, maar waarbij de overheid een beroep doet op een Unierechtelijke rechtvaardigingsgrond Daar waar nationale handelingen in overeenstemming moeten zijn met het Unierecht ('machtigingssituatie'), moeten zij voldoen aan het gehele Unierecht, inclusief de Unierechtelijke grondrechten.

2. ERT wordt klassiek gezien toegepast met betrekking tot nationale maatregelen die kwalificeren als 'beperkingen' van het vrije verkeer. Daarnaast ligt de toekomstige toepassing van deze lijn met betrekking tot 'ontzeggingen' van Unieburgerschap in de zin van artikel 20 VWEU (arresten Zambrano en Rottmann) voor de hand.

3. Met het oog op het beginsel van de allocatie van bevoegdheden is het van belang, dat de ERT -route van toepasselijkheid van Unierechtelijke grondrechten als zelfstandige toetsingsmaatstaf pas in beeld komt nadat vast is gesteld dat de betreffende nationale handeling kwalificeert als 'beperking' of 'ontzegging'. Het Hof lijkt dit consequent te doen, dit met uitzondering van het arrest Karner. Dit arrest lijkt eerder een onbedoelde uitschieter dan boegbeeld voor rechterlijk activisme.

4. Daarnaast kunnen grondrechten een rol spelen bij de kwalificatie van een nationale handeling als een 'beperking' of een 'ontzegging', niet als zelfstandige toetsingsmaatstaf, maar als element in de beoordeling of sprake is van een 'beperking' of een 'ontzegging'. Illustratief zijn de arresten SaynWittgenstein en Vardyn.

5. Met het oog op het causale verband tussen enerzijds de kwalificatie van nationale handelingen als 'beperking' of als 'ontzegging' en anderzijds de toepasselijkheid van Unierechtelijke grondrechten, dient zorgvuldig te worden nagegaan of de betreffende nationale handeling werkelijk zou moeten kwalificeren als 'beperking' of als 'ontzegging'. Immers door deze kwalificatie komt de nationale handeling binnen de werkingssfeer van het Unierecht en worden de grondrechten geactiveerd. 



\section{HOOFDSTUK 6}

\section{GEEN UITVOERING: ANNIBALDI}

\subsection{Inleiding}

De Toelichting bij artikel 51, lid 1, van het Handvest verwijst naar het arrest Annibaldi en benadrukt hiermee, dat het Handvest niet van toepassing is op "een nationale wettelijke regeling die niet binnen het kader van het gemeenschapsrecht valt" of op "een situatie die niet onder het gemeenschapsrecht valt". ${ }^{1}$ Met andere woorden: zuiver nationale situaties vallen buiten het bereik van de Uniegrondrechten. Het Hof heeft deze uitleg van artikel 51, lid 1, van het Handvest bevestigd in onder meer het arrest Åkerberg: ${ }^{2}$

"19. Uit vaste rechtspraak van het Hof volgt namelijk in wezen dat de in de rechtsorde van de Unie gewaarborgde grondrechten toepassing kunnen vinden in alle situaties die door het Unierecht worden beheerst, maar niet daarbuiten. In zoverre heeft het Hof reeds eraan herinnerd dat het een nationale regeling die niet binnen het kader van het Unierecht valt, niet aan het Handvest kan toetsen. Wanneer daarentegen een nationale regeling binnen het toepassingsgebied van het Unierecht valt, moet het Hof, ingeval het om een prejudiciële beslissing wordt verzocht, alle uitleggingsgegevens verschaffen die de nationale rechter nodig heeft om te kunnen beoordelen of deze regeling verenigbaar is met de grondrechten waarvan het de eerbiediging verzekert (...)."

De verwijzing naar de zaak Annibaldi in de Toelichting maakt ook duidelijk, dat niet elke aanknoping met het Unierecht volstaat om de Unierechtelijke grondrechten te activeren. Zo waren er in Annibaldi verschillende aanknopingspunten, maar ging het toch om een zuiver nationale situatie. In dit hoofdstuk wordt ingegaan op zuiver nationale situaties waarin de algemene rechtsbeginselen en het Handvest niet van toepassing zijn. Hiervoor zal een onderscheid worden gemaakt tussen enerzijds voorbeelden van situaties die in het geheel geen aanknoping bevatten met het Unierecht (paragraaf 6.2) en anderzijds voorbeelden van situaties waarin wel een aanknoping met het

1 HvJEU van 18 december 1997, zaak C-309/96, Annibaldi, punten 13 en 24. Zoals gezegd blijkt uit de totstandkomingsgeschiedenis van artikel 51, lid 1, Handvest, dat de toevoeging van het Annibaldi arrest welbewust in de Toelichting is gekomen op verzoek van een aantal leden van de Conventie die vreesden dat het toepassingsgebied van het Handvest te ruim zou zijn. Tettinger e.a. 2006, Art. 51, punt 39.

2 HvJEU van 26 februari 2013, zaak C-617/10, Åkerberg Fransson. Zie o.a. ook HvJEU van 13 juni 2013, zaak C-45/12, Hadj Ahmed, punt 56. 
Unierecht kan worden gedestilleerd, maar de algemene rechtsbeginselen en het Handvest desalniettemin niet van toepassing zijn (paragraaf 6.3). Tot slot wordt de rechtspraak 'zuiver nationale maatregelen' besproken in het licht van het beginsel van allocatie van bevoegdheden (paragraaf 6.4).

\subsection{Het ontbreken van enige aanknoping}

De algemene rechtsbeginselen en het Handvest zijn niet van toepassing in situaties die geen enkele aanknoping bevatten met het Unierecht. Het enkele beroep op een algemeen rechtsbeginsel of het Handvest is niet voldoende voor de toepasbaarheid ervan. Dit bleek reeds uit oudere beschikkingen waarin het Hof zich kennelijk onbevoegd verklaart inzake de toepassing van algemene rechtsbeginselen en is bevestigd in een aanzienlijke hoeveelheid beschikkingen met betrekking tot het Handvest. ${ }^{3}$ Ter illustratie zullen enkele van deze beschikkingen worden besproken.

Een eerste voorbeeld is de zaak Vajnai die ziet op de vraag naar de toepasselijkheid van het non-discriminatiebeginsel als algemeen rechtsbeginsel. ${ }^{4}$ In deze zaak ging het om de strafrechtelijke vervolging van Vajnai, de vice-voorzitter van de Hongaarse Arbeiderspartij wegens het in het openbaar, tijdens een demonstratie, op zijn kleding dragen van een vijfpuntige rode ster van karton met een doorsnede van vijf centimeter. Op grond van het Hongaarse wetboek

3 HvJEU van 12 november 2010, zaak C-339/10, Estov; HvJEU van 1 maart 2011, zaak C457/09, Chartry, punten 22-25; HvJEU van 23 mei 2011, gevoegde zaken C-267/10 en C-268/10, Rossius, punten16-19; HvJEU van 22 september 2011, zaak C-538/10, Lebrun, punten 18 en 19 en zaak C-314/10, Pagnoul, punten 23 en 24; HvJEU van 14 december 2011, gevoegde zaken C-483/11 en C-484/11, Boncea, punten 29-34; HvJEU van 7 juni 2012 (arrest), zaak C-27/11, Vinkov, punten 56-60; HvJEU van 7 juni 2012 (arrest), zaak C-27/11, Vinkov, punten 56-60; HvJEU van 6 juni 2013, zaak C-14/13, Cholakova; HvJEU van 22 september 2011, zaak C-538/10, Lebrun, punten 18 en 19 en zaak C314/10, Pagnoul, punten 23 en 24; HvJEU van 14 december 2011, gevoegde zaken C483/11 en C-484/11, Boncea, punten 29-34; HvJEU van 14 december 2011, zaak C462/11, Cozman, punt 15; HvJEU van 14 december 2011, zaak C-434/11, Corpul Naţional al Poliţistitor I; HvJEU van 15 november 2012, zaak C-369/12, Corpul Naţional al Poliţisstilor II, punt 15; HvJEU van 10 mei 2012, zaak C-134/12, MAI, punt 13; HvJEU van 12 juli 2012, zaak C-466/11, Currà, punt 26 en HvJEU van 21 februari 2013, zaak C312/12, Ajdini, punten 23-26 (in Ajdini gaat het Hof kort in op de positie van onderdanen van derdelanden). HvJEU van 30 mei 2013, zaak C-106/13, Fierro et Marmorale, punt 13. HvJEU van 6 juli 2012, zaak C-16/12, Hermes Hitel és Faktor. Niet alle beschikkingen zijn beschikbaar in het Nederlands.

4 HvJEU van 6 oktober 2005, zaak C-328/04,Vajnai. Zie ook HvJEU van 3 oktober 2008, zaak C-287/08, Savia, punt 9; HvJEu van 27 november 2009, zaak C-333/09, Noël, punt 12. 
van strafrecht behelsde dit het gebruik van een „symbool van het totalitarisme” in strijd met de wet. Vajnai beriep zich op het Unierechtelijke non-discriminatiebeginsel. Zulks omdat het gebruik van symbolen van de internationale arbeidersbeweging in de ene lidstaat is verboden, terwijl het dragen van dezelfde symbolen op het grondgebied van een andere lidstaat niet tot straffen leidt.

Het Hof verklaarde zich kennelijk onbevoegd, en overwoog als volgt:

"12. Het is vaste rechtspraak dat wanneer een nationale wettelijke regeling binnen de werkingssfeer van het gemeenschapsrecht valt, het Hof, ingeval het om een prejudiciële beslissing wordt verzocht, alle uitleggingsgegevens moet verschaffen die de nationale rechter nodig heeft om te kunnen beoordelen of die regeling verenigbaar is met de fundamentele rechten waarvan het Hof de eerbiediging verzekert (zie arrest van 29 mei 1997, Kremzow, C-299/95, Jurispr. blz. I-2629, punt 15).

13. Het Hof heeft die bevoegdheid echter niet ten aanzien van een wettelijke regeling die niet binnen het kader van het gemeenschapsrecht valt, en wanneer het voorwerp van het geding geen enkele aanknoping heeft met de in de bepalingen van de Verdragen bedoelde situaties (zie arrest Kremzow, reeds aangehaald, punten 15 en 16).

14. Vastgesteld moet worden dat het geval van Vajnai geen enkele aanknoping heeft met de in de bepalingen van de Verdragen bedoelde situaties en dat de in het hoofdgeding toegepaste Hongaarse regeling niet binnen het kader van het gemeenschapsrecht valt.”

In de beschikking Estov ging het om de toepasselijkheid van artikel 47 Handvest (effectieve rechtsbescherming) op een bestemmingsplanprocedure uit hoofde van de Bulgaarse ruimtelijke ordeningswetgeving. ${ }^{5}$ Het Hof verklaarde zich kennelijk onbevoegd op grond van de volgende overwegingen:

"12. Aangaande de onderhavige zaak zij echter eraan herinnerd dat de bepalingen van het handvest volgens artikel 51 , lid 1 , ervan gericht zijn ,tot de lidstaten, uitsluitend wanneer zij het recht van de Unie ten uitvoer brengen”, en dat het handvest overeenkomstig artikel 6, lid 1, VEU, dat het handvest bindende kracht verleent, en zoals blijkt uit de verklaring betreffende het Handvest van de grondrechten van de Europese Unie, gevoegd bij de slotakte van de Intergouvernementele Conferentie die het Verdrag van Lissabon heeft aangenomen, voor de Unie geen nieuwe bevoegdheden schept en geen wijzigingen in de bevoegdheden van de Unie brengt.

5 HvJEU van 12 november 2010, zaak C-339/10, Estov. 
13. Het is overigens vaste rechtspraak dat de vereisten die voortvloeien uit de bescherming van de grondrechten, de lidstaten in alle gevallen waarin zij het recht van de Unie moeten toepassen, binden en dat deze lidstaten gehouden zijn zo veel mogelijk te handelen in overeenstemming met die vereisten (...).

14 Aangezien de verwijzingsbeslissing niets concreets bevat dat de conclusie toelaat dat het besluit van de Ministerski savet na Republika Bulgaria van 16 december 2009 een maatregel is ter uitvoering van het recht van de Unie of dat het andere aanknopingsfactoren met dit recht vertoont, is niet aangetoond dat het Hof bevoegd is om de prejudiciële vragen te beantwoorden." (cusivering MdM)

In de beschikking Chartry ging het om de toepassing van artikel 47 Handvest (effectieve rechtsbescherming) op een geschil inzake directe belastingen tussen een Belgische staatsburger en de Belgische Staat. ${ }^{6}$ Het Hof herinnerde er allereerst aan, dat evenals bij de algemene beginselen het geval is, het Handvest ingevolge artikel 51, lid 1, Handvest enkel van toepassing is op handelingen van de lidstaten indien zij het recht van de Unie moeten toepassen. Deze bepaling preciseert immers dat de bepalingen van het Handvest geenszins een verruiming inhouden van de bevoegdheden van de Unie zoals bepaald in de verdragen. Het Hof verklaarde zich vervolgens kennelijk onbevoegd, omdat:

"25. (...) uit geen enkel concreet element van de verwijzingsbeslissing kan worden opgemaakt dat er een band bestaat tussen het voorwerp van het hoofdgeding en het recht van de Unie. Het hoofdgeding (...)vertoont geen enkel aanknopingspunt met een van de situaties die in de Verdragsbepalingen inzake het vrije verkeer(...). Bovendien zijn geen door de betrokken lidstaat ter uitvoering van het recht van de Unie genomen nationale maatregelen in het geding."

Een ander voorbeeld is de beschikking in de Belgische Rossius. Het gaat hier om een zuiver nationaal geschil waarin de verwijzende rechter (in zeer uitgesproken bewoordingen ${ }^{7}$ ) de principiële voorvraag opwerpt of het als legitiem kan

6 HvJEU van 1 maart 2011, zaak C-457/09, Chartry, punten 22-25. Zie ook de beschikkingen HvJEU van 22 september 2011, zaak C-538/10, Lebrun, punten 18 en 19 en zaak C-314/10, Pagnoul, punten 23 en 24 en HVJEU van 14 december 2011, gevoegde zaken C-483/11 en C-484/11, Boncea, punten 29-34.

7 Zie bijvoorbeeld de volgende tussenkopjes in de prejudiciële beslissing: "2.1.1 roken is abnormaal", "2.1.2 het roken van tabak is de vrucht van een collectieve hersenspoeling", "2.1.3 de hardnekkigheid van de tabaksverslaving is (...) te wijten aan de laksheid van de overheid. Zie ook enkele tussenconclusies en stellingen: "men moet wel door en door slecht zijn om zich constant te willen verrijken met (...) producten waarvan officieel is erkend dat zij onvermijdelijk de gezondheid van de gebruikers ervan vernietigen!”, “de 
worden aangemerkt dat een lidstaat accijns heft op een product dat eigenlijk verboden zou moeten worden wegens de gevaren die zij meebrengt voor de volksgezondheid. ${ }^{8}$ De verwijzende rechter wijst op artikel 35 Handvest (recht op toegang tot preventieve gezondheidszorg en op medische verzorging). Het Hof overwoog, dat het bindend worden van het Handvest voor de Unie geen nieuwe bevoegdheden schept en geen wijzigingen in de bevoegdheden van de Unie brengt. Het bindend worden van het Handvest heeft derhalve ook geen gevolgen voor de bevoegdheid van het Hof. Met betrekking tot zijn bevoegdheid stelde het Hof allereerst vast, dat alle relevante elementen van de geschillen zich beperken tot een enkele lidstaat. Voorts wordt overwogen dat het onderwerp van verschil als zodanig niet wordt beheerst door het Unierecht. Het Hof concludeerde dan ook dat de nationale regeling geen maatregel is die het recht van de Unie ten uitvoer brengt. Evenmin bevat het onderwerp van geschil andere aanknopingspunten met het Unierecht. Het Hof verklaarde zich dan ook onbevoegd.

\subsection{Het ontbreken van een toereikende aanknoping}

\subsubsection{Algemeen}

Van zaken waarin in het geheel geen aanknoping is met het Unierecht is het eenvoudig vast te stellen, dat de algemene rechtsbeginselen en het Handvest niet van toepassing zijn. Dit ligt anders bij zaken die wel raakpunten hebben met het Unierecht, maar die niet kunnen worden gebracht onder de lijnen Wachauf en ERT; zaken waarin er wel aanknoping met het Unierecht is, maar de aanknoping onvoldoende is om de grondrechten van de Unie te activeren. In deze paragraaf zullen een aantal van dit soort 'ontoereikende' aanknopingspunten worden besproken. ${ }^{9}$ Dit om de grenzen van Wachauf en ERT in beeld te brengen.

\subsubsection{Het bestaan van Uniebevoegdheden}

Het enkele feit dat het gaat om een nationale handeling of een situatie waarvan

hierboven beschreven situatie is absurd". De verwijzingsbeschikking kan worden nagelezen op de webpagina van het Expertisecentrum Europees recht (http://www.minbuza.nl/ecer onder 'hofzaken', daar zijn alle verwijzingsbeschikkingen in het Nederlands beschikbaar).

8 HvJEU van 23 mei 2011, gevoegde zaken C-267/10 en C-268/10, Rossius, 16-19. De beschikking is niet beschikbaar in het Nederlands.

9 Deze paragraaf is een uitwerking van De Mol 2012-2, 5.3. Zie ook ACA 2011, workingpaper, thema I, vraag 3. 
de Unie op het betrokken terrein beschikt over bevoegdheden is niet voldoende om een nationale maatregelen binnen het toepassingsgebied van het Unierecht te brengen. Dit blijkt uit het arrest Annibaldi. ${ }^{10}$ In deze zaak ging het om de weigering om aan grondeigenaar een vergunning te verlenen voor de aanleg van een boomgaard. De grond bevond zich namelijk in een regionaal park, dat was opgericht voor het behoud van de omgeving en cultureel bezit van het betrokken gebied. De grondeigenaar deed onder meer een beroep op zijn recht van eigendom. Hoewel in het arrest wordt bevestigd, dat de Unie (toen nog de gemeenschap) beschikt over bevoegdheden op het gebied van gemeenschappelijk beleid op de gebieden van landbouw en milieu en ook terzake van cultuur en meer in het bijzonder de instandhouding en bescherming van cultureel erfgoed, oordeelde het Hof dat de betrokken nationale wet niet binnen het toepassingsgebied van het gemeenschapsrecht kwam. ${ }^{11}$

In het arrest Bartsch ging het om een onderscheid op grond van leeftijd in de richtsnoeren van een bedrijfspensioenfonds. ${ }^{12}$ De richtsnoeren vormden geen maatregel ter uitvoering van de kaderrichtlijn gelijke behandeling, richtlijn 2000/78. Bovendien was de implementatietermijn van die richtlijn nog niet verstreken. Anders dan in de zaak Mangold het geval was, behelsde de betrokken regeling evenmin een implementatie van een andere Unieregeling. Om die redenen onderzocht het Hof of de bevoegdheidsbepaling artikel $13 \mathrm{EG}$ (thans artikel 19 VWEU) kon fungeren als een toereikende band met het Unierecht. Het Hof oordeelde, dat:
"18. Artikel 13 EG (...) kan als zodanig situaties (...) zoals in het hoofdgeding (...) niet onder de werkingssfeer van het gemeenschapsrecht brengen voor de toepassing van het verbod van discriminatie op grond van leeftijd."

Het Hof is nog explicieter in de beschikking Polier terzake van de beëindiging van een dienstverband van een werknemer zonder reden. ${ }^{13}$ De geldigheid van de litigieuze nationale regeling werd betwist op basis van de fundamentele Unierechten. De zaak bevatte verder geen aanknopingspunten met het Unierecht, anders dan dat de Uniewetgever bevoegd is om maatregelen te

10 HvJEU van 18 december 1997, zaak C-309/96, Annibaldi.

11 Annibaldi, punten 15, 16 en 21; vergelijk ook HvJEU van 6 maart 2014, zaak C-206/13, Siragusa, die hierna word besproken onder het kopje "Materie van de nationale handeling wordt in zijn algemeenheid bestreken door een Unieregeling”.

12 HvJEU van 23 september 2008, zaak C-427/06, Bartsch, punten 17, 18 en 24. Aldus ook Prechal, De Vries \& Van Eijken 2010, p. 218.

13 Beschikking HvJEU van 16 januari 2008, zaak C-361/07, Polier. De beschikking is niet beschikbaar in het Nederlands. 
nemen voor de bescherming van werknemers bij de beëindiging van arbeidsovereenkomsten. Dit vormde echter onvoldoende aanknoping om de zaak binnen het recht van de Unie te situeren. Het Hof verwoordde dit op de volgende wijze:

"13. Bien que la protection des travailleurs en cas de résiliation du contrat de travail soit l'un des moyens pour atteindre les objectifs fixés par l'article 136 CE et que le législateur communautaire soit compétent dans ce domaine, selon les conditions fixées à l'article 137, paragraphe 2, CE, des situations qui n'ont pas fait l'objet de mesures adoptées sur le fondement de ces articles ne relèvent pas du champ d'application du droit communautaire."14

\section{Tot slot overwoog het Hof in Julian Hernández onomwonden als volgt: ${ }^{15}$}

"36. (...) Het loutere feit dat een nationale maatregel binnen een gebied valt waarop de Unie over bevoegdheden beschikt, kan deze maatregel dus niet binnen de werkingssfeer van het Unierecht brengen en bijgevolg leiden tot de toepassing van het Handvest"

Uit de zaken Annibaldi, Bartsch, Polier en Julian Hernández komt dus naar voren dat het bestaan van bevoegdheden op een bepaald terrein niet voldoende is om de algemene rechtsbeginselen en het Handvest van toepassing te laten zijn. Bevoegdheden van de Unie worden pas relevant indien (i) ze zijn uitgeoefend en (ii) de betreffende nationale handeling binnen de materiële werkingssfeer valt van de betreffende regeling.

\subsubsection{Unieburger uit een andere lidstaat}

Het enkele feit, dat de nationale handeling een Unieburger uit een andere lidstaat betreft is eveneens onvoldoende om de algemene rechtsbeginselen en het Handvest van toepassing te laten zijn. ${ }^{16}$ In dit opzicht is er een belangrijk verschil tussen enerzijds artikel 18 VWEU (verbod van discriminatie op grond van nationaliteit) en anderzijds de algemene rechtsbeginselen en het

14 Vertaling MdM: Hoewel de bescherming van werknemers in geval van beëindiging van de arbeidsovereenkomst één van de middelen is om de in artikel 136 EG vastgestelde doelstellingen te bereiken en de communautaire wetgever ingevolge de in artikel 137, lid 2, EG genoemde voorwaarden bevoegd is op dit terrein, vallen situaties die geen onderwerp zijn van op basis van deze artikelen vastgestelde maatregelen, niet binnen de werkingssfeer van het gemeenschapsrecht.

15 HvJEU van 10 juli 2014, zaak C-198/13, Julian Hernández, zie ook punt 46.

16 Ladenburger 2012, p. 18. 
Handvest. ${ }^{17}$ Voor de toepassing van artikel 18 VWEU is het voldoende dat het gaat om een Unieburger uit een andere lidstaat. ${ }^{18}$ Tot op heden heeft het Hof deze 'burgerschapsbenadering'19 van artikel 18 VWEU niet toegepast op Unierechtelijke grondrechten uit hoofde van de algemene rechtsbeginselen of het Handvest. ${ }^{20}$ Het is ook niet te verwachten, dat het Hof hier in de toekomst toe zal overgaan. Dit zou immers neerkomen op een op zichzelf staande inroepbaarheid van algemene rechtsbeginselen en het Handvest (dat wil zeggen een inroepbaarheid los van andere materiële Unierechtelijke bepalingen), wat nadrukkelijk niet de bedoeling is van artikel 51 Handvest. ${ }^{21}$ Voorts lijkt uit het arrest Dereci te volgen, dat de Unierechtelijke grondrechten niet moeten worden beschouwd als zelfstandige rechten van Unieburgerschap in de zin van artikel 20, lid 2, VWEU.22

\subsubsection{Verdergaande beschermingsmaatregelen, geleidelijke harmonisatie en 'standstill'}

Oplettendheid dient te worden betracht bij Unieregelingen die minimumharmonisatie behelzen waarbij de lidstaten de ruimte hebben tot het nemen van 'verdergaande beschermingsmaatregelen'.23 Deze verdergaande beschermingsmaatregelen vallen in beginsel vermoedelijk buiten het toepassingsgebied van het Unierecht. ${ }^{24}$ Dit kan worden afgeleid uit de arresten Borsana en Eiterköpfe.

17 Aldus ook Eeckhout 2002, p. 969.

18 Zie Prechal, De Vries \& Van Eijken 2010, p. 226; Eeckhout 2002, p. 961-962.

19 Deze term komt van Van der Mei 2009, p. 75-87.

20 Aldus ook: Redactioneel CMLR 2010, p. 1589-1596, voetnoot 7.

21 Gewezen wordt op de totstandkomingsgeschiedenis van het Handvest, waarbij een eerdere tekstversie van artikel 51 van het Handvest waarin werd gesproken van toepassing 'binnen de werkingssfeer' van Unierecht werd vervangen door de huidige tekst. Aldus ook Kapteyn 2004, p. 118. Anders: A-G Jacobs van 9 december 1992, zaak C-168/91, Konstantinidis, punt 46. Hij bepleit het recht om te zeggen 'civis europeus sum' en aldus op te komen tegen elke schending van zijn grondrechten. Zie 6.4 voor een nadere bespreking van dit argument.

22 HvJEU van 15 november 2011, zaak C-256/11, Dereci, punten 67 en 72. Zie ook de standpuntbepaling in die zaak van A-G Mengozzi van 29 september 2011, punten 37 en 38.

23 Het recht om verdergaande maatregelen te hanteren kan volgen uit het Verdrag ( zie bijvoorbeeld de artikelen 153, lid 4 (sociale politiek), 169, lid 4, VWEU (consumentenbeschermimg) en 193 VWEU (milieu) en/of uit de betreffende secundaire regeling.

24 Aldus ook: Redactioneel CMLR 2010, p.1591. Anders: De Cecco 2006, p. 25. Hij stelt dat de toepassing van andere algemene rechtsbeginselen dan het evenredigheidsbeginsel niet op voorhand is uitgesloten. Anders: A-G Sharpston, zaak C-578/08, Chakroun, punt 47: "De lidstaten mogen gunstiger bepalingen vaststellen dan de richtlijn voorschrijft of 
In de zaak Borsana ging het om een nationale maatregel ter zake van de bescherming van werknemers tegen blootstelling aan carcinogene agentia. De maatregel bevatte strengere normen dan de richtlijn 90/394/EEG betreffende de bescherming van de werknemers tegen de risico's van blootstelling aan carcinogene agentia op het werk. Het Hof oordeelde op grond van de rechtsgrondslag en de richtlijn (minimumharmonisatie), dat deze strengere maatregel was toegestaan en dat geen sprake was van een verhindering van het vrije verkeer. ${ }^{25}$ Vervolgens kon een dergelijke regeling en de daaraan verbonden sancties niet worden getoetst aan het evenredigheidsbeginsel:

"40. Omdat het gaat om een met het Verdrag verenigbare maatregel voor een hogere graad van bescherming van de arbeidsomstandigheden en dus om de uitoefening van bevoegdheden die onder artikel 118 A, lid 3, van het Verdrag bij de lidstaat zijn verbleven (...).”

In het arrest Eiterköpfe was het Hof nog duidelijker en maakte onderscheid tussen "waarborgen dat de in de richtlijn genoemde minimumeisen in acht worden genomen" en "verdergaande nationale beschermingsmaatregelen die strengere eisen stellen dan de in de richtlijn genoemde minimumeisen". In het eerste geval is het Unierechtelijke evenredigheidsbeginsel wel van toepassing en in het tweede geval niet. ${ }^{26}$

Ik merk op dat de arresten Borsana en Eiterköpfe zien op de (niet) toepasselijkheid van het evenredigheidsbeginsel. Zoals opgemerkt in hoofdstuk 3.3.3 leid ik daar uit af dat ook de grondrechten niet van toepassing zijn op verdergaande beschermingsmaatregelen, omdat alle algemene rechtsbeginselen (dat wil zeggen de grondrechten en 'andere' algemene rechtsbeginselen) hetzelfde toepassingsgebied hebben dat ook weer gelijk is aan dat van het Handvest. De Cecco echter meent, dat deze arresten niet uitsluiten dat andere algemene rechtsbeginselen wel van toepassing zouden kunnen zijn op verdergaande

toestaat, maar dienen zich daarbij wel te houden aan het beginsel van gelijke behandeling of non-discriminatie."

25 HvJEU van 17 december 1998, zaak C-2/97, Borsana, punten 35-38.

26 HvJEU van 14 april 2005, zaak C-6/03, Eiterköpfe, punten 62-63. In deze zaak ging het om de implementatie van afvalstoffenrichtlijn 1999/31/EG. De bevoegdheid tot het nemen en handhaven van verdergaande beschermingsmaatregelen in het kader van het gemeenschappelijk milieubeleid volgde uit artikel 176 EG (thans 193 VWEU). I.c. ging het onder meer om de volgende verdergaande beschermingsmaatregelen: Het hanteren van kortere termijnen om hoeveelheden afvalstoffen te verminderen dan voorgeschreven door de richtlijn. Voorts had de nationale maatregel betrekking op groter gamma van afvalstoffen. 
beschermingsmaatregelen. ${ }^{27}$ Hij wijst hierbij op de bijzondere rol van het evenredigheidsbeginsel ten opzichte van de mogelijkheid tot het nemen van 'verdergaande maatregelen'. In zijn visie impliceert de mogelijkheid tot het nemen van verdergaande maatregelen nu juist dat de lidstaten verder mogen gaan dan wat de Uniewetgever evenredig en noodzakelijk acht. De mogelijkheid tot het nemen van verdergaande maatregelen zou het evenredigheidsbeginsel om die reden buiten spel zetten. ${ }^{28}$ De redenering van De Cecco overtuigt mij niet. Hoewel het bij minimumharmonisatie inderdaad op voorhand vast staat dat het hanteren van een hoger beschermingsniveau is toegestaan, sluit dit niet uit dat kan worden getoetst aan het proportionaliteitsbeginsel. De proportionaliteit zou immers nog steeds kunnen worden beoordeeld, maar dan in het licht van het hogere nationale beschermingsniveau in plaats van aan de minimumstandaard van de richtlijn. ${ }^{29}$ Bovendien zou de omstandigheid dat het gaat om toegestane verdergaande beschermingsmaatregelen ook aanleiding kunnen zijn om een minder intensieve proportionaliteitstoets toe te passen. ${ }^{30}$ Het lijkt dan ook onwaarschijnlijk, dat het Hof de toepassing van het evenredigheidsbeginsel geheel heeft uitgesloten omwille van de bijzondere rol van het evenredigheidsbeginsel ten opzichte van de mogelijkheid tot het nemen van 'verdergaande maatregelen'. Zeker niet nu dit tot de verwarrende situatie zou leiden dat het ene algemene rechtsbeginsel wel van toepassing zou zijn en de andere algemene rechtsbeginselen, waaronder de grondrechten, niet.

Deze visie lijkt (impliciet) te worden bevestigd door het arrest Dominguez. ${ }^{11}$ In

27 Zie ook A-G Tizanno 18 januari 2005, zaak C-519/03, Commissie/Luxemburg, punt 49 en standpuntbepaling A-G Kokott 7 juli 2010, zaak C-149/10, Chatzi, punten 56-57. De beide A-G's lijken er van uit te gaan dat het gelijkheidsbeginsel kan worden toegepast op het 'verdergaande beschermingsmaatregelen' (i.c. de toekenning van een langer ouderschapsverlof dan voorzien in de minimumharmonisatie richtlijn 96/34). Zie ook Kokott \& Sobotta 2010, p. 11: "the extent of the exception remains open: "Does it only apply to the principle of proportionality or are all EU law principles, notably fundamental rights excluded?"

28 De Cecco 2006, p. 22-27.

29 Bijvoorbeeld naar analogie van de techniek zoals in HvJEU van 19 juni 2008, zaak C219/07, Andibel, punt 31: "Het feit dat in de ene lidstaat minder strikte bepalingen gelden dan in de andere, betekent op zich niet dat de in laatstbedoelde lidstaat geldende bepalingen onevenredig zijn en derhalve onverenigbaar met het gemeenschapsrecht. De enkele omstandigheid dat de ene lidstaat voor een ander stelsel van bescherming heeft gekozen dan de andere, kan namelijk niet van invloed zijn op de beoordeling van de noodzaak en de evenredigheid van de ter zake getroffen regelingen".

30 Zie over evenredigheidsbeginsel en intensiteit van de toetsing: Jans 2000, p. 270-280.

31 HvJEU van 24 januari 2012, zaak C-282/10, Dominguez, punten 45-50. Zie ook A-G Bot van 17 december 2009, zaak C-203/08, Sporting Exchange Betfair en zaak C-258/08, Ladbrokes, punt 103. 
deze zaak ging het over het recht op jaarlijkse vakantie met behoud van loon. Het Unierecht waarborgt ingevolge richtlijn 2003/88 een minimumduur van vier weken. Op grond van de betreffende nationale regeling werd in bepaalde gevallen een langere duur aan vakantie toegekend. Voor werknemers die in een bepaald jaar afwezig zijn geweest wegens ziekteverlof gold dat zij afhankelijk van de oorzaak van hun ziekteverlof al dan niet aanspraak konden maken op verlof van langer dan vier weken. De verwijzende rechter vroeg of dit verenigbaar is met richtlijn 2003/88. Het Hof antwoordde, dat het op grond van de richtlijn is toegestaan om gunstigere maatregelen te nemen. De nationale wetgever kan dus meer recht op vakantie toekennen dan vier weken. Voorts kunnen de lidstaten bepalen dat het recht op jaarlijkse vakantie verschilt afhankelijk van de oorzaak van de afwezigheid van de werknemer om gezondheidsredenen, mits de vakantie minstens even lang is als de voorgeschreven minimumduur van vier weken. ${ }^{32}$ Het Hof toetste het verdergaande deel van de nationale maatregel (vakantierecht > vier weken) derhalve niet aan het algemene gelijkheidsbeginsel. Het arrest Dominguez duidt er derhalve op dat de grondrechten niet van toepassing zijn op 'verdergaande beschermingsmaatregelen'.33 Desondanks moet er ten aanzien van de toepasselijkheid van Uniegrondrechten op verdergaande beschermingsmaatregelen een slag om de arm worden gehouden. Dit met name met het oog op het arrest Chatzi, dat eerder is besproken in hoofdstuk 4.2.34

In het arrest Chatzi stond de raamovereenkomst inzake ouderschapsverlof centraal. Deze raamovereenkomst behelst ook minimumharmonisatie en voorziet in een Unierechtelijk ouderschapsverlof van minimaal drie maanden. Ingevolge de rechtspraak Borsana|Eiterköpfe/Dominguez zouden de Unierechtelijke grondrechten enkel van toepassing moeten zijn op de nationale implementatie van het Unierechtelijk minimum van drie maanden en niet op het verdergaande deel van de nationale maatregel boven de drie maanden. Echter, de uitkomst van dit arrest komt erop neer dat het deel van de nationale maatregel, dat een ouderschapsverlof van langer dan het Unierechtelijke minimum toekent, wel degelijk een rol speelt in de toepassing van het gelijkheidsbeginsel. Het kan namelijk fungeren als aanwijzing dat de nationale maatregel voldoet aan het algemene gelijkheidsbeginsel. Het arrest Chatzi laat

32 Dominguez, punt 49.

33 Zie ook HvJEU van 10 juli 2014, zaak C-198/13, Julian Hernández:“45. (...) een bepaling van nationaal recht als die welke in het hoofdgeding aan de orde is, die werknemers louter een gunstiger bescherming biedt door uitoefening van de door artikel 11, eerste alinea, van richtlijn 2008/94 bevestigde bevoegdheid van de lidstaten, niet kan worden geacht binnen de werkingssfeer van deze richtlijn te vallen"

34 HvJEU van 16 september 2010, zaak C-149/10, Chatzi. 
zich dan ook moeilijk rijmen met de rechtspraak Borsana/Eiterköpfe/Dominguez. Toekomstige rechtspraak zal moeten uitwijzen hoe het Hof om gaat met zogenaamde 'verdergaande beschermingsmaatregelen'. 35

Als de rechtspraak Borsana/Eiterköpfe/Dominguez leidend zal blijken te zijn en de Uniegrondrechten niet van toepassing zijn op verdergaande maatregelen, zijn er in dit verband nog twee punten van aandacht. Ten eerste moet zorgvuldig worden nagegaan of de van toepassing zijnde richtlijn zelf geen restricties stelt aan het nemen van strengere maatregelen. In dit verband wordt gewezen op het arrest Sky Italia. ${ }^{36}$ In deze zaak klaagde Sky Italia over een boete die was opgelegd wegens overschrijding van maximale zendtijden voor televisiereclame. Op grond van de nationale voorschriften inzake de uitzending van televisiereclame beschikten betaalzenders over kortere maximumzendtijden voor reclame dan de vrij toegankelijke zenders. Sky Italia betoogde onder meer dat dit onderscheid in strijd was met het algemene beginsel van gelijke behandeling. De relevante aanknoping met het Unierecht was de audiovisuele mediadiensten-richtlijn (richtlijn 2010/13/EU). Deze richtlijn voorziet in minimumharmonisatie. De richtlijn bevat een expliciete clausule die de lidstaten toestaat om strengere maatregelen te nemen 'op voorwaarde dat deze regels met het recht van de Unie stroken'. Het Hof overwoog dat hieronder ook vallen ' de algemene beginselen van het recht van de Unie'. Het overwoog voorts dat:

"14 (...) waar de richtlijn bepaalt dat het aandeel van televisiereclame- en telewinkelspots per klokuur niet meer dan $20 \%$ mag bedragen, deze bepaling niet uitsluit dat de lidstaten, onder die drempel van $20 \%$, verschillende maximumzendtijden voor televisiereclame vastleggen voor betaalzenders en vrij toegankelijke zenders, mits de voorschriften die die maxima opleggen in overeenstemming zijn met het Unierecht, meer in het bijzonder met de algemene beginselen daarvan, waartoe onder meer het beginsel van gelijke behandeling behoort, en met de door het Verdrag gewaarborgde fundamentele vrijheden."

35 Zie hierover A-G Kokott van 21 februari 2013, gevoegde zaken C-512/11, C-513/11, Terveys- ja sosiaalialan neuvottelujärjestö TSN, punt 71: "In hoeverre, in het geval van richtlijnen die alleen maar minimumvoorschriften bevatten, ruimere en gunstigere regelingen van de lidstaten niettemin binnen de werkingssfeer van die richtlijnen vallen of dat de lidstaten op dat niet uitdrukkelijk bestreken gebied volledige vrijheid genieten, is een vraag die mijns inziens nog niet uitputtend en coherent is beantwoord.” Het Hof komt aan dit onderwerp niet toe; HvJEU van 13 februari 2014, gevoegde zaken C512/11, C-513/11, Terveys-ja sosiaalialan neuvottehijärjestö TSN. 
Vervolgens ging het over tot toetsing aan 'het beginsel van gelijke behandeling dat in de artikelen 20 en 21 van het Handvest is vastgelegd'. Dit is derhalve een geval waarin verdergaande beschermingsmaatregelen wel moeten worden getoetst aan Unie grondrechten, omdat de richtlijn zelf bepaalt dat verdergaande nationale maatregelen binnen het toepassingsgebied van het recht van de Unie vallen.

Het tweede punt van aandacht is dat nationale 'verdergaande beschermingsmaatregelen' (natuurlijk) niet geheel buiten het bereik van het Unierecht vallen. Zoals ook blijkt uit de beide arresten moeten 'verdergaande beschermingsmaatregelen' (net als alle ander nationale maatregelen) verenigbaar zijn met het materiële Unierecht, met name de bepalingen op het gebied van het vrije verkeer. Dit betekent, ook dat 'verdergaande beschermingsmaatregelen' (net als 'gewone' nationale maatregelen) onder omstandigheden toch binnen het toepassingsgebied van de algemene rechtsbeginselen en het Handvest kunnen vallen. Bijvoorbeeld indien zij kwalificeren als belemmeringen van het vrije verkeer en derhalve een beroep moet worden gedaan op een Unierechtelijke rechtvaardigingsgrond. De algemene rechtsbeginselen en het Handvest zullen dan van toepassing zijn krachtens de lijn ERT (zie verder hoofdstuk 5). ${ }^{37}$

Tot slot wordt er op gewezen, dat de Borsana/Eiterköpfe/Dominguez- benadering ook lijkt te worden gehanteerd bij richtlijnen die voorzien in geleidelijke harmonisatie. Een voorbeeld hiervan is het BTW-stelsel. De Zesde BTW richtlijn staat lidstaten zonder voorbehoud toe om bestaande BTW vrijstellingen te blijven toepassen. Voor zover de lidstaten gebruik maken van deze bevoegdheid is geen sprake van uitvoering. De Unierechtelijke grondrechten zijn niet van toepassing op dit soort bestaande nationale vrijstellingen. ${ }^{38}$ In het verlengde hiervan wijs ik op nationale handelingen die op grond van Unierechtelijke 'standstill'voorschriften mogen voortbestaan. Ik beschouw dit soort maatregelen als zuiver interne maatregelen waarop de Uniegrondrechten in beginsel niet van toepassing zijn. Een voorbeeld van een 'standstill'bepaling is artikel 13 van besluit 1/80 van de Associatieraad die is ingesteld op grond van de Associatieovereenkomst tussen de Unie en Turkije. 39 Deze 'standstill'bepaling behelst een verbod tot de invoering van nieuwe nationale maatregelen

37 Zie bijvoorbeeld HvJEU van 19 juni 2008, zaak C-219/07, Andibel, punten 20 -21 en 2742.

38 HvJEU 13 juli 2000, C-36/99, Idéal Tourisme, punten 37 en 38. Zie ook Knook 2005, p. 387-389, p. 380.

39 Andere voorbeelden van standstillvoorschriften zijn artikel 41 van het aanvullend protocol bij de Associatieovereenkomst tussen de Unie en Turkije, artikel 17, lid 6, van de Zesde BTW richtlijn en artikel 64, lid 1 TEU (oud artikel 57, lid 1 VEG). 
die tot doel of tot gevolg hebben dat aan de gebruikmaking door Turkse staatsburgers van het vrije verkeer van werknemers op het nationale grondgebied, strengere voorwaarden worden gesteld dan die welke golden bij de inwerkingtreding van besluit $1 / 80$ voor de betrokken lidstaat. Een dusdanige 'standstill'clausule behelst dus enerzijds een onthoudingsverplichting tot het nemen van 'nieuwe beperkingen', maar impliceert tevens het recht voor de lidstaten om 'bestaande beperkingen' te handhaven. ${ }^{40} \mathrm{Ik}$ meen dat Uniegrondrechten niet van toepassing zijn op 'bestaande beperkingen' die op grond van artikel 13 mogen worden gehandhaafd. Zodra een maatregel echter wel onder moet worden aangemerkt als een 'nieuwe beperking' in de zin van artikel 13 van besluit $1 / 80$, valt deze maatregel onder het Unierecht en lijkt mij dat de Uniegrondrechten daarop in beginsel van toepassing kunnen zijn. ${ }^{41}$

\subsubsection{Het enkel inroepen van materieel Unierecht}

Het enkele feit dat een justitiabele een beroep doet op materieel Unierecht of op nationale wetgeving die Unierecht implementeert, volstaat niet om Unie grondrechten te activeren. Zo ging het in de zaak Iida om een verzoek van een onderdaan van een derde land aan de Duitse autoriteiten om afgifte van 'een verblijfskaart van een familielid van een burger van de Unie'. De Duitse wet waarin in de afgifte van een dusdanige verblijfsvergunning is voorzien beoogde in de uitvoering van Unierecht. Desondanks viel de weigering van de Duitse autoriteiten om de verblijfskaart af te geven niet onder de tenuitvoerlegging van het recht van de Unie in de zin van artikel 51, lid 1, van het Handvest. De reden hiervoor was dat de verzoeker in het hoofdgeding niet binnen de werkingssfeer van het Unierecht viel, omdat hij niet voldeed aan de toepassingsvereisten van het relevante afgeleide recht. ${ }^{42}$ Het enkele beroep op implementatiewetgeving is derhalve niet voldoende, de situatie in het hoofdgeding moet daadwerkelijk binnen de werkingssfeer van het Unierecht vallen. ${ }^{43}$

Ook het arrest Ymeraga is op dit punt duidelijk. ${ }^{44}$ Deze zaak betrof de weigering

40 Zie over deze standstillclausule A-G Wahl van 11 juli 2013, zaak C-225/12, Demir, punten 27-38.

41 Bijvoorbeeld via de ERT-route, zie hierover de bespreking van HvJEU van 7 november 2013, zaak C-225/12, Demir, punt 40 in hoofdstuk 5.3.2.

42 HvJEU van 8 november 2012, zaak C-40/11, Iida, punten 80 en 81.

43 Zie ook A-G Wahl van 26 september 2013, zaak C-363/12, Z, punt 71: "het Handvest kan alleen worden toegepast wanneer een zaak niet enkel betrekking heeft op een bepaling van het Handvest, maar eveneens op een andere rechtsregel van de Unie die rechtstreeks op de zaak toepasselijk is".

44 HvJEU van 8 mei 2013, zaak C-87/12, Ymeraga. 
van de Luxemburgse autoriteiten om de familieleden van Kreshnik Ymeraga een verblijfsrecht als familieleden van een burger van de Unie te verlenen. De betreffende nationale wetgeving implementeerde de richtlijnen 2003/86 en 2004/38. Desondanks kwalificeerde de weigering niet als 'de tenuitvoerlegging van het recht van de Unie'. Het Hof overwoog hier expliciet als volgt:

“42. De wet betreffende het vrije verkeer beoogt weliswaar het Unierecht ten uitvoer te brengen, maar dit neemt niet weg dat de situatie van verzoekers in het hoofdgeding niet door het Unierecht wordt beheerst aangezien Kreshnik Ymeraga noch als begunstigde van richtlijn 2004/38 en - voor de in het hoofdgeding aan de orde zijnde aanvragen - noch als begunstigde van richtlijn 2003/86 kan worden beschouwd (...).”

Overigens is op deze regel een uitzondering denkbaar, namelijk ten aanzien van het recht op een doeltreffende voorziening in rechte en op een onpartijdig gerecht (artikel 47 van het Handvest). Voor de toepassing van deze bepaling van het Handvest zou mijns inziens een enkel beroep op een bepaling van Unierecht wel moeten volstaan. ${ }^{45}$ In dit verband zijn de beschikkingen Pedone, Gentile en Tudoran relevant waarin een beroep werd gedaan op artikel 47 van het Handvest. ${ }^{46}$ In deze zaak overwoog het Hof eerst dat er geen enkel element in het hoofdgeding de conclusie rechtvaardigt, dat de nationale regeling de uitvoering van Unierecht betreft. ${ }^{47}$ Daaraan voegde het Hof vervolgens toe, dat de verwijzingsbeschikking evenmin concrete elementen bevat die er op duiden dat het hoofdgeding de interpretatie of toepassing van een regel van Unierecht (anders dan het Handvest) betreft. ${ }^{48}$ In de recente beschikking Tudoran die ook

45 Aldus ook Ladenburger 2012, p. 20.

46 HvJEU van 7 februari 2013, zaak C-498/12, Pedone; HvJEU van 7 februari 2013, zaak C499/12, Gentile; HvJEU van 3 juli 2014, zaak C-92/14, Tudoran, punt 47

47 De beschikkingen Pedone en Gentile zijn niet beschikbaar in het Nederlands. De Franse taalversies luiden als volgt: “ 13 . La procédure au principal concerne notamment la liquidation des frais et des honoraires d'un avocat italien en Italie relatifs à une action dont aucun élément ne laisse penser qu'elle porterait sur une réglementation nationale mettant en œuvre le droit de l'Union au sens de l'article 51, paragraphe 1, de la Charte. "

48 De Franse taalversies luiden als volgt: «14 Par ailleurs, si le droit à un recours effectif, garanti par l'article 6, paragraphe 1, de la $\mathrm{CEDH}$, auquel se réfère également la juridiction de renvoi, constitue un principe général du droit de l'Union (voir, notamment, arrêt du 22 décembre 2010, DEB, C-279/09, Rec. p. I-13849, point 29, et ordonnance Chartry, précitée, point 25) et a été réaffirmé à l'article 47 de la Charte, il n'en demeure pas moins que la décision de renvoi ne contient aucun élément concret permettant de considérer que l'objet de la procédure au principal concerne l'interprétation ou l'application d'une règle de l'Union autre que celles figurant dans la Charte. " Zie ook HvJEU van 14 maart 2013, zaak C-555/12, Loreti, punt 17 en HvJEU van 30 mei 2013, zaak C-73/13, T., punt 13. 
in het Nederlands beschikbaar is overwoog het Hof als volgt:49

" 47 . Ten tweede bevat de verwijzingsbeslissing geen enkel concreet gegeven op basis waarvan kan worden vastgesteld dat het hoofdgeding, vanwege het voorwerp ervan, kan aanknopen aan andere bepalingen van het Unierecht of dat het betrekking heeft op een nationale regeling waarmee het Unierecht ten uitvoer wordt gebracht in de zin van artikel 51, lid 1, van het Handvest."

\subsubsection{Raakvlak met een Unieregeling}

Zoals opgemerkt in hoofdstuk 3.4, zijn de Unierechtelijke grondrechten niet alleen van toepassing op nationale omzettingsmaatregelen, maar in beginsel op alle nationale maatregelen die binnen de werkingssfeer van specifieke materiële bepalingen van Unierecht vallen. Het is hierbij echter wel zaak om aan de hand van een specifieke regeling of bepaling precies te kijken of zulks inderdaad het geval is. Het enkele feit, dat de materie van de betreffende nationale handeling in zijn algemeenheid wordt bestreken door een Unieregeling volstaat niet. ${ }^{50}$ Vereist is dat de situatie valt binnen de werkingssfeer (materieel, personeel en temporeel) van een bepaling van Unierecht. ${ }^{51}$ In recente rechtspraak wordt deze eis ook wel als volgt geduid:52

“35. Het Hof is met name tot de slotsom gekomen dat de grondrechten van de Unie niet konden worden toegepast in verband met een nationale regeling wegens het feit dat de Unievoorschriften op het betrokken gebied de lidstaten geen specifieke verplichting oplegden voor de in het hoofdgeding aan de orde zijnde situatie (...)."

Hoewel deze omschrijving in de context van de arresten Julian Hernández en Siragusa wel kan worden begrepen, vind ik het wat minder gelukkig, omdat het de suggestie wekt dat enkel sprake kan zijn van uitvoering als sprake is van een specifieke verplichting. Hetgeen niet zo is. ${ }^{53}$ Overigens wordt in het dictum van het aangehaalde arrest Julian Hernández wel weer gesproken in de termen van

49 HvJEU van 3 juli 2014, zaak C-92/14, Tudoran.

50 HvJEU van 10 juli 2014, zaak C-198/13, Julian Hernández, punt 34:“(...) het begrip „ten uitvoer brengen van het Unierecht" in de zin van artikel 51 van het Handvest vereist dat er een zeker verband bestaat tussen de Unierechtelijke handeling en de betrokken nationale maatregel, dat verder gaat dan het dicht bij elkaar liggen van de betrokken materies of de indirecte invloed van de ene materie op de andere (...)".

51 Zie ook HvJEU van 27 maart 2014, zaak C-265/13, Torralbo Marcos.

52 HvJEU van 10 juli 2014, zaak C-198/13, Julian Hernández; zie ook HvJEU van 6 maart 2014, zaak C-206/13, Siragusa, punten 26 en 27.

53 Zie hoofdstuk 4.3. 
binnen de 'werkingssfeer van de richtlijn'.

Een voorbeeld van een zaak die op het eerste gezicht mogelijk binnen de werkingssfeer van een Unierechtelijke regeling leek te vallen, maar waarin het Hof oordeelde van niet, is de gevoegde zaak Gueye en Sanchez. ${ }^{54}$ Deze zaak betrof verzoeken in een strafprocedure door de slachtoffers van huiselijk geweld. De daders hadden als bijkomende straf een straatverbod opgelegd gekregen met betrekking tot de omgeving van het huis. De slachtoffers waren het hier niet mee eens, omdat ze met de daders samenleefden. Op grond van het Spaanse recht is het opleggen van straatverbod verplicht, zulks ook tegen de wil van het slachtoffer. In de procedure werd een beroep gedaan op artikel 7 Handvest (eerbiediging gezinsleven). De mogelijke aanknoping met het Unierecht was kaderbesluit 2001/220/JBZ inzake de status van slachtoffer in strafprocedure. Het kaderbesluit vormde echter onvoldoende aanknoping met het Unierecht om het Handvest te activeren ten aanzien van de regel van nationaal strafrecht die voorzag in het verplichte straatverbod. De reden hiervoor was dat het kaderbesluit minimumnormen stelt voor de bescherming van slachtoffers in het strafproces, zulks met name ten aanzien van de toegang tot de rechter en niet ziet op de harmonisatie van straffen. De precieze formulering van het Hof luidde als volgt:

"69. Ten slotte moet worden vastgesteld dat de verplichting als zodanig om een straatverbod op te leggen overeenkomstig het in de hoofdzaken aan de orde zijnde materiële recht, niet binnen de werkingssfeer van het kaderbesluit valt en dus hoe dan ook niet kan worden beoordeeld in het licht van het Handvest van de grondrechten van de Europese Unie."

Een tweede voorbeeld is de zaak Mayor. ${ }^{55}$ De situatie in het hoofdgeding ging om een collectieve beëindiging arbeidsrelatie wegens overlijden werkgever en de hoogte van de daarmee samenhangende vergoeding. In de procedure werd een beroep gedaan op artikel 30 van het Handvest (bescherming bij kennelijk onredelijk ontslag). De mogelijke aanknoping met het Unierecht was richtlijn 98/59 inzake collectief ontslag. Het Hof oordeelde echter dat het Handvest niet van toepassing was, omdat:

54 HvJEU van 15 september 2011, gevoegde zaken C-483/09 en C-1/10, Gueye en Sanchez, punten 50-52, 69; Zie ook HvJEU van 18 december 1997, zaak C-309/96, Annibaldi, punten 20 en 21.

55 HvJEU van 10 december 2009, zaak C- 323/08, Mayor, punt 59. 
“59. (...) een situatie zoals die welke aan het hoofdgeding ten grondslag ligt, niet binnen de werkingssfeer van richtlijn 98/59 en dus evenmin binnen die van het gemeenschapsrecht valt. (...)”

De reden dat de situatie in het hoofdgeding niet onder de richtlijn viel was dat de nationale regeling zag op (i) een vergoeding wegens (ii) collectieve beëindiging arbeidsrelatie wegens overlijden werkgever, terwijl de richtlijn ziet op (i) procedureregels voor (ii) collectief ontslag.

Een derde, wat meer ingewikkeld, voorbeeld zijn de beschikkingen Vino I en Vino II. Centraal in deze zaken stond een Italiaanse regeling inzake arbeidscontracten voor bepaalde tijd. De regeling bood een lagere bescherming aan werknemers met arbeidscontracten voor bepaalde duur in de postsector ten opzichte van werknemers met arbeidscontracten voor bepaalde duur in andere sectoren. In de zaak werd een beroep gedaan op het algemene verbod van discriminatie (artikelen 20 en 21 Handvest). De mogelijke aanknoping met het Unierecht was richtlijn 1999/70 betreffende de door het EVV, de UNICE en het CEEP gesloten raamovereenkomst inzake arbeidsovereenkomsten voor bepaalde tijd. Deze aanknoping was echter onvoldoende om het Handvest te activeren. Hiertoe overwoog het Hof, dat de raamovereenkomst minimumharmonisatie tot doel heeft en enkel ziet op verschillen in behandeling tussen enerzijds werknemers met een arbeidsovereenkomst voor bepaalde tijd en anderzijds werknemers met een arbeidsovereenkomst voor onbepaalde tijd. Het non-discriminatiebeginsel in de raamovereenkomst is derhalve enkel uitgevoerd en geconcretiseerd met betrekking tot verschillen in behandeling tussen deze twee groepen (werknemers met een contract voor onbepaalde tijd en werknemers met een contract voor bepaalde tijd). Nu het in de Italiaanse regeling ging om verschillen in behandeling binnen de groep werknemers met een arbeidsovereenkomst voor bepaalde tijd viel zij buiten de werkingssfeer van de raamovereenkomst en was het Handvest niet van toepassing. ${ }^{56}$

De beschikking Rivas Montes ziet eveneens op de toepassing van het algemene non-discriminatiebeginsel in combinatie met richtlijn 1999/70 arbeidsovereenkomsten voor bepaalde tijd. ${ }^{57}$ In deze zaak ging het om een overheidswerkgever die voor de berekening van de anciënniteitstoelage onderscheid maakt tussen personeel dat in vaste dienst is (ambtenaren) en personeel dat werkzaam is op contractsbasis. Ook hier onderzocht het Hof of richtlijn 1999/70 arbeids-

() HVJEU van 11 november 2010, zaak C-20/10, Vino I, punten 53, 54, 56, 57 en 64 en HvJEU van 22 juni 2011, zaak C-161/11, Vino II, punten 38 en 39 (de beide beschikkingen zijn niet beschikbaar in het Nederlands).

57 HvJEU van 7 maart 2012, zaak C-178/12, Rivas Montes, punten 39, 42- 45, 47 en 49. 
overeenkomsten voor bepaalde tijd kon dienen als relevant aanknoping met het recht van de Unie. Dit bleek niet het geval. Hiertoe overwoog het Hof conform Vino I en Vino II, dat de richtlijn ziet op verschillen in behandeling tussen enerzijds werknemers met een arbeidsovereenkomst voor bepaalde tijd en anderzijds werknemers met een arbeidsovereenkomst voor onbepaalde tijd die zich in een vergelijkbare situatie bevinden. Aangezien het onderscheidende criterium in Rivas Montes niet de duur (bepaald/ onbepaald) van de rechtsverhouding betrof maar de aard (statutair/ contractsbasis) ervan, oordeelde het Hof dat de richtlijn niet kon dienen als aanknoping met het recht van de Unie. Hierbij overwoog het Hof, dat personeel werkzaam op contractsbasis zowel voor bepaalde tijd als voor onbepaalde tijd verbonden kunnen zijn aan de werkgever. Het Hof benadrukte voorts, dat in de zaak geen sprake lijkt te zijn van een verschil in behandeling op grond van de bepaalde of onbepaalde duur van het contract.

Een vierde zeer expliciet voorbeeld is de zaak Siragusa. ${ }^{8}$ Het hoofdgeding in de zaak Siragusa betrof een bestuursrechtelijke procedure ingesteld door grondeigenaar Siragusa. Siragusa had zonder voorafgaande vergunning wijzigingen aangebracht op zijn grond dat is gelegen in een landschapsbeschermingsgebied. In geschil is het bestuursrechtelijke bevel om de grond in de oorspronkelijke toestand te herstellen. Siragusa beriep zich hierbij op artikel 17 van het Handvest (recht van eigendom). Het arrest spitste zich toe op de vraag of het Handvest van toepassing is. De verwijzende rechter overwoog hiertoe, dat landschapsbescherming deel uitmaakt van milieubescherming en hij wees op verschillende Unierechtelijke bepalingen op milieugebied zoals het Verdrag van Aarhus en de zogenaamde MER (Milieueffectbeoordeling)-richtlijn (richtlijn 2011/92/EU). Het Hof oordeelde dat het Handvest niet van toepassing is. Hij overwoog hierbij dat het begrip 'ten uitvoer brengen van het Unierecht' in de zin van artikel 51, lid 1, van het Handvest vereist, dat sprake is van een verband dat verder gaat dan het dicht bij elkaar liggen van de betrokken materies of de indirecte invloed van de ene materie op de andere (punt 24). Het Hof preciseerde voorts dat sprake moet zijn van een 'specifieke verplichting' van de lidstaten voor de in het hoofdgeding aan de orde zijnde situatie (punt 26).

Tot slot wordt gewezen op de zaak Sindicato dos Bancários do Norte.59 In deze

58 HvJEU van 6 maart 2014, zaak C-206/13, Siragusa.

59 HvJEU van 7 maart 2013, zaak C-128/12, Sindicato dos Bancários do Norte, punt 12. Zie HvJEU van 26 juni 2014, zaak C-264/12, Sindicato Nacional dos Profissionais de Seguros e Afins, punt 21: dezelfde verwijzende rechter (Tribunal do Trabalho do Porto) stelde soortgelijke vragen. In deze zaak ging het om loonsverlagende maatregelen (schrappen 
zaak ging het om een arbeidsrechtelijk geschil tussen een Portugese bank en de vakbonden inzake loonsverlagingen. De bank baseerde zich voor de loonsverlagingen op een nationale wet tot goedkeuring van de algemene rijksbegroting voor 2011. Deze wet bevatte een maatregel van loonsverlagingen bij de overheid en had als doel de overheidsfinanciën te saneren. De vakbonden stelden zich op het standpunt, dat deze loonsverlagende maatregelen onverenigbaar zijn met artikel 31, lid 1 (rechtvaardige en billijke arbeidsomstandigheden en -voorwaarden) van het Handvest. Als aanknoping met het Unierecht werd aangevoerd dat de bezuinigmaatregelen werden genomen met het oog op de verplichtingen van Portugal uit hoofde van het Stabiliteits- en Groeipact om een einde te maken aan een buitensporig tekort. ${ }^{60}$ Het Hof verklaarde zich bij beschikking kennelijk onbevoegd, omdat er geen concrete elementen zijn die erop wijzen dat de nationale wet ziet op de uitvoering van het recht van de Unie. ${ }^{61}$ Helaas ging het Hof niet specifiek in op de stelling van de vakbonden dat de nationale maatregel moet worden gezien als de uitvoering van het Stabiliteits- en Groeipact. Mogelijk gaat het hier om een dusdanig algemene Unierechtelijke resultaatsverplichting (het binnen de perken houden van het nationale begrotingstekort), dat de nationale bezuinigingsmaatregelen redelijkerwijze niet kunnen worden gezien als de toepassing van Unierecht.

\subsubsection{Vrijwillige verwijzingen naar Unierecht}

Het enkele feit dat nationale regelingen (uit eigen beweging) zich voor haar oplossingen voor situaties die niet binnen de werkingssfeer van de betrokken handeling van de Unie vallen, conformeert aan de in deze Uniehandeling gekozen oplossingen, leidt niet tot toepasselijkheid van Unierechtelijke grondrechten. Het is wel zo dat het Hof zich in zulke gevallen bevoegd acht om het Unierecht uit te leggen, indien de Unierechtelijke bepalingen door het nationale recht op rechtstreekse en onvoorwaardelijke wijze toepasselijk zijn gemaakt. ${ }^{62}$ Uit het arrest Cicala volgt dat dit ook kan gelden voor verwijzingen

van kerstgratificatie en vakantiegratificatie) uit hoofde van de nationale wet tot goedkeuring van de algemene rijksbegroting voor 2012.

60 Dit blijkt met name uit de verwijzingsbeschikking d.d. 6 februari 2012 van de Tribunal do Trabalho do Porto.

61 De beschikking is niet in het Nederlands beschikbaar. De Franse taalversie luidt als volgt: "12. Or, malgré les doutes exprimés par la juridiction de renvoi quant à la conformité de la loi de finances pour 2011 avec les principes et les objectifs consacrés par les traités, la décision de renvoi ne contient aucun élément concret permettant de considérer que ladite loi vise à mettre en œuvre le droit de l'Union."

62 HvJEU van 17 juli 1997, zaak C-28/95, Leur-Bloem; HvJEU van 21 december 2011, zaak C-482/10, Cicala, punten 17-20; zie ook HvJEU van 22 december 2010, zaak C-245/09, Omalet, punt 15. Opgemerkt wordt dat wanneer een nationale wettelijke regeling zich 
naar het Handvest. ${ }^{63}$ De bevoegdheid tot uitleg ontleent het Hof aan het belang van de Unie op eenvormige uitleg van het Unierecht. De bevoegdheid tot uitleg doet echter niet aan af het zuiver nationale karakter van de regelingen. De Unierechtelijke grondrechten zijn dan ook niet rechtstreeks van toepassing. ${ }^{64}$ Hetzelfde geldt overigens voor de directe werking en voorrang van Unierecht. In de zaak Agafiţei merkte het Hof hierover als volgt op:65

\begin{abstract}
"47 Weliswaar kan, zoals hierboven in herinnering is gebracht, de noodzaak om de voorschriften van Unierecht eenvormig uit te leggen, rechtvaardigen dat de uitleggingsbevoegdheid van het Hof ook dergelijke voorschriften bevat, ook wanneer zij slechts indirect op een bepaalde situatie van toepassing zijn, doordat een regel van nationaal recht daarnaar verwijst, maar diezelfde overweging kan dat voorschrift van Unierecht geen voorrang op hogere nationale voorschriften verlenen die in een dergelijke situatie vereist dat die regel van nationaal recht of de uitlegging die daaraan is gegeven buiten beschouwing wordt gelaten. Anders wordt de verdeling van de bevoegdheden tussen de Unie en haar lidstaten geschonden.”
\end{abstract}

Overigens lijkt uit het arrest Nolan te volgen, dat het Hof niet altijd bevoegd is in situaties waarin Unierechtelijke regelingen intern toepasselijk zijn gemaakt doordat het nationale recht naar de inhoud ervan verwijst. ${ }^{66}$ In deze zaak ging het om de toepassing van de richtlijn collectief ontslag (richtlijn 98/59). Deze richtlijn sluit werknemers in overheidsdienst expliciet uit van de werkingssfeer ervan. In de betreffende zaak ging het om ontslag van burgerpersoneel van een militaire basis. Het Hof oordeelde dat deze situatie buiten de werkingssfeer van de richtlijn valt. ${ }^{67}$ Vervolgens onderzocht het Hof zijn bevoegdheid op grond van de jurisprudentie Leur-Bloem/Cicala. Hierbij concludeerde het allereerst dat richtlijn 98/59 niet door het nationale recht op rechtstreekse en onvoorwaardelijke wijze toepasselijk is gemaakt op een situatie als die in het hoofdgeding. ${ }^{68}$

voor haar oplossingen voor zuiver interne situaties conformeert aan de in het Unierecht gekozen oplossingen het Hof enkel bevoegd is om de bepalingen van het Unierecht te onderzoeken en niet de precieze strekking van de nationale verwijzing naar het Unierecht. HvJEU van 18 oktober 2012, zaak C-371/11, Punch Graphix Prepress Belgium, punt 27; HvJEU van 7 november 2013, zaak C-313/12, Romeo, punten 23 en 32-37. Zie voor wat uitgebreidere beschrijving van deze rechtspraak en toepassing ervan A-G Cruz Villalón van 25 oktober 2012, zaak C-32/11, Allianz Hungária Biztosító e.a., punten 21-48.

63 HvJEU van 21 december 2011, zaak C-482/10, Cicala, punt 29.

$64 \mathrm{Zij}$ kunnen overigens wel relevant zijn als instrument van uitleg van de betreffende Unierechtelijke regeling.

65 HvJEU van 7 juli 2011, zaak C-310/10, Agafiţei.

66 HvJEU van 18 oktober 2012, zaak C-583/10, Nolan.

67 Nolan, Punt 43.

68 Nolan, punt 52. 
Bij deze vaststelling zou het Hof het gelaten kunnen hebben. Echter het Hof oordeelde ten tweede als volgt:

\begin{abstract}
"53. De Unie heeft er weliswaar belang bij te zorgen voor de eenvormige uitlegging van een bepaling van een handeling van de Unie en de nationaalrechtelijke bepalingen waarbij zij wordt omgezet en van toepassing wordt gemaakt buiten de werkingssfeer van deze handeling.

54. Dit is echter niet het geval indien, zoals in het hoofdgeding, een handeling van de Unie uitdrukkelijk voorziet in een geval van uitsluiting van haar werkingssfeer.

55. Indien de Uniewetgever ondubbelzinnig vermeldt dat de door hem vastgestelde handeling niet op een specifiek gebied van toepassing is, ziet hij immers, in ieder geval tot de vaststelling van eventuele nieuwe Unieregels, af van de doelstelling van eenvormige uitlegging en toepassing van de rechtsregels op dit uitgesloten gebied.

56. Derhalve kan niet worden aangenomen of verondersteld dat de Unie er belang bij heeft dat op een gebied dat door de Uniewetgever is uitgesloten van de werkingssfeer van de door hem vastgestelde handeling, de bepalingen van deze handeling op eenvormige wijze worden uitgelegd."
\end{abstract}

Het lijkt er dus op dat het arrest Nolan een verfijning van de jurisprudentie LeurBloem/Cicala bevat. Kennelijk is het Hof onbevoegd tot uitleg van Unierechtelijke regelingen waarnaar in nationale regelgeving wordt verwezen, indien het gaat om situaties die expliciet van de werkingssfeer van een richtlijn zijn uitgesloten.

\title{
6.3.8 Vrijwillige nationale schadeloosstelling
}

In het arrest Érsekcsanádi Mezögazdasági ging het om schade geleden ten gevolge van de vaststelling, overeenkomstig het Unierecht, van nationale beschermingsmaatregelen tegen aviaire influenza in Hongarije. ${ }^{69}$ Het ging om de instelling van een beschermingsgebied en een verbod op doorvoer van pluimvee in dat beschermingsgebied. Verzoekster in het hoofdgeding, een pluimveebedrijf dat zich onder meer bezighoudt met het vetmesten van kalkoenen, vorderde vergoeding van ten gevolge van deze maatregelen geleden schade. Ingevolge een nationale schadevergoedingsregeling werd dit gedeeltelijk toegekend, maar werd de schadevordering tot vergoeding van gederfde winst afgewezen. Verzoekster beriep zich voor het afgewezen deel op de volgende Uniegrondrechten: de vrijheid van ondernemerschap, het recht op eigendom en het recht

69 HvJEU van 22 mei 2014, zaak C-56/13, Érsekcsanádi Mezögazdasági, punten 51-57. 
op een doeltreffende voorziening in rechte. Het Hof oordeelde dat het Handvest niet van toepassing was en overwoog als volgt:

"52. Geconstateerd moet worden dat aangezien uit het Unierecht geen vergoedingsverplichting kan worden afgeleid, een nationale maatregel zoals die in het hoofdgeding, op grond waarvan de betrokken staat verplicht is de schade en de effectieve uitgaven te vergoeden, maar niet de gederfde winst, niet valt onder het Unierecht, maar uitsluitend berust op de keuze van de nationale wetgever.

$(\ldots)$

55. Derhalve is het Hof niet bevoegd om te beoordelen of een nationale wettelijke regeling zoals die in het hoofdgeding, die niet voorziet in volledige vergoeding van de schade - de gederfde winst daaronder begrepen - die is geleden ten gevolge van de vaststelling, overeenkomstig het Unierecht, van nationale beschermingsmaatregelen tegen aviaire influenza, rechtsgeldig is in het licht van het recht op een doeltreffende voorziening in rechte, het recht op eigendom en de vrijheid van ondernemerschap."

\subsubsection{Louter hypothetisch vooruitzicht uitoefening van het vrije verkeer}

De zaak Kremzow betrof een geschil over de vergoeding van schade wegens onrechtmatige detentie. Kremzow betoogde dat de Oostenrijkse overheid door de onrechtmatige detentie zijn recht op vrije verkeer ex artikel 8A EG (thans artikel 21 VWEU) had geschonden en dat daarom de Unierechtelijke grondrechten van toepassing waren. Het Hof oordeelde als volgt: ${ }^{70}$

"16. Verzoeker in het hoofdgeding is een Oostenrijks onderdaan, wiens situatie generlei aanknoping heeft met een van de situaties bedoeld in de bepalingen van het Verdrag betreffende het vrij verkeer van personen. Immers, ofschoon elke vrijheidsberoving de uitoefening door de betrokkene van zijn recht op vrij verkeer belemmert, vormt blijkens de rechtspraak van het Hof het louter hypothetisch vooruitzicht van deze uitoefening geen toereikende band met het gemeenschapsrecht om toepassing van de communautaire voorschriften te rechtvaardigen (...)."

Overigens moet de situatie van een louter hypothetisch vooruitzicht van uitoefening van het vrije verkeer worden onderscheiden van de Zambrano 'ontzegging van EU burgerschap(srechten)' zoals besproken in hoofdstuk 5.3.

70 HvJEU van 29 mei 1997, zaak C-299/95, Kremzow. Zie ook HvJEU van 8 november 2012, zaak C-40/11, Iida, punt 77. 


\subsection{Beschouwing in het licht van de allocatie van bevoegdheden}

\section{Algemeen beeld}

De behandelde rechtspraak van het Hof laat zien dat de kern van het systeem van toepasselijkheid van de algemene rechtsbeginselen en het Handvest is, dat ze niet afzonderlijk van materiële bepalingen van Unierecht van toepassing kunnen zijn. De toepassing van de algemene rechtsbeginselen en het Handvest is onlosmakelijk verbonden met de toepassing van materieel Unierecht. Hierdoor is de toepasselijkheid van Unierechtelijke grondrechten steeds te herleiden tot de gebondenheid van de Unie aan de grondrechten. Enkel daar waar het (uiteindelijk) gaat om de toepassing van materieel Unierecht is ruimte voor toepassing van Unierechtelijke grondrechten op nationale handelingen. Dit vindt zijn weerslag in de lijnen Wachauf en ERT en wordt bevestigd door Annibaldi. Tot nu toe is geen sprake van toepassing van Unierechtelijke grondrechten buiten die lijnen. Met name accepteert het Hof niet elke band met het Unierecht als toereikende activator van Unierechtelijke grondrechten. In sommige gevallen is dit evident, in andere gevallen weerspiegelt het een terughoudende opstelling van het Hof ten aanzien van het toepassingsgebied van de grondrechten die ik zal toelichten aan de hand van enkele voorbeelden.

\section{A-G Sharpston in Ruíz Zambrano}

Een eerste voorbeeld is de herhaaldelijke bevestiging van dat het bestaan van bevoegdheden van de Unie op een bepaalde terrein niet voldoende is om de algemene rechtsbeginselen en het Handvest van toepassing te laten zijn (arresten Annibaldi, Bartsch, Polier en Julian Hernández). Bevoegdheden van de Unie worden pas relevant indien (i) ze zijn uitgeoefend en (ii) de betreffende nationale handeling binnen de materiële werkingssfeer valt van de betreffende materiële bepaling. Door deze benadering toont het Hof zich respectvol ten opzichte van zowel de verticale als horizontale allocatie van bevoegdheden. In dit verband wordt opgemerkt, dat advocaat-generaal Sharpston in haar conclusie in de zaak Ruíz Zambrano een andere benadering bepleit: ${ }^{71}$

"163. Naar mijn mening zou de duidelijkste regel uiteindelijk een regel zijn die de beschikbaarheid van grondrechtenbescherming onder Unierecht niet liet afhangen van de rechtstreekse werking van een Verdragsbepaling of de vaststelling van secundaire wetgeving, maar van het bestaan en de reikwijdte van een materiële Uniebevoegdheid. Om het anders te formuleren: de regel zou zijn dat zodra er een (uitsluitende of gedeelde) Uniebevoegdheid in een bepaald rechtsgebied was, de grondrechten van de Unie de Unieburger zouden

71 A-G Sharpston van 30 september 2010 in zaak C-34/09, Ruiz Zambrano, punten 163. 
moeten beschermen zelfs wanneer die bevoegdheid nog niet was uitgeoefend."

De door Sharpston voorgestelde benadering staat op gespannen voet met het allocatiebeginsel. Het past niet binnen de lijnen Wachauf en ERT. Bij nationale handelingen die vallen onder de reikwijdte van een materiële (niet-uitgeoefende) Uniebevoegdheid is immers de grondrechtconforme toepassing van het Unierecht niet in het geding. De gebondenheid is dan ook niet terug te herleiden tot de gebondenheid aan grondrechten van de Unie zelf. Er is immers geen sprake van de toepassing van Unierecht. Zolang de betreffende nationale handelingen de bevoegdheden van de Unie niet doorkruisen, kan bovendien evenmin worden gesproken in termen van naleving van Unierecht. Meer algemeen gezegd komt de benadering van Sharpston neer op de inroepbaarheid van Unierechtelijke grondrechten als op zichzelf staande rechten. Immers het voorgestelde criterium maakt het mogelijk dat Unierechtelijke grondrechten van toepassing zijn zonder dat een andere regel van materieel Unierecht van toepassing is. Overigens is ook Sharpston zich hiervan bewust. Zij merkt dan ook op, dat een stap naar een dusdanig criterium niet eenzijdig door het Hof kan worden genomen. Hiervoor is een constitutionele evolutie van de grondslagen van de Unie vereist die zou rechtvaardigen, dat grondrechten onder Unierecht als niet-accessoire rechten kunnen worden ingeroepen. ${ }^{72}$

\section{'Civis europeus sum'}

Een ander belangrijk teken van terughoudendheid is, dat het Hof het inroepen van Unierechtelijke grondrechten niet koppelt aan de hoedanigheid van Unieburger. ${ }^{73}$ Dit is van belang, omdat een dusdanige koppeling 'de facto' zou neerkomen op een zelfstandige niet-accessoire werking van de Unierechtelijke grondrechten (dat wil zeggende toepassing los van materiële bepalingen van Unierecht). ${ }^{74}$ Ook hier geldt dat het Hof ook gehoor had kunnen geven aan pleitbezorgers van een koppeling van Unierechtelijke grondrechten aan Unieburgerschap. Zo bepleitte advocaat-generaal Jacobs in zijn conclusie in de zaak Konstantinidis het recht van Unieburgers om te zeggen 'civis europeus sum'

72 A-G Sharpston van 30 september 2010 in zaak C-34/09, Ruiz Zambrano, punt 163, punten $171-175$.

73 Zie ook hoofdstuk 6.3 onder het kopje "Unieburger uit een andere lidstaat".

74 Zie ook Lenaerts 2000, p. 593. Hij betoogt dat de koppeling van Unierechtelijke grondrechten aan Unieburgerschap inderdaad zou leiden tot een grotere zelfstandige betekenis van het Unieburgerschap, maar dat het gevolg zou zijn een grondrechtentoets op alle terreinen, inclusief zuiver interne situaties. Hiertoe is de Unie, het Hof niet bevoegd. 
en aldus op te komen tegen elke schending van zijn grondrechten. ${ }^{75}$ Ook hier is relevant het standpunt van advocaat-generaal Sharpston in haar conclusie in de zaak Ruiz Zambrano. Zij wijst erop, dat het huidige systeem van Unie grondrechtenbescherming onvolledig en verbrokkeld is en dat dit slecht spoort met de primaire hoedanigheid van Unieburger. ${ }^{76}$ Eeckhout merkt op, dat het Handvest het ideale middel is om het Unieburgerschap meer substantie te geven. ${ }^{77}$

De achterliggende gedachte van het 'civis europeus sum' is dat het recht op Unierechtelijke grondrechtenbescherming en Unieburgerschap hand in hand gaan, zoals ook het recht op non-discriminatie op grond van nationaliteit inherent is aan Unieburgerschap. Naar mijn mening bestaat er, in de context van de Unie, echter een wezenlijk verschil tussen het recht op non-discriminatie op grond van nationaliteit en de andere grondrechten. Het recht op nondiscriminatie op grond van nationaliteit komt immers neer op een recht op nationale behandeling, een recht om niet als vreemdeling te worden behandeld en impliceert daarmee een noodzakelijke erkenning als mede -Unieburger. Het is om die reden dat Unieburgers in andere lidstaten inmiddels in alle mogelijk situaties dit recht op non-discriminatie op grond van nationaliteit kunnen inroepen, zulks ongeacht de invloed van non-discriminatie op hun recht op vrije verkeer. ${ }^{78}$ Het recht op non-discriminatie op grond van nationaliteit vormt aldus een wezenlijk bestanddeel van het Unieburgerschap. ${ }^{79} \mathrm{Bij}$ de toepassing van de overige Unierechtelijke grondrechten ligt dit echter anders. Zij missen de bijkomende functie van het recht op non-discriminatie op grond van nationaliteit die tot doel heeft de Unieburger in den verre vreemdeling af te maken. Het is dan ook niet vanzelfsprekend, dat de hoedanigheid van Unieburger in een andere lidstaat een recht geeft op toepassing van Unierechtelijke grondrechten in welke situatie dan ook.

Een ander argument voor de koppeling van Unierechtelijke grondrechtenbescherming aan Unieburgerschap, is het argument van de omgekeerde

75 A-G Jacobs van 9 december 1992, zaak C-168/91, Konstantinidis, punt 46. Het Hof heeft de A-G niet gevolgd.

76 A-G Sharpston van 30 september 2010, zaak C-34/09, Ruíz Zambrano, punt 170.

77 Eeckhout 2002, p. 971.

() De eerder besproken burgerschapsbenadering; Van der Mei 2009, p. 75-87.

79 Zie ook Ladenburger 2012, p. 20 :"3.1.8 (..)That difference in approach is logical: any discrimination of EU citizens on account of nationality is an attack on the very idea of EU citizenship, a core value specific to the EU whose defence is a central mission of the EU institutions that cannot be left to national constitutional law and to the ECHR, unlike the general mission of upholding, say, freedom of religion or expression.” 
discriminatie. Zo wijst advocaat-generaal Sharpston erop, dat het gevolg van de huidige toepasselijkheid van de Unierechtelijke grondrechten is dat er verschillen ontstaan tussen enerzijds Unieburgers die zich bevinden in een situatie die wordt beheerst door het Unierecht en anderzijds Unieburgers die zich bevinden in een zuiver nationale situatie. ${ }^{80}$ Dusdanige verschillen kunnen heel schrijnend zijn, bijvoorbeeld als het gaat om de toekenning van verblijfsrechten aan familieleden die onderdaan zijn van derde landen.

De door advocaat-generaal Sharpston gesignaleerde verschillen bestaan inderdaad, maar worden niet veroorzaakt door het toepassingsgebied van de Unierechtelijke grondrechten. De oorzaak is het naast elkaar bestaan van verschillende rechtsordes, namelijk de nationale rechtsordes en de Unierechtelijke rechtsorde. Het feit dat het Unierecht krachtig (rechtstreeks en met voorrang) kan doorwerken in het nationale recht doet niet af aan het bestaan van deze verschillende rechtsordes. De implicatie hiervan is, dat afhankelijk van welk recht van toepassing is, er verschillen kunnen bestaan in de rechtspositie van Unieburgers onderling. In de juridische en politieke realiteit van de Unie op dit moment, is het echter onjuist om deze verschillen 'discriminaties' te noemen. Het zijn 'dispariteiten' ten gevolge van het naast elkaar bestaan van verschillende rechtsstelsels. ${ }^{81}$ Voor zover het gaat om grondrechten lijkt het misschien wat cru om het probleem af te doen als 'dispariteit', maar dit is het niet. Met name niet, omdat Unieburgers die zich in zuiver nationale situaties bevinden niet met lege handen staan. Zij kunnen zich immers beroepen op de grondrechtenbescherming uit hoofde van het van toepassing zijnde nationale recht en het EVRM. ${ }^{82}$ Overigens kunnen door advocaat-generaal Sharpston gesignaleerde verschillen enkel worden opgelost door de toekenning van Unierechtelijke grondrechtenbescherming aan alle Unieburgers, en dit onafhankelijk van gebruikmaking van het vrije verkeer. Hiermee zou de Unie een algemene mensenrechtenorganisatie worden, met een algemene bevoegdheid van het Hof ter zake van grondrechtenaangelegenheden. ${ }^{83}$

\section{Verdergaande beschermingsmaatregelen als zuiver nationale bevoegdheden}

Een derde voorbeeld van terughoudendheid van het Hof vormt de rechtspraak Borsana/Eiterköpfe/Dominguez inzake de 'verdergaande beschermingsmaatregelen'. Dat deze maatregelen in beginsel (vermoedelijk) buiten het toepassingsgebied van de algemene rechtsbeginselen en het Handvest vallen, is vanuit

80 A-G Sharpston van 30 september 2010, zaak C-34/09, Ruíz Zambrano, punt 167.

81 Zie over dispariteiten (in de context van directe belastingen): A-G Geelhoed van 23 februari 2006, zaak C-374/04, ACT, pnt 42-54.

82 Zie ook De Witte 1999, p. 873.

83 Eeckhout 2002, p. 972. 
het oogpunt van de allocatie van bevoegdheden zeer genuanceerd en subtiel te noemen. ${ }^{84}$ Immers het zou in deze context wellicht ook verdedigbaar zijn geweest om te stellen, dat de mogelijkheid tot het nemen van 'verdergaande beschermingsmaatregelen' uit het Unierecht volgt. Om die reden zouden deze 'verdergaande beschermingsmaatregelen' ook kunnen worden gekwalificeerd als de 'uitoefening van door het Unierecht verleende bevoegdheden' waarop de algemene rechtsbeginselen en het Handvest wel van toepassing zijn (zie hoofdstuk 4.3). In plaats van deze benadering neemt het Hof in Borsanal Eiterköpfe/Dominguez (kennelijk) als vertrekpunt, dat ingeval van minimumharmonisatie de bevoegdheid voor verdergaande maatregelen bij de lidstaten is gebleven in plaats van dat deze bevoegdheid door het Unierecht is gecreëerd. ${ }^{85}$

Ik onderschrijf de benadering in Borsana/Eiterköpfe/Dominguez. Al moet wel worden opgemerkt dat het maken van een onderscheid tussen de implementatie van de minimumstandaard en het verdergaande nationale deel in de praktijk niet altijd eenvoudig zal zijn. Dit blijkt ook uit een bij de verwijzingsuitspraak in de zaak Iida. ${ }^{86}$ Hierin merkt de verwijzende rechter op dat het vanuit dogmatisch oogpunt meer voor de hand ligt dat het Handvest niet van toepassing is op het deel van een nationale regeling dat verder gaat dan de implementatie van de richtlijn. Echter, hij wijst er tevens op dat deze beperkte uitleg vanuit de rechtspraktijk een grotere inzet van onderzoeksmiddelen zou vergen. Bovendien zal het dikwijls niet mogelijk zijn om vast te stellen welk deel wel en geen omzetting vormt van de richtlijn. Bijvoorbeeld in het geval expliciete implementatie niet heeft plaatsgevonden, omdat de lidstaat meent dat de bestaande nationale rechtstoestand al in overeenstemming is met de richtlijn. De beperkte uitleg zou derhalve ook rechtsonzekerheid meebrengen.

Precieze in plaats van globale benadering inzake de toepasselijkheid van Unierecht

Ten vierde vormen de zaken Gueye en Sanchez, Mayor, Vino I en Vino II, Rivas

84 Anders: Kokott \& Sobotta 2010, p. 11: “(...) it seems to be contradictory. On the one hand measures come within the scope of application of EU law; on the other hand the EU principle of proportionality does not apply."

85 HvJEU van 17 december 1998, zaak C-2/97, Borsana, punt 40. Zie ook De Cecco 2006, p. 9-30. Hij kwalificeert de implementatie van de verplichte minimumstandaard als de uitoefening van Unie bevoegdheden. Bezien vanuit het Unierecht gaat het om gedelegeerde of afgeleide bevoegdheden ('delegation'). De introductie van hogere standaard, kwalificeert hij als de uitoefening van nationale regelgevende bevoegdheid. Bezien vanuit het Unierecht gaat het om geautoriseerde bevoegdheden ('authorization').

() Prejudiciële verwijzing van het Verwaltungsgerichtshof Baden-Württemberg in zaak C40/11, Iida. Te vinden op: http://www.minbuza.nl/ecer onder 'Hof van Justitie/nieuwe hofzaken'. A-G Trstenjak 15 mei 2012, zaak C-40/11, Iida, komt aan dit punt niet toe. Ook het Hof gaat niet in op dit punt. HvJEU van 8 november 2012, zaak C-40/11, Iida. 
Montes, Siragusa en Sindicato dos Bancários do Norte voorbeelden van terughoudendheid. Uit deze rechtspraak blijkt, dat het Hof heel precies kijkt of nationale handelingen die geen uitvoering stricto sensu behelzen, werkelijk binnen de werkingssfeer van een specifieke Unieregeling vallen. De band met het Unierecht moet concreet zijn. Dit is positief vanuit het oogpunt van de allocatie van bevoegdheden, omdat anders het gevaar zou dreigen van een zelfstandige toepassing van Unierechtelijke grondrechten.

Punt van aandacht is echter, dat de uitkomst in de beschikkingen Vino I en Vino II moeilijk te rijmen lijkt met de ruime formulering die het Hof gebruikt in de zaak Kücükdeveci. De zaken gaan allemaal over het bepalen van of een nationale maatregel valt binnen de werkingssfeer van een Unierechtelijke nondiscriminatierichtlijn. Zoals gezegd overwoog het Hof in Kücükdeveci enkel of de materie van de nationale wet (ontslagvoorwaarden) onder de materiële werkingssfeer van richtlijn 2000/78 viel. ${ }^{87}$ In de (latere) Vino-beschikkingen keek het Hof preciezer. Het enkele feit dat de richtlijn dezelfde materie behelsde als de nationale regeling (arbeidsovereenkomsten voor bepaalde tijd) was niet voldoende, het was ook nodig dat het litigieuze verschil in behandeling werd bestreken door de richtlijn. 88

Deze tweede voorwaarde blijkt niet uit het arrest Kücükdeveci, al was er in die zaak wel aan voldaan. Het ging immers om een verschil in behandeling op grond van leeftijd. Dit is één van de gronden genoemd in richtlijn 2000/78. Naar mijn mening is, de Vino-benadering in het licht van het beginsel van de allocatie van bevoegdheden de juiste. Bij de bepaling van de materiële werkingssfeer van non-discriminatiebepalingen en regelingen moet zowel de materie (bijv. arbeid, loon, huisvesting, dienstverlening) als het onderscheidingscriterium (leeftijd, geslacht, ras etc.) in aanmerking worden genomen. Een nationale regeling $\mathrm{Y}$ zou pas binnen de werkingssfeer van een specifieke Unierechtelijke non-discriminatiebepaling of regeling $X$ vallen, indien de nationale regeling $\mathrm{Y}$ zowel dezelfde materie als dezelfde grond voor onderscheid bevat als Unieregeling X. Indien niet aan de beide voorwaarden is voldaan, kan Unieregeling $\mathrm{X}$ ten aanzien van nationale regeling $\mathrm{Y}$ niet fungeren als activator van Uniegrondrechten. Ter concretisering van het vorenstaande kan als voorbeeld worden gewezen op een nationale regeling op het gebied van beloning die toestaat om onderscheid te maken op grond van taal. Richtlijn 2000/78 ziet wel op beloning, maar niet op de discriminatiegrond taal. De nationale regeling valt daarmee buiten de werkingssfeer van richtlijn 2000/78.

87 Arrest van het Hof van 19 januari 2010, zaak C-555/07, Kü̈ükdeveci, punten 23-25.

88 Zie ook Muir 2013-1, p. 1251-1252. 
Deze richtlijn kan derhalve niet dienen om het verbod van discriminatie op grond van taal ex artikel 21 van het Handvest te activeren.

Steun voor deze benadering kan naast in de beschikkingen Vino I en Vino II ook worden gevonden in het arrest Agafiţei.89 Deze zaak gaat niet over de toepassing van Unierechtelijke grondrechten, maar wel over de afbakening van de materiële werkingssfeer van de non-discriminatie richtlijnen 2000/78 en 2000/43. Centraal stond nationale regelgeving die dienden ter uitvoering van deze richtlijnen, maar die naast de in de richtlijnen genoemde gronden nog andere gronden voor discriminatie bevatte. Het Hof overwoog dat het deel van de nationale regeling met betrekking tot de niet in de richtlijn genoemde gronden buiten de werkingssfeer van de richtlijnen viel:

"32. Uit de verwijzingsbeslissing volgt echter dat de in het hoofdgeding aan de orde zijnde discriminatie niet gebaseerd is op een van de door die richtlijnen vermelde gronden, maar daarentegen plaatsvindt op grond van de beroepscategorie, in de zin van het nationale recht, waartoe de betrokkenen behoren of op grond van hun arbeidsplaats.

33. Bijgevolg valt een situatie zoals die welke in het hoofdgeding aan de orde is, niet binnen de respectievelijk bij de richtlijnen 2000/43 en 2000/78 vastgestelde algemene kaders om bepaalde vormen van discriminatie te bestrijden. 34. Zoals met name uit artikel 2, lid 1, van die richtlijnen volgt, is het in deze richtlijnen neergelegde beginsel van gelijke behandeling namelijk van toepassing in samenhang met de in artikel 1 van deze richtlijnen limitatief opgesomde gronden (zie in die zin arrest van 17 juli 2008, Coleman, C303/06, Jurispr. blz. I-5603, punten 38 en 46)."

Ook kan hier een parallel worden getrokken met de eerder besproken rechtspraak Borsana/Eiterköpfe/Dominguez inzake verdergaande beschermingsmaatregelen. Immers uitbreiding van de discriminatiegronden is ook een vorm van verdergaande bescherming.

Zoals gezegd, is de Vino I en II en Agafiţei benadering naar mijn mening de juiste

89 HvJEU van 7 juli 2011, zaak C-310/10, Agafiţei, punten 32-34. Zie ook HvJEU van 23 september 2008, zaak C-427/06, Bartsch. In deze zaak ging het om een onderscheid op grond van leeftijd terzake van pensioenrechten. Het Unierecht (en daarmee de algemene beginselen) was niet van toepassing wegens het ontbreken van een band met het Unierecht. Zulks ondanks het feit dat pensioenrechten moeten worden beschouwd als beloning in de zin van artikel 157 VWEU. Artikel 157 VWEU die ziet op geslacht kon dus kennelijk niet dienen om de pensioenregeling die zag op onderscheid naar leeftijd binnen de werkingssfeer van het Unierecht te brengen. Vergelijk Prechal, de Vries \& Van Eijken 2010, p. 218. Vergelijk ook HvJEU van 24 april 2012, C-571/10, Kamberaj, punt 50 . 
in het licht van het beginsel van allocatie van bevoegdheden. ${ }^{90}$ Indien het voor de toepassing van het beginsel van non-discriminatie op een specifiek grond inderdaad voldoende zou zijn dat de materie van de betreffende nationale regeling zou worden bestreken door een non-discriminatie richtlijn, zonder dat gekeken hoeft te worden of de grond van onderscheid ook door diezelfde richtlijn zou worden bestreken, zouden alle discriminatieverboden van toepassing zijn op alle terreinen die worden bestreken door om het even welke nondiscriminatierichtlijn. Zo zou het verbod van discriminatie op grond van leeftijd ook buiten het terrein van arbeid en beroep kunnen worden toegepast. ${ }^{91}$ In deze context kan echter niet meer gesproken worden van een verzuim tot implementatie en is er geen rechtvaardiging voor de toepassing van Unierechtelijke grondrechten op nationale handelingen die geen uitvoering stricto sensu betreffen. ${ }^{92}$

Een tweede punt van aandacht is Sindicato dos Bancários do Norte. Deze zaak biedt een voorbeeld van nationale maatregelen (bezuinigingsmaatregelen) die wel degelijk zijn genomen met het oog op de voldoening van een Unierechtelijke resultaatsverplichting (het terugbrengen van het nationale begrotingstekort), maar die door het Hof toch niet worden aangemerkt als uitvoering van Unierecht. Dit lijkt me een terechte keuze, omdat ten aanzien van dusdanige maatregelen in redelijkheid niet kan worden gesproken van de toepassing van Unierecht. Bovendien zou het hek van de dam zijn als nationale maatregelen die dienen om begrotingstekorten terug te dringen zouden worden gemarkeerd als

$90 \quad$ Zie ook De Mol 2011-1, p.126-127.

91 Dit zou neerkomen op een aperte doorkruising van het stelsel dat door de Unie wetgever op basis van artikel 19 VWEU tot stand is gebracht. Ten aanzien van de in artikel 19 VWEU genoemde gronden zijn immers welbewust drie verschillende regimes in het leven geroepen. Naast richtlijn 2000/78, bestaan er nog twee kaderrichtlijnen op het gebied van gelijke behandeling, namelijk richtlijn 2000/43/EG van de Raad van 29 juni 2000 houdende toepassing van het beginsel van gelijke behandeling van personen ongeacht ras of etnische afstamming (Pb L 180 van 19.7.2000, blz. 22, hierna "richtlijn 2000/43") en richtlijn 2004/113/EG van 13 december 2004 houdende toepassing van het beginsel van gelijke behandeling van mannen en vrouwen bij de toegang tot en het aanbod van goederen en diensten (Pb L 373 van 21.12.2004, blz. 37, hierna "richtlijn 2004/113"). Het onderscheid in werkingsfeer tussen de verschillende richtlijnen zou aldus voor een deel irrelevant worden. Hetzelfde zou gelden voor een gedeelte van het politieke debat dat plaats vindt naar aanleiding van het voorstel van de Commissie voor een richtlijn betreffende de toepassing van het beginsel van gelijke behandeling van personen ongeacht godsdienst of overtuiging, handicap, leeftijd of seksuele geaardheid buiten de arbeidsmarkt. COM/2008/0426 final.

92 Vergelijk hoofdstuk 4.4. Zie ook A-G Wahl van 26 september 2013, zaak C-363/12, Z., punt 73. Het Hof geeft in deze zaak (m.b.t. onderzoek van de geldigheid van de richtlijn) blijk van dezelfde terughoudendheid: HvJEU van 18 maart 2014, zaak C-363/12, Z. 
'uitvoeringsmaatregelen van Unierecht'. Het verdient wel de voorkeur dat het Hof in toekomstig zaken nauwkeuriger motiveert. In deze zaak was de band met het Unierecht in de verwijzingsbeschikking wel onderbouwd. Het zou beter zijn geweest als het Hof specifiek op de stelling zou zijn ingegaan gelijk het ook deed in bijvoorbeeld Siragusa. Op die manier wordt ook zichtbaar wat de scheidslijn is tussen het gebruik maken van beoordelingsvrijheid waarbij de lidstaten wel zijn gebonden aan Uniegrondrechten (zie hoofdstuk 4.2.1) en de uitvoering van zeer algemene resultaatsverplichtingen waarbij de lidstaten (kennelijk) niet zijn gebonden aan de Uniegrondrechten. ${ }^{93}$

\section{Recht op effectieve rechtsbescherming (artikel 47 van het Handvest)}

Tot slot wijs ik op de bijzondere positie van het recht op een doeltreffende voorziening in rechte en op een onpartijdig gerecht (artikel 47 van het Handvest). Zoals is gezegd in hoofdstuk 6.3.5 worden de Uniegrondrechten niet geactiveerd door het enkele feit dat een justitiabele zich op het standpunt stelt dat regels van Unierecht van toepassing zijn. Het is voor de toepassing van Uniegrondrechten noodzakelijk dat de situatie in het hoofdgeding daadwerkelijk valt onder de werkingssfeer van het Unierecht. Deze regel geldt mogelijk niet voor artikel 47 van het Handvest. Uit de beschikkingen Pedone, Gentile en Tudoran lijkt te volgen dat artikel 47 van het Handvest in beginsel van toepassing in procedures die de interpretatie of de toepassing van een regel van Unierecht als voorwerp hebben. ${ }^{94}$ Het enkele inroepen van Unierecht zou dan voldoende zijn om artikel 47 van het Handvest te activeren. Dit is mijns inziens juist, omdat aldus wordt voorkomen dat een beroep op het Unierecht reeds bij voorbaat kansloos is. Een dusdanige toepassing van artikel 47 van het Handvest kan bovendien worden gekoppeld aan de uitvoering van de artikelen 4, lid 3, VWEU (plicht tot loyale samenwerking) ${ }^{95}$ en van artikel 19, lid 1, tweede alinea

93 De verwijzende rechter legde de kwestie nogmaals voor aan het Hof, en bood aldus een mogelijkheid tot herkansing. Het Hof oordeelde echter: "Het enkele feit dat de verwijzingsbeslissing is geherformuleerd en nogmaals de twijfel is geuit die reeds bestond bij de prejudiciële verwijzing in verband met de begrotingswet voor 2011, volstaat derhalve niet om de bevoegdheid vast te stellen van het Hof om uitspraak te doen op het onderhavige verzoek om een prejudiciële beslissing." HvJEU van 26 juni 2014, zaak C264/12, Sindicato Nacional dos Profissionais de Seguros e Afins, punt 21.

94 HvJEU van 7 februari 2013, zaak C-498/12, Pedone; HvJEU van 7 februari 2013, zaak C499/12, Gentile; zie ook HvJEU van 14 maart 2013, zaak C-555/12, Loreti, punt 17 en HvJEU van 30 mei 2013, zaak C-73/13, T., punt 13; HvJEU van 3 juli 2014, zaak C92/14, Tudoran, punt 47.

95 De plicht van de lidstaten (in casu van de nationale rechter) om het Unierecht te effectueren. Vergelijk HvJEU 13 maart 2007, zaak C-432/05, Unibet, punt 38; HvJEU van 15 april 2008, zaak C-268/06, Impact, punt 44. 
VEU. ${ }^{96}$ Ladenburger merkt over artikel 47 van het Handvest het volgende op:97

"For Article 47 to apply, it suffices that a litigant can convincingly claim, in a national court, to have a subjective right under Union law (other than the Charter) that might be violated by a national act. Then that court is required to perform its role as Union court under Article 19 TEU by granting judicial protection, and its action is covered by Article 47, regardless of any connection between the national act challenged and Union law and whether the subjective right eventually proves to exist.”

\subsection{Conclusies}

1. De aanwezigheid van een Unierechtelijk element is een eerste indicatie voor de vraag of de grondrechten van de Unie van toepassing zijn. Als er geen Unierechtelijk element aanwezig is staat vast dat de Uniegrondrechten niet van toepassing zijn. Als er wel een Unierechtelijk element aanwezig is betekent dit niet automatisch dat de Uniegrondrechten van toepassing zijn (het arrest Annibaldi). In dat geval moet worden onderzocht of de aanknoping met het Unierecht toereikend is om de Uniegrondrechten te activeren.

2. In de hoofdstukken 4 en 5 is in kaart gebracht wanneer sprake is van een band met het Unierecht die de toepasselijkheid met de Uniegrondrechten tot gevolg heeft. In dit hoofdstuk zijn een reeks aanknopingen met het Unierecht aan bod gekomen die blijkens de rechtspraak van het Hof op zich niet volstaan om de Uniegrondrechten te activeren. Voorbeelden van ontoereikende aanknopingen met het Unierecht zijn: het bestaan van Uniebevoegdheden (arresten Annibaldi, Bartsch, Polier en Julian Hernández), het Unieburgerschap (Dereci), het gebruik maken van een bevoegdheid op grond van Unierechtelijke minimumharmonisatieregelingen tot het nemen van verdergaande maatregelen (arresten Borsana, Eiterköpfe, Dominguez) het enkel inroepen door een justitiabele van Unierecht of daarop gebaseerde nationale regelingen (arresten Iida, Ymeraga), de betreffende materie wordt door het Unierecht bestreken (arrest Siragusa), de vrijwillige verwijzing in nationaal recht naar Unierecht (arresten Leur-Bloem en Cicala), een vrijwillige nationale schadeloosstelling in verband met de uitvoering Unierecht (arrest Érsekcsanádi Mezögazdasági) en het louter hypothetische vooruitzicht van de uitoefening van het vrije verkeer (arrest Kremzow).

3. Deze rechtspraak inzake de niet-toepasselijkheid van de Unierechtelijke

96 "De lidstaten voorzien in de nodige rechtsmiddelen om daadwerkelijke rechtsbescherming op de onder het recht van de Unie vallende gebieden te verzekeren.”

97 Ladenburger 2012, p. 20. 
grondrechten bevestigt dat zij enkel van toepassing zijn in combinatie met de toepassing van (specifieke materiële bepalingen van) Unierecht. Deze rechtspraak reflecteert ook een terughoudende opstelling van het Hof ten aanzien van het toepassingsgebied van de grondrechten.

4. In dit hoofdstuk zijn drie punten van aandacht naar voren gekomen. Ten eerste, de ruime formulering in het arrest Kücükdeveci van het begrip 'werkingssfeer'. Hieruit kan mogelijk worden afgeleid, dat bij de bepaling van de materiële werkingssfeer van non-discriminatiebepalingen en regelingen enkel de materie (bijv. arbeid, loon, huisvesting, dienstverlening) van belang is in plaats van de materie en het onderscheidingscriterium (leeftijd, geslacht, ras etc.) tezamen. Dit zou tot bevoegdheidsoverschrijding leiden. In de beschikkingen Vino I en Vino II en het arrest Agafiţei geeft het Hof zich hier echter wel rekenschap van en neemt voor de bepaling van de werkingssfeer van de betreffende richtlijn zowel de materie als het onderscheidingscriterium in aanmerking. Ten tweede is de rechtspraak inzake de verdergaande beschermingsmaatregelen nog wat onzeker, dit komt met name door het arrest Chatzi. Het Hof zou er goed aan doen duidelijkheid te verschaffen. Tot slot bestaat er een verschil tussen het gebruik maken van beoordelingsvrijheid waarbij de lidstaten wel zijn gebonden aan Uniegrondrechten (zie hoofdstuk 4.2.1) en de uitvoering van zeer algemene resultaatsverplichtingen waarbij de lidstaten niet zijn gebonden aan de Uniegrondrechten (beschikking Sindicato dos Bancários do Norte). Hoewel de uiteinden van het spectrum wel zijn in te schatten, zou het Hof er toch goed aan doen om met het oog op het schemergebied ertussen steeds zo precies mogelijk aan te geven wat nu doorslaggevend is. 


\section{DEEL III}

\section{HORIZONTALE DIRECTE WERKING}





\section{HOOFDSTUK 7}

\section{DEFINIËRING EN CONSTITUTIONELE CONTEXT}

\subsection{Inleiding}

Dit deel van het proefschrift gaat over de directe werking van Uniegrondrechten in geschillen tussen particulieren (horizontale directe werking). De horizontale directe werking van Uniegrondrechten bevindt zich in vergelijking met de verticale directe werking in de kinderschoenen. Het bestaan ervan is nog geen vanzelfsprekendheid en zelfs eerder omstreden. De horizontale directe werking van Unierechtelijke grondrechten raakt aan twee verschillende constitutionele vraagstukken. ${ }^{1}$ Allereerst gaat het, net als bij verticale directe werking het geval is, om het Unierechtelijke vraagstuk van de doorwerking van Unierecht in het nationale recht (Europeanisering van nationaal recht) en meer in het bijzonder de doorwerking in nationale horizontale verhoudingen. Hierbij is met name van belang de verdeling van de bevoegdheden tussen de Unie en de lidstaten, maar ook de verdeling tussen het Hof en de Unie wetgever. Ten tweede kan de horizontale directe werking van Unierechtelijke grondrechten niet los worden gezien van het algemene (nationale) constitutionele debat over de toepassing van grondrechten in private verhoudingen (ook wel genoemd de 'derdenwerking van grondrechten' of de 'constitutionalisering van private verhoudingen'). Horizontale directe werking van Uniegrondrechten impliceert immers derdenwerking van die rechten. Deze principiële discussie betreft de vraag naar de aard en de rol van grondrechten in particuliere verhoudingen, alsmede het onderscheid tussen publiek- en privaatrecht. Ook hier gaat het om een bevoegdheidsverdelingsvraagstuk, de verdeling van bevoegdheden tussen publieke autoriteit en private autonomie. In het verlengde ervan liggen ook vragen naar de verdeling van bevoegdheden (machten) tussen enerzijds de rechter (de nationale rechters en het Hof) en anderzijds de wetgever (nationale wetgevers en Uniewetgever). ${ }^{2}$

De twee constitutionele vraagstukken hangen nauw met elkaar samen. Allereerst vanuit een wat meer psychologisch perspectief. Naarmate er voor wat betreft de derdenwerking van (nationale en internationale) grondrechten binnen de lidstaten minder consensus bestaat, zal de horizontale directe werking van Uniegrondrechten tot meer controverse en weerstand leiden. Kort

1 Zie ook Ladenburger 2012, p. 188.

2 Zie ook Claes 2013, p. 34-43. 
gezegd: als de constitutionalisering van private verhoudingen nationaal al gevoelig ligt dan zal Europese constitutionalisering helemaal heikel zijn. De klassieke vragen naar de aard en de rol van grondrechten spelen hier evenzeer een rol, daarbij komt dan de gevoeligheid van het 'binnendringen' van het Europees recht in het nationale privaatrecht. Hoewel de Europeanisering van privaatrecht inmiddels een feit is, 3 is dit verschijnsel nog steeds exotisch en nog minder vanzelfsprekend dan de Europeanisering van het bestuursrecht. Civilisten zijn over het algemeen nog minder gewoon met de invloed van het Unierecht in hun vakgebied. ${ }^{4}$ Daar komt nog bij dat de Unie anders dan de Raad van Europa, geen grondrechtenorganisatie is. De acceptatie die in het nationale recht bestaat ten opzichte van de grondrechten uit het EVRM zal daarom niet vanzelfsprekend bestaan ten opzichte van de grondrechten uit het Handvest.

Ten tweede bestaat er ook een juridische verbondenheid tussen de twee vraagstukken. $\mathrm{Nu}$ Unierechtelijke grondrechten hun oorsprong vinden in de constitutionele tradities die de lidstaten gemeen hebben zijn de constitutionele praktijken in de verschillende lidstaten inzake de derdenwerking van grondrechten relevant voor de mogelijkheid van derdenwerking van Unierechtelijke grondrechten. De vraag naar de horizontale directe werking van Unierechtelijke grondrechten kan dan ook niet enkel worden beschouwd vanuit het perspectief van de Europeanisering van nationaal recht. Het element van de constitutionalisering van private verhoudingen moet ook worden meegenomen.

In dit hoofdstuk wordt ingegaan op deze constitutionele context. Alvorens hier aan toe te komen wordt in paragraaf 7.2 gedefinieerd wat wordt bedoeld met de 'horizontale directe werking van Unierechtelijke grondrechten'. Dit is van belang, omdat de terminologie door de complexe constitutionele context voer is voor Babylonische spraakverwarringen. De juristen uit de verschillende betrokken rechtsgebieden kijken met een andere bril en hanteren daarbij verschillende begrippenkaders. Unierechtelijk wordt meestal gekeken of de doorwerking van het Uniegrondrecht in het nationale recht 'direct' of 'indirect' is en vervolgens of het ook gaat om doorwerking in 'horizontale' geschillen. Men placht daarom eerder te spreken in termen van 'verticale' of 'horizontale' directe werking. Bij de algemene nationale debatten over de derdenwerking van grondrechten ligt de nadruk op de mate van doorwerking van grondrechten op de private rechtsverhouding. Dit komt tot uiting in het (omgekeerde) begrippen-

3 Zie ook Sieburgh 2013, p. 1166: "EU law is a fact in private law".

4 Sieburgh 2011, p. 190; zie Claes p. 37-38. 
kader waarin wordt gesproken van 'directe of 'indirecte' horizontale werking. ${ }^{5}$ Overigens zijn ook binnen de betrokken rechtsgebieden de definities niet vast omlijnd.

In de paragrafen 7.3 tot en met 7.5 wordt de constitutionele context geschetst. Het doel van deze schets is om in kaart brengen wat de mogelijke aanknopingspunten of obstakels zijn voor het aannemen van de horizontale directe werking. Hierbij wordt ten eerst ingegaan op de algemene nationale constitutionele debatten over de rol en aard van grondrechten in particuliere verhoudingen (paragraaf 7.3). Het zal gaan om een verkenning van de vragen en opvattingen die figureren in de nationale debatten. Ten tweede wordt gekeken naar de rechtspraak van het EHRM die betrekking heeft op de werking van het EVRM in particuliere verhoudingen (paragraaf 7.4). Tot slot wordt in paragraaf 7.5 besproken welke factoren relevant zijn voor de vraag naar de legitimiteit van horizontale directe werking van Uniegrondrechten. Zowel mogelijke grondslagen voor het aannemen van horizontale directe werking als obstakels passeren de revue.

\subsection{Definiëring horizontale directe werking}

\subsubsection{Algemeen}

Het begrip 'horizontale directe werking' in dit proefschrift wordt gebruikt als afkorting van het concept 'horizontale directe werking in het nationale recht' van Uniegrondrechten. Het vertrekpunt van dit concept is dat het ziet op de doorwerking van Unierechtelijke grondrechten in het nationale recht. De bestanddelen 'direct' en 'horizontaal' zien beiden op dit vertrekpunt. Zij duiden derhalve beiden de manier waarop het Unierechtelijke grondrecht (door)werkt in het nationale recht.

Het bestanddeel 'direct' duidt op welke wijze het Unierechtelijk grondrecht werkzaam is in het nationale recht. Of anders gezegd: de wijze waarop het grondrecht door een nationale rechter moet worden toegepast. Met 'direct' wordt bedoeld, dat het Unierechtelijk grondrecht deel uitmaakt van het rechterlijke toetsingskader als zelfstandige toetsingsmaatstaf. Het gaat derhalve om de toepassing van een Unierechtelijke grondrecht door de nationale rechter als autonome grond voor toetsing. Tegenover 'directe werking' staat 'indirecte werking'. Bij 'indirecte werking' werkt het Unierechtelijk grondrecht eveneens

$5 \quad$ Zie ook Hartkamp 2013. 
door in het nationale recht en moet de nationale rechter het toepassen. Het gaat hier echter niet om de toepassing door de rechter als zelfstandige toetsingsmaatstaf, maar als instrument van uitleg van nationaal recht. Het bestanddeel 'direct' refereert kortom aan het klassieke leerstuk van 'directe werking' van Unierecht, zoals die ook wordt gehanteerd in een verticale context en die aan de orde is geweest in deel II. Ook in de horizontale context geldt als basisvereiste voor directe werking, dat het betreffende grondrecht technisch geschikt moet zijn voor toepassing door de rechter als zelfstandige toetsingsmaatstaf. Hiervoor is vereist dat een rechter in staat is om op grond van de Unierechtelijke norm een verplichting te destilleren die voldoende duidelijk en onvoorwaardelijk is. Het betreft de vraag of de bepaling naar zijn aard (technisch) geschikt is voor rechtstreekse toepassing zonder dat er behoefte is aan uitvoering door wetgever of bestuur. ${ }^{6}$

Het bestanddeel 'horizontaal' beschrijft in welke geschillen het Unierechtelijk grondrecht doorwerkt. Horizontaal wil zeggen dat het gaat om geschillen tussen particuliere of private partijen (natuurlijke personen en rechtspersonen). Het gaat derhalve om het inroepen van Unierechtelijke grondrechten tegen particuliere wederpartijen. Van belang hierbij is dat naar Unierecht alleen sprake is van horizontale geschillen indien de partijen werkelijk private partijen zijn. Geschillen tegen overheidspartijen, ook in een privaatrechtelijke context, worden gekwalificeerd als verticaal. Op grond van de rechtspraak van het Hof kwalificeert als overheidspartij:

"Een orgaan, ongeacht zijn rechtsvorm, dat krachtens een handeling van het openbaar gezag onder toezicht van dat gezag met de uitvoering van een dienst van openbaar belang is belast en daartoe over bevoegdheden beschikt die verder gaan dan de voor de betrekkingen tussen particulieren geldende regels"

De definitie van het concept 'horizontale directe werking' in dit proefschrift luidt derhalve als volgt:

De toepassing van Unierechtelijke grondrechten door de nationale rechter als zelfstandige toetsingsmaatstaf in een geschil tussen particulieren.

Het gevolg van horizontale directe werking is dat het toepasselijke rechtskader c.q. het toetsingskader wordt gewijzigd. Het Unierechtelijke grondrecht gaat op

6 Zie hoofdstuk 3.2.1.

7 HvJEU van 24 januari 2012, zaak C-282/10, Dominguez, punt 39 en aldaar aangehaalde jurisprudentie. 
directe wijze deel uitmaken van het relevante juridische kader, en wel als zelfstandige rechtsgrond waaraan de rechter moet toetsen.

\subsubsection{Onderscheid in twee varianten}

Binnen het concept horizontale directe (door)werking maak ik onderscheid tussen twee varianten: 'horizontale directe werking (toetsing overheidshandelen)' en 'horizontale directe werking (toetsing particulier handelen)'. De definitie van de eerste variant luidt als volgt:

De toepassing van Unierechtelijke grondrechten door de nationale rechter als zelfstandige toetsingsmaatstaf voor overheidshandelen in een geschil tussen particulieren.

De tweede variant betreft:

De toepassing van Unierechtelijke grondrechten door de nationale rechter als zelfstandige toetsingsmaatstaf voor particulier handelen in een geschil tussen particulieren.

Het verschil tussen deze twee varianten van directe werking zit in het voorwerp van de rechterlijke toetsing. Bij de eerste variant fungeert het Unierechtelijk grondrecht als rechtsnorm op grond waarvan de rechtmatigheid (legaliteit) van een - in beginsel - van toepassing zijnde nationale overheidsregeling wordt beoordeeld. Het voorwerp van de toetsing is dus een overheidsregeling, bijvoorbeeld een wet. Deze vorm van directe werking doet zich voor in horizontale situaties waarin de rechtmatigheid van de litigieuze (rechts)handeling van de private partij afhangt van de rechtmatigheid van een toepasselijke regel van nationaal recht. Als voorbeeld kan worden gedacht aan de volgende situatie:

Een particuliere werkgever verstrekt aan werknemers van jonger dan 21 jaar vier weken vakantie en aan werknemers die ouder zijn dan 21 jaar vijf weken. Zulks op grond van een regel van nationaal arbeidsrecht die luidt als volgt: "Werkgevers zijn verplicht om hun werknemers minimaal vijf weken vakantie te geven. Werkgevers mogen hierop een uitzondering maken voor werknemers van jonger dan 21 jaar, mits het aantal weken minimaal vier weken bedraagt”. Stel dat een jongere werknemer een beroep doet op het Unieverbod van discriminatie op grond van leeftijd, ${ }^{8}$ en dit verbod horizontale

8 In dit voorbeeld wordt buiten beschouwing gelaten de voorvraag of Unie grondrechten wel van toepassing zijn. 
directe werking zou hebben, dan zal een rechter primair moeten kijken naar de verenigbaarheid van de nationale regel van arbeidsrecht met dit verbod. De rechtmatigheid van de gedraging van de werkgever hangt daar immers van af.

Het effect van deze variant van horizontale directe werking zal veelal zijn, dat de nationale rechtsregel die onverenigbaar is met het Unierechtelijke grondrecht buiten toepassing moet blijven. De regel moet worden uitgesloten van het toepasselijke rechtskader. Het gevolg hiervan is dat de rechtmatigheid van de litigieuze (rechts)handeling van de private partij op grond van een andere regel van nationaal recht moet worden beoordeeld. In het bovengenoemde voorbeeld zou dit het volgende betekenen:

Stel dat in het genoemde voorbeeld het Unierechtelijke verbod op discriminatie op grond van leeftijd op de wettelijke uitzondering voor werknemers jonger dan 21 jaar van toepassing zou zijn en bovendien de uitzondering in de nationale wet daarmee onverenigbaar zou blijken te zijn, dan betekent horizontale directe werking (variant toetsing van overheidshandelen) dat de nationale rechter die uitzondering niet mag toepassen. Hiermee komt dus de uitzondering te vervallen en blijft over de (nationaalrechtelijke) plicht voor de werkgever tot het verstrekken van vijf weken vakantie aan alle werknemers, ook die jonger dan 21 jaar.

Bij de tweede variant van horizontale directe werking (toetsing particulier handelen), fungeert het Uniegrondrecht als rechtsnorm op grond waarvan de rechtmatigheid van een zuiver private handeling (bijvoorbeeld een contractuele clausule) wordt beoordeeld. Het voorwerp van toetsing aan het Unie grondrecht is dus een private handeling. Deze vorm van directe werking betekent dat particulieren op dezelfde wijze zijn gebonden aan grondrechten als overheden. Als voorbeeld kan worden gedacht aan de volgende situatie:

Een particuliere onderneming verstrekt werknemers van jonger dan 21 jaar vier weken vakantie en aan werknemers die ouder zijn dan 21 jaar vijf jaar. Hij doet dit uit eigen beweging. Op grond van de nationale wet zijn werkgevers enkel verplicht tot het verstrekken van minimaal vier weken vakantie. Geheel vrijwillig geeft deze onderneming haar werknemers van ouder dan 21 jaar een week extra. Stel dat een jongere werknemer een beroep doet op het Unie verbod van discriminatie op grond van leeftijd, ${ }^{9}$ en dit verbod horizontale directe werking zou hebben, dan betekent dit dat een nationale rechter het verbod van discriminatie direct zal moeten toepassen op het beleid van de

9 In dit voorbeeld wordt buiten beschouwing gelaten de voorvraag of Unie grondrechten wel van toepassing zijn. 
betreffende particuliere onderneming. Als dit beleid onverenigbaar zal blijken te zijn met het discriminatieverbod, zal de werkgever de voordelige behandeling ook moeten geven aan de benadeelde groep van jongere werknemers.

Uit het bovenstaande volgt, dat het afhangt van het nationale rechtskader van welke variant van horizontale directe werking sprake is. Dit betekent dat het onderscheid in de twee varianten vanuit het perspectief van de doorwerking van Unierecht in het nationale recht van ondergeschikt belang is. In deze context is doorslaggevend dat het bij de beide varianten gaat om directe (door)werking in het nationale recht. In beide gevallen moet de nationale rechter Uniegrondrechten toepassen als zelfstandige toetsingsmaatstaf in een geschil tussen particulieren. Het onderscheid tussen de twee varianten komt dan ook niet terug in de rechtspraak van het Hof. ${ }^{10}$

De reden dat ik er in dit proefschrift voor kies om het onderscheid wel te maken, is dat de discussie over de horizontale directe werking van Uniegrondrechten niet los kan worden gezien van het algemene constitutionele debat naar de horizontale werking van grondrechten in private verhoudingen (derdenwerking). Horizontale directe werking van grondrechten impliceert derdenwerking. Op het debat inzake derdenwerking wordt in de volgende paragraaf dieper in gegaan. Voor hier is relevant te weten dat de nadruk van dit debat ligt op de wijze waarop grondrechten kunnen doorwerken in de private rechtsverhouding. Vanuit dit perspectief is het onderscheid tussen de varianten 'toetsing van overheidshandelen' en 'toetsing van particulier handelen' wel degelijk relevant. Hoewel de uiteindelijke uitkomst van het geschil dikwijls hetzelfde zal zijn, ${ }^{11}$ is de juridische invloed op de private rechtsverhouding anders. Bij 'horizontale directe werking (toetsing van overheidshandelen)' is sprake van een indirecte effect van het Uniegrondrecht op de private rechtsverhouding. 'Indirect' omdat de beïnvloeding plaatsvindt via de band van het nationale materiële recht en de particulieren partijen niet rechtstreeks zijn gebonden aan het Unierechtelijke grondrecht. De variant 'horizontale directe werking (toetsing van particulier handelen)' is indringender, omdat de private

10 Zie bijvoorbeeld de rechtspraak inzake het afwijzen van horizontale directe werking van richtlijnen. Het Hof maakt geen onderscheid tussen de twee varianten van horizontale directe werking, ze zijn beide niet toegestaan: HvJEU van 19 januari 2010, zaak C555/07, Kücükdeveci, punt 46 (afwijzing van horizontale directe werking van richtlijn in een situatie die de toetsing van overheidshandelen betreft, namelijk een regel van nationaal arbeidsrecht) en HvJEU van 26 februari 1986, zaak 152/84, Marshall, punt 48 (afwijzing van horizontale directe werking van richtlijn in een situatie die de toetsing van particulier handelen betreft, namelijk het ontslagbeleid van een private werkgever).

11 In het voorbeeld moet de werkgever in beide scenario's alsnog vijf weken vakantie geven aan de jongere werknemers. 
rechtsverhouding direct wordt beïnvloed door het Unierechtelijke grondrecht. Het Uniegrondrecht vormt een norm waaraan private parijen rechtstreeks zijn gebonden.

Tot slot wordt opgemerkt dat het onderscheid tussen de twee varianten van horizontale directe werking wel terug komt in de Unierechtelijke doctrine, maar onder andere benamingen. Bij 'horizontale directe werking (toetsing overheidshandelen)' wordt gesproken van 'uitsluitende werking' of 'uitsluitings-effect' (dikwijls in het Frans 'effet de l'exclusion'). 'Horizontale directe werking (toetsing particulier handelen)' heet in Uniejargon 'substituerende werking' of 'substitutie-effect' (dikwijls in het Frans 'effet de substitution'). De begrippen 'effet de l'exclusion' en 'effet de substitution' zijn voor Uniejuristen herkenbaar. Het nadeel van deze begrippen is echter dat het onderscheid 'uitsluiting' en 'substitutie' niet altijd klopt en daarom verwarrend kan zijn. ${ }^{12}$ Bijvoorbeeld omdat bij substitutie-effect ook sprake kan zijn van 'uitsluiting', bijvoorbeeld als een contractuele clausule ten gevolge van de directe werking van het grondrecht buiten toepassing moet blijven. Een ander voorbeeld is het geval van een feitelijke particuliere handeling die door de toepassing van het Uniegrondrecht een onrechtmatige daad oplevert. De vraag rijst of dan wel kan worden gesproken van substitutie. In eerdere publicaties heb ik desondanks gekozen om het gebruikelijke en herkenbare Unierechtjargon vergezeld van een precieze definiëring te hanteren. In dit proefschrift kies ik voor een andere terminologie, die ik duidelijker en meer accuraat vind.

\subsection{Constitutionalisering van particuliere verhoudingen}

\subsubsection{Een schets van het debat}

Het algemene constitutionele vraagstuk van de derdenwerking van grondrechten hangt samen met de scheidslijn tussen het publiekrecht en het privaatrecht ${ }^{13}$, alsmede de rolverdeling tussen rechter en wetgever. Uiteindelijk gaat dit vraagstuk over de rol van de Staat in de samenleving. ${ }^{14}$ Het vraagstuk is ook wel bekend onder benamingen als: 'horizontale werking van grondrechten', 'constitutionalisering van het privaatrecht' en de Duitse term 'Drittwirkung van grondrechten'. Centraal in dit debat staat de vraag of grondrechten van invloed

12 Ik dank prof. mr. A.S. Hartkamp, prof. mr. drs. C.H. Sieburgh en prof. mr. C.W.A. Timmermans voor hun waardevolle commentaren over de gebruikte terminologie.

13 Voor een relativering van deze scheidslijn zie Sieburgh 2013, p. 1169-1171.

14 Claes 2013, p. 41. Smits 2003, p. 4: "Wie schrijft over de verhouding tussen grondrechten en privaatrecht, schrijft ook over de gewenste mate van beïnvloeding van de private sfeer door de overheid." 
zijn op de rechtsverhoudingen tussen particulieren ${ }^{15}$ en als dit zo is op welke manier.

Het debat is relatief nieuw. De achtergrond van het debat is dat grondrechten van oudsher behoren tot het publiekrecht. Ze zijn oorspronkelijk bedoeld als tegenwicht aan overheidsmacht en als afbakening van de vrije private zone; het private domein waarbinnen individuen autonoom zijn. ${ }^{16}$ De toepassing van grondrechten in het private domein ligt vanuit dit vertrekpunt niet voor de hand. Immers daar waar grondrechten juist dienen om het private domein te vrijwaren van inmengingen kunnen zij niet tevens de regels binnen dat domein bepalen. Tegenwoordig is het echter algemeen geaccepteerd dat grondrechten particuliere verhoudingen wel degelijk kunnen beïnvloeden.

Ondanks dat de invloed van grondrechten in particuliere verhoudingen algemeen is aanvaard, is de kwestie nog altijd niet vanzelfsprekend. Er bestaan uiteenlopende opvattingen over op welke manier dit kan en tot op welke hoogte. ${ }^{17}$ De constitutionele stelsels van de verschillende lidstaten tonen een gevarieerd beeld van de situaties waarin en de wijze waarop grondrechten van toepassing kunnen zijn in horizontale verhoudingen. ${ }^{18}$ In het volgende zal een kort overzicht worden gegeven van de meest relevante aspecten van het constitutionele debat over de derdenwerking van grondrechten.

In dit debat spelen zowel principiële als praktische argumenten een rol. Er kunnen grofweg twee uiterste principiële visies worden onderscheiden. Aan de ene kant de visie volgens welke grondrechten geheel buiten het privaatrechtelijk systeem staan (hierna ook wel: 'de exogene rol van grondrechten'). Aan de andere kant de visie die er vanuit gaat dat de grondrechten geheel in het

15 Dit refereert normaal gesproken naar het vermogensrecht. Het familierecht wordt hier meestal niet toegerekend, omdat publieke overwegingen een grote rol spelen. Smits 2006, p. 11.

16 Anders: Nieuwenhuis \& Hins 2011, p. 170. Zij stellen dat de ontstaansgeschiedenis van de grondrechten niet in de richting van een exclusieve focus op het handelen van de staat. Zij wijzen hierbij op Locke die grondrechten zag als onvervreemdbare natuurlijke rechten. Ook wijzen zij erop dat de leuzen 'vrijheid, gelijkheid en broederschap' van de Franse revolutie zich niet enkel richtten tegen de Koning, maar ook tegen ander machten zoals de adel, de kerk en de gilden. Tot slot wijzen zij erop dat in de verhoudingen van voor 1789 er geen scherp onderscheid bestond tussen publiek en privaatrecht.

17 Alexy 2002, p. 354-355; Claes 2013, p. 40.

18 Zie voor een nuttige vergelijking tussen de constitutionele stelsels van enkele lidstaten (Denemarken, Verenigd Koninkrijk, Frankrijk, Duitsland, Griekenland, Ierland, Spanje en Italië): Oliver \& Fedtke 2007-2. Zie ook De Witte 2009, p. 515-524; Claes, p. 42; Besselink 2012, p. 90-93. 
privaatrechtelijke systeem zijn geïntegreerd (hierna ook wel: 'de endogene rol'). ${ }^{19}$

De voorstanders van een exogene rol van grondrechten baseren zich op de scheidslijn tussen de publieke en de private sfeer. Essentieel is dat particulieren, in tegenstelling tot overheden, niet het algemeen belang hoeven na te streven. Particulieren zijn autonoom. Ze maken hun eigen keuzes (hoe verwerpelijk ook). De toepassing van grondrechten in de private sfeer is onwenselijk, omdat het zou betekenen dat (de ene en enige) gemeenschappelijke standaard wordt opgelegd aan individuen die in beginsel juist keuzevrijheid hebben. ${ }^{20}$

Voorstanders van de endogene functie van grondrechten betogen daarentegen dat grondrechten een uitdrukking vormen van waarden die ten grondslag liggen aan het gehele rechtssysteem. Ze zijn niet alleen fundamenteel binnen het publiekrecht, maar ze liggen ook ten grondslag aan het privaatrecht. ${ }^{21} \mathrm{De}$ aanhangers van de endogene functie van grondrechten menen dat de grondrechten zo fundamenteel zijn dat ze principieel van toepassing zouden moeten zijn zowel in het publieke als in het private domein. Grondrechten zijn derhalve naar hun aard van toepassing in de private sfeer. ${ }^{22}$ Overheid en burger zijn in gelijke mate aan grondrechten gebonden. ${ }^{23}$

Naast principiële argumenten figureren in het debat ook argumenten van meer praktische aard. Zo wordt er op gewezen dat grondrechten niet geschikt zijn voor toepassing in particuliere verhoudingen door hun algemene en diffuse karakter. De rechtvaardigingsgronden of beperkingsclausules van grondrechten zijn bovendien toegesneden op overheden. Hartkamp merkt hierover het volgende op: 24

"De Nederlandse rechter is, evenals de Duitse (...) terughoudend geweest bij het toekennen van directe horizontale werking ${ }^{25}$ aan (nationale of interna-

19 Voermans 2006, p. 34.

20 Sommeregger 2005, p. 48. Zie ook kort en bondig opgeschreven Smits 2003, p. 7: "Overheid en burger zijn nu eenmaal principieel verschillende entiteiten: wat de overheid niet mag, mag de burger vaak wel."

21 Nieuwenhuis 2006, p. 5; Lindenbergh 2006, p. 100.

22 Sommeregger 2005, p. 49.

23 Smits 2003, p. 6.

24 Hartkamp 2011-2, nr. 227.

25 Zijn definitie van horizontale directe werking betekent dat een norm rechtstreeks van invloed is op de (rechts) verhouding tussen particulieren; dat zij leidt tot het ontstaan, de wijziging of het tenietgaan van rechten of verplichtingen in verhoudingen tussen particulieren. Deze definitie komt derhalve overeen met wat in de proefschrift 
tionale) grondrechtenbepalingen. Voor deze terughoudendheid bestaan goede gronden (...). Grondrechtsbepalingen zijn normaal gesproken niet geformuleerd met het oog op betrekkingen tussen burgers onderling. Dat geldt voor de hoofdregel, en dus ook voor de daarop gemaakte uitzonderingen. Deze uitzonderingsbepalingen zijn doorgaans restrictief geformuleerd en moeten volgens de bedoeling van de verdrags- of grondwetgever, ook restrictief worden uitgelegd. Dat betekent dat de bepalingen, als geheel genomen, zich meestal niet voor de toepassing op rechtsverhoudingen tussen burgers onderling lenen, aangezien die toepassing tot onaanvaardbare resultaten zou leiden. Als de eiser zich bijvoorbeeld zou beroepen op zijn recht op eerbiediging van zijn persoonlijke levenssfeer zoals geregeld in art. $10 \mathrm{Grw}$, een recht dat alleen kan worden beperkt door bij of krachtens de wet te stellen regels, zou zijn recht altijd prevaleren boven elk gedrag van de gedaagde dat niet door zo'n regel wordt gerechtvaardigd, zelfs als dit in strijd zou zijn met de regels van maatschappelijke betamelijkheid (...). Dit zou de algemene vrijheid van de burgers om te handelen zoals het hun goeddunkt onaanvaardbaar beperken. Om dit resultaat te vermijden, zou de rechter de hoofdregel van de grondrechtsbepaling zo beperkt (of de uitzondering zo extensief) moeten interpreteren, dat die uitleg in strijd zou komen met de normaal gesproken in 'verticale' zaken wenselijke interpretatie."

Het argument op grond van het algemene en diffuse karakter is overigens niet enkel praktisch, maar bevat het ook een meer principiële kant. Immers daar waar de rechter aan de slag moet met algemene clausules die ook nog eens aanpassing behoeven voor de private context, ontstaat het risico dat de rechter in het vaarwater van de wetgever terecht komt. ${ }^{26}$ Verder zou een directe werking van grondrechten zich slecht verhouden met de belangenafweging die eigen is aan het privaatrechtelijk systeem. Tot slot dreigt het gevaar van een impasse als beide partijen zich beroepen op een grondrecht. ${ }^{27}$ Deze argumenten pleiten derhalve tegen de toepassing van grondrechten in het private rechtsverkeer.

Een belangrijk (principieel) argument vóór de toepassing van grondrechten in het private rechtsverkeer is de bescherming van de zwakke partij. Immers, ook in private rechtsverhoudingen kan sprake zijn van een zwakke versus een machtige particuliere partij, zoals een werkgever, een multinational, of een (geprivatiseerde) onderneming die essentiële diensten (telecommunicatie, zorg, openbaar vervoer) verrichten. In een dusdanige ongelijke context zou de

'horizontale directe werking (toetsing van particulier handelen) wordt genoemd. Hartkamp 2011-2, nr. 42.

26 Zie ook Smits 2003, p. 6 en p.16 met de daar vermelde bronnen.

27 Hartkamp 2011-2, nr. 227. 
zwakke partij belang hebben bij grondrechtenbescherming vis-à-vis zijn machtige wederpartij. ${ }^{28}$

\subsubsection{Verschillende manieren van beïnvloeding van particuliere rechtsverhoudingen}

Er bestaan verschillende manieren en gradaties waarop grondrechten van invloed kunnen zijn in particuliere verhoudingen. Allereerst kan onderscheid worden gemaakt tussen het gebruik van grondrechten door de wetgever en het gebruik door de rechter. Met het gebruik van grondrechten door de wetgever wordt bedoeld dat de wetgever grondrechten uitwerkt in wetgeving die van toepassing is in particuliere verhoudingen. Een voorbeeld van Unierechtelijke wetgeving zijn de non-discriminatie richtlijnen die in hoofdstuk 10 aan de orde komen. ${ }^{29}$

De toepassing van grondrechten die zijn uitgewerkt in privaatrechtelijke wetgeving is in het algemeen minder controversieel. Het bevestigt de principiële gedachte dat grondrechten niet automatisch van toepassing zijn in de private sfeer (exogene rol grondrechten). De doorwerking van grondrechten geschiedt hier immers middels interventie van de wetgever. Het is zelfs de vraag of in dit scenario nog wel gesproken kan worden van de toepassing van grondrechten. ${ }^{30}$ Het komt voorts tegemoet aan het bezwaar op grond waarvan grondrechten als zodanig niet geschikt zijn voor toepassing in private verhoudingen. Bij wetgeving is het mogelijk om specifiek rekening te houden met de bijzondere positie van private actoren. De wetgever kan conflicterende belangen afwegen. ${ }^{31}$ Dit verkleint het risico dat de rechter door de toepassing van algemene normen op de stoel van de wetgever gaat zitten. Het voren-

28 Avbelj 2005, p. 154; Hartkamp 2011-2, nr. 226.

29 Bijvoorbeeld richtlijn 2000/78 of 2000/43. Zie verder over Uniewetgeving inzake grondrechten met betrekking tot private verhoudingen (sociale rechten \& arbeidsrecht, interne markt \& dataprotectie, judiciële samenwerking in burgerlijke zaken): Ladenburger 2012, p.192-199. Een voorbeeld in Nederland is de Algemene Wet Gelijke Behandeling, maar ook bepalingen uit het BW. Smits 2003, p. 9 noemt als voorbeelden: het gelijkheidsbeginsel (onder meer art. 7:646 BW), de bescherming van eigendom (onder meer art. 5:1, 5:2, 5:22 BW en de Onteigeningswet), de contractsvrijheid en privaatautonomie (onder meer art. 6:74 en 6:248 BW), de bescherming van de persoonlijke levenssfeer (onder meer art. 6:167 BW) en de vrije keuze van arbeid (art. 7:653 BW).

30 Claes 2013, p. 41: "There is no agreement on whether conceptually we are still dealing with fundamental (constitutional) rights in their true sense, or whether these laws rather transform fundamental rights into 'normal' (legislative) rights and interests"

31 Zie ook Besselink 2012, p. 96. 
staande neemt niet weg dat ook de toepassing van grondrechten in de private sfeer middels wetgeving niet vrij is van controverse. Zo was de toepasselijkheid van de Unierechtelijke gelijke behandelingsrichtlijnen in zowel de publieke als in de private sector een tamelijk nieuw en controversieel fenomeen. Zulks met name daar waar het toepassingsgebied verder gaat dan het terrein van het arbeidsrecht. ${ }^{32}$ Illustratief is het feit dat het voorstel van de Commissie voor een richtlijn betreffende de toepassing van het beginsel van gelijke behandeling van personen ongeacht godsdienst of overtuiging, handicap, leeftijd of seksuele geaardheid buiten de arbeidsmarkt nog steeds geen richtlijn is. ${ }^{33}$

Met het gebruik van grondrechten door de rechter wordt bedoeld dat de rechter algemene constitutionele normen (soms ook ongeschreven) toepast in particuliere verhoudingen. Dit ligt principieel gevoeliger, omdat bij deze toepassing wordt aanvaard dat grondrechten zonder interventie van de wetgever van toepassing kunnen zijn. Bovendien stuit deze toepassing op praktische bezwaren naar de geschiktheid van algemene constitutionele normen om te worden toegepast in private verhoudingen. ${ }^{34}$ Tevens dreigt het gevaar dat de rechter plaats neemt op de stoel van de wetgever. ${ }^{35}$

Er zijn verschillende methoden van toepassing van grondrechten door de rechter. Over het algemeen wordt onderscheid gemaakt tussen 'directe' en 'indirecte' horizontale werking van grondrechten. ${ }^{36}$ Het moet echter meteen worden opgemerkt dat er nog verdere onderverdelingen kunnen worden

32 De Witte 2009, p. 520-521. Zie bijvoorbeeld over de reacties in Duitsland naar aanleiding van de implementatiewetgeving: Sommeregger 2005, p. 39-40.

33 COM/2008/0426 final: Voor het laatst besproken in de Raad Werkgelegenheid, Sociaal Beleid, Volksgezondheid en Consumentenzaken Brussel op 1-2 december 2011. Zie persmededeling 17943/1/11 REV 1: “(...) De Raad is nu al drie jaar bezig met de bespreking van het voorstel voor een richtlijn. (...) Een aantal kwesties zal nog nader moeten worden besproken, onder meer: (...) de bevoegdheidsverdeling, de algemene werkingssfeer en de subsidiariteit (...).”

34 Het gebruik van constitutionele normen door de rechter op zich kan (ook in verticale verhoudingen) reeds discutabel zijn in het licht van democratische legitimiteit. Oliver \& Fedtke 2007-2, p. 471-472.

35 Zie ook Hartkamp 2011-2, nr. 227.

36 Nota bene: hier verwijs ik naar de begrippenkaders die circuleren in de nationale constitutionele debatten over derdenwerking. Zoals eerder opgemerkt in 7.2.2 beschrijven deze het effect van grondrechten op de horizontale rechtsverhouding tussen particulieren (directe of indirecte horizontale werking). Het onderwerp van dit proefschrift beschrijft de doorwerking van grondrechten in de nationale rechtsorde (horizontale directe werking). In het volgende zal ik aangeven welke begrippen overeenkomen met de door mij gehanteerde definities. 
gemaakt van 'directe' en 'indirecte' werking. ${ }^{37}$ Voorts verschillen de betekenissen van 'directe' en 'indirecte' werking in de verschillende jurisdicties. Heel globaal gezegd gaat het bij 'indirecte' werking 38 om de toepassing van grondrechten op het wettelijk kader dat van toepassing is op de particuliere rechtsverhouding. Het gaat meestal over de uitleg van open normen in het privaatrecht met behulp van grondrechten. ${ }^{39}$ Echter ook de rechtmatigheidstoetsing van de van toepassing zijnde wettelijke regels (in dit proefschrift aangeduid als horizontale directe werking, variant 'toetsing van overheidshandelen' ) wordt soms geschaard onder de noemer 'indirecte werking', zij het dat dit wordt gezien als een 'sterkere' gradatie van indirecte horizontale werking dan het gebruik van grondrechten als instrument van uitleg. ${ }^{40}$

Bij 'directe' werking gaat het om de zelfstandige toepassing van grondrechten op de private rechtsverhouding. ${ }^{41}$ Dat wil zeggen dat de grondrechten zonder tussenkomst van een wettelijke norm of regelgeving van toepassing zijn. Bij directe werking dient de rechter te toetsen aan het grondrecht zelf en hij moet derhalve ook de daarin vervatte beperkingsmogelijkheden in aanmerking nemen. Bij directe werking is het grondrecht het allesbepalende toetsingskader. ${ }^{42}$ In dit proefschrift wordt dit aangeduid als 'horizontale directe werking (variant toetsing van particulier handelen)'.

In het merendeel van de lidstaten is directe horizontale werking van grondrechten niet aanvaard. ${ }^{43}$ Lidstaten waarin directe horizontale werking in bepaalde situaties wel is geaccepteerd zijn Duitsland, Frankrijk, Spanje, Griekenland, Luxemburg, Slovenië, Portugal en Ierland. Tussen deze landen bestaan ook weer verschillen, zo is het in Duitsland alleen aanvaard in het

37 Oliver \& Fedtke 2007-2, p. 470: "These various approaches form a sliding scale with many intermediate shades of grey rather than a system of clearly defined categories, as traditional legal terminology would seem to suggest'.

38 Duitse term: mittelbare Drittwirkung.

39 In Nederland zijn dat bijvoorbeeld normen als 'goede zeden', 'redelijkheid en billijkheid' en 'maatschappelijke zorgvuldigheid', 'goed werkgeverschap'.

40 Zie Gardbaum 2012, p. 180: "Indirect horizontal effect has been further subdivided into stronger and weaker forms. The former means that private law is fully and equally subject to constitutional law; the latter that courts have a duty to take constitutional law into account in interpreting and developing private law."

41 Duitse term: unmittelbare Drittwirkung.

42 Smits 2003, p. 9. Het onderscheid wordt door Smits inzichtelijk gemaakt aan de hand van zijn bespreking van het arrest HR 9 januari 1987, NJ 1987, 828 (Edamse Bijstandsmoeder), p. 13.

43 Besselink 2012, p. 91. 
arbeidsrecht. ${ }^{44}$ Indirecte werking (vooral de variant 'instrument van uitleg') is over het algemeen eerder geaccepteerd, omdat het privaatrecht het relevante toetsingskader blijft en het grondrecht geen zelfstandige grond vormt voor het instellen van rechtsvorderingen. Dit heeft gevolgen voor de afweging door de rechter. Het grondrecht wordt 'slechts' onderdeel van de privaatrechtelijke belangenafweging. Hetgeen betekent dat de waarde die ten grondslag ligt aan het grondrecht wordt meegewogen samen met andere waarden en rechten die in de betreffende private verhouding een rol spelen. De heersende opvatting in de Unie lijkt te zijn de indirecte werking van grondrechten. Voorbeelden van landen waarin grondrechten indirecte horizontale werking hebben zijn Nederland ${ }^{45}$ en Duitsland. ${ }^{46}$ Hartkamp schrijft hierover, dat de Nederlandse rechter:47

"de voorkeur geeft aan een mildere vorm van werking van grondrechten in particuliere verhoudingen, en wel aldus dat hij die rechten -of de daarin belichaamde waarden- in zijn overwegingen tracht te betrekken wanneer hij algemene privaatrechtelijke begrippen toepast, zoals de redelijkheid en billijkheid, strijd met hetgeen volgens ongeschreven recht in het maatschappelijk verkeer betaamt, goede zeden enz. In casus-posities waarin aan beide zijden grondrechten in het spel zijn, worden de onderscheiden (partij) belangen tegen elkaar afgewogen opdat een in het stelsel van het privaatrecht passende oplossing voor het geschil kan worden gevonden (...)”

Uit het voorgaande volgt, dat de horizontale directe werking van Uniegrond-

44 Zie voor nadere beschrijving van de directe werking per land Oliver \& Fedtke 2007-2, p. 481-483: Frankrijk, Ierland, Spanje, Duitsland en Griekenland. Besselink 2012, p. 91-92: Griekenland, Cyprus, Ierland, Luxemburg, Slovenië en Oostenrijk. Smits 2003, p. 7: Ierland.

45 Smits 2003, p. 13-15. Zie voor een overzicht van relevante Nederlandse rechtspraak: Claes \& Gerards 2012: www.nver.nl/documents/FIDE_report_2012_topic_1.pdf,p. 1416.

46 Smits 2003, p. 15 en 16. Het Duitse standaardarrest is de Lüth-zaak. In deze zaak oordeelde het Duitse constitutionele hof (Bundesverfassungsgericht) expliciet dat bij de interpretatie van het Burgerlijk Wetboek rekening moet worden gehouden met de grondrechten. Bijvoorbeeld open normen als $\$ 138$ BGB (rechtshandeling in strijd met de goede zeden), $\$ 242$ (redelijkheid en billijkheid) en $§ 826$ (onrechtmatigheidscategorie goede zeden), maar ook meer concreter regels. De reden hiervoor is dat grondrechten een stelsel van waarden vormen dat zowel het publiekrecht als het privaatrecht beïnvloedt. BVerfGE 7, 198; NJW 1958, 257. Zie voor een overzicht van andere voorbeelden uit de Duitse rechtspraak: Cherednychenko 2007, p. 39-42. Zij wijst er ook op dat de benadering van het Bundesverfassungsgericht in de Duitse doctrine fel is bekritiseerd zowel vanuit de privaatrechtelijke als de publiekrechtelijke hoek.

47 Hartkamp 2011-2, nr. 228. 
rechten in de meeste lidstaten delicaat zal zijn. Hierbij lijkt de variant 'toetsing van overheidshandelen' door de band genomen minder controversieel te zijn dan de variant 'toetsing van particulier handelen'.

\subsection{Het EHRM en horizontale werking}

Naast de opvattingen in de verschillende nationale constitutionele stelsels, is ook de rechtspraak van het Europees Hof voor de Rechten van de Mens (hierna: 'EHRM') relevant. De Uniegrondrechten vinden immers mede hun oorsprong in het EVRM. Het Handvest schrijft bovendien expliciet voor dat met het EVRM corresponderende rechten niet onder het EVRM beschermingsniveau mogen komen (artikel 52, lid 3, Handvest). Voorts is deze rechtspraak relevant met het oog op de toekomstige toetreding van de Unie tot het EVRM.

Bij de bespreking van de rechtspraak van het EHRM is het van belang om voor ogen te houden dat het Straatburgse Hof anders dan het Hof in Luxemburg geen zaken voorgeschoteld krijgt tussen particulieren. De rechtsgang in Straatsburg ziet enkel op procedures tegen de Verdragsluitende Staten. ${ }^{48}$ Bovendien wordt de directe doorwerking van EVRM-grondrechten niet door het volkenrecht geregeld, maar hangt het af van de constitutionele stelsels van de Verdragsluitende Staten. ${ }^{49}$ De vraag naar directe doorwerking van het EVRM komt in horizontale geschillen in de rechtspraak van het EHRM dan ook niet terug. Het EHRM heeft ook geen algemene theorie ontwikkeld over de vraag in hoeverre de EVRM-bescherming zich uitstrekt tot horizontale verhoudingen..$^{50}$ Dit neemt niet weg dat er wel rechtspraak is die van invloed is op horizontale verhoudingen. Deze rechtspraak betreft zaken waarin wordt geklaagd over handelen of nalaten van Verdragsluitende Staten terzake van grondrechtenschendingen door private partijen en is met name gegrond op de door het EHRM ontwikkelde leer van de positieve verplichtingen.

De grondslag van de leer van de positieve verplichtingen is dat de Verdragsluitende Staat hun verdragsverplichtingen niet enkel kunnen schenden door een 'doen' maar ook door een 'nalaten'. Zij zijn niet alleen verplicht om zich van inbreuken op fundamentele rechten van individuen te onthouden, maar zij kunnen onder het EVRM ook verplicht zijn om rechten te waarborgen. Het

48 Artikel 34 EVRM.

49 Nederland heeft een monistisch stelsel. Op grond van de artikelen 93 en 94 Grw. heeft het EVRM in beginsel directe werking.

50 EHRM van 28 juni 2001, zaaknr. 24699/94, VgT Verein gegen Tierfabriken, NJ 2002, 181 m.n. E.J. Dommering, r.o. 46. Zie ook Verhey 2009, p. 520. 
eerste arrest waarin het EHRM de leer van de positieve verplichtingen toepaste was in het arrest Marckx. ${ }^{51}$ Het EHRM oordeelde op grond van artikel 8 EVRM (eerbiediging van de persoonlijke levenssfeer) dat België verplicht ${ }^{52}$ was om de relatie tussen ouders en hun onwettige kinderen op een niet discriminerende wijze te regelen. De stap van klassieke onthoudingsplicht naar positieve verplichting was indertijd een doorbraak die leidde tot een aanzienlijke uitbreiding van het beschermingsgebied van het EVRM. ${ }^{53}$

De leer van de positieve verplichtingen gaat uit van de klassieke verticale verhouding, het gaat altijd om het in gebreke zijn van de Staat. Dit neemt niet weg dat de EVRM-bescherming ook vereist kan zijn in private verhoudingen en dat de Verdragsluitende Staat verplicht is tot het nemen van maatregelen die zien op de verhoudingen tussen particulieren onderling (de bescherming tegen grondrechteninbreuken door particulieren). Van belang bij het leerstuk is dat het in beginsel gaat om resultaatsverplichtingen waarbij de Verdragssluitende staten beschikken over (een zekere) vrijheid ten aanzien van de keuze van middelen. De erkenning van positieve verplichtingen kan 'de facto' 54 resulteren in verplichtingen van de verschillende organen van de Verdragssluitende Staat, waaronder bestuursorganen, de wetgever en de rechter.

Voor dit proefschrift zijn met name van belang de positieve verplichtingen die de rechter in acht moet nemen. Relevant hierbij is dat uit de rechtspraak van het EHRM volgt, dat EVRM-rechten niet enkel positieve verplichtingen voor strafen bestuursrechters met zich kunnen brengen (verticale geschillen), maar ook voor civiele rechters in gedingen tussen particulieren (horizontale geschillen). In bepaalde gevallen toetst het EHRM via de band van de positieve verplichtingen of de nationale rechter (als onderdeel van de Verdragsluitende staat) het EVRM op een juiste wijze in horizontale verhoudingen heeft laten doorwerken. In theorie gaat het EHRM hierbij uit van een marginale toetsing, echter in de

51 EHRM van 13 juni 1979, zaaknr. 58442, Marckx, NJ 1980, 462, m.n. E.A. Alkema, r.o. 13.

52 Het ging om plicht voor de wetgever.

53 Verhey 2009, p. 523-524 met ook verwijzingen naar latere rechtspraak. Het aannemen van een plicht tot het nemen van positieve maatregelen volgt in sommige gevallen expliciet uit het betreffende grondrecht. Voorbeelden van dit soort bepalingen zijn: artikel 13 EVRM (plicht tot bieden van effectieve rechtsbescherming tegen schending van grondrechten) en artikel 6, lid 3 onder c EVRM (toewijzen van gratis advocaat in strafzaken ter waarborging recht op een eerlijk proces). Daarnaast heeft het EHRM ook positieve verplichtingen afgeleid van grondrechten die op het eerste gezicht slechts een onthoudingsplicht lijken te behelzen.

54 Volkenrechtelijk rust de verplichting op de Verdragsluitende Staat, bijv. het Koninkrijk der Nederlanden. 
praktijk wordt steeds vaker een inhoudelijk oordeel gegeven over de wijze waarop de (civiele) rechter de belangen tegen elkaar heeft afgewogen. ${ }^{55}$

Een voorbeeld van een positieve plicht voor de civiele rechter volgt uit het arrest Von Hannover. ${ }^{56}$ Deze zaak betrof een klacht tegen de beslissing van de hoogste Duitse civiele rechter in een civiele zaak aangespannen door prinses Caroline van Monaco tegen uitgevers van enkele boulevardbladen wegens de publicatie van foto's van haar privéleven. De prinses stelde zich in de civiele zaak op het standpunt dat haar privacy was geschonden en ze beriep zich op artikel 8 EVRM (bescherming privéleven). De hoogste Duitse rechter liet het recht op vrijheid van meningsuiting prevaleren en stelde haar in het ongelijk. Het EHRM stelde prinses Caroline in het gelijk. Duitsland had verzaakt positieve maatregelen te nemen om het privéleven ex artikel 8 EVRM te beschermen in de private sfeer.

Een ander voorbeeld is de zaak Pla and Puncernau..$^{57}$ In deze zaak ging het om de vraag of een geadopteerde zoon aanspraak kon maken op de erfenis van zijn grootmoeder. In het testament was bepaald dat de toekomstige erfgenaam de erfenis moest laten gaan aan de (klein)zoon van een 'wettig en canoniek' huwelijk. De nationale rechter diende de vraag te beantwoorden of een geadopteerde zoon kon worden aangemerkt als 'een zoon uit een wettig en canoniek huwelijk'. De hoogste rechter van Andorra oordeelde -mede in het licht van de maatschappelijke opvattingen ten tijde van het opstellen van het testament- van niet. De geadopteerd zoon kon derhalve geen aanspraak maken op de erfenis. In deze zaak toetste het EHRM de uitleg door de nationale rechter van een privaatrechtelijke rechtshandeling (testament). In theorie hanteerde het EHRM hierbij een zeer ruime beoordelingsruimte ('a wide margin of appreciation'), omdat enkel een uitleg die 'manifest onredelijk of willekeurig is of flagrant in strijd is met de algemene beginselen van het EVRM is' kon kwalificeren als een inmenging. De concrete toetsing door het EHRM bleek echter niet marginaal, maar inhoudelijk. Hoewel de uitleg van de Andorrese rechter verdedigbaar was oordeelde het EHRM dat de uitleg van het testament op grond waarvan onderscheid werd gemaakt tussen biologische en adoptieve kinderen flagrant in strijd was met artikel 8 jo. 14 EVRM. 58

55 Verhey 2009, p. 526-527. Zie verder over de rechtspraak van het EHRM betreffende horizontale verhoudingen: Spielmann p. 427-467; Barkhuysen \& Van Emmerik 2006, p. 43-59; Hartkamp 2011-2, nr. 200.; Garlicki 2005, p. 129-145.

56 EHRM van 24 juni 2004, zaaknr. 59320/00, Von Hannover, punt 57. NJ 2005, 22, m.n. E.J. Dommering. NJ 2005, 22 NJCM-Bulletin 2004, p. 1171 m.n. V.J. de Graaf.

57 EHRM 13 juli 2004, zaaknr. 69498/01, Pla and Puncernau, NJ 2005, 508, r.o. 59.

58 Pla and Puncernau, r.o. 60-64. 
Tot slot wordt gewezen op de zaak Khurshid Mustafa. ${ }^{59}$ De klagers waren Irakezen woonachtig in Zweden die van hun particuliere huurbaas de schotelantenne van de gevel van hun huurflat moesten halen op straffe van opzegging van de huurovereenkomst. De Zweedse rechter gaf hen nul op rekest en stelde de verhuurder in het gelijk. Het EHRM oordeelde tot een schending van 10 EVRM. Opmerkelijk hierbij was dat het ging om een zuiver privaat geschil. In dit verband stelde het EHRM dat het, hoewel in theorie niet is geroepen om privaatrechtelijke geschillen te beslechten, niet passief kan blijven als het gaat om een interpretatie door een nationale rechter van een juridisch document (zoals een testament, een privaatrechtelijk contract, een publiekrechtelijk stuk, een wettelijke bepaling of een administratieve praktijk) die onredelijk, willekeurig, discriminatoir, of meer in algemene zin strijdig met de aan de Conventie ten grondslag liggende beginselen lijkt te zijn. In deze zaak ging het om de interpretatie en toepassing door de Zweedse rechter van de huurovereenkomst en wettelijke bepalingen, waaronder ook de bepalingen over vrijheid van informatie zoals neergelegd in de Zweedse grondwet en het EVRM. Het EHRM oordeelde, dat de interpretatie door de Zweedse rechter een schending van artikel 10 EVRM (vrijheid van de vrijheid om inlichtingen of denkbeelden te ontvangen) behelsde. Relevant hierbij was dat de huurders via hun satellietschotel televisieprogramma's in het Arabisch en Farsi wilden ontvangen uit hun land van oorsprong. Hierbij ging het om het ontvangen van politiek en sociaal nieuws, maar ook van culturele expressie en entertainment. Het EHRM overwoog dat het belang van deze vormen van informatie niet mag worden onderschat, zeker niet als het gaat om een immigrantenfamilie die in contact wil blijven met de cultuur en taal van het land van herkomst. De huurders hadden daarom een zwaarwegend belang in deze zaak. Het Hof overwoog voorts dat er geen sprake leek te zijn van alternatieve middelen om deze informatie te ontvangen. Evenmin was sprake van andere zwaarwegende belangen.

De rechtspraak van het EHRM is in het licht van het algemene debat inzake de derdenwerking van grondrechten vergaand te noemen. Het deinst niet terug tot het vellen van inhoudelijke oordelen in privaatrechtelijke geschillen. De plichten uit hoofde van het EVRM voor de nationale rechter komen echter niet neer op de plicht tot toekenning van directe derdenwerking van grondrechten; het ligt ook niet voor de hand om aan te nemen dat de rechtspraak van het EHRM deze kant op zal gaan. Eerder vertoont het leerstuk van de positieve verplichtingen uit hoofde van het EHRM gelijkenis met de door het HvJEU

59 EHRM 16 december 2008, zaaknr. 23883/06, Khurshid Mustafa, punt 50. NJ 2010, 149, m.n. E. A. Alkema. NJCM-Bulletin 34 (2009) 8, p. 892 - 902, m.n. L. Verhey. 
ontwikkelde plicht tot conforme interpretatie (indirecte werking).

\subsection{Legitimiteit van horizontale directe werking}

\subsubsection{Algemeen}

In de volgende hoofdstukken wordt de rechtspraak van het Hof inzake horizontale directe werking van Uniegrondrechten geanalyseerd en tevens geëvalueerd in het licht van het beginsel van de allocatie van bevoegdheden. De centrale vraag hierbij zal zijn in hoeverre de toekenning van (bepaalde vormen) van horizontale directe werking legitiem zijn. Als opmaat voor deze evaluatie wordt in deze paragraaf uiteen gezet welke elementen bij deze evaluatie mogelijk van belang kunnen zijn. Het vertrekpunt hierbij is, dat het Unierecht niet expliciet voorziet in de mogelijkheid van horizontale directe werking van grondrechten, maar in tegendeel lijkt uit te gaan van de klassieke functie van Uniegrondrechten als middel van bescherming tegen overheidsmacht. ${ }^{60}$ Deze constatering sluit echter niet op voorhand uit dat de aanvaarding van horizontale directe werking door het Hof legitiem kan zijn. Nu het Hof bevoegd is om het bestaan van grondrechten (als algemene rechtsbeginselen) te erkennen, mag worden aangenomen dat deze bevoegdheid zich ook uit strekt tot de werking ervan. ${ }^{61}$ Het moet echter wel gaan om erkenning van derdenwerking en niet om uitvinding ervan. Dit betekent dat sprake moet zijn van een grondslag voor directe werking. Daarnaast moet het Hof ook grenzen in acht nemen. Met name moet het Hof opereren binnen de grenzen van het Handvest en van het Unierechtelijke systeem van rechtsbescherming als geheel. In deze paragraaf worden enerzijds mogelijke grondslagen voor horizontale directe werking besproken (paragraaf 7.5.2) en anderzijdswordt in kaart gebracht welke grenzen relevant zijn (paragraaf 7.5.3).

\subsubsection{Mogelijke grondslagen voor horizontale directe werking}

In deze paragraaf wordt geïnventariseerd welke factoren relevant (kunnen) zijn bij de aanvaarding van horizontale directe werking van Uniegrondrechten. Hiervoor zullen de nationale constitutionele tradities (7.5.2.1), de rechtspraak van het EHRM (7.5.2.2), het effectiviteitsbeginsel (7.5.2.3) en het bestaan van horizontale directe werking van Verdragsbepalingen (7.5.2.4) als mogelijke grondslagen voor de erkenning van horizontale directe werking worden besproken

60 Zie hoofdstuk 2.

61 Lenaerts \& Gutiérrez-Fons 2010, p. 1647; Mazák \& Moser 2013, p. 79. 


\subsubsection{Nationale constitutionele tradities}

Het in de vorige paragraaf geschetste constitutionele debat is juridisch relevant voor de mogelijkheid van horizontale directe werking van Uniegrondrechten. De Uniegrondrechten vinden immers hun oorspong in de nationale constitutionele tradities. Ze zouden dan ook kunnen dienen als legitimatie voor de toekenning van bepaalde vormen van derdenwerking aan Uniegrondrechten. In dit verband wordt ook gewezen op artikel 52, lid 4, van het Handvest. Ingevolge deze bepaling moeten Uniegrondrechten die voortvloeien uit de constitutionele tradities die de lidstaten gemeen hebben, in overeenstemming met die tradities worden uitgelegd. De Toelichting op deze bepaling luidt als volgt:

"De uitleggingsregel in lid 4 is gebaseerd op de formulering van artikel 6, lid 3, van het Verdrag betreffende de Europese Unie en houdt rekening met de benadering van gemeenschappelijke constitutionele tradities die door het Hof van Justitie wordt gevolgd (bijv. arrest van 13 december 1979, zaak 44/79, Hauer, Jurispr. 1979, blz. 3727; arrest van 18 mei 1982, zaak 155/79, AM\&S, Jurispr. 1982, blz. 1575). Volgens die regel zouden de betrokken rechten van het Handvest zodanig moeten worden uitgelegd dat een hoge beschermingsnorm wordt gegarandeerd die strookt met het recht van de Unie en die spoort met de gemeenschappelijke constitutionele tradities, in plaats van een strikte aanpak te volgen waarbij een minimale gemeenschappelijke basis wordt gezocht.”

Deze bepaling is dus een aansporing om te streven naar een hoog beschermingsniveau van grondrechtenbescherming. In het in de Toelichting bij artikel 52, lid 4, van het Handvest genoemde arrest Hauer ging het Hof 'te rade' bij de 'constitutionele regelen en praktijken' van de (toen nog negen) lidstaten. Hierbij nam het in aanmerking de 'gemeenschappelijke constitutionele opvattingen en vaste legislatieve praktijken'.62 In het arrest $A M \& S$, dat eveneens in de Toelichting bij artikel 52, lid 4, van het Handvest wordt genoemd, sprak het Hof van het gemeenschapsrecht (thans Unierecht) als een "juridische vervlechting van de Lid-Staten" dat rekening moet houden met "de beginselen en begrippen die de rechtsstelsels van de Lid-Staten gemeen hebben". Het Hof zocht in dat arrest naar de 'gemeenschappelijke criteria' en 'elementen welke de rechtsstelsels van de lidstaten gemeen hebben'. ${ }^{63}$

De opstellers van het Handvest zullen bij artikel 52, lid 4, van het Handvest vermoedelijk hebben gedacht aan de inhoud van de grondrechten en niet zozeer aan de werking ervan. Dit neemt niet weg dat voor de vraag naar

62 HvJEU van 13 december 1979, zaak 44/79, Hauer, punten 20 en 22.

63 HvJEU van 18 mei 1982, zaak 155/79, AM \& S, punten 18, 21 en 22. 
derdenwerking van Uniegrondrechten dezelfde systematiek zou kunnen gelden. Bij de vraag naar de derdenwerking van Unierechtelijke grondrechten zou soortgelijk onderzoek kunnen plaatsvinden. Indien vervolgens gemeenschappelijke constitutionele opvattingen zouden kunnen worden gedestilleerd ten aanzien van (bepaalde vormen) van derdenwerking van grondrechten zou dat naar mijn mening een legitimatie kunnen vormen voor de toekenning van die werking aan Uniegrondrechten. Het is wel van belang om hierbij onderscheid te maken tussen enerzijds constitutionele praktijken in de lidstaten die duiden op de noodzaak om (bepaalde) grondrechten in private verhoudingen te effectueren en anderzijds de wijze waarop dit in de lidstaten vorm wordt gegeven. Hierbij is relevant dat, zoals gezegd in paragraaf 7.3, enerzijds de invloed van grondrechten op private verhoudingen algemeen lijkt te zijn aanvaard, maar er anderzijds een gevarieerd beeld bestaat ten aanzien van de wijze waarop grondrechten in horizontale rechtsverhoudingen kunnen worden toegepast. Met name liggen vergaande vormen van derdenwerking zoals de toepassing van grondrechten door de rechter als een zelfstandige toetsingsmaatstaf gevoelig.

\subsubsection{De rechtspraak van het EHRM}

Ook de rechtspraak van het EHRM zou kunnen dienen als mogelijke legitimatie voor de toekenning van bepaalde vormen van derdenwerking aan Uniegrondrechten. In dit verband is ten eerste het al genoemde artikel 52, lid 3, van het Handvest relevant. Deze bepaling ziet op de rechten in het Handvest die corresponderen met het EVRM. Op grond van deze bepaling mag het Unierechtelijke beschermingsniveau niet lager zijn dan onder het EVRM (het EVRM niveau is het minimum, maar een ruimere bescherming mag wel). Voorts is in dit verband relevant de toekomstige toetreding van de Unie tot het EVRM, zoals voorzien in artikel 6, lid 2, eerste zin, VEU. De Unie (en dus ook het Hof) zal dan ook zelf gebonden zijn aan het EVRM en de uitspraken van het EHRM. Een mogelijke legitimatie voor de toekenning van horizontale directe werking aan het grondrechten uit het Handvest zou dus kunnen zijn dat deze toekenning noodzakelijk is om te voldoen aan het EVRM.

Zoals in paragraaf 7.4 is uiteengezet is het denkbaar dat op grond van de rechtspraak van het EHRM met het EVRM corresponderende grondrechten in bepaalde situaties effect moeten sorteren in horizontale verhoudingen. Er kan dan sprake zijn van een verplichting tot het nemen van positieve maatregelen die ook geldt in horizontale geschillen. Een dusdanige verplichting kan via de band van artikel 52, lid 3, Handvest of in de toekomst uit hoofde van het EVRM-lidmaatschap van de Unie, ook op de Unie (en daarmee op het Hof) 
rusten. Aldus zou het Hof in bepaalde situaties verplicht kunnen zijn om nationale overheden op te dragen om met het EVRM corresponderende Uniegrondrechten te effectueren in horizontale verhoudingen. Het voldoen aan deze plicht zou een mogelijke legitimatie kunnen vormen voor de toekenning van horizontale directe werking. Hierbij moet volledigheidshalve worden aangetekend, dat de rechtspraak van het EHRM in bepaalde omstandigheden weliswaar kan verplichten tot het effectueren van een grondrecht in een private setting (derdenwerking), maar dat het niet verplicht tot het aannemen van horizontale directe werking. De EHRM-leer van de positieve verplichtingen laat immers de ruimte ten aanzien van de keuze van de middelen.

\subsubsection{Het effectiviteitsbeginsel}

Directe werking is het middel bij uitstek om de volle en uniforme werking van Unierecht te verzekeren. De effectiviteit van Uniegrondrechten zou dan ook een grondslag kunnen zijn voor het aannemen van horizontale directe werking. ${ }^{64}$ Het is dan echter wel nodig om twee voorvragen te beantwoorden. Allereerst moet worden onderzocht of (bepaalde) Uniegrondrechten in het algemeen of in specifieke situaties effect zouden moeten sorteren in horizontale verhoudingen (vraag naar het bestaan van derdenwerking). Nu de grondrechten van de Unie van oudsher zijn bedoeld voor verticale verhoudingen is dit geen vanzelfsprekendheid en is het nodig om deze voorvraag te beantwoorden. In de vorige paragrafen is reeds gewezen op de mogelijkheid dat de constitutionele tradities van de lidstaten of de rechtspraak van het EHRM een grondslag zouden kunnen zijn voor het oordeel dat (bepaalde) Uniegrondrechten (in bepaalde situaties) effect moeten sorteren. Daarnaast zou dit oordeel ook kunnen volgen uit de aard van een bepaald grondrecht. Een tweede voorvraag is vervolgens op welke wijze een mogelijke derdenwerking van Uniegrondrechten moet worden geëffectueerd. Leidt de vaststelling dat (bepaalde) Uniegrondrechten in (bepaalde) private verhoudingen effect zouden moeten sorteren automatisch tot de inzet van het middel van horizontale directe werking? Of zijn er andere middelen voor handen die, bijvoorbeeld met het oog op de constitutionele context, de voorkeur verdienen?

\subsubsection{De horizontale directe werking van Verdragsbepalingen}

In het Unierecht is reeds sprake van de horizontale directe werking van Verdragsbepalingen en wel met name de bepalingen inzake het vrije verkeer ${ }^{65}$

64 Zie bijvoorbeeld Safjan 2013, p. 161.

65 Relevante rechtspraak horizontale directe werking Verdragsrechtelijke vrije 
en non-discriminatie. ${ }^{66}$ De advocaten-generaal Bot en Cruz Villalón lijken de toekenning van horizontale directe werking van Uniegrondrechten als een logisch of noodzakelijk gevolg hiervan te beschouwen. ${ }^{67}$ Advocaat-generaal Bot drukt zich als volgt uit:

"85. (...) de omstandigheid dat het hoofdgeding twee particulieren betrof, [kon] zich er helemaal niet tegen verzetten dat een beroep werd gedaan op de uitsluitende werking van dit algemene beginsel van gemeenschapsrecht, aangezien het Hof reeds herhaaldelijk een belangrijkere stap heeft gezet door horizontale rechtstreekse werking te verlenen aan verdragsbepalingen die bijzondere uitdrukkingen van het algemene gelijkheids- en non-discriminatiebeginsel bevatten.”

\section{Advocaat-generaal Cruz Villalón merkt in AMS op:}

“34. (...) Nochtans bestaat het idee dat de fundamentele vrijheden van verkeer of bepaalde beginselen zoals het verbod van discriminatie op grond van geslacht een rol spelen in de rechtsbetrekkingen tussen particulieren reeds lange tijd en is het algemeen aanvaard. In die omstandigheden is het idee dat de andere grondrechten van het Handvest dan de fundamentele vrijheden of het gelijkheidsbeginsel mogelijkerwijs aan een verschillende en, bij wijze van spreken, slechtere regeling binnen het geheel van het Handvest zijn onderworpen, erg problematisch."

De erkenning van het bestaan van horizontale directe werking van de genoemde Verdragsbepalingen geeft inderdaad blijk van een tendens volgens welke fundamentele Unierechten ook horizontale directe werking kunnen hebben. Dit zou relevant kunnen zijn voor de vraag naar de horizontale directe werking van de Uniegrondrechten. De relevante vraag is of de horizontale directe werking van Uniegrondrechten in dezelfde lijn moet worden gezien als

verkeerbepalingen: HvJEU van 12 juli 2012, zaak C-171/11, Fra.bo, punt 32 (vrije verkeer van goederen); HvJEU van 11 december 2007, zaak C-438/05, Viking Line en HVJEU van 18 december 2007, zaak C-341/05, Laval (vrije verkeer van personen). Doctrine over de horizontale directe werking van vrije verkeerbepalingen: Schepel 2013, p. 1211-1230; Prechal \& de Vries, 2009, p. 5 - 24; Van Leuken 2014; A-G Trstenjak van 28 maart 2012, zaak C-171/11, Fra.bo, punten 29-36.

66 Relevante rechtspraak horizontale directe werking Verdragsrechtelijke nondiscriminatiebepalingen: HvJEU van 12 december 1974, zaak 36/74, Walrave and Koch; HvJEU van 8 april 1976, zaak 43/75, Defrenne II en HvJEU van 16 september 1999, zaak C-218/98, Angonese.

67 Zie bijvoorbeeld A-G Bot van 7 juli 2009, zaak C-555/07, Kücükdeveci, punt 85 en A-G Cruz Villalón van 18 juli 2013, zaak C-176/12, AMS, punt 34. 
de horizontale directe werking van deze Verdragsbepalingen of dat de horizontale directe werking van deze Verdragsbepalingen anderszins noopt tot het aannemen van horizontale directe werking van Uniegrondrechten.

Ligt de erkenning van horizontale directe werking van Uniegrondrechten in dezelfde lijn als de reeds bestaande horizontale directe werking van de Verdragsbepalingen?

Naar mijn mening ligt het doortrekken van de lijn minder voor de hand dan het op het eerste gezicht misschien zou lijken. Ik vind het ook wat kort door de bocht om de parallel te trekken zonder aandacht te besteden aan de volgende punten.

Ten eerste hebben de grondrechten uit hoofde van algemene beginselen en het Handvest gemeen met de genoemde Verdragsbepalingen dat het fundamentele normen van primair recht zijn. Tegelijk echter moet worden bedacht dat de grondrechten uit hoofde van algemene beginselen en het Handvest ook verschillen van de genoemde Verdragsbepalingen. Het gaat om verschillende rechtsbronnen. Zoals in deel II van dit proefschrift is benadrukt zijn de grondrechten accessoire rechten die zijn gekoppeld aan de toepassing van materieel Unierecht. De Verdragsbepalingen zijn daarentegen zelfstandige normen van materieel Unierecht. De grondrechten zijn ook algemeen, terwijl de Verdragsbepalingen regels bevatten van materieel recht met een afgebakend toepassingsgebied. ${ }^{68}$ Dit zijn relevante verschillen die zouden moeten worden meegenomen bij de beantwoording van de vraag of het bestaan van de horizontale directe werking van de Verdragsbepalingen gevolgen heeft voor de vraag naar het bestaan van de horizontale directe werking van grondrechten.

Ten tweede zou het antwoord op de vraag of de horizontale directe werking van Uniegrondrechten moet worden gezien als een logisch of noodzakelijk gevolg van de horizontale directe werking van Verdragsbepalingen mijns inziens mede moeten afhangen van de grondslag van de horizontale directe werking van de genoemde Verdragsbepalingen. Als deze horizontale directe werking zou zijn geënt op het grondrechtelijk karakter van de betreffende Verdragsbepalingen vormt dit een mogelijke aanleiding om de lijn door te trekken naar grondrechten in het algemeen. Vanuit dit perspectief zou met name de horizontale directe werking van de Verdragsrechtelijke discriminatieverboden in het vrij verkeer van personen moeten worden onderzocht (de artikelen 18 VWEU, 45, lid 2, VWEU en 157 VWEU). Van deze verboden staat het vast dat zij als uitdrukking van het algemene gelijkheidsbeginsel een

68 Opgemerkt wordt wel dat het toepassingsgebied van artikel 18 VWEU zeer breed is. De horizontale directe werking ervan is echter tot nu toe gekoppeld aan het vrije verkeer. 
grondrechtelijk karakter hebben. Tegelijk hebben zij ook een functie in het proces van Europese eenwording en wel met name in verband met de realisatie van het vrij verkeer. ${ }^{69}$ De relevante vraag is dan ook of het grondrechtelijke karakter van de genoemde verboden als zodanig aanleiding was om over te gaan tot de toekenning van horizontale directe werking of dat deze toekenning eerder was gerelateerd aan de vrije verkeer-functie van die verboden of aan andere bijkomende factoren? Korter gezegd: geeft de horizontale directe werking van deze bepalingen blijk van een opvatting volgens welke discriminatieverboden naar hun grondrechtelijke aard bindend moeten zijn voor particulieren? Ik betwijfel of dit laatste uit de rechtspraak inzake de artikelen 18 VWEU, 45, lid 2, VWEU en 157 VWEU naar voren komt.

Zo lijkt de horizontale directe werking van de artikelen 157 VWEU (het verbod van loondiscriminatie op grond van geslacht) en 45, lid 2, VWEU (het verbod van discriminatie op grond van nationaliteit voor migrerende werknemers) primair te zijn gekoppeld aan het toepassingsgebied van deze bepalingen: het arbeidsrecht. Het Hof lijkt de gebondenheid van particulieren met name te hebben afgeleid uit het doel van de bepalingen om een niet-discriminerende behandeling op de arbeidsmarkt te verzekeren. ${ }^{70}$ Tegelijk kan niet worden uitgesloten dat het grondrechtelijk karakter van deze verboden op grond van geslacht mede bepalend is geweest voor de toekenning van de horizontale directe werking. ${ }^{71}$ Echter zelfs als dit laatste het geval zou zijn, moet hier worden gewezen op het eerder genoemde verschil in toepassingsgebieden. De

69 Het verbod van discriminatie op grond van nationaliteit diende aanvankelijk als noodzakelijk instrument voor het welslagen van de interne markt. Vervolgens heeft het zich in de loop van de tijd, het meest expliciet na de inwerkingtreding van het Verdrag van Maastricht, ontwikkelt tot een essentieel element van Unie burgerschap. Zie ook A-G Jacobs van 30 juni 1993, gevoegde zaken C-92/92 en C-326/92, Phil Collins, punten 10 en 11. Artikel 157 VWEU heeft ook een economisch doel (het opheffing van mededingingsverstoringen tussen in verschillende lidstaten gevestigde ondernemingen). HvJEU van 8 april 1976, zaak 43/75, Defrenne II, punt 9; HvJEU van 10 februari 2000, zaak C-50/96, Deutsche Telekom, punt 54.

70 HvJEU van 16 september 1999, zaak C-218/98, Angonese, punt 35 (de zaak ziet op artikel 48 VEG (thans 45, lid 2 VWEU), maar de overweging ziet ook op artikel 119 VEG (thans artikel 157 VWEU). Deze arresten worden besproken in paragraaf 10.2.3 onder A.

71 Zie Prechal \& de Vries (2009), p. 17. Zij wijzen erop dat in punt 35 wordt overwogen, dat artikel 48 EG een fundamentele vrijheid formuleert en een specifieke toepassing van het in artikel 6 EG-Verdrag (thans artikel 18 VEU) vervatte algemene discriminatieverbod vormt. Zij lezen hierin een mogelijke "fundamental right twist" en ze betogen als volgt: "on this basis it could be concluded that it is, in particular, the fundamental rights character of the prohibition of discrimination on the grounds of nationality that creates the obligation for private individuals, and, ultimately give rise to the full horizontal direct effect." 
toepassingsgebieden van de artikel 157 en 45, lid 2, WVEU zijn zeer nauw omlijnd en beperkt tot onderdelen van het arbeidsrecht, terwijl de grondrechten uit hoofde van de algemene rechtsbeginselen en het Handvest van toepassing zijn binnen de gehele werkingssfeer van het Unierecht.

De mogelijkheid van horizontale directe werking van artikel 18 VWEU lijkt evenmin te zijn gekoppeld aan het grondrechtelijke karakter van het verbod van discriminatie op grond van nationaliteit. Het lijkt eerder functioneel te zijn aan het vrij verkeer, dan een principiële opvatting te reflecteren volgens welke het non-discriminatiebeginsel naar zijn aard ook particulieren bindt. Dit blijkt onder meer uit het feit dat horizontale directe werking van artikel 18 VWEU nog enkel is aanvaard in situaties waarin de particuliere partij een zekere macht uitoefent over particulieren en in staat is om hun voorwaarden op te leggen waardoor de uitoefening van de door het Verdrag gewaarborgde fundamentele vrijheden wordt bemoeilijkt. ${ }^{72}$

Noopt de horizontale directe werking van deze Verdragsbepalingen anderszins tot het aannemen van horizontale directe werking van Uniegrondrechten?

Hierboven is ingezoomd op de vergelijkbaarheid met Verdragsbepalingen. Er is echter ook nog een andere redenering denkbaar ten aanzien van het doortrekken van de horizontale directe werking van de Verdragsbepalingen naar Uniegrondrechten: In verticale situaties is de werkingssfeer van grondrechten immers gekoppeld aan de werking van materieel Unierecht. Dit betekent dat een uitbreiding van de werkingssfeer van materieel Unierecht leidt tot een uitbreiding van de werkingssfeer van de Uniegrondrechten. Als deze systematiek ook zou gelden in horizontale situaties dan zou dit impliceren dat de toepassing van materieel Unierecht tussen particulieren de toepassing van Uniegrondrechten tussen die particulieren activeert. Hierbij kan worden gedacht aan het volgende voorbeeld: Private partij A stelt dat het handelen van private partij B een beperking is op het recht op vrije verkeer. Partij B beroept zich op een rechtvaardigingsgrond. Gesteld dat de situatie inderdaad valt onder het vrije verkeer en dat een beroep in een horizontaal geding mogelijk is, rijst de vraag of nu het handelen van B als vrije verkeersbeperking onder de werkingssfeer van het Unierecht valt, ook de Uniegrondrechten op hem van toepassing zijn. In dat geval zou partij A kunnen aanvoeren dat B niet alleen zijn recht op vrije verkeer beperkt, maar ook inbreuk maakt op een grondrecht. Het gevolg hiervan zou zijn het handelen van B ook moet worden getoetst aan het

72 HvJEU van 12 december 1974, zaak 36/74, Walrave and Koch, punt 18; HvJEU van 3 oktober 2000, zaak C-411/98, Ferlini, punt 50. Deze arresten worden besproken in paragraaf 10.2.3 onder B.1. 
betreffende grondrecht. ${ }^{73}$

De juistheid van deze redenering hangt echter ook hier af van de beantwoording van de principiële voorvraag of Uniegrondrechten van invloed zijn tussen particulieren (vraag naar de derdenwerking van Uniegrondrechten) en zoja op welke wijze. ${ }^{74}$ Het spreekt anders gezegd niet vanzelf om de verticale systematiek te gebruiken in horizontale situaties. Ik betwijfel daarom of (zomaar) gezegd kan worden dat de toepasselijkheid van materieel Unierecht tussen particulieren tevens de grondrechten tussen de particulieren activeert. Ik voorzie ook niet direct problematische situaties als in een scenario zoals hier boven is beschreven het recht op vrije verkeer wel van toepassing zou zijn, maar de Uniegrondrechten niet. De eventuele aantasting van A op zijn grondrechten door B kan via de band van het nationale recht aan de orde komen.

Een eventueel tweesporenbeleid ten aanzien van enerzijds de horizontale directe werking van Uniegrondrechten (geen horizontale directe werking) en anderzijds de horizontale directe werking van Verdragsbepalingen (wel horizontale directe werking) zou mijns inziens wel kunnen wringen als het zou leiden tot situaties waarin particuliere partij A zich ten opzichte van particuliere partij B kan beroepen op zijn recht op vrije verkeer of non-discriminatie uit hoofde van het Verdrag en particuliere partij B zich daar niet tegen kan verweren door een beroep op een grondrecht. Voor het voorkomen van deze situatie is het echter niet nodig om de horizontale directe werking van het betreffende grondrecht te erkennen. Partij B kan immers een beroep doen op een rechtvaardigingsgrond. Een mogelijke rechtvaardigingsgrond die partij $\mathrm{B}$ kan inroepen is de uitoefening van een grondrecht (dit kan een Uniegrondrecht zijn, maar ook een nationaal grondrecht). Deze situatie deed zich voor in de arresten Viking Line en Laval die in hoofdstuk 8 verder zullen worden behandeld. ${ }^{75}$ Hoewel in dit scenario een zekere derdenwerking toekomt aan het grondrecht, is geen sprake van horizontale directe werking. Het grondrecht fungeert als legitiem doel en niet als zelfstandige toetsingsmaatstaf. ${ }^{76}$

\subsubsection{Mogelijke grenzen aan horizontale directe werking}

In deze subparagraaf worden de mogelijke grenzen aan horizontale directe

73 Dit is de horizontale toepassing van de ERT -systematiek (hoofdstuk 5).

74 Vergelijk hoofdstuk 7.5.2.3.

75 HvJEU van 11 december 2007, zaak C-438/05, Viking Line; HvJEU van 18 december 2007, zaak C-341/05 Laval.

76 Zie ook de in hoofdstuk 5.2.1 besproken verticale arresten HvJEU van 12 juni 2003, zaak C-112/00, Schmidberger; HvJEU van 14 oktober 2004, zaak C-36/02, Omega. 
werking in kaart gebracht. Hierbij wordt ingegaan op artikel 51, lid 1, van het Handvest (7.5.3.1) en de rechtspraak van het Hof inzake de horizontale directe werking van richtlijnen (7.5.3.2).

\subsubsection{Artikel 51, lid 1, van het Handvest}

De directe werking van Unierecht is alleen mogelijk voor dwingend recht. Zoals ook in hoofdstuk 3.3.2 is opgemerkt geldt dat zonder gebondenheid aan de betreffende rechtsnorm geen sprake kan zijn van directe werking van die norm. De relevante vraag is dus of Uniegrondrechten in horizontale situaties moeten worden beschouwd als dwingend recht. Het logische vertrekpunt voor de beantwoording van deze vraag is artikel 51, lid 1, van het Handvest. Deze beschrijft immers het toepassingsgebied van de Unierechtelijke grondrechten. Deze bepaling luidt als volgt:

"De bepalingen van dit Handvest zijn gericht tot de instellingen, organen en instanties van de Unie met inachtneming van het subsidiariteitsbeginsel, alsmede, uitsluitend wanneer zij het recht van de Unie ten uitvoer brengen, tot de lidstaten. Derhalve eerbiedigen zij de rechten, leven zij de beginselen na en bevorderen zij de toepassing ervan overeenkomstig hun respectieve bevoegdheden en met inachtneming van de grenzen van de bevoegdheden zoals deze in de Verdragen aan de Unie zijn toegedeeld."

Uit deze bepaling volgt mijns inziens, dat het Handvest zich niet richt tot particulieren. Artikel 51, lid 1, van het Handvest stelt immers, dat de bepalingen van dit Handvest zijn gericht tot enerzijds de instellingen, organen en instanties van de Unie en anderzijds tot de lidstaten. Particulieren worden niet genoemd. Op grond hiervan concludeer ik dat het Handvest dwingend is ten aanzien van nationale en Unie overheden, maar niet ten aanzien van particulieren. ${ }^{77}$

Advocaat-generaal Cruz Villalón in de zaak AMS wijst deze uitleg van artikel 51, lid, van het Handvest expliciet af: ${ }^{8}$

77 Zie ook A-G Trstenjak van 8 september 2011, zaak C-282/10, Dominguez, punt 138; Mazák \& Moser 2013, p. 83 en Kokott \& Sobotta 2010.

78 A-G Cruz Villalón van 18 juli 2013, zaak C-176/12, AMS, punten 29-31. Zie ook: Bernitz, Groussot \& Schulyok 2013-2, p. 12: “(...) it appears to us that Article 51 is rather concerned with the material scope of the Charter and (...) that is not concerned with the question as to the Charter's possible horizontal effects.” 
"30. (...) Ik kan volstaan met de opmerking dat teksten - meestal grondwetteksten - die rechtenverklaringen bevatten, traditioneel niet uitdrukkelijk vermeldden wie de adressaten of de passieve subjecten van die rechten waren en dat spontaan werd aangenomen dat zij aan de overheid waren gericht. Verder blijven de gevallen waarin particulieren uitdrukkelijk als mogelijke adressaten worden vermeld, ver in de minderheid. Dat betekent dat de vraag naar de rol van de grondrechten in privaatrechtelijke betrekkingen meestal door middel van uitlegging, zonder dat op een uitdrukkelijke grondwettelijke bepaling kon worden gesteund, en doorgaans per geval moest worden beantwoord.

31. Zonder dat de bepaling tot in bijzonderheden hoeft te worden uitgelegd, is het mijns inziens vrij duidelijk dat artikel 51, lid 1, van het Handvest in wezen ziet op de vraag in hoeverre enerzijds de instellingen van de Unie en anderzijds de lidstaten gebonden zijn aan de daarin neergelegde grondrechten. Volgens mij wijst niets in de formulering van die bepaling en - tenzij ik mij vergis evenmin in de voorbereidende werkzaamheden of in de toelichtingen bij het Handvest erop dat de auteurs van het Handvest met de formulering van die bepaling de bijzonder complexe kwestie van de werking van de grondrechten in de betrekkingen tussen particulieren hebben willen aansnijden."

Ik acht het juist dat artikel 51, lid 1, van het Handvest de mogelijkheid dat Uniegrondrechten van invloed zijn op particuliere verhoudingen niet uitsluit (de mogelijkheid van derdenwerking). Dat zou zich ook moeilijk verhouden met het in paragraaf 7.5.2.2 besproken artikel 52, lid 3, van het Handvest die tot gevolg kan hebben dat met het EVRM corresponderende rechten in bepaalde effect moeten sorteren in horizontale verhoudingen. Dit neemt echter niet weg, dat de betekenis van artikel 51, lid 1, van het Handvest er bij uitstek in is gelegen om limitatief te bepalen wie in welke situaties gehouden is tot eerbiediging van de Uniegrondrechten. Het ontbreken van particulieren als adressant betekent dat zij niet gehouden zijn de Uniegrondrechten te eerbiedigen.

Samenvattend ben ik van mening, dat artikel 51, lid 1, van het Handvest zich niet verzet tegen het toepassen van Uniegrondrechten in horizontale verhoudingen (derhalve het bestaan van derdenwerking). Artikel 51, lid 1, van het Handvest verzet zich echter wel tegen een toepassing die leidt tot de gebondenheid van particulieren aan Uniegrondrechten (derhalve een bepaalde vorm van derdenwerking). Dit zou met name het geval zijn bij het aannemen van horizontale directe werking in situaties waarin het gaat om de toetsing van particulier handelen aan de grondrechten. De aanname van horizontale directe werking variant 'toetsing overheidshandelen' ligt genuanceerder, omdat het niet noodzakelijk de gebondenheid van particulieren aan Uniegrondrechten hoeft te impliceren. In deze context is sprake van een verticale component en is 
het verdedigbaar dat de gebondenheid van de particulier aan de toe te passen rechtsnorm (in casu een grondrecht) niet is vereist, omdat het onderwerp van toetsing een overheidsregeling is. Het is precies om die reden dat deze variant van horizontale directe werking in het debat over de derdenwerking van grondrechten over het algemeen als een 'lichtere' (minder indringende) variant van derdenwerking wordt beschouwd. Het aannemen van horizontale directe werking variant 'toetsing overheidshandelen' acht ik dan ook niet evident in strijd met artikel 51, lid 1, van het Handvest.

\subsubsection{De rechtspraak inzake horizontale directe werking van richtlijnen}

Uit het bovenstaande is gebleken dat artikel 51, lid 1, van het Handvest niet noodzakelijk in de weg staat aan het aannemen van horizontale directe werking variant 'toetsing overheidshandelen'. Echter, hier zit een andere adder onder het gras. Uit de rechtspraak van het Hof inzake de horizontale directe werking van richtlijnen zou kunnen worden afgeleid dat het aannemen van horizontale directe werking van een norm van een materieel Unierecht altijd de gebondenheid van particulieren veronderstelt aan die rechtsnorm, ongeacht of sprake is van de variant 'toetsing van particulier handelen' of de variant 'toetsing van overheidshandelen' ${ }^{79}$ In deze context heeft het Hof de beide vormen van horizontale directe werking immers verworpen wegens het ontbreken van een verbindend karakter van richtlijnen voor particulieren. Illustratief is de overweging in het arrest Marshall dat: ${ }^{80}$

“48. (...) volgens artikel 189 EEG-Verdrag het dwingende karakter van een richtlijn - waarop de mogelijkheid om er voor de nationale rechter beroep op te doen, is gebaseerd - slechts bestaat ten aanzien van "elke Lid-Staat waarvoor

79 Zie voor een analyse van deze rechtspraak: Craig 2009, p. 349-378. Zie voor een vroege analyse waarin ook wordt ingegaan op het onderscheid tussen de twee varianten van horizontale directe werking Timmermans 1979, p. 550-551 (overigens hanteert hij een engere definitie van directe werking).

80 HvJEU van 26 februari 1986, zaak 152/84, Marshall, punt 48. Recentelijk bevestigt in de arresten HvJEU van 19 januari 2010, zaak C-555/2007, Kücükdeveci, punt 36; HvJEU 24 januari 2012, zaak C-282/10, Dominguez, punt 37 en HvJEU van 15 januari 2014, zaak C176/12, AMS, punt 46. Volledigheidshalve wijs ik op de arresten HvJEU van 30 april 1996, zaak C-194/94, CIA Security International en HvJEU van 26 september 2000, zaak C-443/98, Unilever op grond hiervan is de genoemde rechtspraak niet van toepassing op een situatie waarin de niet-nakoming van een notificatieplicht uit hoofde van Notificatierichtlijn 83/189, die schending van een wezenlijk vormvoorschrift oplevert, de niet-toepasselijkheid van een in weerwil van een van die artikelen vastgesteld technisch voorschrift meebrengt. 
zij bestemd is". Hieruit volgt, dat een richtlijn uit zichzelf geen verplichtingen aan particulieren kan opleggen en dat een bepaling van een richtlijn als zodanig niet tegenover een particulier kan worden ingeroepen.” (cursivering MdM)

Het dwingende karakter van een materiële rechtsnorm 'vis- à -vis' particulieren lijkt derhalve noodzakelijk te zijn voor het aannemen van horizontale directe werking van die norm, ongeacht of het nu gaat om de variant 'toetsing van overheidshandelen' of 'toetsing van particulier handelen'. Bij een coherente benadering van het Unierechtelijke systeem van rechtsbescherming zou dit betekenen dat de horizontale directe werking van Uniegrondrechten enkel aan de orde zou kunnen zijn als Uniegrondrechten dwingend recht zijn voor particulieren. Uit artikel 51, lid 1, van het Handvest blijkt mijns inziens, zoals betoogd in paragraaf 7.5.3.1, dat dit niet het geval is.

\subsection{Conclusies}

1. Het concept 'horizontale directe werking' in dit proefschrift ziet op doorwerking van Uniegrondrechten in het nationale recht. De werking is 'direct' indien het Unierechtelijke grondrecht door de nationale rechter als zelfstandige toetsingsmaatstaf wordt toegepast. De werking is vervolgens 'horizontaal' als het gaat om doorwerking in een geschil tussen particulieren. In dit proefschrift wordt tevens onderscheid gemaakt tussen twee varianten van 'horizontale directe werking': 'toetsing van particulier handelen' en 'toetsing van overheidshandelen'. De variant 'toetsing van particulier handelen' ziet op de toetsing van private handelingen (contracten, feitelijk handelen) aan het Uniegrondrecht. Van 'toetsing van overheidshandelen' is sprake als het gaat om de toetsing van nationale overheidshandelingen (bijvoorbeeld wetgeving) aan het Uniegrondrecht in een geschil tussen particulieren. De varianten 'toetsing van particulier handelen' en 'toetsing van overheidshandelen' zijn beide vormen van horizontale directe (door) werking van Unierecht in het nationale recht. Het onderscheid is dienstig, omdat het iets zegt over intensiteit waarmee het Unierechtelijke grondrecht de private rechtsverhouding beïnvloedt (ook wel de intensiteit van de derdenwerking). Door naast het meer algemene concept van 'horizontale directe werking' gebruik te maken van de twee varianten ervan ('toetsing van particulier handelen' en 'toetsing van overheidshandelen') wordt rekening gehouden met het feit dat het vraagstuk van de horizontale directe werking niet alleen is gerelateerd aan de vraag naar de doorwerking van Unierecht in het nationale recht, maar ook aan de constitutionele vraag naar de invloed van grondrechten in particuliere verhoudingen (derdenwerking). 
2. Het leerstuk van de horizontale directe werking situeert zich in een complex constitutioneel speelveld. Allereerst gaat het, net als bij verticale directe werking het geval is, om het Unierechtelijke vraagstuk van de doorwerking van Unierecht in het nationale recht (Europeanisering van nationaal recht) en meer in het bijzonder de doorwerking in nationale horizontale verhoudingen. Ten tweede kan de horizontale directe werking van Unierechtelijke grondrechten niet los worden gezien van het algemene (nationale) constitutionele debat over de toepassing van grondrechten in private verhoudingen (ook wel genoemd de 'derdenwerking van grondrechten' of de 'constitutionalisering van private verhoudingen'). Horizontale directe werking van Uniegrondrechten impliceert immers derdenwerking van die rechten. Hoewel een zekere invloed van grondrechten in horizontale verhouding algemeen is aanvaard, bestaan er uiteenlopende opvattingen over de wijze waarop dit moet gebeuren. Zo kan er onderscheid worden gemaakt door de toepassing van grondrechten in horizontale verhoudingen door de wetgever en door de rechter. Voor de horizontale toepassing van grondrechten door de rechter geldt dat er verschillende manieren zijn waarop dit kan gebeuren. Voor dit proefschrift is van belang, dat in de meeste lidstaten het gebruik van grondrechten als zelfstandige toetsingsmaatstaf niet aanvaard. Ook de rechtspraak van het EHRM geeft blijk van de mogelijkheid van de invloed van grondrechten in horizontale verhoudingen. Deze rechtspraak laat de Verdragssluitende Staten echter een aanzienlijke vrijheid in de wijze waarop zij de toepassing van grondrechten in horizontale verhoudingen realiseren.

3. Voor het onderzoek naar de legitimiteit van horizontale directe werking van Uniegrondrechten is het van belang om te kijken naar zowel mogelijke grondslagen als naar mogelijke obstakels. De volgende mogelijke grondslagen zijn besproken: De constitutionele stelsels van de lidstaten, de rechtspraak van het EHRM, het effectiviteitsbeginsel en het feit dat de Verdragsrechtelijke verkeersvrijheden en non-discriminatiebepalingen horizontale directe werking hebben. Het is gebleken dat dit mogelijke grondslagen zijn voor het aannemen van horizontale directe werking al nopen zij hier niet toe. Voor wat betreft het bestaan van obstakels voor het aannemen van horizontale directe werking heb ik betoogd dat het Handvest in mijn ogen niet is bedoeld als dwingend recht voor particulieren. Dit leid ik met name af uit artikel 51, lid 1, van het Handvest. Het aannemen van de horizontale directe werking -variant 'toetsing van particulier handelen' beschouw ik daarom als 'ultra vires'. Hierbij moet worden aangetekend, dat de erkenning van horizontale directe werking -variant 'toetsing van overheidshandelen' niet per se in strijd met artikel 51, lid 1, van het Handvest lijkt te zijn. Bij deze variant is immers sprake van een overheids- 
handeling waarop de bindende kracht van het Handvest wel van toepassing is. Bij het aannemen van horizontale directe werking -variant 'toetsing van overheidshandelen' doemt echter een ander obstakel op. Bij de vraag naar het bestaan van horizontale directe werking van richtlijnen heeft het Hof er voor gekozen om dit af te wijzen wegens het ontbreken van een dwingend karakter van richtlijnen voor particulieren. Op grond hiervan zijn de beide vormen van horizontale directe werking niet mogelijk. De rechtsbescherming tegen tekortkomingen van de lidstaten ten aanzien van de naleving van richtlijnen dient in horizontale verhoudingen te geschieden door middel van de vangnetten van richtlijnconforme interpretatie en staatsaansprakelijkheid. Uit de rechtspraak inzake de horizontale werking van richtlijnen, lijkt derhalve te volgen dat het aannemen van horizontale directe werking enkel mogelijk is voor normen van materieel Unierecht die bindend zijn voor particulieren. 


\section{HOOFDSTUK 8}

\section{DE ERKENNING: MANGOLD EN VERDER}

\subsection{Inleiding}

Dit hoofdstuk brengt de ontwikkeling van het leerstuk van de horizontale directe werking van Uniegrondrechten in beeld op basis van de rechtspraak van het Hof. Het leerstuk is gelanceerd in de arresten Mangold en Kücükdeveci. In deze arresten heeft het Hof de stap gezet tot de expliciete erkenning van de mogelijkheid van horizontale directe werking van een Unierechtelijk grondrecht uit hoofde van een algemeen rechtsbeginsel: het algemene beginsel van non- discriminatie op grond van leeftijd. Deze arresten hebben heel wat stof doen opwaaien. Overigens niet alleen vanwege het aannemen van de horizontale directe werking, maar ook wegens de erkenning van een algemeen Unierechtelijk beginsel van non-discriminatie op grond van leeftijd. ${ }^{1}$ Het stof dat deze arresten hebben doen opwaaien is nog steeds niet neergedaald. Naast de kritische geluiden over rechterlijk activisme, roept deze nieuwe lijn inzake horizontale directe werking veel vragen op. De arresten worden tezamen behandeld in paragraaf 8.2 waarin de horizontale directe werking van algemene beginselen van Unierecht centraal staan. Paragraaf 8.3 gaat over de rechtspraak inzake de horizontale directe werking van het Handvest. Met name komen aan de orde de arresten Dominguez en AMS. Dominguez valt op door het stilzwijgen van het Hof over de vraag naar de horizontale directe werking van het Handvest. Het arrest AMS baant de weg voor de horizontale directe werking van het Handvest.

Zoals zal blijken kunnen zowel grondrechten uit hoofde van algemene rechtsbeginselen als grondrechten uit hoofde van het Handvest horizontale directe werking hebben. Het gaat tot nu toe om een horizontale directe werking à la Kücükdeveci. Deze paragrafen vormen de aanloop naar het volgende

1 Deze erkenning als algemeen beginsel van Unierecht was allerminst evident, daar het verbieden van leeftijdsdiscriminatie een relatief recent fenomeen was, en enkel de Finse constitutie naar deze vorm van discriminatie verwees. Zie hierover A-G Mazák van 15 februari 2007, zaak C-411/05, Palacios de la Villa, punt 88. Op de legitimiteit inzake de erkenning van het verbod van discriminatie op grond van leeftijd als algemeen beginsel van Unierecht wordt verder niet ingegaan. Vermoedelijk heeft het Hof zich hier laten inspireren door artikel 21 van het Handvest, dat ten tijde van het arrest nog niet bindend was, maar al wel diende als bron van inspiratie. Zie HvJEU van 19 januari 2010, zaak C555/07, Kücükdeveci, punt 22. Zie ook Lenaerts 2012-1, p. 376. 
hoofdstuk waarin de toepassingsvereisten van de horizontale directe werking à la Kücükdeveci worden gedestilleerd uit de in dit hoofdstuk besproken arresten. Tot slot wordt paragraaf 8.4 aandacht besteed aan de samenloop van de horizontale directe werking van Verdragsbepalingen met het inroepen van grondrechten. De arresten Viking Line en Laval, Dynamic Medien, Las en Familiapress worden hier behandeld.

\subsection{Horizontale directe werking van algemene rechtsbeginselen}

\subsubsection{Algemeen}

In deze paragraaf wordt ingegaan op de horizontale directe werking van Uniegrondrechten als algemene rechtsbeginselen. Het centrale punt van aandacht zijn de enige twee voorbeelden uit de rechtspraak zijn waarin daadwerkelijk horizontale directe werking wordt toegekend aan een Uniegrondrecht: de arresten Mangold en Kücükdeveci. Om te beginnen wordt het arrest Mangold samengevat (paragraaf 8.2.2). Vervolgens wordt aandacht besteed aan de periode tussen de beide arresten (paragraaf 8.2.3). Dan wordt het arrest Kücükdeveci samengevat (paragraaf 8.2.4). Tot slot zullen de beide arresten gezamenlijk worden geanalyseerd (paragraaf 8.2.5).

\subsubsection{Het arrest Mangold: de verrassing}

\subsubsection{Feiten, nationaal kader en prejudiciële vragen}

In de zaak Mangold ging het in essentie om het volgende. ${ }^{2}$ Het betrof een horizontaal arbeidsrechtelijk geschil tussen een particuliere werkgever Helm (advocaat) en werknemer Mangold (56 jaar). Ter discussie stond de clausule uit de arbeidsovereenkomst waarin was geregeld dat de arbeidsovereenkomst gold voor bepaalde tijd. De enige reden voor de bepaalde duur van het contract was, dat Mangold bij het aangaan van de overeenkomst ouder was dan 52 jaar. Hoewel arbeidsovereenkomsten voor bepaalde tijd naar Duits recht alleen waren toegestaan ingeval daarvoor een wettelijke toegestane objectieve reden is, kende de Duitse wet een uitzondering voor werknemers ouder dan 52 jaar. Voor deze groep oudere werknemers gold de mogelijkheid tot het afsluiten van arbeidscontracten voor bepaalde tijd zonder de aanwezigheid van een (andere) objectieve reden. Op grond van het Duitse recht was de litigieuze clausule dan ook expliciet toegestaan. Volgens de heer Mangold bevatte de betreffende nationale regeling een verboden onderscheid op grond van leeftijd.

2 HvJEU van 22 november 2005, zaak C-144/04, Mangold. 


\subsubsection{Oordeel van het Hof}

Het Hof gaf de heer Mangold gelijk. Hij oordeelde dat het in richtlijn 2000/78 3 neergelegde leeftijdsdiscriminatieverbod zich verzet tegen een nationale regeling als de onderhavige. De maatregel bevatte een onderscheid op grond van leeftijd en kon niet worden gerechtvaardigd, omdat de regeling disproportioneel was. ${ }^{4}$ Het Hof verklaarde voor recht als volgt:

"Het gemeenschapsrecht, met name artikel 6, lid 1, van richtlijn 2000/78/EG van de Raad van 27 november 2000 tot instelling van een algemeen kader van gelijke behandeling in arbeid en beroep, moet aldus worden uitgelegd dat het zich verzet tegen een nationale regeling als die welke in het hoofdgeding aan de orde is (...)"

Vervolgens kwam het Hof op de vraag naar welke gevolgen de nationale rechter hieraan zou moeten verbinden. Met name wenste de verwijzende rechter te vernemen of hij verplicht was om een nationale regeling die in strijd is met het Unierechtelijke verbod van discriminatie buiten toepassing te laten. Het Hof oordeelde dat zulks inderdaad het geval was.

Het Hof overwoog hiertoe als volgt:

"74. In de tweede plaats en bovenal is het beginsel van gelijke behandeling in arbeid en beroep niet in richtlijn 2000/78 zelf verankerd. Luidens artikel 1 van deze richtlijn heeft deze enkel tot doel „een algemeen kader te creëren voor de bestrijding van discriminatie op grond van godsdienst of overtuiging, handicap, leeftijd of seksuele geaardheid", terwijl het beginsel dat deze vormen van discriminatie verboden zijn, blijkens de punten 1 en 4 van de considerans van deze richtlijn zijn oorsprong vindt in diverse internationale instrumenten en de gemeenschappelijke constitutionele tradities van de lidstaten.

75. Het beginsel van non-discriminatie op grond van leeftijd moet derhalve worden beschouwd als een algemeen beginsel van gemeenschapsrecht. (...)

76. (...) de inachtneming van het algemene beginsel van gelijke behandeling, met name op grond van leeftijd, [kan] als zodanig niet afhangen van het verstrijken van de termijn die de lidstaten is gelaten voor de omzetting van een richtlijn die ertoe strekt een algemeen kader te creëren voor de bestrijding van discriminatie op grond van leeftijd (...)

77. In deze omstandigheden dient de nationale rechter aan wie een geschil is voorgelegd waarbij het beginsel van non-discriminatie op grond van leeftijd in

3 Kaderrichtlijn gelijke behandeling in arbeid en beroep, richtlijn 2000/78.

4 Punt 65 arrest Mangold. 
geding is, in het kader van zijn bevoegdheid de voor de justitiabelen uit het gemeenschapsrecht voortvloeiende rechtsbescherming te verzekeren en de volle werking daarvan te waarborgen, waarbij hij elke eventueel strijdige bepaling van nationaal recht buiten toepassing moet laten (.....)."

Het dictum van het arrest Mangold luidt-voor zover hier relevant- als volgt:

"Het gemeenschapsrecht, met name artikel 6, lid 1, van richtlijn 2000/78/EG van de Raad van 27 november 2000 tot instelling van een algemeen kader van gelijke behandeling in arbeid en beroep, moet aldus worden uitgelegd dat het zich verzet tegen een nationale regeling als die welke in het hoofdgeding aan de orde is (...)

Het is aan de nationale rechter om de volle werking van het algemene beginsel van non-discriminatie op grond van leeftijd te verzekeren door elke strijdige bepaling van nationaal recht buiten toepassing te laten, ook wanneer de termijn voor omzetting van deze richtlijn nog niet is verstreken."

\subsubsection{Korte analyse}

In Mangold erkent het Hof de horizontale directe werking van het verbod van discriminatie op grond van leeftijd en meer in het bijzonder de variant 'toetsing van overheidshandelen'. Het aannemen van horizontale directe werking van het verbod van discriminatie op grond van leeftijd lag niet voor de hand. Integendeel, er bestonden twee belangrijke obstakels. Ten eerste een obstakel voor het aannemen van directe werking als zodanig. De termijn voor omzetting voor Duitsland van richtlijn 2000/78 was namelijk nog niet verstreken. Aangezien richtlijnen pas directe werking hebben na de uiterste datum van implementatie, zou richtlijn 2000/78 geen directe werking kunnen hebben. ${ }^{5}$ Het tweede obstakel betrof het aannemen van directe werking in een geding tussen particulieren (horizontale directe werking). Het is vaste rechtspraak van het Hof, dat een richtlijn uit zichzelf geen verplichtingen aan particulieren kan opleggen en dat een bepaling van een richtlijn als zodanig niet tegenover een particulier kan worden ingeroepen. ${ }^{6}$ Dit verbod van horizontale directe werking van richtlijnen ziet op de beide varianten van horizontale directe werking variant 'toetsing van overheidshandelen' en variant 'toetsing van

5 HvJEU van 5 april 1979, zaak 148/78, Ratti.

6 HvJEU van 26 februari 1986, zaak 152/84, Marshall, punt 48; HvJEU van 14 juli 1994, zaak C-91/92, Faccini Dori, punt 22 en HvJEU van 7 januari 2004, zaak C-201/02, Wells, punt 56. Deze rechtspraak is gemotiveerd op basis van de tekst van het Verdrag waaruit volgt, dat richtlijnen slechts zijn gericht tot de lidstaten en op het rechtszekerheidsbeginsel. 
particulier handelen'. In Marshall immers oordeelde het Hof ten aanzien van gelijke behandelingsrichtlijn $76 / 2077$ als volgt: ${ }^{8}$

\begin{abstract}
" 48 . Wat het argument betreft dat een richtlijn niet tegenover particulieren kan worden ingeroepen, moet erop worden gewezen, dat volgens artikel 189 EEG-verdrag het dwingende karakter van een richtlijn - waarop de mogelijkheid om er voor de nationale rechter beroep op te doen, is gebaseerd"slechts bestaat ten aanzien van elke Lid-Staat waarvoor zij bestemd is". Hieruit volgt, dat een richtlijn uit zichzelf geen verplichtingen aan particulieren kan opleggen $e n$ dat een bepaling van een richtlijn als zodanig niet tegenover een particulier kan worden ingeroepen. (...) (cursivering $M d M$ )"
\end{abstract}

Ondanks deze twee obstakels oordeelde het Hof in Mangold tot een plicht van de nationale rechter tot het buiten toepassing laten van nationale regelingen in strijd met het verbod van leeftijdsdiscriminatie. Het arrest Mangold kwam als een verrassing.

\title{
8.2.2.4 De aanloop naar Kücükdeveci
}

De Mangold-verrassing heeft geleid tot een veelheid van reacties uit verschillende hoeken. Zo is het arrest zowel in wetenschappelijke artikelen ${ }^{9}$ als in de pers ${ }^{10}$ kritisch besproken. Ook zijn er meerdere advocaten-generaal die kanttekeningen bij het arrest hebben geplaatst. ${ }^{11}$ De zaak leidde ook tot een reeks nieuwe prejudiciële vragen van nationale rechters. ${ }^{12}$ Ook de regeringen

7 Richtlijn 76/207/EEG van de Raad van 9 februari 1976 betreffende de tenuitvoerlegging van het beginsel van gelijke behandeling van mannen en vrouwen ten aanzien van de toegang tot het arbeidsproces, de beroepsopleiding en de promotiekansen en ten aanzien van de arbeidsvoorwaarden. PB L 39 van 14.2.1976, blz. 40-42

8 HvJEU van 26 februari 1986, zaak 152/84, Marshall.

9 Zie bijvoorbeeld: Redactioneel CMLR 2006; Schmidt 2005; Schiek 2006.

10 Zie bijvoorbeeld: R. Herzog and L. Gerken, 'Stop the European Court of Justice', EU Observer, 10 September 2008 and F. Kuitenbrouwer, 'Onbescheiden rechters', NRC Handelsblad, 7 februari 2006.

() De meest substantiële commentaren kwamen van: A-G Geelhoed van 16 maart 2006, zaak C-13/05 Chacón Navas; A-G Mazák van 15 februari 2007, zaak C-411/05, Palacios de la Villa; A-G Colomer van 24 januari 2008, gevoegde zaken C-55/07 en C-56/07, Michaeler; A-G Maduro van 31 januari 2008, zaak C-303/06, Coleman; A-G Trstenjak van 29 maart 2007, zaak C-80/06, Carp; A-G Sharpston van 22 mei 2008, zaak C-427/06, Bartsch en van 30 november 2006, zaak C-227/04 P, Lindorfer en A-G Bot van 7 juli 2009, zaak C-555/07, Kücükdeveci.

12 Bijvoorbeeld de zaken C-267/06, Tadao Maruko, C-411/05, Palacios de la Villa, C-427/06, Bartsch, C-555/07, Kücükdeveci, C-109/09, Deutsche Lufthansa. Auteur is in haar 
van de Lid-Staten roerden zich. Daar waar in Mangold enkel de Duitse regering deel nam aan de procedure, namen in de periode daarna een relatief groot aantal lidstaten deel aan de zogenaamde post-Mangold zaken. ${ }^{13}$ In Duitsland boog het Constitutionele Hof zich zelfs over het arrest Mangold om te bezien of het een 'ultra vires' handeling is en om die reden niet van toepassing in Duitsland. ${ }^{14}$

Een bondige samenvatting van de kritiek is gegeven door Advocaat-generaal Sharpston:
“31. (...) De algemene kritiek luidt dat het Hof (uit eigen wil, zonder goede reden en tegen de wil van de wetgever) de werkingssfeer van een richtlijn heeft uitgebreid, teneinde vóór het einde van de overgangsperiode van die richtlijn en in horizontale omstandigheden daaraan uitvoering te geven aan de hand van een innovatieve verwijzing naar een algemeen beginsel van gemeen- schapsrecht. Een aantal commentatoren hebben dan ook te kennen gegeven dat het Hof volgens hen het met de toekenning van rechtstreekse werking beoogde doel heeft ondermijnd. Voorts is de kritiek geuit dat het arrest aanzienlijke rechtsonzekerheid heeft veroorzaakt.”15

Aan de kant van het Hof bleef het -met uitzondering van de zijde van de advocaten-generaal- vervolgens een dikke vier jaar stil. Dit ondanks van het passeren van een aantal zaken waarin het Hof Mangold had kunnen herroepen, isoleren of verduidelijken (Bartsch, Petersen, Wolf, Hütter, Age Concern England and Palacios de la Villa). ${ }^{16}$ Wel worden in die periode de arresten Laval en Viking

voormalige hoedanigheid van gemachtigde van de Nederlandse regering voor het HvJEU betrokken geweest bij sommige van de genoemde post-Mangold zaken.

13 Bijvoorbeeld in zaak Kücükdeveci, namen deel: Duitsland, Tsjechië, Denemarken, Ierland, Nederland en het Verenigd Koninkrijk.

14 BverG van 6 juli 2010, 2 BvR 2661/06, Honeywell Bremsbelag GmbH. Zie voor de uitleg van 'ultra vires' handelingen de Lissabon uitspraak van 30 juni 2009 van het Bundesverfassungsgericht (BverG van 30 juni 2009, 2 BvE 2/08, 2 BvE 5/08, 2 BvR 1010/08, 2 BvR 1022/08, 2 BvR 1259/08, 2 BvR 182/09of 06/30/2009). In deze uitspraak oordeelde het Bundesverfassungsgericht dat rechtsinstrumenten die een schending van de nationale soevereiniteit behelzen 'ultra vires' zijn en daarom niet van toepassing in Duitsland. Bij uitspraak d.d. 6 juli 2010 heeft het Bundesverfassungsgericht geoordeeld dat de Mangold uitspraak niet kennelijk 'ultra vires' is en geen sprake is van een structurele verandering in de verdeling van de bevoegdheden tussen de Unie en de lidstaten ten koste van laatstgenoemden. Zie ook Kokott 2010, p. 109-112. Reestman 2010; Gerken e.a. 2009; Preis \& Temming 2010.

15 A-G Sharpston van 22 mei 2008, zaak C-427/06, Bartsch.

16 HvJEU van 23 september 2008, zaak C-427/06, Bartsch; HvJEU van 12 januari 2010, zaak C-341/08, Petersen; HvJEU van 12 januari 2010, zaak C-229/08, Wolf; HvJEU van 
Line gewezen (zie verder over deze arresten paragraaf 8.4). Deze zaken betroffen eveneens de derdenwerking van Unierechtelijke grondrechten, maar er was geen sprake van horizontale directe werking van deze grondrechten. ${ }^{17}$ Ondanks dat deze arresten eveneens spraakmakend waren, vormden zij echter geen verduidelijking of bevestiging van Mangold. De zaak Kücükdeveci bracht hierin verandering. De schriftelijke procedure en de mondelinge behandeling in Kücükdeveci draaide met name om de vraag naar de horizontale directe werking van het algemene beginsel van non-discriminatie op grond van leeftijd. ${ }^{18}$ Alle deelnemende lidstaten drongen er op aan om geen horizontale directe werking aan te nemen. Tijdens de mondelinge behandeling werd tevens duidelijk dat de meer algemene vraag naar de horizontale directe werking van Uniegrondrechten complex is. Op de vraag van rechter Rosas aan de lidstaten of algemene beginselen van Unierecht nimmer horizontale directe werking zouden moeten hebben, stelde geen van de lidstaten zich op het algemene standpunt dat aan algemene rechtsbeginselen nimmer een dusdanige werking zou moeten toekomen. Allen benadrukten wel dat in een Kücükdeveci-scenario hiervan geen sprake zou moeten zijn.

Een klein jaar na de mondelinge behandeling wees de Grote Kamer van het Hof arrest. Op het "verrassing!" in Mangold klinkt in het arrest Kücükdeveci een onomwonden "ja echt waar!”; Mangold is niet een 'sui generis' zaak, maar de inzet van een welbewuste lijn die als doel heeft het verbod van discriminatie van leeftijd zo veel mogelijk te effectueren.

\subsubsection{Het arrest Kücükdeveci: een bevestiging en een verduidelijking}

\subsubsection{Feiten, nationaal kader en prejudiciële vragen}

Het arrest Kücükdeveci is gewezen naar aanleiding van prejudiciële vragen die waren gesteld door de Duitse rechter (het Landesarbeitsgericht Düsseldorf). De vragen waren gesteld in het kader van een geding tussen twee private partijen, werkgever Swedex GmbH en werkneemster mevrouw Kücükdeveci. Het

18 juni 2009, zaak C-88/08, Hütter; HvJEU van 5 maart 2009, zaak C-388/07, Age Concern England en HvJEU van 16 oktober 2007, zaak C-411/05, Palacios de la Villa.

17 HvJEU van 11 december 2007, zaak C-438/05, Viking Line; HvJEU van 18 december 2007, zaak C-341/05 Laval. Anders: Ladenburger 2012, p. 36: Hij stelt dat het Hof in Laval horizontale directe werking heeft geaccepteerd van het stakingsrecht (artikel 28 Handvest) maar in een bijzondere situatie en slechts als neveneffect van de toekenning van horizontale directe werking van de vrije verkeerbepaling.

18 Mondelinge behandeling d.d. 31 maart 2009. De auteur van dit proefschrift nam deel aan de mondelinge behandeling als gemachtigde van de Nederlandse regering. 
geschil betrof de berekening van de ontslagtermijn. Op grond van het Duitse burgerlijk wetboek werd deze berekend aan de hand van het aantal vervulde dienstjaren. Naarmate meer dienstjaren waren vervuld werd de ontslagtermijn langer. Op grond van de Duitse wet werden dienstjaren die voor het bereiken van de leeftijd van 25 jaar zijn vervuld niet meegeteld. Met deze uitzondering werd beoogd de werkgever meer flexibiliteit bij het personeelsbeheer te geven door de lasten van die werkgever te verlagen bij ontslag van jonge werknemers waarvan redelijkerwijs een grotere persoonlijke en professionele mobiliteit mag worden verwacht. De Duitse rechter vroeg zich af of de wettelijke uitzondering ten aanzien van dienstjaren die zijn vervuld voor het bereiken van de leeftijd van 25 jaar een Unierechtelijk verboden verschil in behandeling op grond van leeftijd vormde. Indien zulks het geval zou zijn, werd gevraagd naar de gevolgen die de nationale rechter in een geding tussen twee private partijen aan de schending zou moeten verbinden.

\subsubsection{Oordeel van het Hof}

\section{Bestaan van het algemene rechtsbeginsel en verhouding met de richtlijn}

Het Hof bevestigde allereerst de erkenning in Mangold van het verbod van discriminatie op grond van leeftijd als algemeen beginsel van Unierecht is.

"21. In die context heeft het Hof het bestaan erkend van een beginsel van nondiscriminatie op grond van leeftijd dat als een algemeen beginsel van recht van de Unie moet worden beschouwd (...). Richtlijn 2000/78 concretiseert dat beginsel (...).”

Hieraan voegde het Hof een verwijzing naar het Handvest toe:

“22. Eveneens moet erop worden gewezen dat artikel 6, lid 1, VEU bepaalt dat het Handvest van de grondrechten van de Europese Unie dezelfde juridische waarde als de Verdragen heeft. Artikel 21, lid 1, van dat Handvest bepaalt dat elke discriminatie, met name op grond van leeftijd, verboden is."

Ook ging het Hof in op de verhouding tussen het algemene rechtsbeginsel en de richtlijn. Het Hof oordeelde net als in Mangold:

"20. (...) dat niet in die richtlijn zelf het beginsel is neergelegd van de gelijke behandeling in arbeid en beroep, dat zijn oorsprong vindt in diverse internationale instrumenten en de gemeenschappelijke constitutionele tradities van de lidstaten, maar dat de richtlijn enkel beoogt inzake die materies een algemeen kader te creëren voor de bestrijding van discriminatie op grond van diverse redenen, waaronder de leeftijd (...)" 
Later in het arrest komt de verhouding tussen richtlijn 2000/78 en het algemene beginsel nog een keer terug in de overweging dat:

"50. (...) richtlijn 2000/78 het beginsel van gelijke behandeling in arbeid en beroep slechts concretiseert, zonder dat dit beginsel in de richtlijn verankerd is, en $(\ldots)$ dat het beginsel van non-discriminatie op grond van leeftijd een algemeen beginsel van recht van de Unie is voor zover het een bijzondere toepassing is van het algemene beginsel van gelijke behandeling (...)"

\section{Relevante toetsingskader}

Anders dan in Mangold het geval was, ging het Hof in Kücükdeveci expliciet in op de voorvraag naar het relevante toetsingskader. Het Hof onderzocht of "moet worden getoetst aan het primaire recht van de Unie dan wel aan richtlijn 2000/78." 19 Het Hof oordeelde dat het toetsingskader is "het algemene beginsel van het recht van de Unie dat elke discriminatie op grond van leeftijd verbiedt, zoals nader uitgewerkt in richtlijn 2000/78" . ${ }^{20}$ Dit toetsingskader komt terug in het dictum waarin wordt gerefereerd aan "het beginsel van non-discriminatie op grond van leeftijd, zoals geconcretiseerd door richtlijn 2000/78/EG". Omdat naar mijn mening de authentiek Duitse taalversie duidelijker is noem ik deze ook: "das Verbot der Diskriminierung wegen des Alters in seiner Konkretisierung durch die Richtlinie 2000/78/EG” (cursivering MdM) ${ }^{21}$ Het is op grond hiervan dat moet worden nagegaan of het recht van de Unie zich verzet tegen een nationale regeling als die welke in het hoofdgeding aan de orde is.

De toepasselijkheid van het algemene beginsel van non-discriminatie op grond van leeftijd werd als volgt gemotiveerd:

"23. Het beginsel van non-discriminatie op grond van leeftijd geldt in een situatie als in het hoofdgeding alleen als die situatie binnen de werkingssfeer van het recht van de Unie valt.

24. Anders dan in de zaak die leidde tot het arrest van 23 september 2008, Bartsch (C-427/06, Jurispr. blz. I-7245), deed de gestelde discriminerende handelswijze in het hoofdgeding op grond van de aan de orde zijnde nationale regeling zich voor na het verstrijken van de termijn voor de omzetting door de betrokken lidstaat van richtlijn 2000/78, wat de Bondsrepubliek Duitsland betreft, op 2 december 2006.

19 Kücükdeveci, Punt 19.

20 Kücükdeveci, Punt 27.

21 Ik kom hierop terug in hoofdstuk 10.4.2. 
25. Vanaf die datum had de richtlijn tot gevolg dat de in het hoofdgeding aan de orde zijnde nationale regeling, die een materie behandelt die onder diezelfde richtlijn valt, in casu de voorwaarden voor ontslag, binnen de werkingssfeer van het recht van de Unie valt.

26. Een nationale bepaling namelijk als $§ 622$, lid 2, tweede alinea, BGB, die bepaalt dat de tijdvakken van arbeid die een werknemer vóór het bereiken van de leeftijd van 25 jaar heeft vervuld niet in aanmerking worden genomen bij de berekening van de opzegtermijn, betreft immers de voorwaarden voor ontslag van de werknemers. Een dergelijke regeling moet bijgevolg geacht worden regels in te voeren inzake de ontslagvoorwaarden."

De situatie viel derhalve binnen de werkingssfeer van het Unie recht, omdat (1) de gestelde discriminerende handelswijze dateerde van na het verstrijken van de implementatietermijn van richtlijn 2000/78 en (2) de aan de orde zijnde nationale regeling een materie (voorwaarden voor ontslag) behandelde die onder richtlijn 2000/78 valt. ${ }^{22}$

\section{De toetsing van de nationale regeling}

Het Hof ging vervolgens op basis van het algemene beginsel van recht van de Unie dat elke discriminatie op grond van leeftijd verbiedt zoals geconcretiseerd in richtlijn 2000/78, na of het recht van de Unie zich verzet tegen een nationale regeling als die welke in het hoofdgeding aan de orde was. Het Hof deed dit door op basis van de artikelen 2 en 6 van richtlijn 2000/78 te onderzoeken of een nationale regeling als de onderhavige is toegestaan. Zulks bleek niet het geval. Het doel van de regeling was weliswaar legitiem, maar de regeling was niet passend ter verwezenlijking van dit doel.

\section{Plicht nationale rechter bij onverenigbaarheid}

Tot slot ging het Hof in op de gevolgen die aan schending het beginsel van nondiscriminatie op grond van leeftijd, zoals geconcretiseerd in richtlijn 2000/78 moeten worden verbonden. Hiertoe herhaalde het Hof zijn jurisprudentie met betrekking tot het verbod van horizontale werking van richtlijnen.

“46. Inzake gedingen tussen particulieren is het vaste rechtspraak van het Hof dat een richtlijn uit zichzelf aan particulieren geen verplichtingen kan opleggen en dat een bepaling van een richtlijn als zodanig niet tegenover een particulier kan worden ingeroepen (...).”

Dit verbod vormde in de onderhavige zaak echter geen beletsel voor het opleggen van een plicht aan de nationale rechter tot het buiten toepassing laten

22 Zie hierover ook hoofdstuk 4.4. 
van strijdige bepalingen van nationaal recht. Deze plicht volgt uit de noodzaak om de volle werking van het beginsel van non-discriminatie op grond van leeftijd, zoals geconcretiseerd in richtlijn 2000/78, te waarborgen. Relevant hierbij was dat (1) richtlijn 2000/78 het beginsel van gelijke behandeling in arbeid en beroep "slechts concretiseert, zonder dat dit beginsel in de richtlijn verankerd is", en (2) dat het beginsel van non-discriminatie op grond van leeftijd een algemeen beginsel van recht van de Unie is. De relevante overwegingen van het Hof luidden als volgt:

“50. Dienaangaande moet eraan worden herinnerd (...) dat richtlijn 2000/78 het beginsel van gelijke behandeling in arbeid en beroep slechts concretiseert, zonder dat dit beginsel in de richtlijn verankerd is, en bovendien dat het beginsel van non-discriminatie op grond van leeftijd een algemeen beginsel van recht van de Unie is voor zover het een bijzondere toepassing is van het algemene beginsel van gelijke behandeling (zie arrest Mangold, reeds aangehaald, punten 74-76).

51. In deze omstandigheden moet de nationale rechter aan wie een geschil is voorgelegd waarbij het beginsel van non-discriminatie op grond van leeftijd, zoals geconcretiseerd in richtlijn 2000/78, aan de orde is, in het kader van zijn bevoegdheden de voor de justitiabelen uit het recht van de Unie voortvloeiende rechtsbescherming verzekeren en de volle werking daarvan waarborgen, waarbij hij indien nodig elke met dit beginsel strijdige nationale regeling buiten beschouwing moet laten (zie in die zin arrest Mangold, reeds aangehaald, punt 77).

(...)

53. De noodzaak de volle werking van het beginsel van non-discriminatie op grond van leeftijd, zoals geconcretiseerd door richtlijn 2000/78, te verzekeren betekent dat de nationale rechter die meent dat een binnen de werkingssfeer van het Unierecht vallende nationale bepaling onverenigbaar is met dit beginsel en niet conform dit beginsel kan worden uitgelegd, die bepaling buiten beschouwing moet laten (...)"

Het dictum, luidt - voor zover hier relevant - als volgt:

"De nationale rechter aan wie een geschil tussen particulieren werd voorgelegd, moet de naleving verzekeren van het beginsel van non-discriminatie op grond van leeftijd, zoals geconcretiseerd in richtlijn 2000/78, en daarbij indien nodig elke strijdige bepaling van de nationale regeling buiten beschouwing laten, ongeacht de mogelijkheid waarover hij beschikt om in de in artikel 267, tweede alinea, VWEU bedoelde gevallen het Hof van Justitie van de Europese Unie om een prejudiciële beslissing inzake de uitlegging van dit beginsel te verzoeken." 


\title{
8.2.3.3 Korte analyse
}

'De jure' horizontale directe werking variant 'toetsing overheidshandeling” van een algemeen rechtsbeginsel

Het arrest Kücükdeveci maakt duidelijk dat de in Mangold ingezette lijn wordt voortgezet. Bovendien wordt verduidelijkt wat het fundament is van deze lijn: het gaat om de erkenning van horizontale directe werking van het algemene rechtsbeginsel van non-discriminatie op grond van leeftijd. Dit was in Mangold nog niet zo duidelijk. In het arrest leek het steeds te gaan om de toepassing van richtlijn 2000/78. De verenigbaarheid van een nationale regeling als de litigieuze nationale regeling werd immers louter beoordeeld op grond van de richtlijn. Pas bij het 'moment suprême' waarin het Hof toekwam aan gevolgen die de nationale rechter moet verbinden als hij de nationale regeling onverenigbaar met het Unierecht acht, verscheen het (kersverse) algemene rechtsbeginsel ten tonele. In Kücükdeveci maakte het Hof al in het begin van het arrest duidelijk dat het algemene rechtsbeginsel dient als toetsingskader. Ook wordt expliciet duidelijk, dat de horizontale directe werking volgt uit het algemene rechtsbeginsel en niet uit de richtlijn. Overigens gaat het in de beide zaken Mangold en Kücükdeveci om de variant 'toetsing van overheidshandelen'. Op basis van deze arresten kan dan ook niet worden aangenomen dat grondrechten uit hoofde van algemene rechtsbeginselen horizontale directe werking variant 'toetsing particuliere handeling' hebben.

\section{Novum}

De toekenning van horizontale directe werking aan een grondrecht uit hoofde van een algemeen rechtsbeginsel is een novum. Advocaat-generaal Bot denkt daar anders over en wees er in zijn conclusie bij Kücükdeveci op dat ${ }^{23}$

\begin{abstract}
“(...) het Hof reeds herhaaldelijk een belangrijkere stap heeft gezet door horizontale rechtstreekse werking te verlenen aan verdragsbepalingen die bijzondere uitdrukkingen van het algemene gelijkheids- en non-discriminatiebeginsel bevatten.”
\end{abstract}

Hij verwijst hierbij naar arresten Walrave en Koch, Defrenne en Angonese. ${ }^{24}$ Naar mijn mening is het te kort door de bocht om te stellen dat Mangold en Kücükdeveci

23 A-G Bot van 7 juli 2009, zaak C-555/07, Kücükdeveci.

24 A-G Bot van 7 juli 2009, zaak C-555/07, Kücükdeveci, punt 85. Hij wijst ook op het arrest Viking Line. Dit arrest wordt behandeld in paragraaf 8.4. HvJEU van 12 december 1974, zaak 36/74, Walrave and Koch; HvJEU van 8 april 1976, zaak 43/75, Defrenne II en HvJEU van 16 september 1999, zaak C-218/98 Angonese. 
in feite een (logisch) vervolg zijn op deze arresten. ${ }^{25}$ In de genoemde arresten Walrave en Koch, Defrenne en Angonese gaat het immers om uitwerkingen van het non-discriminatiebeginsel in Verdragsbepalingen (de artikelen 18, 45, lid 2, en 157 VWEU). De grondrechten uit hoofde van algemene rechtsbeginselen en het Handvest kunnen echter niet worden gelijkgesteld met de uitwerkingen ervan in het materieel Verdragsrecht. Bij algemene rechtsbeginselen en het Handvest gaat het om algemene constitutionele rechten in hun oorspronkelijke, ongepolijste, ruwe vorm, terwijl de genoemde Verdragsbepalingen bepalingen specifieke uitwerkingen van het non-discriminatiebeginsel behelzen door de Verdragsluitende partijen in regels. Dit is een wezenlijk verschil.

Dit verschil komt ook tot uiting in de motivering van de horizontale directe werking door het Hof. Het Hof heeft bij de erkenning van de Verdragsrechtelijke discriminatieverboden steeds aangeknoopt bij de wil van de Verdragsluitende partijen zoals die tot uiting komt in het toepassingsgebied van de betreffende bepaling in het Verdrag. ${ }^{26} \mathrm{Zo}$ is het verbod van discriminatie op grond van geslacht in artikel 157 VWEU geconcretiseerd ten aanzien van het specifieke onderwerp 'beloning van werknemers' en concretiseert artikel 45 , lid 2 , VWEU het verbod van discriminatie op grond van nationaliteit voor migrerende werknemers met betrekking tot hun arbeidsvoorwaarden. In de arresten Defrenne en Angonese heeft het Hof de horizontale directe werking van die bepalingen aanvaard onder verwijzing naar hun doel een niet-discriminerende behandeling op de arbeidsmarkt te verzekeren. ${ }^{27}$ De horizontale directe werking is daarmee gekoppeld aan de keuze van de Verdragsluitende lidstaten om geslachtsdiscriminatie op de arbeidsmarkt te verbieden. Artikel 18 VWEU is van meer algemene aard en lijkt om die reden ook eerder vergelijkbaar te zijn met grondrechten uit hoofde van het Handvest en de algemene rechtsbeginselen. Deze bepaling verbiedt nationaliteitsdiscriminatie binnen de werkingssfeer van de Verdragen. De werkingssfeer van artikel 18 VWEU lijkt op het eerste gezicht dus niet noodzakelijk te zijn gerelateerd aan het vrije

25 Dit punt kwam ook aan de orde in hoofdstuk 7.5.2.4.

26 Zie uitgebreider De Mol 2011-1. Overigens was dit soms ook bepaald niet voor de handliggend: Zie bijvoorbeeld Prechal 2010-2: "Kon men uit een verplichting die aan de lidstaten was opgelegd ook afleiden dat particuliere werkgevers het beginsel van gelijke beloning moesten naleven en het derhalve ook tegen hen afgedwongen kon worden? In een zeer compacte redenering kwam het Hof tot de conclusie dat het inderdaad zo was. Het argument was in wezen flinterdun: artikel 119 is; 'dwingend' recht. Wat hiermee bedoeld werd is nooit door het Hof uitgelegd. (...) Het arrest werd destijds scherp bekritiseerd. Toch is het Hof er nooit op teruggekomen. In tegendeel, Defrenne II, wordt met regelmaat als precedent gebruikt in andere zaken waarin het probleem van horizontale werking van verdragsbepalingen speelt (...)”.

27 Angonese, punt 35. 
verkeer. Hoewel het Hof de bepaling zeer ruim interpreteert, ${ }^{28}$ is er in de huidige rechtspraak toch (nog) altijd een aanknoping met het vrije verkeer te traceren. ${ }^{29}$ In het verlengde hiervan heeft het Hof ook de horizontale directe werking van deze bepaling expliciet gekoppeld aan die functie. De arresten Walrave en Koch en Ferlini maken duidelijk dat de ratio van de horizontale directe werking van artikel 18 VWEU ligt in de effectiviteit van het vrije verkeer van personen. ${ }^{30}$

\section{Grondslag horizontale directe werking}

Hoewel Kücükdeveci een verduidelijking is van Mangold, legt het Hof nog niet uit wat nu de grondslag is van de horizontale directe werking. Er wordt enkel verwezen naar 'de noodzaak de volle werking van het beginsel van nondiscriminatie op grond van leeftijd, zoals geconcretiseerd door richtlijn 2000/78, te verzekeren'. Deze verwijzing naar de volle werking van het algemene beginsel is zonder verdere uitleg echter nietszeggend. ${ }^{31}$ Wordt daarmee bedoeld dat de toepassing in particuliere relaties van het non-discriminatiebeginsel zit besloten in het beginsel zelf? En zoja; waar volgt dit uit? Is hier van invloed het feit dat de Verdragsrechtelijke discriminatieverboden horizontale directe werking hebben? Is het afgeleid uit het feit dat richtlijn 2000/78, die het verbod van discriminatie op grond van leeftijd concretiseert, van toepassing is in de private sector? Of gaat het Hof uit van een endogene

28 Met name in zaken die zien op de postitie van Unieburgers afkomstig uit andere lidstaten (dus vis -à- vis het gastland, het land van ontvangst).Het Hof hanteert in deze context een zeer ruime interpretatie van de werkingssfeer van artikel 18 VWEU. Unieburgers afkomstig uit andere lidstaten beschikken jegens het gastland over een schier onbeperkt recht op non-discriminatie op grond van nationaliteit. Met name hoeven zij niet aan te tonen dat het recht op nationale behandeling dienstig is aan het vrije verkeer: HvJEU van 18 november 2008, zaak C-158/07, Förster, punten 36-37. HvJEU van 6 oktober 2009, zaak C-123/08, Wolzenburg, punten 46 en 47; Van der Mei 2009, p. 27.

29 Dit komt het meest duidelijk naar voren in de jurisprudentie van het Hof in zaken waarin een beroep wordt gedaan op het verbod van discriminatie op grond van nationaliteit door Unieburgers jegens hun lidstaat van herkomst: Zie bijvoorbeeld HvJEU van 12 juli 2005, zaak C-403/03, Schemmp, punten 22-25. HvJEU van 14 oktober 2008, zaak C-353/06, Grunkin en Paul, punt 17. Zie ook de rechtspraak met betrekking tot de positie van onderdanen van derde landen. Hoewel de tekst van artikel 18 VWEU openlaat dat ook de situatie van onderdanen van derde landen binnen de werkingssfeer ervan kan vallen, biedt de jurisprudentie van het Hof tot nu toe geen steun voor de toepassing van artikel 18 VWEU op onderdanen van derde landen: HvJEU 4 juni 2009, gevoegde zaken nC22/08 en C-23/08, Vatsouras, punt 52; zie bijvoorbeeld Hublet 2009; Van der Mei 2009, p. 75-87; Boeles, 2005, p. 96; Bulterman \& Slot 2005, p. 67.

30 HVJEU van 12 december 1974, zaak 36/74, Walrave and Koch, punt 16-18; HVJEU van 3 oktober 2000, zaak C-411/98, Ferlini, punt 50. Zie ook Van den Bogaert 2005, p. 27.

31 Zie hoofdstuk 7.5.2.3. 
functie van grondrechten op grond waarvan grondrechten naar hun aard ook van toepassing kunnen zijn in de private sfeer? ${ }^{32}$ Het blijft gissen. Het gebrek aan uitleg over de grondslag van de horizontale directe werking is opmerkelijk. Zulks niet alleen gezien de eerder besproken post -Mangold discussie in de doctrine, media en de nationale rechtspraktijk, maar vooral ook doordat dit onderwerp ook een prominent onderdeel uitmaakte van de procedure voor het Hof. Vermoedelijk waren de meningen binnen het Hof verdeeld. ${ }^{33}$

\section{'De facto' horizontale directe werking van de richtlijn}

Uit Kücükdeveci blijkt expliciet, dat het verbod van horizontale directe werking onverminderd blijft gelden, ook ten aanzien van richtlijn 2000/78. Tegelijk echter toont het arrest Kücükdeveci de innige verstrengeling tussen de richtlijn en het algemene beginsel. Een verstrengeling die zo innig is, dat sprake is van 'de facto' horizontale directe werking van (onderdelen van) richtlijn 2000/78. Deze 'de facto' horizontale directe werking is het gevolg van een combinatie van twee factoren. Allereerst wordt het algemene beginsel van nondiscriminatie op grond van leeftijd ingevuld of geconcretiseerd met behulp van de artikelen 2 en 6 van richtlijn 2000/78. Zij vormen het 'de facto' toetsingkader. Ten tweede fungeert richtlijn 2000/78 als (enige) aanknoping met het Unierecht die het algemene rechtsbeginsel activeert. Immers, uit Kücükdeveci blijkt dat het beginsel van non-discriminatie op grond van leeftijd (zoals nader uitgewerkt in richtlijn 2000/78) van toepassing is op elke nationale regeling die onder de werkingssfeer van richtlijn 2000/78 valt. ${ }^{34}$ Op de 'de facto' horizontale directe werking van de richtlijn wordt nader ingegaan in hoofdstuk 10.

De rol van richtlijn 2000/78 bij de horizontale directe werking van het algemene beginsel van non-discriminatie op grond van leeftijd

In Mangold en Kücükdeveci blijkt een zeer prominente rol van richtlijn 2000/78. Dit komt het meest duidelijk naar voren in Kücükdeveci waarin het Hof consequent spreekt van 'het beginsel van non-discriminatie op grond van leeftijd, zoals geconcretiseerd door richtlijn 2000/78'.35 Voorts blijkt in beide zaken dat richtlijn 2000/78 materieel van toepassing was. In beide zaken ging het om een nationale arbeidsrechtelijk regelingen die (i) vielen binnen het bereik van richtlijn 2000/78 inzake arbeid en beroep waarin (ii) het ingeroepen verbod van discriminatie op grond van leeftijd is uitgewerkt. Verder fungeerde

32 Zie over deze opvatting hoofdstuk 7.3.1.

33 Zie ook Lenaerts 2013-1 p. 46: Hij wijst op het belang van consensus binnen het Hof en de beperkingen die dat met zich brengt voor de motivering van arresten, p. 46.

34 Zie ook hoofdstuk 4.4 .

35 Kücükdeveci, punten 27 en 53. 
richtlijn 2000/78 als 'de facto' toetsingskader. ${ }^{36}$ Bovendien is richtlijn 2000/78 een richtlijn die van toepassing is in de private sector. Het is onduidelijk in hoeverre deze omstandigheden een rol hebben gespeeld bij de erkenning van horizontale directe werking. Met name is nog onduidelijk wat nu het precieze voorwerp is van de horizontale directe werking: is dit het 'verbod van discriminatie op grond van leeftijd, zoals geconcretiseerd door richtlijn 2000/78' of het 'verbod van discriminatie op grond van leeftijd' als zodanig? In hoofdstuk 9.5 wordt deze onduidelijkheid verder geanalyseerd.

\subsection{Horizontale directe werking van het Handvest}

\subsubsection{Algemeen}

Sinds Mangold en Kücükdeveci is dus duidelijk dat een Uniegrondrecht als algemeen rechtsbeginsel horizontale directe werking kan hebben. Eén van de prangende vragen was vervolgens of ook grondrechten uit hoofde van het Handvest horizontale directe werking kunnen hebben. Er zijn twee zaken waarin deze vraag expliciet aan de orde is gekomen. Allereerst de zaak Dominguez. ${ }^{37}$ In de procedure voor het Hof stond de vraag centraal of artikel 31, lid 2, van het Handvest (het recht op jaarlijkse vakantie met behoud van loon) horizontale directe werking heeft. Het arrest valt op door de oorverdovende stilte rond deze vraag. Het woord 'Handvest' komt in het arrest zelfs niet terug. Dit arrest wordt besproken in paragraaf 8.3.2. In schril contrast staat de zaak AMS. In deze zaak ging het om artikel 27 van het Handvest (het recht op informatie en raadpleging van de werknemers binnen de onderneming). Het Hof oordeelde dat geen sprake kon zijn van horizontale directe werking, en legt uit waarom. Uit deze motivering blijkt dat de mogelijkheid van horizontale directe werking van het Handvest een feit is. Het arrest AMS wordt uitgewerkt in paragraaf 8.3.3.

\subsubsection{Het arrest Dominguez: een stilte-arrest}

\subsubsection{Samenvatting procedure en arrest}

De zaak Dominguez betrof een geschil mevrouw Dominguez en haar werkgever, het Centre informatique du Centre Ouest Atlantique, over het verzoek van Dominguez om toekenning van jaarlijkse vakantie met behoud van loon over het tijdvak tussen november 2005 en januari 2007. Zij had in die periode

36 Zie hierover hoofdstuk 10.4.2.

37 HvJEU 24 januari 2012, zaak C-282/10, Dominguez. 
geen vakantie opgenomen omdat zij met ziekteverlof was. Op grond van het nationale recht bestaat het recht op jaarlijkse vakantie met behoud van loon slechts als de werknemer tijdens de referentieperiode ten minste tien dagen (of een maand) daadwerkelijk heeft gewerkt. De nationale rechter twijfelde over de verenigbaarheid van deze nationale bepaling met artikel 7 , lid 1 , van richtlijn 2003/88 en over de gevolgen van een onverenigbaarheid in een geding tussen twee particulieren.

In de verwijzingsbeschikking werd enkel verwezen naar het recht op jaarlijkse betaalde vakantie als vervat in richtlijn 2003/88. Aan het Handvest werd niet gerefereerd. Evenmin noemde de verwijzende rechter de arresten Mangold en Kücükdeveci. Echter in de procedure voor het Hof speelde de horizontale directe werking variant 'toetsing overheidshandelen' van het Handvest een zeer prominente rol. Zo werden parijen in de convocatie van de mondelinge behandeling uitgenodigd om in te gaan op de horizontale directe werking in samenhang met artikel 31 (2). ${ }^{38}$ Ook advocaat-generaal Trstenjak besteedde in haar lijvige conclusie uitgebreid aandacht aan de kwestie van de horizontale directe werking van het Handvest en de toepasselijkheid van Mangold en Kücükdeveci. Zij sprak zich op basis van de artikelen 51 en 52 (2) uit tegen de horizontale directe werking van het Handvest. ${ }^{39} \mathrm{Zij}$ meende voorts, dat het recht op jaarlijkse vakantie met behoud van loon mogelijk een algemeen rechtsbeginsel is. Dit algemene rechtsbeginsel zou echter geen horizontale directe werking moeten hebben. $\mathrm{Zij}$ wees hierbij op het vereiste van een coherente grondrechtenbescherming. ${ }^{40}$ Tot slot meende zij dat de Mangold en Kücükdeveci-aanpak niet van toepassing is. ${ }^{41}$

Het Hof was oorverdovend stil. ${ }^{42}$ De primairrechtelijke status van het recht op jaarlijkse vakantie met behoud van loon wordt niet genoemd. Zelfs de gebruikelijke verwijzing in richtlijn 2003/88- zaken naar artikel 31, lid 2, van het Handvest blijft achterwege. ${ }^{43}$ Dit valt op. Ook omdat uit het arrest blijkt dat het Hof er veel aan is gelegen om het recht op jaarlijkse vakantie met behoud

38 Zie ook punt 2 van het rapport ter terechtzitting waarin artikel 31 (2) van het Handvest deel uitmaakt van het juridisch kader, punt 2.

39 Dominguez, punten 71-88.

40 Dominguez, punten 89-143.

41 Dominguez, punten 144-170.

42 Zie ook Pech 2012.

43 Vergelijk bijvoorbeeld met: HvJEU van 15 september 2011, zaak 155/10, Williams, punt 18; HvJEU van 22 november 2011, zaak C-214/10, KHS, punt 31;HvJEU 3 mei 2012, zaak C-337/10, Neidel, punt 40; HvJEU van 21 juni 2012, zaak C-78/11, ANGED, punt 17; HvJEU van 8 november 2012, gevoegde zaken C-229/11 en C-230/11, Heimann, punt 22 . 
van loon effectief te doen zijn. Zo wordt uitgebreid aandacht besteed aan de plicht tot richtlijnconforme interpretatie en de mogelijkheid dat het geding wellicht toch verticaal is. Echter voor wat betreft de horizontale directe werking van het recht op jaarlijkse vakantie met behoud van loon wordt vastgehouden aan de traditionele Faccini Dori lijn:

“37. Volgens vaste rechtspraak kan een richtlijn uit zichzelf aan een particulier geen verplichtingen opleggen en kan zij dus als zodanig niet tegenover hem worden ingeroepen (...)"

\subsubsection{Korte analyse}

Het is duidelijk dat Mangold /Kücükdeveci niet van toepassing is. Het is onduidelijk waarom niet. Er zijn meerdere verklaringen waarom Mangold |Kücükdeveci niet van toepassing zou zijn. ${ }^{44}$ Aanvankelijk leek een eerste verklaring te kunnen zijn dat het recht op jaarlijkse betaalde vakantie geen algemeen rechtsbeginsel is en dat daarom Mangold /Kücükdeveci niet kon worden toegepast. Dit is ook betoogd door de Franse en de Nederlandse regering. ${ }^{45}$ Het Hof laat het in het midden ${ }^{46}$ en herhaalt enkel zijn vaste jurisprudentie op grond waarvan het recht van elke werknemer op jaarlijkse vakantie met behoud van loon moet worden beschouwd als een bijzonder belangrijk beginsel van sociaal recht van de Unie. ${ }^{47}$ Met het in de volgende paragraaf te bespreken arrest AMS lijkt deze verklaring inmiddels te kunnen worden weggestreept. Uit dit arrest lijkt namelijk te volgen dat ook het Handvest horizontale werking heeft en dat het hierbij niet relevant is of het betreffende grondrecht tevens een algemeen rechtsbeginsel is.

Een tweede mogelijke verklaring voor het niet toepassen van Mangold |Kücükdeveci is, dat in casu het Handvest temporeel niet van toepassing was, omdat de feiten in het hoofdgeding dateren van voor 1 december 2009, de

44 Zie voor zes mogelijke verklaringen voor de niet-toepasselijkheid van Mangold |Kücükdeveci: De Mol 2012-1.

45 Dit is ook betoogd door de Franse en de Nederlandse regering. Zie A-G Trstenjak van 8 september 2011, zaak C-282/10, Dominguez, punten 30 en 33.

46 Een obstakel voor de kwalificatie als algemeen rechtsbeginsel zou kunnen zijn dat het recht niet algemeen genoeg is om hiervoor te kwalificeren. Het is immers beperkt tot een specifiek rechtsgebied, het arbeidsrecht. Hier kan weer tegen in worden gebracht dat er meer algemene rechtsbeginselen zijn die niet van toepassing zijn op het gehele rechtssysteem maar enkel op deelgebieden. Hierbij kan worden gedacht aan het 'ne bis in idem' en 'pacta sunt servanda'. Zie hoofdstuk 2.2.1.

47 Dominguez, punt 16. 
datum van het bindend worden van het Handvest. 48

Een derde mogelijke verklaring is dat het recht op jaarlijkse betaalde vakantie in de richtlijn verder gaat dan de enkele concretisering van artikel 31, lid 2, van het Handvest. Terwijl artikel 31, lid 2, van het Handvest enkel rept van het bestaan van een recht op jaarlijkse betaalde vakantie, bepaalt de richtlijn dat dit recht vier weken verlof behelst. Dit zou relevant kunnen zijn zeker als de Mangold |Kücükdeveci -horizontale directe werking enkel ziet op de horizontale directe werking van een grondrecht zoals geconcretiseerd in een richtlijn (zie hoofdstuk 9.5). Tegelijk stond in Dominguez enkel het bestaan van het recht op vakantie ter discussie staat en niet de periode ervan. In zoverre is de richtlijn wel enkel een concretisering van het grondrecht.

Het komt erop neer dat het arrest Dominguez geen enkele duidelijkheid verschaft omtrent de mogelijkheid van horizontale directe werking van andere grondrechten. Gezien de loop van de prejudiciële procedure en de conclusie van de advocaat-generaal is dit ronduit vreemd. Het arrest bevestigt hiermee wel dat het onderwerp horizontale directe werking van grondrechten ook binnen het Hof gevoelig ligt.

\subsubsection{Het arrest AMS: een voortborduren op Kücükdeveci}

\subsubsection{Feiten, nationaal kader en prejudiciële vragen}

AMS is een leerbedrijf dat werklozen of mensen in een achterstandssituatie helpt op de arbeidsmarkt te re-integreren. Vakbondsorganisaties eisen dat AMS een werknemersvertegenwoordiging toestaat. Volgens AMS is dat naar Frans recht niet nodig, omdat de organisatie minder dan 50 werknemers telt. Volgens de vakbonden is de Franse nationale regeling op dit punt in strijd met art. 27 Handvest en met Richtlijn 2002/14/EG. ${ }^{49}$ Deze richtlijn is onder meer van toepassing op ondernemingen met meer dan 50 werknemers. De litigieuze Franse bepaling uit de code du travail implementeerde de richtlijn en bepaalde dat bij de berekening van de grootte van het personeelsbestand bepaalde personen (gesubsidieerde werknemers) niet worden meegerekend. De verwijzende rechter (het Cour de Cassation) twijfelde over de verenigbaarheid

48 Het litigieuze tijdvak was 3.1.2005 tot 7.1.2007. Zie over de temporele werkingssfeer van het Handvest (in een verticale context): HvJEU van 3 juli 2014, gevoegde zaken C-129/13 en C-130/13, Kamino, punt 29.

49 Richtlijn 2002/14/EG van het Europees Parlement en de Raad van 11 maart 2002 tot vaststelling van een algemeen kader betreffende de informatie en de raadpleging van de werknemers in de Europese Gemeenschap - Gezamenlijke verklaring van het Europees Parlement, de Raad en de Commissie over de vertegenwoordiging van de werknemers. 
van de nationale bepaling met betrekking tot de berekeningswijze van de omvang van het personeelsbestand en over de gevolgen die hij aan een eventuele onverenigbaarheid zou moeten verbinden in een geding tussen particulieren en verzocht om een prejudiciële beslissing over de volgende vragen:

"1) Kan het grondrecht op informatie en raadpleging van de werknemers, neergelegd in artikel 27 van het [Handvest], zoals gepreciseerd in de bepalingen van richtlijn [2002/14], in een geding tussen particulieren worden aangevoerd om een nationale maatregel ter uitvoering van [deze] richtlijn te toetsen aan het Unierecht?

2) Zo ja, moeten die bepalingen aldus worden uitgelegd dat zij zich verzetten tegen een nationale wettelijke bepaling die van de berekening van het aantal werknemers van de onderneming, met name ter bepaling van de wettelijke drempels voor het oprichten van organen voor de vertegenwoordiging van het personeel, [gesubsidieerde] werknemers [...] [uitsluit]?”

\subsubsection{Oordeel van het Hof}

Het Hof herformuleerde de prejudiciële vragen aldus, dat de verwijzende rechter wenst te vernemen of:
“23. (...) artikel 27 van het Handvest, alleen of gelezen in samenhang met de bepalingen van richtlijn 2002/14, aldus moet worden uitgelegd dat dit artikel van het Handvest, wanneer een nationale bepaling ter uitvoering van deze richtlijn, zoals artikel L. 1111-3 van de code du travail, onverenigbaar is met het recht van de Unie, kan worden ingeroepen in een geding tussen particulieren teneinde die nationale bepaling buiten toepassing te laten.” (cursivering auteur)

Het Hof toetste eerst aan de richtlijn en oordeelde dat de wijze waarop de Franse regeling een bepaalde categorie van werknemers van de berekening van het personeelsbestand uitsluit, onverenigbaar is met de richtlijn. Vervolgens overwoog het Hof op basis van vaste rechtspraak dat de richtlijn geen horizontale directe werking hebben. Evenmin was in deze zaak ruimte voor richtlijnconforme interpretatie. Nu de opties van horizontale directe werking van de richtlijn en richtlijnconforme interpretatie aldus te hebben afgekaart kwam het Hof toe aan de eigenlijke vraag of artikel 27 Handvest, alleen of gelezen in samenhang met de bepalingen van richtlijn 2002/14, kan worden ingeroepen in een geding tussen particulieren om de niet met deze richtlijn overeenstemmende nationale bepaling buiten toepassing te laten. Het Hof overwoog dat hiervoor moet worden nagegaan of de situatie in het hoofdgeding vergelijkbaar is met de zaak Kücükdeveci. Hiertoe overwoog het 
Hof eerst dat de in de Unie gewaarborgde grondrechten toepassing kunnen vinden in alle situaties die door het recht van de Unie worden beheerst. Aangezien de in het hoofdgeding aan de orde zijnde nationale regeling richtlijn 2002/14 uitvoert, kon artikel 27 Handvest in het hoofdgeding worden toegepast. Vervolgens echter kwam het Hof tot het oordeel dat in een geding als het onderhavige artikel 27 Handvest niet als zodanig kan worden ingeroepen om met richtlijn 2002/14 onverenigbare nationale bepalingen buiten toepassing te laten. Doorslaggevend was dat het verbod in richtlijn 2002/14 om bij de berekening van het personeelsbestand van de onderneming een bepaalde categorie van personen uit te sluiten, niet als rechtstreeks toepasselijk rechtsvoorschrift uit artikel 27 van het Handvest kan worden afgeleid. Aan deze vaststelling wordt niet afgedaan door artikel 27 van het Handvest te lezen in samenhang met de bepalingen van richtlijn 2002/14. Aangezien dit artikel op zich immers niet volstaat om aan particulieren een recht te verlenen dat zij als zodanig kunnen inroepen, geldt dit eveneens voor een dergelijke lezing in samenhang. Het Hof eindigde met een herinnering aan de Francovichrechtspraak: de partij die is benadeeld doordat het nationale recht niet met het recht van de Unie strookt, kan in voorkomend geval vergoeding van de geleden schade verkrijgen. Tot slot luidde het dictum:

"Artikel 27 van het Handvest van de grondrechten van de Europese Unie, alleen of gelezen in samenhang met de bepalingen van richtlijn 2002/14/EG (...), moet aldus worden uitgelegd dat dit artikel van het Handvest, wanneer een nationale bepaling ter uitvoering van deze richtlijn, (...), onverenigbaar is met het recht van de Unie, niet kan worden ingeroepen in een geding tussen particulieren teneinde die nationale bepaling buiten toepassing te laten.

\subsubsection{Korte analyse}

Het arrest AMS is het eerste arrest waarin het Hof voortborduurt op Kücükdeveci. Hoewel in AMS geen horizontale directe werking aan een grondrecht wordt toegekend, vormt het toch een verduidelijking van de Kücükdeveci-benadering.

\section{Horizontale directe werking à la Kücükdeveci van het Handvest a priori mogelijk}

Uit het arrest AMS blijkt ten eerste, dat het Handvest horizontale directe werking variant 'toetsing van overheidshandelen' kan hebben. ${ }^{50}$ Het Hof overweegt in punt 41 immers expliciet dat het nodig is om na te gaan "of de situatie in het hoofdgeding vergelijkbaar is met die in de zaak die tot het reeds

50 Zie ook Lazzerini 2014, p. 921; De Waele 2014, p. 59-60. Anders: Frantziou 2014. 
aangehaalde arrest Kücükdeveci heeft geleid, zodat artikel 27 van het Handvest, alleen of gelezen in samenhang met de bepalingen van richtlijn 2002/14, kan worden ingeroepen in een geding tussen particulieren om in voorkomend geval de niet met deze richtlijn overeenstemmende nationale bepaling buiten toepassing te laten." Indien het Handvest principieel geen horizontale directe werking zou hebben, zou deze exercitie overbodig zijn en had het eerder voor de hand gelegen dat het Hof zou hebben vastgesteld dat Kücükdeveci niet geldt voor grondrechten uit het Handvest. Uit de overweging van het Hof leid ik derhalve af dat bepalingen van het Handvest a priori horizontale directe werking à la Kücükdeveci kunnen hebben. Hierbij is het niet noodzakelijk dat het betreffende grondrecht tevens kwalificeert als algemeen beginsel van Unierecht. Het Hof stelt namelijk niet eerst vast dat artikel 27 van het Handvest als zodanig kwalificeert en het ligt ook niet voor de hand dat artikel 27 aldus zou kwalificeren. In AMS wordt derhalve een parallel getrokken tussen de horizontale directe werking van grondrechten uit hoofde van Handvest en de algemene beginselen van Unierecht. Dit is met het oog op de coherente toepassing van Uniegrondrechten positief te noemen. Het sluit ook aan bij de parallel inzake het toepassingsgebied van Uniegrondrechten uit hoofde van de beide bronnen.

Horizontale directe werking à la Kücükdeveci kan ook van toepassing zijn op andere grondrechten dan op discriminatieverboden

Uit het arrest AMS blijkt tevens dat de Kücükdeveci-horizontale directe werking ook van toepassing kan zijn op andere grondrechten dan op discriminatieverboden. Het is echter onduidelijk of elk grondrecht uit het Handvest potentieel in aanmerking komt voor deze horizontale directe werking of dat dit afhangt van het soort recht. Het Hof zegt hier verder niets over. Zo besteedt het geen bijzondere aandacht aan het feit dat artikel 27 Handvest naar zijn aard is bedoeld om effect te sorteren in particuliere verhoudingen (zij het door middel van wetgeving). Het vertrekpunt lijkt eerder te zijn de overweging in punt 42 , dat:

"de in de rechtsorde van de Unie gewaarborgde grondrechten toepassing kunnen vinden in alle situaties die door het recht van de Unie worden beheerst (...)."

Uit deze overweging volgt mogelijk dat enkel doorslaggevend is dat het gaat om een "situatie die door het recht van de Unie wordt beheerst". Dit zou kunnen betekenen dat alle Uniegrondrechten a priori in aanmerking zouden komen voor horizontale directe werking. Daarbij moet worden aangetekend, dat het voor sommige grondrechten op voorhand duidelijk zal zijn dat zij geen effect 
kunnen sorteren in private verhoudingen, zoals bijvoorbeeld artikel 41 Handvest (recht op behoorlijk bestuur).

Grondslag horizontale directe werking wordt niet uitgelegd

Opvallend is dat het Hof in het geheel geen aandacht besteed aan de principiële vraag waarom het bepalingen uit het Handvest horizontale directe werking kunnen hebben. Het overweegt slechts, dat

"42. (...) de in de rechtsorde van de Unie gewaarborgde grondrechten toepassing kunnen vinden in alle situaties die door het recht van de Unie worden beheerst (zie arrest van 26 februari 2013, Åkerberg Fransson, C$617 / 10$, nog niet gepubliceerd in de Jurisprudentie, punt 19).”

Doorslaggevend lijkt enkel te zijn dat het gaat om een situaties die door het recht van de Unie wordt beheerst. Dit zou erop kunnen duiden, dat het Hof als principieel uitgangspunt neemt dat grondrechten naar hun aard ook van toepassing zijn in de private sfeer. ${ }^{51}$

\section{Artikel 27 van het Handvest in casu geen directe werking}

Hoewel de betreffende zaak een situatie betrof die door het recht van de Unie wordt beheerst en het Handvest zodoende kon worden toegepast (zie het hierboven aangehaalde punt 42), was horizontale directe werking niet mogelijk. Het Hof overweegt als volgt:

"45.Uit de bewoordingen van artikel 27 van het Handvest blijkt dus duidelijk dat dit artikel pas zijn volle werking verkrijgt nadat het nader is bepaald in Unierechtelijke en nationaalrechtelijke voorschriften.

46. Het tot de lidstaten gerichte verbod in artikel 3, lid 1, van richtlijn 2002/14 om bij de berekening van het personeelsbestand van de onderneming een bepaalde categorie van personen die oorspronkelijk voor deze berekening in aanmerking kwam, daarvan uit te sluiten, kan echter, als rechtstreeks toepasselijk rechtsvoorschrift, noch uit de bewoordingen van artikel 27 van het Handvest, noch uit de toelichtingen bij dit artikel worden afgeleid."

Het manco zat hem derhalve in het voldoen aan de technische eisen voor directe werking (de eisen van voldoende nauwkeurig en onvoorwaardelijk). Het blijft in het midden of artikel 27 van het Handvest nimmer kan voldoen aan die eisen of dat dit alleen geldt in de context van de onderhavige zaak. Het eerste lijkt te volgen uit punt 45 . Dit doet denken aan de zaak Casteels waarin het onder meer ging om de vraag naar de horizontale directe werking variant

51 Zie over deze opvatting hoofdstuk 7.3. 
'toetsing particulier handelen' van artikel 48 VWEU.52 Het Hof overwoog hier ondubbelzinnig als volgt:

"14. Dienaangaande dient te worden opgemerkt dat artikel 48 VWEU niet beoogt te werken als een rechtstreeks geldende rechtsregel. Het vormt een rechtsgrondslag op basis waarvan het Europees Parlement en de Raad volgens de gewone wetgevingsprocedure de maatregelen kunnen vaststellen welke op het gebied van de sociale zekerheid noodzakelijk zijn voor de totstandkoming van het vrije verkeer van werknemers.

15. Deze bepaling vereist dus een optreden van de Uniewetgever en haar gevolgen hangen er derhalve vanaf of de genoemde Unie-instellingen een handeling vaststellen. Zij kan als zodanig particulieren dus geen rechten geven waarop zij zich voor de nationale rechter kunnen beroepen.

16. Bijgevolg dient op de eerste vraag te worden geantwoord dat artikel 48 VWEU geen rechtstreekse werking heeft waarop een particulier zich in een geding voor een nationale rechter kan beroepen tegenover een werkgever uit de privésector."

In punt 46 van $A M S$ zoemt het Hof echter in op de context van de zaak. In deze zaak ging het om de effectuering van het verbod in artikel 3, lid 1, van richtlijn 2002/14 om bij de berekening van het personeelsbestand van de onderneming een bepaalde categorie van personen die oorspronkelijk voor deze berekening in aanmerking kwam, daarvan uit te sluiten. Een dusdanig verbod kon niet als rechtstreeks toepasselijk rechtsvoorschrift van artikel 27 van het Handvest worden afgeleid.

Hoe dan ook, in deze zaak is niet aan de technische eisen voldaan. Het is ook duidelijk, dat als het grondrecht niet voldoet aan de technische eisen voor directe werking, de richtlijn niet kan worden gebruikt om dit 'gebrek' te repareren; in casu door het verbod met behulp van de bepalingen van richtlijn 2002/14 in artikel 27 van het Handvest te lezen. Vereist is dat de Handvestbepaling op zich moet volstaan om aan particulieren een recht te verlenen dat zij als zodanig kunnen inroepen.

De rol van richtlijn 2002/14 bij de horizontale directe werking van artikel 27

Bij de bespreking van het arrest Kücükdeveci is opgemerkt dat er sprake is van een verstrengeling van het algemene beginsel van non-discriminatie op grond van leeftijd met richtlijn 2000/78. Het gaat om een dusdanig innige verstrengeling dat de 'de jure' toepassing van het grondrecht als algemeen

52 HvJEU van 10 maart 2011, zaak C-379/09, Casteels, punten 13-15. Zie ook A-G Kokott van 11 november 2010, zaak C-379/09, Casteels, punten 28-32. 
rechtsbeginsel 'de facto' neerkomt op de toepassing van de richtlijn. De vraag die openstaat is of de Kücükdeveci -benadering betekent dat het grondrecht als zodanig horizontale direct werking kan hebben of dat dit enkel kan 'zoals geconcretiseerd' in materieel recht. Het arrest AMS lost deze onduidelijkheid niet op. Aan de ene kant wordt in verschillende overwegingen en ook in het dictum steeds uitgegaan van de vraag naar de horizontale directe werking van artikel 27 van het Handvest "alleen of gelezen in samenhang met de bepalingen van richtlijn 2002/14/EG”. Dit duidt erop dat ook zonder de richtlijn sprake kan zijn van horizontale directe werking van het grondrecht 'alleen'. Aan de andere kant speelt ook in dit arrest de richtlijn een prominente rol. Hoewel de verwijzende rechter enkel vraagt naar de uitleg en directe werking van artikel 27 van het Handvest, gaat het Hof toch eerst in op de uitleg en werking van richtlijn 2002/14/EG. Ook in het deel van het arrest dat wel ziet op de uitleg en werking van artikel 27 van het Handvest komt de richtlijn weer terug. Dit schept een beeld van samenspel tussen grondrecht en richtlijn. In hoofdstuk 10.4 wordt op dit punt verder ingegaan.

\subsection{Zij- uitstapjes: samenloop met de horizontale directe werking van Verdragsbepalingen}

In de vorige paragrafen zijn de arresten Mangold, Kücükdeveci, Dominguez en AMS aan bod gekomen die betrekking hadden op de nieuwe lijn van het Hof inzake de horizontale directe werking van Uniegrondrechten. In deze paragraaf wordt volledigheidshalve een zijuitstapje gemaakt naar de arresten Viking Line, Laval, Dynamic Medien en Las waarin sprake is van de horizontale directe werking van Verdragsbepalingen inzake het vrije verkeer waarbij grondrechten een rol spelen. ${ }^{53}$ Dit zijn voorbeelden van de toepassing van Uniegrondrechten in horizontale geschillen die niet neerkomen op horizontale directe werking, maar wel een vorm van derdenwerking van grondrechten impliceren.

\section{Viking Line \& Laval}

Viking Line is gewezen na Mangold en voor Kücükdeveci. Het betrof een horizontaal geding tussen enerzijds de internationale en Finse vakbonden van varend personeel en anderzijds ferrymaatschappij Viking Line inzake een collectieve actie en dreigingen met een dergelijke actie om Viking ervan af te schrikken, een van haar onder Finse vlag varende schepen onder de vlag van een andere lidstaat te brengen. Viking vorderde een verbod van deze acties. Het Hof

53 Zie meer algemeen ook hoofdstuk 8.4. HvJEU van 11 december 2007, zaak C-438/05, Viking Line; HvJEU van 18 december 2007, zaak C-341/05 Laval; HvJEU van 14 februari 2008, zaak C-244/06, Dynamic Medien; HvJEU van 16 april 2013, zaak C-202/11, Las. 
overwoog, dat artikel $43 \mathrm{EG}$ aan een particuliere onderneming rechten toekent, die zij kan inroepen tegen een vakvereniging of een verbond van vakverenigingen. ${ }^{54}$ Bovendien oordeelde het Hof dat acties zoals aan de orde in het hoofdgeding, beperkingen van de vrijheid van vestiging zijn in de zin van artikel 43 EG. ${ }^{55}$ Vervolgens spitste de zaak zich toe om de vraag naar de mogelijkheid tot rechtvaardiging. Hiertoe beriepen de vakbonden zich op hun recht een collectieve actie te voeren (artikel 28 van het Handvest). Het Hof overwoog:

"77. Het recht om een collectieve actie te voeren die de bescherming van werknemers tot doel heeft, vormt een legitiem belang dat in beginsel een beperking van een van de door het Verdrag gewaarborgde fundamentele vrijheden kan rechtvaardigen (...)"

In het arrest Laval ging het om een soortgelijke toepassing van een Uniegrondrecht.

In beide zaken was het onderwerp van toetsing aan het Unierecht een private handeling. De betreffende Verdragsbepalingen hadden dan ook horizontale directe werking variant 'toetsing particulier handelen'. Uit de arresten blijkt, dat in zo'n geval een grondrecht kan worden ingeroepen als afweer. Het mogelijke gevolg hiervan is dat particuliere partij A een inbreuk op zijn Verdragsrechtelijke recht op vrije verkeer door B moet dulden wegens een succesvol beroep van B op een grondrecht. Aldus komt aan het grondrecht een zekere derdenwerking toe, echter er is geen sprake van horizontale directe werking van het grondrecht. ${ }^{56}$ Het grondrecht fungeert immers niet als zelfstandige toetsingsmaatstaf, maar als 'legitiem doel', als rechtvaardigingsgrond. De toepassing van het grondrecht in Viking Line en Laval is vergelijkbaar met de verticale zaken Omega en Schmidberger zoals besproken in hoofdstuk 5.2.1.57 Tot slot wordt voor de goede orde opgemerkt dat het in deze context niet hoeft te gaan om een grondrecht van de Unie. Het kan ook gaan om het inroepen van een nationaal grondrecht.

54 Viking Line, punten 56-66.

55 Viking Line, punten 68-74.

56 Anders Ladenburger 2012, p. 36: Naar zijn mening heeft het Hof de horizontale directe werking van het stakingsrecht aanvaard (artikel 28 van het Handvest), maar in een specifieke situatie en enkel als neveneffect van de aanvaarding van de horizontale directe werking van een Verdragsrechtelijk recht op vrije verkeer tegen vakanbonden.

57 HvJEU van 12 juni 2003, zaak C-112/00, Schmidberger, punt 74; zie HvJ EU van 14 oktober 2004, zaak C-36/02, Omega, punt 35. 


\section{Dynamic Medien}

Het ging hier om een geding tussen twee vennootschappen Dynamic Medien en Avides Media. Avides Media verkocht met behulp van postorderverkoop via het internet beelddragers zonder dat deze zijn gekeurd en geclassificeerd met het oog op de bescherming van de minderjarigen. Centraal in de procedure voor het Hof stond de vraag of de nationale wettelijke regeling inzake de goedkeuring en classificatie verenigbaar is met het vrije verkeer van goederen. Deze nationale regeling behelsde namelijk een verbod op de verkoop en de overdracht per postorder van beelddragers die niet door een bevoegde nationale autoriteit of een nationale instantie voor zelfregulering zijn gekeurd en geclassificeerd met het oog op de bescherming van de minderjarigen en waarop geen van deze autoriteit of instantie afkomstige vermelding is aangebracht van de leeftijd vanaf welke de beelddragers mogen worden bekeken. Het Hof oordeelde dat de nationale regeling een beperkingen ex artikel $28 \mathrm{VEG}$ is. Als rechtvaardiging van de regeling werden de rechten van het kind ingeroepen. Het Hof erkende dat dit een legitiem doel is die een beperking op het vrije verkeer van goederen kan rechtvaardigen ${ }^{58}$ en overwoog hierbij als volgt:

“39. Dienaangaande moet eraan worden herinnerd dat de bescherming van de rechten van het kind wordt erkend in verschillende internationale instrumenten waaraan de lidstaten hebben meegewerkt of waarbij zij zich hebben aangesloten, zoals het (...) Internationaal Verdrag inzake burgerrechten en politieke rechten alsmede het (...) Verdrag inzake de rechten van het kind. Het Hof heeft reeds eraan herinnerd dat deze internationale instrumenten behoren tot de instrumenten ter bescherming van de rechten van de mens, waarmee het rekening houdt bij de toepassing van de algemene beginselen van gemeenschapsrecht (...).

41. De bescherming van het kind is tevens verankerd in (...) het Handvest (...), waarvan artikel 24 , lid 1 , bepaalt dat kinderen recht hebben op de bescherming en de zorg die nodig zijn voor hun welzijn (...).”

In deze zaak ging het derhalve om de horizontale directe werking variant 'toetsing overheidshandelen' van het vrije verkeer van goederen. Ook in deze context kan een grondrecht worden ingeroepen als rechtvaardiging van de nationale regeling die kwalificeert als een beperking van het vrije verkeer. Hoewel aan het grondrecht een zekere derdenwerking toe komt, is ook hier geen sprake van horizontale directe werking van het grondrecht omdat het niet fungeert als zelfstandige toetsingsmaatstaf.

58 Dynamic Medien, punt 42. 
Las

In Las ging het om een soortgelijke toepassing van het grondrecht in een horizontaal geschil als in Dynamic Medien. De zaak betrof een arbeidsrechtelijk geschil tussen werknemer Las (Nederlander) en zijn werkgever, de in België gevestigde vennootschap PSA Antwerp betreffende de ontslagvergoeding uit hoofde van de arbeidsovereenkomst. ${ }^{59}$ In de ontslagprocedure beriep Las zich op de nietigheid van de arbeidsovereenkomst wegens strijd ervan met het Vlaamse taaldecreet. Deze Vlaamse regeling verplichtte elke werkgever die zijn exploitatiezetel op Vlaams grondgebied om arbeidsovereenkomsten met een grensoverschrijdend karakter uitsluitend op te stellen in de officiële taal van de Vlaamse Gemeenschap, op straffe van door de rechter ambtshalve aan te voeren nietigheid van deze overeenkomsten. De arbeidsovereenkomst was in het Engels opgesteld. De werkgever, PSA Antwerp, stelde zich op het standpunt dat het Vlaamse taaldecreet buiten toepassing moet blijven wegens strijd met het vrije verkeer van werknemers (artikel 45, lid 2, VWEU). Het ging in deze zaak dus om de horizontale directe werking variant 'toetsing van overheidshandelen' van artikel 45, lid 2, VWEU. Naar het oordeel van het Hof is een regeling als het Vlaams taaldecreet een beperking van het vrije verkeer van werknemers. Daarom onderzocht het Hof of de regeling kon worden gerechtvaardigd. In dit verband voerde de Belgische regering aan dat het taaldecreet onder meer diende ter bevordering en stimulering van de officiële talen van België. Hierbij verwees de Belgische regering naar artikel 22 van het Handvest op grond waarvan de Unie haar rijke verscheidenheid van cultuur en taal eerbiedigt. Het Hof overwoog dat:

"27. De doelstelling bestaande in het bevorderen en stimuleren van het gebruik van het Nederlands - een van de officiële talen van het Koninkrijk België - is dus een rechtmatig belang dat in beginsel een beperking kan rechtvaardigen van de verplichtingen die door artikel 45 VWEU worden opgelegd."

Uiteindelijk oordeelde het Hof dat een dergelijk decreet disproportioneel was en daarmee niet kon worden gerechtvaardigd. Ook hier ging het weliswaar om het inroepen van een grondrecht om een beroep op het vrije verkeer van een particuliere partij om een inbreuk af te weren, maar niet om de horizontale directe werking van het grondrecht. Het grondrecht dient niet als toetssteen maar slechts als legitieme reden. ${ }^{60}$

59 HvJEU van 16 april 2013, zaak C-202/11, Las. Zie ook hoofdstuk 10.2.4.2.

60 Overigens is artikel 22 Handvest gericht tot de Unie en ligt het om die reden niet voor de hand dat nationaal handelen daaraan kan worden getoetst. 
Uit de zaken Viking Line, Laval, Dynamic Medien en Las blijkt dat grondrechten in een horizontaal geding als rechtvaardigingsgrond kunnen worden ingeroepen voor publieke en private handelingen die a priori kwalificeren als schendingen van Verdragsbepalingen. Dit impliceert wel derdenwerking van het grondrecht, maar geen horizontale directe werking ervan.

\subsection{Conclusies}

1. Uniegrondrechten kunnen horizontale directe werking variant 'toetsing van overheidshandelen' hebben. Dit geldt zowel voor grondrechten uit hoofde van de algemene rechtsbeginselen (arresten Mangold en Kücükdeveci) als voor grondrechten uit het Handvest $(A M S)$. Er zijn nog veel vragen naar aanleiding van de genoemde arresten. Met name is onduidelijk of het enkel gaat om horizontale directe werking variant 'toetsing van overheidshandelen' of dat ook de ander variant van horizontale directe werking 'toetsing van particulier handelen' aan de orde zou kunnen zijn. Tevens is ongewis of de toepasselijkheid van materieel Unierecht waarin het betreffende grondrecht wordt geconcretiseerd constitutief is voor horizontale directe werking à la Mangold/Kücükdeveci.

2. De erkenning van de mogelijkheid van horizontale directe werking is een welbewuste stap die het Hof heeft doorgezet in weerwil van de veelheid aan kritische reacties uit verschillende hoeken na Mangold in Kücükdeveci. Tegelijk handelt het Hof stapje voor stapje voor wat betreft de uitwerking van de precieze reikwijdte en implicaties van deze rechtspraak. Dit volgt uit de totale stilte in het arrest Dominguez, maar ook uit de summiere motivering van de arresten Mangold, Kücükdeveci en AMS. Het lijkt erop, dat het onderwerp binnen het Hof gevoelig ligt.

3. Tot nu toe heeft het Hof enkel nog de horizontale directe werking van het algemene beginsel van non-discriminatie op grond van leeftijd erkend. Voor de volledigheid wordt wel gewezen op een aantal arresten inzake de horizontale directe werking van Verdragsbepalingen Viking Line, Laval, Dynamic Medien, en Las waarin grondrechten een rol speelden; zij dienden als rechtvaardigingsgrond voor private of publieke handelingen die a priori in strijd zijn met een Verdragsrechtelijk verbod. Deze toepassing impliceert een zekere derdenwerking van het grondrecht, maar niet de horizontale directe werking ervan. 



\section{HOOFDSTUK 9}

\section{NADERE ANALYSE VAN DE RECHTSPRAAK}

\section{$9.1 \quad$ Inleiding}

Uit het overzicht in de rechtspraak in het vorige hoofdstuk is gebleken, dat Uniegrondrechten horizontale directe werking kunnen hebben. Het maakt daarbij niet uit of het gaat om grondrechten uit hoofde van de algemene beginselen van Unierecht of van het Handvest. In dit hoofdstuk zal deze rechtspraak nader worden geanalyseerd. Ten eerste zal worden ingegaan op de toepassingsvereisten van de horizontale directe werking. Ten tweede zal de rechtspraak worden geëvalueerd in het licht van het beginsel van allocatie van bevoegdheden. Een handicap bij het destilleren van de toepassingsvereisten is de summiere motivering in de relevante arresten en wel met name ten aanzien van de grondslag van de horizontale directe werking. Nu de rechtspraak nieuw, onduidelijk en bovendien controversieel is, zal ik uitgaan van een terughoudende uitleg op grond waarvan horizontale directe werking enkel kan worden aangenomen in situaties die in vergaande mate vergelijkbaar zijn aan de situaties in Mangold en Kücükdeveci. ${ }^{1}$ Dit zijn immers de enige twee arresten waarin horizontale directe werking daadwerkelijk is aangenomen. Bovendien blijkt uit het arrest AMS dat ook het Hof de vergelijkbaarheid van de situatie in het hoofdgeding met Kücükdeveci als vertrekpunt neemt. ${ }^{2}$ In welke andere situaties sprake kan zijn van horizontale directe werking zal in toekomstige rechtspraak duidelijk moeten worden. Uit de Mangold en Kücükdeveci gelezen in samenhang met AMS kunnen vier toepassingsvereisten voor horizontale directe werking worden gedestilleerd.

Allereerst moet het ingeroepen grondrecht technisch geschikt zijn om in het hoofdgeding rechtstreeks te worden toegepast. Dit is een gebruikelijk vereiste voor directe werking. (paragraaf 9.2). Ten tweede moet het gaan om een grondrechtenschending die is te herleiden tot een nationale overheidshandeling. Het onderwerp van toetsing aan het Uniegrondrecht dient derhalve een overheidshandeling te zijn. Of anders gezegd: vooralsnog kan enkel worden uitgegaan van het bestaan van horizontale directe werking variant 'toetsing van overheidshandelen'. Deze voorwaarde wordt besproken in paragraaf 9.3 Deze

1 HvJEU van 22 november 2005, zaak C-144/04, Mangold; HvJEU van 19 januari 2010, zaak C-555/07, Kü̈ü̈deveci.

2 Zie ook HvJEU van 15 januari 2014, zaak C-176/12, AMS, punt 41. 
overheidshandeling moet ten derde kwalificeren als een handeling die Unierecht ten uitvoer legt of toepast (paragraaf 9.4). Het gaat hier om de gebruikelijke voorwaarde voor de directe werking van Uniegrondrechten (zie deel II van dit proefschrift). Naast deze 'gewone' voorwaarde moet rekening worden gehouden met een bijkomende voorwaarde. De zaken Mangold en Kücükdeveci hebben namelijk gemeen dat de situatie in het hoofdgeding viel binnen de materiële werkingssfeer van richtlijn 2000/78. Deze richtlijn concretiseert het verbod van discriminatie op grond van leeftijd in de private sector. Mogelijk was deze omstandigheid een noodzakelijke voorwaarde voor horizontale directe werking à la Mangold en Kücükdeveci (paragraaf 9.5).

Als alle voorwaarden zijn vervuld kan het bestaan van horizontale directe werking van het Uniegrondrecht worden aangenomen. Als één van de voorwaarden niet is vervuld, hoeft dit niet automatisch te betekenen dat er geen sprake is van horizontale directe werking van het Uniegrondrecht. Dit is alleen het geval als niet is voldaan aan de eerste en/of de derde voorwaarde. Deze voorwaarden staan vast en het niet vervullen van één van deze voorwaarden betekent dat geen sprake is van horizontale directe werking van het grondrecht. Het bestaan van de tweede en vierde voorwaarde is onzeker. Als één van deze voorwaarden niet is vervuld, bestaat er derhalve twijfel omtrent het bestaan van horizontale directe werking van het Uniegrondrecht.

In paragraaf 9.6 wordt de erkenning van horizontale directe werking geëvalueerd in het licht van het beginsel van allocatie van bevoegdheid. Hierbij zal worden teruggegrepen op het in hoofdstuk 7.5 geschetste referentiekader waarin met name vraagtekens zijn gesteld bij de aanwezigheid van mogelijke grondslagen voor de toekenning van horizontale directe werking en tevens is gewezen op de grenzen van artikel 51, lid 1, van het Handvest.

\subsection{Eerste voorwaarde: technische geschiktheid}

Voor directe werking is vereist, dat het ingeroepen grondrecht technisch geschikt is voor toepassing door de rechter als zelfstandige toetsingsmaatstaf. De rechter moet in staat zijn om op grond van de Unierechtelijke norm een verplichting te destilleren die onvoorwaardelijk en voldoende nauwkeurig is om in het geschil dat voorligt te kunnen worden toegepast. Het betreft de vraag of de bepaling naar zijn aard (technisch) geschikt is voor rechtstreekse toepassing zonder dat er behoefte is aan uitvoering door wetgever of bestuur. Van belang hierbij is dat het bestaan van een beoordelingsmarge niet in de weg staat aan de 
technische mogelijkheid van directe werking. ${ }^{3}$ Een ruime beoordelingsmarge kan wel van invloed zijn op de intensiteit van de toetsing. Dit vraagstuk naar de technische geschiktheid van het grondrecht hangt samen met de rol van de rechter en de afbakening van rechterlijke taak met die van de wetgever. De technische vereisten van directe werking hebben als doel om te voorkomen dat aan de rechter een wetgevende functie wordt toegekend. Uit de rechtspraak inzake de verticale directe werking die is behandeld in deel II blijkt dat een groot aantal grondrechten voldoen aan de technische eisen voor directe werking.

De eis dat een grondrecht technisch geschikt is voor rechtstreekse werking geldt (vanzelfsprekend) ook in een horizontale context. ${ }^{4}$ In de arresten Mangold en Kücükdeveci kwam dit punt niet specifiek aan de orde. Dit wekt geen verwondering. In deze zaken ging het om de toepassing van het verbod van discriminatie op grond van leeftijd. Het is vaste rechtspraak dat verboden van discriminatie op een specifieke grond technisch geschikt zijn om directe werking te hebben, ook in horizontale geschillen. ${ }^{5}$ Het wekt dan ook geen verbazing dat verboden van discriminatie uit hoofde van artikel 21 van het Handvest technisch geschikt worden geacht voor directe werking. Het Hof bevestigt dit in AMS door te oordelen dat:

“47. Het (...) beginsel van non-discriminatie op grond van leeftijd, neergelegd in artikel 21, lid 1, van het Handvest, op zich volstaat om aan particulieren een subjectief recht te verlenen waarop als zodanig een beroep kan worden gedaan.”

In AMS lag dit anders. Daar ging het om artikel 27 van het Handvest met als titel 'Het recht op informatie en raadpleging van de werknemers binnen de onderneming' die luidt als volgt:

"Werknemers en hun vertegenwoordigers moeten in de gevallen en onder de voorwaarden waarin het recht van de Unie en de nationale wetgevingen

3 Zie de rechtspraak van het Hof inzake de directe werking van richtlijnen. Zie met name ook de volgende arresten waaruit blijkt dat ook bepalingen met een ruime beoordelingsmarge rechtstreekse werking kunnen hebben: HvJEU van 1 februari 1977, zaak 51/76, VNO; HvJEU van 24 oktober 1996, zaak C-72/95, Kraaijeveld; HvJEU van 7 september 2004, zaak C-127/02, Kokkelvissers.

4 Vergelijk HvJEU van 8 april 1976, zaak 43/75, Defrenne II, punten 25, 26 en 31; HvJEU van 10 maart 2011, zaak C-379/09, Casteels, punten 13 -16.

5 Zie bijvoorbeeld HvJEU van 12 december 1974, zaak 36/74, Walrave and Koch; HvJEU van 8 april 1976, zaak 43/75, Defrenne II en HvJEU van 16 september 1999, zaak C218/98, Angonese. 
en praktijken voorzien, de zekerheid hebben, dat zij op passende niveaus tijdig worden geïformeerd en geraadpleegd.”

Zonder een algemeen oordeel te geven over de technische geschiktheid voor de directe werking van dit grondrecht als zodanig, oordeelt het Hof dat artikel 27 in casu geen directe werking heeft. Het Hof komt tot dit oordeel door het in het hoofdgeding ingeroepen verbod als vertrekpunt te nemen en te kijken of dit uit artikel 27 van het Handvest kan worden afgeleid. In AMS ging het om de effectuering van het verbod in artikel 3, lid 1, van richtlijn 2002/14 om bij de berekening van het personeelsbestand van de onderneming een bepaalde categorie van personen die oorspronkelijk voor deze berekening in aanmerking kwam, daarvan uit te sluiten. Het Hof oordeelde dat een dusdanig verbod niet als rechtstreeks toepasselijk rechtsvoorschrift van artikel 27 van het Handvest worden afgeleid. Relevant hierbij was dat artikel 27 van het Handvest een opdracht bevat aan (nationale en Unie) overheden. Dit gegeven komt terug in de overwegingen van het Hof:

\begin{abstract}
“44. Tevens moet worden vastgesteld dat artikel 27 van het Handvest, met als opschrift „Het recht op informatie en raadpleging van de werknemers binnen de onderneming", bepaalt dat de werknemers, in de gevallen en onder de voorwaarden waarin het recht van de Unie en de nationale wetgevingen en praktijken voorzien, de zekerheid moeten hebben dat zij op verschillende niveaus worden geïnformeerd en geraadpleegd.

45. Uit de bewoordingen van artikel 27 van het Handvest blijkt dus duidelijk dat dit artikel pas zijn volle werking verkrijgt nadat het nader is bepaald in Unierechtelijke en nationaalrechtelijke voorschriften.”
\end{abstract}

Vervolgens is van belang, dat de richtlijn niet mag worden gebruikt om dit 'gebrek' van artikel 27 van het Handvest te repareren, door het verbod er in samenhang met de bepalingen van richtlijn 2002/14 in te lezen. Vereist is dat de Handvestbepaling op zich moet volstaan om aan particulieren een recht te verlenen dat zij als zodanig kunnen inroepen. In dit geval oordeelde het Hof dat het ingeroepen recht wel rechtstreeks uit richtlijn volgt, maar het niet zelfstandig uit artikel 27 van het Handvest kan worden afgeleid. De richtlijn gaat in dit opzicht dus verder dan het Handvest. Dit is een verschil met Kücükdeveci waarin wordt benadrukt dat richtlijn 2000/78 enkel een concretisering is van het algemene beginsel van non-discriminatie op grond van leeftijd en het algemene non-discriminatie beginsel als zodanig (kennelijk) voldoet aan de eisen van technische geschiktheid voor directe werking.

De zaak AMS maakt duidelijk dat het ingeroepen grondrecht in de gegeven situatie zelfstandig moet volstaan om aan particulieren een subjectief recht te 
verlenen waarop een beroep kan worden gedaan. Het is duidelijk dat in AMS niet aan deze eis was voldaan. Het in die zaak ingeroepen verbod kon wel worden afgeleid uit de richtlijn, maar niet uit het Handvest. In Mangold en Kücükdeveci daarentegen kon het verbod van discriminatie op grond van leeftijd wel als zodanig uit het Handvest worden afgeleid (en ook uit de richtlijn). Het is erg jammer, dat het Hof de vraag naar de technische geschiktheid van het grondrecht in Dominguez heeft overgeslagen. Hier deed zich, net als AMS, de situatie voor dat de richtlijn meer behelsde dan een enkele concretisering van artikel 31, lid 2, van het Handvest; terwijl artikel 31, lid 2, van het Handvest enkel rept van het bestaan van een recht op jaarlijkse betaalde vakantie, bepaalt de richtlijn dat dit recht vier weken verlof behelst. Het verschil met AMS is echter, dat het in die zaak ingeroepen recht wel degelijk als rechtstreeks toepasselijk rechtsvoorschrift kan worden afgeleid uit de bewoordingen van artikel 31, lid 2, van het Handvest (alleen). In Dominguez stond namelijk enkel het bestaan van het recht op vakantie ter discussie staat en niet de periode ervan. In zoverre is de richtlijn wel enkel een concretisering van artikel 31, lid 2, van het Handvest en voldeed artikel 31, lid 2, van het Handvest in casu aan de eisen van technische geschiktheid. De vraag rest waarom in Dominguez het Handvest dan niet is toegepast. Zoals eerder opgemerkt zou de reden kunnen zijn dat het Handvest ratione temporis niet van toepassing was in het hoofdgeding.

\subsection{Tweede voorwaarde: nationale overheidshandeling}

Zoals reeds is opgemerkt ging het in Mangold, Kücükdeveci en AMS om 'horizontale directe werking variant toetsing van overheidshandelen'. Dit betekent dat er sprake moet zijn van een geschil waarin een nationale overheidshandeling het onderwerp vormt van toetsing aan het Unierechtelijke grondrecht. Anders gezegd: de gestelde schending van het grondrecht (bijv. de discriminatie) moet terug te voeren zijn op een overheidshandeling. Hierbij doet het niet ter zake om wat voor een soort overheidshandelen het gaat. Unierechtelijk is het enkel relevant dat het gaat om handelen dat is toe te schrijven aan de overheid (de lidstaat). Het kan dus ook (juist) gaan om privaatrechtelijke regelingen. In de zaken Mangold, Kücükdeveci en AMS ging het om regelingen op het terrein van het arbeidsrecht.

Uit de rechtspraak kan niet worden afgeleid of Uniegrondrechten ook horizontale directe werking hebben indien de gestelde grondrechtenschending niet is terug te herleiden tot nationale regelgeving, maar louter berust op een handeling of gedraging van een private partij (horizontaal directe werking 'variant toetsing particulier handelen'). Een arrest waarin mogelijk een 
voorschot is genomen op deze mogelijkheid is het arrest HK Danmark. ${ }^{6}$

HK Danmark betrof een horizontaal geding waarin ten aanzien van een particuliere bedrijfspensioensverzekering een beroep werd gedaan op het Unieverbod van leeftijdsdiscriminatie. Het Hof overwoog als opmerking vooraf:

"17. Vooraf dient te worden vastgesteld dat het hoofdgeding gaat over een geschil tussen twee particulieren over een beweerde leeftijdsdiscriminatie die niet voortvloeit uit een wettelijk vereiste of een collectieve arbeidsovereenkomst, maar uitsluitend uit de tussen Kristensen en Experian gesloten arbeidsovereenkomst (...).”

Er is ook een nationale wettelijke regeling in het spel, namelijk een bepaling van de Deense antidiscriminatiewet die luidt als volgt:

„Niettegenstaande het bepaalde in de $\S 2$ tot en met 5 verzet deze wet zich niet tegen de vaststelling, in ondernemings- en sectoriële regelingen inzake sociale zekerheid, van een toetredingsleeftijd, noch tegen het gebruik, in het kader van die regelingen, van leeftijdscriteria in de actuariële berekeningen. Het gebruik van leeftijdscriteria mag niet leiden tot discriminatie op grond van geslacht."

Deze bepaling in de Deense wet geeft uitvoering aan artikel 6, lid 2, van richtlijn 2000/78 die luidt als volgt:

“2. Niettegenstaande artikel 2, lid 2, kunnen de lidstaten bepalen dat de vaststelling, in ondernemings- en sectoriële regelingen inzake sociale zekerheid, van een toetredingsleeftijd of van een leeftijd voor het verkrijgen van het recht op pensioen- of invaliditeitsuitkeringen, inclusief de vaststelling van verschillende leeftijden voor werknemers of voor groepen of categorieën werknemers, in de ondernemings- en sectoriële regelingen inzake sociale zekerheid, en het gebruik, in het kader van die regelingen, van leeftijdscriteria in de actuariële berekeningen, geen discriminatie op grond van leeftijd vormt, mits dat niet leidt tot discriminatie op grond van geslacht."

Daar waar de verwijzende rechter de vraag stelde in termen van de uitleg van artikel 6, lid 2, van de richtlijn en de mogelijkheden voor de lidstaten onder deze bepaling, lijkt het Hof de weg in te slaan van de horizontale directe werking van de richtlijn op de particuliere handeling, de bedrijfspensioensverzekering. $\mathrm{Na}$ de vaststelling door het Hof dat het gaat om een geschil tussen particulieren,

6 HvJEU van 26 september 2013, zaak C-476/11, HK Danmark. 
wordt gewezen op de vaste rechtspraak op grond waarvan een richtlijn geen horizontale directe werking hebben. Vervolgens wordt als volgt overwogen:

"19. Daarnaast moet echter eveneens in herinnering worden gebracht dat het Hof de gelding van een beginsel van non-discriminatie op grond van leeftijd heeft erkend, dat als een algemeen beginsel van het recht van de Unie moet worden beschouwd en dat voor het gebied van arbeid en beroep in richtlijn 2000/78 nader is uitgewerkt (zie in die zin reeds aangehaald arrest Kücükdeveci, punt 21). Het verbod van iedere discriminatie, met name op grond van leeftijd, is opgenomen in artikel 21 van het Handvest (...), dat sinds 1 december 2009 dezelfde juridische waarde heeft als de Verdragen.”

20. Het beginsel van non-discriminatie op grond van leeftijd geldt in een situatie als in het hoofdgeding echter slechts als die situatie binnen de werkingssfeer van het recht van de Unie valt (arrest Kücükdeveci, punt 23).

21. Dat is in de onderhavige zaak het geval. Ten eerste beoogt $§ 6 a$ van de antidiscriminatiewet immers uitvoering te geven an artikel 6 , lid 2, van richtlijn 2000/78. Het is binnen deze context - en in ieder geval na het verstrijken van de termijn voor de uitvoering van richtlijn 2000/78 door de betrokken lidstaat, die voor het Koninkrijk Denemarken is verstreken op 2 december 2006 - dat de beweerde discriminerende handelswijze in het hoofdgeding zich heeft voorgedaan.

22. Ten tweede valt de beweerde discriminerende bedrijfspensioenverzekering in het hoofdgeding binnen de werkingssfeer van richtlijn 2000/78. (...)

31. Uit het voorgaande volgt dat het in artikel 21 van het Handvest vervatte beginsel van non-discriminatie op grond van leeftijd, dat nader is uitgewerkt in richtlijn 2000/78, de basis dient te vormen voor het onderzoek van de vraag of het recht van de Unie in de weg staat aan een bedrijspensioenverzekering als aan de orde in het hoofdgeding." (cursivering MdM)

Het opmerkelijke aan deze overwegingen is dat de bedrijfspensioensverzekering (een particuliere handeling) wordt getoetst aan artikel 21 van het Handvest en niet de nationale wettelijke regeling (publieke handeling). ${ }^{7}$ Desondanks acht ik het te vroeg om op basis van dit arrest te concluderen dat de mogelijkheid van horizontale directe werking variant 'toetsing van overheidshandelen' reeds door het Hof is aanvaard. Uiteindelijk blijkt artikel 21 van het Handvest niet in de weg te staan aan een bedrijfspensioenregeling, waardoor de gevolgen die een nationale rechter in een dusdanige situatie moet verbinden aan een onverenigbaarheid met artikel 21 van het Handvest ongewis blijft. Daarnaast kan ik mij maar moeilijk voorstellen dat het Hof een dusdanige principiële stap zo geruisloos en in een kleine kamer zou nemen. Ik meen dan

7 Zie ook HK Danmark punten 33, 54 en 69 en het dictum. 
ook dat de vraag naar de horizontale directe werking variant 'toetsing particulier handelen' nog open staat en dat toekomstige rechtspraak moet worden afgewacht.

\subsection{Derde voorwaarde: uitvoeringshandeling}

In deel II is reeds ingegaan op de rol van artikel 51, lid 1, van het Handvest als toegangspoort voor directe werking; de directe werking van grondrechten kan alleen aan de orde zijn bij de toepassing van Unierecht. Dit wordt ook bevestigd door de arresten Mangold, Kücükdeveci en AMS. In alle drie de arresten wordt expliciet vastgesteld, dat het moet gaan om situaties die vallen binnen de werkingssfeer van het Unierecht. ${ }^{8}$ Zo overweegt het Hof in Kücükdeveci:

"23. Het beginsel van non-discriminatie op grond van leeftijd geldt in een situatie als in het hoofdgeding alleen als die situatie binnen de werkingssfeer van het recht van de Unie valt."

In AMS overweegt het Hof

"42. (...) uit vaste rechtspraak volgt dat de in de rechtsorde van de Unie gewaarborgde grondrechten toepassing kunnen vinden in alle situaties die door het recht van de Unie worden beheerst (zie arrest van 26 februari 2013, Åkerberg Fransson, C-617/10, nog niet gepubliceerd in de Jurisprudentie, punt 19).”

Aldus legt het Hof de koppeling met artikel 51, lid 1, van het Handvest. Dit overigens zonder deze bepaling expliciet te noemen, de koppeling blijkt uit de verwijzing naar het arrest $\AA$ kerberg Fransson en het aldaar genoemde criterium dat het moet gaan om een situaties 'die door het recht van de Unie worden beheerst'. ${ }^{9}$ Dit betekent dat artikel 51, lid 1, van het Handvest ook een sleutelrol vervult bij de horizontale directe werking van Uniegrondrechten.

Uit de arresten Mangold, Kücükdeveci en AMS blijkt dat de door het Hof gehanteerde systematiek in horizontale zaken dezelfde is als bij verticale zaken. Het vertrekpunt is de litigieuze nationale overheidshandeling die het onderwerp vormt van de toetsing aan het betreffende discriminatieverbod. Het is deze nationale handeling die moet kwalificeren als uitvoeringshandeling van Unierecht. In Mangold was zulks het geval omdat de nationale wettelijke

8 Mangold, punt 75; Kücükdeveci, punt 25; AMS, punt 42.

9 AMS, punt 42. 
regeling kwalificeerde als een uitvoeringsmaatregel van richtlijn 1999/70.10 In Kücükdeveci was het algemeen beginsel van non-discriminatie op grond van leeftijd van toepassing, omdat de aan de orde zijnde nationale regeling een materie behandelde die onder richtlijn 2000/78 valt, de voorwaarden voor ontslag. ${ }^{11}$ In deze zaak kwamen overigens ook de temporele aspecten aan bod waarbij het Hof aanknoopte bij de feiten van het hoofdgeding. Voor de toepasselijkheid van het non-discriminatiebeginsel was relevant dat 'de gestelde discriminerende handelswijze in het hoofdgeding op grond van de aan de orde zijnde nationale regeling' zich voor deed na het verstrijken van de termijn voor de omzetting door de betrokken lidstaat van richtlijn 2000/78.12 In AMS overwoog het Hof, dat de in het hoofdgeding aan de orde zijnde nationale regeling richtlijn 2002/14 uitvoert.13 In deze arresten ging het dus steeds om Wachauf-situaties. ${ }^{14}$

De vraag die nog openstaat is of Uniegrondrechten ook in aanmerking komen voor horizontale directe werking variant 'toetsing overheidshandelen" indien het gaat om een nationale handelingen die kwalificeren als ERT-uitvoering. ${ }^{15}$ Het ligt voor de hand dat dit inderdaad het geval zal zijn. Een vroeg voorbeeld van ERT-uitvoering in een horizontaal geding is Familiapress. ${ }^{16}$ Het ging in deze zaak om de toetsing van een publiekrechtelijke nationale maatregel aan een Unierechtelijk grondrecht (artikel 10 EVRM als algemeen rechtsbeginsel) en wel in een geding tussen particulieren. Het is echter wat voortvarend om deze zaak te kwalificeren als een voorbeeld 'avant la lettre' van Mangold /Kücükdeveci. In deze zaak werd immers geen aandacht besteed aan het horizontale element en aan de gevolgen die de rechter in een geding tussen particulieren zou moeten verbinden aan de eventuele constatering van onverenigbaarheid met artikel 10 EVRM als algemene beginsel van Unierecht. Desondanks illustreert het arrest wel in wat voor een soort situatie sprake kan zijn van ERT-uitvoering in een geschil tussen particulieren. Eveneens illustratief voor de wijze waarop het Handvest in een horizontaal geding in beeld kan komen is het arrest

10 Mangold, punt 75.

11 Kücükdeveci, punt 25. Zie hierover hoofdstuk 4.4.

12 Kücükdeveci, punten 24-25.

13 AMS, punt 43.

14 De lijn Wachauf ziet op alle nationale maatregelen waarbij de lidstaten Unierecht uitvoeren als vertegenwoordiger van de Unie (zie hoofdstuk 4).

15 De ERT-lijn ziet op nationale maatregelen die in beginsel in strijd zijn met een verbodsbepaling van Unierecht (bijv. een vrije verkeerbepaling), maar waarbij de overheid een beroep doet op een Unierechtelijke rechtvaardigingsgrond (zie hoofdstuk $5)$.

16 Het arrest is behandeld en samengevat in hoofdstuk 5.2.1. 
Pelckmans. ${ }^{17}$ Deze zaak betrof een geding tussen tuincentra over het zeven dag per weken open zijn. De verwerende partijen in het hoofdgeding hielden hun tuincentra zeven dagen per week open. Pelckmans stelde zich op het standpunt dat deze praktijk in strijd is met de Belgische Openingsurenwet, en verzocht de rechtbank van koophandel te Antwerpen om de staking van deze praktijk te bevelen en deze verwerende partijen te gelasten een rustdag per week in acht te nemen. De verwijzende rechter wenste te vernemen of de Belgische Openingsurenwet verenigbaar was met de artikelen 20 en 21 van het Handvest in samenhang met de Verdragsbepalingen inzake het vrije verkeer van goederen en diensten. Het Hof oordeelde echter dat het Handvest niet van toepassing was, omdat er geen concreet element in de zaak aanwezig was waardoor de aan de orde zijnde juridische situatie binnen het toepassingsgebied van het Unierecht valt en wel met name omdat de nationale wettelijke regeling niet viel onder de vrije verkeersbepalingen.

\subsection{Vierde voorwaarde: samenspel met Uniewetgeving}

De vraag die rijst is of de Mangold en Kücükdeveci- horizontale directe werking steeds geldt zodra het betreffende Unierechtelijke grondrecht ex artikel 51, lid 1, van het Handvest van toepassing is, of dat er nog een bijkomende voorwaarde moet zijn vervuld. In beide zaken blijkt namelijk een zeer prominente rol van richtlijn 2000/78. Dit komt het meest duidelijk naar voren in Kücükdeveci waarin het Hof consequent spreekt van 'het beginsel van nondiscriminatie op grond van leeftijd, zoals geconcretiseerd door richtlijn 2000/78'.18 Voorts was richtlijn 2000/78 in de beide zaken materieel van toepassing. In beide zaken ging het om een nationale arbeidsrechtelijk regelingen die (i) vielen binnen het bereik van richtlijn 2000/78 inzake arbeid en beroep waarin (ii) het ingeroepen verbod van discriminatie op grond van leeftijd is uitgewerkt. Verder fungeerde richtlijn 2000/78 steeds als 'de facto' toetsingskader. Daarbij is richtlijn 2000/78 een richtlijn die van toepassing is in de private sector.

17 HvJEU van 8 mei 2014, zaak C-483/12, Pelckmans, punten 9, 24-25.

18 Kücükdeveci, punten 27 en 53. De Duitse taalversie (procestaal) luidt als volgt: 'Verbots der Diskriminierung wegen des Alters in seiner Konkretisierung durch die Richtlinie 2000/78'. Zie ook het arrest HvJEU van 11 april 2013, gevoegde zaken C-335/11 en C337/11, HK Danmark, punten 31, 32, 37, 69 en dictum: "het artikel 21 van het Handvest vervatte beginsel van non-discriminatie op grond van leeftijd, dat nader is uitgewerkt in richtlijn 2000/78 (...) en meer in het bijzonder de artikelen 2 en 6, lid 1, van deze richtlijn.” 
Het is denkbaar dat deze omstandigheden een rol hebben gespeeld bij de overwegingen van het Hof terzake van de erkenning van horizontale directe werking. Wellicht heeft enkel 'het verbod van discriminatie op grond van leeftijd, zoals geconcretiseerd door richtlijn 2000/78' horizontale directe werking en niet 'het verbod van discriminatie op grond van leeftijd' als zodanig. Dit zou betekenen dat alleen sprake zou zijn van horizontale directe werking van discriminatieverboden in situaties die vallen binnen de materiële werkingssfeer van de non-discriminatierichtlijn waarin ze zijn geconcretiseerd. ${ }^{19}$ Zo zou de horizontale directe werking van het verbod van discriminatie op grond van leeftijd zijn gekoppeld aan richtlijn 2000/78 en enkel gelden op het terrein van arbeid en beroep.

De arresten bevatten echter ook aanwijzingen die er op duiden dat het wel degelijk gaat om de horizontale directe werking van het algemene beginsel van non-discriminatie op grond van leeftijd als zodanig, dat wil zeggen ook zonder de toevoeging 'zoals geconcretiseerd in richtlijn 2000/78'. De restrictieve lezing van de Mangold en Kücükdeveci waarbij alleen 'het verbod van discriminatie op grond van leeftijd, zoals geconcretiseerd door richtlijn 2000/78' horizontale directe werking toekomt, zou betekenen dat deze arresten niet meer zijn dan een omzeiling van het verbod van horizontale directe werking van richtlijnen. Echter, als enkel omzeiling de bedoeling zou zijn geweest had het Hof kunnen volstaan met het formuleren van een uitzondering op dit verbod. Dit heeft het Hof niet gedaan. In plaats daarvan is welbewust gekozen voor een andere dogmatische benadering, die uitgaat van de directe werking van een algemeen beginsel van Unierecht. Uit het arrest blijkt ook niet dat het de bedoeling was om de werking van dit algemene beginsel te beperken tot het terrein van arbeid en beroep. Integendeel het Hof spreekt expliciet in Kücükdeveci van de (gehele) werkingssfeer van het Unierecht:

"23. Het beginsel van non-discriminatie op grond van leeftijd geldt in een situatie als in het hoofdgeding alleen als die situatie binnen de werkingssfeer van het recht van de Unie valt.”

Tot slot fungeerde richtlijn 2000/78 in het arrest Mangold niet als 'activator' van het algemene beginsel van non-discriminatie op grond van leeftijd. In deze zaak was het beginsel van toepassing omdat de betreffende nationale regeling een uitvoeringsmaatregel was van een andere richtlijn, richtlijn 1999/70. Richtlijn 2000/78 kon in die zaak ook niet worden toegepast, omdat de termijn voor omzetting nog niet was verstreken.

19 Zie Muir 2011. 
Het arrest AMS verschaft op dit punt geen uitsluitsel, maar lijkt wel te wijzen in de richting van horizontale directe werking van het grondrecht als zodanig. Allereerst wordt hier zonder voorbehoud in gezegd, dat de in de rechtsorde van de Unie gewaarborgde grondrechten toepassing kunnen vinden in alle situaties die door het recht van de Unie worden beheerst. ${ }^{20}$ Bovendien wordt in het dictum expliciet voor recht verklaard, dat artikel 27 in dit geding van het Handvest 'alleen' of 'gelezen in samenhang met de bepalingen van richtlijn 2002/14/EG' geen horizontale directe werking heeft. ${ }^{21}$ Dit lijkt open te laten dat artikel 27 'alleen' (dat wil zeggen zonder de richtlijn) horizontale directe werking zou kunnen hebben. Diezelfde suggestie gaat uit van de overweging waarin staat dat het beginsel van non-discriminatie op grond van leeftijd, neergelegd in artikel 21, lid 1, van het Handvest, 'op zich volstaat' om aan particulieren een subjectief recht te verlenen waarop als zodanig een beroep kan worden gedaan. ${ }^{22}$ Toch is het nog nodig een slag om de arm te houden. Ook in deze zaak speelt de richtlijn een prominente rol. Ook hier gaat het om een situatie die valt binnen het toepassingsgebied van de richtlijn (richtlijn 2002/14/EG) en toetst het Hof eerst aan de richtlijn.

Samenvattend meen ik dat het samenspel met de richtlijn in Kücükdeveci niet doorslaggevend is geweest en dat deze vierde voorwaarde niet zal blijken te bestaan. Voorlopig is het echter op basis van de beschikbare arresten nog geen uitgemaakte zaak. Het is daarom verstandig om er vooralsnog rekening te houden met een restrictieve uitleg van Mangold en Kücükdeveci op grond waarvan enkel het verbod van discriminatie op grond van leeftijd, zoals geconcretiseerd door richtlijn 2000/78' horizontale directe werking heeft en niet 'het verbod van discriminatie op grond van leeftijd' als zodanig. Meer algemeen gezegd moet voorlopig worden uitgegaan van een dubbele toegangspoort. Allereerst de algemene toegangspoort van artikel 51, lid 1, van het Handvest, op grond waarvan de litigieuze nationale overheidshandeling moet vallen binnen het toepassingsgebied van het Unierecht. En ten tweede de bijzondere toegangspoort voor horizontale geschillen, op grond waarvan de situatie in het hoofdgeding moet vallen binnen het toepassingsgebied van Uniewetgeving die het ingeroepen grondrecht concretiseert in private verhoudingen. Voor zaken waarin niet voldaan is aan de tweede toegangspoort zou het nuttig zijn om prejudiciële vragen te stellen aan het Hof. ${ }^{23}$

20 AMS, punt 42.

21 Zie ook AMS, punten 23 en 41.

22 AMS, punt 47.

23 Wellicht dat de aanhangige zaak C-117/14, Nisttahuz Poclava (Juzgado de lo Social no. 23 de Madrid d.d. 11 maart 2014) die ziet op de horizontale directe werking van artikel 30 van het Handvest (ontslagbescherming) een kans biedt om duidelijkheid te verschaffen. 


\subsection{Beschouwing in het licht van de allocatie van bevoegdheden}

\subsubsection{Algemeen}

In deze paragraaf wordt de horizontale directe werking à la Kücükdeveci beschouwd in het licht van het beginsel van allocatie van bevoegdheden. Dit hoofdstuk borduurt voort op de constitutionele context gegeven in hoofdstuk 7. Bij de beschouwing zal niet alleen aandacht worden besteed aan de gevolgen van Kücükdeveci die nu reeds vaststaan (paragraaf 9.6.2), maar zullen ook de openstaande vragen worden behandeld in het licht van het allocatiebeginsel (paragrafen 9.6.3 tot en met 9.6.5).

\subsubsection{Horizontale directe werking variant toetsing van overheidshandelen}

Volle werking als grondslag

Het is duidelijk, dat het Hof in Mangold en Kücükdeveci het belang van de volle werking van het beginsel van non-discriminatie op grond van leeftijd welbewust heeft laten prevaleren. Hiervoor heeft het Hof bezwaren uit het oogpunt van het beginsel van rechtszekerheid en het beginsel van allocatie van bevoegdheden opzij geschoven. Dit is niet expliciet zichtbaar in de arresten, maar volgt impliciet uit het arrest bezien in de context van de procedure voor het Hof. De lidstaten hebben in die procedure zowel schriftelijk als mondeling rechtszekerheids- en bevoegdheidsverdelingsbezwaren met klem voor het voetlicht gebracht. Deze punten kwamen ook terug in de academische discussie en in de conclusies van verschillende advocaten -generaal. Hieruit kan dus worden afgeleid dat het Hof een groot gewicht heeft toegekend aan de effectiviteit van het algemene Uniebeginsel van non-discriminatie.

In hoofdstuk 7.5.2.3 is reeds opgemerkt dat het effectiviteitsbeginsel enkel als grondslag voor de erkenning van horizontale directe werking van grondrechten van de Unie kan dienen als vast staat dat (bepaalde) Uniegrondrechten effect zouden moeten sorteren in (bepaalde) particuliere verhoudingen. Het Hof slaat deze belangrijke voorvraag echter over. Dit is vanuit het oogpunt van legitimiteit en rechtszekerheid hinderlijk.

Nieuwe functie en rol van Uniegrondrechten?

Mogelijk heeft het Hof met deze verwijzing naar de 'volle werking' een nieuwe principiële stap gezet in het Unierechtelijke systeem van grondrechten op grond waarvan grondrechten niet alleen de overheid, maar ook particulieren binden. Dit zou niet alleen een tournure binnen het Unierecht betekenen dat tot 
dusver uitging van een klassieke functie van grondrechten op grond van het rechtstaatbeginsel, maar is ook ingrijpend voor het merendeel van de lidstaten waar deze functie van grondrechten nog niet algemeen is aanvaard. ${ }^{24}$ Bovendien zou dit mijns inziens evident in strijd komen met artikel 51, lid 1, van het Handvest op grond waarvan het Handvest enkel dwingend is voor nationale en Unie overheden. Het is afwachten of de rechtspraak van het Hof inderdaad zo moet worden begrepen. Het Hof geeft immers geen uitleg.

\section{Offocus op verticale component?}

Het kan ook zijn dat het Hof niet uitgaat van de gebondenheid van particulieren aan grondrechten, maar dat de focus in de zaken Mangold en Kücükdeveci ligt op het verticale element; de overheidshandeling die het onderwerp vormt van de toetsing en waarop de bindende kracht van het Handvest wel van toepassing kan zijn. Indien het Hof inderdaad de verticale component als uitgangspunt neemt en niet uitgaat van de gebondenheid van particulieren aan grondrechten, is geen sprake van een evidente frictie met artikel 51, lid 1, van het Handvest.

Zoals ook opgemerkt in hoofdstuk 7.5.2.3 legitimeert dit nog niet het aannemen van middel van horizontale directe werking. Het Hof had kunnen kiezen voor een meer terughoudende opstelling door bijvoorbeeld aansluiting te zoeken bij de leer van de positieve verplichtingen van het EHRM en daarbij gebruik te maken van de Unierechtelijke vangnetten 'conforme interpretatie'25 en 'staatsaansprakelijkheid' ${ }^{26}$. Tevens kan worden gedacht aan een met het

24 Zie ook Timmermans 2004, p. 389: "The authority of the court depends in the first place on the persuasive character of its decisions and their reasoning. But in cases of a more constitutional nature, the Court will inevitably have to take into consideration the possible reception of its decisions in Member States when ruling on an issue.”

25 Van nationaal recht of de uitleg van Unierecht in overeenstemming met de grondrechten (HvJEU van 18 juli 2013, zaak C-426/11, Alemo-Herron, punt 30; HvJEU van 15 mei 2014, zaak C-135/13, Szatmári Malom, punt 70). Zie ook HvJEU van 29 januari 2008, zaak C-275/06, Promusicae, punten 68 en 70: In deze zaak maakt het Hof gebruikt van een tweetrapsraket door erop te wijzen dat de lidstaten (1) verplicht zijn om hun nationale recht richtlijnconform uit te leggen en (2) de richtlijn grondrechtconform uit te leggen. Zie ook HvJEU van 11 november 2011, zaak C-70/10, Scarlet, punt 54; HvJEU van 27 maart 2014, zaak C-314/12, UPC Telekabel, punt 46; A-G Cruz Villalón van 22 mei 2014, zaak C-201/13, Deckmyn, punten 76 en 85.

$26 \mathrm{Bij}$ grondrechtconfome interpretatie zou het gaan om de plicht om het nationale recht zoveel mogelijk uit te leggen in overeenstemming met Uniegrondrechten. Bij staataansprakelijkheid zou het dan gaan om aansprakelijkheid wegens schending van een eventuele plicht van de lidstaat om een schending van een grondrecht te voorkomen in een horizontale situatie. Zie naar analogie HvJEU van 9 december 1997, zaak C-265/95, Commissie/ Frankrijk (Spaanse aardbeien), punt 31 en HvJEU van 12 juni 2003, zaak C- 
leerstuk van de nationale procedurele autonomie ${ }^{27}$ vergelijkbare systematiek: het Hof stelt op het niveau van het Unierecht vast dat (bepaalde) Uniegrondrechten in een gegeven horizontale situatie effect moeten sorteren (bestaan van derdenwerking). Ingevolge het beginsel van loyale samenwerking rust (ook) op de nationale rechters de plicht om dit te bewerkstelligen. Het is echter een aangelegenheid van de interne rechtsorde van elke lidstaat om te bepalen op welke wijze dit gebeurt, waarbij de lidstaten evenwel gehouden zijn in elk geval een doeltreffende bescherming van die rechten in de betreffende horizontale situatie te verzekeren. Met name moet worden voldaan aan het gelijkwaardigheidsbeginsel en het doeltreffendheidsbeginsel. De keuze voor dit lichtere geschut was mijns inziens gezien de constitutionele context gepast geweest en wel om de volgende redenen.

\section{Redenen voor een meer genuanceerde benadering}

Ten eerste impliceert ook de variant 'toetsing van overheidshandelen' van horizontale directe werking een vorm van derdenwerking die weliswaar minder indringend is dan horizontale directe werking variant 'toetsing van particulier handelen', maar die toch verder gaat dan het in de meeste lidstaten geaccepteerde gebruik van grondrechten als instrument van uitleg van open normen.

Ten tweede is in de horizontale context naast het effectiviteitsbeginsel ook het rechtszekerheidsbeginsel van belang; de rechtszekerheid van de particuliere wederpartij kan bij de horizontale directe werking van grondrechten in het geding zijn. ${ }^{28}$ Dit is ook zichtbaar in Mangold en Kücükdeveci. Door te oordelen dat de nationale rechter verplicht is om met dit beginsel onverenigbare regelingen buiten toepassing te laten, óók in een geding tussen particulieren, is aan benadeelde partijen als meneer Mangold en mevrouw Kücükdeveci een effectief rechtsmiddel in handen gegeven. De rompslomp van een aparte schadestaatprocedure ${ }^{29}$ werd hen aldus bespaard. De keerzijde is de positie van de wederpartijen van meneer Mangold en mevrouw Kücükdeveci. Neem bijvoorbeeld de rechtspositie van Swedex GmbH, de werkgever van mevrouw Kücükdeveci. Door de horizontale directe werking van het grondrecht wordt Swedex GmbH geconfronteerd met een langere ontslagtermijn dan aanvankelijk op basis van de nationale wet gold. Hoe verhoudt zich dit tot het

112/00, Schmidberger, punt 60. Zie voor alternatieven voor horizontale directe werking ook: De Vries \& Van Mastrigt 2013, p. 274-276.

27 Zie algemeen over dit leerstuk hoofdstuk 4.5.1.

28 Zie Mazák \& Moser 2013, p. 80 incl. voetnoot 103.

29 Immers zonder het aannemen van horizontale directe werking zouden voor deze partijen enkel nog overblijven het vangnet van de staatsaansprakelijkheid wegens schending van Unierecht. HvJEU van 19 november 1991, C-6/90 en C- 9/90, Francovich. 
rechtszekerheidsbeginsel dat eveneens een algemeen beginsel van Unie recht is? ${ }^{20}$ Had Swedex GmbH moeten begrijpen dat de Duitse bepaling in strijd was met een Uniegrondrecht? Relevant hierbij is dat geen sprake was van een flagrante schending van het verbod van discriminatie op grond van leeftijd en dat het onderzoek naar de verenigbaarheid van de nationale regeling met het non-discriminatie beginsel complex is. ${ }^{31} \mathrm{Had}$ Swedex $\mathrm{GmbH}$ onder deze omstandigheden moeten weten of begrijpen dat het Unie beginsel de expliciete Duitse bepaling opzij zou kunnen zetten?

Ten derde komt een benadering die inzoomt op het verticale element neer op het opsplitsen van het leerstuk van horizontale directe werking in de twee varianten 'toetsing van overheidshandelen' en 'toetsing van particulier handelen', waarbij de eerste variant wel wordt erkend en de tweede niet. Een dusdanige benadering is niet coherent met de rechtspraak van het Hof op grond waarvan richtlijnen horizontale directe werking geheel ontberen wegens het ontbreken van gebondenheid van particulieren aan richtlijnen. ${ }^{32}$

\section{Afwezigheid van motivering}

Tot slot moet worden opgemerkt, dat nu het Hof desondanks heeft gekozen voor een controversiële benadering hij er beter aan zou hebben gedaan om zorgvuldig te motiveren wat de grondslag is van de horizontale directe werking. Dit zou mogelijk hebben bijgedragen aan de aanvaardbaarheid van de benadering en aldus hebben kunnen voorzien in legitimiteit achteraf. In elk geval zouden er dan minder onduidelijkheden zijn geweest dan nu het geval is, hetgeen ten goede zou zijn gekomen aan de rechtszekerheid.

\subsubsection{Openstaande vraag: relevantie van Uniewetgeving in private sector}

In paragraaf 9.5 is opgemerkt dat onduidelijk is of de Mangold/Kücükdeveci horizontale directe werking enkel geldt voor 'verboden van discriminatie zoals geconcretiseerd in non-discriminatierichtlijnen' of dat het ook geldt voor verboden van discriminatie als zodanig. Het is denkbaar dat het Hof de toepasselijkheid van een non-discriminatierichtlijn die ziet op de private sector heeft laten meewegen in zijn erkenning van horizontale directe werking. Deze richtlijnen zijn immers een uiting van de wil van de Uniewetgever om de betref-

30 Zie bijvoorbeeld HvJEU 14 januari 2010, zaak C-226/08, Stadt Papenburg, par. 45

31 Uit de rechtspraak over het verbod van discriminatie op grond van leeftijd blijkt dat het oordeel naar de verenigbaarheid met het nationale recht behoorlijk complex kan zijn. Vergelijk bijvoorbeeld Palacios de la Villa, punten 56-57 en 68; Age Concern, punt 44.

32 Zie hoofdstuk 7.5.5.2; Mazák \& Moser 2013, p. 81. 
fende discriminatieverboden in bepaalde private sectoren van toepassing te doen zijn. De wetgever heeft die gebieden aangewezen. Door de horizontale directe werking van discriminatieverboden (of grondrechten in het algemeen) enkel te erkennen in situaties waarin de Uniewetgever het betreffende discriminatieverbod van toepassing heeft verklaard in particuliere verhoudingen wordt de bepaling van het toepassingsgebied overgelaten aan de Uniewetgever.

Op het eerste gezicht lijkt een dusdanige beperking van de horizontale directe werking respectvol te zijn naar de wetgever; globaal gezien sluit de horizontale directe werking immers aan bij beslissingen van de Uniewetgever. Een wat preciezere blik onthult echter de vreemde situatie waarin het Hof de ene keuze van de Uniewetgever wel respecteert (de sector waarin het verbod horizontaal geldt), maar de andere keuze niet (namelijk de keuze om het verbod via de nationale wetgeving van toepassing te doen zijn). ${ }^{33}$ Dat is hinken op twee gedachten.

Het hele samenspel tussen algemeen beginsel en richtlijn in Mangold| Kücükdeveci is ook nog om een andere reden dubieus. Delen van de richtlijn krijgen als onderdeel van het grondrecht een eigen en nieuwe zelfstandig leven. ${ }^{34}$ Dit doorkruist het Unierechtelijke systeem van rechtsbronnen. Het zou zuiverder zijn om in gevallen waarin een non-discriminatierichtlijn van toepassing is, de rol van non-discriminatiebeginsel te beperken tot (1) instrument van uitleg en (2) toetsingsmaatstaf voor het beoordelen van de geldigheid van de richtlijn. Er zou dan grote terughoudendheid moeten worden betracht om het non-discriminatiebeginsel als autonome regel toe te passen. Het wel toepassen van het non-discriminatiebeginsel als autonome regel kan er immers toe leiden, zoals advocaat-generaal Colomer opmerkte in zijn conclusie in Michaeler, "dat de invloedssfeer van de richtlijnen, via de achterdeur en buiten de democratische besluitvormingsprocedures om, zou worden uitgebreid". 35

Ik meen dan ook, dat het Hof in toekomstige zaken over de horizontale directe werking van grondrechten er goed aan zou doen om de innige verstrengeling tussen richtlijn en grondrecht te verbreken en een duidelijk onderscheid aan te brengen tussen enerzijds de toepassing van het grondrecht en anderzijds de

33 Zie ook Mazák \& Moser 2013, p. 82.

34 Mazák \& Moser 2013, p. 81: "Its inherent logic amounts to a coincidence of opposites whereby the general principle and the directive appear in relation to each other at the same time as separate and mutually dependent, corroborative and undermining, causal and resultant".

35 A-G Ruiz-Jarabo Colomer van 24 januari 2008, gevoegde zaken C-55/07 en C-56/07, Michaeler, punten 17-25. 
toepassing van secundair recht. Met name zou het grondrecht volledig moeten worden ontkoppeld van de richtlijn. Deze ontkoppeling zou ten eerste moeten gelden voor de vraag naar de horizontale directe werking van het primairrechtelijke grondrecht. Het zou niet zo moeten zijn dat de beantwoording van deze principiële vraag afhangt van het secundaire recht. Ten tweede zou ook de inhoud van het grondrecht niet moeten worden bepaald aan de hand van secundairrechtelijke bepalingen. Dit betekent dat moet worden nagegaan wat de precieze inhoud is van het grondrecht als zodanig en welke zaken product zijn of zouden moeten zijn van wetgevende keuzes. Deze zaken zouden dan niet in aanmerking moeten worden genomen bij de inhoudelijke toets aan het grondrecht. Zo zou een discriminatieverbod als algemeen rechtsbeginsel of ex artikel 21 van het Handvest moeten worden toegepast, zoals advocaat-generaal Sharpston het uitdrukt, in zijn "naakte, onverbloemde vorm", dat wil zeggen dat het moet gaan om een "duidelijke, onbehouwen of willekeurige discriminatie". 36

\subsubsection{Vervolgstap: erkenning van volledige horizontale directe werking?}

In Mangold, Kücükdeveci en AMS ging het om de variant 'toetsing van overheidshandelen". Of de volgende stap de erkenning van volledige horizontale directe werking is inclusief de variant 'toetsing van particulier handelen' moet worden afgewacht. In een zaak waarin het Hof wordt geconfronteerd met deze vraag zal het moeten kiezen tussen twee kwaden.

Het aannemen van horizontale directe werking 'variant toetsing van particulier handelen' zou getuigen van een zeer vergaande vorm van rechterlijk activisme. Dit allereerst omdat artikel 51, lid 1, Handvest zich in mijn ogen verzet tegen het aannemen van dwingende rechtskracht van Uniegrondrechten voor particulieren. ${ }^{37}$ Ten tweede ligt deze variant van horizontale directe werking een stuk gevoeliger in het algemene debat over de derdenwerking van grondrechten. De werkelijke gebondenheid van particulieren aan grondrechten is in de lidstaten maar zelden aanvaard. ${ }^{38}$

Het afwijzen van horizontale directe werking 'variant toetsing van particulier handelen' echter leidt tot een differentiatie van het leerstuk van horizontale directe werking in twee varianten. Hetgeen zou leiden tot incoherenties met de

36 A-G Sharpston van 22 mei 2008, zaak C-427/06, Bartsch, punt 49.

37 Zie hoofdstuk 7.5.3.1.

38 Zie hoofdstuk 7.3. 
rechtspraak inzake de horizontale directe werking van richtlijnen. ${ }^{39}$ Immers daar geldt dat nu richtlijnen niet dwingend zijn voor particulieren, zij in het geheel geen horizontale directe werking hebben. ${ }^{40}$

\subsubsection{Nieuwe problematiek bij aanvaarding van volledige horizontale directe werking (1): toepassing van artikel 51, lid 1 , van het Handvest}

Als het Hof de horizontale directe werking 'toetsing van particulier handelen' zou aanvaarden, boort dit een geheel nieuwe problematiek aan: de bepaling van wanneer zuiver particuliere handelingen binnen het toepassingsgebied van het Unierecht vallen. Oftewel: de kwalificatie van particuliere handelingen als 'uitvoering' of 'toepassing' van Unierecht in de zin van artikel 51, lid 1, Handvest. De problematiek doet zich nog niet voor bij de huidige horizontale directe werking 'toetsing van overheidshandelen' à la Kücükdeveci, omdat in deze context voor de toepassing van artikel 51, lid 1, Handvest 'gewoon' bij de nationale overheidshandeling kan worden aangeknoopt. Bij zaken waarin het zal gaan om de horizontale directe werking 'toetsing van particulier handelen' ligt dit anders. Het gaat dan niet om toetsing van een overheidsregelingen aan het Uniegrondrecht, maar om de toetsing van een zuivere private handelingen. Indien het Hof zou overgaan tot de erkenning van horizontale directe werking 'toetsing van particulier handelen' rijst dan ook de vraag of en zoja wanneer dit soort handelingen kunnen kwalificeren als uitvoeringshandelingen van Unierecht.

Op grond van een strikte lezing van artikel 51, lid 1, van het Handvest kunnen private handelingen nimmer kwalificeren als de 'uitvoering van Unierecht'. Immers het concept van uitvoering wordt in deze bepaling expliciet gekoppeld aan het handelen van de lidstaten:

"De bepalingen van dit Handvest zijn gericht tot de instellingen, organen en instanties van de Unie met inachtneming van het subsidiariteitsbeginsel, alsmede, uitsluitend wanneer $z i j$ het recht van de Unie ten uitvoer brengen, tot de lidstaten. (...) (cursivering MdM)"

39 Zie hoofdstuk 7.5.3.2.

40 Overigens moet worden opgemerkt dat er ook kritische kanttekeningen kunnen worden geplaatst bij de benadering van het Hof inzake de werking van richtlijnen. Zie hierover Craig 2009, p. 349-378. 
Deze observatie hangt nauw samen met mijn eerdere stelling dat artikel 51, lid 1, van het Handvest zich verzet tegen de mogelijkheid van horizontale rechtstreekse werking variant 'toetsing van particulier' handelen, omdat particulieren niet als rechtssubject in artikel 51, lid 1, van het Handvest staan genoemd. ${ }^{41}$ Als het Hof derhalve over dit obstakel heen mocht stappen door over te gaan tot de erkenning van volledige horizontale directe werking, impliceert dit waarschijnlijk ook dat het zal uitgaan van een ruime lezing van artikel 51, lid 1, van het Handvest waarbij uitsluitend wordt gekeken naar het concept van 'de toepassing van Unierecht' (en de koppeling met het 'handelen door de lidstaat' wordt losgelaten). De vraag die dan rijst is onder welke omstandigheden private handelingen als 'uitvoering van Unierecht' of 'toepassing van Unierecht' kunnen kwalificeren.

In deel II van dit proefschrift is gebleken dat Uniegrondrechten accessoire rechten zijn en derhalve enkel van toepassing zijn in situaties waarin een specifieke regel van materieel Unierecht in het geding is. Dit zal vanzelfsprekend ook moeten gelden in een horizontale context. ${ }^{42}$ In deel II van dit proefschrift is voorts uiteengezet dat in de rechtspraak twee hoofdcategorieën van uitvoering/toepassing Unierecht zichtbaar zijn: de lijnen Wachauf en ERT. Situaties die onder deze lijnen kunnen worden gebracht zijn Unierechtelijk en de grondrechten van de Unie zijn daarop van toepassing. Situaties die buiten deze lijnen vallen zijn zuiver nationaal. Deze lijnen in de rechtspraak zijn geënt op overheidshandelen. In hoeverre zijn deze lijnen toepasbaar op privaat handelen?

\section{De Wachauf-lijn en private handelingen}

In de lijn Wachauf gaat het om de lidstaat als vertegenwoordiger van de Unie, als vooruitgeschoven Uniepost. ${ }^{43}$ Zuiver particulier handelen zal niet snel kwalificeren als Wachauf-uitvoering. Particulieren fungeren normaal gesproken niet als vooruitgeschoven Uniepost. Wel is het denkbaar dat lidstaten de uitvoering van Unierecht aan particulieren 'uitbesteden'. Een voorbeeld zou kunnen zijn artikel 18 van richtlijn 2000/78 op grond waarvan de lidstaten de sociale partners kunnen belasten met de uitvoering van deze richtlijn. In een dusdanige situatie is in feite al geen sprake meer van zuiver privaat handelen en een zuiver horizontale situatie, maar is eerder sprake van een (quasi) verticale setting.

41 Zie hoofdstuk 7.5.3.1.

42 Dit blijkt ook uit HvJEU van 22 november 2005, zaak C-144/04, Mangold, punt 75; HvJEU van 19 januari 2010, zaak C-555/07, Kücükdeveci, punt 23 en HvJEU van 15 januari 2014, zaak C-176/12, AMS, punt 42.

43 Zie hoofdstuk 4. 
Voorzichtigheid moet worden betracht met de subcategorie die is besproken in hoofdstuk 4.4 en die is gebaseerd op het arrest Kücükdeveci. Op basis van deze benadering zijn de grondrechten van toepassing op nationale overheidshandelingen die binnen de materiële werkingssfeer van een richtlijn vallen. Ik heb in die context opgemerkt dat deze benadering gerechtvaardigd is, mits het gaat om handelingen die een uiting zijn van een verzuim tot implementatie. Als de stap naar volledige horizontale directe werking van grondrechten is gezet, zou het misschien verleidelijk kunnen zijn om deze benadering toe te passen op private handelingen waardoor Uniegrondrechten op talloze private rechtsverhoudingen van toepassing zouden zijn, namelijk in alle verhoudingen die worden bestreken door Unie richtlijnen. ${ }^{44}$ Bedacht moet dan worden dat de ratio van verzuim tot implementatie per definitie niet opgaat voor private handelingen. Richtlijnen zijn immers niet bindend voor particulieren. ${ }^{45}$ Dit betekent dat richtlijnen ook niet gebruikt zouden moeten worden om de toepassing van grondrechten op privaat handelen te activeren. ${ }^{46}$

\section{De ERT-lijn en private handelingen}

De ERT-lijn ziet op nationale maatregelen die in beginsel in strijd zijn met een verbodsbepaling van Unierecht (klassiek gezien met een vrije verkeersbepaling), maar waarbij een beroep wordt gedaan op een Unierechtelijke rechtvaardigingsgrond. ${ }^{47}$ De toepassing van het Uniegrondrecht vindt plaats in het onderzoek naar de vraag of een beperkende maatregel kan worden gerechtvaardigd. Nationale beperkende maatregelen die onverenigbaar zijn met Uniegrondrechten kunnen niet worden gerechtvaardigd. Concreet betekent dit dat beperkende maatregelen die tevens een inmenging vormen op een grondrecht moeten worden getoetst aan dat grondrecht.

$\mathrm{Nu}$ de horizontale directe werking 'toetsing van particulier handelen' van vrije verkeersbepalingen een feit is, ${ }^{48}$ zou de ERT-route ook toepasbaar kunnen zijn als het Hof de stap zet naar de erkenning van horizontale directe werking

44 Ik denk aan de non-discriminatierichtlijnen die worden behandeld in hoofdstuk 10.4, maar ook kan worden gedacht aan private handelingen die vallen onder privaatrechtelijke richtlijnen bijvoorbeeld inzake oneerlijke contractsbedingen (richtlijn 93/13), misleidende en vergelijkende reclame (richtlijn 2006/114), overeenkomsten op afstand (richtlijn 97/7) en consumentenkoop en -garanties (richtlijn 99/44). Zie voor een kort overzicht van privaatrechtelijke richtlijnen: Hartkamp 2011-2, annex I.

45 Zie ook hoofdstuk 10.5.2.

46 Zie ook hoofdstuk 10.5.2. Heikel in dit opzicht zou kunnen zijn HvJEU van 11 april 2013, gevoegde zaken C-335/11 en C-337/11, HK Danmark, punt 22.

47 Ziehoofdstuk 5.

48 HvJEU van 11 december 2007, zaak C-438/05, Viking Line en HVJEU van 18 december 2007, zaak C-341/05, Laval. 
'toetsing van particulier handelen' van grondrechten. Sterker nog, ik vermoed dat indien Uniegrondrechten inderdaad dwingend recht zouden blijken te zijn voor particulieren, dit met name relevant zal blijken te zijn in deze context. Bij de vraag of de beperking door private partij $A$ op het recht op vrije verkeer van private partij B kan worden gerechtvaardigd, zou partij B dan kunnen aanvoeren dat A niet alleen zijn recht op vrije verkeer beperkt, maar ook inbreuk maakt op een grondrecht. Het gevolg hiervan zou zijn het handelen van A ook moet worden getoetst aan het grondrecht.

Overigens merk ik op, dat de effectuering van Uniegrondrechten in deze juridische context ook vorm kan worden gegeven door middel van de grondrechtconforme uitleg van Unierecht. De toepassing van grondrechten zou kunnen plaatsvinden op het niveau van de uitleg van de Unierechtelijke rechtvaardigingsgrond. Op deze wijze kan de doorwerking van Uniegrondrechten worden geëffectueerd zonder dat hiervoor de gebondenheid van particulieren hoeft te worden aangenomen. 49

\subsubsection{Nieuwe problematiek bij aanvaarding van volledige horizontale directe werking (2): welke grondrechten?}

Indien het Hof de horizontale directe werking 'toetsing van particulier handelen' van grondrechten zou aanvaarden is het de vraag welke grondrechten hiervoor in aanmerking komen. De beantwoording van deze vraag hangt allereerst af van de grondslag van de toegekende directe werking. Afhankelijk van deze grondslag zal de horizontale directe werking a priori voor alle grondrechten kunnen gelden (bijvoorbeeld als het Hof uit zou gaan van een endogene rol van grondrechten ${ }^{50}$ ) of enkel voor sommige (bijvoorbeeld de grondrechten die op grond van de rechtspraak van het EHRM effect moeten sorteren in particuliere verhoudingen ${ }^{51}$ of grondrechten waarvan het Hof anderszins zou oordelen dat ze zien op private verhoudingen).

Als een grondrecht a priori in aanmerking komt voor horizontale directe werking moet (vanzelfsprekend) ook nog worden gekeken of het betreffende grondrecht hiervoor technisch geschikt is. ${ }^{52}$ Een vraag die in toekomstige rechtspraak moet worden beantwoord is of alle grondrechten die in een verticale context technisch geschikt zijn bevonden ook automatisch technisch

49 Vergelijk de systematiek in: A-G Cruz Villalón van 22 mei 2014, zaak C-201/13, Deckmyn, punten 76 en 85.

50 Zie voor dit begrip hoofdstuk 7.3.

51 Zie hoofdstuk 7.4.

52 Vergelijk hoofdstuk 9.2. 
geschikt moeten worden bevonden voor directe werking in een horizontale context. Het is niet eenvoudig om deze vraag in abstracto te beantwoorden, omdat de technische geschiktheid voor directe werking nauw is gerelateerd aan hetgeen in een concreet geschil wordt gevorderd. Ik kan mij echter voorstellen dat in een horizontale context eerder geconcludeerd zal moeten worden dat enkel een marginale toetsing aan het grondrecht aan de orde zal kunnen zijn op grond waarvan alleen aperte schendingen kunnen worden 'gesanctioneerd'. 53

\subsection{Conclusies}

1. Uniegrondrechten kunnen horizontale directe werking hebben. De bestaande rechtspraak laat nogal wat onduidelijkheden over het hoe, waarom en wanneer. Dit noopt tot een voorzichtige benadering omtrent het aannemen van horizontale directe werking van Uniegrondrechten. Op basis van de huidige stand van het recht kan het bestaan van horizontale directe werking van Uniegrondrechten worden aangenomen indien is voldaan aan vier voorwaarden:

i. Het ingeroepen grondrecht moet ten eerste technisch geschikt zijn om in het hoofdgeding rechtstreeks te worden toegepast.

Als aan deze voorwaarde niet is voldaan, staat vast dat geen sprake is van horizontale directe werking van het Uniegrondrecht.

ii. Het gaan om een grondrechtenschending die is te herleiden tot een nationale overheidshandeling. Het onderwerp van toetsing aan het Uniegrondrecht dient derhalve een overheidshandeling te zijn.

Als het gaat om een particuliere handeling en aan deze voorwaarde derhalve niet is voldaan, bestaat twijfel over het bestaan van horizontale directe werking van het Uniegrondrecht.

iii. Deze overheidshandeling moet kwalificeren als een handeling die Unierecht ten uitvoer legt of Unierecht toepast ex artikel 51, lid 1, van het Handvest.

Als aan deze voorwaarde niet is voldaan, staat vast dat geen sprake is van horizontale directe werking van het Uniegrondrecht.

iv. De situatie in het hoofdgeding valt binnen het materiële toepassingsgebied van Uniewetgeving die het betreffende grondrecht concretiseert.

Als aan deze voorwaarde niet is voldaan, bestaat twijfel over het bestaan van horizontale directe werking van het Uniegrondrecht.

53 Zie ook Temple Lang 2013, p. 110-112. 
2. Het aannemen van de horizontale directe werking à la Kücükdeveci staat op gespannen voet met het beginsel van allocatie van bevoegdheden. Met name omdat het gaat om een vorm van derdenwerking van Uniegrondrechten die binnen de lidstaten niet algemeen is geaccepteerd en het onduidelijk is op grond waarvan het aannemen ervan noodzakelijk is. Bovendien levert horizontale directe werking spanning op met het rechtszekerheidsbeginsel. Er bestaan lichtere middelen om de doorwerking van grondrechten in particulieren verhoudingen (daar waar dat nodig zou zijn bijvoorbeeld uit hoofde van het EVRM) te bewerkstelligen en waarbij de klassieke verticale functie van grondrechten wordt behouden. De meest voor de handliggende methoden zijn de plicht tot grondrechtconforme interpretatie, het leerstuk van staatsaansprakelijkheid en de systematiek van de nationale procedurele autonomie. De gebrekkige motivering draagt bovendien niet bij aan de legitimiteit van de benadering.

3. Een expliciete beperking in toekomstige rechtspraak van horizontale directe werking à la Kücükdeveci tot 'grondrechten zoals geconcretiseerd in Uniewetgeving' zou niet leiden tot een verminderding van spanning met het beginsel van allocatie van bevoegdheden. Het zou integendeel juist zuiverder zijn om horizontale directe werking à la Kücükdeveci los te koppelen van de toepassing van materieel recht dat grondrechten concretiseert. Bovendien is dit ook duidelijker en gemakkelijker in de toepassing.

4. Vroeg of laat komt het Hof voor de vraag te staan of de grondrechten van de Unie volledige horizontale directe werking (d.w.z. inclusief de variant 'toetsing van particulier handelen') hebben. Het Hof bevindt zich dan in een positie waarin het moet kiezen tussen twee kwaden:

i. Acceptatie van horizontale directe werking 'toetsing particulier handelen': in dit geval staat vast dat particulieren gebonden kunnen zijn aan Uniegrondrechten, hetgeen in mijn ogen evident in strijd is met artikel 51, lid 1, van het Handvest.

ii. Afwijzing van horizontale directe werking 'toetsing particulier handelen': in dit geval ontstaat een splitsing tussen het concept van horizontale directe werking in twee varianten ('toetsing particulier handelen' en 'toetsing overheidshandelen') die zich moeilijk laat rijmen met het verbod van beide varianten van horizontale directe werking van richtlijnen.

5. Als het Hof de variant 'toetsing particulier handelen' zou aanvaarden, boort dit een geheel nieuwe problematiek aan. Allereerst de bepaling van wanneer zuiver particuliere handelingen binnen het toepassingsgebied van het Unierecht vallen. Oftewel: de kwalificatie van particuliere handelingen als 'uitvoering' of 'toepassing' van Unierecht in de zin van artikel 51, lid 1, Handvest. De toepassing van artikel 51, lid 1, Handvest op privaat handelen 
vereist een ruime en kunstmatige uitleg ervan. De lijn ERT lijkt het meest in aanmerking te komen voor toepassing op particulier handelen en wel in samenhang met de horizontale directe werking van de vrije verdragsbepalingen. Ten tweede is het de vraag welke grondrechten voor horizontale directe werking 'toetsing van particulier handelen' in aanmerking komen. De beantwoording van deze vraag zal afhangen van de grondslag van de horizontale directe werking en van hoe in een horizontale context moet worden omgegaan met de eisen van technische geschiktheid van een grondrecht. 



\section{HOOFDSTUK 10}

\section{DISCRIMINATIEVERBODEN}

\section{$10.1 \quad$ Inleiding}

In dit hoofdstuk wordt op basis van de analyse Mangold /Kücükdeveci gelezen in samenhang met AMS (hoofdstukken 8 en 9) ingegaan op de concrete gevolgen van deze rechtspraak voor discriminatieverboden uit hoofde van het algemene beginsel van non-discriminatie en artikel 21 van het Handvest. De reden om de bespreking van de concrete gevolgen te beperken tot discriminatieverboden is dat de horizontale directe werking hiervan binnen het Unierecht een voortrekkersrol vervult. Het is het enige grondrecht dat thans op basis van de arresten Mangold en Kücükdeveci horizontale directe werking heeft. De horizontale directe werking van andere grondrechten bevindt zich nog in een veel priller stadium. Op basis van AMS is weliswaar duidelijk dat andere grondrechten horizontale directe werking kunnen hebben, maar er is nog geen rechtspraak waarin het daadwerkelijk is toegekend. In dit hoofdstuk zal eerst worden onderzocht op welke discriminatieverboden deze directe werking van toepassing is (paragraaf 10.2). Ten tweede wordt onderzocht in welke situaties discriminatieverboden horizontale directe werking à la Kücükdeveci kunnen hebben (paragraaf 10.3). Volledigheidshalve wordt bij de bespreking van de verboden van discriminatie op grond van geslacht en nationaliteit ook aandacht besteed aan de horizontale directe werking van uitwerkingen van deze verboden in de artikelen 18, 45, lid 2 en 157 VWEU. Tot slot worden de bevindingen in dit hoofdstuk besproken in het licht van het beginsel van allocatie van bevoegdheden (paragraaf 10.4).

\subsection{Welke discriminatieverboden?}

\subsubsection{Algemeen}

De arresten Mangold en Kücükdeveci zien op het verbod van discriminatie op grond van leeftijd als algemeen rechtsbeginsel. ${ }^{1}$ In paragraaf 10.2.2 wordt eerst onderzocht in hoeverre de aanpak ook geldt voor andere discriminatieverboden. Hierbij wordt gekeken of de aanpak ook geldt voor het verbod van discriminatie op grond van leeftijd uit hoofde van artikel 21 van het Handvest.

1 HvJEU van 22 november 2005, zaak C-144/04, Mangold; HvJEU van 19 januari 2010, zaak C-555/07, Kücükdeveci. 
Voorts wordt in paragraaf 10.2.3 ingegaan op discriminatie op andere gronden dan leeftijd. Zoals zal blijken zal de Mangold /Kücükdeveci-benadering zo goed als zeker gelden voor alle discriminatieverboden op de gronden die zijn genoemd in artikel 19 VWEU (geslacht, ras of etnische afstamming, godsdienst of overtuiging, handicap, leeftijd en seksuele geaardheid). Hierbij maakt het geen verschil of het nu gaat om discriminatieverboden uit hoofde van artikel 21 van het Handvest of als algemene beginselen van Unierecht.

\subsubsection{Verbod van leeftijdsdiscriminatie ex artikel 21 van het Handvest}

In de beide zaken Mangold en Kücükdeveci ging het om de toepassing van het verbod van discriminatie op grond van leeftijd als algemeen beginsel van Unierecht. De Mangold en Kücükdeveci- horizontale directe werking geldt derhalve in elk geval voor dit discriminatieverbod. Het verbod van discriminatie op grond van leeftijd is ook neergelegd in artikel 21 van het Handvest. De eerste vraag is derhalve of het verbod van discriminatie op grond van leeftijd uit hoofde van deze bepaling eveneens horizontale directe werking heeft of dat Mangold |Kücükdeveci enkel geldt voor het algemene beginsel van nondiscriminatie op grond van leeftijd. Uit het arrest AMS lijkt te volgen dat dit het geval is. Het Hof overweegt in deze uitspraak onder verwijzing naar Kücükdeveci immers dat: ${ }^{2}$

"47. (...) het (...) beginsel van non-discriminatie op grond van leeftijd, neergelegd in artikel 21, lid 1, van het Handvest, op zich volstaat om aan particulieren een subjectief recht te verlenen waarop als zodanig een beroep kan worden gedaan."

Het algemene rechtsbeginsel van non-discriminatie en artikel 21 van het Handvest worden in een adem genoemd. Ik acht het zo goed als zeker dat het Hof de Mangold en Kücükdeveci- horizontale directe werking ook zal aannemen voor het verbod van discriminatie op grond van leeftijd uit hoofde van artikel 21 van het Handvest. Ook los van de genoemde overweging uit AMS ligt dit voor de hand. Het algemene beginsel van non-discriminatie op grond van leeftijd is immers gelijk aan het verbod van discriminatie op grond van leeftijd in artikel 21 van het Handvest. Het gaat om hetzelfde grondrecht. ${ }^{3}$ Dit blijkt uit

2 HvJEU van 15 januari 2014, zaak C-176/12, AMS.

3 Zie ook de authentieke Duitse taalversie van de arresten Mangold en Kücükdeveci waarin ook in de context van het algemene rechtsbeginsel van non-discriminatie op grond van leeftijd steeds wordt gesproken van 'het verbod van discriminatie op grond van leeftijd' welke terminologie gelijk is aan artikel 21 van het Handvest. 
het arrest Prigge waarin het Hof met betrekking tot de verhouding tussen het algemene rechtsbeginsel en artikel 21 Handvest als volgt overwoog:4

\begin{abstract}
“38. Wat de toepassing van richtlijn 2000/78 betreft, zij eraan herinnerd dat het Hof het bestaan heeft erkend van een beginsel van non-discriminatie op grond van leeftijd dat als een algemeen beginsel van het recht van de Unie moet worden beschouwd (...) Het verbod van iedere discriminatie, met name op grond van leeftijd, is opgenomen in artikel 21 van het Handvest van de grondrechten van de Europese Unie (hierna: „Handvest”), dat sinds 1 december 2009 dezelfde juridische waarde heeft als de Verdragen.”
\end{abstract}

Het ligt niet voor de hand om ten aanzien van hetzelfde grondrecht voor wat betreft de doorwerking ervan in het nationale recht onderscheid te maken tussen de twee bronnen van primair Unierecht; het Handvest en de algemene rechtsbeginselen. Of anders gezegd als het verbod van discriminatie op grond van leeftijd als algemeen rechtsbeginsel horizontale directe werking heeft dan heeft hetzelfde verbod uit hoofde van het Handvest dat vermoedelijk ook. Immers, zoals is opgemerkt in hoofdstuk 2.1 staan de beide bronnen van Uniegrondrechten (algemene rechtsbeginselen en het Handvest) op voet van gelijkheid naast elkaar en kunnen zij in beginsel ook gelijktijdig worden toegepast. Een tweesporenbeleid met betrekking tot de horizontale directe werking van hetzelfde grondrecht zou daarom vanuit het oogpunt van de coherente toepassing van de twee primairrechtelijke bronnen van Unie grondrechten onwenselijk zijn. ${ }^{5}$ Daar komt bij dat de grondslag voor het aannemen van horizontale directe werking van het discriminatieverbod als rechtsbeginsel evenzeer zal gelden voor hetzelfde verbod uit hoofde van het Handvest. Deze grondslag was immers 'de noodzaak de volle werking van het beginsel van non-discriminatie op grond van leeftijd te verzekeren'. ${ }^{6}$ Vermoedelijk zal deze noodzaak onverminderd gelden bij de toepassing van artikel 21 van het Handvest.

4 HVJEU van 13 september 2011, zaak C-447/09, Prigge, punt 38. Zie ook A-G Cruz Villalón 19 mei 2011, zaak C-447/09, Prigge, punt 26. Kücükdeveci, punt 22.

5 Vergelijk in dit verband A-G Trstenjak 8 september 2011, zaak C-282/10, Dominguez, punt 29. Die het argument overigens precies omgekeerd gebruikt, namelijk daar waar een recht uit het Handvest horizontale directe werking ontbeert (in casu artikel 31, lid 2, van het Handvest) deze werking ook niet zou moeten worden gegeven aan hetzelfde recht als algemene rechtsbeginsel. Ik deel haar mening. Echter bij het beginsel van nondiscriminatie op grond van leeftijd als is de toekenning van horizontale directe werking al een voldongen feit.

6 Kücükdeveci, punt 53. 


\subsubsection{Verboden van discriminatie op andere gronden dan leeftijd}

De volgende vraag is dan voor welke andere discriminatieverboden uit hoofde van de algemene rechtsbeginselen of artikel 21 van het Handvest de Mangold |Kücükdeveci-benadering nog meer geldt. Kan op basis van Mangold en Kücükdeveci reeds voor andere discriminatieverboden horizontale directe werking worden aangenomen of moet daarvoor worden gewacht op toekomstige rechtspraak? Naar mijn mening is het zo goed als zeker, dat de Mangold en Kücükdeveci- horizontale directe werking niet enkel geldt voor het verbod van discriminatie op grond van leeftijd, maar ook voor andere discriminatieverboden die zijn genoemd in artikel 21 van het Handvest. ${ }^{7}$

Ook hier geldt dat het doortrekken van de lijn Mangold en Kücükdeveci naar andere discriminatieverboden logischerwijze volgt uit de grondslag van de horizontale directe werking, die is 'de noodzaak de volle werking van het beginsel van non-discriminatie op grond van leeftijd te verzekeren'. Niet valt in te zien waarom die noodzaak in mindere mate zal gelden voor andere gronden van non-discriminatie dan de grond leeftijd. Wel is het mijns inziens voorlopig- noodzakelijk om onderscheid te maken tussen enerzijds de in artikel 19 VWEU genoemde gronden (geslacht, ras of etnische afstamming, godsdienst of overtuiging, handicap, leeftijd en seksuele geaardheid) en anderzijds overige in artikel 21 van het Handvest genoemde gronden (nationaliteit, kleur, sociale afkomst, genetische kenmerken, taal, politieke of andere denkbeelden, het behoren tot een nationale minderheid, vermogen, geboorte en de opencategorie 'iedere discriminatie'). Ik zal hierna toelichten waarom.

A. Artikel 19 VWEU-discriminatie gronden: geslacht, ras of etnische afstamming, godsdienst of overtuiging, handicap, leeftijd en seksuele geaardheid

\section{Mangold en Kücükdeveci-horizontale direct werking}

De positie in het Unierecht van de verboden van discriminatie op grond van de andere in artikel 19 VWEU $^{8}$ genoemde gronden (geslacht, ras of etnische

7 Zie ook Prechal 2009, p. 10; A-G Jääskinen van 15 juli 2010, zaak C-147/08, Römer, punt 129.

8 Artikel 19 VWEU (oud artikel 13 VEG) luidt als volgt: “1. Onverminderd de andere bepalingen van de Verdragen, kan de Raad, binnen de grenzen van de door de Verdragen aan de Unie verleende bevoegdheden, met eenparigheid van stemmen, volgens een bijzondere wetgevingsprocedure, op voorstel van de Commissie en na goedkeuring door het Europees Parlement, passende maatregelen nemen om discriminatie op grond van geslacht, ras of etnische afstamming, godsdienst of overtuiging, handicap, leeftijd of seksuele geaardheid te bestrijden. 2. (...)" 
afstamming, godsdienst of overtuiging, handicap, en seksuele geaardheid) is in zeer grote mate vergelijkbaar met het verbod van discriminatie op grond van leeftijd. Ze hebben naast hun plaats in artikel 19 VWEU gemeen dat ze zijn genoemd in het eerste lid van artikel 21 van het Handvest, en zijn geconcretiseerd in Uniewetgeving (gelijke behandelingsrichtlijnen) die van toepassing is in de private sector. ${ }^{9} \mathrm{Ik}$ acht het daarom zo goed als zeker dat de Mangold en Kücükdeveci- horizontale directe werking van toepassing is op deze verboden.

\section{Reeds bestaande horizontale directe werking van artikel 157 VWEU}

Overigens merk ik voor de volledigheid op, dat het verbod van geslachtsdiscriminatie ten aanzien van beloningen van werknemers ook horizontale directe werking heeft middels artikel 157 VWEU.10 Het gaat om volledige horizontale directe werking binnen de werkingssfeer van deze bepaling; horizontale directe werking is derhalve mogelijk in zowel situaties waarin het gaat om de toetsing van overheidshandelen als in situaties die zien op de toetsing van particulier handelen. De werkingssfeer van artikel 157 VWEU is beperkt tot 'beloningen'11 van 'werknemers'12. Andere arbeidsvoorwaarden dan beloning vallen niet onder het toepassingsbereik van artikel 157 VWEU.13

Deze volledige horizontale directe werking van artikel 157 VWEU (indertijd artikel 119 EEG-Verdrag) is voor het eerst erkend in het arrest Defrenne II. ${ }^{14}$ In deze zaak ging het om een geschil tussen een stewardess en haar particulier

9 Richtlijnen 2000/78, 2000/43 en 2004/113

10 Deze bepaling vormt een specifieke uitdrukking van het algemene beginsel van gelijke behandeling: HvJEU van 26 juni 2001, C-381/99, Brunnhofer, punt 28; HvJEU van 17 september 2002, zaak C-320/00, Lawrence, punt 12; HvJEU van 3 oktober 2006, zaak C17/05, Cadman, punt 28 .

11 Dit begrip omvat "alle voordelen die de werkgever direct of indirect aan de werknemer uit hoofde van zijn dienstbetrekking betaalt”: HvJEU van 9 februari 1982, zaak 12/81, Garland, punt 10; HvJEU van 13 februari 1996, C-342/93, Gillespie, punt 12.

12 Als werknemer in de zin van deze bepaling wordt bedoeld iemand die gedurende een bepaalde tijd voor een ander en onder diens gezag prestaties levert waar een vergoeding tegenover staat. Dit betekent, dat de bepaling in beginsel niet van toepassing is op zelfstandige dienstenverrichters, tenzij door het bestaan van een relatie van ondergeschiktheid tot de dienstenontvanger in feite sprake is van een verhulde arbeidsverhouding. HvJEU van 13 januari 2004, zaak C-256/01, Allonby, punten 43, 68 en 71. Dit sluit overigens niet uit, dat in sommige gevallen ook anderen dan de werknemer zich op de bepaling kunnen beroepen, zoals rechtverkrijgenden of de nabestaanden van een werknemer. HvJEU van 6 oktober 1993, C-109/91, Ten Oever, punt 18 en HvJEU van 28 september 1994, zaak C-200/91, Coloroll, punt 18.

() HvJEU van 13 mei 1986, zaak 170/84, Bilka, punt 41.

14 HvJEU van 8 april 1976, zaak 43/75, Defrenne II. 
werkgeefster, Sabena. Onderwerp van geschil was dat vrouwelijke werknemers in salaris waren achtergesteld bij mannelijke collega's die gelijke arbeid verrichtten. Ten aanzien van de directe werking in een geschil tussen particulieren oordeelde het Hof als volgt:

"39. Dat immers artikel 119 dwingend recht is, zodat het verbod van discriminatie tussen mannelijke en vrouwelijke werknemers niet slechts geldt voor overheidshandelingen, doch eveneens van toepassing is op alle overeenkomsten die een collectieve regeling van arbeid in loondienst inhouden, alsmede op contracten tussen particulieren."15

\section{B. Overige discriminatiegronden}

Naast de hierboven genoemde gronden van non-discriminatie noemt artikel 21 van het Handvest nog de gronden nationaliteit, kleur, sociale afkomst, genetische kenmerken, taal, politieke of andere denkbeelden, het behoren tot een nationale minderheid, vermogen en geboorte. Voorts is artikel 21 van het Handvest niet limitatief, maar kent de open categorie 'iedere discriminatie'. Ook voor de discriminatieverboden op deze gronden kan worden gezegd dat horizontale directe werking noodzakelijk is om 'de volle werking van het beginsel van non-discriminatie te verzekeren'. Dit betekent dat er rekening mee moet worden gehouden dat de Mangold/Kücükdeveci- horizontale directe werking op hen van toepassing zal zijn. Het is echter prematuur om hier nu reeds vanuit te gaan. Zoals gezegd blinken de arresten Mangold en Kücükdeveci niet uit in helderheid en zijn de precieze toepassingsvereisten niet vast te stellen. Met name is onduidelijk in hoeverre het samenspel met gelijke behandelingsrichtlijn 2000/78 wezenlijk was voor het anvaarden van horizontale directe werking. Het is juist op dit punt dat de discriminatieverboden op deze 'overige' gronden verschillen van het verbod van discriminatie op grond van leeftijd. In het volgende wordt nader ingaan op de verschillen met het verbod van discriminatie op grond van leeftijd.

\section{B.1 Nationaliteit}

\section{Mangold en Kücükdeveci horizontale directe werking}

Het verbod van discriminatie op grond van nationaliteit is eveneens een algemeen beginsel van Unierecht ${ }^{16}$, maar neemt een bijzondere plaats in. Dit verbod bestaat binnen het Unierecht al veel langer en is neergelegd in artikel 18 VWEU. Ook in artikel 21 van het Handvest staat het apart vermeld, en wel in het tweede lid. Dit verbod van discriminatie komt niet terug in de gelijke behandelingsrichtlijnen die van toepassing zijn in de private sector. Integendeel

15 Zie over de term ‘dwingend’ Lenaerts \& Gutiérrez-Fons 2010, p. 1648, voetnoot 104.

() HvJEU van 27 oktober 2009, zaak C-115/08, ČEZ, punt 91. 
het is er expliciet buiten gelaten. ${ }^{17}$ Het is daarom te vroeg om conclusies te trekken ten aanzien van dit verbod.

Wel moet worden gewezen op het arrest $\check{C} E Z .18$ In dit arrest ging het om de toepassing van het verbod van discriminatie op grond van nationaliteit als algemeen rechtsbeginsel. Het ging om een privaatrechtelijke procedure ingesteld door eigenaren van in Oostenrijk gelegen percelen grond tegen de nabij in Tsjechië gelegen kerncentrale van Temelín. Volgens eisers verhinderde (het risico) van radioactiviteit van de centrale een normaal gebruik van hun grond. Zij vorderden daarom op grond van het Oostenrijks burgerlijk wetboek, dat de centrale een einde moest maken aan de hinder of het gevaar van hinder door radioactieve straling. De Oostenrijkse wet maakt met betrekking tot de ontvankelijkheid van dit soort vorderingen onderscheid tussen enerzijds vorderingen ingesteld tegen installaties met een buitenlandse (niet-Oostenrijkse) vergunning en anderzijds vorderingen ingesteld tegen installaties met een binnenlandse vergunning. Tegen installaties met een buitenlandse vergunning kon wel een preventief rechterlijk bevel worden geëist. Tegen installaties met een binnenlandse vergunning kon dit niet. Nadat dat het Hof vaststelde, dat het verbod van discriminatie op grond van nationaliteit zich verzet tegen de toepassing van een regeling van een lidstaat als die welke in het hoofdgeding aan de orde was, oordeelde het als volgt:

"138. (...) Het staat (...) aan de nationale rechter om de nationale bepalingen die hij moet toepassen, zo veel mogelijk in overeenstemming met de eisen van het gemeenschapsrecht uit te leggen. Indien een dergelijke conforme toepassing onmogelijk is, is de nationale rechter gehouden om het gemeenschapsrecht in volle omvang toe te passen en de door dit recht aan particulieren toegekende rechten te beschermen, waarbij hij zo nodig de nationale bepalingen buiten toepassing moet laten indien de toepassing daarvan in het betrokken geval tot een met het gemeenschapsrecht strijdig resultaat zou leiden (.....”

Op grond van de partijen die het arrest staan vermeld lijkt het erop dat het verbod van discriminatie door ČEZ wordt ingeroepen tegen een overheidspartij, het Land Oberösterreich en dat het derhalve zou gaan om verticale directe werking. Echter uit de feiten van het arrest blijkt dat niet alleen het Land Oberösterreich eisende partij in het hoofdgeding was maar ook 'andere

17 Artikel 3, lid 2 van richtlijn 2000/43: Deze richtlijn is niet van toepassing op verschillen in behandeling gebaseerd op nationaliteit (...) Zie ook artikel 3, lid 2 van richtlijn 2000/78.

18 HvJEU van 27 oktober 2009, zaak C-115/08, ČEZ. Zie De Mol 2010-3. 
particuliere eigenaren'. ${ }^{19}$ Het arrest zou derhalve ook kunnen worden geïnterpreteerd als een voorbeeld van horizontale directe werking variant 'toetsing overheidshandelen'. Nu in de procedure voor het Hof en in het arrest in het geheel geen aandacht wordt besteed aan het horizontale element en de particuliere grondeigenaren bovendien niet staat vermeld als partij bovenaan het arrest, is het wat voorbarig om conclusies te trekken.

Dit arrest vormt, tezamen met de jurisprudentie Mangold en Kücükdeveci aanleiding tot het stellen van prejudiciële vragen. Vooral als zou blijken dat in Mangold en Kücükdeveci het samenspel tussen richtlijn 2000/78 en het algemene beginsel van non-discriminatie op grond van leeftijd niet van belang is geweest bij de erkenning van het bestaan van horizontale directe werking van het algemene beginsel van non-discriminatie op grond van leeftijd, en de benadering van het Hof neer komt op de erkenning van horizontale directe werking van het rechtsbeginsel alleen, lijkt het logisch dat aan het verbod van discriminatie op grond van nationaliteit eenzelfde werking zal toekomen.

\section{Reeds bestaande horizontale directe werking van de artikelen 18 en 45, lid 2, VWEU}

Overigens merk ik, evenals bij het verbod van discriminatie op grond van geslacht, voor de volledigheid op, dat het verbod van discriminatie op grond van nationaliteit reeds horizontale directe werking heeft middels de artikelen 18 en 45 , lid 2 , VWEU.

Artikel 18 VWEU, eerste alinea bevat een algemeen verbod van discriminatie op grond van nationaliteit. ${ }^{20}$ Het Hof heeft de horizontale directe werking van artikel 18 VWEU erkend. Voor wat betreft de mogelijkheid van horizontale directe werking in situaties die de toetsing van particulier handelen impliceren gaat het echter enkel nog om horizontale directe werking in bijzondere omstandigheden. De twee relevante arresten zijn Walrave en Koch en Ferlini.21

$19 \check{C} E Z$, punt 41 .

20 Oud artikel 12 VEG (Verdrag van Amsterdam). Daarvoor artikel 6 (Verdrag van Maastricht). Aanvankelijk artikel 7 (Verdrag van Rome). Deze bepaling is tot het Verdrag van Lissabon tekstueel altijd hetzelfde gebleven. Eerst bij de invoering van het Verdrag van Lissabon is de werkingssfeer ervan uitgebreid. Vanaf de inwerkingtreding daarvan is het verbod niet langer van toepassing binnen de werkingssfeer van het Verdrag, maar van toepassing binnen de werkingssfeer van de "Verdragen". Dit betekent, dat waar voorheen het verbod enkel van toepassing was binnen de oude eerste pijler (het EG-Verdrag) het thans van toepassing is op alle gebieden van het Unierecht. Derhalve ook op het terrein van het gemeenschappelijk buitenlands en veiligheidsbeleid en de ruimte van vrijheid, veiligheid en recht.

21 HVJEU van 12 december 1974, zaak 36/74, Walrave and Koch; HVJEU van 3 oktober 2000, zaak C-411/98, Ferlini. 
In het arrest Walrave en Koch ging het om een geschil voor de rechtbank Utrecht tussen enerzijds de internationale wielrenbond Union Cycliste Internationale en de Nederlandse en Spaanse wielerbonden en anderzijds twee Nederlandse gangmakers van wielrenwedstrijden. Onderwerp van geschil was een bepaling uit het reglement van de internationale wielrenbond betreffende wereldkampioenschappen wielrennen met motorgangmaking, volgens welke "de gangmaker van dezelfde nationaliteit moet zijn als de wielrenner". Ten aanzien van de verenigbaarheid van deze bepaling met het Unierecht overwoog het Hof ten aanzien van onder meer artikel 7 van het EEG -Verdrag (de voorloper van artikel 18 VWEU) als volgt:

"16. Overwegende dat de artikelen 7, 48 en 59 in hun onderscheidene toepassingsgebieden alle discriminaties op grond van nationaliteit verbieden; 17. Dat het verbod van deze discriminaties niet alleen geldt voor het optreden van het openbaar gezag maar zich ook uitstrekt tot bepalingen van andere aard, strekkende tot collectieve regeling van arbeid in loondienst en dienstverrichtingen.”

Uit deze overwegingen blijkt derhalve dat ook particuliere regelingen moeten voldoen aan artikel 7 EEG-Verdrag (thans artikel 18 VWEU). Als reden gaf het Hof:

"18. Dat immers de opheffing tussen de Lid-Staten van belemmeringen voor het vrije verkeer van personen en het vrij verrichten van diensten - fundamentele doelstellingen van de gemeenschap, vermeld in artikel 3 , sub c van het verdrag -, in gevaar zou worden gebracht, indien de opheffing van door de staten gestelde belemmeringen kan worden ontkracht door belemmeringen voortvloeiend uit krachtens hun eigen rechtsbevoegdheid door niet onder het publiekrecht vallende verenigingen of lichamen verrichte handelingen"22

De zaak Ferlini betrof een geding tussen meneer Ferlini en een Luxemburgs ziekenhuis (het Centre hospitalier de Luxembourg, het CHL), ter zake van de kosten van bevalling en verblijf van zijn echtgenote in de kraamkliniek van het CHL. Het door CHL in rekening gebrachte bedrag was het resultaat van onder meer de door de vereniging van Luxemburgse ziekenhuizen ('EHL') eenzijdig en uniform vastgestelde discriminatoire tarieven. Het Hof oordeelde dat

22 Andere redenen voor horizontale directe werking worden ook vermeld in de punten 18 en 19 van dit arrest. Echter deze overwegingen lijken eerder betrekking te hebben op de artikelen 48 en 50 EEG-Verdrag en niet op artikel 7 EEG-Verdrag, de voorloper van artikel 18 VWEU. 
“50. (...) dat artikel 6, eerste alinea, van het Verdrag ook van toepassing is in gevallen waarin een groep of een organisatie als de EHL een zekere macht uitoefent over particulieren en in staat is hun voorwaarden op te leggen waardoor de uitoefening van de door het Verdrag gewaarborgde fundamentele vrijheden wordt bemoeilijkt (zie, in deze zin, arresten van 12 december 1974, Walrave en Koch, 36/74, Jurispr. blz. 1405; 8 april 1976, Defrenne II, 43/75, Jurispr. blz. 455, en 15 december 1995, Bosman, C-415/93, Jurispr. blz. I4921)."

De arresten Walrave en Koch en Ferlini maken duidelijk dat de ratio van de horizontale directe werking van artikel 18 VWEU ligt in de effectiviteit van het vrije verkeer van personen. ${ }^{23}$ De achterliggende gedachte is dat in bepaalde situaties het afwijzen van horizontale directe werking de effectiviteit van het vrije verkeer zou kunnen ondermijnen. In het verlengde hiervan geldt dat bij de huidige stand van de rechtspraak artikel 18 VWEU enkel horizontale directe werking (toetsing particulier handelen) heeft indien de effectiviteit van het vrije verkeer in het geding zou kunnen zijn. Bij gelijkwaardige rechtsverhoudingen zal hiervan geen sprake zijn. Vereist is dan ook dat de discriminerende partij beschikt over een zekere macht. Meer in het bijzonder moet het gaan om macht ter zake van de uitoefening van het vrije verkeer van de gediscrimineerde partij. De mogelijkheid van horizontale directe werking variant toetsing particulier handelen is derhalve (vooralsnog) beperkt tot bijzondere omstandigheden.

Daarnaast heeft artikel 18 VWEU horizontale directe werking in situaties waarin het gaat om de toetsing van overheidshandelen. Dit blijkt uit het arrest Phil Collins. ${ }^{24}$ Deze zaak betrof een civielrechtelijk geschil tussen de zanger Phil Collins en een distributeur van fonogrammen over de verkoop in Duitsland van een cd met opnames van een concert in de VS. De zanger had geen toestemming gegeven voor de opnames. Phil Collins vorderde daarom in kort geding een verbod op de verkoop van de cd. Op grond van het Duitse recht bestond echter geen recht om dit te vorderen. Zulks omdat het optreden buiten Duitsland had plaatsgevonden en Phil Collins niet de Duitse nationaliteit bezat. Voor Duitse kunstenaars daarentegen bestond wel een recht om in rechte een verbod te vorderen van de verbreiding van zonder toestemming vervaardigde opnamen van optredens, en wel ongeacht de plaats van het optreden. Het belangrijkste punt in de procedure voor het Hof was de vraag of het auteursrecht binnen de werkingssfeer van artikel 7 EEG-Verdrag (thans artikel 18 VWEU) viel. Het Hof overwoog als volgt:

23 Zie ook Van den Bogaert 2005, p. 27.

24 HvJEU van 20 oktober 1993, gevoegde zaken C-92/92 en C-326/92, Phil Collins (bevestigd in HvJEU van 30 juni 2005, zaak C-28/04, Tod's, punt 18). 
"27. Uit het voorgaande vloeit voort, dat het auteursrecht en de naburige rechten, die met name wegens hun gevolgen voor het intracommunautaire handelsverkeer van goederen en diensten binnen de werkingssfeer van het Verdrag vallen, aan het algemene non-discriminatiebeginsel van artikel 7 , eerste alinea, van het Verdrag zijn onderworpen, zonder dat het nodig is een verband te leggen met de specifieke bepalingen van de artikelen 30, 36, 59 en 66 van het Verdrag."

Voorts overwoog het Hof dat de betreffende nationale regeling discriminatoir is en onverenigbaar met artikel 7 EEG-Verdrag. Voor wat betreft de doorwerking van deze bepaling in het nationale recht oordeelde het Hof vervolgens als volgt:

"34. Volgens vaste rechtspraak van het Hof vloeit het in artikel 7, eerste alinea, van het Verdrag neergelegde recht op gelijke behandeling rechtstreeks voort uit het gemeenschapsrecht (arrest Cowan, reeds aangehaald, r.o. 11). Derhalve kan voor de nationale rechter een beroep op dit recht worden gedaan teneinde discriminerende nationale bepalingen die de aan eigen onderdanen toegekende bescherming onthouden aan onderdanen van andere Lid-Staten, buiten toepassing te doen verklaren.

35. Mitsdien moet op de gestelde vraag worden geantwoord, dat artikel 7 , eerste alinea, van het Verdrag aldus moet worden uitgelegd, dat auteurs of uitvoerende kunstenaars uit een andere Lid-Staat, of hun rechtverkrijgenden, zich voor de nationale rechter rechtstreeks op het in die bepaling neergelegde non-discriminatiebeginsel kunnen beroepen om de aan de nationale auteurs en uitvoerende kunstenaars voorbehouden bescherming te verkrijgen.”25

Het discriminatieverbod vervat in artikel 45 VWEU is een uitwerking van artikel 18 VWEU. De begunstigden van het verbod zijn migrerende Uniewerknemers. Het verbod geldt ten aanzien van de werkgelegenheid, de beloning en de overige arbeidsvoorwaarden. ${ }^{26}$ Artikel 45 (2) VWEU heeft dezelfde horizontale directe werking als artikel 157 VWEU, dat wil zeggen dat volledige horizontale directe werking mogelijk is in situaties die vallen onder de

25 Opvallend hierbij is dat geen aandacht wordt besteed aan het feit dat het terzake gaat om een geschil tussen twee particulieren. Uit de conclusie van A-G Jacobs van 30 juni 1993 en de schriftelijke opmerkingen van de Commissie d.d. 10 juli 1992 komt evenmin naar voren dat de horizontale context bijzondere aandacht heeft genoten tijdens de procedure.

26 Het recht geldt voor werknemers, maar kan worden ingeroepen door anderen zoals bijvoorbeeld werkgevers of arbeidsbemiddelaars: HvJEU van 11 januari 2007, zaak C208/05, ITC, punten 22 en 23; HvJEU van 13 december 2012, zaak C-379/11, Caves Krier Frères, punt 28 en HvJEU van 16 april 2013, zaak C-202/11, Las, punt 18. 
werkingssfeer van artikel 45, lid 2, VWEU. Dit volgt uit het arrest Angonese. ${ }^{27}$ Deze zaak betrof een geschil tussen Angonese, een Italiaans onderdaan met als moedertaal Duits, die in de provincie Bolzano woont, en een particuliere bankinstelling te Bolzano, de Cassa di Risparmio. Het onderwerp van geschil was de sollicitatie door Angonese op een vacature bij de Cassa di Risparmio. Een onderdeel van de sollicitatieprocedure was een vergelijkend onderzoek. Om tot dit onderzoek te kunnen worden toegelaten was het bezit van een bepaald tweetaligheidsattest (Italiaans/Duits) vereist. Dit attest kon enkel worden verkregen door het doen van een examen dat enkel in de provincie Bolzano werd georganiseerd. De inwoners van de provincie Bolzano hadden de gewoonte, met het oog op het zoeken naar werk, voor alle zekerheid dat attest te behalen. Het behalen van dat attest wordt als een bijna verplichte fase van de normale opleiding gezien. Angonese had zijn opleiding in Oosterijk genoten en beschikte derhalve niet over het arrest. Wel had de verwijzende rechter vastgesteld, dat Angonese, ofschoon niet in het bezit van dat attest, perfect tweetalig was. Angonese had om tot het vergelijkend onderzoek voor de aanwerving van personeel te worden toegelaten, andere stukken overgelegd waaruit zijn tweetaligheid bleek. Desalniettemin ontzegde de Cassa di Risparmio hem de toegang tot het vergelijkend onderzoek, wegens het ontbreken van het gevraagde attest. In de procedure voor het Hof gaat het onder meer om de vraag of een door een werkgever, zoals de Cassa di Risparmio, opgelegde verplichting, die het recht om aan een vergelijkend onderzoek voor de aanwerving van personeel deel te nemen, afhankelijk stelt van het bezit van één enkel diploma, zoals het attest, een met artikel 48 EG (thans artikel 45, lid 2, VWEU) strijdige discriminatie oplevert. Ten aanzien van de toepassing van deze bepaling op particulieren overwoog het Hof als volgt:

"36. Het in artikel 48 van het Verdrag geformuleerde verbod van discriminatie op grond van nationaliteit is derhalve ook van toepassing op particulieren.”

\section{B.2 Kleur, sociale afkomst, genetische kenmerken, taal, politieke of andere}

denkbeelden, het behoren tot een nationale minderheid, vermogen en geboorte

De overige in artikel 21 van het Handvest genoemde verboden van discriminatie (op grond van kleur, sociale afkomst, genetische kenmerken, taal, politieke of andere denkbeelden, het behoren tot een nationale minderheid, vermogen en geboorte) niet uitgewerkt in secundair Unierecht. Het is daarom te vroeg om op grond van Mangold en Kücükdeveci conclusies te trekken ten aanzien van deze discriminatieverboden. Ook hier geldt echter weer dat als de benadering van het Hof neer komt op de erkenning van horizontale directe

27 HvJEU van 16 september 1999, zaak C-218/98, Angonese. 
werking van het rechtsbeginsel als zodanig de kans aanzienlijk is dat Mangold| Kücükdeveci-horizontale directe werking van toepassing zal zijn.

\section{B.3 'Iedere discriminatie'}

Artikel 21 van het Handvest verbiedt tot slot 'iedere discriminatie'. Hier valt dus potentieel elke (gelijke of ongelijke) behandeling onder. Het beginsel van nondiscriminatie verbiedt immers niet enkel de ongelijke behandeling van gelijke gevallen, maar ook de gelijke behandeling van ongelijke gevallen. Daar waar bij discriminatieverboden op specifieke genoemde gronden reeds vast staat wat een verdachte grond voor het maken van onderscheid is, moet bij het verbod van 'iedere discriminatie' eerst worden nagegaan of sprake is van gelijke of ongelijke gevallen. Dit vergt een analyse en impliceert altijd een waardeoordeel. ${ }^{28}$ Het aannemen van horizontale directe werking van een dusdanig open verbod ligt (nog) gevoeliger dan bij het aannemen van een dergelijke werking bij discriminatieverboden op specifieke gronden. Uit Mangold en Kücükdeveci, die zien op discriminatieverboden op specifieke gronden, kan niet worden afgeleid dat het algemene gelijkheidsbeginsel horizontale directe werking heeft.

\subsection{In welke situaties?}

\subsubsection{Algemeen}

In paragraaf 10.2 is vastgesteld, dat de Mangold /Kücükdeveci-horizontale directe werking zo goed als zeker van toepassing is op discriminatieverboden op de in artikel 19 VWEU genoemde gronden. Dit betekent dat voor deze discriminatieverboden de implicaties van Mangold /Kücükdeveci wat preciezer in beeld kunnen worden gebracht dan voor andere discriminatieverboden het geval is. In deze paragraaf zal dan ook voor de discriminatieverboden op de in artikel 19 VWEU genoemde gronden worden na gegaan in welke situaties sprake zou kunnen zijn van horizontale directe werking variant 'toetsing van overheidshandelen'. In hoofdstuk 8.2.3.3 is reeds opgemerkt dat de Kücükdeveci benadering als concreet gevolg heeft de 'de facto' horizontale directe werking variant 'toetsing van overheidshandelen' van discriminatieverboden in nondiscriminatie richtlijnen. Hierop zal in paragraaf 10.3.2 worden ingegaan. In paragraaf 10.3.3 wordt aandacht besteed aan horizontale directe werking variant 'toetsing van overheidshandelen' in situaties die vallen buiten de

28 A-G Mazák van 15 februari 2007, zaak C-411/05, Palacios de la Villa, punten 90-93. A-G Sharpston 22 mei 2008, zaak C-427/06, Bartsch, punt 44-46. 
werkingssfeer van non-discriminatierichtlijnen, maar die wel vallen binnen het toepassingsgebied van het Unierecht.

\subsection{2 'De facto' horizontale directe werking van non-discriminatie richtlijnen}

Deze paragraaf borduurt voort op de vaststelling dat Kücükdeveci als gevolg heeft, dat het verbod van discriminatie op grond van leeftijd in richtlijn 2000/78 'de facto' horizontale directe werking ('toetsing van overheidshandelen') heeft. Voorop moet worden gesteld dat de 'de facto' horizontale directe werking niet voor de hele richtlijn geldt, maar alleen voor de bepalingen in richtlijn 2000/78 die het algemene rechtsbeginsel (of de equivalent in artikel 21 van het Handvest) 'slechts' concretiseren. De onderdelen van de richtlijn die 'verder gaan' dan het rechtsbeginsel hebben - naar mag worden aangenomen - geen 'de facto' horizontale directe werking.

Vooralsnog lijkt het met name te gaan om de horizontale directe werking van de materiële richtlijnbepalingen die invulling geven aan het eigenlijke verbod van discriminatie. Dit sluit allereerst aan bij de authentieke Duitse taalversie, die steeds expliciet spreekt van 'het verbod van discriminatie op grond van leeftijd' als algemeen rechtsbeginsel. Voorts wordt in de beide arresten getoetst aan de artikelen 2 ("Het begrip discriminatie") en 6 ("Rechtvaardiging van verschillen in behandeling op grond van leeftijd") van de richtlijn. Deze bepalingen vormen beiden een bestanddeel van het verbod van discriminatie. Ten derde komt deze benadering overeen met artikel 21 van het Handvest die bevestigt dat het beginsel van non-discriminatie als algemeen rechtsbeginsel in wezen neer komt op een verbod van discriminatie. ${ }^{29}$ Toekomstige rechtspraak zal duidelijk moeten maken aan welke bepalingen uit de richtlijn 'de facto' horizontale directe werking toekomt. Naast de artikelen 2 en 6 die in de zaken Mangold en Kücükdeveci werden toegepast zal artikel 4 ("Wezenlijke beroepsvereisten”) ook moeten worden gezien als 'slechts' een concretisering van het algemene beginsel. De bepalingen uit deel II ("Rechtsmiddelen en handhaving van rechten”) zijn van een andere aard (procedureel) en zullen mogelijk niet worden gezien als een concretisering van het algemene beginsel. In dit verband wordt ook gewezen op het onderscheid dat het Hof in Mangold zelf al maakt tussen enerzijds de inachtneming van het algemene beginsel van gelijke behandeling op grond van leeftijd, en anderzijds de bepalingen uit de richtlijn die er toe

29 Zie HVJEU van 13 september 2011, zaak C-447/09, Prigge, punt 38. Zie ook A-G Cruz Villalón 19 mei 2011, zaak C-447/09, Prigge, punt 26. Kücükdeveci, punt 22. Het algemene beginsel van non-discriminatie op grond van leeftijd is gelijk aan het verbod van discriminatie op grond van leeftijd ex artikel 21 van het Handvest. 
strekken een algemeen kader te creëren voor de bestrijding van discriminatie op grond van leeftijd, vooral wat betreft de organisatie van passende beroepsmogelijkheden, de bewijslast, de bescherming tegen represailles, de sociale dialoog en positieve acties. ${ }^{30}$

Zoals is vastgesteld in paragraaf 10.2 zal de Kücükdeveci benadering zeer vermoedelijk gelden voor alle verboden van discriminatie op de in artikel 19 VWEU genoemde gronden. Deze verboden hebben gemeen dat ze zijn geconcretiseerd in non-discriminatierichtlijnen. Aan deze wetgeving zal vermoedelijk ook de 'de facto' horizontale directe werking à la Kücükdeveci toekomen. In het volgende wordt een overzicht gegeven van de betreffende discriminatieverboden en hun bijbehorende richtlijnen. ${ }^{31}$

\section{A. Verboden van discriminatie op grond van godsdienst of overtuiging, handicap,} leeftijd of seksuele geaardheid (richtlijn 2000/78)

De verboden van discriminatie op grond van godsdienst of overtuiging, handicap, leeftijd of seksuele geaardheid zijn geconcretiseerd in richtlijn 2000/78. Deze concretiseringen zullen dus horizontale directe werking (toetsing overheidshandelen) hebben. Dit betekent dat particulieren deze verboden vis -à-vis andere particulieren kunnen inroepen ter bestrijding van discriminatoire overheidsregelingen die vallen binnen de werkingssfeer van richtlijn 2000/78.

De werkingssfeer van deze richtlijn ziet op een breed scala van zaken die gerelateerd zijn aan arbeid en beroep. Het gaat zowel om arbeid in loondienst als om arbeid als zelfstandige. Blijkens artikel 3 van richtlijn 2000/78 vallen onder de werkingssfeer van de richtlijn:

“a) de voorwaarden voor toegang tot arbeid in loondienst of als zelfstandige en tot een beroep, met inbegrip van de selectie- en aanstellingscriteria, ongeacht de tak van activiteit en op alle niveaus van de beroepshiërarchie, met inbegrip van bevorderingskansen;

b) de toegang tot alle vormen en alle niveaus van beroepskeuzevoorlichting, beroepsopleiding, voortgezette beroepsopleiding en omscholing, met inbegrip van praktijkervaring;

c) werkgelegenheid en arbeidsvoorwaarden, met inbegrip van ontslag en beloning;

30 Mangold, punt 76. In deze overweging gaat het Hof in op de relevantie van de implementatietermijn.

31 Zie over EU non-discriminatierecht: Gijzen 2006; Bell 2004; Schiek \& Chege 2009. 
d) het lidmaatschap van of de betrokkenheid bij een werkgevers- of werknemersorganisatie of enige organisatie waarvan de leden een bepaald beroep uitoefenen, waaronder de voordelen die deze organisaties bieden.”

Zoals eerder is gesteld, zullen alleen de bepalingen van richtlijn 2000/78 die het algemene non-discriminatiebeginsel en artikel 21 Handvest 'slechts' concretiseren 'de facto' horizontale directe werking hebben. De onderdelen van de richtlijn die 'verder gaan' dan het rechtsbeginsel hebben -naar mag worden aangenomen- geen horizontale directe werking. Vooralsnog lijkt het met name te gaan om de horizontale directe werking van de materiële richtlijnbepalingen die invulling geven aan het eigenlijke verbod van discriminatie. Dit zijn in elk geval de artikelen 2 en 6 van richtlijn 2000/78 en waarschijnlijk ook artikel 4 ("Wezenlijke beroepsvereisten").32

Voor wat betreft het verbod van discriminatie op grond van handicap wordt op twee bijzonderheden gewezen. Ten eerste heeft het Hof in Coleman ${ }^{33}$ geoordeeld, dat het verbod van directe discriminatie op grond van handicap niet alleen geldt ten aanzien van personen die zelf gehandicapt zijn, maar ook ten aanzien van personen die worden gediscrimineerd wegens de handicap van hun kind. Ook personen die zijn geassocieerd met gehandicapten kunnen derhalve een beroep doen op de horizontale directe werking van het verbod van discriminatie op grond van handicap.

De tweede bijzonderheid betreft artikel 5 van de richtlijn. Op grond van deze bepaling moet de werkgever, naargelang de behoefte, in een concrete situatie passende maatregelen nemen om een persoon met een handicap te faciliteren. De vraag rijst of artikel 5 van de richtlijn slechts een concretisering is van het algemene non-discriminatiebeginsel en artikel 21 Handvest of dat het verder gaat. Enerzijds kan worden betoogd dat deze positieve verplichting verder gaat dan het verbod tot discriminatie op grond van handicap uit hoofde van het primaire recht. Anderzijds lijkt het Hof in de zaak Chacón Navas de bepaling wel degelijk te zien als onderdeel van het discriminatieverbod. ${ }^{34}$ Het dictum in deze zaak luidt namelijk als volgt:

32 Zie over artikel 6, lid 2, van richtlijn 2000/78: HvJEU van 11 april 2013, gevoegde zaken C-335/11 en C-337/11, HK Danmark, punten 40 e.v. getiteld "Artikel 6, lid 2, van richtlijn $2000 / 78$ als rechtvaardigingsgrond voor het verschil in behandeling op grond van leeftijd".

33 HvJEU van 17 juli 2008, zaak C-303/06, Coleman. Zie over het begrip 'handicap': HvJEU van 11 juli 2006, zaak C-13/05, Chacón Navas; HvJEU van 11 april 2013, gevoegde zaken C-335/11 en C-337/11, HK Danmark.

34 HvJEU van 11 juli 2006, zaak C-13/05, Chacón Navas. 
"Het in de artikelen 2, lid 1, en 3, lid 1, sub c, van richtlijn 2000/78 vastgestelde verbod van discriminatie op grond van handicap op het gebied van ontslag verzet zich tegen een ontslag wegens een handicap dat, rekening houdend met de verplichting om in redelijke aanpassingen voor gehandicapten te voorzien, niet gerechtvaardigd wordt door het feit dat de betrokken persoon niet bekwaam, in staat en beschikbaar is om de essentiële taken van zijn functie uit te voeren."

Het lijkt erop dat het niet nemen van redelijke aanpassingen een relevante factor is in de beoordeling van of al dan niet sprake is van discriminatie. Mogelijk zou dus ook de plicht tot het nemen van redelijke aanpassingen horizontale directe werking kunnen hebben. Overigens lijkt deze vaststelling op het eerste gezicht eerder relevant te zijn in de context van een zaak waarin het gaat om de toetsing van de rechtmatigheid van private handelingen, dan in een situaties waarin het gaat om de toetsing van overheidsmaatregelen.

\section{B. Verboden van discriminatie op grond van ras of etnische afstamming (richtlijn 2000/43)}

De verboden van discriminatie op grond van ras of etnische afstamming zijn geconcretiseerd in richtlijn 2000/43. Ze hebben dus horizontale directe werking (toetsing overheidshandelen) in zaken waarin het gaat om nationale overheidsregelingen die vallen binnen de werkingssfeer van richtlijn 2000/43. ${ }^{35}$ Deze richtlijn heeft een zeer brede werkingssfeer. Ze is niet alleen van toepassing op het hierboven bij richtlijn 200/78 omschreven gebied van arbeid en beroep in loondienst en als zelfstandige, maar is ook daarbuiten van toepassing.

Artikel 3 van richtlijn 2000/43 vermeldt in aanvulling op artikel 3 van richtlijn 200/78 de volgende gebieden:

“e) sociale bescherming, met inbegrip van sociale zekerheid en gezondheidszorg;

f) sociale voordelen;

g) onderwijs;

h) de toegang tot en het aanbod van goederen en diensten die publiekelijk beschikbaar zijn, met inbegrip van huisvesting." 36

35 Richtlijn 2000/43/EG van de Raad van 29 juni 2000 houdende toepassing van het beginsel van gelijke behandeling van personen ongeacht ras of etnische afstamming, PB L 180 van 19.7.2000.

36 Zie bijvoorbeeld zaak Belov. In deze zaak ging het om rechtsverhoudingen tussen eindgebruikers en private aanbieders van diensten van algemeen belang (elektriciteit). De A-G 
Ook hier geldt dat alleen de bepalingen van richtlijn 2000/43 die het algemene non-discriminatiebeginsel en artikel 21 Handvest 'slechts' concretiseren 'de facto' horizontale directe werking hebben. Dit zullen in elk geval de artikelen 2 (het begrip discriminatie) en 4 (wezenlijke en bepalende beroepsvereisten) zijn.

C. Verbod van discriminatie op grond van geslacht (richtlijnen 2004/113, 2006/54 en 2010/41)

Voor Mangold en Kücükdeveci had het verbod van discriminatie op grond van geslacht enkel horizontale directe werking ten aanzien van loondiscriminaties. Bij discriminaties ten aanzien van andere arbeidsvoorwaarden kon in horizontale geschillen geen beroep worden gedaan op de directe werking van het verbod van discriminatie op grond van geslacht. Dit volgde uit de eerder besproken arresten Defrenne II en Marshall. ${ }^{77} \mathrm{Na}$ Mangold en Kücükdeveci is dit onderscheid tussen 'beloning' en 'andere arbeidsvoorwaarden' verdwenen, althans voor wat betreft het bestaan van horizontale directe werking (toetsing overheidshandelen). Het verbod van discriminatie op grond van geslacht kan nu ook direct worden ingeroepen in horizontale geschillen om discriminatoire nationale overheidsregelingen die binnen de werkingssfeer van richtlijn 2006/54 vallen buiten werking te stellen. ${ }^{38}$ Deze richtlijn ziet op arbeid en beroep en ziet volgens artikel 3 ervan op:

“a) de toegang tot het arbeidsproces, met inbegrip van promotie, en tot beroepsopleiding;

b) arbeidsvoorwaarden, met inbegrip van beloning;

c) ondernemings- en sectoriële regelingen inzake sociale zekerheid.”

Een tweede verandering ten opzichte van het vroegere Defrenne II en Marshallregime is dat na Mangold en Kücükdeveci nu niet alleen werknemers in loondienst een beroep kunnen doen op de horizontale directe werking van het verbod van discriminatie op grond van geslacht, maar ook zelfstandigen dit nu kunnen. Immers ook aan het discriminatieverbod vervat in richtlijn 2010/41 zal horizontale directe werking (toetsing overheidshandelen) toekomen. ${ }^{39}$

accepteert horizontale directe werking (toetsing overheidshandelen). A-G Kokott van 20 september 2012, zaak C-394/11, Belov, punten 80-83.

37 Hoofdstuk 7.5.3.2.

38 Richtlijn 2006/54/EG van het Europees Parlement en de Raad van 5 juli 2006 betreffende de toepassing van het beginsel van gelijke kansen en gelijke behandeling van mannen en vrouwen in arbeid en beroep (herschikking), PB L 204 van 26.7.2006, blz. 23-36.

39 Richtlijn 2010/41/EU van het Europees Parlement en de Raad van 7 juli 2010 betreffende de toepassing van het beginsel van gelijke behandeling van zelfstandig werkzame mannen en vrouwen en tot intrekking van Richtlijn 86/613/EEG van de Raad, PB L 180 van 15.7.2010, blz. 1-6. 
Tot slot zal aan het verbod van discriminatie op grond van geslacht nu ook horizontale directe werking toekomen buiten het gebied van arbeid en beroep. Het verbod zal deze werking toekomen in zaken waarin het gaat om nationale overheidsregelingen die vallen binnen de werkingssfeer van richtlijn 2004/113. ${ }^{40}$ Deze richtlijn is blijkens artikel 3 ervan van toepassing op ${ }^{41}$
"alle personen die goederen of diensten aanbieden die zonder onderscheid des persoons publiekelijk beschikbaar zijn met betrekking tot zowel de overheidssector als de particuliere sector, met inbegrip van overheidsinstanties en die buiten de privé- en de gezinssfeer worden aangeboden, alsmede op de in die context verrichte transacties.
(...)
Deze richtlijn is niet van toepassing op media- en reclame-inhoud, noch op het onderwijs.
(...)
Deze richtlijn is niet van toepassing op aangelegenheden in verband met arbeid en beroep en ook niet op aangelegenheden in verband met arbeid als zelfstandige, voorzover die aangelegenheden onder andere communautaire wetgevingsbesluiten vallen"

\subsubsection{Horizontale directe werking buiten de werkingssfeer van non- discriminatie richtlijnen}

De discriminatieverboden op de in artikel 19 VWEU genoemde gronden hebben dus in ieder geval horizontale directe werking variant 'toetsing van overheidshandelen' in situaties die vallen onder de verschillende nondiscriminatierichtlijnen. De volgende vraag die rijst is of ook sprake zal zijn van deze horizontale directe werking in situaties die vallen buiten het bereik van de non-discriminatierichtlijnen, maar binnen het toepassingsgebied van het Unierecht.

Het antwoord op deze vraag hangt af van de precieze toepassingsvereisten van horizontale directe werking à la Mangold en Kücükdeveci, ${ }^{42}$ waarbij het met name onzeker is of het noodzakelijk is dat de litigieuze nationale overheidshandeling valt binnen het toepassingsgebied van Uniewetgeving die het betreffende discriminatieverbod concretiseert. Als in toekomstige rechtspraak

40 Richtlijn 2004/113/EG van de Raad van 13 december 2004 houdende toepassing van het beginsel van gelijke behandeling van mannen en vrouwen bij de toegang tot en het aanbod van goederen en diensten, PB L 373 van 21.12.2004, blz. 37-43.

41 Zie bijvoorbeeld HvJEU van 11 maart 2011, zaak C-236/09, Test-Achats (levensverzekeringen).

42 Zie hoofdstuk 9. 
zou blijken deze eis niet geldt, betekent dit dat discriminatieverboden ook horizontale directe werking variant 'toetsing van overheidshandelen' buiten het toepassingsgebied van non-discriminatiewetgeving kunnen hebben en wel op talloze gebieden. Immers alsdan zal enkel doorslaggevend zijn of de litigieuze nationale overheidsregeling kwalificeert als 'uitvoering van Unierecht' in de zin van artikel 51, lid 1, van het Handvest.

\subsubsection{Volledige 'de facto' horizontale directe werking van non- discriminatie richtlijnen}

In hoofdstuk 9 is vooruitgeblikt op de mogelijke erkenning door het Hof van horizontale directe werking variant 'toetsing van particulier handelen' van Uniegrondrechten en daarmee ook van discriminatieverboden uit hoofde van artikel 21 van het Handvest. $\mathrm{Nu}$ dit een reële mogelijkheid is, wordt in deze paragraaf aandacht besteed aan de vraag of dit ook de 'de facto' volledige horizontale directe werking (dat wil zeggen inclusief de variant toetsing van particulier handelen) van de non-discriminatie richtlijnen met zich zou brengen. Ik meen van niet. De 'de facto' horizontale directe werking variant 'toetsing van particulier handelen' van de non-discriminatie richtlijnen zou zich slechts in exceptionele omstandigheden (moeten) kunnen voor doen.

Zoals gezegd is de 'de facto' horizontale directe werking in Kücükdeveci het gevolg van het samenspel van twee factoren. De eerste factor was het gebruik van richtlijn 2000/78 als 'de facto' toetsingskader. De tweede factor betrof de wijze waarop de zaak binnen de werkingssfeer van het Unierecht werd gebracht (en in het verlengde daarvan het algemene beginsel van non-discriminatie werd geactiveerd). Het enkele feit dat nationale overheidsregelingen onder de materiële werkingssfeer van richtlijn 2000/78 viel was voldoende om het algemene non-discriminatiebeginsel te activeren. ${ }^{43}$ Het ging hier derhalve om de toepassing van een ruime uitleg van het concept 'uitvoering van Unierecht'. Strikt genomen is (juist) geen sprake van uitvoering, maar van een verzuim daartoe (niet-implementatie). Deze benadering is desalniettemin gerechtvaardigd, omdat de toepasselijkheid van het grondrecht wel degelijk is terug te voeren op de plicht van de lidstaat tot uitvoering c.q. tot eerbiediging van de richtlijn. ${ }^{44}$ Welnu het is precies ten aanzien van deze tweede factor (de koppeling van de zaak aan het Unierecht) dat er een wezenlijk verschil bestaat tussen de twee varianten van horizontale directe werking. Bij de variant

43 Maar let op: pas vanaf het verstrijken van de uiterste datum van implementatie van die richtlijn.

44 Zie hoofdstuk 4.4.1. 
'toetsing van particulier handelen' gaat het immers niet om overheidshandelen, maar om zuiver privaat handelen. De 'verzuim tot implementatie'- redenering die geldt bij overheidshandelingen gaat niet op voor particulier handelen. ${ }^{45}$ Particulieren zijn immers niet gehouden tot uitvoering of eerbiediging van richtlijnen. Dit betekent dat private handelingen die onder de materiële werkingssfeer van een non-discriminatie richtlijn vallen niet louter om die reden binnen de werkingssfeer van het Unierecht vallen. Het enkele feit dat de private handeling een materie behandelt die onder de werkingssfeer van een non-discriminatierichtlijn valt is dan ook niet voldoende om discriminatieverboden uit hoofde van het algemene non-discriminatiebeginsel of artikel 21 van het Handvest te activeren. Van 'de facto' horizontale directe werking variant 'toetsing van particulier handelen' van non-discriminatie richtlijnen via de Kücükdeveci- constructie kan dan ook geen sprake zijn. Dit zou alleen anders zijn als er sprake is van een bijkomende factor op grond waarvan het algemene non-discriminatiebeginsel of artikel 21 van het Handvest kan worden geactiveerd. Hierbij kan dan worden gedacht aan het van toepassing zijn van de ERT route zoals beschreven in hoofdstuk 9.6.5.1.

\subsection{Beschouwing in het licht van de allocatie van bevoegdheden}

In Mangold en Kücükdeveci heeft het Hof de horizontale directe werking 'variant toetsing van overheidshandelen' van het verbod van discriminatie op grond van leeftijd erkend. Zoals betoogt in paragraaf 10.2.3 kan uit deze arresten zeer waarschijnlijk worden afgeleid dat aan alle verboden van discriminatie op de in artikel 19 VWEU genoemde gronden (geslacht, ras of etnische afstamming, godsdienst of overtuiging, handicap, leeftijd en seksuele geaardheid) deze werking toekomt. In hoofdstuk 9.6 heb ik de erkenning van horizontale directe werking van Uniegrondrechten al in zijn algemeenheid bekritiseerd. Het Hof had beter kunnen kiezen voor een meer terughoudende opstelling. In dit hoofdstuk zijn de concrete gevolgen van Mangold en Kücükdeveci uitgebreid in beeld gebracht. Dit beeld bevestigt het in hoofdstuk 9 ingenomen standpunt dat de benadering spanning oplevert met het allocatiebeginsel.

Het meest in het oogspringende gevolg van de erkenning van horizontale directe werking van discriminatieverboden à la Kücükdeveci is de 'de facto' horizontale directe werking 'variant toetsing van overheidshandelen' van bepalingen in richtlijnen die deze discriminatieverboden concretiseren. Hiermee wordt feitelijk afbreuk gedaan aan het verbod van horizontale directe werking van richtlijnen. Dit verhoudt zich moeizaam met artikel 288 VWEU

45 Zie ook hoofdstuk 9.6.5.1. 
waaruit blijkt dat richtlijnen zijn gericht tot de lidstaten en op basis waarvan dat het Hof consequent oordeelde dat: 46

"een richtlijn uit zichzelf aan particulieren geen verplichtingen kan opleggen en dat een bepaling van een richtlijn als zodanig niet tegenover een particulier kan worden ingeroepen"

De 'de facto' horizontale directe werking variant 'toetsing overheidshandelen' van bepalingen in non-discriminatie richtlijnen doorkruist bovendien de bedoeling van de Uniewetgever. De Uniewetgever heeft weliswaar beoogd dat de verboden van discriminatie op de in artikel 19 VWEU genoemde gronden gelden in de private sector, echter dit zou moeten gebeuren middels het nationale recht en niet via het Unierecht. Dit volgt uit de keuze voor het instrument van een richtlijn. ${ }^{47}$

Daarbij weerspiegelt het bestaan van het Unierechtelijke stelsel van nondiscriminatie richtlijnen een opvatting volgens welke de toepassing van grondrechten in private verhoudingen geen vanzelfsprekendheid zijn (exogene rol grondrechten). Wetgevend optreden (zowel door de Unie als door nationale wetgevers) lijkt noodzakelijk te zijn. Meer in het bijzonder kan uit het stelsel van non-discriminatie richtlijnen worden afgeleid dat de Unie de Uniewetgever zich met name een taak toedicht ten aanzien van het aanwijzen van in welke gebieden de verschillende discriminatieverboden moeten gelden.48 Het belangrijkste verschil tussen de verschillende non-discriminatie richtlijnen is immers hun toepassingsgebied. Zo zijn de discriminatieverboden op grond van godsdienst of overtuiging, handicap, leeftijd of seksuele geaardheid slechts van toepassing met betrekking tot arbeid en beroep ${ }^{49}$ Het verbod van discriminatie op grond van ras en etnische afstamming daarentegen is breder van toepassing, bijvoorbeeld ook met betrekking tot het publiekelijk aanbieden van goederen en diensten..$^{50}$ Uitbreiding van toepassingsgebied is niet eenvoudig zo blijkt uit de huidige (stil)stand van het wetgevingsproces van het voorstel van de Commissie inzake uitbreiding ervan. ${ }^{51}$

46 Kücükdeveci, punt 46 en aldaar aangehaalde rechtspraak.

47 Op grond van artikel 19 VWEU had de Unie wetgever ook kunnen kiezen voor een verordening.

48 Alsmede het tijdspad. Opgemerkt wordt dat de toekenning in Mangold en Kücükdeveci van 'de facto' horizontale directe werking van richtlijn 2000/78 reeds voor het verstrijken van de uiterste termijn voor implementatie het door de Uniewetgever uitgezette tijdspad doorkruist. Dit blijkt uit Mangold.

49 Richtlijn 2000/78.

50 Richtlijn 2000/43.

51 COM/2008/0426 final. 
Ook de toelichting bij artikel 21 van het Handvest lijkt uit te bevestigen dat deze niet is bedoeld voor rechtstreekse toepassing op particulieren. Hierin staat namelijk:

“(...) Artikel 21, lid 1, creëert daarentegen generlei bevoegdheid om met betrekking tot het optreden van de lidstaten of van particulieren antidiscriminatiewetten vast te stellen; evenmin bevat het een algeheel discriminatieverbod op deze zeer uiteenlopende gebieden. In plaats daarvan heeft dit lid alleen betrekking op discriminerend optreden van de instellingen en organen van de Unie, wanneer zij de hun op grond van de Verdragen verleende bevoegdheden uitoefenen, en van de lidstaten, wanneer zij het recht van de Unie uitvoeren. (...)"

Deze omstandigheden dwingen tot grote terughoudendheid.52 Deze terughoudendheid komt niet terug in Mangold en Kücükdeveci. Integendeel deze rechtspraak komt neer op het opzij zetten of omzeilen van keuzes van de wetgever met behulp van het algemene non-discriminatiebeginsel. Dit is een eerste indicatie dat het Hof zijn boekje te buiten is gegaan. Deze indicatie leidt echter niet noodzakelijk tot de conclusie dat het Hof zijn bevoegdheid heeft overschreden. Het opzij zetten van door de wetgever gemaakte keuzes kan legitiem zijn door de toepassing van primair recht. De Uniewetgever kan de toepassing van normen van primair recht niet verminderen. Dit volgt uit de hiërarchie van Unie normen. ${ }^{53}$ Als op grond van het primaire recht zou moeten worden aangenomen dat het primairrechtelijke verbod van discriminatie op grond van leeftijd horizontale directe werking heeft kan deze werking niet teniet worden gedaan door de keuze van de wetgever voor een richtlijn. Zoals onder meer is betoogd in hoofdstuk 7.5 is betoogd kan naar mijn mening echter niet worden gezegd dat het primaire recht noopt tot het aannemen van horizontale directe werking.

\subsection{Conclusies}

1. Nu het in de zaken Mangold en Kücükdeveci gaat om de horizontale directe werking van een discriminatieverbod (het verbod van discriminatie op grond van leeftijd) kunnen de gevolgen van deze rechtspraak voor discriminatieverboden wat concreter in beeld worden gebracht en wel met name voor de discriminatieverboden op de gronden die zijn genoemd in artikel 19 VWEU (geslacht, ras of etnische afstamming, godsdienst of overtuiging, handicap, leeftijd en seksuele geaardheid). Hierbij maakt het

52 Vergelijk A-G Trstenjak van 30 juni 2009, zaak C-101/08, Audiolux, punt 107.

53 Vergelijk A-G Bot van 7 juli 2009, zaak C-555/07, Kücü̈kdeveci, punt 70. 
naar alle waarschijnlijkheid geen verschil of het nu gaat om de toepassing van die discriminatieverboden uit hoofde van artikel 21 van het Handvest of als algemene beginselen van Unierecht. Voor de toepasselijkheid van de Kücükdeveci -benadering op de discriminatieverboden op de overige in artikel 21 van het Handvest genoemde gronden (nationaliteit, kleur, sociale afkomst, genetische kenmerken, taal, politieke of andere denkbeelden, het behoren tot een nationale minderheid, vermogen, geboorte en de open categorie 'iedere discriminatie') moet verdere rechtspraak worden afgewacht.

2. Een in het oogspringend gevolg van Mangold en Kücükdeveci is dat de discriminatieverboden op grond van geslacht, ras of etnische afstamming, godsdienst of overtuiging, handicap, leeftijd en seksuele geaardheid in nondiscriminatierichtlijnen zeer waarschijnlijk 'de facto' horizontale directe werking variant 'toetsing van overheidshandelen' hebben. Indien het Hof zou overgaan tot de erkenning van volledige horizontale directe werking (dus inclusief de variant 'toetsing van particulier handelen') zou dit echter niet moeten betekenen dat non-discriminatie richtlijnen volledige 'de facto' horizontale directe werking hebben. $\mathrm{Nu}$ richtlijnen niet bindend zijn voor particulieren ligt het niet voor de hand dat zij kunnen dienen om Uniegrondrechten te activeren in geschillen tussen particulieren.

3. Het is nog niet duidelijk of discriminatieverboden op grond van geslacht, ras of etnische afstamming, godsdienst of overtuiging, handicap, leeftijd en seksuele geaardheid (de artikel 19 VWEU -gronden) horizontale directe werking variant 'toetsing van overheidshandelen' hebben buiten de toepassingsgebieden van non-discriminatie richtlijnen (maar binnen het toepassingsgebied van het Unierecht). Dit hangt af van de vraag in hoeverre het samenspel met richtlijn 2000/78 Mangold en Kücükdeveci van doorslaggevend belang was bij de toekenning van horizontale directe werking.

4. De concrete gevolgen van de Kücükdeveci -benadering en met name het gevolg van 'de facto' omzeiling van het gebrek aan horizontale directe werking van non-discriminatierichtlijnen bevestigt de conclusie in hoofdstuk 9 dat de benadering spanning oplevert met het beginsel van allocatie van bevoegdheden. 


\section{DEEL IV}

SYNTHESE, CONCLUSIES EN AANBEVELINGEN 



\section{HOOFDSTUK 11}

\section{DIRECTE WERKING OP DREEF EN OP DRIFT}

\subsection{Inleiding}

Het leerstuk van de directe werking van Uniegrondrechten is 100 procent '(court-)made' in Luxemburg. Zowel de grondrechten zelf als de directe werking ervan zijn oorspronkelijk voortbrengselen van het Hof. De rechtspraak van het Hof nam in dit proefschrift dan ook een centrale plaats in. Het diende als basis voor alle drie de onderzoeksvragen, het onderzoek naar de stand van het recht, de vraag naar de nog openstaande punten en ook de toetsingskaders voor de vraag naar de legitimiteit zijn deels geformuleerd op basis van de rechtspraak van het Hof zelf. Dit slothoofdstuk bevat een synthese en presenteert de conclusies en aanbevelingen. Dit gebeurt aan de hand van de drie genoemde deelonderzoeksvragen waarbij onderscheid wordt gemaakt tussen verticale directe werking (paragraaf 11.2) en horizontale directe werking (paragraaf 11.3). De eindconclusie en aanbevelingen staan in paragraaf 11.4.

\subsection{Verticale directe werking}

\subsubsection{Stand van het recht}

De mogelijkheid van verticale directe werking van Uniegrondrechten is reeds sinds lange tijd een gegeven. Het vertrekpunt hiervan is dat de Unie een rechtsorde is die is gebaseerd op de 'rule of law'. Dit betekent in de eerste plaats dat de instellingen, instanties en organen van de Unie zelf gebonden zijn aan Uniegrondrechten. In de tweede plaats kunnen ook de lidstaten gebonden zijn aan Uniegrondrechten. De gebondenheid van de lidstaten betreft echter een gebondenheid die is afgeleid van de gebondenheid aan de grondrechten van de Unie zelf. Dit is een belangrijk verschil met het EVRM en de Raad van Europa. De Unie is geen mensenrechtenorganisatie. Het verzekeren van de eerbiediging van Uniegrondrechten in Europa vormt geen missie op zich. Er bestaat derhalve geen 'algemene' en 'zelfstandige' gebondenheid van de lidstaten aan de Uniegrondrechten. De toepassing van Uniegrondrechten is verbonden met de toepassing van materieel Unierecht. Dit is van wezenlijk belang bij de vraag wanneer sprake is van verticale directe werking. De gebondenheid van de lidstaten aan Uniegrondrechten is immers een prealabele voorwaarde voor verticale directe werking van Uniegrondrechten. Zonder gebondenheid van de lidstaten aan Uniegrondrechten kan van directe werking geen sprake zijn. $\mathrm{Nu}$ 
de gebondenheid van de lidstaten een afgeleide is van de gebondenheid van de Unie, gaat het er steeds om dat de gebondenheid van de Unie zelf in het geding is opdat van verticale directe werking sprake kan zijn. Of anders gezegd: er kan enkel sprake zijn van verticale directe werking als de (grondrechtconforme) toepassing van Unierecht of Uniehandelen in het geding is.

Het bovenstaande vindt zijn weerslag in artikel 51, lid 1, van het Handvest dat een bevestiging vormt van de rechtspraak van het Hof inzake het toepassingsgebied van algemene beginselen van Unierecht. De twee bronnen van Unierechtelijke grondrechten (de algemene beginselen van Unierecht en het Handvest) hebben hetzelfde toepassingsgebied en artikel 51, lid 1, van het Handvest is hierbij leidend. Deze bepaling noemt als criterium, dat het moet gaan om nationale handelingen die kwalificeren als een uitvoeringshandeling van Unierecht. De toelichting bij deze bepaling verduidelijkt dat het moet gaan om het optreden van de lidstaten 'binnen het toepassingsgebied van het recht van de Unie'. Het komt er op neer, dat Uniegrondrechten 'enkel' van toepassing zijn op de toepassing van Unierecht. Of zoals het Hof in Åkerberg Fransson (andersom) zegt: ${ }^{1}$

"Wanneer het Unierecht toepasselijk is, impliceert dit dat de door het Handvest gewaarborgde grondrechten toepassing vinden."

De relevant vraag voor de toepasselijkheid van artikel 51, lid 1, van het Handvest is steeds of sprake is van een situatie waarin materieel Unierecht in het spel is waaraan de betreffende nationale handeling 'uitvoering' of 'toepassing' geeft of zou moeten geven. Bij een ontkennende beantwoording van deze vraag geldt dat de toepassing van Uniegrondrechten niet aan de orde is, althans niet aan de orde zou moeten zijn. Bij een bevestigende beantwoording daarentegen, geldt dat de Uniegrondrechten onvermijdelijk van toepassing zijn. Bij de beantwoording van de vraag is relevant dat niet is vereist dat het gaat om 'verplichte' toepassing of uitvoering van Unierecht. ${ }^{2}$ Het is ook niet vereist dat de materiële bepaling van Unierecht rechtsreeks van toepassing is op de feiten van het hoofdgeding, het kan immers (juist) zo zijn dat materieel Unierecht enkel in het geding is via het van toepassing zijnde nationale recht.

Het formuleren van een concreter criterium dan de abstracte vraag of sprake is van een situatie waarin materieel Unierecht in het spel is waaraan de betreffende nationale handeling 'uitvoering' of 'toepassing' geeft of zou moeten

1 HvJEU van 26 februari 2013, zaak C-617/10, Åkerberg Fransson, punt 21.

2 Zie bijvoorbeeld HvJEU van 22 oktober 2013, zaak C-276/12, Sabou, maar ook de rechtspraak die is behandeld in hoofdstuk 4.3. 
geven, is lastig. Het is wel mogelijk om meer vat op de materie te krijgen door een omschrijving van de mogelijke situaties in categorieën. Globaal gezien kunnen twee categorieën worden onderscheiden waarin sprake is van de 'uitvoering' of 'toepassing' van Unierecht in de zin van artikel 51, lid 1, van het Handvest. Ten eerste een categorie op basis van het arrest Wachauf, 3 die ziet op nationale maatregelen die Unierecht uitvoeren. De lidstaat handelt als vooruitgeschoven post (vertegenwoordiger) van de Unie (bijv. als Uniebestuurder, Uniehandhaver, Unietoezichthouder, Unierechter). Handelingen die in deze hoedanigheid worden verricht, moeten worden beschouwd als Unierecht onder nationale vlag en daarom zijn de Uniegrondrechten van toepassing. De bestaande rechtspraak over situaties die onder Wachaufuitvoering kunnen vallen, is casuïstisch en uiteenlopend. Het concept Wachaufuitvoering bevat een brede waaier aan situaties. De rechtspraak is wel coherent en het is mogelijk om de waaier te classificeren in vier subcategorieën van nationale overheidshandelingen:

i. Klassieke omzettingshandelingen; ${ }^{4}$

ii. Handelingen op grond van Uniebevoegdheden; ${ }^{5}$

ii. Handelingen die onder de werkingssfeer van materieel Unierecht vallen; 6

iv. Effectuering, sanctionering en handhaving van Unierecht. ${ }^{7}$

Met klassieke omzettingsmaatregelen (i) wordt bedoeld nationale maatregelen die op grond van specifieke Unierechtelijke omzettingsverplichtingen worden genomen (bijvoorbeeld de omzetting van een richtlijn). De categorie handelingen op grond van Unierecht verleende bevoegdheden (ii) bevat handelingen in uitoefening van bevoegdheden die de lidstaten ontlenen aan het Unierecht. Een voorbeeld is het geval waarin een Unieregeling voorziet in de mogelijkheid om af te wijken van de implementatieverplichting of voorziet in optionele uitzonderingen op de hoofdverplichting/regel. Overigens is deze tweede categorie van 'uitvoering' niet altijd strikt te onderscheiden van de eerste. Het belangrijkste verschil is dat het bij de eerste categorie gaat om 'verplichte' uitvoering en het bij deze categorie gaat om 'onverplichte' uitvoering. De twee categorieën tezamen kunnen ook wel worden omschreven als 'materiële uitvoering'. Ten derde zijn de Unierechtelijke grondrechten van toepassing op nationale maatregelen die binnen de werkingssfeer van specifieke materiële bepalingen van Unierecht vallen (iii). Bij deze categorie gaat het in

3 HVJEU van 13 juli 1989, zaak 5/88, Wachauf. Zie hoofdstuk 4.

4 Zie hoofdstuk 4.2.

5 Zie hoofdstuk 4.3.

6 Zie hoofdstuk 4.4.

7 Zie hoofdstuk 4.5. 
wezen om nationale maatregelen die een uiting zijn van een verzuim tot uitvoering. Tot slot moeten nationale handelingen die dienen ter effectuering, sanctionering of handhaving van Unierecht eveneens worden gekwalificeerd als uitvoeringsmaatregelen (iv). Dit zijn maatregelen die in feite de uitvoering van artikel 4, lid 3, VEU (beginsel van loyale samenwerking) behelzen. Op basis van het beginsel van loyale samenwerking zijn in de rechtspraak tal van plichten voor lidstaten geconcretiseerd. De meeste ervan komen neer op de plicht om er voor te zorgen dat het Unierecht effectief is. In tegenstelling tot de 'klassieke omzettingsmaatregelen' (categorie i) gaat het hierbij om algemene niet nader gespecificeerde plichten om het Unierecht handen en voeten (en tanden) te geven, waarbij de lidstaten een grote vrijheid genieten die desalniettemin wordt begrensd door de Unierechtelijke grondrechten. De categorie zou ook geduid kunnen worden als 'procedurele uitvoering'. Een voorbeeld van nationale handelingen die onder deze categorie vallen zijn nationale handelingen die onder de nationale procedurele autonomie vallen.

De tweede hoofdcategorie vloeit voort uit het arrest ERT. ${ }^{8}$ De lidstaat wordt hier benaderd in de hoedanigheid van rechtssubject van Unierecht. De ERT-lijn ziet op nationale maatregelen die in beginsel in strijd zijn met een verbodsbepaling van Unierecht, maar waarbij de lidstaat een beroep doet op een Unierechtelijke rechtvaardigingsgrond. De gedachte is dat dit soort maatregelen alleen gerechtvaardigd kunnen zijn krachtens het Unierecht als zij in overeenstemming zijn met het gehele Unierecht, dat wil zeggen inclusief de Uniegrondrechten.

De ERT-route is in elk geval van toepassing op maatregelen die kwalificeren als beperkingen van het vrije verkeer. Van belang hierbij is dat steeds een onderscheid moet worden gemaakt tussen (1) de kwalificatie van een nationale handeling als een 'beperking' en (2) de vraag of de beperking kan worden gerechtvaardigd. De verticale directe werking van het Uniegrondrecht is pas aan de orde bij de tweede stap, nadat vast staat dat de nationale maatregel een beperking van het vrije verkeer is. Overigens kunnen Uniegrondrechten ook relevant zijn bij de eerste stap, de kwalificatie als 'beperking'. Het gaat hierbij echter niet om de directe werking van het Uniegrondrecht, maar om de invloed ervan op deze kwalificatie.

Het ligt in de lijn der verwachting dat de ERT-route ook van toepassing is buiten het vrije verkeer, bijvoorbeeld in de context van artikel 20 VWEU. Dit kan echter nog niet met zekerheid worden afgeleid uit de bestaande rechtspraak van

8 HvJEU van 18 juni 1991, zaak C-260/89, ERT. Zie hoofdstuk 5. 
het Hof. Dit punt wordt daarom verder besproken in paragraaf 11.2.2.2.

Unierechtelijke grondrechten zijn niet van toepassing in situaties die buiten de lijnen Wachauf en ERT vallen, zelfs niet in situaties die andersoortige aanknopingen met het recht van de Unie bevatten. ${ }^{9}$ Voorbeelden van aanknopingen met het Unierecht die (op zichzelf) niet leiden tot de toepasselijkheid van Unierechtelijke grondrechten zijn: (i) het enkele bestaan van bevoegdheden van de Unie op het betreffende terrein, ${ }^{10}$ (ii) het enkele feit dat het een Unieburger uit een andere lidstaat betreft (dit is derhalve een verschil met artikel 18 VWEU), ${ }^{11}$ (iii) het feit dat het gaat om op grond van Unierecht toegestane verdergaande beschermingsmaatregelen ingeval van minimumharmonisatie, ${ }^{12}$ (iv) het enkele inroepen van materieel Unierecht of van daarop gebaseerde nationale implementatie (overigens activeert dit mogelijk wel artikel 47 van het Handvest), ${ }^{13}$ (v) het enkele feit dat de materie van de nationale handeling in algemene zin wordt bestreken door het Unierecht, ${ }^{14}$ (vi) vrijwillige verwijzingen in nationaal recht naar Unierecht, ${ }^{15}$ (vii) de vrijwillige nationale schadeloosstelling voor nadelige gevolgen van maatregelen van de Unie, ${ }^{16}$ en (viii) het louter hypothetische vooruitzicht op uitoefening van het vrije verkeer. ${ }^{17}$

\subsubsection{Legitimiteit en rechterlijk activisme}

\subsubsection{Bestaan van verticale directe werking}

De erkenning van de gebondenheid van de lidstaten aan de Uniegrondrechten in Wachauf en ERT en in het verlengde daarvan het bestaan van verticale directe werking, is algemeen aanvaard en levert geen spanning op met het beginsel van allocatie van bevoegdheden. Het vormt een logische en noodzakelijke vervolgstap op de vaststelling dat de Unie een rechtsorde is waarbinnen de grondrechten moeten worden geëerbiedigd. ${ }^{18}$ De toepassing van Unierecht

\footnotetext{
9 HvJEU van 18 december 1997, zaak C-309/96, Annibaldi. Zie hoofdstuk 6.

10 Hoofdstuk 6.3.2.

11 Hoofdstuk 6.3.3.

12 Hoofdstuk 6.3.4.

13 Hoofdstuk 6.3.5.

14 Hoofdstuk 6.3.6.

15 Hoofdstuk 6.3.7.

16 Hoofdstuk 6.3.8.

17 Hoofdstuk 6.3.9.

18 HvJEU 12 november 1969, zaak 29/69, Stauder. HvJEU van 17 december 1970, zaak 11/70, Internationale Handelsgesellschaft. HvJEU van 14 mei 1974, zaak 4/73, Nold II, punt 13.
} 
vindt immers voor een zeer groot deel plaats op het nationaal niveau. De gebondenheid van de lidstaten aan de Uniegrondrechten volgt bovendien uit artikel 51, lid 1, van het Handvest die bevestigt dat ook de lidstaten gehouden kunnen zijn om de Uniegrondrechten te eerbiedigen. Evenmin controversieel zijn de twee hoofdcategorieën van situaties waarin de lidstaten de Uniegrondrechten moeten eerbiedigen: de Wachauf-situatie en de ERT-situatie. Ze zijn beide genoemd in de Toelichting bij artikel 51, lid 1, van het Handvest. De rode draad in beide situaties is de eerder genoemde noodzaak tot de grondrechtconforme toepassing van Unierecht. Bij de beschouwing van het leerstuk van verticale directe werking in het licht van het allocatiebeginsel gaat de aandacht derhalve uit naar de wijze waarop het Hof de rechtspraak Wachauf en ERT heeft uitgewerkt. Gaat het in de nationale situaties waarin Uniegrondrechten ingevolge de rechtspraak van het Hof van toepassing zijn steeds om de handhaving van de 'rule of law' binnen de Unie rechtsorde of is (ook) sprake van een lancering van Uniegrondrechten in zuiver nationale situaties?

Het algemene beeld is dat de rechtspraak van het Hof inderdaad als leidmotief heeft het verzekeren van de grondrechtconforme toepassing van Unierecht. Het Hof opereert behoedzaam en lijkt geen missionaire aspiraties te hebben. In de volgende paragrafen wordt dit voor de beide hoofdcategorieën Wachauf en ERT toegelicht.

\subsubsection{Uitwerking in de Wachauf-waaier}

Uit de analyse van de rechtspraak in de lijn Wachauf blijkt, dat de verticale directe werking in het overgrote deel van de gevallen kan worden herleid tot de noodzaak van de grondrechtconforme toepassing van het Unierecht en derhalve past binnen de grenzen van artikel 51, lid 1, van het Handvest. In het algemeen stelt het Hof zich behoedzaam en terughoudend op. Met name accepteert het Hof niet elke band met het Unierecht als toereikende activator van Unierechtelijke grondrechten. In sommige gevallen is dit evident, in andere gevallen weerspiegelt het een terughoudende opstelling van het Hof ten aanzien van het toepassingsgebied van Unierecht en daarmee van de grondrechten. Dit neemt niet weg dat de Uniegrondrechten van toepassing zijn in situaties waarin dit op het eerste gezicht wat minder voor de hand lijkt te liggen en zelfs te ver lijkt te gaan. Toch kan ook in die situaties de toepassing van Uniegrondrechten worden begrepen in het licht van het verzekeren van de grondrechtconforme toepassing van Unierecht. De gebondenheid van de lidstaten aan de grondrechten is daarmee steeds te herleiden tot de gebondenheid van de Unie zelf aan de grondrechten. 
Het arrest Chatzi vormt een uitzondering op het algemene beeld, dat de rechtspraak van het Hof in overeenstemming is met artikel 51, lid 1, van het Handvest. ${ }^{19}$ In dit arrest lijkt het te gaan om de toepassing van het algemene gelijkheidsbeginsel op een klassieke uitvoeringsmaatregel à la Wachauf. De uitkomst van het arrest komt echter neer op een zelfstandige werking van het algemene gelijkheidsbeginsel, los van de uitvoering van Unierecht. Dit komt gedeeltelijk ook door de gedurfde materiële invulling van het gelijkheidsbeginsel. Dit arrest is derhalve een arrest dat niet onder de ratio van de lijnen Wachauf en ERT kan worden gebracht. Het staat daarmee mijns inziens op gespannen voet met artikel 51, lid 1, van het Handvest en het beginsel van allocatie van bevoegdheden.

$\mathrm{Nu}$ de rechtspraak van het Hof in de lijn Wachauf in zijn algemeenheid binnen de grenzen van artikel 51, lid 1, van het Handvest blijft, acht ik deze gelegitimeerd vanuit het oogpunt van het allocatiebeginsel. Dit neemt niet weg, dat ik meen dat er ruimte is voor versterking van de legitimiteit van deze rechtspraak. Opvallend is, dat het weliswaar mogelijk is om de rechtspraak uit te leggen in het licht van artikel 51, lid 1, van het Handvest, maar dat deze uitleg in de arresten zelf dikwijls niet wordt gegeven. Van een dogmatische onderbouwing van het (niet) aanmerken van bepaalde nationale handelingen als uitvoering in de zin van artikel 51 , lid 1 , van het Handvest is lang niet altijd sprake. Het ontbreken van een voor de toepassing van artikel 51, lid 1, van het Handvest concreter criterium dan de abstracte vraag of sprake is van een situatie waarin materieel Unierecht in het spel is waaraan de betreffende nationale handeling 'uitvoering' of 'toepassing' geeft of zou moeten geven, acht ik begrijpelijk. Gezien de brede waaier van mogelijke situaties van Wachaufuitvoering lijkt het ondoenlijk om tot één dusdanige concrete (paraplu) toets te komen. Tegelijkertijd echter is er een aanzienlijke hoeveelheid rechtspraak voor handen waaruit bestendige stereotypen van Wachauf -situaties kunnen worden ontward die wel kunnen bijdragen aan een concretisering van het abstracte artikel 51-criterium. Deze stereotypen worden in de rechtspraak lang niet altijd geëxpliciteerd en dogmatisch onderbouwd, terwijl dit wel mogelijk zou moeten zijn. Hier zie ik derhalve een kans voor het verstevigen van de legitimiteit van de rechtspraak. Door de explicitering en onderbouwing van de verschillende Wachauf -situaties zou de rechtspraak van het Hof grijpbaarder en begrijpelijker worden. Hetgeen de rechtszekerheid en aanvaardbaarheid ervan ten goede zou kunnen komen. In hoofdstuk 11.2.3.1 zal ik deze algemene bevinding verwerken in concrete suggesties.

19 HvJEU van 16 september 2010, zaak C-149/10, Chatzi. 


\subsubsection{Uitwerking in de ERT-route}

De ratio van de $E R T$-gebondenheid aan de fundamentele rechten is dezelfde als bij de Wachauf-gebondenheid aan de grondrechten, namelijk de grondrechtconforme toepassing van Unierecht. Het enkele feit dat de lidstaten in een andere hoedanigheid worden benaderd (als rechtssubjecten in plaats van als uitvoerders- vertegenwoordigers van Unierecht) doet hier niet aan af. Van belang is wel, dat de toepassing van de ERT-route er niet toe leidt dat materiële verplichtingen worden gecreëerd op grond van grondrechten. Zolang echter de ERT-gebondenheid aan de fundamentele rechten enkel van toepassing is op nationale maatregelen die in beginsel in strijd zijn met een verbodsbepaling van Unierecht, maar waarbij de overheid een beroep doet op een Unierechtelijke rechtvaardigingsgrond, dreigt dit gevaar niet. Immers in dit scenario moet de nationale maatregel (die a priori onder een Unieverbod valt) zijn bestaansrecht ontlenen aan (een uitzonderingsmogelijkheid op grond van) het Unierecht. $\mathrm{Nu}$ het recht van de Unie in overeenstemming moet zijn met de Unierechtelijke grondrechten, kan het Unierecht enkel het groene licht geven aan nationale maatregelen die in overeenstemming met de Unierechtelijke grondrechten zijn. De systematiek zit ook dicht aan tegen de grondrechtconforme uitleg van Unierecht (namelijk van een rechtvaardigingsrond). De ERT-route als zodanig lijkt dus geen spanning op te leveren met het allocatiebeginsel. Zulks ook niet indien het zou worden toegepast buiten de context van het vrije verkeer, bijvoorbeeld in het kader van artikel 20 VWEU.

Er zijn twee manieren waarop de toepassing van de ERT-route wel op gespannen voet kan komen te staan met het beginsel van de allocatie van bevoegdheden. Ten eerste bij een te ruime uitleg van de materiële werkingssfeer van de bepaling 'waarbinnen' de ERT-route wordt toegepast, bijvoorbeeld de betreffende vrije verkeersbepaling of artikel 20 VWEU. Als de drempel om een nationale maatregel als 'beperking' of 'ontzegging' te kwalificeren laag ligt, wordt daarmee ook de drempel voor de toepasselijkheid van de Unierechtelijke grondrechten verlaagd. Ongerechtvaardigde uitbreidingen van de materiële werkingssfeer van het Unierecht leiden tot ongerechtvaardigde uitbreidingen van het toepassingsgebied van Uniegrondrechten.

De ERT-route kan ten tweede controversieel zijn als het grondrecht fungeert als zelfstandige toetsingsmaatstaf bij de kwalificatie als 'beperking' of 'ontzegging'. Hierdoor ontstaat het risico van directe werking in zuiver nationale situaties. In de context van artikel 20 VWEU is het extra van belang ervoor te waken, dat de inroepbaarheid van Unierechtelijke grondrechten niet wordt gekoppeld aan de (enkele) hoedanigheid van Unieburger. Dit is nadrukkelijk niet de bedoeling 
van het Handvest. Het is daarom van belang om steeds strikt onderscheid te maken tussen enerzijds (i) de kwalificatie van de betreffende nationale handeling als 'beperking' van het vrije verkeer of 'ontzegging' van Unieburgerschap en (ii) anderzijds de rechtvaardiging daarvan. De directe werking van Unierechtelijke grondrechten kan pas aan de orde zijn bij de tweede stap: de vraag naar de mogelijkheid tot rechtvaardiging. De functie van Unierechtelijke grondrechten is dan dat zij de mogelijkheid tot rechtvaardiging begrenzen. Indien grondrechten reeds bij de eerste stap (de kwalificatie als 'beperking' of als 'ontzegging') zouden worden toegepast als toetsingsgrond, leidt dit tot een zelfstandige toepassing van grondrechten (los van andere bepalingen van materieel Unierecht). Of anders gezegd: er is dan niet voldaan aan het vereiste, dat de toepassing van Uniegrondrechten pas relevant wordt nadat vaststaat dat een specifieke bepaling van materieel Unierecht van toepassing is.

Het Hof lijkt deze systematiek consequent te hanteren. Er zijn echter twee zaken die in dit opzicht ongelukkig zijn. De eerste zaak is het arrest Karner. ${ }^{20}$ Het Hof past een Unierechtelijk grondrecht toe zonder eerst vast te stellen, dat de nationale handeling kwalificeert als een beperking van het vrije verkeer. $\mathrm{Nu}$ het arrest deze mogelijkheid wel openlaat en het arrest niet is bevestigd in latere rechtspraak, lijkt het te gaan om een onbedoelde, maar onhandige uitschieter. De tweede zaak is Dereci waarin voor het eerst naar Unierechtelijke grondrechten wordt verwezen met betrekking tot 'ontzeggingen' van Unieburgerschap ex artikel 20 VWEU.21 Het arrest laat helaas veel ruimte voor twijfel over de vraag wanneer de toepassing van Unierechtelijke grondrechten aan de orde komt; is dit pas na de kwalificatie van de nationale handeling als ontzegging of is dit toch reeds in het kader van die kwalificatie? Het Hof zou er verstandig aan doen om dit soort onduidelijkheden te vermijden en bij zaken waarin grondrechten worden toegepast op grond van ERT steeds een strikte scheiding aan te brengen tussen enerzijds de kwalificatie als 'beperking c.q. 'ontzegging' en anderzijds de mogelijkheid tot rechtvaardiging. Zoals gezegd, zou de toepassing van Unierechtelijke grondrechten als zelfstandige toetsingsgrond pas in beeld moeten komen bij de mogelijkheid tot rechtvaardiging. Het arrest Grogan biedt een goed voorbeeld van een zaak waarin het Hof het onderscheid duidelijk aanbrengt. ${ }^{22}$

Het bovenstaande betekent overigens niet, dat elk gebruik van Unierechtelijke grondrechten in het stadium van de kwalificatie als 'beperking' of als

20 HvJEU van 25 maart 2004, zaak C-71/02, Karner.

21 HvJEU van 15 november 2011, zaak C-256/11, Dereci.

22 HvJEU van 4 oktober 1991, zaak C-159/90, Grogan, punt 31. 
'ontzegging' verdacht is vanuit het oogpunt van de allocatie van bevoegdheden. Illustratief zijn de arresten Sayn-Wittgenstein en Vardyn.23 Deze twee arresten inzake het naamrecht hebben gemeen, dat het Hof reeds in het kader van zijn onderzoek naar het bestaan van een beperking van het vrije verkeer aandacht besteedde aan het recht op bescherming van het privé -leven uit hoofde van de artikelen 8 EVRM en 7 Handvest. Toch wordt hiermee geen afbreuk gedaan aan het hierboven besproken vereiste, dat de kwalificatie van de nationale handeling als 'beperking' een prealabele voorwaarde is voor de directe werking van een Unierechtelijke grondrecht via de ERT-route. Het grondrecht fungeerde in deze zaken niet als zelfstandige toetsingsmaatstaf, maar diende om het belang van de naam van een persoon te illustreren en te onderstrepen. Aldus werd de toon gezet voor de overwegingen erna waarin het Hof op grond van het criterium het bestaan van 'ernstige ongemakken' naging of sprake is van een beperking van het vrije verkeer. Terughoudendheid is hier echter wel op zijn plaats, de scheidslijn tussen het gebruik van het Unierechtelijke grondrecht als element in de beoordeling naar de vraag of sprake is van 'beperking' en het (feitelijk) gebruik van het grondrecht als zelfstandig toetsingskader, kan dun zijn. Indien de enkele inmenging in een grondrecht zou volstaan om een nationale maatregel te kwalificeren als een belemmering van het vrije verkeer bestaat het risico dat het Uniegrondrecht een zelfstandig leven gaat leiden los van de toepassing van materieel Unierecht. Zaken waarin de toepassing van Uniegrondrechten reeds plaats vindt bij de kwalificatie van een nationale maatregel als 'beperkend' zijn daarom heikel en verdienen steeds bijzondere aandacht en een nauwkeurige motivering.

\subsubsection{Openstaande vragen en aandachtspunten}

\subsubsection{De Wachauf-waaier}

Zoals gezegd bevat Wachauf-uitvoering een brede waaier aan situaties die kan worden onderverdeelde in vier subcategorieën:

i. klassieke omzettingshandelingen;

ii. handelingen op grond van Uniebevoegdheden;

iii. handelingen die onder de materiële werkingssfeer van Uniewetgeving vallen;

iv. handelingen terzake van de effectuering, sanctionering en handhaving van Unierecht.

23 HvJEU van 22 december 2010, zaak C-208/09, Sayn-Wittgenstein, punt 52; HvJEU van 12 mei 2011, zaak C-391/09, Vardyn, punt 66. 
De genoemde subcategorieën zijn bestendig en bieden redelijk wat houvast. Desondanks is er ruimte voor verduidelijking en verfijning van de bestaande rechtspraak. Ik zal hieronder uiteenzetten op welke punten dit zou kunnen. Zoals gezegd in hoofdstuk 11.2.2.1 meen ik dat het Hof er goed aan zou doen om in toekomstige rechtspraak kansen op verduidelijking en verfijning aan te grijpen om aldus de legitimiteit van de rechtspraak te verstevigen.

\section{Explicitering van subcategorie iv: effectuering, sanctionering en handhaving van Unierecht}

Op grond van een analyse van de rechtspraak komt het bestaan van deze subcategorie duidelijk naar voren. ${ }^{24} \mathrm{Ik}$ acht het bestaan van deze subcategorie ook gerechtvaardigd. Echter de aandacht die het arrest Åkerberg Fransson heeft getrokken maakt duidelijk, dat het bestaan van deze categorie nog wat verborgen is en ook weerstand kan oproepen. ${ }^{25}$ Met het oog hierop is het wenselijk, dat het Hof de toepassing van Uniegrondrechten op de effectuering, sanctionering en handhaving van Unierecht in toekomstige rechtspraak expliciet benoemt en zorgvuldig motiveert. Dit vooral in gevallen waarin geen specifieke Uniebepalingen van toepassing zijn die verplichten tot de effectuering, sanctionering en handhaving van Unierecht, zoals bijvoorbeeld artikel 325 VWEU (plicht tot fraudebestrijding) of bepalingen van secundair recht. ${ }^{26}$

Hierbij is het allereerst van belang dat wordt benoemd, dat het bij dit soort nationale handelingen in wezen gaat om uitvoeringshandelingen van artikel 4, lid 3, VEU (plicht tot loyale samenwerking) waarop de Uniegrondrechten van toepassing zijn. In het arrest Åkerberg Fransson wordt wel aan deze bepaling gerefereerd, maar wordt niet geëxpliciteerd dat deze bepaling op zichzelf (dat wil zeggen zonder specifieke bepaling inzake de effectuering, sanctionering en handhaving van Unierecht) kan leiden tot uitvoeringsmaatregelen in de zin van artikel 51, lid 1, van het Handvest. Het zou ten tweede verhelderend zijn als het Hof daarbij ook onder woorden brengt om de uitvoering van welke subverplichting op grond van artikel 4, lid 3, VEU het gaat. Artikel 4, lid 3, VEU is immers een zeer algemene bepaling op grond waarvan het Hof nadere plichten heeft geformuleerd. Als het bijvoorbeeld gaat om de overtreding van een bepaling van Unierecht waarbij de Unieregeling geen specifieke sanctie stelt, zou het Hof onder verwijzing naar zijn vaste rechtspraak kunnen overwegen dat de lidstaat op grond van artikel 4, lid 3, VEU verplicht is om alle passende

\footnotetext{
24 Zie hoofdstuk 4.5 .

25 HvJEU van 26 februari 2013, zaak C-617/10, Åkerberg Fransson.

26 Een voorbeeld waarin het wel ging om zo'n specifieke plicht is HvJEU van 26 september 2013, zaak C-418/11, Texdata Software.
} 
maatregelen te nemen om de doeltreffende toepassing van het Unierecht te verzekeren. Hierbij is het ten derde zaak om precies aan te geven op welke materiële bepaling van Unierecht de effectuering, sanctionering en handhaving ziet. Zo wordt ook zichtbaar gemaakt dat bij deze constructie sprake moet zijn van een dubbele EU-link: allereerst moet er een identificeerbare plicht op grond van artikel 4, lid 3, VEU zijn (zoals gezegd zijn deze plichten 'court-made') en ten tweede moet er een bepaling van materieel Unierecht in het geding zijn waarop die plicht ziet. Ik meen dat deze motiveringswijze het bestaan van deze vorm van verticale directe werking van Uniegrondrechten meer transparant zal maken en het daarmee ook kan bijdragen aan de aanvaarding ervan.

\section{Verhouding tussen Rewe-riedel en de toepassing van Uniegrondrechten}

De grondrechten zijn ook van toepassing op de uitoefening door de lidstaten van hun nationale procedurele autonomie (zoals bijvoorbeeld nationale regels omtrent onverschuldigd betaalde bedragen, rechtsmiddelen, verjarings- en vervaltermijnen, ontvankelijkheid in rechte). ${ }^{27}$ Op grond van de klassieke Reweriedel is de procedurele autonomie begrensd door de beginselen van gelijkwaardigheid en doeltreffendheid. ${ }^{28}$ De rechtspraak van het Hof is niet eenduidig ten aanzien van de verhouding tussen de toepassing van de Uniegrondrechten en de Rewe-riedel. Soms, zoals in de arresten Alassini en Ecotrade, is sprake van een aparte eigen toets aan de grondrechten naast de Rewe-riedel ('een Rewe-riedel-plus') ${ }^{29}$ en in andere gevallen zoals in het arrest Pohotovost lijkt de toets aan de grondrechten onderdeel uit te maken van het doeltreffendheidsvereiste. ${ }^{30}$ Voorts maakt het Hof, bijvoorbeeld in de arresten $V E B I C$ en H.N., ook gebruik van formules waarin de Rewe-riedel helemaal niet terug komt en enkel wordt verwezen naar de grondrechten en doeltreffendheid van de onderliggende materieelrechtelijke Unieregeling. ${ }^{31}$ Het Hof zou er goed aan doen om te kiezen voor een heldere en eenduidige aanpak. Een Rewe-riedelplus verdient mijns inziens de voorkeur waarbij een onderscheid wordt gemaakt tussen de toets aan de grondrechten en de toepassing van de Rewe -riedel. Dit voorkomt onnodig ingewikkelde en kunstmatige constructies waarbij de toets aan de grondrechten moet worden gepast in het stramien van het doeltreffendheidsvereiste. Bovendien komt zo ook duidelijker tot uitdrukking dat

27 Ziehoofdstuk 4.5.1.1.

28 HvJEU van 16 december 1976, zaak 33/76, Rewe-Zentralfinanz en Rewe-Zentral.

29 HvJEU van 18 maart 2010, gevoegde zaken C-317/08, C-318/08, C-319/08 en C320/08, Alassini; HvJEU 8 mei 2008, gevoegde zaken C-95/07 en C-96/07, Ecotrade. De term Rewe-riedel-plus komt van Sevenster 2010.

30 HvJEU van 27 februari 2014, zaak C-470/12, Pohotovost.

31 HvJEU van 7 december 2010, zaak C-439/08, VEBIC; HvJEU van 8 mei 2014, zaak C$604 / 12, H . N$. 
handelingen die vallen onder de procedurele autonomie uitvoeringshandelingen in de zin van artikel 51, lid 1, van het Handvest zijn.

\section{Minimumharmonisatie, geleidelijke harmonisatie en 'standstill'}

In geval van minimumharmonisatie waarbij het Unierecht expliciet en onvoorwaardelijk $\mathrm{k}^{32}$ bepaalt dat nationale 'verdergaande beschermingsmaatregelen' zijn toegestaan geldt op grond van de arresten Borsana, Eiterköpfe en Dominguez dat deze 'verdergaande beschermingsmaatregelen' buiten het bereik van de Uniegrondrechten vallen. ${ }^{33}$ De Unierechtelijke grondrechten zijn ingevolge deze arresten enkel van toepassing op de nationale implementatie van het Unierechtelijk minimum en niet op het verdergaande deel van de nationale maatregel. In het arrest Chatzi lijkt het Hof de Uniegrondrechten echter wel toe te passen op het 'verdergaande nationale deel'. ${ }^{34}$

Toekomstige rechtszaken die betrekking hebben op 'verdergaande beschermingsmaatregelen' verdienen dan ook bijzondere aandacht. ${ }^{35}$ Het stellen van expliciete prejudiciële vragen zou bijvoorbeeld nuttig zijn. Het Hof op zijn beurt kan dan (duidelijk) antwoorden. Hierbij zou niet alleen aan bod moeten komen of de grondrechten van toepassing zijn op 'verdergaande beschermingsmaatregelen', maar ook waarom dit al dan niet zo is. Het lijkt mij het meest waarschijnlijk en het meest wenselijk, dat de Uniegrondrechten niet van toepassing zijn op dit soort maatregelen. Het is dan wel nuttig om aan te geven waarom niet en vooral om aan te geven waarin zij verschillen van handelingen die ingevolge Wachauf-subcategorie ii (handelingen op grond van Uniebevoegdheden) wel binnen het bereik van de Uniegrondrechten liggen. Immers ook de bevoegdheid tot het nemen van verdergaande maatregelen wordt door het Unierecht expliciet genoemd in ofwel het secundaire recht of in het primaire recht (bijvoorbeeld de artikelen 153, lid 4 (sociale politiek), 169, lid 4, VWEU (consumentenbescherming) en 193 VWEU (milieu) VWEU). Ik meen dat de ratio waarom de uitoefening van de bevoegdheid tot het nemen van verdergaande beschermingsmaatregelen desondanks buiten het bereik van de grondrechten blijft is, dat het hier gaat om nationale bevoegdheden waarvan het Unierecht expliciet bevestigt dat ze bij de lidstaten zijn gebleven. Hiermee

32 Een voorbeeld waarbij niet is voldaan aan 'onvoorwaardelijk': HvJEU van 18 juli 2013, zaak C-234/12, Sky Italia.

33 HvJEU van 17 december 1998, zaak C-2/97, Borsana; HvJEU van 14 april 2005, zaak C6/03, Eiterköpfe; HvJEU van 24 januari 2012, zaak C-282/10, Dominguez.

34 HvJEU van 16 september 2010, zaak C-149/10, Chatzi.

35 Zie hierover A-G Kokott van 21 februari 2013, gevoegde zaken C-512/11, C-513/11, Terveys-ja sosiaalialan neuvottelujärjestö TSN, punt 71. 
verschillen de 'verdergaande beschermingsmaatregelen' van subcategorie ii waarin het gaat om bevoegdheden die door het Unierecht zijn gecreëerd.

In het verlengde van de problematiek van de toepassing van Uniegrondrechten op verdergaande beschermingsmaatregelen rijst ook de vraag hoe moet worden omgegaan met de uitvoering van richtlijnen die voorzien in geleidelijke harmonisatie, zoals bijvoorbeeld de Zesde richtlijn inzake BTW. Deze richtlijn staat lidstaten zonder voorbehoud toe om bestaande BTW vrijstellingen te blijven toepassen. Kwalificeert het gebruikmaken van deze bevoegdheid als uitvoering? Zijn de Uniegrondrechten van toepassing op dit soort bestaande BTW vrijstellingen? Hoe zit het met nationale handelingen die vallen onder 'standstill' bepalingen? Kwalificeren bestaande maatregelen die onder de 'standstill' vallen als uitvoering in de zin van artikel 51, lid 1, van het Handvest? Ook hierbij zou aandacht moeten zijn voor de theoretische vraag die ten grondslag ligt aan deze vraagstukken. Het gaat er steeds om onderscheid te maken tussen enerzijds gevallen waarin het Unierecht bevoegdheden in het leven roept (Uniegrondrechten van toepassing ingevolge Wachauf-categorie ii) en anderzijds gevallen waarin het Unierecht bevestigt dat bepaalde bevoegdheden bij de lidstaten zijn gebleven (Uniegrondrechten niet van toepassing).

\section{Kücükdeveci-criterium}

In Kücükdeveci ging het om de toepasselijkheid van Unierechtelijke grondrechten op nationale maatregelen die -naar nationaal recht- niet bedoeld zijn als omzettingsmaatregel, maar die wel binnen de werkingssfeer van specifieke materiële bepalingen van Unierecht vallen. Hoewel de conclusie dat dit soort maatregelen 'uitvoering' in de zin van artikel 51, lid 1, van het Handvest, behelzen juist is, wordt in Kücükdeveci een te ruime formulering gehanteerd van het begrip werkingssfeer die bovendien niet in overeenstemming lijkt te zijn met de beschikkingen Vino I en Vino II . Ik acht het wenselijk, dat het Hof op dit punt duidelijkheid verschaft en wel door explicieter en preciezer aan te geven wanneer een situatie binnen de materiële werkingssfeer van een non-discriminatierichtlijn valt. Met name zou het Hof mijns inziens in toekomstige rechtspraak consequent kunnen expliciteren, dat in geval van niet-implementatie enkel nationale handelingen binnen de werkingssfeer van Unierechtelijke nondiscriminatiebepalingen en regelingen vallen indien zowel de materie als het onderscheidingscriterium van de nationale handeling wordt gedekt door de betreffende Unieregeling. Voorts zou de verduidelijking dat het hier in wezen gaat om de toepassing van Uniegrondrechten op nationale maatregelen die een uiting zijn van een verzuim tot uitvoering welkom zijn. 
Duidelijke motivering in schemergebiedzaken

In de beschikking Sindicato dos Bancários do Norte ${ }^{36}$ verklaarde het Hof zich kennelijk onbevoegd wegens het ontbreken van concrete elementen die erop wijzen dat de nationale wet ziet op de uitvoering van het recht van de Unie. ${ }^{37}$ Het Hof verzuimt echter uit te leggen hoe het tot dit oordeel komt. Het ging in deze zaak namelijk wel degelijk om nationale maatregelen (bezuinigingsmaatregelen) die waren genomen met het oog op de voldoening van een Unierechtelijke resultaatsverplichting (het terugbrengen van het nationale begrotingstekort). Vermoedelijk achtte het Hof het verband tussen de nationale maatregelen en de Unierechtelijke verplichting te weinig concreet. Het verdient de voorkeur dat het Hof in toekomstig zaken nauwkeuriger motiveert en precies duidelijk maakt wat de doorslag geeft. Overigens realiseer ik mij dat dit lastig kan zijn.

\section{Toepasselijkheid van artikel 47 van het Handvest}

In het algemeen geldt dat Uniegrondrechten pas van toepassing zijn als de situatie in het hoofdgeding daadwerkelijk valt onder de werkingssfeer van regels van materieel Unierecht. De Uniegrondrechten worden niet geactiveerd door het enkele feit dat een justitiabele zich op het standpunt stelt dat regels van Unierecht (via de band van het nationale recht) van toepassing zijn. Het lijkt erop dat op deze regel een uitzondering geldt voor het recht op een doeltreffende voorziening in rechte en op een onpartijdig gerecht (artikel 47 van het Handvest). ${ }^{38}$ Het enkele beroep op materieel Unierecht lijkt voldoende om artikel 47 van het Handvest te activeren. Toekomstige rechtspraak moet duidelijk maken of en in hoeverre deze aanname klopt.

\subsubsection{ERT-route}

Zoals gezegd zijn lidstaten via de ERT-route gebonden aan grondrechten bij handelingen die in beginsel in strijd zijn met een verbodsbepaling van Unierecht, maar waarbij de lidstaat een beroep doet op een Unierechtelijke recht-

36 HvJEU van 7 maart 2013, zaak C-128/12, Sindicato dos Bancários do Norte, punt 12. Zie ook in de herhaling: Zie HvJEU van 26 juni 2014, zaak C-264/12, Sindicato Nacional dos Profissionais de Seguros e Afins, punt 21.

37 De beschikking is niet in het Nederlands beschikbaar. De Franse taalversie luidt als volgt: ' 12 Or, malgré les doutes exprimés par la juridiction de renvoi quant à la conformité de la loi de finances pour 2011 avec les principes et les objectifs consacrés par les traités, la décision de renvoi ne contient aucun élément concret permettant de considérer que ladite loi vise à mettre en œuvre le droit de l'Union.'

38 HvJEU van 7 februari 2013, zaak C-498/12, Pedone; HvJEU van 7 februari 2013, zaak C499/12, Gentile; zie ook HvJEU van 14 maart 2013, zaak C-555/12, Loreti, punt 17 en HvJEU van 30 mei 2013, zaak C-73/13, T., punt 13. 
vaardigingsgrond. De ERT-route is in elk geval van toepassing op maatregelen die kwalificeren als beperkingen van het vrije verkeer. Een vraag die in toekomstige rechtspraak verder moet worden beantwoord is of de ERT-gebondenheid aan de Unierechtelijke grondrechten zich ook kan voordoen in situaties buiten het vrije verkeer. Ik meen dat dit wel het geval zal moeten zijn. De ratio van deze route, volgens welke het Unierecht niet kan machtigen tot maatregelen in strijd met Uniegrondrechten, is evenzeer van toepassing in 'machtiging'-situaties buiten het vrije verkeer. De ERT -toepasselijkheid van Uniegrondrechten zou daarom mijns inziens moeten gelden voor alle 'nationale handelingen die in beginsel in strijd zijn met een verbodsbepaling van Unierecht, maar waarbij de lidstaat een beroep doet op een Unierechtelijke rechtvaardigingsgrond'.

Dit zal met name relevant zijn voor nationale maatregelen die binnen de werkingssfeer van artikel 20 VWEU vallen, doordat ze de ontneming van EU burgerschap impliceren of leiden tot de "ontzegging van het effectieve genot van belangrijkste aan de status van burger van de Unie ontleende rechten" (zoals in de arresten Rottmann en Ruiz Zambrano ${ }^{39}$ ). 40 Het ligt voor de hand dat de lidstaten ook gebonden zijn aan de Uniegrondrechten bij handelingen die in beginsel in strijd zijn met artikel 20 VWEU ('ontzeggingen'), maar waarbij de lidstaat een beroep doet op een Unierechtelijke rechtvaardigingsgrond. Dit blijkt echter nog niet expliciet uit de rechtspraak.

Door het arrest Dereci bestaat bovendien onduidelijkheid over op welke wijze grondrechten (bijvoorbeeld artikel 7 van het Handvest) een rol kunnen spelen in de kwalificatie als 'ontzegging'. ${ }^{41}$ Kunnen grondrechtelijke argumenten daar een (solo) rol spelen en zo ja op welke wijze? Ik meen dat dezelfde systematiek zou moeten gelden als in het vrije verkeer; Uniegrondrechten kunnen pas fungeren als zelfstandige toetsingsmaatstaf nadat is vastgesteld dat een nationale maatregel een 'ontzegging' in de zin van artikel 20 VWEU behelst. Meer in het bijzonder moet er voor worden gewaakt dat de vaststelling van een inmenging in een grondrecht op zich volstaat om een nationale maatregel te kwalificeren als een 'ontzegging'. Het Hof zou er goed aan doen om dit in de toekomstige rechtspraak ondubbelzinnig te bevestigen.

39 HvJEU van 2 maart 2010, zaak C-135/08, Rottmann; HvJEU van 8 maart 2011, zaak C34/09, Ruiz Zambrano.

40 Een ander voorbeeld is bijvoorbeeld de toepassing van de ERT-route bij de 'rule of reason' ex artikel 13 van besluit 1/80 van de Associatieraad die is ingesteld op grond van de Associatieovereenkomst tussen de Unie en Turkije. HvJEU van 7 november 2013, zaak C-225/12, Demir, punt 40.

41 HvJEU van 15 november 2011, zaak C-256/11, Dereci. 


\subsubsection{Handvest-rechten en Handvest -beginselen}

Het Handvest maakt onderscheid tussen zogenaamde 'rechten' en 'beginselen'. Het onderscheid tussen Handvest-rechten en Handvest-beginselen blijkt uit de artikelen 51, lid 1 en artikel 52, lid 5, Handvest. Dit onderscheid is relevant voor de directe werking van grondrechten, omdat uit artikel 52, lid 5, Handvest blijkt dat ten aanzien van beginselen een beperking van de rechterlijke bevoegdheid geldt. De betekenis van deze beperking is echter uitermate onduidelijk. Uit artikel 52, lid 5, van het Handvest blijkt expliciet dat Handvest-beginselen directe werking kunnen hebben, hierin wordt immers melding gemaakt van de mogelijkheid van wettigheidstoetsing. Het is echter onduidelijk waar de betekenis van de beperking hem in zit.

In toekomstige rechtspraak zal moeten blijken welke grondrechten kwalificeren als Handvest-beginselen en tevens zal moeten worden verhelderd of Handvestbeginselen directe werking kunnen hebben ten aanzien van alle nationale maatregelen die ingevolge artikel 51, lid 1, van het Handvest binnen het toepassingsgebied van het Unierecht vallen of enkel ten aanzien van nationale maatregelen die Handvest-beginselen uitvoeren. Voorts moet duidelijk worden welke gevolgen de directe werking van Handvest-beginselen kan hebben. Ik meen dat de bepaling aldus moet worden uitgelegd, dat de rechterlijke bevoegdheid ten aanzien van beginselen is beperkt in de zin dat toewijzing van positieve maatregelen (de uitoefening van een subjectief recht) op basis van enkel het beginsel, dat wil zeggen in afwezigheid van uitvoeringsmaatregelen, niet is toegestaan. Een wettigheidstoetsing op grond van Handvest-beginselen zou in principe moeten kunnen, ook bij nationale handelingen die geen uitvoering van het betreffende beginsel behelzen (maar wel uitvoering van Unierecht ex artikel 51, lid 1, van het Handvest). Dit neemt niet weg dat de uiteindelijke betekenis van artikel 52, lid 5, Handvest in de praktijk mogelijk gering zal zijn. De intensiteit van rechterlijke toetsing wordt immers mede bepaald door de aard van de norm. Naarmate deze meer beoordelingsvrijheid bevat en minder precies is (hetgeen bij Handvest-beginselen automatisch het geval zal zijn), zal de rechter zich sowieso meer terughoudend moeten opstellen.

\subsection{Horizontale directe werking}

\subsubsection{Stand van het recht}

De grondrechten van de Unie kunnen horizontale directe werking hebben. Het maakt daarbij niet uit of het gaat om grondrechten uit hoofde van de algemene 
beginselen van Unierecht (Mangold en Kücükdeveci) of van het Handvest $(A M S) .{ }^{42}$ Het leerstuk staat echter nog in de kinderschoenen, er zijn nog veel vragen. Er zijn buiten Mangold en Kücükdeveci, die beiden zien op de horizontale directe werking variant 'toetsing van overheidshandelen' van het verbod van discriminatie op grond van leeftijd als algemeen beginsel van Unierecht, geen voorbeelden in de rechtspraak van de toekenning van horizontale directe werking van Uniegrondrechten. Daarbij zijn deze arresten aanleiding tot veel onduidelijkheden. Een belangrijke oorzaak hiervoor is het stilzwijgen van het Hof ten aanzien van de grondslag van de horizontale directe werking van Uniegrondrechten.

Vaart het Hof een koers op grond waarvan (bepaalde) grondrechten van de Unie in alle Unierechtelijke situaties van toepassing zijn, ongeacht of het een verticale of een horizontale situatie betreft? Een dusdanige koers zou een aanzienlijke evolutie betekenen van het Unierechtelijke systeem van grondrechtenbescherming die is gegrond op de klassieke opvatting van grondrechten als beschermingsmiddel tegen overheidsmacht en zou bovendien revolutionair zijn in het merendeel van de lidstaten. Het zou immers betekenen, dat (bepaalde) grondrechten van de Unie ook dwingend recht zijn voor particulieren. Bij deze koers hoort dan ook de erkenning van volledige horizontale directe werking van (die) grondrechten dat wil zeggen zowel de variant 'toetsing van overheidshandelen' als de variant 'toetsing van particulier handelen'.

Een andere mogelijkheid is dat het Hof nog steeds uitgaat van de oorspronkelijke (verticale) functie van Uniegrondrechten, maar hierbij een zeer ruime opvatting hanteert op grond waarvan ze ook in horizontale gedingen kunnen fungeren als zelfstandige toetsingsmaatstaven van overheidshandelen. Deze mogelijkheid impliceert een splitsing in het concept van horizontale directe werking van grondrechten, waarbij van de variant 'toetsing van overheidshandelen' wel sprake is, maar de variant 'toetsing van particulier handelen' niet aan de orde zou zijn.

Het is tenslotte ook mogelijk, dat het Hof het bestaan van (een vorm van) horizontale directe werking van Uniegrondrechten koppelt aan de toepasselijkheid van secundair recht dat het ingeroepen grondrecht concretiseert in de private sector, zoals bijvoorbeeld een non-discriminatierichtlijn.

De bestaande onduidelijkheden nopen tot een voorzichtige benadering omtrent het aannemen van horizontale directe werking van Uniegrondrechten. Op basis

42 HvJEU van 22 november 2005, zaak C-144/04, Mangold; HvJEU van 19 januari 2010, zaak C-555/07, Kücükdeveci; HvJEU van 15 januari 2014, zaak C-176/12, AMS. 
van de huidige stand van het recht kan het bestaan daarvan enkel worden aangenomen in situaties die vergelijkbaar zijn met Kücükdeveci. Uit een analyse van Kücükdeveci in samenhang met Mangold en AMS volgt dat het bestaan van horizontale directe werking van een Uniegrondrecht enkel kan worden aangenomen als voldaan is aan vier voorwaarden. Allereerst moet het ingeroepen grondrecht technisch geschikt zijn om in het hoofdgeding rechtstreeks te worden toegepast. Dit is een gebruikelijk vereiste voor directe werking. Ten tweede moet het gaan om een grondrechtenschending die is te herleiden tot een nationale overheidshandeling. Het onderwerp van toetsing aan het Uniegrondrecht dient derhalve een overheidshandeling te zijn. Of anders gezegd: vooralsnog kan enkel worden uitgegaan van het bestaan van horizontale directe werking variant 'toetsing van overheidshandelen'. Deze overheidshandeling moet ten derde kwalificeren als een handeling die Unierecht ten uitvoer legt of Unierecht toepast. Het gaat hier om de gebruikelijke voorwaarde voor de directe werking van Uniegrondrechten uit hoofde van artikel 51, lid 1, van het Handvest. Naast deze 'gewone' voorwaarde voor toepasselijkheid van grondrechten moet rekening worden gehouden met de bijkomende voorwaarde, dat de situatie in het hoofdgeding valt binnen het toepassingsgebied van Uniewetgeving (bijvoorbeeld een non-discriminatierichtlijn) die het betreffende grondrecht concretiseert in de private sector (ik noemde deze voorwaarde eerder in mijn proefschrift 'de dubbele toegangspoort').

Indien aan alle vier de voorwaarden is voldaan mag worden aangenomen, dat sprake is van de horizontale directe werking van het Uniegrondrecht. Indien niet is voldaan aan de eerste voorwaarde (het grondrecht is technische ongeschikt) en/of de derde voorwaarde (er is geen sprake van toepassing van Unierecht in de zin van artikel 51, lid 1, van het Handvest) kan worden aangenomen dat geen sprake is van de horizontale directe werking van het Uniegrondrecht. Deze voorwaarden mogen namelijk als vaststaand worden verondersteld. Indien niet is voldaan aan de tweede voorwaarde (het gaat om de toetsing van particulier handelen) en/of aan de vierde voorwaarde (afwezigheid van concretisering in Uniewetgeving) is reden voor twijfel over het bestaan van horizontale directe werking. Het bestaan van deze voorwaarden staat namelijk niet vast.

De arresten Mangold en Kücükdeveci zien op de toekenning van horizontale directe werking van een verbod van discriminatie, namelijk het verbod van discriminatie op grond van leeftijd. Het is derhalve mogelijk om de gevolgen van de Kücükdeveci -benadering voor discriminatieverboden wat concreter in beeld te brengen. ${ }^{43}$ Allereerst lijkt de Kücükdeveci -horizontale directe werking

43 Ziehoofdstuk 10. 
zo goed als zeker toepasbaar te zijn op alle discriminatieverboden op de gronden die zijn genoemd in artikel 19 VWEU (geslacht, ras of etnische afstamming, godsdienst of overtuiging, handicap, leeftijd en seksuele geaardheid). Ten tweede volgt uit AMS dat wat voor de discriminatieverboden uit hoofde van het algemene non-discriminatiebeginsel geldt, vermoedelijk ook geldt voor artikel 21 van het Handvest. Ten derde heeft Kücükdeveci de 'de facto' horizontale directe werking (variant toetsing van overheidshandelen) tot gevolg van de concretisering van het verbod van discriminatie op grond van leeftijd in richtlijn 2000/78. Naar mag worden aangenomen geldt deze 'de facto' horizontale directe werking (toetsing van overheidshandelen) voor de concretiseringen van alle discriminatieverboden op de artikel 19 VWEU-gronden in non-discriminatierichtlijnen. ${ }^{44}$

\subsubsection{Legitimiteit en rechterlijk activisme}

Daar waar de erkenning van het bestaan van verticale directe werking als zodanig algemeen is aanvaard en geen spanning oplevert met het beginsel van allocatie van bevoegdheden, ligt dit anders bij de erkenning van horizontale directe werking van Uniegrondrechten. Het aannemen van horizontale directe werking van Uniegrondrechten komt (potentieel) neer op een wezenlijk andere benadering van Uniegrondrechten dan de klassieke benadering van bescherming tegen overheidsmacht (in casu Uniemacht in brede zin) en situeert zich in een complexer constitutioneel speelveld. Het leerstuk raakt niet alleen aan de verticale verdeling van bevoegdheden (tussen de Unie en de lidstaten), maar ook aan de rolverdeling tussen rechter en wetgever.

Bovendien kan de horizontale directe werking van Unierechtelijke grondrechten niet los worden gezien van de algemene (nationale) constitutionele debatten over de toepassing van grondrechten in private verhoudingen ('derdenwerking van grondrechten'). De horizontale directe werking van Uniegrondrechten impliceert immers derdenwerking van die rechten. Ondanks dat de invloed van grondrechten in particuliere verhoudingen algemeen is aanvaard, bestaan er binnen de lidstaten uiteenlopende opvattingen over op welke manier dit kan en tot op welke hoogte. De constitutionele stelsels van de verschillende lidstaten tonen een gevarieerd beeld van de situaties waarin en de wijze waarop grondrechten van toepassing kunnen zijn in horizontale verhoudingen. Het gebruik

44 Dit zou dan gelden voor de discriminatieverboden in de richtlijnen 2000/78, 2000/43, 2006/54, 2010/41, 86/613, 2004/113. Zie hoofdstuk 10.3.2. 
van grondrechten door de rechter als zelfstandige toetsingsmaatstaf is in het merendeel van de lidstaten niet aanvaard. ${ }^{45}$

Het aannemen van horizontale directe werking (die het gebruik van grondrechten door de rechter als zelfstandige toetsingsmaatstaf impliceert) is derhalve bepaald geen vanzelfsprekendheid. In elk geval kan niet worden gezegd dat het Unierecht zou nopen tot het aannemen van horizontale directe werking. Het is overigens wel denkbaar dat het Hof in bepaalde gevallen een zekere derdenwerking van Uniegrondrechten zou moeten verzekeren (bijvoorbeeld uit hoofde van het EVRM in samenhang met artikel 52, lid 3, van het Handvest $\left.{ }^{46}\right) .{ }^{47} \mathrm{Ik}$ ben van mening dat de rechtspraak van het Hof inzake de horizontale directe werking van Uniegrondrechten blijk zou moeten geven van dit complexe en delicate constitutionele speelveld. Met name zou het gevarieerde beeld en de gevoeligheid in de nationale constitutionele stelsels ten aanzien van (vormen van) derdenwerking van grondrechten aanleiding moeten zijn voor een terughoudende en zorgvuldige opstelling door het Hof. Het is vanuit dit perspectief dat ik de arresten Mangold en Kücükdeveci zal bespreken. Ik meen dat er een aantal kritische kanttekeningen moeten worden geplaatst bij de benadering van het Hof in Mangold en Kücükdeveci.

Allereerst baseert het Hof zich op de effectiviteit ('volle werking') van het nondiscriminatiebeginsel, maar verzuimt het om an te geven waarom het noodzakelijk is dat het non-discriminatiebeginsel (of Uniegrondrechten in het algemeen) in een private setting moet worden geëffectueerd. Ik beschouw het niet beantwoorden van deze vraag naar de grondslag van de derdenwerking van Uniegrondrechten als een wezenlijk manco, omdat de derdenwerking van grondrechten in het algemeen en van Uniegrondrechten in het bijzonder geen vanzelfsprekendheid is. Tevens zou de beantwoording van deze voorvraag inzicht hebben gegeven in de implicaties van de ingezette lijn.

Ten tweede impliceert de erkenning van horizontale directe werking van Uniegrondrechten een vorm van derdenwerking die verder gaat dan de in de lidstaten meer algemeen aanvaarde functie van grondrechten als instrument van uitleg. Hierbij moet wel worden aangetekend, dat de Mangold/ Kücükdeveci variant van horizontale directe werking 'toetsing van overheidshandelen' een minder indringende en controversiële vorm van derdenwerking behelst dan de variant 'toetsing van particulier handelen' en daarmee ook eerder als aanvaard-

45 Zie hoofdstuk 7.3.

46 Zie hoofdstuk 7.5.2.2.

47 Zie hoofdstuk 7.5.2. 
baar zal worden beschouwd. De erkenning van deze variant impliceert niet per se de gebondenheid van particulieren aan grondrechten en betekent daarmee ook niet noodzakelijk een afwijking van de klassieke functie van grondrechten (beschermingsmiddel tegen overheidsmacht). Bij deze variant is immers sprake van een verticale component die als aanknoping kan dienen voor de toepasselijkheid van grondrechten. Dit onderscheid is ook relevant met het oog op artikel 51, lid 1, van het Handvest. Door de verticale component is deze vorm van horizontale directe werking van grondrechten niet strijdig met artikel 51, lid 1, van het Handvest.

Ten derde maakt de concrete toepassing van horizontale directe werking in de zaken Mangold en Kücükdeveci de spanning zichtbaar met de horizontale en verticale allocatie van bevoegdheden. ${ }^{48}$ Dit komt door het eigenaardige samenspel van het grondrecht (verbod van discriminatie op grond van leeftijd) en de richtlijn (richtlijn 2000/78) waardoor delen van de richtlijn als onderdeel van het grondrecht een nieuw en zelfstandig court- made leven krijgen. Of anders gezegd: er is sprake van een vereenzelviging van het beginsel van nondiscriminatie en (onderdelen van) de richtlijn. De horizontale directe werking van het grondrecht doorkruist bovendien de bedoeling van de Uniewetgever dat het verbod van discriminatie op grond van leeftijd in de private sector van toepassing zou zijn door middel van nationale wetgeving. Meer algemeen gezegd is sprake van doorkruising van het Unierechtelijke systeem van rechtsbronnen.

Ten vierde had het Hof kunnen opteren voor lichter geschut. Hoewel ik niet uitsluit, dat aan (bepaalde) Uniegrondrechten een zekere derdenwerking zou moeten toekomen (bijvoorbeeld via de band van artikel 52, lid 3, Handvest of in de toekomst uit hoofde van het EVRM-lidmaatschap van de Unie), betekent dit nog geen grondslag voor de erkenning van horizontale directe werking van die grondrechten. Immers bij de vraag naar de derdenwerking van grondrechten gaat het er niet alleen om of grondrechten invloed kunnen hebben op private verhoudingen, maar moet ook worden nagedacht over de wijze waarop dit zou moeten gebeuren. Bij de beantwoording van deze vraag is relevant, dat de directe werking binnen het Unierecht over het algemeen een probaat middel is om de volle en uniforme werking ervan te verzekeren. Zoals ik echter eerder aangaf moet bij de vraag naar de wijze waarop de mogelijke derdenwerking van Uniegrondrechten moet worden geëffectueerd ook rekening worden gehouden met het gevoelige en complexe constitutionele speelveld. Hierbij is relevant, dat er ook andere middelen dan de erkenning van horizontale directe werking

48 Ziehoofdstuk 10. 
hadden kunnen worden ingezet. Bijvoorbeeld het middel van de plicht tot grondrechtconforme interpretatie of van het recht op schadevergoeding door de Staat wegens schending van Unierecht (Francovich). Ook had het Hof kunnen opteren voor het aannemen van een Unierechtelijke plicht voor nationale rechters om in bepaalde situaties de toepassing van Uniegrondrechten in horizontale verhoudingen te effectueren, maar met de vrijheid om dit te doen met behulp van hun nationale technieken en methodes (volgens een met het leerstuk van de nationale procedurele autonomie vergelijkbare systematiek). ${ }^{49}$

Ten vijfde heeft het Hof zich met de erkenning van horizontale directe werking 'variant toetsing van overheidshandelen' in een benarde positie gemanoeuvreerd waar in toekomstige rechtspraak moet worden gekozen tussen twee 'kwaden'. Er komt immers een moment waarop het Hof moet beslissen of ook de andere variant van horizontale directe werking, de toetsing van particulier handelen, moet worden aanvaard. De aanvaarding van deze vorm van horizontale directe werking impliceert per definitie de gebondenheid van particulieren aan Uniegrondrechten en is daarom in mijn ogen evident in strijd met artikel 51, lid 1, van het Handvest en is vergaand voor het merendeel van de lidstaten. Als het Hof daarentegen niet 'all the way' zou gaan, door te verklaren dat Uniegrondrechten geen horizontale directe werking hebben als dit in de betreffende nationale juridische context leidt tot de toetsing van particulier handelen, leidt dit tot een opsplitsing van het leerstuk van horizontale directe werking in de twee varianten die de coherentie van het van Unierecht niet ten goede zal komen. Met name zou dit haaks staan op de aanpak ten aanzien van (het ontbreken) van horizontale directe werking van richtlijnen. Immers in deze context heeft het Hof de beide varianten van horizontale directe werking consequent afgewezen wegens het feit dat richtlijnen naar hun aard niet zijn gericht aan particulieren.

Tot slot acht ik nog relevant de weerstand en commotie die het arrest Mangold in verschillende geledingen heeft veroorzaakt en die het Hof niet kan zijn ontgaan. Het Hof heeft in weerwil van het complexe constitutionele speelveld en deze weerstand na Mangold welbewust gekozen voor het doorzetten van de toekenning van horizontale directe werking van Uniegrondrechten. Dit alles is gebeurd zonder een motivering. Er is geen uitleg over de grondslag van de nieuwe doctrine gegeven en evenmin is ingegaan op de in de procedure voor het Hof ingebrachte tegenargumenten voor horizontale directe werking. Mede gezien de intensiteit van het debat in de doctrine en in de procedures voor het Hof acht ik dit kwalijk. Als het Hof kiest voor een nieuwe doctrine, is het beter

49 Zie verder hoofdstuk 11.3.3. 
die uit te leggen en zo precies mogelijk te omschrijven. Een grote mate van transparantie, ook bij heikele kwesties, kan bijdragen aan acceptatie van rechterlijke uitspraken (en daarmee aan de legitimiteit achteraf) en voorkomt rechtsonzekerheid. Ik ben mij er van bewust dat het gebrek aan motivering kan zijn ingegeven door de noodzaak om consensus te bereiken binnen het Hof, maar bij dit soort principiële beslissingen zou er niet te veel water bij de wijn moeten worden gedaan ten aanzien van de motivering, met name niet ten aanzien van essentiële punten zoals de grondslag van de nieuwe doctrine van horizontale directe werking van grondrechten. ${ }^{50}$

Op grond van het geheel van de bovengenoemde kanttekeningen beschouw ik de toekenning van horizontale directe werking van Uniegrondrechten als activistisch.

\subsubsection{Openstaande vragen en aandachtspunten}

In de vorige paragrafen kwam reeds aan bod dat er een aanzienlijk aantal fundamentele vragen open staan terzake van het leerstuk van de horizontale directe werking van Uniegrondrechten. Het is van groot belang dat deze punten in toekomstige zaken worden opgehelderd.

Grondslag van de horizontale directe werking c.q. van de derdenwerking van (bepaalde) Uniegrondrechten

Het grootste manco in de zaken Mangold en Kücükdeveci is de onduidelijkheid over de grondslag van de horizontale directe werking c.q. de derdenwerking van Uniegrondrechten. Ik vermoed dat dit geen toeval is en dat de kwestie binnen het Hof zeer gevoelig ligt. Het Hof lijkt per zaak te bekijken welke stap wordt genomen. De vraag naar de grondslag van horizontale directe werking en derdenwerking van Uniegrondrechten is echter van groot belang voor de precieze gevolgen. Het verdient daarom aanbeveling dat het Hof zich spoedig hierover uitspreekt door met name aan te geven waarom (bepaalde) Uniegrondrechten in (bepaalde) horizontale situaties van toepassing zijn.

\section{Relevantie van het samenspel met de richtlijn 2000/78}

Een heet hangijzer is de vraag in hoeverre het samenspel met richtlijn 2000/78 in Mangold en Kücükdeveci van doorslaggevend belang was bij de toekenning van horizontale directe werking. Indien het samenspel met richtlijn 2000/78 niet doorslaggevend was, kan de vierde voorwaarde ('de dubbele toegangspoort') achterwege blijven en is het dus niet vereist dat de situatie in het

50 Zie hierover hoofdstuk 1.2. 
hoofdgeding valt binnen het materiële toepassingsgebied van Uniewetgeving die het betreffende grondrecht concretiseert. Uniegrondrechten die voldoen aan de technische eisen van directe werking zullen daarmee in alle situaties die uit hoofde van artikel 51, lid 1, van het Handvest binnen het toepassingsgebied van het Unierecht vallen horizontale directe werking variant 'toetsing van overheidshandelen' hebben. Het is wenselijk dat het Hof op dit punt duidelijkheid verschaft.

Ik meen dat het Hof er goed aan zou doen om de innige verstrengeling tussen richtlijn en grondrecht te verbreken en een duidelijk onderscheid zou moeten aanbrengen tussen enerzijds de (materiële) toepassing van het grondrecht en anderzijds de toepassing van secundair recht. Hiervoor zou ten eerste duidelijk moeten worden gemaakt, dat het grondrecht (nadat de toepasselijkheid ervan is vastgesteld conform artikel 51, lid 1, van het Handvest) als zodanig dient als zelfstandige toetsingsmaatstaf. Ten tweede zou de inhoud van het grondrecht zelfstandig moeten worden bepaald en niet moeten worden ingevuld met behulp van secundair recht.

Bovendien meen ik dat in situaties die vallen binnen de werkingssfeer van Uniewetgeving waarin grondrechten worden geconcretiseerd (bijvoorbeeld een non-discriminatierichtlijn), de grondrechten primair moet worden toegepast op de betreffende Uniewetgeving. Dit betekent dat de grondrechten vooral een rol zouden moeten spelen als instrument van uitleg en maatstaf voor de toetsing van de geldigheid van de betreffende Uniewetgeving, maar dat een zeer grote terughoudendheid gepast is ten aanzien van de directe werking ervan.

Erkenning van volledige horizontale directe werking inclusief de variant'toetsing van particulier handelen'

Op basis van de huidige rechtspraak is het niet duidelijk of Uniegrondrechten ook horizontale directe werking kunnen hebben in situaties waarin het Uniegrondrecht zou dienen als toetsingsmaatstaf van particulier handelen. Dit is een lastige en heikele vraag. Desondanks zou het Hof er goed aan doen om deze hete aardappel niet door te schuiven naar toekomstige zaken, maar waar het kan duidelijkheid te verschaffen. Hierbij moet het Hof kiezen tussen twee kwaden. De erkenning van deze vorm van horizontale directe werking druist mijns inziens apert in tegen artikel 51, lid 1, van het Handvest en zou neerkomen op een fundamenteel andere benadering van de rol van grondrechten dan tot nu toe het geval is zowel binnen de Unie als binnen het merendeel van de lidstaten. De afwijzing van deze vorm van horizontale directe werking is echter weer nadelig voor de coherentie en eenvoud van het Unierecht doordat 
het concept van horizontale directe werking wordt opgesplitst in twee varianten.

Ik meen, dat het beste kan worden gekozen voor de afwijzing van deze volledige horizontale directe werking. Gezien het complexe constitutionele speelveld vind ik het een brug te ver om de gebondenheid van particulieren aan Uniegrondrechten aan te nemen. Meer algemeen meen ik dat het voorkeur verdient om in toekomstige rechtspraak een onderscheid aan te brengen tussen enerzijds de vraag naar of een (bepaald) Uniegrondrecht in (bepaalde) horizontale situaties van toepassing is (bestaan van derdenwerking) en anderzijds de vraag naar op welke wijze deze derdenwerking gestalte zou moeten krijgen (wijze van derdenwerking). De vraag naar het bestaan van derdenwerking moet mijns inziens door het Unierecht worden bepaald. Waarbij het wel pas geeft om steeds uit te leggen waarom Uniegrondrechten in bepaalde private situaties effect zouden moeten sorteren. Dat blijft steeds de relevante voorvraag. Voor de vraag naar de wijze waarop de derdenwerking zou moeten worden geëffectueerd, zou op grond van het Unierecht in elk geval de plicht tot de grondrechtconforme interpretatie van het nationaal recht en het leerstuk van staatsaansprakelijkheid wegens schending van Unierecht van toepassing kunnen zijn. Voor het overige zou aan de nationale rechter de vrijheid kunnen worden gelaten om de uit hoofde van het Unierecht geldende derdenwerking te effectueren door middel van de nationale technieken en methodes zulks met inachtneming van de Rewe -beginselen van gelijkwaardigheid en effectiviteit. ${ }^{51}$ Ik meen dat hierdoor wordt gekomen tot een uniforme en effectieve doorwerking van Uniegrondrechten in horizontale verhoudingen, maar tevens ruimte wordt gelaten voor de nationale technieken om dit doel te bewerkstelligen.

\subsection{Eindconclusie en aanbevelingen}

Het contrast tussen de rechtspraak inzake de verticale directe werking en de horizontale directe werking van Uniegrondrechten is groot en wel op twee punten: ten eerste de mate waarin de leerstukken zijn uitgekristalliseerd en ten tweede de mate van legitimiteit van de rechtspraak. Het leerstuk van de directe werking van Uniegrondrechten is daardoor zowel op dreef als op drift.

Het leerstuk van de verticale directe werking van Uniegrondrechten is al een eind op stoom en is tot wasdom gekomen. Zowel het bestaan van verticale directe werking als de uitwerking ervan in concrete situaties is legitiem. De

51 HvJEU van 16 december 1976, zaak 33/76, Rewe-Zentralfinanz en Rewe-Zentral. 
vrees dat het Hof 'gewapend' met het bindende Handvest de Uniegrondrechten van toepassing zal verklaren op nationale maatregelen die in wezen los staan van het Unierecht acht ik op basis van de huidige rechtspraak ongegrond.

Het is niet eenvoudig om op grond van artikel 51, lid 1, van het Handvest een sluitende en handzame toets te formuleren voor de vaststelling of de Uniegrondrechten in een specifieke situatie van toepassing zijn. De vraag of sprake is van een situatie waarin materieel Unierecht in het spel is waaraan de betreffende nationale handeling 'uitvoering' of 'toepassing' geeft of zou moeten geven, is wel behulpzaam maar nog steeds abstract. Het formuleren van een concreter criterium lijkt echter lastig te zijn. Het meeste houvast bestaat naar mijn mening als deze vraag wordt gebruikt in combinatie met de in dit proefschrift voorgestelde classificatie in vijf categorieën van nationale overheidshandelingen: (i) klassieke omzettingshandelingen, (ii) handelingen op grond van Uniebevoegdheden, (iii) handelingen die onder de werkingssfeer van Uniewetgeving vallen, (iv) effectuering, sanctionering en handhaving van Unierecht en (v) nationale maatregelen die in beginsel in strijd zijn met een verbodsbepaling van Unierecht, maar waarbij de lidstaat een beroep doet op een Unierechtelijke rechtvaardigingsgrond. Nu de categorieën zijn gebaseerd op een aanzienlijke hoeveelheid rechtspraak over een lange periode die over het algemeen coherent is, acht ik het bestaan van deze categorieën betrouwbaar. Vooralsnog omvatten deze categorieën alle situaties die onder artikel 51, lid 1, van het Handvest vallen. Het kan niet worden uitgesloten dat er in de toekomst categorieën bij komen, al acht ik dit onwaarschijnlijk.

De verticale directe werking van grondrechten is derhalve een leerstuk met een vaste koers in kalm vaarwater. Wel zijn er een aantal aandachtspunten. Zo kan de legitimiteit van de Wachauf-waaier worden verstevigd door meer aandacht te besteden aan de explicitering en dogmatische onderbouwing van de verschillende mogelijke varianten. Verder is oplettendheid geboden voor de wijze waarop de ERT-route moet worden toegepast bij post-Zambrano zaken (toepassing van artikel $20 \mathrm{VWE}$ ) en wel met name ten aanzien van de vraag in hoeverre artikel 7 van het Handvest van invloed zal zijn op de kwalificatie van nationale handelingen als 'ontzeggingen'. De overige aandachtspunten heb ik uitgewerkt in de tien onderstaande aanbevelingen.

Het leerstuk van de horizontale directe werking van Uniegrondrechten staat nog in de kinderschoenen. Op dit punt zal het Hof nog wat halsbrekende toeren moeten uithalen en alle zeilen moeten bijzetten. De belangrijkste stap hier zal zijn het expliciet aanvaarden of afwijzen van de mogelijkheid van volledige horizontale directe werking (dat wil zeggen inclusief de variant 'toetsing van particulier handelen'). In de inleiding is opgemerkt dat het arrestenduo Mangold 
en Kücükdeveci een storm van kritiek heeft veroorzaakt. De kritiek acht ik terecht. De Mangold en Kücükdeveci rechtspraak schiet tekort op veel fronten: de motivering van de arresten is mager, vooral omdat de grondslag van de horizontale directe werking c.q de derdenwerking ontbreekt. De gekozen aanpak is inconsistent met de rechtspraak betreffende de horizontale directe werking van richtlijnen en doorkruist die zelfs. De arresten leveren spanning op met het allocatiebeginsel en veroorzaken door hun onduidelijkheid ook nog eens een aanzienlijke rechtsonzekerheid. Ik beschouw de Mangold en Kücükdeveci daarom als een vorm van rechterlijk activisme. Ik meen ook dat de paradoxale term struisvogelactivisme op zijn plaats is. Op cruciale punten (met name de grondslag van de horizontale directe werking c.q. de derdenwerking) en momenten (Dominguez) wordt immers gezwegen (de kop in het zand gestoken). Zo lijkt het alsof het Hof zelf ook niet precies weet welke kant het opgaat en wat de consequenties van de ingeslagen weg zijn. Ik acht het dan ook van groot belang, dat duidelijk wordt op welk fundament de arresten Mangold en Kücükdeveci steunen.

Ik besluit mijn proefschrift met een reeks van aanbevelingen die zich primair richten tot het Hof, maar die tevens kunnen dienen als leidraad voor de nationale rechters en procespartijen, alsmede voor de actoren in Hofzaken.

\section{A. Aanbevelingen terzake van het leerstuk van verticale directe werking}

A.1 Explicitering en theoretische onderbouwing verschillende typen van Wachaufuitvoering

Het formuleren van een voor de toepassing van artikel 51, lid 1, van het Handvest concreter criterium dan tot nu toe naar voren komt in de rechtspraak lijkt niet eenvoudig te zijn. Mede gezien de variatie aan situaties die kunnen kwalificeren als de 'uitvoering' of 'toepassing' van Unierecht lijkt het ondoenlijk om tot één concrete (paraplu) toets te komen. Dit probleem kan worden ondervangen door gebruik te maken van de beschikbare aanzienlijke hoeveelheid rechtspraak waaruit bestendige stereotypen van situaties kunnen worden ontward die kunnen bijdragen aan een concretisering van het abstracte artikel 51-criterium. Deze stereotypen, en met name de typen van Wachauf-uitvoering, worden in de rechtspraak lang niet altijd geëxpliciteerd en dogmatisch onderbouwd, terwijl dit wel mogelijk zou moeten zijn. Hier zie ik een kans om de toepassing van artikel 51, lid 1, van het Handvest te vereenvoudigen en te verhelderen. Het verdient daarom aanbeveling om in toekomstige rechtspraak de verschillende Wachauf -situaties te explici- 
teren en te onderbouwen. Ik merk overigens op, dat de meer recente rechtspraak van het Hof, zoals bijvoorbeeld het arrest Siragusa, ${ }^{52}$ reeds blijk geeft van een uitgebreide motivering van de (niet-) toepasselijkheid van de grondrechten van de Unie. Dit is toe te juichen en het is wenselijk dat het Hof deze lijn doorzet en ook in toekomstig zaken zo nauwkeurig mogelijk blijft aangeven wat de doorslag geeft. De aanbevelingen hierna bevatten suggesties op specifieke punten van aandacht.

A.2 Explicitering en verduidelijking van de toepassing van grondrechten op de nationale effectuering, sanctionering en handhaving van het Unierecht

De toepassing van grondrechten op de nationale effectuering, sanctionering en handhaving van het Unierecht blijkt gevoelig te kunnen liggen. Het is daarom raadzaam om deze variant van uitvoering van het Unierecht steeds expliciet benoemen en stapsgewijs te motiveren. Hierbij is met name van belang dat wordt benoemd, dat het bij dit soort nationale handelingen in wezen gaat om de uitvoering van het beginsel van loyale samenwerking. Voorts verdient het aanbeveling om zichtbaar te maken dat sprake moet zijn van een dubbele EU-link: Allereerst moet er een identificeerbare plicht tot de effectuering, sanctionering en handhaving van Unierecht zijn op grond van de algemene bepaling artikel 4, lid 3, VEU (overigens zijn deze plichten 'court-made') of op grond van specifieke Uniebepalingen (bijvoorbeeld artikel 325 VWEU (plicht tot fraudebestrijding) of bepalingen van secundair recht). Ten tweede moet het (uiteindelijk) gaan om de effectuering, sanctionering en handhaving van een bepaling van materieel Unierecht.

\section{A.3 Verhouding met de Rewe-riedel}

Bij de toepassing van Uniegrondrechten op nationale handelingen die vallen binnen de procedurele autonomie is het wenselijk om een eenduidige en heldere lijn in te nemen ten aanzien van de verhouding tussen de Rewe-riedel en de Uniegrondrechten. Het hanteren van een Rewe-riedel-plus waarbij een onderscheid wordt gemaakt tussen enerzijds de toets aan de grondrechten en anderzijds de toepassing van de Rewe -beginselen van gelijkwaardigheid en doeltreffendheid verdient hierbij mijns inziens de voorkeur.

52 HvJEU van 6 maart 2014, zaak C-206/13, Siragusa (het ging in deze zaak om de niettoepasselijkheid van Uniegrondrechten). Zie ook HvJEU van 10 juli 2014, zaak C198/13, Julian Hernández. 


\section{A.4 Uitzondering voor artikel 47 van het Handvest}

In het algemeen geldt dat Uniegrondrechten pas van toepassing zijn als de situatie in het hoofdgeding daadwerkelijk valt onder de werkingssfeer van regels van materieel Unierecht. Voor de activering van Uniegrondrechten volstaat niet het enkele feit dat een justitiabele zich op het standpunt stelt dat regels van materieel Unierecht (via de band van het nationale recht) van toepassing zijn. Het verdient aanbeveling om in toekomstige rechtspraak duidelijk te maken of en in hoeverre op deze regel een uitzondering geldt voor het recht op een doeltreffende voorziening in rechte en op een onpartijdig gerecht (artikel 47 van het Handvest). Het lijkt mij noodzakelijk, dat artikel 47 van het Handvest reeds van toepassing kan zijn door het enkele beroep op materieel Unierecht. Dit is immers een prealabele voorwaarde voor de effectuering van het Unierecht. In wezen gaat het hier om de toepassing van de artikelen 4, lid 3 en 19, lid 1, 2e alinea VEU.

\section{A.5 Verdergaande beschermingsmaatregelen}

Speciale aandacht zou moeten uitgaan bij de toepassing van Uniegrondrechten op nationale maatregelen die kwalificeren als 'verdergaande beschermingsmaatregelen'. Een expliciete bevestiging van de arresten Borsana, Eiterköpfe en Dominguez op grond waarvan deze 'verdergaande beschermingsmaatregelen' buiten het bereik van de Uniegrondrechten vallen is wenselijk. Het is daarbij van belang dat aandacht wordt geschonken aan de vraag waarom 'verdergaande beschermingsmaatregelen' buiten het bereik van het Unierecht vallen. De bevoegdheid tot het nemen van deze maatregelen wordt immers wel expliciet genoemd in het Unierecht. Waarin verschillen zij dan van nationale handelingen die zijn genomen in de uitoefening van Uniebevoegdheden (Wachaufcategorie ii)? Ik meen dat het verschil is dat het bij 'verdergaande beschermingsmaatregelen' gaat om nationale bevoegdheden waarvan het Unierecht expliciet bevestigt dat ze bij de lidstaten zijn gebleven. Hiermee verschillen de 'verdergaande beschermingsmaatregelen' van Wachaufsubcategorie ii waarin het gaat om bevoegdheden die door het Unierecht zijn gecreëerd.

\section{A.6 Geleidelijke harmonisatie en 'standstill'}

Het is nog onduidelijk of Uniegrondrechten van toepassing zijn op bestaande nationale handelingen die 'profiteren' (in de zin dat zij (tijdelijk) mogen blijven voortbestaan) van een traject van geleidelijke harmonisatie of van 'standstill' bepalingen. Ik zie hier een parallel met de in de vorige aanbeveling genoemde problematiek van de 'verdergaande 
beschermingsmaatregelen'. Ook hier gaat het mijns inziens niet om gevallen waarin het Unierecht bevoegdheden in het leven roept (Uniegrondrechten zijn wel van toepassing), maar om gevallen waarin het Unierecht bevestigt dat bepaalde bevoegdheden bij de lidstaten zijn gebleven (Uniegrondrechten zijn niet van toepassing). Zo voorziet bijvoorbeeld de Zesde richtlijn inzake BTW in geleidelijke harmonisatie. Deze richtlijn staat lidstaten zonder voorbehoud toe om bestaande BTW vrijstellingen te blijven toepassen. Ik meen dit soort bestaande BTW vrijstellingen niet zouden moeten kwalificeren als uitvoering in de zin van artikel 51, lid 1, van het Handvest. Hetzelfde zou moeten gelden voor zogenaamde 'bestaande of oude maatregelen' die ingevolge 'standstill' bepalingen mogen blijven bestaan. Zij kwalificeren mijns inziens evenmin als uitvoering in de zin van artikel 51, lid 1, van het Handvest.

\section{A.7 Het verzuim tot uitvoering als uitvoering}

Uit met name het arrest Kücükdeveci blijkt, dat de Unierechtelijke grondrechten van toepassing zijn op nationale maatregelen die -naar nationaal recht- niet bedoeld zijn als omzettingsmaatregelen, maar die wel binnen de werkingssfeer van specifieke materiële bepalingen van Unierecht vallen. In Kücükdeveci wordt echter niet uitgelegd waarom deze niet-uitvoering toch uitvoering is in de zin van artikel 51, lid 1, van het Handvest. Het zou goed zijn als dit in toekomstige zaken wordt gepreciseerd. Ik acht de toepassing van Uniegrondrechten op dit soort maatregelen begrijpelijk voorzover de maatregelen een uiting zijn van een 'verzuim van uitvoering'.

\section{A.8 De toepassing van de ERT-route buiten het vrij verkeer.}

De ERT-route wordt tot nu toe enkel toegepast en gemotiveerd met betrekking tot vrij verkeer-bepalingen. De ratio van deze route, volgens welke het Unierecht niet kan machtigen tot maatregelen in strijd met Uniegrondrechten, is echter ook van toepassing in 'machtiging'-situaties buiten het vrije verkeer. De ERT-toepasselijkheid van Uniegrondrechten zou daarom mijns inziens moeten gelden voor alle 'nationale handelingen die in beginsel in strijd zijn met een verbodsbepaling van Unierecht, maar waarbij de lidstaat een beroep doet op een Unierechtelijke rechtvaardigingsgrond'. Ook hier ligt een kans om in toekomstige rechtspraak de toepassing van artikel 51, lid 1, van het Handvest te verduidelijken. Dit kan door te wachten op een zaak waarin zich een 'machtigings'-situatie voor doet buiten het vrije verkeer en daarop ERT van toepassing te verklaren, maar het kan ook door de ERTformule bij een eerste gelegenheid te veralgemeniseren. In het arrest 
Pfleger heeft het Hof reeds een stap tot verduidelijking van de ERT-route gezet. ${ }^{53}$ Een volgende stap zou kunnen zijn om de gebruikte formule bij een volgende gelegenheid algemener te maken, bijvoorbeeld op de volgende wijze: ${ }^{5}$

(i) Dat wanneer een lidstaat zich beroept op dwingende vereisten van algemeen belang ter rechtvaardiging van een nationale regeling die a priori is verboden door een bepaling van Unierecht, deze door het Unierecht geboden rechtvaardigingsgrond moet worden uitgelegd in het licht van de algemene rechtsbeginselen van het Unierecht en met name de inmiddels in het Handvest neergelegde grondrechten. De betrokken nationale regeling kan dus slechts rechtvaardiging vinden in de bedoelde uitzonderingen, wanneer zij in overeenstemming is met de grondrechten waarvan het Hof de eerbiediging verzekert (zie in die zin arrest $E R T$, punt 43 ).

(ii) Uit die rechtspraak volgt dat een nationale regeling, die a priori is verboden door een bepaling van Unierecht, slechts in aanmerking kan komen voor de in het Unierecht neergelegde uitzonderingen om die nationale regeling te rechtvaardigen voor zover dat in overeenstemming is met de grondrechten waarvan het Hof de eerbiediging verzekert. Die verplichting om de grondrechten in acht te nemen valt duidelijk binnen de werkingssfeer van het Unierecht en dus van het Handvest. Het gebruik door een lidstaat van de in het Unierecht neergelegde uitzonderingen om een nationale regeling die a priori is verboden door een bepaling van Unierecht te rechtvaardigen, moet derhalve worden geacht „het recht van de Unie ten uitvoer [te] brengen" in de zin van artikel 51 , lid 1 , van het Handvest.

\section{A.9 De ERT-route en artikel 20 VWEU}

De vraag naar de toepasselijkheid van Uniegrondrechten via de ERTroute lijkt met name actueel te zijn in de context van artikel 20 VWEU. Het verdient daarom aanbeveling om in toekomstige rechtspraak in die context onomwonden duidelijk te maken dat Uniegrondrechten van toepassing zijn op nationale maatregelen die binnen de werkingssfeer van artikel 20 VWEU vallen. Hierbij zou wel moeten gelden, dat de grondrechten pas directe werking hebben nadat is komen vast te staan dat de betreffende nationale maatregel onder artikel 20 VWEU valt (de maatregel kwalificeert als 'ontzegging'). Het arrest Dereci laat helaas ruimte voor twijfel over de vraag wanneer de toepassing van Unie-

53 HvJEU van 30 april 2014, zaak C-390/12, Pfleger, punten 35 en 36.

54 Ik heb de overwegingen in Pfleger de punten 35 en 36 als basis genomen. 
rechtelijke grondrechten aan de orde komt; 55 is dit pas na de kwalificatie van de nationale handeling als ontzegging of is dit toch reeds in het kader van die kwalificatie? Het Hof zou er verstandig aan doen om dit soort onduidelijkheden te vermijden en bij zaken waarin grondrechten worden toegepast op grond van ERT steeds een strikte scheiding aan te brengen tussen enerzijds de kwalificatie als 'beperking c.q. 'ontzegging' en anderzijds de mogelijkheid tot rechtvaardiging. Zoals gezegd, zou de toepassing van Unierechtelijke grondrechten als zelfstandige toetsingsgrond pas in beeld moeten komen bij de mogelijkheid tot rechtvaardiging. Het arrest Grogan biedt een goed voorbeeld van een zaak waarin het Hof het onderscheid duidelijk aanbrengt. ${ }^{56}$

\section{A.10 De rol van Uniegrondrechten bij de kwalificatie van een nationale maatregel} als 'beperkend' of 'ontzeggend'

In het verlengde van het bovenstaande punt merk ik op dat niet elk gebruik van Unierechtelijke grondrechten in het stadium van de kwalificatie als 'beperking' of als 'ontzegging' verdacht is vanuit het oogpunt van de allocatie van bevoegdheden. Illustratief zijn de arresten SaynWittgenstein en Vardyn. ${ }^{57}$ Het grondrecht fungeerde in deze zaken niet als zelfstandige toetsingsmaatstaf, maar diende als element in de vraag of sprake was een beperking van het vrije verkeer. Terughoudendheid is hier echter wel op zijn plaats, de scheidslijn tussen het gebruik van het Unierechtelijke grondrecht als element in de beoordeling naar de vraag of sprake is van 'beperking' en het (feitelijk) gebruik van het grondrecht als zelfstandig toetsingskader, kan dun zijn. In toekomstige rechtspraak moet er voor worden gewaakt om uit de enkele inmenging in een grondrecht te concluderen tot een beperking van het vrije verkeer. Zaken waarin de toepassing van Uniegrondrechten reeds plaats vindt bij de kwalificatie van een nationale maatregel als 'beperkend' of 'ontzeggend' zijn daarom heikel en verdienen steeds bijzondere aandacht en een nauwkeurige motivering.

55 HvJEU van 15 november 2011, zaak C-256/11, Dereci.

56 HvJEU van 4 oktober 1991, zaak C-159/90, Grogan, punt 31.

57 HvJEU van 22 december 2010, zaak C-208/09, Sayn-Wittgenstein, punt 52; HvJEU van 12 mei 2011, zaak C-391/09, Vardyn, punt 66. 


\section{B. Aanbevelingen inzake het leerstuk van de horizontale directe werking van grondrechten van de Unie}

\section{B.1 Algemeen}

Het is duidelijk dat de rechtsvragen inzake de horizontale directe werking van grondrechten van de Unie niet eenvoudig zijn en soms ook niet in één arrest uitputtend kunnen worden behandeld. Toch verdient het aanbeveling om daar waar mogelijk wel antwoord te geven op openstaande kwesties. Als bovendien terzake van een gevoelig en principieel punt een weg wordt ingeslagen is het maar het beste om dit te doen in klare taal en niet omfloerst.

\section{B.2 Grondslag van de horizontale directe werking c.q. de derdenwerking van} Uniegrondrechten

Het verdient aanbeveling om in toekomstige rechtspraak aan te geven wat de grondslag is van de horizontale directe werking c.q. de derdenwerking van Uniegrondrechten, met name zou niet moeten worden volstaan met algemene verwijzingen naar de volle werking van een grondrecht.

B.3 Rol van secundair recht bij bepaling horizontale directe werking c.q. derdenwerking van een Uniegrondrechten

Toekomstige rechtspraak zou duidelijk moeten maken of Uniegrondrechten als zodanig horizontale directe werking c.q. derdenwerking kunnen hebben of enkel indien het voor de private sector is uitgewerkt in secundair recht. Ik meen, dat de principiële vraag naar de horizontale directe werking c.q. derdenwerking van een primairrechtelijke grondrecht niet (enkel) zou moeten afhangen van het secundaire recht.

B.4 Onderscheid tussen toepassing van het grondrecht en de toepassing van secundair recht

In zaken waarin het zowel gaat om de uitleg van het grondrecht als om de uitleg van secundair recht waarin het betreffende grondrecht wordt uitgewerkt zou het wenselijk zijn om steeds een duidelijk onderscheid aan te brengen tussen enerzijds de (materiële) toepassing van het grondrecht en anderzijds de toepassing van secundair recht. Met name zou de inhoud van het grondrecht zelfstandig moeten worden bepaald en niet moeten worden ingevuld met behulp van secundair recht. Dit betekent dat moet worden nagegaan wat de precieze inhoud is van het grondrecht als zodanig en welke zaken product zijn of zouden moeten 
zijn van wetgevende keuzes. Deze zaken zouden dan niet in aanmerking moeten worden genomen bij de inhoudelijke toets aan het grondrecht.

B.5 De rol van grondrechten in situaties die vallen binnen de werkingssfeer van Uniewetgeving waarin grondrechten worden geconcretiseerd

In situaties die vallen binnen de werkingssfeer van Uniewetgeving waarin grondrechten worden geconcretiseerd (bijvoorbeeld een nondiscriminatierichtlijn) zouden de grondrechten primair moet worden toegepast op de betreffende Uniewetgeving. Dit betekent dat de grondrechten vooral een rol zouden moeten spelen als instrument van uitleg en maatstaf voor de toetsing van de geldigheid van de betreffende Uniewetgeving, maar dat een zeer grote terughoudend in acht moet worden genomen ten aanzien van de directe werking ervan.

\section{B.6 De vraag naar volledige horizontale directe werking}

Een openstaande rechtsvraag is of een Uniegrondrecht kan dienen als een zelfstandige toetsingsmaatstaf voor particulier handelen (de vraag naar volledige horizontale directe werking). Deze vraag zou mijns inziens ontkennend moeten worden beantwoord.

\section{B.7 Onderscheid tussen bestaan van derdenwerking en de wijze waarop}

Meer algemeen meen ik dat het voorkeur verdient om in toekomstige rechtspraak een onderscheid aan te brengen tussen enerzijds de vraag naar of (bepaalde) Uniegrondrechten in (bepaalde) horizontale situaties van toepassing zijn (de vraag naar het bestaan van derdenwerking) en anderzijds de vraag naar op welke wijze deze derdenwerking gestalte zou moeten krijgen. Het bestaan van derdenwerking zou door het Unierecht moeten worden bepaald. Waarbij het overigens wel pas geeft om primair uit te leggen waarom Uniegrondrechten in bepaalde private situaties effect zouden moeten sorteren. Dat blijft steeds de relevante voorvraag. Voor de vraag naar de wijze waarop de derdenwerking zou moeten worden geëffectueerd, kan op grond van het Unierecht in elk geval de plicht tot de grondrechtconforme interpretatie van het nationaal recht en het leerstuk van staatsaansprakelijkheid wegens schending van Unierecht van toepassing zijn. Voor het overige zou aan de nationale rechter de vrijheid kunnen worden gelaten om de uit hoofde van het Unierecht geldende derdenwerking te effectueren door middel van de nationale technieken en methodes zulks met inachtneming van de Rewe -beginselen van gelijkwaardigheid en effectiviteit. ${ }^{58} \mathrm{Ik}$ meen dat hierdoor wordt

58 HvJEU van 16 december 1976, zaak 33/76, Rewe-Zentralfinanz en Rewe-Zentral. 
DEEL IV SYNTHESE, CONCLUSIES EN AANBEVELINGEN

gekomen tot een uniforme en effectieve doorwerking van Uniegrondrechten in horizontale verhoudingen, maar tevens ruimte wordt gelaten voor de nationale technieken om dit doel te bewerkstelligen. 


\section{SUMMARY}

\section{THE DIRECT EFFECT OF THE FUNDAMENTAL RIGHTS OF THE EU}

\section{Research Questions}

This thesis investigates in which situations, according to the case law of the Court of Justice of the European Union (hereinafter 'the Court'), Union fundamental rights have direct effect and whether this can be considered to be legitimate, particularly in the light of the principle of allocation of powers. Three sub-questions are answered:

(i) In which situations, according to the case law of the Court, Union fundamental rights have direct effect (state of the law)?

(ii) To what extent can this case law be considered to be legitimate, particularly in the light of the principle of allocation of powers (legitimacy and judicial activism)?

(iii) On which points is further clarification needed (outstanding questions and concerns)?

\section{Scope and Structure}

The research focuses on Union fundamental rights deriving from the 'courtmade' general principles of Union law (Article 6 (3) TEU) and the Charter of Fundamental Rights of the European Union (Article 6 (3) TEU) (hereinafter: the Charter). The concept of direct effect is used to describe the way in which Union law influences proceedings before national courts. This effect will be considered as 'direct' if Union law applies as an autonomous ground for legal review before a national court. The use of Union law as an autonomous ground for review can be contrasted with the use of Union law as a tool of interpretation of national legislation (indirect effect).

The legitimacy of the Court's case-law is evaluated in the light of the following factors: clarity and soundness of the reasoning, consistency and coherence and legal certainty. Particular attention is paid to the principle of allocation of powers. This concept can be subdivided into the horizontal and vertical allocation of power. The horizontal allocation of powers, also known as 'institutional balance' or 'the principle of separation of powers of the Union', is enshrined in Article 13 (2) TEU: 
"Each institution shall act within the limits of the powers conferred on it in the Treaties, and in conformity with the procedures, conditions and objectives set out in them. The institutions shall practice mutual sincere cooperation.”

The vertical allocation of powers deals with the division of powers between the Union and its Member States and is laid down in Article 5 (2) TEU:

"Under the principle of conferral, the Union shall act only within the limits of the competences conferred upon it by the Member States in the Treaties to attain the objectives set out therein. Competences not conferred upon the Union in the Treaties remain with the Member States."

The research is divided into two main parts: the direct effect of Union fundamental rights in proceedings initiated by private parties against public parties (vertical direct effect) and the direct effect of Union fundamental rights in proceedings initiated by private parties against another private party (horizontal direct effect) of Union fundamental rights. Both parts contain a mapping of the relevant case law of the Court and an evaluation of that case law in the light of the principle of allocation of powers.

\section{Findings on Vertical Direct Effect}

\subsection{Stand of the Law}

The vertical direct effect of Union fundamental rights was recognized by the Court already some time ago. The landmark cases are Wachauf ${ }^{1}$ and ERT $T^{2}$. These cases involve the vertical direct effect of Union fundamental rights as general principles of Union law. Since then, vertical direct effect has been recognized in a considerable number of cases. The existence of vertical direct effect of Union fundamental rights has been confirmed in Article 51 (1) of the Charter. According to his provision the Charter is only binding upon the Member States "when they are implementing Union law". The Explanations relating to Article 51 (1) of the Charter refer to acting within "the scope of Union law". Article 51 (1) of the Charter already gained substantial attention in the case law of the Court. It turns out that the scope of application of the Charter and of general principles of Union law is the same.

According to the case law on general principles of Union law and to later case law concerning the Charter, the minimum requirement for the application of

1 CJEU 13 July 1989, case 5/88, Wachauf.

2 CJEU 18 June 1991, case C-260/89, ERT. 
Union fundamental rights is that there must be a connection with Union law. ${ }^{3}$ However, not every connection with Union law suffices to trigger the application of general principles of Union law or the Charter. ${ }^{4}$ The national act at issue must qualify as an act of implementation. The concept of 'implementation covers all execution ('mise en œuvre') of Union law by the Member States. It can be divided in two main forms of implementation: implementation à la Wachauf and implementation à la ERT. I consider these two main categories as exhaustive.

In a Wachauf situation, a Member State is acting as 'agent' of the EU. The Wachauf implementation covers a wide range of situations. I classified the case law in four subcategories of national acts that cover the existing case law of the Court:

i. Classic acts of implementation:

This category covers national acts that are taken on the ground of a specific duty of implementation, e.g. the implementation of a Directive.

ii. The exercise of the powers conferred by Union law6:

An example of this category are decisions made by the Member States on the basis of a discretion or exception available to them under EU legislation.

iii. Acts falling within the scope of Union legislation?

This category essentially concerns the omission of implementation.

iv. Remedies, sanctioning and enforcement ${ }^{8}$ :

This category can be seen as measures implementing the duty of sincere cooperation laid down in Article 4 (3) TEU. According to this principle, in absence of relevant EU rules, Member States are obliged to ensure the effectiveness of EU rights and duties of Union law. Measures falling within the national procedural autonomy are an example of this category.

3 See e.g. CJEU 1 March 2011, Case C-457/09, Chartry, paras. 22-25.

4 See e.g. CJEU 11 November 2010, Case C-20/10, Vino I, paras 53, 54, 56, 57 and 64 and CJEU 22 June 2011, C-161/11, Vino II, paras. 38 en 39.

5 See e.g. CJEU 10 July 2003, Joines Cases C-20/00 en C- 64/00, Booker Aquaculture; CJEU 12 September 2006, Case C-300/04, Eman en Sevinger.

6 See e.g. CJEU 6 December 2012, Joined Cases C-356/11 en C-357/11, O. and S; CJEU 22 October 2013, Case C-276/12, Sabou.

7 See e.g. CJEU 19 January 2010, Case C-555/07, Kücükdeveci.

8 See e.g. CJEU 10 November 2011, Case C-405/10, Garenfeld; CJEU 26 February 2013, Case C-617/10, Åkerberg Fransson; CJEU 26 September 2013, Case C-418/11, Texdata Software. 
I do not consider it likely that future case law will result in additional Wachauf subcategories, but this cannot be excluded

The second main category, ERT implementation, concerns the situation in which a Member State uses an exception provided for by EU law in order to justify a national act that falls a priori under a prohibition of Union law. The ERT route applies, in any case, to measures qualifying as restrictions of the free movement. It is likely that it will also apply outside free movement situations, for example in Zambrano situations that concern national measures having the effect of depriving citizens of the Union of the genuine enjoyment of the substance of the rights conferred by virtue of their status as citizens of the Union (Article 20 TEU). ${ }^{9}$ With regard to the application of the ERT route, it is important to make a distinction between, on the one hand, the qualification of a national measure as 'restriction of free movement' or as a 'deprivation of citizen rights' and, on the other hand, the question whether the restriction or deprivation can be justified on grounds of a derogation of Union law. Vertical direct of Union fundamental rights is only legitimate at the second stage, and. therefore only after an assessment that the national act at issue qualifies as a 'restriction' or deprivation'. Only in that scenario will the national acts fall within the scope of Union law. In addition to this, it is possible that fundamental rights pop up at the first stage, namely as relevant factors in the qualification of a measure as a 'restriction' or deprivation'.

Union fundamental rights do not have direct effect in situations that cannot be brought under the two main categories of Wachauf and ERT, even though it is possible to discern some sort of EU link. Examples of the case law in which the EU connection is not sufficient to trigger the application of Union fundamental rights are:

i. The sole existence of Union powers in the field of the situation at issue ${ }^{10}$;

ii. The situation at issue concerns a Union citizen from another Member State;

iii. The national act qualifies as 'more stringent protective measures of domestic law' (acts going beyond the minimum requirements laid down by Union) ${ }^{11}$;

iv. The sole fact that the claimant in the main proceedings relies on Union law; ${ }^{12}$

9 CJEU 8 March 2011, Case C-34/09, Ruiz Zambrano; CJEU 8 May 2013, Case C-87/12, Ymeraga.

10 CJEU 18 December 1997, Case C-309/96, Annibaldi.

11 CJEU 17 December 1998, Case C-2/97, Borsana. 
v. The situation concerns a subject matter that is covered in a broad manner by Union law; ${ }^{13}$

vi. Voluntary references in national law to Union law ${ }^{14}$;

vii. Voluntary provisions of national law providing for compensation for damage sustained as a result of the adoption of national protection measures in accordance with EU law; 15

viii. A purely hypothetical prospect of exercising free movements rights. ${ }^{16}$

\subsection{Legitimacy and Judicial Activism}

The vertical direct effect of Union fundamental rights in Wachauf and ERT settings is legitimate as a necessary corollary of the principle that the Union is bound by 'the rule of law', since the implementation and application of Union law often takes place at the national level. Moreover, the duty for Member States to respect fundamental rights when implementing Union law has been confirmed in Article 51 (1) of the Charter. The ultimate test for the legitimacy of vertical direct effect of a Union fundamental right in a specific situation is the question whether the application of Union law in conformity with fundamental rights is at issue. When this is the case, vertical direct effect is justified. When this is not the case, the situation is a purely internal situation in which Union fundamental rights do not apply.

The pre and post Charter case law of the Court regarding vertical direct effect of fundamental rights shows judicial restraint. The Court generally respects the limits of Article 51 (1) of the Charter in the sense that the applicability of Union fundamental rights is indeed confined to situations in which the application of Union law in conformity with fundamental rights is at stake. An exception to this overall picture was established in the Chatzi case in which the equality principle was applied outside the context of Union law. ${ }^{17}$

It must be furthermore noted that sometimes the Court applies Union fundamental rights in spite of strong opposing views of Member States and even of the European Commission, for example in the Åkerberg Fransson, Sabou

12 CJEU 8 May 2013, Case C-87/12, Ymeraga. The sole reliance on Union law might however trigger the application of Art. 47 of the Charter.

13 CJEU 15 September 2011, Joined Cases C-483/09 en C-1/10, Gueye and Sanchez.

14 CJEU 21 December 2011, Case C-482/10, Cicala.

15 CJEU 22 May 2014, Case C-56/13, Érsekcsanádi Mezögazdasági.

16 CJEU 29 May 1997, Case C-299/95, Kremzow

17 CJEU 16 September 2010, Case C-149/10, Chatzi. 
and Toshiba cases. ${ }^{18}$ In my view, these cases fit the Article 51 (1) of the Charter criterion. However, numerous and strong opposing views call for extra precise reasoning. Toshiba is an example in which the Court failed to carry out this extra precise reasoning. Another point of attention is the reasoning of judgments that fit in the line ERT. As mentioned earlier, the vertical direct effect of Union fundamental rights is in principle legitimate, but this is only after the national act at issue is qualified as a 'restriction of free movement' or as a 'deprivation of citizen rights'. The Court seems to apply this classification, but there are two cases that might be confusing: the Karner and Dereci cases. ${ }^{19}$ These cases could be read as the possibility of granting of vertical direct effect of a Union fundamental right to national acts that do not a priori qualify as a 'restriction' or 'deprivation'. In my view, however, this is not what the Court intended to do. I do not think the Court overstepped its purview, but the cases are unfortunate and do exemplify the necessity of clear and precise reasoning.

I consider the case law regarding the vertical direct effect of Union fundamental rights legitimate in the light of the principle of allocation of powers, as the Court generally respects the limits of Article 51 (1) of the Charter. In the meantime I note that even though it is possible to explain the majority of the cases in the light of Article 51 (1) of the Charter, the cases often lack such explanation. The overall legitimacy of the approach would strengthen if the different situations of (non-) implementation and their doctrinal underpinnings would be more explicit. In the next section concrete recommendations will be made.

\subsection{Questions and concerns}

The case law on vertical direct effect is settled. The two main categories, Wachauf and ERT, and the refinement of the Wachauf spectrum into four subcategories offers considerable clear insight. However, the case law could be clarified and refined on the following points:

\section{Clarification of the Wachauf subcategory iv (remedies, sanctioning and enforcement)}

This subcategory could be more explicit. It could be clarified in these kinds of cases that Union fundamental rights apply because the national acts at stake could be considered as the implementation of Article 4 (3) TEU (the duty of

18 CJEU 26 February 2013, Case C-617/10, Åkerberg Fransson; CJEU 22 October 2013, Case C-276/12, Sabou; CJEU 14 February 2012, Case C-17/10, Toshiba.

19 CJEU 25 March 2004, Case C-71/02, Karner; CJEU 15 November 2011, Case C-256/11, Dereci. 
sincere cooperation). In addition, it would be helpful to identify explicitly which duty is at issue by virtue of Article 4 (3) TEU.

Consistency with regard to national acts falling within the national procedural autonomy

The fundamental rights of the Union also apply to national acts falling within the national procedural autonomy. The case law is however not consistent with regard to the relationship between, on the one hand, the Rewe principles of equivalence and effectiveness and, on the other hand, the fundamental rights. ${ }^{20}$ In some cases, such as Allassini and Ecotrade, the fundamental rights review takes place separately. ${ }^{21}$ In other cases, like in Pohotovost, fundamental rights are examined as part of the Rewe principle of effectiveness. ${ }^{22}$ In VEBIC and H.N. the Court only examined in the light of fundamental rights without referring to the Rewe principles. Consistency is needed. ${ }^{23}$ I would opt for a clear separation between, on the one hand, the application of fundamental rights and, on the other hand, the Rewe principles of equivalence and effectiveness.

\section{Minimum harmonization, gradual harmonization and standstill}

According to Borsana, Eiterköpfe and Dominguez, Union fundamental rights do not seem to apply to national acts going beyond minimum requirements laid down by Union legislation ('more stringent protective measures of domestic law'). ${ }^{24}$ However Chatzi causes confusion, as it seems to be a case in which the Court did apply fundamental rights to more stringent protective measures of domestic law. ${ }^{25}$ An explicit confirmation that fundamental rights, in principle, ${ }^{26}$ do not apply to more stringent protective measures of domestic law would be useful. In addition to that, it could be clarified why those measures fall outside the scope of Union law and how they differ from measures under Wachauf subcategory ii (the exercise of the powers conferred by Union law). In my view, the distinction is that more stringent protective measures of domestic law are not taken on the basis of powers created by Union law but on the basis of powers in relation to which Union law confirms that they remained powers of the Member States. The same kind of questions arise with regard to national

20 CJEU 16 December 1976, Case 33/76, Rewe-Zentralfinanz en Rewe-Zentral.

21 CJEU 18 March 2010, Joined Cases C-317/08, C-318/08, C-319/08 and C-320/08, Allassini; CJEU 8 May 2008, Joined Cases C-95/07 and C-96/07, Ecotrade.

22 CJEU 27 February 2014, Case C-470/12, Pohotovost.

23 CJEU 7 December 2010, Case C-439/08, VEBIC; CJEU 8 May 2014, Case C-604/12, H.N.

24 CJEU 17 December 1998, Case C-2/97, Borsana; CJEU 14 April 2005, Case C-6/03, Eiterköpfe; CJEU 24 January 2012, Case C-282/10, Dominguez.

25 CJEU 16 September 2010, Case C-149/10, Chatzi.

26 See for a possible exception: CJEU 18 July 2013, Case C-234/12, Sky Italia. 
measures that are (still) allowed under gradual harmonization legislation or standstill clauses.

Refinement of the Kücükdeveci criterion on the scope of Union law

In Kücükdeveci, the prohibition of discrimination based on age applied, because the national act at issue concerned a subject matter (dismissal) that was covered by a non-discrimination Directive (Directive 2000/78). ${ }^{27}$ Even though I agree that the national act at issue falls within the scope of Union law (namely as a measure that can be considered as a failure to implement Directive 200/78), the criterion that is used to define the 'scope of Union law' is too broad. In Vino I and Vino II, the Court is more precise by considering both whether the relevant directive (Directive 1999/70) covers the subject matter of the national act at issue and whether the alleged discrimination falls under that directive. ${ }^{28}$

\section{Reasoning in the twilight zone}

In Sindicato dos Bancários do Norte, the Court considered that the national measure at issue could not be considered to be implementation in the sense of Article 51 (1) of the Charter. ${ }^{29}$ The Court just stated that there was no concrete element. However, the preliminary reference mentions that the Portuguese measure had been taken to consolidate public finances in a serious economic and financial crisis with a view to general obligations deriving from the Stability and Growth Pact. It is unfortunate that the Court did not explain why the connection with the Stability and Growth Pact was insufficiently concrete.

\section{Application of Article 47 of the Charter}

As a general rule Union fundamental rights only apply in disputes actually falling within the scope of substantive Union law. Possibly there is an exception to this rule with regard to Article 47 of the Charter (Right to an effective remedy and to a fair trial). It seems that this provision applies as soon as the applicant in the main proceedings relies on a substantive rule of Union law. ${ }^{30}$ Future case law will have to clarify whether this assumption is correct.

\section{Application of ERT route outside of free movement situations}

It is likely that the ERT route not only applies in free movement situations, but it applies in all situations in which a Member State needs to benefit from the

27 CJEU 19 January 2010, Case C-555/07, Kücükdeveci.

28 CJEU 11 November 2010, Case C-20/10, Vino I, paras 53, 54, 56, 57 and 64 and CJEU 22 June 2011, C-161/11, Vino II, paras. 38 en 39.

29 CJEU 7 March 2013, Case C-128/12, Sindicato dos Bancários do Norte.

30 CJEU 7 February 2013, Case C-498/12, Pedone; CJEU 7 February 2013, Case C-499/12, Gentile; CJEU 14 March 2013, Case C-555/12, Loreti; CJEU 30 May 2013, Case C-73/13, T. 
exceptions provided for by EU law in order to justify a measure that would otherwise be prohibited. However, this has not been considered in a clear cut way in the Court's case law. Future case law has to give a decisive answer.

\section{Horizontal direct effect}

\subsection{State of the Law}

The horizontal direct effect of Union fundamental rights is a given in the current state of the law but with a great amount of unknown factors. The landmark cases for the existence of horizontal direct effect of Union fundamental rights are Mangold and Kücükdeveci. ${ }^{31}$ In these cases, the horizontal direct effect of the prohibition of discrimination based on age was recognized (Mangold and Kücükdeveci). In addition, these cases implicitly revealed that the Mangold/ Kücükdeveci horizontal direct effect applies to all Article 19 TFEU grounds of non-discrimination: sex, racial or ethnic origin, religion or belief, disability, age, or sexual orientation. AMS clarified that other fundamental rights can also be capable of having horizontal direct effect and that the Mangold/ Kücükdeveci approach in principle applies both to fundamental rights as general principles of Union law and as fundamental rights under the Charter. ${ }^{32}$

The crucial question is under which conditions the Mangold/Kücükdeveci horizontal direct effect applies. Since the approach lacks sufficient reasoning and is controversial from several perspectives, a prudent reading is appropriate. So far, it is only safe to say that Mangold/Kücükdeveci horizontal direct effect will apply in circumstances that are comparable to those cases. When looking at the Mangold and Kücükdeveci cases in conjunction with AMS, it is possible to distil four conditions for the application of the Mangold/Kücükdeveci horizontal direct effect. Firstly, the fundamental right at issue should be unconditional and sufficiently precise. This is the usual technical requirement for direct effect. If this requirement is not fulfilled, it is certain that direct effect is out of question. Secondly, the alleged violation of a fundamental right should be a public act. Thus, the horizontal direct effect should result in the examination on the basis of a Union fundamental right of a public act. It is not certain whether purely private acts (such as factual behaviour or contractual clauses) should also be reviewed on the basis of Union fundamental rights. Future case law has to clarify this issue. The third condition is the application of Article 51 (1) of the Charter. The

31 CJEU 22 November 2005, Case C-144/04, Mangold; CJEU 19 January 2010, Case C555/07, Kücükdeveci.

32 CJEU 15 January 2014, Case C-176/12, AMS. 
object of review should qualify as 'the implementation of Union law'. The existence of this condition is a given; horizontal direct effect of Union fundamental rights cannot occur outside the scope of Union law. Finally, the existence of a fourth condition cannot be excluded. This condition would be that it concerns a situation falling within the scope of Union legislation (for example a non-discrimination directive) that expresses the fundamental right at issue and that applies in the private sector. I tend to believe that this condition does not exist. However, the existing case law is not conclusive. Future case law has to clarify this.

The concrete result of Mangold and Kücükdeveci is that prohibitions of nondiscrimination based on sex, racial or ethnic origin, religion or belief, disability, age, or sexual orientation contained in non-discrimination directives have 'de facto' horizontal direct effect. ${ }^{33}$

\subsection{Legitimacy and judicial activism}

The issue of horizontal direct effect of Union fundamental rights is far more complex and controversial then the issue of vertical direct effect. It involves the application of fundamental rights in the private sphere (third-party effect or 'Drittwirkung' of fundamental rights or 'constitutionalisation of private law') and it therefore deviates from the classic 'rule of law' function of fundamental rights as a means to protect private individuals against public authorities. Third-party effect of fundamental rights is a sensitive topic on which the views in the Member States differ. In most Member States, the use of fundamental rights as an autonomous basis of examination in horizontal disputes is not accepted and controversial. Moreover, the limits of Article 51 (1) of the Charter are relevant in this context. According to this provision, the Charter is addressed to the Union and to the Member States. The provision does not mention private individuals. In my view, this means that there is no duty for private individuals to

33 Directive 2000/78/EC of 27 November 2000 establishing a general framework for equal treatment in employment and occupation, OJ L 303, 2.12.2000, p. 16-22; Directive 2000/43/EC of 29 June 2000 implementing the principle of equal treatment between persons irrespective of racial or ethnic origin, [2002] OJL 180/22; Directive 2006/54 of the European Parliament and of the Council of 5 July 2006 on the implementation of the principle of equal opportunities and equal treatment of men and women in matters of employment and occupation (recast), [2006] OJ L 204/23; Directive 2010/41/EU of the European Parliament and of the Council of 7 July 2010 on the application of the principle of equal treatment between men and women engaged in an activity in a self-employed capacity and repealing Directive 86/613/EEC, [2010] OJ L 180/1; Directive 2004/113/EC of 13 December 2004 implementing the principle of equal treatment between men and women in the access to and supply of goods and services, [2004] OJ L 373/37. 
respect Union fundamental rights as such. On the other hand, arguably, certain fundamental rights might also need protection in horizontal situations, for example in the light of their purpose or wording or by virtue of the case law of the European Court of Human Rights. This complex constitutional setting should be reason for judicial restraint and sophistication. The Mangold/ Kücükdeveci approach, however, seems to be the opposite. In my view, this approach lacks legitimacy due to several reasons.

The Mangold /Kücükdeveci approach firstly involves a third-party effect that goes beyond the commonly accepted horizontal function of fundamental rights as a tool of interpretation. It must, however, be noted that Mangold /Kücükdeveci involved the review of public acts in a horizontal setting. This is less controversial than the review of private acts in a horizontal setting. As was mentioned in the previous paragraph, it is not certain that the Court is willing to accept horizontal direct effect of fundamental rights in situations involving the review of private acts. The difference between the review of public acts and the review of private acts is that the latter implies the duty for private parties to respect fundamental rights, whereas in the case of the review of public acts, it is still possible to focus on a vertical element. This is also a relevant distinction with a view to Article 51 (1) of the Charter that seems to exclude the possibility of the review of a private act. The review of a public act, on the other hand, does not manifestly violate Article 51 (1) of the Charter.

Secondly, the principle of non-discrimination is expressed in several Directives. This reflects the decision of the Union legislature to render prohibitions of discrimination effective in the private sector through national legislation. After all, directives do not have horizontal direct effect. The Mangold /Kücükdeveci approach thwarts this decision, as it leads to de facto horizontal direct effect of the prohibitions of discrimination in the directives.

Thirdly, there were more sophisticated options available to render the principle of non-discrimination or fundamental rights in general effective in horizontal settings, such as the duty to interpret national and Union legislation in the light of Union fundamental rights or the Francovich doctrine of State liability. ${ }^{34}$ Another possibility would have been classification comparable to that of the national procedural autonomy, according to which Union law would oblige the national judge to enforce a fundamental right at issue in a horizontal dispute, but it would leave it to the domestic legal system of each Member State to designate the applicable judicial techniques and remedies.

34 CJEU 19 November 1991, Joined Cases C-6/90 and C-9/90, Francovich. 
Fourthly, by recognizing the possibility of horizontal direct effect in situations that involve the review of public acts, the Court had manoeuvred into an awkward position in which it eventually has to choose between two evils. There will come a moment in which the Court has to rule on the possibility of horizontal direct effect in situations involving the review of private acts. The rejection of that option would amount in a (new) splitting up of the concept of horizontal direct effect between situations that involve the review of a public act (horizontal direct effect possible) and situations that involve the review of a private act (no horizontal direct effect). This would be inconsistent with the case law on the (total lack of) horizontal direct effect of Directives. On the other hand, the acceptance of full horizontal direct effect would, in my view, manifestly violate Article 51 (1) of the Charter, because it implies the duty for private individuals to respect Union fundamental rights.

Finally, Mangold and Kücükdeveci do not explain why the principle of nondiscrimination should be enforced in a private setting. This is not self-evident. The lack of explanation is unsatisfactory, especially in the light of the commotion and resistance after Mangold. Thorough reasoning would benefit the acceptance of the approach and therewith its legitimacy.

\subsection{Questions and concerns}

\section{Foundation of the approach}

As mentioned in the previous paragraph, Mangold and Kücükdeveci do not explain why the principle of non-discrimination should be effective in a horizontal setting. This evokes considerable legal uncertainty, because the foundation of the approach also determines its reach. It is recommendable that the Court unfolds on what grounds the principle of non-discrimination (or other fundamental rights) should be effective in a horizontal setting.

Relevance of the interplay between the principle of non-discrimination and Directive 2000/78

Mangold and Kücükdeveci are not conclusive on the question whether the principle of non-discrimination based on age has full horizontal direct effect or that the horizontal direct effect is limited to specific situations falling within the scope of application of non-discrimination directives such as Directive 2000/78. An explanation on this issue would be useful. In my view, it would be best to cut the intense entanglement between Union fundamental rights and secondary law. In particular, it is not desirable to indentify the content of a fundamental right as a general principle of Union law or under the Charter with that of secondary legislation. 
Existence of full horizontal direct effect

So far, it is not clear whether horizontal direct effect of a Union fundamental right would be possible if it would function as a basis for the examination of purely private acts. I propose that this option should be denied, because it would lead to a duty for private parties to respect fundamental rights. I consider this to be a manifest violation of Article 51 (1) of the Charter. I realize that this will result in an inconsistency with the Court's case law on the (full denial) of horizontal direct effect of directives, however, with Mangold and Kücükdeveci, the Court embarked on a path ultimately leading to a choice between two evils. The inconsistency with the doctrine of horizontal direct effect of directives seems to be the best evil.

\section{Final conclusion}

The doctrines of vertical and horizontal direct effect contrast with each other. The doctrine of vertical direct effect blossomed. Both its existence as well as its elaboration in the case law seems legitimate. It does remain difficult to formulate a concrete test to determine in which situations vertical direct effect of Union fundamental rights occurs. However, thanks to a considerable amount of consistent case law it is possible to classify five situations in which Union fundamental rights do have vertical direct effect. On the contrary, the doctrine the horizontal direct effect of Union fundamental rights is scarcely out of the egg. The little case law is puzzling. The reach of the doctrine is shadowy. Its legitimacy is scant. 



\section{VALORISATIE-ADDENDUM ${ }^{1}$}

\section{Algemene beschrijving}

De centrale vraag in het proefschrift luidt als volgt: In welke situaties hebben de grondrechten van de Unie op grond van de rechtspraak van het Hof van Justitie van de Europese Unie (hierna: het Hof) directe werking en is deze rechtspraak, met name in het licht van het beginsel van allocatie van bevoegdheden, legitiem?

Zoals ook is opgemerkt in hoofdstuk 1.3 van het proefschrift, is de beantwoording van deze vraag niet alleen van wetenschappelijk belang, maar ook van belang voor de rechtspraktijk in brede zin. Dit geldt in het bijzonder voor de eerste en derde deelonderzoeksvragen die zien op het in kaart brengen van de stand van het recht en de openstaande vragen en aandachtspunten. ${ }^{2}$

Allereerst is kennis omtrent het toepassingsgebied van Uniegrondrechten en de nog openstaande vragen van belang voor nationale rechters en procespartijen. Wanneer kunnen Uniegrondrechten zonder meer worden ingeroepen en in welke situaties is aanleiding voor voorzichtigheid en/of het stellen van prejudiciële vragen? Voorts is precieze kennis van de stand van de rechtspraak van het Hof relevant voor de actoren (waaronder de nationale regeringen) bij de procedures voor het Hof. Met het oog op een doelmatige procesvoering is kennis van de al gelopen races en de nog te lopen races noodzakelijk. Ook wetgevers, bestuurders en beleidsmakers moeten beschikken over precieze kennis van het toepassingsgebied van Uniegrondrechten, zodat duidelijk is wanneer de overheid is gebonden aan Uniegrondrechten. Tot slot is de toepassing van Uniegrondrechten gekoppeld aan het materiële Unierecht. Nieuwe Uniewetgeving heeft gevolgen voor het toepassingsgebied van Uniegrondrechten, dit geldt ook voor Uniewetgeving die niet ziet op de uitwerking van grondrechten. Dit betekent dat ook de nationale onderhandelaar in Brussel baat heeft bij een

1 Zoals bedoeld in artikel 23, lid 5, van het Promotiereglement Universiteit Maastricht 2013.

2 Zie hoofdstuk 1.2. De drie deelonderzoeksvragen luiden als volgt:

(i) In welke situaties hebben Uniegrondrechten op grond van de rechtspraak van het Hof directe werking (stand van het recht)?

(ii) In hoeverre is deze rechtspraak, met name in het licht van het beginsel van allocatie van bevoegdheden, legitiem (legitimiteit en rechterlijk activisme)?

(iii). Op welke punten moet het leerstuk van directe werking van Uniegrondrechten nog verder worden uitgewerkt (openstaande vragen en aandachtspunten)? 
goede sensor voor het 'binnenhalen' van Uniegrondrechten in deelgebieden van het nationale recht door nieuwe Uniewetgeving.

Met het oog op het hierboven omschreven belang voor de rechtspraktijk in brede zin heb ik mij in het proefschrift ook nadrukkelijk tot de rechtspraktijk gericht. Dit komt met name tot uiting in de precieze beschrijving en classificatie van situaties waarin de directe werking van Uniegrondrechten zich kan voor doen. Ik heb bovendien getracht om de vertaalslag naar de praktijk te maken door gebruik te maken van concrete voorbeelden en door te anticiperen op vragen die zouden kunnen leven in de rechtspraktijk. Voorts heb ik een aantal aanbevelingen gedaan die kunnen bijdragen aan de toekomstige rechtsontwikkeling van het leerstuk van de directe werking van Uniegrondrechten. Deze aanbevelingen richten zich primair tot het Hof, maar kunnen tevens dienen als leidraad voor nationale rechters en procespartijen, alsmede voor de actoren in Hofzaken. De aanbevelingen staan vermeld in hoofdstuk 11.4 en zijn aan het slot van dit addendum onder punt 2 samengevat.

Tot slot merk ik op dat ik al tijdens mijn onderzoek in de gelegenheid ben geweest om mijn kennis uit hoofde van het onderzoek te delen met en te vertalen naar de rechtspraktijk. Zoals ook beschreven in hoofdstuk 1.4 was ik betrokken bij het seminar van de 'Europese Vereniging van Raden van Staten' en hoogste administratieve gerechten ('ACA') over de betekenis van het Handvest voor de nationale bestuursrechtspraak dat op 24 november 2011 plaats vond bij de Raad van State. ${ }^{3}$ Voorts heb ik lezingen en cursussen gegeven over het onderwerp van het proefschrift aan de rechterlijke macht, de Directie Advisering van de Raad van State en de rijksoverheid. Tot slot ben ik naar aanleiding van deelpublicaties van mijn onderzoek een aantal keren benaderd met vragen uit de rechtspraktijk, waaronder ook vanuit de advocatuur (zowel binnen als buiten Nederland). Ik verwacht dat deze vormen van kennisoverdracht ook in de toekomst door zullen gaan.

3 Voor meer informatie over ACA-Europe: zie www.aca-europe.eu. 


\section{Lijst van aanbevelingen}

De aanbevelingen hieronder zijn een samenvatting van de aanbevelingen in hoofdstuk 11.4.

\section{A. Aanbevelingen terzake van het leerstuk van verticale directe werking}

A.1 Explicitering en theoretische onderbouwing verschillende typen van Wachaufuitvoering

Het formuleren van een voor de toepassing van artikel 51, lid 1, van het Handvest concreter criterium dan tot nu toe naar voren komt in de rechtspraak lijkt niet eenvoudig te zijn. Dit probleem kan worden ondervangen door de verschillende typen van uitvoering, en name de typen van Wachauf-uitvoering, te expliciteren en te onderbouwen. De aanbevelingen hierna bevatten suggesties op specifieke punten van aandacht.

A.2 Explicitering en verduidelijking van de toepassing van grondrechten op de nationale effectuering, sanctionering en handhaving van het Unierecht

Het is daarom raadzaam om deze variant van uitvoering van het Unierecht steeds expliciet benoemen en stapsgewijs te motiveren. Hierbij is met name van belang dat wordt benoemd, dat het bij dit soort nationale handelingen in wezen gaat om de uitvoering van het beginsel van loyale samenwerking.

\section{A.3 Verhouding met de Rewe-riedel}

Bij de toepassing van Uniegrondrechten op nationale handelingen die vallen binnen de procedurele autonomie is het wenselijk om een eenduidige en heldere lijn in te nemen ten aanzien van de verhouding tussen de Rewe-riedel en de Uniegrondrechten. Het hanteren van een Rewe-riedel-plus waarbij een onderscheid wordt gemaakt tussen enerzijds de toets aan de grondrechten en anderzijds de toepassing van de Rewebeginselen van gelijkwaardigheid en doeltreffendheid verdient hierbij mijns inziens de voorkeur.

\section{A.4 Uitzondering voor artikel 47 van het Handvest}

Het lijkt mij noodzakelijk, dat in toekomstige rechtspraak duidelijk wordt dat artikel 47 van het Handvest reeds van toepassing kan zijn door het enkele beroep op materieel Unierecht. Dit is immers een prealabele 
voorwaarde voor de effectuering van het Unierecht. In wezen gaat het hier om de toepassing van de artikelen 4 , lid 3 en 19, lid 1, 2e alinea VEU.

\section{A.5 Verdergaande beschermingsmaatregelen}

Een expliciete bevestiging van de arresten Borsana, Eiterköpfe en Dominguez op grond waarvan zogenaamde 'verdergaande beschermingsmaatregelen' buiten het bereik van de Uniegrondrechten vallen is wenselijk. Het is daarbij van belang dat aandacht wordt geschonken aan de vraag waarom 'verdergaande beschermingsmaatregelen' buiten het bereik van het Unierecht vallen en waarin zij verschillen van nationale handelingen die zijn genomen in de uitoefening van Uniebevoegdheden (Wachauf-categorie ii)? Ik meen dat het verschil is dat het bij 'verdergaande beschermingsmaatregelen' gaat om nationale bevoegdheden waarvan het Unierecht expliciet bevestigt dat ze bij de lidstaten zijn gebleven. Hiermee verschillen de 'verdergaande beschermingsmaatregelen' van Wachauf-subcategorie ii waarin het gaat om bevoegdheden die door het Unierecht zijn gecreëerd.

\section{A.6 Geleidelijke harmonisatie en 'standstill'}

Het is nog onduidelijk of Uniegrondrechten van toepassing zijn op bestaande nationale handelingen die 'profiteren' (in de zin dat zij (tijdelijk) mogen blijven voortbestaan) van een traject van geleidelijke harmonisatie of van standstill bepalingen. Ik zie hier een parallel met de in de vorige aanbeveling genoemde problematiek van de 'verdergaande beschermingsmaatregelen'. Ook hier gaat het mijns inziens niet om gevallen waarin het Unierecht bevoegdheden in het leven roept (Uniegrondrechten zijn wel van toepassing), maar om gevallen waarin het Unierecht bevestigt dat bepaalde bevoegdheden bij de lidstaten zijn gebleven (Uniegrondrechten zijn niet van toepassing).

A.7 Het verzuim tot uitvoering als uitvoering

Uit het arrest Kücükdeveci blijkt, dat de Unierechtelijke grondrechten van toepassing zijn op nationale maatregelen die -naar nationaal recht- niet bedoeld zijn als omzettingsmaatregelen, maar die wel binnen de werkingssfeer van specifieke materiële bepalingen van Unierecht vallen. Het zou goed zijn als dit in toekomstige zaken wordt gepreciseerd waarom deze vorm van niet-uitvoering toch kwalificeert als uitvoering. 
A.8 De toepassing van de ERT-route buiten het vrij verkeer.

De ERT-route wordt tot nu toe enkel toegepast en gemotiveerd met betrekking tot vrij verkeer-bepalingen. De ratio van deze route, volgens welke het Unierecht niet kan machtigen tot maatregelen in strijd met Uniegrondrechten, is echter ook van toepassing in 'machtiging'-situaties buiten het vrije verkeer. De ERT -toepasselijkheid van Uniegrondrechten zou daarom mijns inziens moeten gelden voor alle 'nationale handelingen die in beginsel in strijd zijn met een verbodsbepaling van Unierecht, maar waarbij de lidstaat een beroep doet op een Unierechtelijke rechtvaardigingsgrond'. Ook hier ligt een kans om in toekomstige rechtspraak de toepassing van artikel 51, lid 1, van het Handvest te verduidelijken.

\section{A.9 De ERT-route en artikel 20 VWEU}

De vraag naar de toepasselijkheid van Uniegrondrechten via de ERTroute lijkt met name actueel te zijn in de context van artikel 20 VWEU. Het verdient daarom aanbeveling om in toekomstige rechtspraak in die context onomwonden duidelijk te maken dat Uniegrondrechten van toepassing zijn op nationale maatregelen die binnen de werkingssfeer van artikel 20 VWEU vallen. Hierbij zou wel moeten gelden, dat de grondrechten pas directe werking hebben nadat is komen vast te staan dat de betreffende nationale maatregel onder artikel 20 VWEU valt (de maatregel kwalificeert als 'ontzegging').

A.10 De rol van Uniegrondrechten bij de kwalificatie van een nationale maatregel als 'beperkend' of 'ontzeggend'

In het verlengde van het bovenstaande punt merk ik op dat niet elk gebruik van Unierechtelijke grondrechten in het stadium van de kwalificatie als 'beperking' of als 'ontzegging' verdacht is vanuit het oogpunt van de allocatie van bevoegdheden. Illustratief zijn de arresten Sayn-Wittgenstein en Vardyn. ${ }^{4}$ Het grondrecht fungeerde in deze zaken niet als zelfstandige toetsingsmaatstaf, maar diende als element in de vraag of sprake was een beperking van het vrije verkeer. Terughoudendheid is hier echter wel op zijn plaats, de scheidslijn tussen het gebruik van het Unierechtelijke grondrecht als element in de beoordeling naar de vraag of sprake is van 'beperking' en het (feitelijk) gebruik van het grondrecht als zelfstandig toetsingskader, kan dun zijn. In toekomstige rechtspraak moet er voor worden gewaakt om uit de enkele inmenging in een grondrecht te concluderen tot een beperking van het vrije verkeer.

4 HvJEU van 22 december 2010, zaak C-208/09, Sayn-Wittgenstein, punt 52; HvJEU van 12 mei 2011, zaak C-391/09, Vardyn, punt 66. 
Zaken waarin de toepassing van Uniegrondrechten reeds plaats vindt bij de kwalificatie van een nationale maatregel als 'beperkend' of 'ontzeggend' zijn daarom heikel en verdienen steeds bijzondere aandacht en een nauwkeurige motivering.

\section{B. Aanbevelingen inzake het leerstuk van de horizontale directe werking van grondrechten van de Unie}

\section{B.1 Algemeen}

Het is duidelijk dat de rechtsvragen inzake de horizontale directe werking van grondrechten van de Unie niet eenvoudig zijn en soms ook niet in één arrest uitputtend kunnen worden behandeld. Toch verdient het aanbeveling om daar waar mogelijk wel antwoord te geven op openstaande kwesties. Als bovendien terzake van een gevoelig en principieel punt een weg wordt ingeslagen is het maar het beste om dit te doen in klare taal en niet omfloerst.

B.2 Grondslag van de horizontale directe werking c.q. de derdenwerking van Uniegrondrechten

Het verdient aanbeveling om in toekomstige rechtspraak aan te geven wat de grondslag is van de horizontale directe werking c.q. de derdenwerking van Uniegrondrechten, met name zou niet moeten worden volstaan met algemene verwijzingen naar de volle werking van een grondrecht.

B.3 Rol van secundair recht bij bepaling horizontale directe werking c.q. derdenwerking van een Uniegrondrechten

Toekomstige rechtspraak zou duidelijk moeten maken of Uniegrondrechten als zodanig horizontale directe werking c.q. derdenwerking kunnen hebben of enkel indien het voor de private sector is uitgewerkt in secundair recht. Ik meen, dat de principiële vraag naar de horizontale directe werking c.q. derdenwerking van een primairrechtelijke grondrecht niet (enkel) zou moeten afhangen van het secundaire recht.

B.4 Onderscheid tussen toepassing van het grondrecht en de toepassing van secundair recht

In zaken waarin het zowel gaat om de uitleg van het grondrecht als om de uitleg van secundair recht waarin het betreffende grondrecht wordt uitgewerkt zou het wenselijk zijn om steeds een duidelijk onderscheid aan te brengen tussen enerzijds de (materiële) toepassing van het grondrecht en anderzijds de toepassing van secundair recht. 
B.5 De rol van grondrechten in situaties die vallen binnen de werkingssfeer van Uniewetgeving waarin grondrechten worden geconcretiseerd

In situaties die vallen binnen de werkingssfeer van Uniewetgeving waarin grondrechten worden geconcretiseerd (bijvoorbeeld een non-discriminatierichtlijn) zouden de grondrechten primair moet worden toegepast op de betreffende Uniewetgeving.

B.6 De vraag naar volledige horizontale directe werking

Een openstaande rechtsvraag is of een Uniegrondrecht kan dienen als een zelfstandige toetsingsmaatstaf voor particulier handelen (de vraag naar volledige horizontale directe werking). Deze vraag zou mijns inziens ontkennend moeten worden beantwoord.

B.7 Onderscheid tussen bestaan van derdenwerking en de wijze waarop

Meer algemeen meen ik dat het voorkeur verdient om in toekomstige rechtspraak een onderscheid aan te brengen tussen enerzijds de vraag naar of (bepaalde) Uniegrondrechten in (bepaalde) horizontale situaties van toepassing zijn (de vraag naar het bestaan van derdenwerking) en anderzijds de vraag naar op welke wijze deze derdenwerking gestalte zou moeten krijgen. Het bestaan van derdenwerking zou door het Unierecht moeten worden bepaald. Voor de vraag naar de wijze waarop de derdenwerking zou moeten worden geëffectueerd, kan op grond van het Unierecht in elk geval de plicht tot de grondrechtconforme interpretatie van het nationaal recht en het leerstuk van staatsaansprakelijkheid wegens schending van Unierecht van toepassing zijn. Voor het overige zou aan de nationale rechter de vrijheid kunnen worden gelaten om de uit hoofde van het Unierecht geldende derdenwerking te effectueren door middel van de nationale technieken en methodes zulks met inachtneming van de Rewebeginselen van gelijkwaardigheid en effectiviteit. ${ }^{5}$

${ }^{5}$ HvJEU van 16 december 1976, zaak 33/76, Rewe-Zentralfinanz en Rewe-Zentral. 



\section{LIJST VAN AANGEHAALDE JURISPRUDENTIE}

\section{Hof van Justitie van de Europese Unie (HvJEU)}

Arresten en beschikkingen

HvJEU van 12 juli 1957, gevoegde zaken 7/56 en 3t/m 7/57, Algera e.a.

HvJEU van 5 februari 1963, zaak 26/62, Van Gend en Loos

HvJEU van 15 juli 1964, zaak 6/64, Costa-Enel

HvJEU 12 november 1969, zaak 29/69, Stauder

HvJEU van 17 december 1970, zaak 11/70, Internationale Handelsgesellschaft

HvJEU van 14 mei 1974, zaak 4/73, Nold II

HvJEU van 4 december 1974, zaak 41/74, Van Duyn

HvJEU van 12 december 1974, zaak 36/74, Walrave and Koch

HvJEU van 8 april 1976, zaak 43/75, Defrenne II

HvJEU van 16 december 1976, zaak 33/76, Rewe-Zentralfinanz en Rewe-

Zentral

HvJEU van 1 februari 1977, zaak 51/76, VNO

HvJEU van 15 juni 1978, zaak 149/77, Defrenne III

HvJEU van 5 april 1979, zaak 148/78, Ratti

HvJEU van 13 december 1979, zaak 44/79, Hauer

HvJEU van 9 februari 1982, zaak 12/81, Garland

HvJEU van 18 februari 1982, zaak 77/81, Zuckerfabrik Franken

HvJEU van 18 mei 1982, zaak 155/79, AM \& S

HvJEU van 10 april 1984, zaak 14/83, Von Colson en Kamann

HvJEU van 26 februari 1986, zaak 152/84, Marshall

HvJEU van 23 april 1986, zaak 294/83, Les Verts

HvJEU van 13 mei 1986, zaak 170/84, Bilka

HvJEU van 30 september 1987, zaak 12/86, Demirel

HvJEU van 13 juli 1989, zaak 5/88, Wachauf

HvJEU van 19 juni 1990, zaak C-213/89, Factortame

HvJEU van 10 juli 1990, zaak 326/88, Hansen

HvJEU van 18 juni 1991, zaak C-260/89, ERT

HvJEU van 4 oktober 1991, zaak C-159/90, Grogan

HvJEU van 19 november 1991, gevoegde zaken C-6/90 en C-9/90,

Francovich

HvJEU van 14 december 1991, advies 1/91, EER

HvJEU van 7 juli 1992, zaak C-370/90, Singh

HvJEU van 6 oktober 1993, C-109/91, Ten Oever

HvJEU van 20 oktober 1993, gevoegde zaken C-92/92 en C-326/92, Phil

Collins

HvJEU van 14 juli 1994, zaak C-91/92, Faccini Dori 
HvJEU van 28 september 1994, zaak C-200/91, Coloroll HvJEU van 6 juli 1995, zaak C-62/93, BP Supergaz HvJEU van 13 februari 1996, C-342/93, Gillespie HvJEU van 30 april 1996, zaak C-194/94, CIA Security International HvJEU van 24 oktober 1996, zaak C-72/95, Kraaijeveld HvJEU van 27 februari 1997, zaak C-177/95, Ebony Maritime

HvJEU van 29 mei 1997, zaak C-299/95, Kremzow HvJEU van 26 juni 1997, zaak C-368/95, Familiapress HvJEU van 17 juli 1997, zaak C-28/95, Leur-Bloem HvJEU van 9 december 1997, zaak C-265/95, Commissie/ Frankrijk (Spaanse aardbeien)

HvJEU van 18 december 1997, Gevoegde zaken C-286/94, C-340/95, C401/95 en C-47/96, Garage Molenheide

HvJEU van 18 december 1997, zaak C-309/96, Annibaldi

HvJEU van 29 mei 1997, zaak C-299/95, Kremzow

HvJEU van 26 juni 1997, zaak C-368/95, Familiapress

HvJEU van 17 juli 1997, zaak C-28/95, Leur-Bloem

HvJEU van 18 december 1997, zaak C-129/96, Inter-environnement Wallonie HvJEU van 17 december 1998, zaak C-2/97, Borsana HvJEU van 8 juli 1999, zaak C-186/98, Nunes en de Matos HvJEU van 16 september 1999, zaak C-218/98, Angonese HvJEU van 10 februari 2000, zaak C-50/96, Deutsche Telekom HvJEU van 28 maart 2000, zaak C-7/98, Krombach HvJEU van 13 april 2000, zaak C-292/97, Karlsson HvJEU van 18 mei 2000, zaak C-107/97, Rombi HvJEU van 13 juli 2000, C-36/99, Idéal Tourisme HvJEU van 26 september 2000, zaak C-443/98, Unilever HvJEU van 3 oktober 2000, zaak C-411/98, Ferlini HvJEU van 11 januari 2001, C-226/99, Siples HvJEU van 12 juli 2001, zaak C-262/99, Louloudakis HvJEU van 12 juli 2001, zaak C-189/01, Jippes HvJEU van 11 juli 2002, zaak C-60/00, Carpenter HvJEU van 17 september 2002, zaak C-320/00, Lawrence HvJEU van 12 december 2002, zaak C-442/00, Rodríguez Caballero HvJEU van 10 april 2003, zaak C-276/01, Steffensen HvJEU van 20 mei 2003, gevoegde zaken C-465/00, C-138/01 en C-139/01, Rundfunk

HvJEU van 12 juni 2003, zaak C-112/00, Schmidberger HvJEU van 10 juli 2003, gevoegde zaken C-20/00 en C- 64/00, Booker Aquaculture

HvJEU van 23 september 2003, zaak C-109/01, Akrich 
HvJEU van 6 november 2003, zaak C-101/01, Lindqvist

HvJEU van 13 januari 2004, zaak C-256/01, Allonby

HvJEU van 23 maart 2004, zaak C-138/02, Collins

HvJEU van 25 maart 2004, zaak C-71/02, Karner

HvJEU van 7 september 2004, zaak C-127/02, Kokkelvissers

HvJEU van 14 oktober 2004, zaak C-36/02, Omega

HvJEU van 16 december 2004, zaak C-520/03, Olaso Valero

HvJEU van 10 maart 2005, gevoegde zaken C-96/03 en C-97/03, Tempelman en Van Schaik

HvJEU van 14 april 2005, zaak C-6/03, Eiterköpfe

HvJEU van 26 april 2005, zaak C-376/02, Stichting Goed Wonen

HvJEU van 3 mei 2005, gevoegde zaken C-387/02, C-391/02 en C-403/02,

Berlusconi

HvJEU van 30 juni 2005, zaak C-28/04, Tod's

HvJEU van 12 juli 2005, zaak C-403/03, Schempp

HvJEU van 6 oktober 2005, zaak C-328/04,Vajnai

HvJEU van 22 november 2005, zaak C-144/04, Mangold

HvJEU van 13 december 2005, zaak C-177/05, Guerrero Pecino

HvJEU 21 februari 2006, zaak C-152/03, Ritter-Coulais

HvJEU van 11 mei 2006, zaak C-384/04, Federation of Technological Industries

HvJEU van 15 juni 2006, zaak C-28/05, Dokter

HvJEU van 27 juni 2006, zaak C-540/03, EP/Raad

HvJEU van 4 juli 2006, zaak C-212/04, Adeneler

HvJEU van 11 juli 2006, zaak C-13/05, Chacón Navas

HvJEU van 7 september 2006, zaak C-81/05, Cordero Alonso.

HvJEU van 12 september 2006, zaak C-300/04, Eman en Sevinger.

HvJEU van 14 september 2006, gevoegde zaken C-181/04 tot en met C-

183/04, Elmeka

HvJEU van 11 januari 2007, zaak C-384/05, Piek

HvJEU 11 januari 2007, zaak C-208/05, ITC

HvJEU van 13 maart 2007, zaak C-432/05, Unibet

HvJEU van 5 juli 2007, zaak C-430/05, Ntionik en Pikoulas

HvJEU van 27 september 2007, zaak C-409/04, Teleos

HvJEU van 27 september 2007, zaak C-184/05,Twoh

HvJEU van 16 oktober 2007, zaak C-411/05, Palacios de la Villa

HvJEU van 11 december 2007, zaak C-438/05, Viking Line

HvJEU van 18 december 2007, zaak C-341/05 Laval

HvJEU van 16 januari 2008, zaak C-361/07, Polier

HvJEU van 17 januari 2008, zaak C-246/06, Velasco Navarro

HvJEU van 29 januari 2008, zaak C-275/06, Promusicae

HvJEU van 14 februari 2008, zaak C-244/06, Dynamic Medien 
HvJEU van 21 februari 2008, Zaak C-271/06, Netto Supermarkt HvJEU van 1 april 2008, zaak C-267/06, Tadao Maruko HvJEU van 15 april 2008, zaak C-268/06, Impact HvJEU van 8 mei 2008, gevoegde zaken C-95/07 en C-96/07, Ecotrade HVJEU van 12 juni 2008 (beschikking), zaak C-364/07, Vassilakis HvJEU van 19 juni 2008, zaak C-219/07, Andibel HvJEU van 10 juli 2008, zaak C-25/07, Sosnowska HvJEU van 17 juli 2008, zaak C-94/07 Raccanelli HvJEU van 17 juli 2008, zaak C-303/06, Coleman HvJEU van 23 september 2008, zaak C-427/06, Bartsch HvJEU van 3 oktober 2008, zaak C-287/08, Savia HvJEU van 14 oktober 2008, zaak C-353/06, Grunkin en Paul HvJEU van 18 november 2008, zaak C-158/07, Förster HvJEU van 18 december 2008, zaak C-349/07, Sopropé HvJEU van 20 januari 2009, gevoegde zaken C-350/06 en C-520/06, Bectu HvJEU van 5 maart 2009, zaak C-388/07, Age Concern England HvJEU van 23 april 2009, gevoegde zaken C-378/07 tot en met C-380/07, Angelidaki

HvJEU 4 juni 2009, gevoegde zaken nC-22/08 en C-23/08, Vatsouras HvJEU van 18 juni 2009, zaak C-88/08, Hütter HvJEU van 17 september 2009, zaak C-242/06, Sahin HvJEU van 6 oktober 2009, zaak C-123/08, Wolzenburg HvJEU van 15 oktober 2009, zaak C-101/08, Audiolux HvJEU van 22 oktober 2009, zaak C-301/08, Irène Bogiatzi HvJEU van 27 oktober 2009, zaak C-115/08, ČEZ HvJEU van 29 oktober 2009, zaak C-174/08, NCC Construction Danmark HvJEU van 27 november 2009, zaak C-333/09, Noël HvJEU van 10 december 2009, zaak C- 323/08, Mayor HvJEU van 23 december 2009, zaak C-403/09 PPU, Detiček HvJEU van 12 januari 2010, zaak C-341/08, Petersen HvJEU van 12 januari 2010, zaak C-229/08, Wolf HvJEU 14 januari 2010, zaak C-226/08, Stadt Papenburg HvJEU van 19 januari 2010, zaak C-555/07, Kücükdeveci HvJEU van 2 maart 2010, zaak C-135/08, Rottmann HvJEU van 18 maart 2010, gevoegde zaken C-317/08, C-318/08, C-319/08 en C-320/08, Allassini

HvJEU van 27 april 2010, gevoegde zaken C-536/08 en C-539/08, X HvJEU van 3 juni 2010, zaak C-203/08, Sporting Exchange Betfair HvJEU van 16 september 2010, zaak C-149/10, Chatzi HvJEU van 5 oktober 2010, zaak C-400/10 PPU, McB HvJEU van 28 oktober 2010, zaak C-367/09, SGS Belgium e.a. 
HvJEU van 9 november 2010, gevoegde zaken C-92/09 en C-93/09, Schecke HVJEU van 11 november 2010, zaak C-20/10, Vino I HvJEU van 11 november 2010, zaak C-232/09, Danosa HvJEU van 12 november 2010, zaak C-339/10, Estov HvJEU van 7 december 2010, zaak C-439/08, VEBIC HvJEU van 22 december 2010, zaak C-279/09, DEB HvJEU van 22 december 2010, zaak C-245/09, Omalet HvJEU van 22 december 2010, zaak C-208/09, Sayn-Wittgenstein HvJEU van 25 januari 2011, zaak C-382/08, Neukirchinger HvJEU van 1 maart 2011, zaak C-457/09, Chartry HvJEU van 1 maart 2011, zaak C-236/09, Association Belge des

Consommateurs Test-Achats

HvJEU van 8 maart 2011, zaak C-34/09, Ruiz Zambrano

HvJEU van 10 maart 2011, zaak C-379/09, Casteels

HvJEU van 11 maart 2011, zaak C-236/09, Test-Achats

HvJEU van 31 maart 2011, zaak C-546/09, Aurubis Balgaria

HvJEU van 5 mei 2011, zaak C-434/09, MCarthy

HvJEU van 10 mei 2011, zaak C-147/08, Römer

HvJEU van 12 mei 2011, zaak C-391/09, Vardyn

HvJEU van 23 mei 2011, gevoegde zaken C-267/10 en C-268/10, Rossius

HvJEU van 22 juni 2011, zaak C-161/11, Vino II

HvJEU van 7 juli 2011, zaak C-310/10, Agafiţei.

HvJEU van 13 september 2011, zaak C-447/09, Prigge

HvJEU van 15 september 2011, zaak 155/10, Williams

HvJEU van 15 september 2011, gevoegde zaken C-483/09 en C-1/10, Gueye en Sanchez

HvJEU van 22 september 2011, zaak C-538/10, Lebrun

HvJEU van 22 september 2011, zaak C-314/10, Pagnoul

HvJEU van 10 november 2011, zaak C-405/10, Garenfeld

HvJEU van 11 november 2011, zaak C-70/10, Scarlet

HvJEU van 15 november 2011, zaak C-256/11, Dereci

HvJEU van 22 november 2011, zaak C-214/10, KHS

HvJEU van 1 december 2011, zaak C-145/10, Painer

HvJEU van 6 december 2011, zaak C-329/11, Achughbabian

HvJEU van 14 december 2011, gevoegde zaken C-483/11 en C-484/11,

Boncea

HvJEU van 14 december 2011, zaak C-462/11, Cozman

HvJEU van 14 december 2011, zaak C-434/11, Corpul Naţional al Poliţiştilor I HvJEU van 21 december 2011, zaak C-499/10, Vlaamse Oliemaatschappij HvJEU van 21 december 2011, zaak C-465/10, Ministre de l'Intérieur, de l'Outre-mer, des Collectivités territoriales et de l'Immigration 
HvJEU van 21 december 2011, gevoegde zaken C-411/10 en C-493/10, N.S. HvJEU van 21 december 2011, zaak C-482/10, Cicala

HvJEU van 24 januari 2012, zaak C-282/10, Dominguez

HvJEU van 14 februari 2012, zaak C-17/10, Toshiba

HvJEU van 24 april 2012, C-571/10, Kamberaj

HvJEU van 7 maart 2012, zaak C-178/12, Rivas Montes

HvJEU van 29 maart 2012, gevoegde zaken C-7/10 en C-9/10, Kahveci en Inan

HvJEU van 29 maart 2012, zaak C-1/11, Interseroh Scrap

HvJEU van 24 april 2012, zaak C-571/10, Kamberaj

HvJEU van 3 mei 2012, zaak C-337/10, Neidel

HvJEU van 10 mei 2012, zaak C-134/12, MAI

HvJEU van 5 juni 2012, zaak C-489/10, Bonda

HvJEU van 7 juni 2012, zaak C-27/11, Vinkov

HvJEU van 21 juni 2012, zaak C-78/11, ANGED

HvJEU van 28 juni 2012, zaak C-7/11, Caronna

HvJEU van 6 juli 2012, zaak C-16/12, Hermes Hitel és Faktor

HvJEU van 12 juli 2012, zaak C-284/11, EMS-Bulgaria Transport

HvJEU van 12 juli 2012, zaak C-466/11, Currà

HvJEU van 12 juli 2012, zaak C-171/11, Fra.bo

HvJEU van 19 juli 2012, zaak C-470/11, Garkalns

HvJEU van 10 oktober 2012, C-364/10, Hongarije/Slowakije

HvJEU van 18 oktober 2012, zaak C-583/10, Nolan.

HvJEU van 18 oktober 2012, zaak C-371/11, Punch Graphix Prepress Belgium HvJEU van 18 oktober 2012, zaak C-525/11, Mednis

HvJEU van 6 november 2012, zaak C-245/11, K.

HvJEU van 8 november 2012, zaak C-40/11, Iida

HvJEU van 8 november 2012, gevoegde zaken C-229/11 en C-230/11,

Heimann

HvJEU van 15 november 2012, zaak C-369/12, Corpul Naţional al Poliţistilor II

HvJEU van 22 november 2012, zaak C-277/11, M.M.

HvJEU van 6 december 2012, gevoegde zaken C-356/11 en C-357/11, O. en $S$.

HvJEU van 13 december 2012, zaak C-379/11, Caves Krier Frères

HvJEU van 15 januari 2013, zaak C-416/10, Križan

HvJEU van 7 februari 2013, zaak C-498/12, Pedone

HvJEU van 7 februari 2013, zaak C-499/12, Gentile

HvJEU van 21 februari 2013, zaak C-312/12, Ajdini

HvJEU van 26 februari 2013, zaak C-617/10, Åkerberg Fransson

HvJEU van 26 februari 2013, zaak C-399/11, Melloni 
HvJEU van 7 maart 2013, zaak C-128/12, Sindicato dos Bancários do Norte HvJEU van 14 maart 2013, zaak C-555/12, Loreti

HvJEU van 11 april 2013, zaak C-401/11, Soukupová

HvJEU van 11 april 2013, gevoegde zaken C-335/11 en C-337/11, HK

Danmark

HvJEU van 16 april 2013, zaak C-202/11, Las

HvJEU van 18 april 2013, zaak C-413/11, Germanwings

HvJEU van 8 mei 2013, zaak C-87/12, Ymeraga

HvJEU van 30 mei 2013, zaak C-106/13, Fierro et Marmorale

HvJEU van 30 mei 2013, zaak C-73/13, $T$.

HvJEU van 6 juni 2013, zaak C-14/13, Cholakova

HvJEU van 6 juni 2013, zaak C-648/11, MA

HvJEU van 13 juni 2013, zaak C-45/12, Hadj Ahmed

HvJEU van 27 juni 2013, zaak C-93/12, ET Agrokonsulting-04-Velko Stoyanov

HvJEU van 4 juli 2013, zaak C-233/12, Gardella

HvJEU van 18 juli 2013, zaak C-234/12, Sky Italia

HvJEU van 18 juli 2013, zaak C-501/11, Schindler

HvJEU van 18 juli 2013, zaak C-426/11, Alemo-Herron

HvJEU van 19 september 2013, zaak C-5/12, Betriu Montull

HvJEU van 10 september 2013, zaak C-383/13 PPU, G. en R.

HvJEU van 26 september 2013, zaak C-418/11, Texdata Software

HvJEU van 26 september 2013, zaak C-195/12, Industrie du bois de Vielsalm

HvJEU van 26 september 2013, zaak C-476/11, HK Danmark

HvJEU van 22 oktober 2013, zaak C-276/12, Sabou

HvJEU van 7 november 2013, zaak C-313/12, Romeo

HvJEU van 7 november 2013, zaak C-225/12, Demir

HvJEU van 14 november 2013, zaak C-4/11, Puid

HvJEU van 15 januari 2014, zaak C-176/12, AMS

HvJEU van 13 februari 2014, gevoegde zaken C-512/11, C-513/11, Terveys-

ja sosiaalialan neuvottelujärjestö TSN

HvJEU van 27 februari 2014, zaak C-470/12, Pohotovost

HvJEU van 6 maart 2014, zaak C-206/13, Siragusa

HvJEU van 18 maart 2014, zaak C-628/11, International Jet Management

HvJEU van 18 maart 2014, zaak C-363/12, Z.

HvJEU van 27 maart 2014, zaak C-265/13, Torralbo Marcos

HvJEU van 27 maart 2014, zaak C-314/12, UPC Telekabel

HvJEU van 30 april 2014, zaak C-390/12, Pfleger

HvJEU van 8 mei 2014, zaak C-483/12, Pelckmans

HvJEU van 8 mei 2014, zaak C-604/12, H. N.

HvJEU van 8 mei 2014, zaak C-329/13, Stefan

HvJEU van 15 mei 2014, zaak C-135/13, Szatmári Malom 
HvJEU van 22 mei 2014, zaak C-356/12, Glatzel

HvJEU van 22 mei 2014, zaak C-56/13, Érsekcsanádi Mezögazdasági

HvJEU van 12 juni 2014, zaak C-314/13, Peftiev

HvJEU van 26 juni 2014, zaak C-264/12, Sindicato Nacional dos Profissionais de Seguros e Afins

HvJEU van 3 juli 2014, zaak C-92/14, Tudoran

HvJEU van 3 juli 2014, gevoegde zaken C-129/13 en C-130/13, Kamino

HvJEU van 10 juli 2014, zaak C-198/13, Julian Hernández

HvJEU van 10 juli 2014, zaak C-138/13, Dogan

Conclusies en standpuntbepalingen

A- G Jacobs van 9 december 1992, zaak C-168/91, Konstantinidis

A-G Jacobs van 30 juni 1993, gevoegde zaken C-92/92 en C-326/92, Phil

Collins

A-G Mischo van 20 september 2001, gevoegde zaken C-20/00 en C-64/00, Booker Aquaculture

A-G Jacobs van 11 juli 2002, zaak C-112/00, Schmidberger

A-G Tizanno van 18 januari 2005, zaak C-519/03, Commissie/Luxemburg

A-G Geelhoed van 23 februari 2006, zaak C-374/04, ACT

A-G Geelhoed van 16 maart 2006, zaak C-13/05, Chacón Navas

A-G Sharpston van 30 november 2006, zaak C-227/04 P, Lindorfer

A-G Mazák van 15 februari 2007, zaak C-411/05, Palacios de la Villa

A-G Trstenjak van 29 maart 2007, zaak C-80/06, Carp

A-G Maduro van 12 september 2007, zaak C-380/05, Centro Europa

A-G Ruiz-Jarabo Colomer van 24 januari 2008, gevoegde zaken C-55/07 en

C-56/07, Michaeler

A-G Maduro van 31 januari 2008, zaak C-303/06, Coleman

A-G Sharpston van 22 mei 2008, zaak C-427/06, Bartsch

A-G Trstenjak van 30 juni 2009, zaak C-101/08, Audiolux

A-G Bot van 7 juli 2009, zaak C-555/07, Kücükdeveci

A-G Bot van 17 december 2009, zaak C-203/08, Sporting Exchange Betfair en zaak C-258/08, Ladbrokes.

A-G Cruz Villalón van 6 juli 2010, zaak C-306/09, I.B.

A-G Kokott (standpuntbepaling) van 7 juli 2010, zaak C-149/10, Chatzi

A-G Jääskinen van 15 juli 2010, zaak C-147/08, Römer

A-G Kokott van 30 september 2010, zaak C-236/09, Association Belge des

Consommateurs Test-Achats

A-G Sharpston van 30 september 2010, zaak C-34/09, Ruíz Zambrano

A-G Kokott van 11 november 2010, zaak C-379/09, Casteels

A-G Bot van 5 april 2011, zaak C-108/10, Scattolon

A-G Cruz Villalón van 19 mei 2011, zaak C-447/09, Prigge 
A-G Kokott van 8 september 2011, zaak C-17/10, Toshiba

A-G Trstenjak van 8 september 2011, zaak C-282/10, Dominguez

A-G Trstenjak van 22 september 2011, zaak C-411/10, N.S.

A-G Mengozzi (standpuntbepaling) van 29 september 2011, zaak C-256/11, Dereci

A-G Kokott van 15 december 2011, zaak C-489/10, Bonda

A-G Trstenjak van 21 januari 2012, zaak C-591/10, Littlewoods

A-G Bot van 27 maart 2012, zaak C-83/11, Rahman

A-G Trstenjak van 28 maart 2012, zaak C-171/11, Fra.bo

A-G Kokott van 19 april 2012, zaak C-416/10, Križan

A-G Bot van 26 april 2012, zaak C-277/11, M.M.

A-G Trstenjak van 15 mei 2012, zaak C-40/11, Iida

A-G Bot van 7 juni 2012, zaak C-451/11, Dülger

A-G Cruz Villalón van 12 juni 2012, zaak C-617/10, Åkerberg Fransson

A-G Bot van 12 juni 2012, zaak C-283/11, Sky Österreich

A-G Trstenjak van 27 juni 2012, zaak C-245/11, K

A-G Kokott van 20 september 2012, zaak C-394/11, Belov

A-G Bot van 27 september 2012, gevoegde zaken C-356/11 en C-357/11, O en $S$.

A-G Bot van 2 oktober 2012, zaak C-399/11, Melloni

A-G Sharpston van 18 oktober 2012, zaak C-396/11, Radu

A-G Cruz Villalón van 25 oktober 2012, zaak C-32/11, Allianz Hungária

Biztosító e.a.

A-G Bot van 14 maart 2013, zaak C-93/12, Agrokonsulting-04-Velko Stoyanov

A-G Jääskinen van 18 april 2013, zaak C-4/11, Puid

A-G Kokott van 16 mei 2013, zaak C-234/12, Sky Italia

A-G Kokott van 6 juni 2013, zaak C-276/12, Sabou

A-G Wahl van 11 juli 2013, zaak C-225/12, Demir

A-G Cruz Villalón van 18 juli 2013, zaak C-176/12, AMS

A-G Wahl van 26 september 2013, zaak C-363/12, Z

A-G Sharpston van 14 november 2013, zaak C-390/12, Pfleger

A-G Bot van 28 november 2013, gevoegde zaken C-501/12 tot en met C506/12, C-540/12 en C-541/12, Specht

A-G Cruz Villalón van 12 december 2013, Gevoegde zaken C-293/12, C594/12, Digital Rights Ireland

A-G Wahl van 12 december 2013, zaak C-470/12, Pohotovost

A-G Sharpston van 12 december 2013, Gevoegde zaken C-141/12, C372/12, Y.S.

A-G Sharpston van 12 december 2013, zaak C-456/12, O

A-G Cruz Villalón van 28 januari 2014, zaak C-583/12, Sintax Trading

A-G Bot van 2 april 2014, zaak C-112/13, A/B 
A-G Jääskinen van 13 maart 2014, zaak C-562/12, MTÜ Liivimaa Lihaveis A-G Cruz Villalón van 22 mei 2014, zaak C-201/13, Deckmyn A-G Bot van 12 juni 2014, zaak C-311/13, Tümer

A-G Wathelet van 25 juni 2014, zaak C-249/13, Boudjlida

Aanhangige zaken

Zaak C-117/14, Nisttahuz Poclava (Juzgado de lo Social no. 23 de Madrid d.d. 11 maart 2014)

\section{Overige rechtspraak}

EHRM van 13 juni 1979, zaaknr. 58442, Marckx, NJ 1980, 462

EHRM van 28 juni 2001, zaaknr. 24699/94, VgT Verein gegen Tierfabriken, NJ 2002, 181

EHRM van 24 juni 2004, zaaknr. 59320/00, Von Hannover, punt 57. NJ 2005, 22

EHRM 13 juli 2004, zaaknr. 69498/01, Pla and Puncernau, NJ 2005, 508 BverG van 24 april 2013, 1 BvR 1215/07

BverG van 6 juli 2010, 2 BvR 2661/06, Honeywell Bremsbelag GmbH BverG van 30 juni 2009, 2 BvE 2/08, 2 BvE 5/08, 2 BvR 1010/08, 2 BvR 1022/08, 2 BvR 1259/08, 2 BvR 182, Lissabon 


\section{LIJST VAN AANGEHAALDE LITERATUUR \& OVERIGE BRONNEN}

\section{Literatuur}

Adams e.a. 2013

M. Adams, H. de Waele, J. Meeusen and G. Straetmans, Judging Europe's Judges: The Legitimacy of the Case Law of the European Court of Justice, Oxford: Hart Publishing 2013.

Alexy 2002

R. Alexy, A Theory of Constitutional Rights, Oxford: Oxford University Press 2002.

Avbelj 2005

M. Avbelj, 'Is there Drittwirkung in EU Law', in: Sajó and Uitz 2005, p. 145157.

Barkhuysen \& Van Emmerik 2006

T. Barkhuysen en M. Van Emmerik, 'Constitutionalisation of Private Law: the European Convention on Human Rights Perspective', in: Barkhuysen \& Lindenbergh 2006, p. 43-59.

Barkhuysen \& Lindenbergh 2006

T. Barkhuysen en D. Lindenbergh (red.), Constitutionalisation of Private Law, Oegstgeest: Martinus Nijhoff Publishers 2006.

Barkhuysen, Emmerik en Loof 2009

T. Barkhuysen, M.L. Emmerik en J.P. Loof (red.), Geschakeld recht: verdere

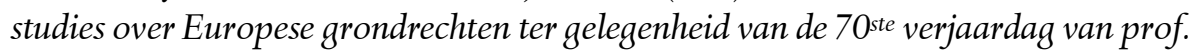
Mr. E.A. Alkema, Deventer: Kluwer 2009.

Barkhuysen, Bos \& Ten Have 2011

T. Barkhuysen, A.W. Bos \& F. ten Have, 'Een verkenning van de betekenis van het Handvest van de grondrechten van de Europese Unie, Deel 1: De inhoud, de juridische status en het toepassingsbereik van het Handvest, in het bijzonder in horizontale verhoudingen', NTBR 2011/68.

\section{Bell 2004}

M. Bell, Anti-Discrimination Law and the European Union, Oxford Studies in European Law, Oxford: Oxford University Press 2004. 
Bengoetxea 2010

J. Bengoetxea, 'Case C-101/08, Audiolux SA and Others v. Groupe Bruxelles Lambert SA (GBL) and Others, Bertelsmann AG and Others, Judgment of the Court of Justice (Fourth Chamber) of 15 October 2009', CMLRev. 47 (2010) 4, p. 1173-1186.

Bernitz \& Nergelius 2000

U. Bernitz \& J. Nergelius (red.), General Principles of European Community Law, European Monographs no. 25, Den Haag: Kluwer Law International 2000.

Bernitz, Nergelius \& Cardner 2008

U. Bernitz, J. Nergelius \& C. Cardner (red.), General Principles of EC Law in a Process of Development, European Monographs no. 62, Den Haag: Kluwer Law International 2008

Bernitz, Groussot \& Schulyok 2013-1

U.Bernitz, X. Groussot en F. Schulyok (red.), General principles of EU Law and European Private Law, European Monographs no. 84, Alphen aan den Rijn: Kluwer Law International 2013.

Bernitz, Groussot \& Schulyok 2013-2

U. Bernitz, X. Groussot \& F. Schulyok, 'Vision, Essence and Narratives of General Principles and European Private Law: An Introduction', in: Bernitz, Groussot \& Schulyok 2013-1, p. 1-21.

Besselink, Pennings en Prechal 2010

L. F.M. Besselink, F. Pennings en S. Prechal (red.), The Eclipse of the Legality Principle in the European Union, Deventer: Kluwer Law International 2010.

Besselink 2012

L.F.M. Besselink, 'General Report', The Protection of Fundamental Rights postLisbon, The Interaction between the EU Charter of Fundamental Rights, the European Convention on Human Rights (ECHR) and National Constitutions, Reports of the XXV FIDE Congress Tallinn Volume I: Tartu University Press 2012, p. 63-139.

Beukers, van Harten en Prechal 2010

T.W.B. Beukers, H.J. van Harten en S. Prechal (red.), Het recht van de Europese Unie in 50 klassieke arresten, Den Haag: Boom Juridische Uitgevers 2010. 
Boeles 2005

P. Boeles, 'Europese burgers en derdelanders: wat betekent het verbod van discriminatie naar nationaliteit sinds Amsterdam', SEW(2005) 12, p. 500513.

Boer, de 2013

N. De Boer, 'Addressing rights divergences under the Charter: Melloni', CMLRev. 50 (2013) 4, p. 1083-1104.

Van den Bogaert 2005

S. Van den Bogaert, Practical Regulation of the Mobility of Sportsmen in the EU Post Bosman, European Monographs 48, Den Haag: Kluwer Law International 2005.

Bomer 2012

A.H. Bomer, De doorwerking van algemene rechtsbeginselen in de BTW (diss. Maastricht), 2012.

Bousta 2013

R. Bousta, "Who Said There is a "Right to Good Administration"? A Critical Analysis of Article 41 of the Charter of Fundamental Rights of the European Union', EPL 2013, p. 481-488.

Brkan 2013

M. Brkan, 'L'arrêt Melloni: nouvelle pierre dans Ia mosaïque de Ia protection des droits fondamentaux dans I'Union européenne' Revue des Affaires Européennes (2013) 1, p. 139-145.

De Búrca 2011

G. De Búrca, 'The Evolution of EU Human Rights Law', in: P. Craig \& G. De Búrca (red.), The Evolution of EU Law, Oxford: Oxford University Press, p. 465-495.

Bulterman \& Slot 2005

M.K. Bulterman en P.J. Slot, 'Harmonisatie van wetgeving betreffende migrerende EU-burgers en derdelanders: op weg naar een uniform toetsingskader?', SEW (2005) 9, p. 346- 362.

Cambien 2011

N. Cambien, 'Noot bij zaak C-34/09, Gerardo Ruiz Zambrano/Office national de l'emploi (ONEm)', SEW (2011) 9, p. 411-413. 
Cherednychenko 2007

O.O. Cherednychenko, 'The harmonisation of contract law in Europe by means of the horizontal effect of fundamental rights', ELR 1 (2007), p. 38-58.

Claes 2013

M. Claes, 'The European Union, its Member States and their Citizens', in: Leczykiewicz en Weatherhill 2013, p. 29-53.

Claes \& Gerards 2012

M. Claes en J.H. Gerards (rapporteurs), 'Protection of Fundamental Rights post-Lisbon: The Interaction between the EU Charter of Fundamental Rights, the European Convention on Human Rights (ECHR) and National Constitutions', Nationale FIDE rapport 2012:

www.nver.nl/documents/FIDE_report_2012_topic_1.pdf

\section{Cragl 2014}

P. Cragl, 'A giant leap for European Human Rights? The final agreement on the European Union's accession to the European Convention on Human Rights', CMLRev. 51 (2014) 1, 13-58.

Craig 2009

P. Craig, 'The legal effects of Directives: policy, rules and exceptions', 34 (2009) 3 E.L. Rev., p. 349-378

Craig 2010

P. Craig, The Lisbon Treaty. Law, politics and treaty reform, Oxford: Oxford University Press 2010.

De Cecco 2006

F. De Cecco, 'Room to move? Minimum harmonization and fundamental rights', CMLRev. 43 (2006) 1, p. 9-30.

Dawson, De Witte \& Muir 2013

M. Dawson, B. De Witte en E. Muir, Judicial Activism at the European Court of Justice, Cheltenham: Edward Elgar Publishing Limited 2013.

Denman 2010

D. Denman, 'The Charter of Fundamental Rights', E.H.R.L.R (2010) 4, p. 349359. 
Dougan 2007

M. Dougan, 'When worlds collide! Competing visions of the relationship between direct effect and supremacy', CMLRev. 44 (2007) 4, 931-963.

Dougan 2008

M. Dougan, 'The Treaty of Lisbon 2007, winning minds, not hearts', CMLRev. 45 (2008) 3, p. 617-703.

Dworkin 1977

R. Dworkin, Taking rights seriously, Cambridge: Harvard University Press 1977.

Eeckhout 2002

P. Eeckhout, 'The EU Charter of Fundamental Rights and the Federal Question', CMLRev. 39 (2002) 5, p. 945-994.

Van Eijken 2012-1

H. van Eijken, 'Ruiz Zambrano the aftermath: de impact van artikel 20 VWEU op de Nederlandse rechtspraak', NTER (2012) 2, p. 4-18.

Van Eijken 2012-2

H. Van Eijken, 'Case C-391/09, Malgozata Runevic-Vardyn and Lukasz Pawel Wardyn v. Vilniaus miesto savivaldybes administracija and Others, Judgment of the Court (Second Chamber) of 12 May 2011', CMLRev. 49 (2012) 2, p.809-826.

Van Eijken \& S.A. De Vries 2011

H. Van Eijken en S.A. De Vries, 'A New Route into the Promised Land? Being a European Citizen after Ruiz Zambrano', E.L. Rev. 36 (2011) 5, p.704-721.

Van Elsuwege, Devisscher \& Van Bossuyt 2010

P. Van Elsuwege, P. Devisscher en A. Van Bossuyt, 'Het Handvest van de grondrechten van de Europese Unie: implicaties voor de nationale rechtsorde', TPR 2010, p. 1-52.

Engström 2011

J. Engström, 'The Principle of Effective Judicial Protection after the Lisbon Treaty', REALaw 4 (2011) 2, p. 53-68. 
Fontanelli 2011

F. Fontanelli, 'General Principles of the EU and a Glimpse of Solidarity in the Aftermath of Mangold and Kücükdeveci', EPL 17 (2011) 2, p. 225-240.

Fontanelli 2013

F. Fontanelli, 'Hic Sunt Nationes: The Elusive Limits of the EU Charter and the German Constitutional Watchdog: Court of Justice of the European Union: Judgment of 26 February 2013, Case C-617/10 Åklagaren v. Hans Åkerberg Fransson', EUConst. 9 (2013) 2, p. 315-334.

Fontanelli 2014

F. Fontanelli, 'National Measures and the Application of the EU Charter of Fundamental Rights - Does curia.eu Know iura.eu?', H.R.L.R. 14 (2014) 2, 135.

Frantziou 2014

E. Frantziou, 'Case C-176/12 Association de Médiation Sociale: Some Reflections on the Horizontal Effect of the Charter and the Reach of Fundamental Employment Rights in the European Union', EUConst. 10 (2014) 2, forthcoming.

Gardbaum 2012

S. Gardbaum, 'The Place of Constitutional Law in the Legal System', in: Rosenfeld en Sajó 2012, p. 169-185.

Garlicki 2005

L. Garlicki, 'Relations between Private Actors and the European Convention on Human Rights', in: Sajó \& Uitz 2005, p. 129-145.

Gazin 2013

F. Gazin, 'Mandat d'arrêt européen. Reconnaissance mutuelle versus protection des droits fondamentaux : prévalence accordée à la première en droit pénal de l'UE', Europe (2013) 4, p. 23

Gerken e.a. 2009

L. Gerken, V. Rieble, G.H. Roth, T. Stein en R. Streinz, 'Mangold' als ausbrechender Rechtsakt, München: Sellier European Publishers 2009. 
Gijzen 2006

M.H.S. Gijzen, Selected Issues in Equal Treatment Law: a Multi-Layered

Comparison of European, English and Dutch Law (diss. Maastricht), Ius

Commune Europepaeum Series no. 61, Maastricht: Intersentia 2006.

Graig \& De Búrca 2011

P. Graig and G. de Búrca, The Evolution of EC Law, Oxford: Oxford University Press 2011 (2 ed).

De Groot \& Selling 2011

G.R. de Groot en A. Seling, 'Case note 2: The consequences of the Rottmann judgment on Member State autonomy - The European Court of Justice's avant-gardism in nationality matters', EUConst. 7 (2011) 1, p. 150-160.

Groussot 2006

X. Groussot, General Principles of Community Law, The Hogendorp Papers 6, Groningen: Europa Law Publishing 2006.

Groussot, Pech \& Petursson 2011

X. Groussot, L. Pech, en G.T. Petursson, 'The Scope of Application of EU Fundamental Rights on Member States' Action: In Search of Certainty in EU Adjudication', Eric Stein Working Paper 1/2011, p. 1-35.

Hailbronner en Thym 2011

K. Hailbronner en D. Thym, 'Case C-34/09, Gerardo Ruiz Zambrano v. Office national de l'emploi (ONEm), Judgment of the Court of Justice (Grand Chamber) of 8 March 2011', CMLRev. 48 (2011) 4, p.1253-1270.

Hancox 2013

E. Hancox, 'The meaning of "implementing" EU law under Article 51(1) of the Charter: Åkerberg Fransson', CMLRev. 50 (2013) 5, p. 1411-1431.

Hartkamp 2011-2

A. Hartkamp, Europees recht en Nederlands Vermogensrecht, Asser-serie 3-I, Deventer: Kluwer 2011.

Hartkamp 2013

A. Hartkamp,'The Terminology of European Law Scholars and of Private Law Scholars Compared', in: Bernitz, Groussot \& Schulyok 2013-1, p. 189-199. 
Hartkamp e.a. 2014

A.S. Hartkamp, C.H. Sieburgh en L.A.D. Keus, J. Kortmann en M.H. Wissink (red.), The Influence of EU Law on National Private Law, Serie Onderneming en Recht, deel 81-1, Deventer: Kluwer 2014.

Hinarejos 2011

A. Hinarejos, 'Extending Citizenship and the Scope of EU Law', CLJ 70 ( 2011) 2, p. 309-312.

Herdegen 1999

M. Herdegen, 'The Origins and Development of the General Principles of Community Law', in: U. Berntiz and J. Nergelius (red), General Principles of European Community Law, Den Haag: Kluwer Law International 1999, p. 325.

Herdegen 2008

M. Herdegen, "General Principles of EU Law - the Methodological

Challenge”, in: Bernitz, Nergelius \& Cardner 2008, p. 343-357.

Heringa \& Verhey 2001

A.W. Heringa en L. Verhey, 'The EU Charter: Text and Structure', MJ 8 (2001)1, p. 11-32.

Hofmann en Mihaescu 2013

H.C.H. Hofmann and C. Mihaescu, 'The Relation between the Charter's Fundamental Rights and the Unwritten General Principles of EU Law: Good Administration as the Test Case', EUConst. 9 (2013) 1, p. 73-101

Huber 2008

P.M. Huber, 'The Unitary Effect of the Community's Fundamental Rights:

The ERT-Doctrine Needs to be Reviewed', EPL14 (2008) 3, p. 323-333.

Hublet 2009

Ch. Hublet, "The Scope of Article 12 of the Treaty of the European

Communities vis-à-vis Third-Country Nationals: Evolution at Last?', ELJ 15 (2009) 6, p. 757-774.

Jacobs 2001

F.G. Jacobs, 'Human rights in the European Union: the role of the Court of Justice', E.L. Rev. 26 (2001) 4, p. 331-341. 
Jacqué 2004

J.J. Jacqué, 'The principle of institutional balance', CMLRev. 46 (2004) 2, p. 383-391.

Jacqué 2004

J.P. Jacqué, 'La Charte des droits fondamentaux de l'Union européenne:

Aspects juridiques généraux', REDP 14 (2002) 1, p. 107-126

Jans 2000

J.H. Jans, 'Evenredigheid Revisited', SEW (2000) 7/8, p. 270-280.

Jessurun d'Oliveira 2011

H.U. Jessurun d'Oliveira, 'Court of Justice of the European Union: Decision of 2 March 2010, Case C-315/08, Janko Rottman v. Freistaat Bayern Case Note 1 Decoupling Nationality and Union Citizenship?', EUConst. 7 (2011) 1, p. 138-150.

Kapteyn 2004

P.J.G. Kapteyn, 'Reikwijdte Handvest grondrechten EU als onderdeel Grondwet Europa', Themis (2004) 3, p. 111-119.

Kapteyn 2010

P.J.G. Kapteyn, 'Stauder', in: Beukers, van Harten en Prechal 2010, p. 38-51.

Knook 2005

A. Knook, 'The Court, the Charter, and the vertical division of powers in the European Union', CMLRev. 42 (2005) 2, p. 367-398.

Kokott \& Sobotta 2010

J. Kokott en C. Sobotta, 'The Charter of Fundamental Rights of the European Union after Lisbon', EUI Working Papers, Academy of European Law, nr. 2010/06.

Kokott 2010

J. Kokott, 'The Basic Law at 60 - From 1949 to 2009: The Basic law and Supranational Integration', GLJ 11 (2010) 1, p. 99-114.

Koopmans 1993

T. Koopmans, 'Judicial activism and procedural law' , ERPL 1 (1993) 1-2, p. $67-81$. 
Ladenburger 2012

C. Ladenburger, FIDE 2012 -Institutional Report Session on "Protection of Fundamental Rights post-Lisbon - The interaction between the Charter of Fundamental Rights, the European Convention of Human Rights and National Constitutions, http://www.fide2012.eu/General+and+EU+Reports/id/217

Lansbergen \& Miller 2011

A. Lansbergen en N. Miller, 'Court of Justice of the European Union European Citizenship Rights in Internal Situations: An Ambiguous Revolution? Decision of 8 March 2011, Case C-34/09 Gerardo Ruiz Zambrano v. Office national de l'emploi (ONEM)', EUConst. 7 (2011) 2, p. 287-307.

\section{Lazzerini 2014}

N. Lazzerini, 'Case C-176/12, Association de médiation sociale v. Union locale des syndicats CGT and Others, Judgment of the Court of Justice (Grand Chamber) of 15 January 2014', CMLRev. 51 (2014) 3, p. 907-933.

Leczykiewicz en Weatherhill 2013

D. Leczykiewicz en S. Weatherhill (red.), The Involvement of EU Law in Private Law Relationships, Studies of the Oxford Institute of European and Comparative Law Volume 16, Oxford: Hart Publishing 2013.

Lenaerts 2000

K. Lenaerts, 'Fundamental rights in the European Union', E.L.Rev. 25 (2000) 6, p. 575-600.

Lenaerts 2007

K. Lenaerts, 'The Rule of Law and the Coherence of the Judicial System of the European Union', CMLRev. 44 (2007) 6 p. 1625-1659.

Lenaerts 2012-1

K. Lenaerts, 'Exploring the Limits of the EU Charter of Fundamental Rights', EuConst. 8 (2012) 3, p. 375-403.

Lenaerts 2012-2

K. Lenaerts, “'Civis europeaus sum': van grensoverschrijdende aanknoping naar status van burger van de Unie”, SEW (2012) 1, p. 2-13. 
Lenaerts 2013

K. Lenaerts, 'The Court's Outer and Inner Selves: Exploring the Extranal and Intrenal Legitimacy of the European Court of Justice', in: Adams e.a. 2013, p. 13-61.

Lenaerts 2013-2

K. Lenaerts, 'How the ECJ Thinks: a Study on Judicial Legitimacy', Fordham Int'L.J. 36 (2013) 5, p. 1302-1371.

Lenaerts \& Corthout 2006

K. Lenaerts en Corthaut, 'Of birds and hedges: The role of primacy in involving norms of EU Law', ELRev. 31 (2006) 3, 287-315.

Lenaerts \& Gutiérrez-Fons 2010

K. Lenaerts en J.A. Gutiérrez-Fons, 'The constitutional allocation of powers and general principles of EU law', CMLRev. 47 (2010) 6, p. 1629-1667.

Van Leuken 2014

R. Van Leuken, 'Direct Horizontal Effect of the Fundamental Freedoms', in: Hartkamp e.a. 2014, p. 73-92.

Lindenbergh 2006

S. Lindenbergh, 'The Constitutionalisation of Private Law in the

Netherlands', in: Barkhuysen \& Lindenbergh 2006, p. 97-129.

Lock 2011

T. Lock, 'Walking on a tightrope: the draft ECHR accession agreement and the autonomy of the eu legal order', CMLRev. 48 (2011) 4, p. 1025-1054.

Mazák \& Moser 2013

J. Mazák en M. Moser, 'Adjudication by Reference to General Principles of EU Law: A Second Look at the Mangold Case Law’, in: Adams e.a. 2013, p. 6187.

Van der Mei 2009

A.P. van der Mei, 'EU-burgerschap en de reikwijdte van het verbod van discriminatie op grond van nationaliteit', NTER (2009) 8-9, p. 75-87 
Van der Mei, Van den Bogaert \& De Groot 2011

A.P. Van der Mei, S.C.G. Van den Bogaert en G.R. De Groot, 'De arresten Ruiz Zambrano en McCarthy: Het Hof van Justitie en het effectieve genot van EU-burgerschapsrechten', NTER 2011-6, p.188-199.

Meyer 2011

J. Meyer, Charta der Grundrechte der Europäischen Union, Baden-Baden:

Nomos 2011.

De Mol 2010 - 1

M. de Mol, 'Kücükdeveci: Mangold Revisited - Horizontal Direct Effect of a General Principle of EU Law: Court of Justice of the European Union (Grand Chamber) Judgment of 19 January 2010, Case C-555/07, Seda Kücükdeveci v. Swedex GmbH', EUConst. 6 (2010) 2, p. 293-308.

De Mol 2010-2

M. de Mol, 'Zaak C-555/07, Kücükdeveci', EHRC (2010) 11, p. 510-520.

De Mol 2010-3

M. de Mol, 'C-115/08, Land Oberösterreich/ČEZ', SEW (2010) 3, p. 124129.

De Mol 2011-1

M. de Mol, 'The Novel Approach of the HVJEU on the Horizontal Direct Effect of the EU Principle of Non-Discrimination: (Unbridled) Expansionism of EU law?', MJ 18 (2011) 1/2, p. 109-135.

De Mol 2011- 2

M. de Mol, 'Küccikdeveci: Hotărârea Mangold revăzută - Efectul direct orizontal al unui principiu general al dreptului UE', R.R.D.E. 4 (2011), p. $57-71$.

De Mol 2011-3

M. de Mol, 'Abordarea originală a CJUE privind efectul direct orizontal al principiului UE al nediscriminării: Expansionism (nestăvilit) al dreptului UE?', R.R.D.E. 5 (2011), p. 55-78. 
De Mol 2012-1

M. de Mol, 'Dominguez: A deafening silence; Court of Justice of the European Union (Grand Chamber). Judgment of 24 January 2012, Case C282/10, Maribel Dominguez v Centre informatique du Centre Ouest Atlantique and Préfet de la région Centre)', EUConst. 8 (2012) 2, p. 280 - 303.

De Mol 2012-2

M. de Mol, 'Het toepassingsgebied van Unierechtelijke grondrechten \& het beginsel van de allocatie van bevoegdheden', Maastricht Faculty of Law Working Paper 2012/6. Vindplaats:

http://www.unimaas.nl/bestand.asp?id=13782.

De Mol 2013

M. de Mol, Dominguez: O tăcere asurzitoare. Curtea de Justiţie a Uniunii Europene (Marea Cameră). Hotărârea din 24 ianuarie 2012, cauza C282/10, Maribel Dominguez/Centre informatique du Centre Ouest Atlantique şi Préfet de la région Centre, R.R.D.E., 2 (2013), p. 67-88.

De Mol 2014-1

M. de Mol, 'De toepassing van Uniegrondrechten op nationaal recht en het allocatiebeginsel', NTM|NJCM-Bull. 38 (2013) 6, p. 1-26.

De Mol 2014-2

M. de Mol, 'Horizontal Direct Effect of Union Prohibitions of

Discrimination', in: Hartkamp e.a. 2014, p. 219-249.

De Mol 2014-3

M. de Mol, 'Noot bij HvJEU Zaak C-176/12, AMS', EHRC 2014/70.

De Mol, Pahladsingh \& van Heijningen 2012

M. de Mol, A. Pahladsingh en L. van Heijningen, 'Inroepbaarheid in rechte van het Handvest van de Grondrechten van de Europese Unie:

Toepassingsgebied en het onderscheid tussen 'rechten' en 'beginselen', SEW (2012) 6, p. 222-237.

Muir 2011

E. Muir, 'Of Ages in - and Edges of - EU Law', CMLRev. 48 (2011)1 , p. 3962. 
Muir 2013-1

E. Muir, 'The Transformative Function of EU Equality Law',E.R.P.L. 21 (2013) 5/6, p. 1231-1253

Muir 2013- 2

E. Muir, 'The Court of Justice: a fundamental rights institution amongst others', in: Dawson, De Witte en Muir 2013, p. 76-102.

Nieuwenhuis \& Hins 2011

A.J. Nieuwenhuis en A.W. Hins, Hoofdstukken grondrechten, Nijmegen: Ars Aequi Libri 2011.

Nieuwenhuis 2006

H. Nieuwenhuis, 'Fundamental Rights Talk. An Enrichment of Legal Discourse in Private Law?', in: Barkhuysen \& Lindenbergh 2006, p. 1-9.

Nieuwenhuis, Reestman \& C. Zoethout 2010

A. Nieuwenhuis, J.-H. Reestman \& C. Zoethout (red.), Rechterlijk activisme: opstellen aangeboden aan prof. mr. J.A. Peters, Nijmegen: Ars Aequi 2010.

Oliver 2011

P. Oliver, 'Case-note case C-279/09 DEB', CMLRev. 48 (2011) 6, p. 20232040.

Oliver \& Fedtke 2007-1

D. Oliver and J. Fedtke (red.), Human Rights and the Private Sphere - A

Comparative Study, Londen: Routledge-Cavendish 2007

Oliver \& Fedtke 2007-2

D. Oliver en J. Fedtke, 'Comparative Analysis', in: Oliver \& Fedtke 2007-1, p. 467-520.

Pech 2010

L. Pech, “A Union Founded on the Rule of Law': Meaning and Reality of the Rule of Law as a Constitutional Principle of EU Law', EUConst. 6 (2010) 3, p. $359-396$.

Pech 2012

L. Pech, 'Between judicial minimalism and avoidance: The Court of Justice's sidestepping of fundamental constitutional issues in Römer and Dominguez', CMLRev. 49 (2012) 6, p. 1841-1880. 
Peers 2013

S. Peers, T. Hervey, J. Kenner and A. Ward (red.), The EU Charter of

Fundamental Rights - A Commentary, Oxford: Hart Publishing, 2013.

Prechal 2005

S. Prechal, Directives in EC Law, Oxford: Oxford University Press 2005 (2 ed.).

Prechal 2009

S. Prechal, 'Non-discrimination Does Not Fall Down from Heaven': The Context and Evolution of Non-discrimination in EU Law', EricStein Working Paper No 4/2009.

Prechal 2010-1

S. Prechal, 'Competence Creep and General Principles of Law', REALaw 3 (2010) 1, p. 5-22.

Prechal 2010-2

S. Prechal, 'Defrenne: de Europese gelijke beloningssaga met verstrekkende gevolgen', AA 2010, 283-284.

Prechal \& de Vries 2009

S. Prechal and S. A. de Vries, 'A Seamless Web of Judicial Protection in the Internal Market?', E.L.Rev. 34 (2009) 1, p. 5 - 24

Prechal, De Vries \& Van Eijken 2010

S. Prechal. S. de Vries en H. van Eijken, 'The Principle of Attributed Powers and the 'Scope of EU Law', in: Besselink, Pennings en Prechal 2010, p. 213-247.

Prechal \& Widdershoven 2011

S. Prechal en R. Widdershoven, 'Redefining the Relationship between 'Reweeffectiveness' and Effective Judicial Protection', REALaw 4 (2011) 2, p. 31-50.

Preis \& Temming 2010

U. Preis en F. Temming, 'Der EuGH, das BVerfG und der Gesetzgeber Lehren aus Mangold II', NZA 27 (2010), p. 185-198.

Redactioneel CMLRev. 2003

Editorial Comments, 'Freedoms unlimited? Reflections on Mary Carpenter v. Secretary of State', CMLRev. 40 (2003) 3, p. 547-543. 
Redactioneel CMLRev. 2006

Editorial Comments, 'Horizontal direct effect - A law of diminishing coherence?', CMLRev. 43 (2006) 1, p. 1-8.

Redactioneel CMLRev. 2008

Editorial Comments, 'The Court of Justice in the limelight - again', CMLRev. 45 (2008) 6, p. 1571-1579.

Redactioneel CMLRev. 2010

Editorial comments, 'The scope of application of the general principles of Union law: An ever expanding Union?' CMLRev. 47 (2010) 6, p. 1593-1596.

Redactioneel CMLRev. 2013

Editorial comments, 'Ultra vires - has the Bundesverfassungsgericht shown its teeth?', CMLRev. 50 (2013) 4, p. 925-930.

Redactioneel NTM/ NJCM -Bull. 2013

Redactioneel 'Grondrechtenbescherming in de EU; Hoe ver moet de Europese arm reiken?', NTM/ NJCM-Bull. 38 (2013) 2, p. 189-191.

\section{Reestman 2010}

J.H. Reestman, 'De pacificatie van Karlsruhe (2010): het Bundesverfassungsgericht en 'ultra vires'-toetsing van Europese Uniebesluiten'. In: Nieuwenhuis, Reestman \& Zoethout 2010, p. 201-215.

Reestman \& Besselink 2013

JHR and LB, 'After Åkerberg Fransson and Melloni', EUConst. 9 (2013) 2, p. 169-175.

Rosenfeld en Sajó 2012

M. Rosenfeld en A. Sajó (red.), The Oxford Handbook of Comparative

Constitutional Law, Oxford: Oxford University Press 2012.

Safjan 2013

M. Safjan, 'Transformation or Deformation of the Paradigm?', in: Bernitz, Groussot \& Schulyok 2013-1, p. 155-171.

Sajó \& Uitz 2005

A. Sajó and R. Uitz (red.), The constitution in private relations: expanding constitutionalism, Utrecht: Eleven International Publishing 2005. 
Sarmiento 2013

D. Sarmiento, 'Who's afraid of the Charter? The Court of Justice, national courts and the new framework of fundamental rights protection in Europe', CMLRev. 50 (2013) 5, p. 1267-1304.

Schepel 2013

H. Schepel, 'Freedom of Contract in Free Movement Law: Balancing Rights and Principles in European Public and Private Law', E.R.P.L (2013) 5/6, p. 1211-1230.

Schiek 2006

D. Schiek, 'The ECJ Decision in Mangold: A Further Twist on Effects of Directives and Constitutional Relevance of Community Equality Legislation', I.L.J 35 (2006), p. 329-341.

Schiek \& Chege 2009

D. Schiek en V. Chege (red.), European Union Non-Discrimination Law, Comparative perspectives on multidimensional equality law, Londen: Cavendish Publishing 2009.

\section{Schmidt 2005}

M. Schmidt, 'The Principle of Non-discrimination in respect of Age:

Dimensions of the ECJ's Mangold Judgment', 7 German Law Journal (2005), p. 506-524.

Sevenster 2010

H.G. Sevenster, 'Rewe - Franse appelen in Duitsland', in: Beukers, van Harten \& Prechal 2010, p. 129-135.

Sieburgh 2011

C.H. Sieburgh, 'Legitimiteit van de confrontatie van Europees recht en burgerlijk recht van nationale origine', in: Voermans, Borgers \& Sieburgh 2011, p. 187-242.

Sieburgh 2013

C. Sieburgh, 'A Method to Substantively Guide the Involvement of EU Law in Private Law Matters', E.R.P.L. 21 (2013) 5/6, p. 1165-1188

Smits 2003

J.M. Smits, Constitutionalisering van het vermogensrecht, Preadvies Nederlandse Vereniging voor Rechtsvergelijking, Deventer: Kluwer 2003. 
Smits 2006

J. Smits, 'Private Law and Fundamental Rights: a Sceptical View', in:

Barkhuysen \& Lindenbergh 2006, p. 9-23.

Sommeregger 2005

G. Sommeregger, 'The horizontalization of Equality: The German Attempt to Promote Non-Discrimination in the Private Sphere via Legislation', in: Sajó \& Uitz 2005, p. 33-55.

Spielmann 2007

D. Spielmann, 'The European Convention on Human Rights. The European Court of Human Rights', in: Oliver \& Fedtke 2007-1, p. 427-467.

Swennen 2012

F. Swennen, 'Noot bij zaken C-208/09, Sayn-Wittgenstein en C-391/09, Vardyn, SEW (2012) 2, p. 76-81.

Temple Lang 2013

J. Temple Lang,'Emerging European General Principles in Private Law', in: Bernitz, Groussot \& Schulyok 2013-1, p. 65-121

Tettinger e.a. 2006

Tettinger, Stern, Ladenburger, Kölner Gemeinschaftskommentar zur

Europäischen Grundrechte-Charta, München: C. H. Beck, 2006.

Thym 2013

D. Thym, 'Separation versus Fusion - or: How to Accommodate National Autonomy and the Charter? Diverging Visions of the German Constitutional Court and the European Court of Justice', EUConst. 9 (2013) 3, p. 391-419.

Timmermans 1979

C.W.A. Timmermans, 'Directives: their Effect within the National Legal Systems' , C.M.L.Rev. 16 (1979) 4, p. 533-555.

Timmermans 2004

C.W.A. Timmermans, 'The European Union's judicial system' Common Market Law Review, 41 (2004) 2, p. 393-405.

Tridimas 2006

T. Tridimas, The General Principles of EU Law, Oxford: Oxford University Press 2006 (2e ed., 2006). 
Verhey 2009

L.F.M. Verhey, Horizontale werking van grondrechte: de stille Straatsburgse revolutie, in: Barkhuysen, Emmerik en Loof 2009, p. 517-537.

Vervaele 2013

J. Vervaele, 'The Application of the EU Charter of Fundamental Rights (CFR) and its Ne bis in idem Principle in the Member States of the EU', REALaw 6 (2013) 1, p. 113-134.

De Visser 2013-1

M. De Visser, 'Dealing with Divergences in Fundamental Rights Standards', MJ (2013) 4, p. 576-588.

De Visser 2013-2

M. de Visser, 'A Cautionary Tale: Some Insights Regarding Judicial Activism from the National Experience', in: Dawson, De Witte \& Muir 2013, p. 188-211.

Voermans 2006

Voermans, 'Applicability of Fundamental Rights in Private law: what is the Legislature to do? AnIntermezzo from a Constitutional Point of View', in: Barkhuysen \& Lindenbergh 2006, p. 33-43.

Voermans, Borgers \& Sieburgh 2011

W.J.M. Voermans, M.J. Borgers, C.H. Sieburgh, Controverses rondom legaliteit en legitimitatie (preadvies NJV 2011), Deventer: Kluwer 2011.

De Vries \& Van Mastrigt 2013

S. de Vries en R. van Mastrigt, 'The Horizontal Direct Effect of the Four Freedoms: From a Hodgepodge of Cases to a Seamless Web of Judicial Protection in the EU Single Market?', in: Bernitz, Groussot \& Schulyok 2013-1, p. 249-281.

De Waele 2009

H.C.F.J.A. de Waele, Rechterlijk Activisme en het Europees Hof van Justitie, Den Haag: Boom Juridische Uitgevers 2009 (diss.).

De Waele 2014

H.C.F.J.A. de Waele, 'Horizontale werking van het EU-

Grondrechtenhandvest: de kogel lijkt door de kerk', NTER (2014) 5, p. 58-64. 
Weiler 1986

J.H.H. Weiler, Eurocracy and Distrust: Some Questions Concerning the European Court of Justice in the Legal Order of the European Communities", Wash. L. Rev. (1986) 1, p. 1103-1142.

Weiler 1996

J.H.H. Weiler, 'The Jurisprudence of Human Rights in the European Union: Integration and Disintegration, Values and Processes', Harvard Jean Monnet Working Paper No 2/96.

Weiler 1999-1

J.H.H. Weiler, 'The transformation of Europe', in: The Constitution of Europe: 'Do the New Clothes Have an Emperor?' and Other Essays on European Integration, Cambridge: Cambridge University Press 1999, p. 10-102.

Weiler 1999-1

J.H.H. Weiler, 'Fundamental rights and fundamental boundaries: on the conflict of standards and values in the protection of human rights in the European legal space', in: The Constitution of Europe: 'Do the New Clothes Have an Emperor?' and Other Essays on European Integration, Cambridge: Cambridge University Press 1999, p. 102-128.

De Witte 1999

B. De Witte, 'The Past and Future Role of the European Court of Justice in the Protection of Human Rights', in: P. Alston, M. Bustelo en J. Heenan (red.), The EU and Human Rights, Oxford: Oxford University Press 1999, p. 859-899.

De Witte 2000

B. De Witte, 'Institutional Principles: A Special Category of General Principles of EC Law', in: Bernitz \& Nergelius 2000, p. 143-161.

De Witte 2009

B. de Witte, 'The crumbling public/private divide: horizontality in European anti-discrimination law', Citizenship Studies 13(2009) 5, p. 515-524.

De Witte 2011

B. de Witte, 'Direct effect, supremacy, and the nature of the legal order', in: Graig \& De Búrca 2011, p. 323-363.

De Witte 2013

B. De Witte, 'Article 53', in: Peers e.a. 2013, p. 1523-1538. 


\section{Overige bronnen}

ACA

Stukken ACA-seminar d.d. 24 november 2011 van de Europese Vereniging van Raden van Staten en hoogste administratieve gerechten (hierna: ACA) over de betekenis van het Handvest voor de nationale bestuursrechtspraak: http://www.aca-europe.eu/en/colloquiums/sem_2011_theHague.html.

\section{Commissie}

Mededeling van de Commissie over de aard van het Handvest van de grondrechten van de Europese Unie. COM/2000/0644 def.

Mededeling van de Commissie betreffende het Handvest van de grondrechten van de Europese Unie ingediend door de heer Vitorino in overeenstemming met de Voorzitter, COM/2000/0559 def., punten 7 en 10. Mededeling van de Commissie over de aard van het

Handvest van de grondrechten van de Europese Unie. COM/2000/0644 def. Europese Commissie, Verslag over de toepassing van het EU-Handvest van de grondrechten 2010, http://bookshop.europa.eu/en/2010-report-on-theapplication-of-the-eu-charter-of-fundamental-rights-pbNA3111087|

Europese Raad

Conclusies van het voorzitterschap Europese Raad Keulen 3 en 4 juni 1999, bijlage IV.

\section{Media}

F. Kuitenbrouwer, 'Onbescheiden rechters', NRC Handelsblad, 7 februari 2006.

R. Herzog en L. Gerken, 'Stop the European Court of Justice', EU Observer, 10 September

2008 



\section{LIJST VAN GEBRUIKTE AFKORTINGEN}

$\begin{array}{ll}\text { AA } & \text { Ars Aequi } \\ \text { A-G } & \text { Advocaat- Generaal } \\ \text { CLJ } & \text { Consumer Law Journal } \\ \text { CML. Rev. } & \text { Common Market Law Review } \\ \text { EHRC } & \text { European Human Rights Cases } \\ \text { EHRLR } & \text { European Human Rights Law Review } \\ \text { ELR } & \text { Erasmus Law Review } \\ \text { ELJ } & \text { European Law Journal } \\ \text { E.L. Rev. } & \text { European Law Review } \\ \text { EPL } & \text { European Public Law } \\ \text { ERPL } & \text { European Review of Private Law } \\ \text { EUConst } & \text { European Constitutional Law Review } \\ \text { Fordham Int'L.J. } & \text { Fordham International Law Journal } \\ \text { GLJ } & \text { German Law Journal } \\ \text { HRLR } & \text { Human Rights Law Review } \\ \text { HvJEU } & \text { Hof van Justitie van de Europese Unie } \\ \text { ILJ } & \text { Industrial Law Journal } \\ \text { MJ } & \text { The Maastricht Journal of European and } \\ & \text { Comparative Law } \\ \text { NTBR } & \text { Nederlands Tijdschrift voor Burgerlijk Recht } \\ \text { NTER } & \text { Nederlands Tijdschrift voor Europees Recht } \\ \text { NTM/NJCM-Bull. } & \text { Nederlands Tijdschrift voor de Mensenrechten } \\ \text { NZA } & \text { Neue Zeitschrift für Arbeitsrecht } \\ \text { REALaw } & \text { Review of European Administrative Law } \\ \text { REDP } & \text { Revue européenne de droit public } \\ \text { RRDE } & \text { Revista Română De Drept European } \\ \text { SEW } & \text { Tijdschrift voor Europees en economisch recht } \\ \text { TPR } & \text { Tijdschrift voor Privaatrecht } \\ \text { Wash. L. Rev. } & \text { Washington Law Review } \\ & \end{array}$





\section{CURRICULUM VITAE}

Mirjam de Mol is geboren op 18 januari 1974 te Leiden. Ze groeide op in Katwijk aan Zee. Na het behalen van haar VWO diploma in 1992 aan het Adelbert College te Wassenaar, studeerde zij een jaar Franse taal en cultuur aan de Université Catholique de l'Ouest in Angers (Frankrijk). Van 1993 tot 1998 studeerde ze Nederlands Recht aan de Universiteit Maastricht, waarvan een semester aan de Uppsala Universitet (Zweden) en een semester aan de Université de Montpellier I (Frankrijk). In 1998 behaalde ze haar diploma Nederlands Recht met vakthematische aantekening Europese Recht en Taal Studies ('cum laude'). Aansluitend, in 1999, behaalde ze haar Degree of Master of European Studies ('very good') aan het Europa College te Brugge (België).

Haar beroepsmatige leven begon zij als advocaat bij AKD te Brussel en Eindhoven (1999-2003). Zij was werkzaam in de verbintenisrechtelijke procespraktijk en de sectie Europees recht en mededingingsrecht. Zij was tevens medewerker van het Wetenschappelijk Bureau. In de periode 20032009 was zij senior jurist Europees Recht bij de Directie Juridische Zaken, Afdeling Europees Recht van het Ministerie van Buitenlandse Zaken. Zij trad met name op als gemachtigde van de Nederlandse regering voor het Hof van Justitie van de EU. Tot 2005 was zij tevens secretaris van de Interdepartementale Commissie Europees Recht.

In 2009 trad Mirjam de Mol als promovenda in dienst bij de Universiteit Maastricht. Zij maakt deel uit van de Ius Commune Onderzoeksschool en van het Maastricht Centre of European Law. Tijdens haar promotie-onderzoek publiceerde zij verscheidene artikelen. In 2011 won zij voor haar artikel 'The Novel Approach of the CJEU on the Horizontal Direct Effect of the EU Principle of Non-Discrimination' de Ius Commune Prijs van de Ius Commune Onderzoeksschool. In 2011 verrichtte ze voorts contracts-onderzoek bij de Raad van State ten behoeve van het seminar Handvest Grondrechten EU van de 'Europese Vereniging van Raden van Staten' en hoogste administratieve gerechten ('ACA'). Sinds 2009 is Mirjam de Mol tevens raadsheer plaatsvervanger bij het College van Beroep voor het Bedrijfsleven.

Mirjam de Mol is gehuwd met Leo Aerden en is moeder van drie kinderen, Wouter Domingo (2004), Olivia (2006) en Leonora (2012). 



\section{INHOUDSOPGAVE}

\section{DEEL I INLEIDENDE HOOFDSTUKKEN}

HOOFDSTUK 1

ALGEMENE INLEIDING

$1.1 \quad$ De directe werking van Uniegrondrechten: een reveil 3

1.2 Doel en probleemstelling 8

$\begin{array}{lll}1.3 & \text { Belang } & 12\end{array}$

1.4 Methode 13

$\begin{array}{lll}1.5 & \text { Taal } & 14\end{array}$

$\begin{array}{lll}1.6 & \text { Opzet } & 15\end{array}$

HOOFDSTUK $2 \quad 19$

UNIERECHTELIJKE SYSTEEM VAN

GRONDRECHTENBESCHERMING

2.1 Inleiding 19

2.2 Grondrechten uit hoofde van algemene rechtsbeginselen 25

2.2.1 Rechtsbron de 'algemene beginselen van Unierecht' 25

2.2.2 Grondrechten uit hoofde van algemene rechtsbeginselen $\quad 30$

2.3 Het Handvest 33

2.3.1 Algemeen 33

2.3.2 Toepassinggebied: artikel 51, lid 1

2.3.3 Mogelijkheid van beperkingen: artikel 52, lid $1 \quad 36$

2.3.4 De verhouding van het Handvest met de Verdragen: 37 artikel 52, lid 2

2.3.5 Uitlegging en de rol van internationaal en nationaal recht: 37 artikel 52, leden 3, 4 en 6

2.3.6 Samenloop van de toepassing van het Handvest met 39 nationale grondrechten: artikel 53

2.3.7 Onderscheid tussen Handvest-rechten en 44 Handvest-beginselen: artikel 52, lid 5

2.3.7.1 Algemeen 44

2.3.7.2 Handvest-beginselen en directe werking 48

2.4 Conclusies 55 


\section{DEEL II VERTICALE DIRECTE WERKING}

HOOFDSTUK 3

DEFINIËRING EN CONSTITUTIONELE CONTEXT

3.1 Inleiding 61

3.2 Definiëring verticale directe werking 61

3.2.1 Algemeen 61

3.2.2 Gevolgen directe werking 64

$\begin{array}{lll}3.3 & \text { Toetsingskader voor de legitimiteit } & 69\end{array}$

3.3.1 Algemeen 69

3.3.2 Samenhang tussen gebondenheid en directe werking $\quad 69$

3.3.3 Artikel 51, lid 1, van het Handvest als vertrekpunt 70

3.3.4 De betekenis van Wachauf en ERT 75

$\begin{array}{lll}\text { 3.3.4.1 Algemeen } & 75\end{array}$

$\begin{array}{lll}\text { 3.3.4.2 Het arrest Wachauf } & 76\end{array}$

$\begin{array}{lll}\text { 3.3.4.3 Het arrestERT } & 78\end{array}$

3.3.4.4 De grondrechtconforme toepassing van 80 Unierecht als grondslag

3.3.4.5 Verschillende technieken voor grondrechtconforme 82 toepassing

$\begin{array}{lll}3.4 & \text { Conclusies } & 84\end{array}$

HOOFDSTUK $4 \quad 87$

WACHAUF -UITVOERING

$\begin{array}{lll}4.1 & \text { Algemeen } & 87\end{array}$

4.2 Klassieke omzettingshandelingen $\quad 88$

4.2.1 Analyse van de rechtspraak van het Hof 88

4.2.2 Beschouwing in het licht van de allocatie van 93 bevoegdheden

4.3 Uitoefening van op grond van Unierecht verleende $\quad 97$ bevoegdheden

4.3.1 Analyse van de rechtspraak van het Hof $\quad 97$

$\begin{array}{lll}\text { 4.3.1.1 Een eerste verkenning } & 97\end{array}$

4.3.1.2 BTW-rechtspraak en het arrest Garage Molenheide $\quad 99$

4.3.1.3 Rechtspraak inzake het Handvest 103

4.3.2 Beschouwing in het licht van de allocatie van 109 bevoegdheden

4.4 Maatregelen die onder de werkingssfeer van materieel 112 Unierecht vallen

4.4.1 Analyse van de rechtspraak van het Hof 
4.4.2 Beschouwing in het licht van de allocatie van bevoegdheden

4.5 Effectuering, sanctionering en handhaving van Unierecht 116

4.5.1 Analyse van de rechtspraak van het Hof 116

4.5.1.1 De effectuering van Unie rechten: nationale procedure regels 116

4.5.1.2 Naleving van Unierecht: sanctionering en toezicht 120

4.5.2 Beschouwing in het licht van de allocatie van 125 bevoegdheden

4.6 Conclusies

HOOFDSTUK 5

ERT-UITVOERING

5.1 Inleiding 133

5.2 De ERT-route bij beperkingen van het vrije verkeer 134

5.2.1 Analyse van de rechtspraak van het Hof 134

5.2.2 Beschouwing in het licht van de allocatie van bevoegdheden 137

5.2.2.1 Algemeen 137

5.2.2.2 Oprekking van de materiële werkingssfeer van vrije $\quad 139$

5.2.2.3 Grondrechten bij de kwalificatie als ‘beperking' 142

5.3 De ERT-route bij ontzeggingen van Unie 146 burgerschap(srechten)

5.3.1 Analyse van de rechtspraak van het Hof 146

5.3.2 Beschouwing in het licht van de allocatie van bevoegdheden 152

5.4 Conclusies 155

HOOFDSTUK 6

GEEN UITVOERING: ANNIBALDI

$\begin{array}{lll}6.1 & \text { Inleiding } & 157\end{array}$

6.2 Het ontbreken van enige aanknoping 158

6.3 Het ontbreken van een toereikende anknoping 161

6.3.1 Algemeen 161

6.3.2 Het bestaan van Uniebevoegdheden 161

6.3.3 Unieburger uit een andere lidstaat 163

6.3.4 Verdergaande beschermingsmaatregelen, geleidelijke 164 harmonisatie en 'standstill'

6.3.5 Het enkel inroepen van materieel Unierecht 170

$\begin{array}{lll}\text { 6.3.6 Een Unieregeling } & 172\end{array}$

$\begin{array}{lll}\text { 6.3.7 Vrijwillige verwijzingen naar Unierecht } & 176\end{array}$

$\begin{array}{lll}\text { 6.3.8 Vrijwillige nationale schadeloosstelling } & 178\end{array}$ 
6.3.9 Louter hypothetisch vooruitzicht uitoefening 179 van het vrije verkeer

6.4 Beschouwing in het licht van de allocatie van 180 bevoegdheden

6.5 Conclusies

\section{DEEL III HORIZONTALE DIRECTE WERKING}

HOOFDSTUK 7

DEFINIËRING EN CONSTITUTIONELE CONTEXT

7.1 Inleiding

7.2 Definiëring horizontale directe werking

7.2.1 Algemeen

7.2.2 Onderscheid in twee varianten

7.3 Constitutionalisering van particuliere verhoudingen 200

7.3.1 Een schets van het debat

200

7.3.2 Verschillende manieren van beïnvloeding van

204

7.4 Het EHRM en horizontale werking

7.5 Legitimiteit van horizontale directe werking

$\begin{array}{lll}7.5 .1 & \text { Algemeen } & 212\end{array}$

7.5.2 Mogelijke grondslagen voor horizontale directe werking 212

7.5.2.1 Nationale constitutionele tradities 213

7.5.2.2 De rechtspraak van het EHRM 214

7.5.2.3 Het effectiviteitsbeginsel 215

7.5.2.4 De horizontale directe werking van Verdragsbepalingen 215

7.5.3 Mogelijke grenzen aan horizontale directe werking 220

7.5.3.1 Artikel 51, lid 1, van het Handvest 221

7.5.3.2 De rechtspraak inzake de horizontale directe werking 223

$\begin{array}{lll}7.6 & \text { Conclusies } & 224\end{array}$

HOOFDSTUK 8

DE ERKENNING: MANGOLD EN VERDER

8.1 Inleiding 227

8.2 Horizontale directe werking van algemene rechtsbeginselen 228

$\begin{array}{lll}\text { 8.2.1 Algemeen } & 228\end{array}$

8.2.2 Het arrest Mangold: een verrassing 228

8.2.2.1 Feiten, nationaal kader en prejudiciële vragen 228

8.2.2.2 Oordeel van het Hof 229

8.2.2.3 Korte analyse 230 
8.2.2.4 De aanloop naar Kücükdeveci 231

8.2.3 Het arrest Kücükdeveci: een bevestiging en 233 een verduidelijking

8.2.3.1 Feiten, nationaal kader en prejudiciële vragen 233

8.2.3.2 Oordeel van het Hof 234

8.2.3.3 Korte analyse 238

8.3 Horizontale directe werking van het Handvest 242

8.3.1 Algemeen 242

8.3.2 Het arrest Dominguez: een stilte-arrest 242

8.3.2.1 Samenvatting procedure en arrest 242

8.3.2.2 Korte analyse 244

8.3.3 Het arrest AMS: een voortborduren op Kücükdeveci 245

8.3.3.1 Feiten, nationaal kader en prejudiciële vragen 245

8.3.3.2 Oordeel van het Hof 246

$\begin{array}{lll}\text { 8.3.3.3 Korte analyse } & 247\end{array}$

8.4 Zij-uitstapjes: samenloop met de horizontale directe 251

$\begin{array}{ll}8.5 & \text { Conclusies } \\ & 255\end{array}$

HOOFDSTUK 9

NADERE ANALYSE VAN DE RECHTSPRAAK

9.1 Inleiding 257

9.2 Eerste voorwaarde: technische geschiktheid 258

9.3 Tweede voorwaarde: nationale overheidshandeling 261

9.4 Derde voorwaarde: uitvoeringshandeling 264

9.5 Vierde voorwaarde: samenspel met Uniewetgeving 266

9.6 Beschouwing in het licht van de allocatie van bevoegdheden 269

9.6.1 Algemeen 269

9.6.2 Horizontale directe werking variant toetsing 269 van overheidshandelen

9.6.3 Openstaande vraag: relevantie van Uniewetgeving 272 in private sector

9.6.4 Vervolgstap: erkenning van volledige horizontale 274 directe werking?

9.6.5 Nieuwe problematiek bij aanvaarding van volledige 275 horizontale directe werking (1): toepassing artikel 51, lid 1, van het Handvest

9.6.6 Nieuwe problematiek bij aanvaarding van volledige 278 horizontale directe werking (2): welke grondrechten?

9.7 Conclusies 
HOOFDSTUK 10

DISCRIMINATIEVERBODEN

10.1 Inleiding 283

10.2 Welke discriminatieverboden? 283

10.2.1 Algemeen 283

10.2.2 Verbod van leeftijdsdiscriminatie ex artikel 21 van het Handvest

10.2.3 Verboden van discriminatie op andere gronden 286 dan leeftijd

10.3 In welke situaties? 295

10.3.1 Algemeen 295

10.3.2 'De facto' horizontale directe werking van non-discriminatie 296 richtlijnen

10.3.3 Horizontale directe werking buiten de werkingssfeer 301 van non-discriminatie richtlijnen

10.3.4 Volledige 'de facto' horizontale directe werking van 302 non-discriminatie richtlijnen

10.4 Beschouwing in het licht van de allocatie van bevoegdheden 303

10.5 Conclusies 305

DEEL IV SYNTHESE, CONCLUSIES EN AANBEVELINGEN

HOOFDSTUK 11

DIRECTE WERKING OP DREEF EN OP DRIFT

11.1 Inleiding 309

$\begin{array}{lll}11.2 & \text { Verticale directe werking } & 309\end{array}$

$\begin{array}{ll}\text { 11.2.1 Stand van het recht } & 309\end{array}$

11.2.2 Legitimiteit en rechterlijk activisme 313

11.2.2.1 Bestaan van verticale directe werking $\quad 313$

11.2.2.2 Uitwerking in de Wachauf-waaier 314

11.2.2.3 Uitwerking in de ERT-route 316

$\begin{array}{ll}\text { 11.2.3 Openstaande vragen } & 318\end{array}$

11.2.3.1 De Wachauf-waaier 318

11.2.3.2 ERT-route 323

11.2.3.3 Handvest-rechten en Handvest -beginselen 325

11.3 Horizontale directe werking 325

11.3.1 Stand van het recht 325

11.3.2 Legitimiteit en rechterlijk activisme 328

11.3.3 Openstaande vragen en aandachtspunten 332

11.4 Eindconclusie en aanbevelingen 334 
Summary

345

Valorisatie-addendum

359

Lijst van aangehaalde jurisprudentie

367

Lijst van aangehaalde literatuur \& overige bronnen

377

Lijst van gebruikte afkortingen

399

Curriculum Vitae

401

Inhoudsopgave

403

Dankwoord

411 



\section{DANKWOORD}

De wens om ooit een proefschrift te schrijven speelde al door mijn hoofd sinds mijn afstuderen in 1998. Gedurende tien jaar werkte ik met veel plezier in de praktijk. Tegelijkertijd groeide het verlangen naar het schrijven van een proefschrift; ik zag het als een grote intellectuele uitdaging en een mogelijkheid om mij verder te verdiepen en mijn geest te verruimen. Het was best een spannende stap om het roer daadwerkelijk om te gooien, maar ik heb er nooit een moment spijt van gehad. Ik kijk in grote dankbaarheid terug op deze periode die mij enorm veel heeft gebracht. Ik heb het verrichten van promotieonderzoek ervaren als een op weg gaan en een op weg zijn. Het was geen uitgestippeld en geëffend pad en dat er ook nog een eindpunt aan zou zitten leek tot op het laatste ogenblik zeer onwerkelijk. Er werd mij wel eens gevraagd of het niet saai was, maar dat was het geen moment. Ik ging de weg ook niet alleen. In de verschillende fases waren er mensen die mij terzijde stonden, ieder op zijn eigen moment en manier. Een aantal mensen wil ik in het bijzonder noemen en bedanken.

Ik begin met mijn ouders Jaap en Henny de Mol- van Dongen. Pappa en mamma, jullie zijn er altijd onvoorwaardelijk voor mij, al heel mijn leven lang. In het traject van het proefschrift gaven jullie mij met name de rek en armslag door waar mogelijk bij te springen met de kinderen. Dit geldt in het bijzonder ook voor jou mamma. Heel erg bedankt.

Mijn promotoren Hildegard Schneider en Bruno de Witte ben ik zeer grote dank verschuldigd. Hildegard, zonder jou was ik er vermoedelijk niet aan begonnen. Jouw enthousiasme, vertrouwen en voortvarendheid makkten het voor mij makkelijker om de sprong in het diepe te wagen. Ook tijdens het onderzoek was je voor mij een steun in de rug. Als de tijden woelig waren, door je kalmte en als het tijd was voor doorpakken door je vertrouwen en optimisme. De laatste jaren was je decaan, maar desondanks was het altijd mogelijk om even te overleggen als dat nodig was. Hoe druk ook, elk gesprek voer je met volle aandacht.

Bruno, vanaf het prille begin in mijn studietijd (blok 2.2. Inleiding in het internationaal en Europees recht) heb ik mogen profiteren van jouw enthousiasme voor en diepgaand inzicht in het Europees recht. Zo schreef ik mijn eindscriptie bij jou. Typerend toen was dat je altijd net wat meer vroeg dan ik dacht te kunnen. Zo ging het ook nu. Jouw (ogenschijnlijk) kleine en terloopse opmerkingen kostten dikwijls hoofdbrekens, maar tilden het 
proefschrift of artikel altijd weer een stuk op. Op het eind heb je met zachte hand de druk op de ketel gezet, waardoor de vaart er in kwam en bleef.

Hildegard en Bruno, jullie beiden heel hartelijk bedankt.

Ik dank tevens de leden van de promotiecommissie: Monica Claes, Leonard Besselink, Anne Pieter Van der Mei, Hanna Sevenster en Ellen Vos. Het moment dat ik het proefschrift bij jullie 'afleverde' vond ik wel bijzonder en spannend. Jullie allen veel dank voor het zorgvuldig lezen en waardevol becommentariëren van mijn werk.

Lieve paranimfen Boukje Molleman en Marianne Gijzen, veel dank dat jullie de eindspurt met mij lopen tot en met de verdediging toe!

Ik wil ook graag mijn collega's van de Universiteit Maastricht, met name ook de leden van het Maastricht Centre of European Law, bedanken. Ondanks dat ik een groot deel van de tijd niet fysiek in Maastricht aanwezig was, heb ik jullie collegialiteit als zeer prettig ervaren. Een bijzonder woord van dank gaat uit naar Suzanne Jongste, Licette van der Poll en Jolande Pletzers. Werken op afstand is niet altijd makkelijk. Jullie waren altijd bereid om via de e-mail een handje te helpen. Dank jullie wel.

Ik noem ook Caroline ten Dam. Caroline, wij verlieten bijna gelijktijdig DJZ/ER van het Ministerie van Buitenlandse Zaken. Jij ging naar Brussel voor een detachering bij de Commissie en inmiddels ben je op de PV-EU belandt. Ik beschouw jou nog steeds als mijn collega, sterker nog als 'e-kamergenoot'. In de afgelopen vijf jaar hebben wij zeer frequent, zo niet dagelijks, met elkaar gemaild over het Europees recht. Ik zou jouw precieze blik en scherpe juridische inzichten niet willen missen. Inmiddels zijn we natuurlijk ook veel meer dan collega's en 'e-kamergenoten'. Tussen de bedrijven door kwamen alle aspecten van onze levens aan bod. Dank je wel voor je betrokkenheid.

In het prille begin, tijdens de eerste lezing die ik gaf over het arrest Kücükdeveci, ontmoette ik twee privaatrechtelijke EU pioniers: Carla Sieburgh en Arthur Hartkamp. Carla en Arthur, wij hadden van meet af aan levendige en inspirerende uitwisselingen over de betekenis van Uniegrondrechten voor het privaatrecht. Ik heb daar veel plezier aan beleefd en het heeft mijn blik verruimd. Veel dank daarvoor.

Liesbet van den Broeck mag in dit dankwoord niet ontbreken. Liesbet, wij kennen elkaar van de zittingen in Luxemburg waar jij agent was van de 
Belgische regering en ik van de Nederlandse. We hielden contact en trokken zo samen op in het schrijven van onze proefschriften. Ik dank je hartelijk voor je steun van de afgelopen jaren en je spontane lachbuien over mijn Nederlandse uitdrukkingen.

En dan: Boukje Molleman, Somia Azahaf en Angélique Mählmann. Lieve girls, we studeerden samen rechten in Maastricht en in Frankrijk en we hebben nog steeds een heel fijne vriendschap. We zien elkaar natuurlijk veel te weinig. Gelukkig valt er nog heel wat dagelijks te lachen en uit te wisselen in onze Whatsapp-groep. Op het laatst hebben jullie mij ook echt aangemoedigd in treffende bewoordingen als: "Huphuphup. Zet hem op Mir!". Het heeft geholpen, dank jullie wel.

Tijdens het promotietraject, in 2012, werd Leonora geboren. Haar komst was een enorm groot cadeautje, maar het werd wel zoeken naar mogelijkheden om verder te werken aan het proefschrift. Ze was graag bij haar mamma en liet zich niet zo makkelijk en lang onderbrengen bij anderen. Ik ben daarom een heel speciaal woord van dank verschuldigd aan Emilie O'Herne, Janske Meijer en Valérie Blussé. Jullie hebben alle drie met eindeloos veel geduld en liefde voor Leonora gezorgd zodat ik regelmatig een paar uur kon werken. Bedankt.

Een warm woord van dank gaat uit naar Michel Hagen pr. voor zijn betrokkenheid, raad en daad, en naar Guust Aerden voor zijn belangstelling en luisterend oor. In dit rijtje wil ik ook stilstaan bij mijn schoonvader Sjef Aerden die is overleden in 2011. Hij maakte het eerste deel van het proefschrifttraject mee en zijn enthousiasme en aanmoediging waren hartverwarmend. Hij las graag mijn concept stukken en voorzag ze van zorgvuldig handgeschreven commentaar. Ik denk daar in dankbaarheid aan terug.

Dan kom ik nu bij mijn echtgenoot Leo Aerden. Leo, je hebt het altijd gezegd: "Na mijn promotie ben jij aan de beurt om te promoveren." Ik vond dat eerlijk gezegd niet helemaal reëel; want hoe zou dat kunnen een promotie en baan en jonge kinderen? Uiteindelijk heb je gelijk gekregen. Ik koos ervoor om mijn toenmalige baan op te zeggen en het avontuur aan te gaan. Het is gelukt en we deden het samen. Jij hebt mij altijd door dik en dun gesteund. Ook het gewone leven ging door en we hebben in de afgelopen vijf jaar veel meegemaakt; jij brak je rug, we verloren je vader en we kregen ons derde kindje en nog veel meer. De laatste maanden waren best wel pittig, je was dikwijls delen van weekeinden en vakanties alleen op pad met drie kinderen zodat ik aan mijn proefschrift kon werken, geen sinecure. Leo dankjewel, ik kijk uit naar onze volgende avonturen samen. 
Lieve Leo, Wouter Domingo, Olivia en Leonora. Ik draag mijn proefschrift aan jullie op, omdat jullie de schatten zijn bij wie mijn hart ligt.

Mirjam de Mol

Wassenaar, 15 juli 2014. 


\section{Directe werking op dreef en op drift}

Dit boek behandelt het leerstuk van de directe werking van de grondrechten van de Europese Unie. De rechtspraak van het Hof van Justitie van de Europese Unie (het Hof) neemt hierbij een centrale plaats in. In het boek is de stand van het recht (inclusief openstaande vragen) in kaart gebracht. Het bevat tevens een beschouwing van de legitimiteit van de rechtspraak van het Hof en wel met name in het licht van het beginsel van allocatie van bevoegdheden.

Het boek bestaat uit twee hoofddelen. Een deel dat ziet op de directe werking van Uniegrondrechten in de relatie tussen particulieren en nationale overheden ('verticale directe werking') en een deel dat gaat over de directe werking van Uniegrondrechten in de relatie tussen particulieren onderling ('horizontale directe werking'). Er wordt uitgebreid ingegaan op artikel 51, lid 1, van het Handvest van de Grondrechten van de Europese Unie dat bepalend is voor de vraag in welke situaties sprake is van de directe werking van Uniegrondrechten. De betekenis van deze bepaling wordt verhelderd door een inventarisatie van de verschillende artikel 51 -situaties. Tevens is een analyse gemaakt van de nieuwe benadering van het Hof inzake de horizontale directe werking in de arresten Mangold en Kücükdeveci, waarbij onder meer toepassingsvereisten zijn geformuleerd. Het boek bevat tot slot een reeks van aanbevelingen die zich primair richten tot het Hof, maar die tevens kunnen dienen als leidraad voor de nationale rechters en procespartijen, alsmede voor de actoren in Hofzaken.

Dit boek laat zien dat het contrast tussen de rechtspraak inzake de verticale directe werking en de horizontale directe werking van Uniegrondrechten groot is. Het leerstuk van de verticale directe werking van Uniegrondrechten is al een eind op stoom en is tot wasdom gekomen. Zowel het bestaan van verticale directe werking als de uitwerking ervan is gelegitimeerd. Het leerstuk van de horizontale directe werking staat daarentegen nog in de kinderschoenen. Er is slechts een handvol rechtspraak met veel losse eindjes. Bij de legitimiteit ervan kunnen bovendien kritische kanttekeningen worden geplaatst. 